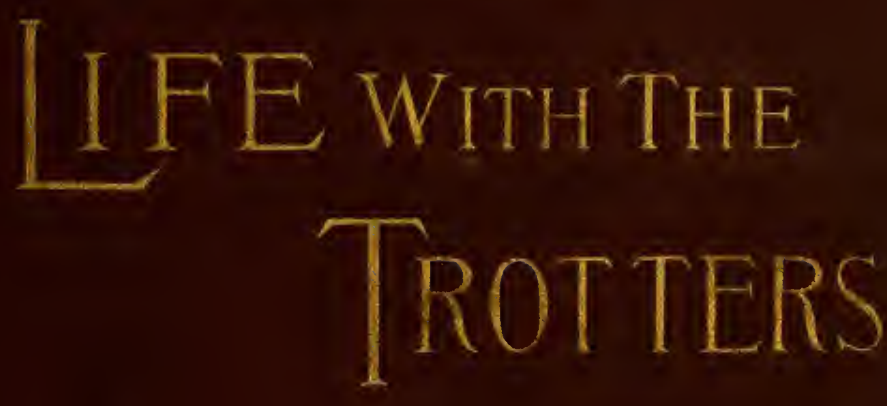




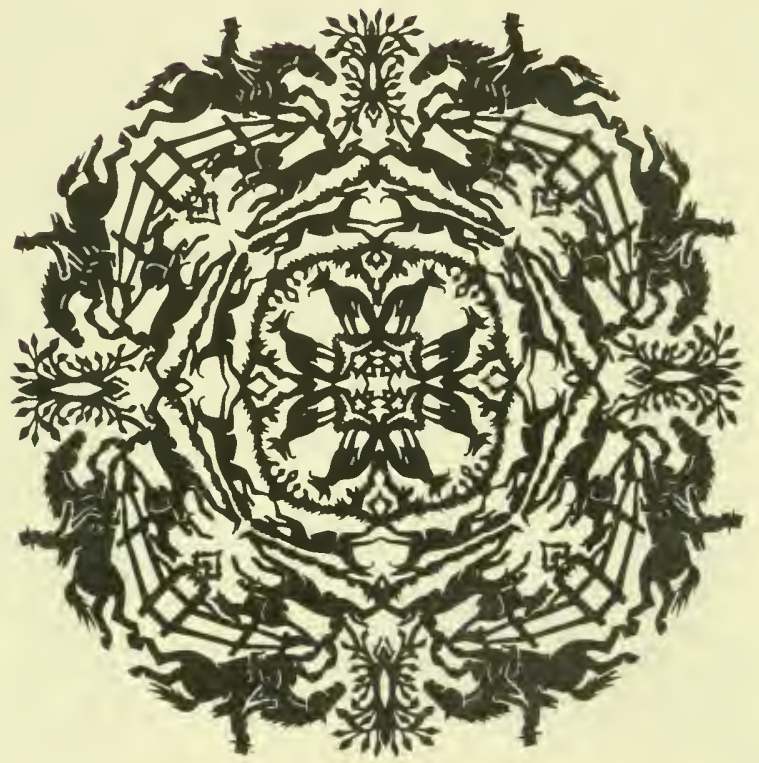

JOHN A.SEAVERNS 


\section{TUFTS UNIVERSITY LIBRARIES

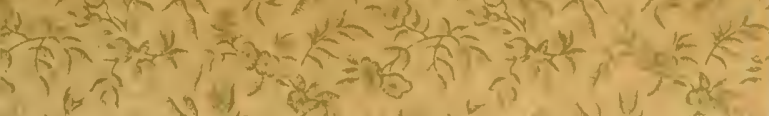 (y)

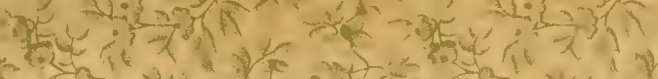

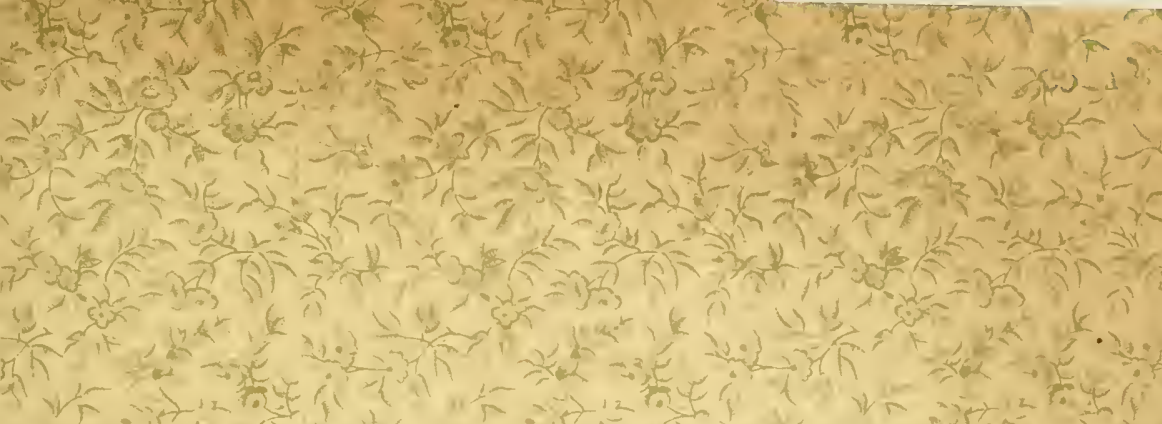

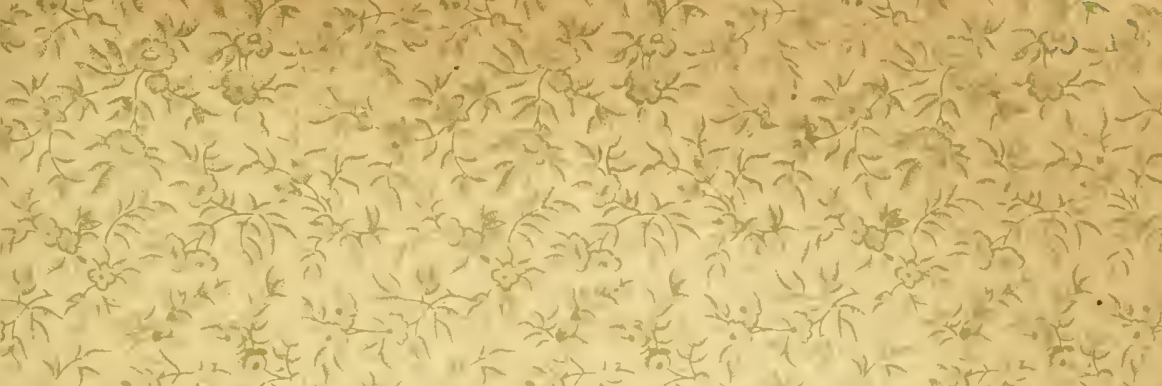
$=x_{i}$

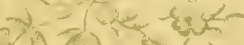

(5.2.

$17,-i=035$ 





\section{LIFE WITH THE TROTTERS}

BY

\section{J OH N S P L N,}

WITI A CHAPTER ON

\section{HOW GOLDSMITH MAID AND DEXTER WERE TRAINED.}

(From Information furnished by Mr. BudD Doble.)

PRICE, THREE DOLLARS.

Сн I CA G :

H. T. White, Editor and Publisuer.

1889.

Order from the Publisher, H. T. WHITE, Loch Box $2 \% 0$, Chicago, Ill. 
Entered, according to Act of Congress, in the Tear 1889, by HENRY TEN EYCK WIITE AND AMANDA SILAN, In the Oftice of the Librarian of Congress, at Washington, I. C.

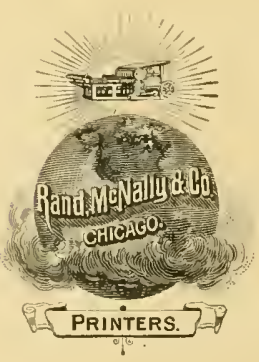




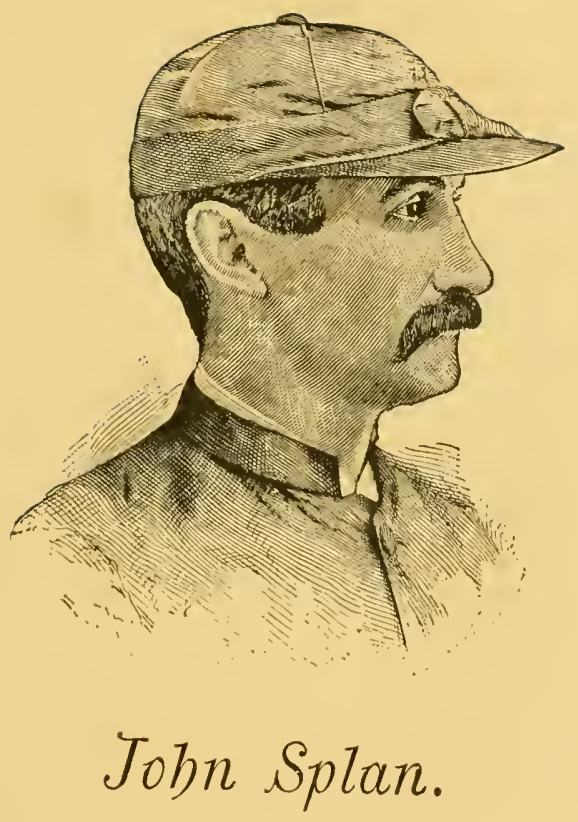




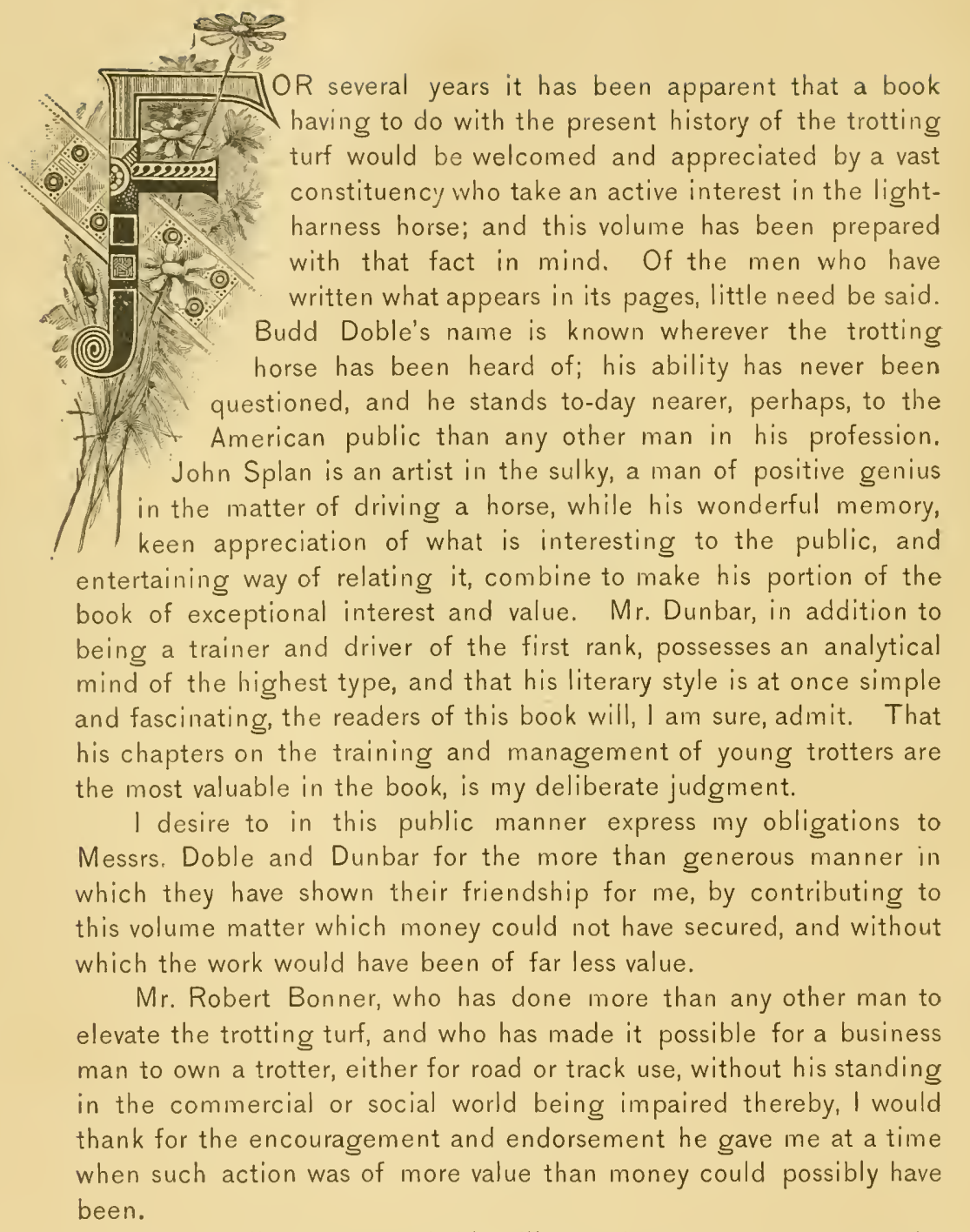

For unsolicited acts of friendliness that can be but partially repaid by an acknowledgment of this character, I am indebted to Messrs. R. A. Bower, John R. Walsh, and C. H. Durphy, of Chicago. 


\section{CONTENTS.}

\section{CHAPTER I.}

Boyhood days at Little Falls, N. Y.-Running away from home and reaching the Buffalo track-Pelham Tartar, $\mathrm{my}$ first trotter-Something about the stallion Byron-How old-time trotters were trained-Pilot Temple, Tackey, and Dixie-The pacer Billy Boyce-A trip to CubaI return to New York City and go to work for Dan Mace-"Lucy Jimmy" teaches me to rub a trotter-Tempest and her fevered feetStarting out on my own account as a trainer-My first race and the glory thereof-Lady Saulpangh and her races-The great mateh at Paterson, N. J.-Fun on Staten Island.

\section{CHAPTER II.}

Kansas Chief, first a cattle herder, then ridden by a gentleman, and next a 2:30 trotter-His feet fail and he is given away after being sold for $\$ 7,500-$ Traded to MIr. Simmons, he comes into my hands-Ilow his feet were treated-A great campaign from the lakes to the seaboard-Don't trot your horse when he is out of eondition-Kansas Chief's last races-IIow Dan Nace discovered Rarus- $\Lambda$ talk in the hotel at night-The story of a game, handsome, and honest horse. . . . . . . 28

\section{CHAPTER III.}

Rarus, the first trotter to beat 2:14-How he was bred and raised by a Long Island farmer-The old gentleman thought by his neighbors to be too enthusiastic abont the colt-His first race on the Island-Irow he eame into my hands, after making a record of $2: 20^{3}-1-\Lambda$ successful trip through the central circuit, winning all his races but oue-IIow Jim Crawford fooled the pool buyers-Going West and beating the famous BodineEntering Rarus in a race against the crack trotters of the land. . 53 


\section{CHAPTER IV.}

Rarus wins his first race against the crack trotters of the country-A private trial in fast time over the Fleetwood track-The trip to California with Goldsmith Maid-Ancther fast mile in private, and a refusal of $\$ 45,000 \mathrm{for}^{\circ}$ the gelding-Inly Daniels and the cattle raiser at Chico-Inside facts about the race in which Rarus beat Goldsmith Mraid-Coming East again and lowering his record to 2:16-The wonderful race against Great Enstern at Fleetwood Park.

\section{CH.APTER V.}

How Rarus was wintered at Clevelund-Barred from the free-to-all races in the summer of 18:8-He trots in 2:14 at Cleveland-Uncle Ben Wright's unlucky bets-The record lowered to 2:131 1 at Buffalo-A great race at Hartford-Gus Glidden aud Edwin Forrest-Trouble at Minneapolis, and a great wagon performance at Chiengo-Another trip to California-An accident in the stable, and what the veterinary said-Trotting in $2: 131 / 2$ to save Mr. Couklin's \$10-The sale to Mr. Robert Bonner, etc. 112

\section{CIIAPTER VI.}

The pacer Johnston, and the manner in which he was trained to beat all the records-1 nervous, fretful horse that would not feed well-Treatment at Cincinnati during the winter months-Slow work in the spring-Speed comes gradually-Dave Colross turns up in the nick of time, and takes care of the horse- $\mathbf{A}$ mile in 2:10 at Milwaukee, and then 2:061/4 at Chicago-Mattic Hunter, Swcetser, Gem, and other famous pacers. 146

\section{CHAPTER VII.}

The story of the fast, game and reliable stallion Wedgewood-A horse that had a succession of hard races during his career-Going close to 2:20 the first time he started--Desperate contests in the mud at St. Louis and Cincinnati, and a glorious victory at Washington-Down the central circuit the next season, winning every race in which he started-A peculiar horse to train and drive- What came of trying to please a friend-Laying up heats, and sparring with the judges as well as the other drivers-A welltold tale of a great horse's campaign from the lakes to the sea. $\quad$. 172

\section{CHAPTER VIII.}

Trotters witl romantic hi tories that I hare driven-The gray gelding Charley Ford, that was first a turf outlaw, then made a record of $2: 16: 3$; was valued at $\$ 15,000$, and finally sold for $\$ 300-$ Ford's match with the stallion Bonesetter, and how he was trained for it-IIe is the only horse that ever won 
a heat from Maud S; the story of the incident-The great race at Chicago with Hannis, where "the taleut" was on the wrong side-Adelaide, a little mare that had one remarkable peculiarity; no matter how hot the day, or severe the race, she would not sweat-Drawing wood into Watertown, N. Y., by the side of her dam, she is purchased by a horseman and makes a record of $2: 19$ - A pony in size and weight, she beats some of the best horses in the country, every ounce of her being race-horse materialPlanter and his good qualities-The wonderful affection of the trotter Bay for an old white horse. . . . . . . . 193

\section{CHAPTER IX.}

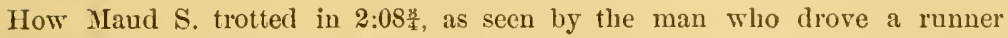
alongside of the mare-What Splan knows of Guy, the sensational trotter of 1888 -Driving him to a road-cart in $2: 1 \%$, the horse being barefoot-The story of how Colonel West discovered Kentucky Prince, the sire of GuyTrotters are born, not made-Jay-Eye-See's good races down the circuit in 1857, beating Arab, the crick trotter of the yen-Clingstone's race against the watch in $2: 14-$ His great victory over IIarry Wilkes at DetroitHow he was trained for this race and driven in it. . . . 215

\section{CHAPTER X.}

Nobby, the most peculiar horse Splan ever drove; a wild, scary fellow that had a wonderful flight of speed-The race at Cleveland in which Tobby beat a lot of eracks-Mr. David Bonner's well-remembered complimentStufing a lıorse's ears with cotton, and some incidents connected with the practice-Needle Gun, and the trouble he made on a ferry boat-W. J. Gordon's horses, his breeding farm, and his character as a man - Chat about what certain drivers have done with particular families of horses Protection's great race against J. B. Richardson. . . . 245

\section{CHAPTER XI.}

Other drivers who hawe male a name in connection with certain families of horses-Morrill Higloe and the Spragne strain of blood-Frank Vin Ness with IIary and Rosaline. Wilkes-Jock Bowen, and how he fooled some people who imagined that he could not clrive a pacer well-Horace brown romes from a family of practical horsemen-billy Wecks an excellent rider, as well as a good reinsman-Charless Marvin the man who hats lorought out nearly all the fast so: s and d:unghters of Electionerer-Some facts ahout Governor Stanford's venture in the breeding of trotters-Plnek lais at good dral more to do with sureese than luck-Governor stanford in some

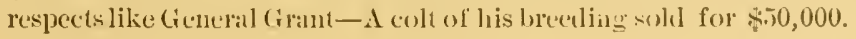

$2 \pi 2$ 


\section{CHAPTER XII}

IIow to train the trotter and keep him in good fettle-His mouth the first thing to be looked after-An experience with Fanny Witherspoon-Don't pull a horse, and he will not pull you-Overfeeding and is consequences-Give watel at all times-The groom must be neat in appearanec and not a drinking man-Too many blankets a bad idea-Some points about boots-The use of pads and sponges-Mambrino Sparkle's bad feet, and the great races she trotted-Why clipping is beneficial-Work in the early spring-Teaching trotters to score well-Sulkies, road-carts, timing-watches, etc.

298

\section{CHAPTER XIII.}

Work a horse with the watch, but don't try to make him beat it-Doble and Goldsmith Maid-The pacer Johnston never worked out at top speedOne speeding each week is ordinarily sufficient-Preparations for a raceDeportment on the track-How to talk to tle judges-Laring up heats an important matter-How to drive after the word is given $-\mathrm{A}$ case of bad judgment in a postponed race-Shipping horses from point to point-The training and management of trotting stallions. . . . . 324

\section{CHAPTER XIV.}

Calmar, a horse that needed only proper shoeing to improve his record eight seconds and make him win good races-His gallant figlit with Woodford Chief at Cincinnati-A kind word for George A. Baker, once a prominent figure on the trotting turf-How Lady DeJarnette was given a fast record by changing her check-rein-Hints to owners of horses-Wilson's race in which he went a mile in $2: 16 \frac{1}{4}$, and the mistakes that caused him to be defeated-Sufficient preparation is what makes good eampaigners, while lack of work results disastrously-Fred Folger's career an illustration of this-Why Budd Doble put tips on Jack the day before the $\$ 10,000$ race at Rochester-The peculiar manner in which Wolford's Z. was shod and how it improved him-The pacer Argyle, and the trotter Colonel Lewis-Trotters affected in a marked degree by changes of climate-Little Gypsy's great race at Cleveland-Pen sketckes of noted characters on the trotting turf.

350

\section{CHAPTER XV.}

The trotting interest one that extends throughout the land and is growing every year-Famous road riders of New York City and elsewhere-Commodore Vanderbilt's present to his spiritual adviser-Robert Bonner and his sons, the Rockefellers, Mr. Frank Work, and others-Men in other eities who love the trotter for the plasure and health they derive from driving-Some 
hints about the purchase and eare of a road horse-Decide just what jou want the animal for, and then use him for that purpose only-Don't expect your gardener to also be capable of taking good care of your road horses-A few practical suggestions that will commend themselves to all owuers of horses.

\section{CHAPTER XVI.}

Budd Doble writes in a elatty and interesting manner of Goldsmith Maid and Dexter-How the famous brown gelding was placed in his stable by Hiram Woodruff-The soung man's doubts and fears over the responsibility he had assumed-Lowering Dexter's record in the first race he drove him, and becoming more confident-The season ends with a mile in 2:18 under saddle-Trotting in 2:17 at Buffalo the following year and beating the world's record-How the joung reinsman felt on that momentous occasion-Dexter is purchased by Mr. Robert Bommer and retired from the turf-The story of Goldsmith Mairl, the champion trotter of her day, and that for many years was Queen of the Turf-She was rough-gaited when Mr. Doble got her, and could not beat 2:30-Her first race a disappointment to him-A new system of truining adopted the following spring with good results-The wonderful intelligence di-played by the Maid both in the stable and on the track-She knew when a race was coming off and became terribly excited-Figuring to get the best of her opponents--Her wonderful affection for Old Charlie-A happy family of three that was tinally broken up.

402

\section{CHAPTER XVII.}

The education of trotting-bred colts-Early development, and the reasons therefor-Fast youngster's the ones that sell well-Colt handling now a distinct branch of the trainer's art-The man who handles a colt must learn to control his temper-Hints albout the best time to have foals dropped-Treatment of the mare at this scason-Teach the suckling colt that man is a friend, not an eneny-The story of a veterinarian, and what one experienee taught Dunbar-Putting on the halter-Handle the colt frequently, lut do not lead him much-IIow to put mares and their foals in a field-Accilents on a stock farm generally due to carelessuess-Management of the mare and foal in the stable-Turning ont the youngsters during their first summer-Preparations for weaning time that will be found rery valualuleLooking after the appetites of the colts when they have been weanedWhen the work of leading colts alongside of al horse should begin-The proper method of doing this explained in detail- I straight, covered track better than a circular one-Colts differ as much in disposition, etc., as matured horses, and must be trated accordingly-No absolute rule by which to train ean be laid down. 


\section{CHAPTER XVIII.}

The training of colts gone into in cletail-How the breaking harness should be put on and made use of-Proper adjustment of the lines an important feature-Teaching the pupil to obey the word of command-The first hitch to the breaking cart-Don't have visitors around at this time-Preparing for the stakes in which the young trotters are entered-Accustom the colt to other horses, and then speed him a little-Keep your own counsel as to what is being done-Don't be alarmed at what you read concerning other people's colts-June a good month in which to test your material a littleThe prompting horse should not be allowed to beat the pupil or carry him too fast-lieep a recold of what each animal cloes and how he does it-No two colts can be trained exactly alike-The first trial of the most promising youngsters - A surprise often in store for the trainer at this time-Driving on the road occasionally a good pl'n-The earnest work to be done in August -Shipping the colts to the place where they are to trot-What to do when fou reach the track-All ready for the first race with the young trotter.

\section{CHAPTER XIX.}

Preparing the colt for the yearling race-Accustoming him to objects about the track-No training necessary at this stage-Be on time when the race is called, and don't keep people waiting-Scoring lalf a dozen yearling rolts a tedious job- What to do after the word is given-No occasion to be in a hurry to get the pole-Do your best work on the straight side-How to drive when you look like a winner in the home stretch-The secr $t$ of your success is in careful and intelligent methods of training-Shipping the colt home again and preparing him for another race in October- $\Lambda$ mile once in awhile well within his speed-The quality of sulkiness-Some inside history about the famous trotter Guy-IIow he went a mile to pole in 2:17- In exciting experience with Guy when he ran away on a trot, and stopped only from force of habit-A terrible accident prevented by the horse's intelligence-What the writer accomplished in one season by the methods of training described. . . . . . . . 440 


\section{LIFE WITH THE TROTTERS.}

\section{CHAPTER I.}

Boyhood Days at Little Falls, N. Y.-Running Away from Ilome and Reaching the Buffalo Track-Pellam Tartar, my First Trotter-Something about the Stallion Byron-How Old-Time Trotkers were Trainel-Pilot Temple, Tackey, and Dixic-The Pacer, Billy Boyce-A Trip to CubaI Return to New York ('ity and go to Work for Din Mace-" Lucy Jimmy "Tcaches me to liub a Trotter-Tempest and Her Fevered FeetStarting out on my Own decount as a Trainer-My First Race and the Glory Thereof-Lady Saulpaugh and Her Races-The Great Match at Paterson, X.J.-Fun on Staten Island.

I was born at Little Falls, Herkimer County, N. Y., on the 6th day of May, 1849, and from the time that I cam remember, horses had a fascination for me.

Like most comntry towns, the one where I first saw the light had a livery stable, and this one was rm by a man named Mort Bellinger, a good soul, who was not ammoyed if a boy who liked a howe hmug aromed his place. It was at the Bellinger stable that I got my first icleas of horseflesh, and by the time I was seren years old latd a fair notion of a horse. There had been a half-mile track at Little Falls for a good many years, and Charlie Champlin was the star of the driving faternity in that part of the comntry then. He used to have trotters at the track, and they were the first fast horses I ever saw. Mbout this time my mother found that I was paying a little ton murh attention to horses, and insisted on sending ne to solool. Tike most hoys, this plan did not take well with me, and after three days at school I holted the track and went fome. Then my mother gave me the altermative of going to school 
or being sent to a famner. I chose the fanmer, as I thonght there was a better chance of getting away from there than there wonld be from school, and so I went farming with a man named Trilliam Broadwell. He lived near Trenton. This was in the spring of the year. Rural life disagreed with me right from the start, there being too much work in it, and too little time for play. But in spite of this, I staid with Broadwell abont two years; and during that time, when the comnty fail came off, I saw the first trotting race of my life. It was at Trenton, and over a track abont a third of a mile in circumference that was laid ont in an orchard belonging to a man named John Tammer. That was the first day I ever saw John Minphy, whom everybody now linows as a driver of trotters. He rode a black horse nnder saddle for a man named Douglas against a chestmut horse that went in harness and was driven by Bob Champlin. The glory of that race decided me as to my future course. I went home and dreamed of the trotters, but darent talk much about them, as the farmer was a good deal inclined to religion, and rery little to horses.

The following spring I took my bundle and broke away from the farm, determined to see what there was in life. I was then about thirteen years old, and my first move was to drop in on a man named Bowen, who had a son abont my age. Mr. Bowen had the reputation of being the greatest horse fancier in that part of the country. He bought a great many horses to ship on to New York. I made myself generally nseful in rubbing and leading the horses abont. It was at this time that the oil excitement broke ont in Pennsylvania, and I went down there to explore the comntry and look for a fortune. With the little money I had I went into a partnership with a man in a pair of horses and a flatboat, drawing oil. There was plenty of noney in the scheme, but it cane too slowly for me, so I finally sold out my interest in the concern and went to New Tork City. TThile there I met a gentleman from Buffalo, who was interested in a crockery store. This man's name was George 
E. Newman, and after a little talk he made me believe I would make a better crockery merchant than anything else. The result of that talk was that I accompanied him to Buffalo to go into his store and learn the business. Wrhen I found that the first step in the life of a crockery merchant was to carry out portions of the stock in a hand basket, I shied at the first tum, and that was the end of my life as a merchant. I asked if there was a race-track in the neighborhood, and was directed to what has since been the famons mile track at Buffalo. On reaching there, I inquired for the best trainer, and, fortunately for myseif. I was directed to $\mathrm{Mr}$. John Sterenson. I said to him that I was looking for a chance to learn to be a driver of trotter's He replied that my size and age were a little against me, but that if I could wait he could see no leason why in time I might not succeed. We struck wy a mutual admiration right there, and I laid down my bundle. Mr. Sterenson took a great interest in me, and gave me every opportunity to not only learn, but also to practice driving. I have never forgotten his kindness, and never go near his city without paying hins a personal visit.

The first horse I erer llore was a stallion called Pelham Tartar, and that belonged to Mr. C. J. Wells, at that time mayor of Buffalo, and always a stanch firiend of the trotting turf. I remember distinctly that I was so small and short that it was necessary for me to put my feet on the closs-bar of the sulky, my legs not being long enough to enable me to reach the stirrups. I don't think that Mr. Sterenson ever had a horse on his place that he took as much pains in training as he did with me. Pelham Tartar' was a handsome hrown stallion about sixteen hands high. He was bred in Canada, and at that time was looked npon as a very promising horse in the way of a trotter. Ife was fine-gaited, perfectly level-headed, and I remember him, not only as the first horse of which I had charge, but also as the first one that I ever drove a mile in three minutes. The first day I drove Pelham Tartar Mr. Sterenson had ont a 
gray mare belonging to $\mathrm{Mr}_{\mathrm{r}}$. Henry $\mathrm{C}$. Jewett, who has since then become well linown as one of the leading breeders of the country, and we went a mile in about three minntes. I felt rery prond of my work, as Mr. Stevenson told me that 1 had performed as well as he conld have done himself. $\mathrm{Mr}$. Stevenson, probably in order to keep a watchful eye on my young efforts, gave me the pole and laid on my wheel with the gray mare cluring the trip, advising me at different parts of the mile what to do, and telling me abont how well we were going. If he had not told me it was three minntes I wonld have thought it was two, which fact will give an idea of how little I knew at that time about different rates of speed, and it also goes to show how exhilarated a man can become behind a trotter.

I spent that season in Mr. Stevenson's employ; and another horse that I sometimes trained was Bylon, a chestnut stallion by Royal George, that afterward made a record of $2: 25 \frac{1}{2}$, and lias since sired a number of 2:30 horses, as well as the dam of the famons filly Susie S., that trotted such a grand race at St. Lonis in 188\%, wimning the fourth heat in 2:20, and stamping helself as the best three-year-old ont that season. Byron was bred in Canada, and was brought to Buffalo hy a livery-stable lieeper named Effner, who in those days managed to get hold of about all the good horses that camer to the town for sale. He saw that Byron had some speed, and it was not long before he sold him to Framk Perew, then as now a solid citizen of Buffalo and prominent in marine circles, and who has always been a great admirer of trotters. It was just after Mr. Perew had bought Byron that the stallion was sent to Mr. Stevenson's stable, and in that way came under my observation.

The first dollar I ever earned for driving a trotter was with this horse. One day $\mathrm{Mr}$. Perew came ont with a friend to see Byron, and in the course of some talk he offered to bet five dollars that I. could drive him a mile in 2:40. The bet was made, and I went ont with the horse and drove him a mile in 2:38.3. Mr. Perew made me a present of the ten 
dollars, which I thought was a good deal of money. I don't think there was ever a time that I was more pleased or felt richer than at that moment. This was my first experience in driving a horse against the watch, and since then, with Rarus, the pacer Johnston, and others, I have traveled from the Atlantic to the Pacific and from Mimnesota to Kentucky, giving exhibitions of speed with noted animals before andiences that sometimes numbered fifty thousand, and for a great deal of money, and yet the satisfaction of that morning when I sent Byron around the Buffalo track, hoping he would do what his owner had deemed him capable of, and knowing that the performance, if successful, would be a credit to me, has never been excelled. I have diven Rarus when the shouts of the people conkd be heard for blocks away, and I have seen him rome down the home stretch at Kansas City when the crowd was so great that there was barely a lane through the mass of human beings for the horse to trot. I was excited enough then, and also the first time he beat Goldsmith Maid's record for me, and since then I have experienced the feeling of gratification that comes to a man when he performs some feat in his chosen profession that shows his ability; but for all that, the mile in 2:38 $\frac{3}{4}$ with Byron will always be the star drive of my early experiences in the sulky.

When the trotting season was over Mr Stevenson kindly arranged to send me to school. Number 16, Delaware street, was the edncational institution at which I made my debut, and I want to pay tribute right here to Mr. Fullerton. our principal and teacher, for his patience with me, for I am sure that I not only made many a break myself, but also cansed other boys who were naturally steadily inchined, to clo likewise.

After three months at school the days of spring came, and I went to work with Mr. IVilliam King, who had some colts he wanted jogged. But this was rather slow wolk for ine, and I soon began to pine for the delights of the lacetrack. On stating the case to Mr. King he agleed with me, 
and I made another 'hange, this time going with Mr. Isaac Woodruff, brother of the celeblated Hisam Wrodruff; and he also seemed inclined to give me the benetit of his long experience, and showed me everything that he could in the way of training and ariving a trotter. I rubbed for him the bay gelding Derby, formerly called Dutchman. This was the first horse that I had regular charge of to groom; and at this point it will be of interest to yomm driver's and boys of the present generation who have an interest in trotters, as well as some older heads for whom the same subject lias fascinations, to tell something of the old methods of taking "ale of a trotter. In those days there was no training of colts, and the preparation of a horse for a race was some thing that involved months of time, and a terrific strain, not only on the constitution and legs of the horse, but on the minds and hodies of ererybody connected with him. It was considered a work of art to bring a trotter to the post for a lare, and really in those days it was necessary to tit a horse with more care than now, because a trotter was liable to be called on at any time to go in any kind of a raceeither in hanness, nnder saddle, or to wagon, and to do these things at one, two, or three miles. In other words, the trotter of my boyhood days was an animal from which not only speed was expected, but versatility and a tremendous amount of enrlurance.

The way we nsed to handle an old-time trotter was about like this: I remember very distinctly that Mr. Woodruff was an early riser. About four o'clock was his usual time, and to me that seemed something terrible. Onr rontine of work was this: First, the horse was given a light feed of oats and his morning toilet made. Then he was taken ont and led hy the halter for an hour, brought in, groomed, logss rubbed, and then we had an early brealilist. After that whaterer work he was to do in the waty of training' le got then. 'They gave a hor'se a great deal more jogging, and monel more sweating under blankets and hoods, and a lar greater amount of work in varions ways than is 
now the custom. It was the old-fashioned idea that a horse must be reduced in flesh, and they were " drawn" more like race-horses than at present. For instance, no one thonght of giving a horse water the night before his race. He would get a small feed of hay and onts, and then the muzzle was put on. On the morning of his race the feed would be reduced still more, with rery little water, and as a rule the horse was given a good deal of work on that morning: While his lace was being trotted he got very little water between heats. They clothed the trotters in those days much more than at present, and the rubbing and grooming was something terlible, both to man and horse. There were generally two men to every horse, or rather a man and a boy, the latter being called a helper; and as a rule both were kept busy from morning till night working aronnd the horse. I have seen horses made so sore by this treatment that they wonld hardly let you put a hand on them, and there is no doubt in my mind that in many instances animals were made vicions, and their otherwise good tempers and dispositions rumed by this ronstant friction by rubbing, and working with currycombs, etc.

At the end of this season I made the acquaintance of $\mathrm{Mr}$. J. C. Kelly, a resident of Illinois. In the words of Horace Greeley, he advised me to go west, and the result was that I entered into a contract with him and went to Jacksonrille, I11., where he had a lace-track, a livery stable, and a farm. My duties were to help hin train and drive and make myself generally useful. I soon fomd that in Kelly i had struck a real wide-awake, all-round horse jockey. He bought and sold a great many horses for the carriage, the road, and for draught purposes. Fe could pick out a horse that was liable to step along some as quick as any man 1 exer saw, and after he had selected him could make the animal show what he was eapable of. In him I found a man who seemed glad to give me all the points that would be of use to me. I saw Kelly drive a good many races for a great deal 
of money, and I douht very nuch whether the boys of the present clay would have much adrantage over him. He afterward located in St. Lonis, where I went with him to the old Abbey track. It was here that I first met some of the noted horsenten of that day, such as the Carr brothers, who owned Tackey and Dixie at that time. They were two gray mares, full sisters, and considered very well-bred ones for those days, being by Pilot, Jx', and out of a mare by Bellfounder. They were hoth inst-class race-horses for what they could do, Tackey being particularly hard to beat in a long-distance race. Their owners were always willing to back them against all comers. They were trained at this time by a man named. James Rutherford. The men who owned the mares have since become prominent citizens of St. Louis, and Tackey has made herself famous as a brood mare by producing the stallion Pilot Medium, that is the sire of the gray gelding Jack, with which my friend Budd Doble won so much money last year, including the big \$10,0)( stake at Rochester ; Naiad Queen, that my other old friend. Jack Phillips, drore to a record of 2:201 $\mathrm{J}_{\mathrm{r}}$, that produced Onie D., that my other friend, handsome Jimmy Goldsmith, went a mile with better than 2:20 last year ; and Classleader, the gray gelding that led his class home in 2:221 over the Cleveland track in 1887 under my pilotage. I think of these things now, when I come to put my experiences on paper, and it causes a feeling of mingled regret and pride to pass timough a man as he recalls how many years have gone by since the time he saw old Tackey trotting at St. Louis and the day that he drove her son under the wire a winner at Cleveland. Tackey was a mack in her day, and her record of 2:26 is fully as creditable as one of 2:20 would be in these times. She has been a wonclefully good brood mare, just as she was a good track mare, and in her and her full sister. Dixie, the Pilot, Jr., family has a romple of representatives that sustained its reputation well at all stages of their lives. Dixie also produced a trotter, it being the brown mare Dixie sprague, 
that made a record of 2:2.5 $\frac{1}{4}$ in lier first race, she being. by Governor Sprague.

My old-time friend Matt Colrin was then in the heyday in his glory, and associated with his name will always be that of the stallion Pilot 'Temple, a son of Pilot, Jr', that had the distinction of being ont of the dam of Flora Temple, the first trotter to beat 2:20. In all my experience I have never seen a harder pair to beat than Matt and Pilot Temple. As hustlers they were first class. Pilot Temple was what is known as a "handy" horse. Whenerer he was tired Colvin would grab him up in his arms for a few jumps and let him rtur, and then set him down trotting again. That was more feasible in those days than now, when the judges are strong for honest trotting during the entire mile. Pilot Temple trotted for many a year over all kinds of tracks. In all kinds of weather, rain or shine, hot or cold, the little bay was always ready for his race, and he receired plenty of training besides, for in those days a man who didn't drive his horse an homr or so every day was thonght to be neglecting his business. After living to be orer thirty years of age Pilot Temple died in St. Lonis a few years ago. Matt Colvin, who drove lim for so many years, is still alive and a resiclent of Kansas City, able to hold his own with any of the new drivers. Thongh orer' serenty years of age, Matt has gone west to grow mp with the comntry.

Another famous performer, and a great pacer in his day, that was at the St. Louis track, was Billy Boice. He was a member of the Corbean family. and a bright bay hor'se about fifteen and a half hands high. He resembled the latter-day pacer Johnston very much in his gait and formation. and was fast and game, being able to go one or two mile heats; and after pacing a good many races in hamess

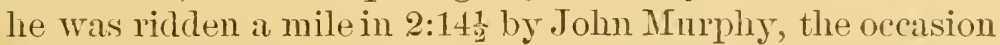
being a race at Buffalo between Billy Boice and Rolla Golddust, that was a celebrated saddler of those days. This was the first time that 2:15 was ever beaten by a pacer, either in harness or under saddle, and as it was considered 
something wonderful in that day, and I saw the race, I will give some idea of how Jim Rockey and Murphy rode their respective horses.

Rolla Golddust won the first heat, Boice making two breaks, but in the seconc mile Boice went away steadily, and took the pole on the turn, never being headed, finishing the mile in $2: 1 \frac{1}{2}$; and it should be noted that this time by a pacer moder saddle was never beaten until Johnston did it in 1888 at Cleveland, where Creorge Starr rode him a mile in 2:14. On this latter occasion I drove the runner that accompanied Johnston, and I think that he conld have gone better than he did, but Mr. Starr"s idea was to simply

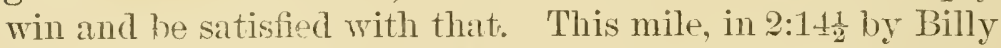
Boice, shows what a wonderful horse he was in his day, for at that time a 2:20 horse was an absolute novelty, and as for any harness animal, trotter or pacer, going a mile in $2: 15$, it had not been thought of. Of course, since then there have keen a good many $2: 1 \tilde{5}$ pacers, but it has taken fifteen yeal's of training, breeding, and driving, and all the improved construction of vehicles to bring them down to the present standard, so that Boice must have been a phenomenon. I have no doubt that, with his natural speed and the improved facilities in the way of tracks, better vehicles, ete., he would have been a star performer in the present day and able to hold his own with the best.

From St. Louis I took a trip with a Spaniard to Harana, Cuba. This Spaniart was buying a shipload of lowses to take there. I thonght it would be a novelty to see a foreign country, and so arranged with this gentleman to go with the first consignment of horses. Havana was a dull place to me. No race-tracks, no trotter's, and nobody that I could see who conld talk English, and as that was the only language I knew I was what might be called a homesick boy. I stated the case to my new-fonnd friend, and he sympathized with me and released me from my contract. Then I concluded to ship for New Tork. Taking the tirst boat for the United States, I reached New York City in 
April, and made the acquaintance of a man who was my friend until death claimed hint--Mr. Dan Mace. I could spin a long yarn here concerning my experience with the man who, in his time, was not only a master of his profession, but the oldest one in it; but there are so many incidents connected with my stay with Mace, and so much to be said of his methods in the training and driving of trotters, that I shall reserve that for a subseqnent chapter which will deal exchusively with that subject.

I had met Mace once, years before, at Buffalo, and he had said to me that if I erer visited New York he wonld be glad to have me come and see him. It was on this invitation of the past that I walked into his office. He had a stable on Forty-ninth street near Broadway, and kept his training-stable at the Fashion track, Long Island. This was in 1S6t, and at that time Mace was the recognized master of his profession.

In looks, Dan Mace was not a handsome man. He weighed abont 140 pounds, with short legs and wonderfully strong body and arms. His eyes and hair were very black at this time. In disposition he was as brave as any man I ever saw. I don't think there was anything in the world he was afraid of. His temper was perfection. In all nuy years of exp rience with him (and I knew him as well as any man conld know another), I never saw Mace ont of temper. No matter what prorocation he might have had he always seemed to control himself to perfection. Tis age was an uncertain quantity. I never saw anyone who knew just what it was, and he never would tell. At that time Mace numbered among his patrons such well known turfites as John Morrissey, Henry Genet, William Turnbull, who was the lifelong friend of Commodore Vanderbilt; Edward Jones, the celebrated politician; Gorernor Sprague, of Rliode Island; Uncle Ben Wright, of Boston, who always had more match races on hand than any man I ever saw; W. P. Balch, now of Boston; Ed Maynarl, of the sane rity; "Loosh" Appleby, who has since become relebrated as one of the 
leading bookmakers on the rumning turf ; William Sannders, better known as " Uncle Bill," who owned at that time and since some of the most celebrated horses in the country; Z. E. Simmons (of whom I shall have something to say later), and many other's whose names do not occur to me just now, but who were among the best citizens of New York, and its wealthiest and most respected men.

Mace, in spite of the fact that he was not a man of booklearning, was always popular with, and respected by, his patrons. Mien who did not know Dan Mace got a false impression as to his talent in matters ontside of the sulky. I have never heard anyone question his ability when he sat behind a trotter at any stage of the game, but I have heard men say that his business capacity outsicle of that was not good. My impression of Mace is that he was a much smarter business man than anyone gave him credit for being. Mace made money by the basketful and gave it away the same, nerer making any effort until the last few years of his life to sare anything. To prove that his business ability was good, I may say that in the last five years of his life, when his health was bad, he earned and saved something like $\$ 50,000$, and it seems to me this wonld be a difficult task for a man to accomplish unless he had some real business capacity. I think Mace's great success was dne, not only to his being a natural genius in the matter of horses, but also becunse he was a deep student, and the most industrions man I ever saw in the business. In addition to these qualities, Nace had the very rare one of absolute fidelity to his patrons. If one of the men who were giving him horses to be trained was to (perthaps under the influence of a few glasses of champagne and a good dimner') match his road horse against another animal of the same class, and send him to Mace to be trained, Dan would goat that animal with as nuch patience and determination, and spend as much time and personal attention on him as thongh the animal was a reritable flyer-a Maud S. or a Dexter of its day. 'This was a religion with Mace. It 
made no difference to him whether the horse was a good one or' a poor one; if lie undertook to train him and took a man's money for doing that work, the animal was fitted and driven to the very best of his ability, which meant that he was prepared as well as any man in America could do the job. It was only by the exercise of meeasing industry that he was enabled to supervise the care of his many horses as he did for the best years of his life. He was the first man "1p in the morning and the last to bed at night, and during every moment of the time, except when he was eating. he was doing something. I have never seen any man who could accomplish as much in the way of training a stable of horses as Dan Mace. He conld give more orders, ride more miles, look after more details, and give everything in general better attention than two ordinary men. Nace's treatment of everybody he came in contact with was of the very best. If a boy blacked his boots he was well treated and liberally paid. If aboy rubbed a howe for him Mace treated lim like a gentleman and paid lim like a prince. Noney was never an object to him.

When I introduced myself to Mr. Mace I told him I was anxions to be a trainer and driver. He asked me if I thonght I fully understood the care of a trotter while in training. I replied that 1 did not. He then adrised me to first mastel that part of horse-training, saying that he considered it of as much importance to have a horse properly groomed and rared for while in training as any other part of the preparation. This was a golden rule with Mace, and my experience of thirty years with the trotters has proven to me that it is just as good to-day as it was when Mace told it to me, and that the personal care that is given to a trotter may make or mar the horse either for track or road use. I then went to work for Mace with that nnderstanding, and he placed me under a man by the nane of "Lncy .Jimmy," who has since become as celebrated in his line of business, the care of trotting horses, as Mace was in lis. This man's right name is Jinmy Kenney, but like many another rub- 
ler he got his nom de plume from a horse he looked after, in Jimmy's case it being the famous mare Lucy, that ()rin Hickok drove in her best races, and that became so relebrated as the stable companion of Goldsmith Maid. In "Lucy Jimmy" I found a good friend, and as distinet a wharacter as I have erer met. He was, without exception, the most faithful fellow $\mathrm{I}$ ever saw, and in all his half century of connection with the trotting turf he has never, to my lsnowledge, made a false more or break. His absolute tidelj.ty to the interests of the man for whom he is working is something not often met with. Twenty years after I was his pupil, and at a time when I had driven horses to the best records of the day, both at trotting and pacing, this trait of Jimmy's character was illustrated to me in a rery lndicrous and convincing manner. It came abont in this way :

Along in 1883 or $1884 \mathrm{my}$ old-time friend, companion, and adviser, Counsellor Cravford, had in his stable a couple of stallions that were among the cracks in their class. One was the bay horse Voltaire, and the other a chestnut stallion, Robert McGregor, that is about as handsome a horse as one will find in a day's journey. At the time of which I speak, Jimmy rubbed Voltaire, and Mr. Crawford had the horse entered in a race at Grand Rapids, Miclı., and as there was no one there to drive him Jimmy concluded to have me, his old-time pupil, handle him in the race. He came to see me abont it, and the incident brought up a train of thought regarding the day when I went over to the Fashion track, a boy, to learn to be a trotting-horse driver. Jimmy stated the case to me and asked if I wonld drive Voltaire. Of course I consented. Jimmy said that the horse had a chance to win, perhaps, second money, and thought I lad better lay him up a heat or two, let the others fight, and then get my position in the last end of the race. I thonght it a good idea, and told him so, but when we got the word for the first heat sereral of the other horses made a break, and I concluded that would be a good chance for me to win the heat 
and secure my portion of the money. So I cut loose right then and there, and after a hard struggle succeeded in getting the stallion to the wire ahead of the other's. As I came back to the stand .Jimmy was standing there, bucket in hamd, and regarding me with a look of half disapproval. I saw in an instant what the trouble was, and on dismonnting from the sulky said to the old man : "IV ell, Jimmy, I dich't drive exactly as you directed." 'This confession on my part evidently mollified the old man, for he replied in a friendly tone: "Tis all right; yer orders were not positive."

When Jimmy took me in charge at the Fashion track he had a mare he was rubbing that belonged to Mr. William IImphrey, who afterward became famous as the owner of Judge Fullerton. This nare's name was Tempest, and she was matched against a horse that belonged to Mr. John Hatrbeck. I recollect distinctly that she had a great deal of tronble with her feet, and a part of my duties was to get up) early in the morning and lead her out in the long grass while the dew was on it, in order that what the poet calls "the tears of night" might allay the ferer in lee feet, and perhaps, as in case of the race-horse WVar Jig, that Jim MIurphy, the well-known rumning-horse man. owned and thained, it might prove efficacious where all human remedies laad failed, and indnce a cure that could not otherwise be bronght about. Murphy tells to this day that when he bought IVar Jig the horse was broken down, but that in leading him throngh the dew-laden grass the son of War Dance stepped upon a leaf of shamrock and the juice from this had such a magical effect upon the injured leg that ever thereal iter it was the best of the fom. Whether the dew did it or not, 'Tempest came to her lace in good shape. Mr. Humplirey and all his friends had her well backed; Jimmy himself had a few pool tickets on her, and by way of showing me that my services had been appreriated he hought one small pool for me. I don't think that eithel Mr. Mace, who drove Tempest, or Jinmy, who had rubbed the mare, watched her any closer or took any more interest in the race than I did- 
not so much for my pool ticket, but because I had become thoronghly interested in my business and was anxions to learn all I could. Tempest won easily, and we were all correspondingly joyful.

I count among the happiest days of $m y$ life those that I spent as Jimmy's pupil. While he was willing to work all the time himself he gave me a fair sinare of time to sleep and eat, go fishing, and run foot races with the other boys. In those days I was considerable of a sprinter, and could stepr off any distance, from a hundred yards up, and always get my share of the money, thereby replenishing my little store of cash, which in the case of rubbers is never too large. Jimmy was always willing to back me for his pile against anybody of my size or age, even going so far on one occasion as to match me to lift a weight; which match, by the way, I won.

After spending some time under Jimmy's tuition, I was thought capable of taking charge of a horse myself, and was given a chestnut gelding called William H. Taylor, owned at that time by the Hon. Erastus Corning, of Albany, a gentleman who has always been prominent in national politics, who was a great friend of President Lincoln, and who in his latter days has been a breeder of trotters, having had, anong others, the celebrated gelding George Palmer, the stallion Harry Clay; and eren now he has in the stud in Kentucky a son of Harry Clay, called Shawmut, that has a record of 2:26. I kept this position for a year, and at the end of that tine Mr. Mace told me he thought I had better. try to start out training horses myself. He said not to work for anyone on a salary, but to bianch out, and it would be better to drive a 2:40 horse under my own management than to drive the best trotter in the land and work on a salary for any man. He argued that the first thing a man should do was to make a name for himself. My subsequent experience convinced me that in this, as in many other things, Mace was right.

About this time I made the acquaintance of a character 
by the name of Jolm Suydam. He was what you would call a country horseman; at one time lad an interest in a stage line and lived in Kingston, N. Y. Throngh the winter I had been telling Mrr. Suydam of my hopes and prospects, and he said he had two friends who lived in Columbia County on the Hudson River, and that they had a farm and track, and he thought they would like to make arrangements with me to go there and train some colts they had. He also said he had a friend of the name of Lasher, a hotel keeper, who had a horse called Black Doctor that could trot a mile in 2:50. Through his influence I was given the position, and Black Doctor was the first horse I ever hill to train under my own management ; also the first horse I ever drove in a race. He was a handsome black gelding, about fifteen and is half hands high. He was a good actor and breaker. I started in to take care of him myself, as well as to train him, rightly arguing that I could not afford to hire too much help, and thinking that with the experience I had I ought to be able to rub him as well as any man I could hire. I soon found that the Doctor could trot a mile in about 2:40, and you may be sure that I kept that to myself, and my first move was to enter him in a race where he would not have to go better than about three minutes. Then $I$ sent word to the owner, and he came orer the day of the race, bet what money he could that the horse wonld win, and when the bell tapped I went out with my war paint on to make the best fight I could for the money, and at the same time to make my bow to the public as a professional trainer and driver.

The track was laid ont on a man's fiurm, withont any fence or grand stand, and there was only a little platform built for the judges to stand on. There was no poolselling, everybody betting his money out of hand, and probably five hundred people were on himd to witness the contest. There were no four-in-hand dlatgs there, no band of music playing French operas or Germin symphonies, no beantiful club house with its balconies filled with pretty women, 
whose bright toilets, set off against the green of the sward and the blue of the sky, make the picture more attractive; no poolseller, shrieking at the top of his roice to get the money in at the best odds; no brightly painted sulkies, with spidery wheels that flashed in the smnlight; no officions policeman to grab the small boys who were trying to get under the fence and let the man with the badge walk orel the horses ; no drivers with silk jackets, waxedmoustaches, and a general air of contentment and prosperity ; and in those days neither my old antagonist, T. J. Tail, ex-secretary of the National Trotting Association, or the organization of which he was formany years the head and front, had been thonght of in connection with trotting. 'The driver's appeared, each in a costume of his orm, mostly consisting of an absence of coat, with a hat or cap drawn tightly orer the head so that the wind made by the speed of the horse wonld not disaruange it, and the sulkies were abont as much like the present ones as an improved two-wheel hay-rake wonld be. They were big, heary, and clumsy, and instead of being built on the most scientific principles, they were high-seated, with shafts so big that nowadays they wonld. be more fit for an express wagon than a race relicle. I mention these things to show horsemen of the present day to what handicaps the old-time trotters were subjected. I felt when I started in this race a good deal as I did when I spoke my first piece at school-a little timid-but made up my mind to gire them the best I had in the shop, win or lose. 1 had heard some stories about the speed of one or two of the animals I had to contend with, but we liad not gone far in the first mile before it was erident they were all at ny mercy. Black Doctor won in straight heats, and the best time was about three minntes. I was looked mpon by the crowd as a wonder. A youngster that conk come in with a green horse and beat all the old timers was not often heard of in those dilys, and I was a phenomenon. From that da y husiness rame in, and I was able to employ a couple of rubbers, spread ont with a few new tools; I found a man 
who was willing to buy a horse or two, and started with my stable for the pumpkin fairs.

At this time I got hold of a brown mare that I named. Lady Salpaugh, in compliment to a friend of mine, and she was afterward called Constance. Trhen I got her this mare was good for a mile in about three minutes, but after about two months of careful handling she showed me 2:38, which in those days was a clip that would gret the money almost anywhere. In fact we thought we lad what the boys call "a cinch" on all the three-minute purses. We trotted through Columbia and Dutchess Counties with fair success, and then the whole outfit crossed orer to Orange County, the centre of horse-breeding in New Tork, and where all the crack performers of the day were certain to be found. There we fell in with such reterans of the sulky as Bill Bodine, the first man that ever drove Goldsmith Maid; Tke Hoyt, Jess Woods, Jersey Bill, who sold Goldsmith Maid to Mlen Goldsmith for \$600; Jim Post, who was afterwald a poolseller, and IV. C. Trimble, who has since had some of the most noted horses in the land, and whose fitting of Garnet two years ago and giving him a record of $2: 19$ is still fresh in the public mind, and a good many of the pool. buyel's remember it sakly, as it showed that the old man's hand had not lost its cumning. IV e started Lady Salpaugh in the three-minute class, and after a consultation with her owner concluded it would be best to lay her up the first heat, which was done. In the second heat I went ont to win, but in spite of all I could do the mare was beaten. Jersey Bill, who had a few tickets on the mare, came to the stall and gave me a little advice in the matter of driving, which tips I followed in the third heat, and landed the mare a winner. From that time she won easily. I trotted the Lady a number of races that season, winning a fair' share of them and getting money out of the balance.

The best horse I had driven ${ }_{1}$ ) to this time was Major Edsall, a son of Alexander's Abdallah, that afterward made a name for himself as the sire of Robert MaGregor, 
2:17 $\frac{1}{2}$, and he in turn sired Bomnie McGresor, record 2:16. As Alexander's Abdallah died while yet a young horse in Kentucky, where but few people had an opportmuity of seeing him, and as sereral of his sons, notably tlmont and Belmont, liave sired some of our fastest trotters and also got a number of very fast pacer's, I think it will be of interest, especially to breeders and horsemen, to give some account of the appearance and characteristics of Major Edsall. He was a rery handsome, strongly built, light hay horse, about fifteen and a half hands high, a good scorer, handy breaker, and an honest all-round racehorse. He was trained by a man of the name of Jim Bertholf in Goshen, N. Y., but as Bertholf was a good deal orer weight he concluded to have me drive him. This was at Binghamton, N. Y. I remember two of my opponents in this race. One was the reteran William H. Doble, father of Budd, and the other 'Tom Carpenter. As I remember it Major Edsall got second money in this race, and I am particularly certain that the old heads did not give me mmch the best of it. But I hustled around, helped myself to all I conld get, and said nothing. That night I met Mr. Doble. He asked me what my name was, and my age, and after learning these points he remarked dryly: "TVell, you are pretty industrions with a horse and sulky," which I considered a great compliment. The following spring my friend Suydam bought Lady Salpangh, and we named her Constance. She had at that time a record of 2:40, and Suyclam gave for her $\$ 1,800$, which would look like a long price now for a 2:40 horse. I trotted her with some success that season, and she wound up with a record of 2:34. I trained Constance and my other lrorses that year at Paterson, N. J. I hacl several other fair performers, but she was considered the star of the stable.

At Paterson that year there was a race between two roadhorses which created a good deal of talk, and an account of it will show the difference between the time made then and now. Mr. Post, one of my patrons, had a chestnut mire, 
and we matched her against a horse called One-Eyed Riley that belonged to a Mr. Hopper, the race to be trotted on the Fourth of July over the Paterson track for \$250 a side, the winner to take the gate money. Drivers in those days tried to keep everybody from finding ont how good a horse they had, and if it was desired to give them a trial the work was done early in the morning by moonlight. There was a great deal of talk and feeling abont the race with One-Eyed Riley. I had a man to watch the other party and see what they were doing with their horse. One night about eleven o'clock he came on a rum and called me out of bed, saying' the other fellows were getting ready to give their hol'se a trial. I domned my clothes and flew to the track, and sme enongh One-Eyed Riley and his driver and friends were there and had the outside gate locked. I remember that the driver of Riley was a German. I hid in the grand stand and started and stopped my watch when the trial was given. It was dark, and at that time I could not tell how well he had gone. After Riley finished the mile his driver said to the owner, speaking German all the time, that the horse went crooked with him. The owner said that was all right, he would go straight on the day of the race. I conld not understand what they were saying, but my agent could talk German, and he kept me posted. On looking at my watch when my room was reached, I found that Riley's mile was in 3:07, and then I knew we had them beaten. I got word to them the following night that my mare would be given a trial, and Mr. Post came down. Wre were certain that the other side was watching us, so I drove the mare in 3:16. I think the medicine took, for the next morning some of Mrr. Hopper's friends came to Mrr. Post's office and bet him $\$ 250$ more that Riley would beat his mare. On the day of the race the elite of Paterson came down to witness the contest. My mare beat Riley, the fastest heat being 3:07. I think that there was close to $\$ 5,000$ bet on that race. With that kind of a horse now a man would have considerable trouble to win that amount of money. 
The day after this race is always fresh in my mind from the fact that it was the first occasion on which I met Commodore Vanderbilt, the father of Wrilliam II. Tanderbilt, who afterward became famous as the owner of Mand S., but who at the time of which I write lived on his father's farm on Staten Island. The Commodore told me that on this farm he had a first-class track, and he thought it would be a good place for me to train horses, as a great many gentlemen from New York lived down there, and they winted some one that conld train, drive, and look alter their road and track horses. The following year I moved my stable there, and it was on Staten Island that I met a great many men who have since become famous in their different walks in life. Captain Jake Tanderbilt, the Commodore's brother, and who is now more than eighty rears old, was my every-day companion. Te had all sorts of laces, and Captain Jake was one of the moving spirits in everything in the way of sport. He was always ready to match his own horses and drive them limself, or have anyone else drive them, and, by the way, I have seen but few amateus who conld get more out of a trotter than the Captain. IThen he was eighty years of age he could and did send the trotter Boston down the road with the best drivers in New York City, and never took a back seat for any of them. I think he was better plensed to brush with Mace and the other professionals when he met them on the road than against anyloody else.

Constance showed us a trial that year in 2:26, and I thought that she was a reritable wonder, but like many another man I lived long enongh to find I was mistaken. With that speed in my stable I concluded that staten Island was too small for me. The Fleetwood track and Prospect Park were then in finll bloom. I got her owner's clieck, made an entry in a few races, put my traps in order, and started with Constance for the field of battle. It did not take me long to learn, however, that I was in too (leep) water. When I struck ont with a few drivers like my 
friend Mace, Mike Roden, Hiram Howe, John L. Doty, to say nothing of the two Carpenter boys, Jock Bowen, Sam McLaughlin, Billy Borst, with Col. Dickey thrown in as a helper, I found that the opening for a boy with a country trotter was very small, so I came in from third base with Constance, went to Prospect Park, and opened a training: stable. About this time I made the acquaintance of a man to whom, more than any other one person, I owe whaterer success I may have had in my line. This was Z. E. Simmons, who had been a strong supporter of the trotting turf from its infancy, haring at that time owned a lorse that has since become the most celebrated one in the world. I speak of that fimmons trotter, sire of trotters, and founder of a trotting family-George TVilkes. Besides Wilkes, Mr. Simmons had owned Ethan Allen, that was the greatest horse of that day with a lumning mate. He had also owned and sold to Mrr. Robert Bomner the bay mare Pocahontas for the then unheard-of price of $\$ 40,000$. In making the acquaintance of Mrr. Simmons I fell in with. one who has been a life-long friend. He had at that time a number of horses, and among the lot was what proved to be my first great horse, Kansas Chief. 


\section{CHAPTER II.}

Kansas Chief, first a cattle herder, then ridden by a gentleman, and next a 2:30 trotter-His feet fail and he is given away after being sold for $\$ 7,500-$ Traded to Mr. Simmons, he comes into my hands-How his feet were treated-A great campaign from the lakes to the seaboard-Don't trot your horse when he is out of condition-Kansas Chief's last races-How Dan Mace discovered Rarus-A talk in the hotel at night-The story of a game, handsome, and honest horse.

Kansas Chief was a handsome bay gelding with a white face and four white legs. He was sixteen hands ligh, and his breeding has never been anthentically established, but in disposition and appearance he was as bloodlike as any lace-horse I ever saw.

He was originally a saddle-horse, and owned by Mr. B. F. Akers of Kansas, who also at one time owned Ethan Allen and Governor Sprague. Mr. Akers told me that he bought Kansas Clief as a saddle-horse for a friend of lis, getting the gelding from a man who diove cattle up the trail between Mexico and Colorado. He was then but four years old, and was as fine a saddler as $\mathrm{Mr}^{2}$. Akers had ever seen, but did not suit the man for whom he was bought, being too high-lifed. Mr. Akers took him back, broke him to harness, and began to Jrive him on the road, the horse being by this time fire years old. He showed a good way of going, with some slight speed, and the following season he was jut in training, with the resnlt that it was soon possible to drive him a mile in 2:30. Akers then brought the horse to the Buffalo meeting and started him in a three-minute race. Kansas Chief was beaten the two first heats by a horse called Bob. The Chief was driven by a resident of Pittsburgh, but Doble then got up behind him and he won in straight heats. He was then 
sold by Mr. Akers to Mr. Arthur Gillender of New York, who has always been prominent on the turf and well-known as the owner of Sensation and Hojeful, two lorses that in their day were stars of the first magnitnde. Mr. Gillender placed Kansas Chief in the hands of George Ferguson, one of the old-time school of horse drivers, and as faithful, painstaking, and careful a man as I ever knew. Mr. Ferguson was the first man to build in New York City a model stable for the boarding of gentlemen's road horses, a business that is still carried on by his son Frank, a worthy young man in every respect.

The following season Mr. Ferguson began to train Kansas Chief, but he seemed to have lost his speed. I think now, from what I learned of the horse afterward, that the climate and the change in treatment affected him. He was a horse that had always been nsed to the open air and the grass of the Western plains, not getting much grain. The training, the difference in climate, the clothing, etc., seemed to have a bad effect on his whole system, and about this time he developed a disease of the feet, and while sometimes he would show speed he was not snccessful in any of his races. I think he was trained a short time by Mace and showed a mile at Prospect Park in about 2:25, but his feet hurt him so that Mace had to stop training him. Mr. Gillender, becoming discouraged, sold the Chief to Dunn Walton, a man whose heart is as big as his body is long; and that is saying a good deal. Walton was an old friend and companion of Mace, and he was also very frienclly with $\mathrm{Mr}$. Simmons, so much so that they used to trade horses on an average of abont seven times a week, and in one of these daily horse-swaps Kansas Chief was transferred to Mr. Simmons' stables. He was brought to Prospect Park, and I want to say here that what I have thus far written concerning Kansas Chief is from hearsay, although I believe it to be strictly correct in all essential points, but from this time on whatever is written about the horse comes from my personal knowledge and experience. 
I made a contract with Simmons to work for him on a salary, to train and drive his horses, he reserving the right to advise and counsel with me, a fact which proved of nore ralue to me than my salary, as I had the adrantage of his experience. Mr. Simmons was in his clay one of the greatest match-makers we erer had. It was not an uncommon thing for him to make races for his horses when the stakes were as as high as $\$ 5,000$ a sicle, and it was he who matched Ethan Allen and rumning mate against Dexter in harness. Mr. Simmons nerer told me how much money he won on that race, but it must have been a large amount, as Dexter was a great favorite, and Mace had given Ethan a trial and convinced Mr. Simmons he would smely win. In that case it was only a question of how much the other party was willing to bet. Mr. Simmons had a great deal of faith in Kansas Chief, and told me he was certain the horse would beat 2:20, and in those days that amount of speed meant to beat every horse in the wolld, with the exception of perhaps two or three. The day I took Kansas Chief he was shod with tips in front and what might be called a half shoe, weighing about six or seren onnces, behind. The reason of this was that his feet had become very much contracted and sore. Mr. Simmons thought that by shoeing him in this way the pressure would be brought on the frog and force the foot out into its normal position. WVe commenced at him very guardedly, giving him slow work and doing everything we could think of to relieve his feet. Along in September he showed a mile in about 2:30, and we felt rery much encouraged. The same treatment of the feet was continued, and just before the track closecl in the fall $\mathrm{Mr}$. Simmons came over

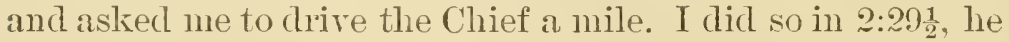
being still shod in the same manner, and after I got out of the sulky Mr. Simmons asked me if I thought I could drive him better than that. I said I thought I could, and he appointed a day to come over and see me drive him again. When the time came I asked Mr. Simmons if I 
should drive the Chief as fast as I could. He saicl no, to let him go easy the first half, and then send him the last part of the mile. I started from the half-mile pole, and Mr. Simmons stood by the stables. I was not much of a judge of pace at that time, and when the Chiei and myself came along where Mr. Simmons was I asked him if I was going fast enongh. He told me to clive along, and I set sail with the horse. When I finished the mile and came back to the stable Mr. Simmons asked me if I had driven the horse as fast as I conld. I said no, that I could drive him at least two seconds better. "If you are right about that he is a pretty fair horse," replied Mr. Sim-

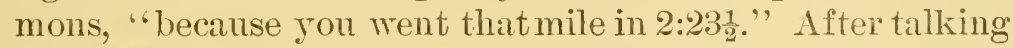
with Mr. Simmons we conclnded not to do anything more that season in the way of training, but to bencl all our energies to the work of getting the Chief's feet in proper condition, his mile in 2:23: $\frac{1}{2}$ having convinced us that he was a sure enough trotter if his feet conld be got right.

TVe then took him to Mr. Simmons' prirate stable in New Iork City, and began a conrse of treatment that improved him to such an extent that he afterward trotted and won some hard races, and for the benefit of those who may have similar cases to deal with I want to tell what we dirl with this horse. M[r. Simmons sent for J)r. Bryden, a man who made a specialty of horses' feet. He consulted with $M r$ r. Simmons regarding the sore feet, and also what wonld be good treatment to relieve them. Dr. Bryclen said to take the shoes from the Chief, have his feet thoroughly opened with a knife, and then poultice them every night with boiled turnips and bran, put on warm. I think that this will grow a horse's foot out better than any treatment I have ever seen. A great many people say that it is unnatural to poultice a horse's feet. If the foot of a horse is sound and all right I don't know that there is any occasion to ponltice it, but if a trotter is crippled in his feet you are obliged to do things to relieve him that might be considered by some people unnatural. At all events we poulticed 
Kansas Chief's feet behind and in front every night that winter, gave him moderate exercise through the day, fed him light, kept him in only fair condition as to flesh, gave him medicine for his blood and stomach, and about twice a week we brushed him at three-quarter speed, which in those days was considered a great innovation, as it was contrary to all the rules for the treatment of a trotting horse. I remember that a great many people said Mr. Simmons was all wrong in his treatment of the horse, but as I had faith in what my employer said, and he was paying all the bills, I was perfectly satisfied to do just as he directed.

When spring came we took Kansas Chief to Prospect Park, and one day we went out on the bonlevard to drive, Mr. Simmons being behind the Chief, while I had a good bay horse that could trot some and run right well. TVe stepped them down the road aways, and soon found that Kansas could trot faster than mine could rum, so that I made np my mind that Mr. Simmons' treatment of him had been right. We kept on with him in this way until about the first of June, I driving him nnder Mr. Simmons' directions. Up to this time his fastest mile on the track had been about 2:25. When the season was so far advanced that all the stables were being organized $\mathrm{Mr}$. Simmons thought it would be best to have the Chief trotted a few races in the country, thus giving me a chance to drive him, and also ascertain whether or not he was good enongh to be entered through the grand circuit. There was a circuit of meetings through the IVest, commencing at Jackson, Mich., which was considered the Buffalo of the Western country. There were well-known men managing the Jackson track in those days, among them Don Robinson, D. B. Hibbard, S. S. Vaughn, and others who have since become prominent in the same line. Associated with trotting in Michigan were some of the best-known men and horses in the land, and the first of them that comes to my mind is WVilliam McLaughlin. He was the Dan Mace of the Western country. In personal appearance and manner McLaughlin was a 
rough-and-ready sort of man, and those attributes of his character, no doubt, prevented him from extending his sphere of operations; but when he was in his prime no man could outdrive him. He was a good deal such a character as were Jim Rockey, "Nosey" Brown, Mike Roden, etc.a class of men who could get up behind a horse they had never before seen and in almost every instance drive him as well or better than the man who had put in months of time training the animal. In other words, they could get out of a horse all there was in him, being natural reinsmen. McLaughlin was ready to take any chance to win.

This was the summer of 1874, and the only horse I had in charge was Kansas Chief. A crippled horse, by the way, is a handful for any man to train, and I have told other drivers, friends of mine, that with one horse that needed constant attention there was plenty of opportunity for all the talent the trainer has at his command-in other words, so many different conditions exist with an ailing horse that there is hardly a phase of the business that will not come up in his particular case.

I had as groom for Kansas Chief a man of the name of Mike Ward, who had served his time under such wellknown trainers as Horace Jones, Sam McLaughlin, and Mace; and what Mike did not know about taking care of an ailing horse, or one of any kind, was not in the books. Mr. Simmons advised with me as to the plan of campaign. "Don't work your horse too hard," he said. "Go easy, trot a few races, and let the Chief get himself into condition. 'Try and hare your horse in good shape by the time the big circuit opens, and if he is then worth trotting we will get some money with him." I followed this adrice, trotting Kansas a couple of easy races at Jackson and Saginaw, Mich., and Colmmbus, Ohio, and then we went to Indianapolis, where the Chief won the first race of his career with me. It was a well-contested one from start to finish, there being plenty of betting and the purse the first big one we had come to. Everyone was anxions to get first 
money, the purse being $\$ 1,500$. The celebrated Col. Baker, from Seneca Falls, N. Y., was up behind Tom Keeler, and always ont for the money. IV. H. Crawford was there with Ammie Collins, Hanked by the New Tork delegation. who wanted to back her, and Logan was backed by a contingent from the rumal districts, so that on the whole there was pretty lively speculation. Major Barker, a well-known New Yorker in those days, but long since dead, was the pool-seller. He told me that if I thonght my horse had a chance to win he would put some money on and clivide the profits. I said the Chief had a chance in that company, but advised that not orer a hundred dollars be inrested, as I had in my mind one thing. I was trotting over a rough track against a lot of good horses and men and did not want to take any chances of luurting my horse. Barker finally said he wonld play a hundred dollars, which would win abont a thousand if our plans did not miscarry. Tom Keeler went ont and won the first two heats, but all this time Kansas was hardly in sight, being laid up at the tail of the hunt. In the third heat I trailed until we tumed into the home stretch, at which point I swming the Chief well to the outside, and when I gave him his head the white-faced fellow made short work of the others. When we went under the wire in the lead the fielders who had been backing the ontfit for ten dollars in a hundred sent mp a howl of the character that is never heard outside the State of Indiana. I think, from the expression on Mr. Baker's countenance, that he was a little surprised, and when we scorer for the next heat there was an evident disposition on the part of $m y$ opponents to see that I got none the best of it. When the word was given I again trailed until the half-mile pole was reached, at that point moving into second place. As we turned into the stretch Keeler was in the lead. Again I gave the old horse his head, with the same result, an easy win at the finish. With Kansas and Keeler having two heats apiece the boys began to hedge in the pool-box. I told Major Barker to stand 
pat with our money, as, barring accidents, I would win sure.

There was a collision in the next heat, howerer, which came near upsetting my scheme, as in going past the lualfmile pole Keeler ran into me and took sereral spokes ont of my sulky. Kansas Chief, naturally a high-lifed horse, started on a rum, and acted as though he had made up his mind to get away with me. I took him to the extreme outside of the track, and when he struck a trot Keeler was certainly serenty-five yards in the lead, and going for all there was in him. I cut Kansas loose light there, and if erer I was in a humy that was the time. With Keeler having two heats won, and serenty-five yards in the lead at the half-mile pole in the deciding heat, and three or four gentlemen between him and me that I knew would not pull ont to let me throngh, the situation was rather gloomy. After Kinsas got well into his stride, I leaned orer and tonched him gently on the shonlders with the whip. He showed me a rate of speed then that I had often dreamed about, but never expected to have at the end of a pair of lines. At the head of the stretch I had them all beaten but Keeler, and he was tiring. Seeing this, I stopped driving my horse, let him get his breath, and about an eighth of a mile from the wire cut him loose again. He soon mored up to Keeler's head, and the race was orer. Mr. Baker complained that my horse did a good deal of rumning, but when the judges replied that they were thinking abont distancing him for foul driving he abandoned the argument.

The Dexter Park meeting at Chicago was the commencement of the grand circuit, and all the stables of the country were there to do battle for the money. Every man who had a horse entered intended to turn him loose; and to show what a good lot there were in the race that Kansas won, I may say that the other starters were Mollie, John H., Harry Mitchell, Phil Sheridan, Fox, Dan, Gen. Howard, Columbia Chief, Greorge Judd, and Hattie. In the pool-selling the night before the race George Judd had the call. He 
was a big roan gelding owned by a party of people at the stock-yards, and all Chicago turned out to back him. Phin Smith drove Judd, and as he was very sweet on the horse's chances there was a large amount bet on him. The famous "forty-niner," Uncle Jack Batchelor, was there with John H., and as the sequel proved, he had him keyed up for this occasion with the intention of putting all the boys under water. Then the pool-selling began Batchelor came down with the bank roll and took a stand in front of the anctioneer, telling him he had come to bet all his money, as he might as well get broke there as to go further and meet the same fate. Hattie, another local horse, had some following, and Mollie was there trotting in the interest of the Detroit people, and with Bill McLanghlin in the sulky, and Capt. John DeMass to navigate the currency into the pool-box, she was notorerlooked by many. Phil Sheridan had some backing from Wisconsin, where he was owned, so that on the whole, the race was the big betting erent of the year thus far, and we knew that if the Chief could win there would be a chance to take down such a pile that we would not have to walk to Cleveland.

As Mr. 7. E. Simmons conld not come himself, his brother TVilliam dropped in the night before the race thinking he might have a chance to bny a few cheap tickets on the Chief. All the talent thonght that the race Kansas Chief won at Indianapolis was a scratch, and as at that time I was but a boy, they dicl not take much stock in his chances at Chicago. I told Mrr. Simmons that Kansas wonld win, and win sure, and on the strength of my opinion and what he knew personally of the Chief, he began in a quiet way to lay his money on him. When it came to the race we concluded that the best plan would be to do some waiting, as the field was very large, and I have found that in such cases the unexpected almost always happens-that is to say, some horse that no one is looking for will jump out and go a heat fast enough to cork himself and all the rest that try to keep np with him. In this instance Batchelor made a 
fight for the first heat and won it with John H. in 2:25 $\frac{1}{2}$, which was a great clip for that class of horses, considering that the track was not fast. It is possible that Batchelor might hare won the second heat, but he met with an accident as he turned into the stretch, being run into by Howard, which enabled Mollie to win the heat in 2:27, Batchelor being thrown from the sulky. In the meantime the pace that John H. set in the first heat had taken the trot out of him, and he could not go much, but in doing what he had he made the Chicago contingent rery blue, as George Judd was distanced in the first heat, Hattie and Columbia Chief being also behind the flag, so that the field was now smaller, and I thought my chances improved by this fact. We scored up for the third heat, and my idea was to get a position where there would be no chance of accident, and be within striking distance at the half-mile pole, making my drive from there to the wire. Harry Mitchell, a horse that could trot some and rum a good deal, led to the half, in company with John $H$. and Mollie. In passing that point I spoke to Kansas, and he moved up to them in such an easy manner that it satisfied $m$ he wonld win the heat smre. I laid within two lengths of the others, stopped driving, and trailed around the upper turn, so that when they swung into the stretch I was enabled to go well to the ontside, knowing there was better footing there, and I wanted to be away from the others. When I gave Kansas his head he went to them without an effort, and won the heat by a neck with something to spare. The time was $2: 28$, and this was the first time he had beaten $2: 30$ in a race. After dismounting from the sulky I said to $\mathrm{Mr}$ Simmons that, barring accidents, the race was orer. The result proved my opinion to be correct, as in the next two he:its we were nerer in trouble, and I may add that in these heats General Howard and Fox were distanced, so that at the finish there were only five of the original dozen on the track.

From Chicago we went to Cleveland, where the Chief won a good race from a field which included a couple of 
trotters that he had not previously met, they being James Howell, Jr., and Fleety Golddust. In the second heat of this race Kansas rednced his record to $2: 24 \frac{1}{2}$, and this, of course, made me a very happy young man.

Between his races the Chief had bnt little work. putting in all the time nursing him, relying on his extreme speed and gameness to carry him through on the day of the race. During the winter we had poulticed his feet, as narrated in a former chapter, and after the campaign began the practice was continned, poultices being applied about twice a week, fearing that if it were done more frequently his feet might become too soft. We walked him in the dew as much as possible, gave his feet a bath in warm water occasionally, and used a lotion of Pond's Extract and arnica. Wekept a swab on his feet, wet with liniment all the time, and it is one of the best remedies for acnte soreness in a horse's feet I erer tried. In the Cleveland race Kansas Chief wore shoes that weighed about eight ounces in front and fire ounces behind.

IVe left Cleveland thinking there was a fair chance to win first money at Buffilo, but when we arrived there the track was rery hard, and the Chief was far from being over the effects of the Cleveland race. In working him out one morning he hit one of his forward legs a terrible blow, the lesult being a big swelling and plenty of fever. All these things aided in causing him to lose the race, which fell to Fleety Golddust. We looked the horse over that night, and it seemed to on minds that his turf career was over, for awhile at least, as he was rery lame and sore in his forward feet, and a forward leg was greatly swollen from the effects of the blow noted above. His shoes were taken off, and Mike Trard started in to nurse him. That night, Mr. Simmons left for New York, telling me to use my own judg. ment about starting the horse at Ctica. We went to Utica, and the day after our arrival had the Chief's shoes nailed on and gave him a slow jog of fire miles. He was so lame and sore that I decided not to start him, and so wrote Mr. Sim- 
mons. This was on Monday, and the next day a telegram. came from Mr. Simmons, saying: "Dont draw the horse. I will be there the day of the race and decide whether to trot him or not." The Chief was so sore and lame that I was sure Mr. Simmons would draw him, so I had his shoes taken off, and did not work him at all-simply had him walked, his feet poulticed, and ererything done to relieve the pain. The morning of the race bronght Mr. Simmons. who concluded to start the horse. The shoes were put on, and, as usual, there were plenty of touts around who saw that Kansis was rery lame, and had not been worked all the week. When the betting on the race began, it was dollars to apples against the Chief. Most of the money went on Stewart Maloney, owned by Mrr. Peters, a theatrical man, of Philadelphia; and Mike Goodin, one of the old school of drivers, who has now retired from the turf and become the proprietor of the Bingham Honse in Philadelphia, had the mount behind him. In those dars, a Philadelphia horse, if he had any chance to win, was certain to be well backed. I told Mr. Simmons that, to my notion, it was impossible for any horse as lame as the Chief was to win the lace, but he said: "Go on, and give them the best fight you can. I am going to bet some money on Kansas, and if I lose wont say a word."

I think we must have scored twenty times for the first heat. Kansas came up on every gait except a trot, and when I would go to stop him at the end of a score it seemed as though he would fill down. At last the judges told me that if I did not get the word the next time they wonld send the others off withont me. Mr. Simmons suggested that I take the Chief well down the stretch, and let him rome to the stand on a run, and if the judges gave the word try and catch him afterwad. As I had tried every other plan I conkl think of, this was agreed to. When we reached the wiré, Maloney was in front on a trot, Kansals next to him and rumning. "The judges said, "go," and I let my leose gallop for abont fifty yards, he striking a big trot when I 
caught him. Maloney was a very speedy horse, and led to the half, but from there to the wire Kansas gave him a horse race all the way, finally beating him out by a head, in $2: 2 . \frac{1}{2}$, both loorses finishing under the whip. Some of the ontsiders were disposed to complain about the judges giving me the heat, on account of lle run Kansas had made in the first part of the mile, but we got the heat, and I think were entitled to it. In taking the Chief to the stable after this heat, it seemed to me that he would never come back to the track. Sam McLanghlin came along and said that if that horse won the race he would come down and take off his hat to him. I put the Chief's forward feet in a tub of lot water, and let him stand there the entire twenty minutes between the heats, keeping the water at the same temperature all the time. We gave his body and legs a thorongh rubbing, but when they called us for the second heat he went on the track as lame a horse as I ever saw in a race. It was the same old story, more tedious scoring. Kansas got the word on a break; Maloney led to the half, and finished under the whip, Kansas gradually drawing up to him, and

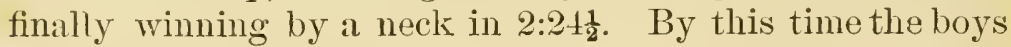
made mp their minds that they were to be beaten by a lame horse. Again we soaked the Chief's feet in hot water, and when a start was made in the third mile, Maloney was again away in front, and led to the liead of the home stretch, wliere Kansas orerhauled him and won by a head, in 2:26. I have driven a good many horses, and some that I considered very game, but I think that Kansas Chief's, under the circumstances detailed, was as great an exhibition of courage as any horse or hmman being ever made. As Mr. Simmons and myself stood in front of the stable watching the boys cool him out, McLaughlin came along with his hat in his hand, and said to Mr. Simmons: "It that horse was a man he'd be a hero," and I think all who have read the story of the race will agree with Sam.

We were to go to Springfield the following week, but the horse was in such horrible shape that we decided to 
ship him home, not thinking it possible that he could start. Mr. Simmons left for New York that night, and I was to ship the horse the following day; but on going to the stable in the morning I was greatly surprised when Mike Ward told me that he thought Kansas was not as lame as he had been before his race. On jogging him I was pleased to find that Mike was right, and that my plans conld be changed. So I shipped the horse to Springfield, and on getting there found the track soft and pliable, so that I gave the Chief two slow miles two days before his race. I moved him the last quarter of the second mile in $34_{4}^{\frac{1}{4}}$ seconds. Mr. Simmons said that was good enough, and if they could beat him the day of the race they conld have the money. Of course we laid seen the entries, and among them was the stallion Smuggler, that at Buffalo, in a \$10,000 purse won by Thomas Jefferson, had taken the first and second heats in $2: 22 \frac{1}{2}, 2: 2\left(\frac{3}{4}\right.$. Another to start against us was Fleety Golddust, that had beaten the Chief a race at Buffalo; so that we knew that at least two of our opponents were good, under favorable circumstances, for a mile close to 2:20. But we figured on the adrantage of the track, and we knew our horse was game and a first-class actor. Mr. Simmons said: "The'short turns will pozzle Smuggler. He will hardly get around them withont making a break, and that will cost him his chances of the race. The deep track will make Fleety give it up before she has won three heats."

We decided to lay up a heat at Springfield, as usual. There was a great deal of scoring, smuggler being unsteady; but when we finally got away Fleety Golddnst showed in front and was never headed, winning in 2:25. There was a lot of scoring for the second heat, but at last they were sent away with Kansas in fourth place. Fleety Golddust led as usual, and after turning into the back stretch I sent the Chief along, becanse the back stretch of the Springfield track was then very long and the home stretch short, so that I wanted to make the fight early in the mile. The 
Chief went through that stretch like the wind-so fast, indeed, that when he came alongside of Fleety Golddust she made a break, and Kansas won easily in 2:29. In this heat, Smuggler, who had made a break, was distanced, thus putting one of the fastest holses in the race out of our way. The betting on this race was something enormons, all of Mr. Green's friends and the New York contingent backing Fleety Golddust. Smuggler was owned by Col. II. S. Russell, of Boston, and had shown some great trials, a mile in 2:20 being one of them. The Yankees, with their accustomed shrewdness, thought this was as good a chance as they would get to add a few dollars to their bank accounts, and backed smuggler freely. Tom. Carpenter came along just before the race started, and $\mathrm{Mr}$. Simmons arranged for him to quietly place a certain amonnt on the Chief. Tom in his dry way said: "Eph, take my advice; keep your" money in your pocket, and buy oats with it for Kansas to eat." "You put the money on as I direct," responded Mr. Simmons, "'and if I lose I will hustle aromnd and see that Kansas doesn't go hungry."

With Smuggler distanced it looked as though the race was orer. The Chief won the third heat easily in 2:25. In the fourth heat, going around the first turn, which, by the way, was very short and dangerous, McLanghlin accidentally ran into me and knocked several spokes ont of my wheel. This caused a break, and when we tumed into the back stretch Kansas was the last horse My first idea was to lay up the heat, but when the leading horses reached the halfmile pole I could see that they had done all they wanted to in the trotting line, and so started Kansas for the heat. Fleety was three lengths ahead of me at the head of the home stretch; but half way to the wire Kansas was at her head, and from there it was easy for him, the mile being in $2: 2 \%$, this making the second deciding heat for big money that I had won that season, after meeting with an accident and losing a dozen lengths thereby.

At this meeting I drove a race for $M r^{2}$. Simmons that I 
think pleased him more and gave me greater confidence in my ability as a driver than anything I had thus far done. In all the races I had driven Kansas Chief it did not seem to me as though I deserved any credit, as I felt that almost any man could have won with bim. I had the best horse. The race at Springfield that I speak of was one in which I drove Bella against May Queen, H. C. Hill, Mac, Royal George, Magnolia, James Howell, Jr., Young Rattler, Harry Spanker, Kitty Cook, Hampton, Reserve, and Effie Dean. Bella was a handsome bay mare by Rysdyk's Hambletonian, dam by Jupiter, and she was bred by James McMann and George Wilkes, who was the editor of the Spivit of the Times. McMann, who, by the way, is still in the flesh and hale and hearty at nearly 75 year's of age, was for many years the driver of Flora Temple and other celebrated horses of that day. After Hiram Woodruff had given up Flora, McMann drove her to a record of $2: 19 \frac{3}{4}$, that being the first time 2:20 was beaten by a trotter. McMann owned a mare by Jupiter they called Lady McMamn, and he and George Wilkes made an arrangement to breed a colt from the mare, Wilkes paying for the services of Rysdyk's Hambletonian, and McMann furnishing the mare. In the comse of time, when Bella was five or six years old. Wilkes and MicMann closed their deal and the mare came into the sole possession of Mr. Wrilkes. He sent her to the stable of Mr. Simmons, telling that gentleman he wished he wonld have her worked and sell her. Mr. Simmons drove her one day, and came back and told me she would make a trotter sure. He said her owner asked for her $\$ 1,500$, which he considered a very cheap price for that kind of a mare. I went out and drove her the next day, but I did not like her, and so told Mr. Simmons. He still insisted that I shonld buy her, and offered to pay for her and wait for his money until such time as she had won it for me. I declined his rery kind offer, and lived long enongh to be very sorry I did not accept it. He sold her to a friend of his the following spring, and 
Mr. Simmons trained her. While I was away with Kansas Chief throngh the TVestern country, he found that Bella had a good deal of speed, and adrised his friend to enter her throngh the circnit, which he did, commencing at Buffalo. Mr. Phillips drove her her Buffalo race, and as it was her first start, and the first trip away from home, she was rery nervous, irritable, and acted badly, being easily beaten, although showing considerable speed.

At Utica she acted better, but was beaten again. After the Ltica race, Mr.Phillips told me he would be unable to be at Springfield, and asked me to drive the mare for him. Mr. Simmons was satisfied with the arrangement, and when we arrived at Springfield, Bella was placed in my charge. I found in working her ont for the race that she was what I considered a game mare with plenty of speed. Nashville Girl, better known as May Queen, was in Mr. Green's stable, and had won all her races throngh the circuit. She was looked upon by the pool-buyers and talent as a sure winner. In the betting, Nashrille Girl was favorite, $\$ 100$ to $\$ 20$ orer the field. Mr. Simmons said to me, "Splan, I don't know that yon have any chance to win the race, but I want you to drive it just as you would a race that you thought you were able to win. With all these starters, there is bound to be a great deal of scoring. The track is soft and deep, and the day repr warm. They are sure to get tired, and the thing for you to do is to nrotect your own mare all you can both in scoring and after you get the word, and don't make a move to win a heat until you see indications that the others are ready to sit down." The first heat Nashville Girl won easily in 2:26 $\frac{3}{4}$, and there and then everybody gave up the race to her. In the second heat Hickok went out with James Howell, Jr., and gave her a fight. They trotted a dead heat in 2:24. This did not change the looks of the race very much, as everyone knew that Howell would not cone back another heat. Effie Dean had been distanced in the first heat, but the other's were still in the fight. In the 
third heat Nashville Girl won without effort in 2:28. She out-trotted all the other's from start to finish.

I drove my mare all this time with a riew of simply saving her distance, and I noticed that most of the other drivers were hustling their lorses during all of this time as though they were in a hurry. With Nashville Girl hav. ing two heats and being a 2:20 trotter, we made up our minds if we were to get anything we would liave to go out this time or the race would be orer. Mr. Simmons was rely anxious that I should go away steady and lieep Bella on a trot and take the chances of beating Nashrille Girl, if I had any, in the stretch. Hickok and his party had all piled their money on the field against Nashville Girl, and when the judges said "go" in this heat he went out to give her a fight right from the start with Howell. She out-trotted him all the way, and I trailed in behind next to the pole, thinking I would get an opening there and get through. After going about three-quarters of a mile in that position, I saw Green draw his whip and hit Nashrille Girl. She failed to respond. I could see that Hickok noticed Green's action, as he sat down and commenced to drive Howell like one that was mad. After about a hundred yards of that kind of treatment Howell cried enough. I told Hickok that if he wanted to see Nashville Girl beaten, to pull out and let me through and that I would do the trick for him. He looked somewhat surprised, but pulled out, and before Green could realize the fact, Bella had Nashville Girl beaten. To say that the public, the talent, and myself were surprised doesn't describe it. The time was 2:30, but the crowd saw that I had a better horse than the farorite, just then.

After the heat was orer and the horses led back to the cooling ground, I looked them all over, and the only one that I saw that seemed able to get its breath at all was Bella. IVe concluded if they trotted the race out that night the money was ours, and it looked as though they would have plenty of time to do it in. In the filth heat, when they gave the word, I took Bella back, and Nashville Girl went away with 
the lead again. She was in front all the way for the first seren-eighths of a mile; from there home they had a horse race, and Bella beat her in 2:31 by a head. It looked to outsiders and myself as though we would have plenty of time to trot ont the race, int there was some delay caused by scoring in another race, and Green being slow about bringing Nashville Girl out on time when the horses were called, caused our race to be postponed until the following day; Nashville Girl having won two heats and made a dead heat with James Howell, Jr., and Bella two heats. Effie Dean had been distanced in the first heat, Kittie Cook drawn in the third, Reserve distanced in the second, Harry Spanker and Hampton distanced in the third, and Youmg Rattler drawn at the end of the fifth, so that for the finish of the contest next day there were left to start of the once big field only Nashville Girl, H. C. Hill, Mack, Royal George, Magnolia, and Howell. In the evening abont the hotel and pool-room there was a great deal of talk and excitement orer the race. Everybody was trying to hedge their money in some way. Of conrse, it looked as though Bella's chance was lost by the postponement. Mr. Simmons said to me: "Take good care of our mare and try and bring her. out in good shape to-morrow. W'e have got a fighting chance, and we will take it." In scoring for the sixth hear, Bella was inclined to be unsteady, and Nashrille Girl appeared to be able to out-trot her easily. Then the word was given, Nashville Girl went ont with the lead. In going to the first turn Bella made a wild break and lost her chance for the heat, and to me it looked as though the race was decided, but about this time II. C. Hill, a horse that had not before looked dangerous in the race, cut loose after Nashville Girl, canght her about fifty yards from the wire, and beat her ont a head in 2:28 $\frac{1}{2}$. Wre got the word in the next heat with Nashville Girl again in the lead, Hill second, and Bella third. They went to the turn in this position. Nashville Girl broke, but I went on with Bella, winning the heat. After the heat, Mr. Green claimed to the 
jndges that I had fouled him in going around the turn. They allowed his claim and gare the heat to H. C. Hill, who finished second to me, and placed me outside, the time being $2: 29 \frac{1}{2}$. I hardly think the judges intended to do me an injury, but am still of the opinion that they decided wrongfully, as I was sure then, and am yet, that I did not interfere with Mr. Green in any way. There was a great deal of money on the race, and a great deal of ontside influence brought to bear, which I think may have affected the judges" decision to a certain extent. Mr. Simmons said: "Sit still; we will beat her yet."

The race had now got to a place where three horses had two heats apiece, and in the two heats trotted on the second day, Magnolia and another had heen distanced, redncing the field to five. When scored for the deciding heat I was well up on the ontside, and Mrr. Simmons and myself had decided that we had better trail away and make the fight after we had got into the stretch. When the judges said "go," Hill and Nashrille Girl went out in front. Bella went away at a good stiff pace, and I kept her well in hand. As we moved down the back stretch the others had a lead of about four lengths. She closed up half that distance on them as they passed the three quarter-mile post. When we turned into the stretch, Nashrille Girl had the pole, Hill on her wheel, and Bella next. There was a hard, smooth path on the extreme outside of the track. I took Bella over there and set sail for the heat. She gained on them, but very slowly. At the distance stand, it seemed to me that she was head and head with them. Green rallied his mare and she ont trotted Bella again for abont fifty yards. Once more Bella got on even terms with her, and struggling on, beat her to the wire by a head in 2:301 . Thus ended the first real battle in which a horse and sulky were my weapons and my opponents some of the foremost drivers in the land. I, boylike, of conrse felt correspondingly delighted, and received a great many compliments, but the two that pleased me most was one from my employer, Mr. Simmons, in which 
he told me that I had driven well, and the other from the partner of all my joys and sorrows, Mrs. Splan.

I turned off from the story of Kansas Chief"s races after the one at Springfield, which we won when there seemed to be no chance of victory. Our next engagement was at Hartford, where we trotted the Chief, as it were ont of his class. Wre started him there in the 2:24 race, where he met what afterward became two of the most celebrated horses of their day. I speak now of Hopeful, the grey gelding that

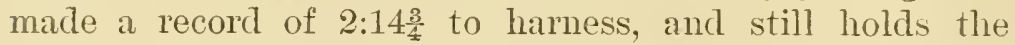
world's record to wagon-2:16 $\frac{1}{2}$, and Lncille Golddust, whom Charley Green afterward drove to a record of 2:16 $\frac{1}{4}$, and whose first foal, Lucille's Baby, made a record last year of $2: 20 \frac{1}{2}$, and bids fair to eclipse the performance of her famous dam. We had heard'great reports of Hopeful's speed, and from that concluded that we would not be able to beat him, and, as we.still had some rery raluable engagements with Kansas Chief, Mr. Simmons suggested that if I found we conld not win, to make the race as easy as possible for Kansas; which I did. Hopeful won the race in

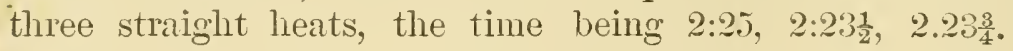
Susie got second money, Kansas Chief third, and Lucille Golddust fourth; the other horses in the race being Joker, that Mr. Jay Gould drove on the road after he had retired from the turf, and Ella Wright, that Budd Doble drove. Joker was driven by Jimmy Dongres, and together they made a pair that were hard to beat. Dongrey has made himself famons in more lines than one. He has trained and driven some of the best horses in this country, and done it as well as any man. When it comes to training a game chicken, Dongrey can beat anyone, and his war roosters have gained him fame and money when the race. tracks were under the snow. As a politician he has also shone, having been canal superintendent on the Erie under the Tweed administration, and it was through no dishonesty or mismanagement of the canal by Dougrey that Tweed fell. After the banishment of his political 
leader, Mr. Dougrey returned to the sulky again, and as late as $18 s 8$ brought out a first-class campaigner in the hig chestnut gelding T. T. S., that trotted two laces a week all the way down the line against some of the best ones in the country, and seldom failed to get a part of the money.

In looking back orer the campaign, I thought I saw where I had male some serious mistakes with Kansas Chief. Perhaps I had done as well as anyone, taking into consideration that it was the first time I had gone through the hig circuit with a horse. One thing I am sure of, we were all wrong in starting him after he had begin to lose his form. He had been kept at an edge, trotted a great many good races, and beaten some of the best horses of his year. Perhaps if he had been sound he might hare gone right on, but in the condition of his feet it was almost impossible to expect him to continue to take his work and go a race, and if we had stopped him after his Boston race it would hare been much better. I simply state this as my opinion after looking the battles all over; and I believe that in order to make oneself perfect in any business in life a man must be sure to take account of all the mistakes he makes; and as I an writing this book hoping there may be in its pages some information of ralue to other people, I shall from time to time make a note of mistakes I think I have made in training, driving, etc.

That winter we took Kansas Chief to the farm of Sam Mclaughlin in Newburgh, Orange 'County, N. Y., to be cared for. Mike IVard, his rubber, went with the horse, and we commenced to treat his feet where we left off in the spring. IVe gave him medicine to cool his blool and tone up his stomach, had a nice warm stall with plenty of bedding prepared for him, and cluring the wam part of the day he was allowed to run out in the paddock. When the spring cume he looked and acted like a colt. His feet were grown out and rery much improved. His lens appeared very clein and sound. When the training season opened we took him to Fleetwood Park, and I think that was a 
mistake, as he never liked the track, it seeming hard work for him to go down and up the hill, the first half of Fleetwood being rery much down grade, and the last half an up-grade. The first half seemed to be the hardest for him. I never saw any holse that could trot up the hill faster than he could. The way I account for this was, that coming rip the hill took the weight off from his forward feet, and then he was naturally a game and good finisher.

Wre trotted a race at Fleetwood against Hopeful and Sensation, the Chief winning it in slow time, as all three horses were out of condition, and the race set them all back. I was unable to trot Kansas Chief again until October 9, and then he went to Prospect Park, and started against what afterward became one of the most famous horses in this country. I mean Rarus; a horse that I have more to thank for than any other one I erer drove. 'The only other starter, besides Kansas Chief and Rarus, was Joker. Rarus won the race in three straight heats, I contenting nnyself with second money. I made no effort with Kansas Chief, as I knew he could not beat Rarus, and I was not going to repeat the mistake I had made in the spring, by giving him a hard race when he was ont of condition. The following week we went to Point Breeze Park, Philadelphia. There we struck in with Rarus and Mace with Sensation. 'There was a good deal of betting, with Rarus a strong favorite, as he had been winning all his races. Sensation won the race. I believe that Jimmie Page, a very clever gentleman, who drove Rarus, complained that Nace and myself had not given him any the best of it in some of the heats. At any rate we got the money; and right here I want to show what a bright, smart fellow Dan Mace was in his business. In talking over the race that night, at the hotel, in our rooms, alone, Mace said to me: "Splan, that horse Rarus can trot faster than any horse I ever saw, and some day will make a mark." I said "Dan, how did you find that out?" He told me that, going around the upper turn in the last heat, it was quite plain that Rarus was out-trotting Sensa- 
tion, and when he cut him loose on a run for tifty or seventy-five yards, Rarus trotted faster than Sensation could run. Rarus finally broke, and that ended the battle. This race proved to me that Kinsas Chief was coming back to his old form, as he went the first two heats in 2:23 and 2:24, and, as Point Breeze was never a fast track, I was satisfied with him then. I trotted him two other races that sason, beating Adelaide and Rarns, but neither of them need special mention.

These were the last races I ever drove Kansas Chief. Anything that can be said in favor of a true and brave horse, can be said, with truth, about him. I want to say that I never think of the horses that I have driven withont bringing Kansas Chief to my mind. I have told of his looks, his training, etc., and will finish this chapter by describing the way in which I bitted and harnessed him, and his peculiarities in and out of the stable. I drove him with a plain snaffle bit and an over-check and check bit, with his head checked well up; in fact, I think he went with his head higher than any other horse I ever had. We put on him in front a light pair of quarter boots, and behind there were scalpers, shin and passing boots. In the stable he was a very mild and docile horse, but did not take very kindly to strangers. He acted a good deal like a man who might have had dyspepsia all his life. In jogging or working alone he was disposed to be lather sulky. On race days, when he heard the brass band, and we commenced to take down his harness and put on his boots, he would begin to get very measy and walk around the stall. He was always a good feeder, and, when free from soreness, a very easy horse to drive. He had one peculiar habit with his tongue that I never saw in any other horse. In his races he would put his tongue out about two inches between his front teeth, and go the whole mile in that manner. He would pinch his tongue so hard with his teeth that, at the finish of a mile, the end of it wonld look as black as a hat. Then Kansas Chief left my hands, he was placed in charge of 
David Muckle, a gentleman who has made a reputation for himself in the trotting world. Everybody knows him ly the name of "Davy." He started in, a boy, in the early years of trotting, and served his time under such wellknown people as Horace Jones, Hiram Troodruff, and that school of trainers. In Mnckle's hands Kansas Chief, in $18 \% 6$, beat some of the greatest horses on the turf, including Rams, Bodine, Maud, Nettie, and a host of others. This year ended his active turf career. Mr. Simmons let a friend of his in Alabama have him, where he now is, and I hear he has still got all his old-time fire and determination. 


\section{CHAPTER III.}

Rarus, the first trotter to beat 2:14-How he was bred and raised by a Long Island farmer-The old gentleman thought by his neighbors to be too enthusiastic about the colt-His first race on the Island-How he came into my hands, after making a record of $2: 203 / 4-\Lambda$ successful trip through the central circuit, winning all his races but one-How Jim Crawford fooled the pool buyers-Going West and beating the famous BodineEntering Rarus in a race against the crack trotters of the land.

Away back in the war times, or rather, just after the Rebellion, there lived in one of the prettiest parts of Long Island, and with a farm overlooking the Sonnd, an old gentleman named R. B. Conklin. In his younger days Mr. Conklin lad been a stage-carpenter, and, in the pursnit of his trade, drifted to New York, of which city he was a resident for many years. His business brought him in contact with the world a great deal, and a natural love of trotting was fostered and enconraged by the fact that in the vicinity of New York there were two of the leading tracks of the day. and two more, the Fashion and Union, on Long Island.

Being an economical man, as well as an industrions one, Mr. Conklin had sared some portion of his earnings, and by the time he had reached the meridian of life was the possessor of a fine little farm at Greenport, Long Island, where he began in a modest way the raising of a few colts. During his trip to New Tork City Mr. Conklin had noticed in one of the markets there a ligg bay stallion, not a finelyfinished horse in any seuse, but one of wonderful power and resolution, that fultilled the menial duty of hauling a fish waagon. At this time the fame of Rysdyk's IIambletonian was just being made, and there were several of his 
sons that were siring numbers of fast trotters. Mr. Conklin beliered, from the formation of the bay stallion that drew the fish wagon, that he was a descendant of Abdallah, the sire of Rysdyk's Hambletonian, and, with this fancy in his mind, he bought the horse, then well adranced in years and possessed of no pleasant temper, and took him to the Long Island farm. It was characteristic of Mr. Conklin, than whom a more kindly old gentleman nerer lived, to have implicit faith in everything with which he became connected, and the stallion was no exception to the rule. In those days horses, no matter how well bred, were made useful, and so Mr. Conklin's purchase was put to work on the farm, drawing a cart and assisting generally in the cultivation of the place. Mr. Conklin had, previonsly to this time, secured a mare called Nancy Awful. This mare was by a thoroughbred horse, called Telegraph, that belonged to the Burr family, the father and uncle of Carl Burr owning him jointly; and right here I may say that no man has a more extended reputation as a handler of young trotting stock. and the develoner of trotters, than this same Carl Burr, now grown to such an age that he has grandchildren at his knee. To Carl Burr is clue much of the credit of dereloping the numerous fast youngsters that hare come from the Stony Ford farm of Mr. Chas. Backman. All the sons and danghters of the famous Clay mare, Green Mountain Maid, were giren their first lessons in the sulky by Mr. Burr, and when it is remembered that this mare produced six that have beaten 2:30, and that she is also the dam of the great stallion Electioner, it will be seen that Mr. Burr's influence on the history of the trotter is no slight one.

But to return to Mr. Conklin and the colt. In due time the daughter of Telegraph was bred to the stallion called Conklin's Abdallah, and the old gentleman predicted then and there that the produce would be the greatest trotter that the world had erer seen. It was really a sort of religion with the old gentleman - this absolute belief in the greatness of the 
stallion and the mare owned by him, and that their mion would result in a phenomenon among horses. The dam of Rarus was a gray mare, fifteen hands and three inches high, and, with ordinary road work, conld trot close to three minutes, and had plenty of spinit and determination-in fact, a little too much to be pleasant. To show that her pliysical qualities were of the best, it may be said that she lived to be over thirty year's old. Then the mare's foal was finally dropped it proved to be a bay colt, long and rangy in contour, with plenty of life and spirit. Thus far the old man's predictions had been fulfilled, for the animal was certainly one of which any breeder might be proud. From the day of its birth it was treated differently from any other animal on the place. As soon as it had been weaned a suitable stall was built, in a big barn, for its accommolation, and, from that day forth, nothing was left undone to secure its comfort. Of course, what Mr. Conklin thought of the colt was known to his neighbors, for, in matters of this kind, gossip soon spreads throughout a village, and it was not long before Conklin and his colt were the talk of that end of Long Island. The neighbor's had always given Mr. Conklin credit for being a steady-going, hard-headed, conservative old man, with plenty of sense and no small amount of cantion, and when they listened to his rhapsodies abont the bay colt, and saw the preparations he made for its comfort and convenience, there were not a few of them who really thought that the old gentlemin had become a little daft on the subject.

Of conrse, their views did not fail to reach him-talls of this kind always comes to the one of whom it is saidbut it never altered the old man one iota in his course with regard to the bay colt. He firmly believed that he had the commg trotter, and he was bound that through no omission of his should any mishap befall the animal. Then the colt was three years old it was broken to harness, and, during the following summer, took part in a little race on the Island, winning the contest in about three minutes. Then the 
old man was more certain than ever that he had the wonder of the world, and redoubled his efforts in the way of care, etc.; had a special stable built for the colt, with an office adjoining, where, in winter, all seated around a big fire, lie would entertain his neighbor's telling them what a great horse that colt was going to be. About this time Mr. Conklin gave lim the name of Rarus, which is a Latin adjective meaning rare, it being his idea that the point of perfection in horseflesh had been reached in the colt. For the next two years Mr. Conklin gave almost his entire time to the care anch edncation of this colt. He bought himself a light wagon, got a set of clouble harness, secmed an old lumner, and, as he was a very heavy man and did not want to compel the colt to draw his weight, he hooked him by the side of the rumer, and in this manner, orer the sandy roads of Long Island, the future conqueror of Goldsmith Maid, and champion trotter of the world, received his first lessons in trotting at the hands of his owner, the stage carpenter.

Abont the time Rarus was six years old Mr. Conklin had for a friench a man by the name of James Meade, an expressman from Brooklyn. Mr. Meade advised that Rarus be put in the hands of his son, who was something of a horseman, and young Meade drove him in some local races, in which he took part with success. The first regularly recorded event in which the name of Rarus appears is a race trotted on the 21st of Angust, 1874, at Hornellsville, N. I., the purse being $\$ 600$. In this race the horse was entered by James G. Meade, his opponents being Knox, Kilpatrick, Willie Golddust, Kittie Ǩnler, Ethan, and Bay Jimmie, not one of whom was ever prominent in trotting circles. Knox won the first heat of this race in 2:47, and then Rarus took the

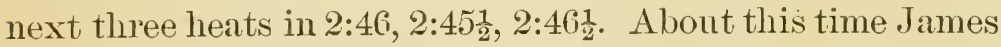
Page, a prominent horseman and stable-keeper of Brooklyn, who was always more or less interested in trotters, arranged with $\mathrm{Mr}$. Conklin to train and drive Rarus. Whether Page drove the horse in his race at Hornellsville 
I cannot positively say, but on October 12, of the same year, Rarus appeared in the race at Prospect Park, where he struck a much better class of horses, his opponents being the little bay mare Adelaide (of whom I shall have more to say hereafter), Falmouth Boy, Roadmaster, Volunteer Maid, T. J Stevens, Compeer, Effie Dean, Lady Trimble, and Carrie White. The lace was a rery hotly contested one, six heats being required to settle the question. Rarns won the first heat in 2:301 second and third heats, each mile being trotted in 2:34. Adelaide then went to the front, trotting the fourth in 2:30 $\frac{1}{4}$, and the fifth in 2:32, after which the race was postponed until the following day, when Rarus came ont with renewed speed, and captured the sixth and seventh heats in $2: 30$ and $2: 30 \frac{1}{4}$.

The horse was kept at Prospect Park, and two weeks later started in another race over same track against a field of five, the only one of the lot that ever became prominent being the black mare May Bird, the daughter of George Wilkes, that afterward proved herself one of the best all-around performers of her speed I have ever seen, inasmuch as she obtained a saddle record of $2: 19 \frac{3}{4}$, a harness record of $2: 21$, and drew a wagon a mile in $2: 24 \frac{1}{2}$. These records were all made in hotly-contested races. May Bird was afterward soid to $\mathrm{Mr}$. Robert Bonner, a man who has paid out nearly half a million dollars in cash for trotters, owning at one time Rarus, Dexter, and Mand S. In this race at Prospect Park, May Bird set the pace rather faster than Rarus had been going, winning the first heat in 2:27. He took the second heat in 2:30, and in the third he trotted a mile in 2:28 $\frac{1}{2}$, this being the first time that he had beaten 2:30. May Bird beat him out in the fourth leat, but, with his usual resolution, the big bay horse came back faster in the fifth mile, and won by a neck in 2:30) $\frac{1}{4}$. 'These were two good races for a horse that had not been asked to beat three minutes until a few weeks previous, but on the 30 th of October he was pulled out again, and trotted another race 
over the same traek against the horses that he had beaten in the two previous erents, no less than ten of them starting against him. When the battle began May Bird seemed to have a little the most speed. It was late in the year, and the weather was cold. The daughter of Creorge Wilkes took the first and serond heats in 2:30 $\frac{1}{4}, 2: 30$; after which Rarus wore her down and won the third, fourth, and

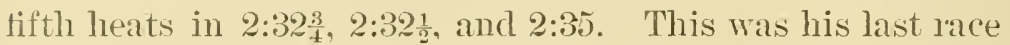
in 1874, and he went into winter quarters with a record of $2: 28 \frac{1}{2}$.

In the spring of 1875 he was again placed in the hands of Mr. James Page. He was given a few preparatory races, trotting throngh Michigan and Indiana, and on the 2:2 of July came to Sandusky, Olio, where he started against Lady Mack, Carrie L., and Belle. He won the first heat of this race in 2:31, Carrie L. took the second in 2:32:3. Rarus

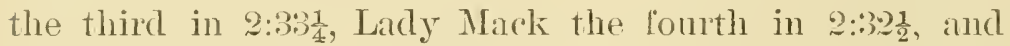
Rarus the fifth in 2:32. He was then taken to Cleveland, where the grand circuit began, and entered in a $\$ ., 5)(0)$ purse, where he was called upon to beat some of the best horses of the day in their class, the other starters being Molly Morris, Carrie, Era, Belle Brasfield, Mazo-Manie, Snowball, and Bertie. This was the first gennine battle that I had ever seen Rarus win. In all his other races he had shown moderate speed, with a good deal of determination to hang on. People who saw this race will never forget the excitement there was abont it at the time. In the orer-night betting, every horse was backed as thongh each owner thonght he had the purse won. Mazo-Manie represented Wisconsin, having been sold to Mr. E. II. Brodhead, of Milwankee, a man whose horses always went for the money. His friends and the public, knowing this, plunged with all their might. Molly Morris, the fastest trotter of her inches in the world, belonged at that tinte to William Armstrong, now a famous pool-seller. Willian McLanghlin, or "Red Bill," as the boys loved to call him, held the reins over Molly. She had shown him trials close 
to 2:20, and Armstrong and his friends, thinking they had a good thing, kept their own counsel and put down their money. Carrie, a mare that had proved herself a first-class race nag, and was owned by Mr. Myron P. Bush of Buffalo, had Mace for a pilot, and all New York ready to bet on her. From Philadelphia came IVilliam H. Doble, noted for his own ability as a driver, and also as being father of Budd Doble, who had Snowball in the race. Morrell Highte represented Jllinois with the gray mare Bertie, that had speed enongh to ont-trot the wind. These, with Belle Brastield and Raurus, made the field.

Molly Morris won the first heat, from start to finish, in

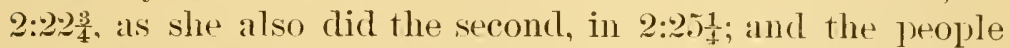
from Michigan, as they saw their favolite pony coming to the front twice, and "Red Bill " at the lead of the procession, commenced to get ready to telegraph home the news of a victory. In the third heat, Molly led until well into the stretch, when Carrie came alongside and gave her a race from there to the stand, both horses and drivers doing their utmost to win the heat. After the finish there was a great teal of excitement, it being difficult to know just who had won, but the judges awarded the heat to Carrie, in $2: 2+\frac{1}{4}$. Now rame a change in the race. Mr. Page, lacking contidence in his own ability, asked Mr. John L. Doty to drive Ralus. Mr: Doty is a man not so well-known to turfgoers now as he was at that time. Doty ame originally from New Jersey, and was always considered one of the rery best trainers and drivers of the old school. Although he was well along in years at this time, he was willing to get 11 , and make a fight with the boys, which he dicl, and, as the l'esult showed, successfully. I have always thought that the owner and backer's of Rarus owed to .Mr. Doty a vote of thanks for the masterly mamner in which he handled him the balance of the race. When the word was given in the fourth heat, Molly Moris rushed away with the lead, Doty contenting himself with fouth plares. At the halfmile post he cut loose, and that was the first time I ever 
saw Ralus go at a late of speed to malie me think he might be able to trot in $2: 20$. As he rouncled into the stretch, he was in third position, and, fiom there to the stand, the race was ats exciting as one conld wish for. Rarus closerl inch hy inch; he seemed to grow longer and bigger, and Molly Morris shorter and smaller. It looked an uneven battlethe pony, scarcely fomteen hands high, trotting and struggling against a horse that stool orer sixteen liands-and when he overtook her at the distance-stand, and beat her to

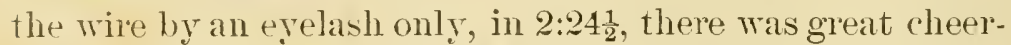
ing, and I think that the sympathy of a great many in the andience was with Molly Morris on account of her size and her honest attempt to win. Rarns won the next heat, but not until he had had another determined battle, and went a second faster than in the fomth mile. In the deciding heat they had all had enough of it, and Rams won in 2:26 $\frac{1}{4}$. In

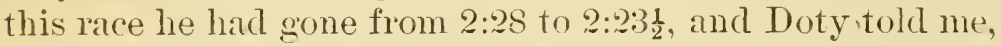
that night, at the hotel, that he considered him, by long odds, the fastest and best horse that he had ever driven. That rather sumpised me, as I hail sern Doty have some very good ones, and I felt that he lad Rams a little overrated on aceount of his rictory. It Buffalo he net about the same lot of horses the following week, but Molly Morris turned the tables on him, and beat him in straight heats, in

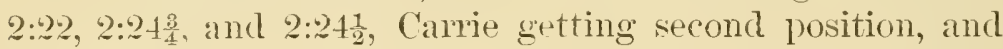
Rarms third. Doty told me that night that he thought the track being hard hurt Rarus, as he did not seem disposed to extend himself, and at no part of the race, excepting the finish of the last heat, did he show anything like his Cleveland speed. From what I knew of Rarus afterward, I think that Mr. Doty gare the right solution of his defeat. While the first heat of this race might have been faster than lie conld have gone, he had shown his ability to beat 2:24, which was the time of the last heat.

'The following week, it Rochester', they had another royal battle. Some of the heats of this race were trotted in the nut, which accomnts for the great variation in time. Rarus 
won the first heat in $2: 2: 3 \frac{1}{2}$, Molly Morris the second in $2: 24 \frac{1}{2}$, and then the rain rame on, making the track stower. 'This told against Molly Morris more than any of the others, and Rarus beat her in 2:20. By this time the track was rery heavy and anchored them both, Rarus having a very long stride. Evil won the fourth heat in $2: 393 \frac{1}{2}$, and them the race went over until the following day, when, on a good track, Rarus again lowered his record, trotting a mile in $2: 2 \cdot 2$.

At Utica about the same lot of horses started. Bommer, a chestmut gelding, driven by dack Feek, won the first heat in 2:22. Feek is one of the ormaments of the profession, both from the standpoint of skill and in personal apyearance. He is often ralled by his intimate friends "Handsome Jack Feek," and his looks warant the compliment. There is one thing that the boys always know, when Jack Feek starts a horse in a race for the money he is in the pink of condition, and this was nerer better illustrated than at Cleveland last summer, when he came out against serenteen others, all of whom could beat 2:20, with the little mare Lady IV hitefoot, and, withont asking their permission or consulting an ybody, took the second, third, and fourth heats of the race and the last dollar that was played in the pool-boxes, all the miles being in 2:19 or better. Alter this race the price of salt abont Syracuse was reduced away below the high-tariff late. In the Utica race the second heat was won hy Bertie in 2:27, and then Rarus went on and took the next three in $2: 25,2: 2: 3$, and 2:23. He was sick at Springtield, and did not stalt there, but at Hartford, on the first of September, he was again in form, and made another material reduction in his record. some new competitor's were met here, among them heing Frank J. (that my old friend Jack Bachelor, whose linen duster and spectacles were in those dary familiar from one end of the land to the other, (lrove), Parkis Abdallal,, Crown Prince, and Trimmph. Frank J. had shown his owner' a trial or two that made him think well of his chances, and whenever Bachelor beliered he had a good thing he was willing 
to play the limit. 'T'o prove this latter' statement, I will cite an instance in his areer concerning an occasion when he was interested in a faro game. As hesat behind the dealing box a flashily dressed man came in and saill: " IV ell, Lncle. what's your limit!. Bach looked at him :mol replied: "From the green earth to the blue sky above. my splithaired friend form the city," and Bach meant what he said. On another occasion Bach was presiding at the lair of the tiger in the far. Trest, when in dropped a miner who had just struck a rich rein of ore, and whose pockets were filled with little bags containing gold dust. 'The stranger was of the type of mam that one rearls abont in norels. He had a fieree monstande, his lace wore a stage-rillain scowl, and the ench of a conple of bigr revolver's peeped ont coquettishly from his hip-pockets. Ile began setting the little bags of gold dust down, and finally centered his affection on the jack. By this time the other players had taken their bets from the lay ont and were watching the stranger. He smrounded the jack with a donble row of little canvas bags, put two or three mon'r on the comers, and then stopped, still holding a comple of bag's in his hand. "Have I got to the linit?" he asked Bach. The old nam looked up over his spectacles, with the air of a college professor, and sald in that high, squeaky roice that all the boys know so well: " No, sir, you have mot reached the limit: put down the other two bags, and then jump on yourself."

So when Bach started Frank .J. in the Hartford lace he played him in just the same way. He went out and drove for his own money. He won the first heat in $2: 2: 3 \frac{3}{4}$ very handily. In the next heat we saw one of the grandest battles that had come off that year. Frank.J. lead all the way to within fifty yards of the wire, where Rams rlosed and beat hin out an eyelash in 2:2018.9 which was a second and a quarter faster than he had ever gone hefore, and proved that Bach was right abont his horse, which he had deemed capable of a mile in 2:21. In the next heat Frank J. broke, and Rarus wom easily in 2:2:1. In the fourth heat they 
renewed the battle, and it was anyour's lace to the finisl, where Ratus landed a wimner in $2: 2 \cdot 2 \frac{3}{4}$. this being the finstest and best race he had ever trotted. 'Two days later he performed over the same track against Annie Collins, Little Fred, Adelaide, and Bonner. He won this lace in straight heals, the time being $2: 21 \frac{1}{4}, 2: 2 \frac{1}{2}$, and $2: 24 \frac{3}{4}$. This race wals conceded to Rarus, and all the betting was on the place. Crawford's mare had not shown any remarkable speed heretofore, the most of the money going on Bonner. Mr. Crawford took advantage of public sentiment, something which he has done on several occasions, and placed his money on Annie Collins for second place, and the result of the lace shows the wisclom of the whole transaction, becanse Annie Collins went the best race of her life, making Rans trot the first mile in $2: 21 \frac{1}{4}$ to beat her, and the second and third in 2:22: $\frac{1}{2}$ and $2: 24 \frac{3}{4}$. All of Rarus's other races through the balance of this season were fully described in a former chapter in connection with Kansas Chief.

At the end of this season Rarus was taken home to his owner's farm, on Long Island, and placed in his own qualters, which he had left withont fame, bnt to which he returned encircled by the halo of glory that in those days a record of 2:20) $\frac{3}{4}$ would give to any horse. The Long Islanclers are all horsemen, and they appreciated the fact that $\mathrm{M} / \mathrm{r}$. Conklin's prophecies, which they deemed wild and risionary at the time, had been nore than fulfilled, and in the frosty days of November, and all dming the following winter, they would stroll up to the barn, sit around the glowing stove in the office, and listen to the old gentleman as he recomnted the triumphs that the bay gelding had won in the hig rities of the land.

The first time that evel I saw Ml. Conklin to know him was the next morning after Kansas Chief had beaten Rarns the last race in Prospect Park, in the fall of 187.). I was out at the stable, looking over Kansas, when I saw, walking toward me, a gentleman who looked as though, in the prime of life, he might lave been a man of great size and strength. 
I asked who he was, and one of the boys told me that was Mr. Conklin, the owner of Rarus. I stepped out and said good norning to him, and we naturally fell to chatting about the result of the race the day before. He felt very much (ast down to think that Rarus had been beaten; was willing to acclonowledge that Kansas was a good horse, but not that he was the superior of Rarus. I told him his horse lad ton long a seasom, and was ont of condition, and at the same time told him that I thought Rarns showed speed enough in the race to convince me that lie was the fastest horse I ever saw. This remark of mine nust have touched a sympathetic chord in the old man's heart, for from that day intil he died no man had a wrmer friend than I had in Mr. Conklin. In the course of our conversation he told me that. if he erer made a change of drivers, I shonld have the first chance with his horse, and gave me a pressing invitation to come over to Long Island, and visit him at his home. This invitation I accepted, later on. About the 1st of January I took a Long Island train to Mr. Conklin's honte. I arrived there at six o' clock in the erening, and was invited in 10 an old-fashioned farm-honse supper, and introduced to Mr. Conklin's family. After doing ample justice to the goort things at the table, of which there was no lack, the old gentleman lit lis lantern. put on lis big coat and hoots. and we started ont to risit Rarus. I found the horse in the stall, as pleasantly situated as I ever saw lim afterward. Plenty of room, good bedding, lots of blankets, and in the room adjoining the stall, fitted up as an office, was a nice fire and romfortable chairs, which the old gentleman had provided for the reception of his friends. WThen he ordered the blankets taken off Rarus, I could see, by the light of the lantern, that he had filled out and dereloped into a grand looking horse. He seemed to have entirely recorered from his summer's campaign, and was rery much imploved in every way. We sat down and talked until bedtime, and in the conse of our conversation I asked Mr. Conklin if he would sell his horse. For leasons which it is not necessary 
to explain, he said to me that he would, at the same time giving me his reasons, and I may say here that it was not becanse he had lost confidence in his horse, as he still insisted, and, I am sure, believed, that he would erentually be the greatest trotter the world ever saw.

After a pleasant risit of a day or two, I returned to New York, and, one day in my rambles, met Mr. James Wallace, who was at that time one of the most liberal patrons of the trotting turf. Mr. Wallace was always ready to buy a good horse, pay a good price for him, trot him, and give the driver everything that was made with hin. In the course of our conversation 1 told $\mathrm{Mr}$. IVallace what I thought of Rarus, and also informed him of what Mr. Conklin had said about selling. He told me to find ont just what would buy Rarus, and made an appointment to see me again. I met him afterward, and stated the price, which I had found out from Mr. Conklin. Wallace said that if I would, under a certain contract, undertake to train and drive his liorses, he would buy Rarus. I aceepted his proposition, and the first of the month started in under the contract. I wrote Mr. Conklin, and he came to New York to close the deal with Mr. IVallace. About this time some one of the many people thereabouts, who were always ready to advise ererybody about their own business, told Mr. Wallace that Rartus was an unsound horse, and adrised him, under no consideration, to buy him. Mr. Wallace sent for me, and stated the case. He told me to pay Mr. Conklin liberally for any trouble that he might have been at, but, under the circumstances, he thought it would not be advisable to buy Rarus. He said, however, that he would buy any good horse that might alpeal on the turf in the spring. Mr. Conklin did not seem nuch disappointed when I told him what Mr. Wallace had said, simply saying: "Tery well; the1'e may cone a day when he will want to buy him and can't" - words that afterward came true, as Mr. Wallace, on one occasion afterward, told me he would give s20.0(n) for the hou'se.

In the spring of 1870 Mr. Conklin gave his horse, to 
train and drive, to Mr. dantes D. McManm, a man whom I had seen drive lateres in the days when I nsed to play hookey from sclool and hide my books muder a lumber pile. He took the horse to Philadelphia, and trotted him in the spring races aqainst his old opponent, Kansas Chief, then in the hands of Mr. Dare Muckle. Kansas heat him three latces in succession, Rands seeming to hate none of his old-tine speed or dash. About this time Mr. MeNann, feeling that he was too old to leave home to (ampaign the horse, suggested that he would turn the horse orel to me. I had given Mr. Mallace a contract for my services for the rear, and could not take the house withont his consént. So strongly was I impressed with the greatness of Rams that 1 was willing to give 11]' a good contract, witl a certainty, for the (diance of getting him to train and drive. I went and stated the case to Mr. IVallace, and he adrised me. for my own good, not to give up the contuat and take Rarus, but said that if I insisted he would rousent to the arrangenent, which he dicl. By this time Mr. MreMamn had boonght Rarus to a half-mile track on Long Island, owned by the Barclay Brothers. Alout the 1st of July I went one morning, with Mrr. Conklin and McMann, to this place, and, for the first time in my life, sat behind Rarus. Mr. McMamn adrised me to give him a mile in about 2:40, and, twenty minutes later. to drive him another mile in about 2:30, and, if I liked him, to let him step along the last quarter, which I dicl. I was much pleased with him, and, while Mr. Mr.Mamn told me he thought him a great horse, I was full sure that he was greater than eren he thought. Mr. Conklin made me the proposition that I take the horse and enter him, and pay his expenses, and have half what he woll. I was perfectly willing to accept the contract, but the next thing was, where could I get the money to pay the expenses? I hethought myself of Mr. Simmons, knowing that if I found him I would have no trouble to get what money I needed; but on my return to New York, Mr. Simmons was out of town, and no one seemed to know where he was. The entries through 
the grand circuit closed that night, and whatever was done had to be done before eleven o'clock. My financial standing at that time was such that there was not much chance for me to effect a loan at any of the National banks, so I concluded to look around for some place where they loaned money on less security. I happened to meet that genial man and fellow-sportsman, Col. Jim Crawford, who had been a side partner of I'ncle Jack Bachelor, and who was always willing to atke an even shance on anything from jack-straws to fox-hunting. I stated the case to him, and told him how much money I thought it would take to pay the expenses of entering Rarus through the circuit. He took me to his hotel, had the safe opened, drew ont his bank roll, and counted out to me the amount of money that I wanted. I therenpon entered Rarus through the grand circuit, commencing at Cleveland and ending at Hartford, and the following week I shipped him west from Long Island to Cleveland. At this time he was rather high in flesh and short of work, and I har but little time before his first race, but still I beliere that, had the track been good that day, he would have won that.

The only other stan'tel in the Cleveland race beside May Queen and Rarus was General Garfield, a horse that was driven by Ed. Brown, better known as "Nosey," who was born in New York City, but who at that time had made Chicago his home for a good many years. He is dead and gone now, but, in his day and tine. no man was a better "atch" driver than "Nosey," and, in this respect, he greatly resembled Dan Mace, being able to jump up at a moment's notice behind any horse, good or bad, and drive him about as well as lie could go. Nosey was a chatureter; in personal appearance he was somewhat uncouth. and not much given to the foibles of the toilet, but he had a big liealt, a ready tongue, and was abont as witty as they made them. As a hustler we never had his equal, and, more than this, he could tell a good story well, evell when the point was against hinself. A famous yam of his in chirago 
to-ilay is one that he used to relate with great grusto-how he, in walking alone one cold winter day on the IVest Side, espied a beantiful terrier dog that seemed to be without an owner. Feeling pity for the animil, "Nosey" reached down, and a moment later the dog had a warm resting place beneath his orercoat. Just then the owner of thr animal appeared, and "Nosey," who was muare that the pup) belonged to anybody, was soon engaged in a lively scrapp with the man. "I liung on to the pup)," he used to saly, "as we rolled over" on the ground. I downed my man, and got "1) and ran away, with the log still under my orercoat. When I paused for breath I looked nnder my coat, but the pup was dead. It seems that I had fallen on him, and he was maslied out as flat as a postage stamp. It was the only fight that I had won that winter, and the prize was a dead dog that the police would not let me put in the street, and that nobody seemed to want."

In the Cleveland race May Queen was a long farorite. The track was deep, owing to a good deal of rain haring fallen. In working Ralus out before the race, I found that he was abont as helpless a horse in that sort of footing as I had ever seen. I made up my mind that he had no chance to win, and that I wonld simply go along and sare my distance. May Queen won easily in struight heats, in

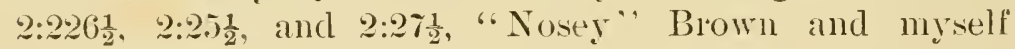
haring a good race for second money, which Rarus won after a pretty tight finish. This was my first lace with Rarus, but the track was so bad that I had no chance to do anything in the race to give me anyopinion as to his ability. From there we went to Buflilo where the purse was $\$ 3,(0) 0$, where we again met May Qneen and General Gartield, Carlie being also in the race. A few days before the Buflalo meeting, Mr. Conklin snggested that I take Rarus out, give him some work, and see what I thought of him. I followed his suggestion and drove lim the first mile in 2:30; the second lieat I lhove lim in 2:22, and, when 1 wastold how fast he had gone, was rery much surprised, as 
I was positive I could have driven hin a good deal faster. I went ont to give him another mile, and told $\mathrm{Mr}$. Craw ford I would take him to the half-mile post slow, and let him rome home as fast as he contd. I was rather anxious 111 self to see just how much speed he had.

I drove him down to the half in 1:13, and, when I spoke to him there, he cut loose at a rate of speed that, to say the least, smiprised me. When I finished, the nile I asked Mr. Crawford how well he had gone, and he said 2:20. I could not think it possible, as I knew I could have driven Rarus the last half very much faster than I did. 'That made the last half of the mile 1:(1). Quite a number of the betting men around saw it, and they could not make up their minds what was in the wind. They fancied I was a little too liberal in showing my goods. One of them asked Craw ford why I had done it, and he told them we had every confidence in the horse, and wanted to show the public something that would give them a little confidence also. The gentleman answered, "All right. Crawford, but I will have my money on May Queen the day of the aace," which promise he kept, as he was the first man I saw at the poolbox when the race came off. May Queen, by the way, was the same mare that, moler the name of Nashville (tirl, had made a record of $2: 20$ the previous year, and had shown herself to be a first-class lace mare. At this time she was owned by Mr. Joseph Harker, of New York, a great friend of Commodore Vinderbilt, and was in the stable of Mr. Charlie Green when he wis in the heyday of his glory, and, moler those circumstances, it was not strange that she was a farorite at $\$ 100$ to $\$ 20$ orer the field, as she had beaten the other horses, and everyone suplosed she would do it again. In talking the matter over with $\mathrm{Mr}$. Crawford, we ronchuded to put some money on Rarus, and take onr rhances, which we hid, and it paid us a hamdsome profir. In looking the field over we saw no one in it that we thonght conld make a fight with May Qneen, and started in the race with the determination to go at her light from the start, 
if no one else did so. In groing to the first turn, after getting the work in the first heat, May Queen made a break, and I noticed that when Green went to catch hel she tore off one of her forward shoes. She was a mare that had to have a good deal of weight to keep her from paring, and I made i1) my mind that her chances for the heat were gone. At this time I was in thind position, Mace being in second place, with Carrie, 'This mare led to the quarter-pole, where Rarus passed hel, and going by the half-mile pole. I heand Mace cry ont, "Gro on, Splan, May Queen is distanced." I knew Mace was pretty cute, and I did not take lis word for it, thinking lie might be trying to get me to drive ny horse a hard heat and pump him, thereby giving him a rhance to rome along with his male and " ko" me for the money. In going through the last quarter I had a chance to look ovel my shoulder, and satisfied myself that May Queen was really distanced. I drove along at about the same late of speed, and finished the heat in $2: 24 \frac{1}{4}$, with Nay Queen belind the flag.

'To say that there was a lubbub on the track does not describe the scene. 'The pool-buyers rushed down to the quarter' stretch like a flock of sheep, and commenced to give the judges a great deal of advice as to how to decide the heat. The judges gave Rarus the heat. placed Carrie second, and Garfield third, saying nothing about May Queen. Mr. Crawford stepped over to the pool-box, and straightway played his money on Rarus, and had the field sold against him. I great many people, thinking that May Queen was not and would not be distanced, played the field. When we anme out on the track for the serond heat, May Queen was there, with Doble in the sulky. I immediately went to the judges' stand, and asked if they intended to allow May Queen to start. They said they did, and I asked them on what grounds or under what rule they were acting. These were two questions that they seemed nuble to answer. I therempon told them that if they allowed her to start and she beat me I would certainly protest their decision, and I be- 
lieve that by taking it to the boand of appeals it would be decided in my favor. They held a short consultation and then distanced May Queen. Then the grand howl of the day came from the people who had played the field against Kansas, expecting May Qneen to start for their moner. One enterprising individual went so far as to get out an injunction against the pool-seller paying over his money to Rams in case he shonld win the race. Mr. J. Gorman was selling the pools at this time, and before he lelt the city a man got hin put in jail on a charge of turning over to us the money we had won on Rarus, but through the political influence of some of our friends we got John ont of the sweat-box in time to go to Rochester with us. The second heat Rarus won easily in $2: 25 \frac{1}{2}$, but in the third he threw a boot and made a break. I laid him up, and Car-

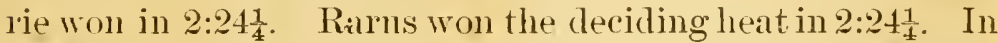
this race he was not called on in any place to extend himself or go at his highest rate of speed. With the exception of the place where he threw his boot he acted rery steadily, and $\mathrm{Mr}$. Conklin, Mr. Crawford, and myself felt we were on the high road to prosperity.

At Rochester, Garfield was the only starteragainst Rarus, and the betting was all on our hor'se, le being a favorite at $\$ 100$ to $\$ 10$. He won withont an effort in struight heats, the time being $2: 27 \frac{3}{4}, 2: 22 \frac{1}{4}, 2: 24 \frac{8}{4}$. At Utica, the following week, Clementine, General Garfield and Carrie started against Rarus. This was Clementine's first race in the circuit that year, and as Budd Doble liad her in charge, there was some little money played on the field against our horse, Clementine having gone some good laces the season before. Rams won without an effort in $2: 22 \frac{1}{2}, 2: 21 \frac{1}{2} .2: 23$, the second mile being the fastest that I had driven him up to this time ip a race, although in his work he had shown me 2:20.

I had now driven Rarus four good races, and will tell something about how I worked him. Up to this time I had not made any changes in any way, simply having him shod, hooted, harnessed and driven about as the boy told me who 
rubbed him he had been heretofore. He had on him, I should think, at this time, abont fifteen or sixteen ounce shoes. I noticed that when he got strung ont at a 2:20 gait he seemed to spraw, or in other words go longer than lie ought to. This made me conclude to experiment a little with a lighter shoe. I had given him after the Buffalo race no work to speak of, never driving him a mile better than 2:30, and only brushing him a little at the finish of his miles. I would jog him about tive or six miles a day, giving him plenty to eat. I was satisfied that he did not need any extra preparation to beat the hor'ses he was liable to meet, so never made any attempt to screw him up. From Utica we went to Ponghkeepsie. Clementine was the only other stiirter. I will here relate an inciclent which will show what effect on the betting a little information will sometimes have. In the first betting orer night, Rarus was bringing $\$ 100$, and Clementine from $\$ 15$ to $\$ 20$. C. S. Dempsey, a man who is familiarly known to the boys as "Old Iempse," had the pool-selling. Thhen Dempsey opened his box, Crawford stepped up and told him to put $\$ .500$ on Clementine for him, and that if he grot that on before he came back, to jut on $\$ 500$ more. Craw ford and myself went to the theatre, and on our letmru to the hotel, the first man we met was a well-known character named Paddy Dooley. Paddy dragged us both into a darkí corner and wanted to'know what was the matter with Ranss. Then I asked him why he wanted to know, he told me that in the opening betting Rums was the favorite s100 to s20. but before the betting closed Clementine was the ('hoice, she selling at $\$ 100$, Rarus $\$ 75$. Dooley added that the scene about the pool-box put him in mind of Black Friday in Wall street. Of course, Mr. Crawford and myself were very much surprised at the information, and went to bed leaving Dooley as much in the dark as he was at the start. The next morning we went to the track, and gave the groom of Rarus positive orders not to open the stall doors to anybody, and that if people asked about the con- 
dition of the horse, to refer them to me, which I think he must hive done, as I was interviewed by a great many people that morning as to what was the matter. When the betting opened at the track, there were two pool-sellers, Dempsey and Major Barker. Mr. Crawford picked out two friends of his, and sent one to eateh box, with order's to buy erery ticket that was sold on Rams. The betting opened with Clementine the favorite at $\$ 100$, Rarus bringing about \$so. Mr. Crawford's friends sent the money in on Rarris in such a shower, howerel, that by the time the bell tapped, Rams was the far orite at $\$ 100$, while Clementine went begging at sis. By this time the people. especially the poolbuyers who had been squeezed in the deal, were looking for a chance to commit murder. The track was very lough and full of holes, and immediately after the horses got the word in the first heat, Rarus made a break, and I never mored for the heat. Clementine took it in 2:261, and then Rarus won in straight heats, the time of the miles being :2:24, 2:2.5, $2 \cdot 29 \frac{1}{2}$; and Crawford's scheme against the smart men about the pool-boxes turned out well. When Craw for stepped up that night to pay Dempsey the thousand dollars that he had played on Clementine with lim, Dempsey looked at him. "IV'ell," he says, "you' ve got me this tine, but you will never do it again." Is a pointer, I would advise the boys not to try and repeat Crawford's attempt to deceive Dempsey, as it would be rery lialle to fail. for since that time the old man has grown as wise as the best of them, and has an eye like an eagle, and a land like the talons of a hawk, to discorer and seize any stray grood things that may be flopping around in the general souftle during the trotting season. "Dempse" is a chatacter. When he started out on the trotting turf, it was as a buyer of pools; but his education and plilosophy soon taught hin that the inside of the box, especially in the fall, was more apt to be fur-lined than the outside, and it was not long hefore he had a stand at the rircnit meetings, and a poolbox of his own. He made money at the business, and has 
a farm in Pennsylvania where he raises all kinds of blooded live stock, from rabbits to Durham bulls. He paid me the compliment of niming his best horse Jack Splan.

From Poughkeepsie we went to Hartford, where Rants

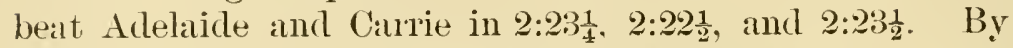
this time I had become thoroughly satisfied that Rarus could go better with a lighter shoe. I ralled in Charles Huey, a man in whose ability as a shoer of trotting horses I have the greatest faith. Iney originated in Buffalo. At one of the early meetings in Buffalo, Mare had occasion to eall in a blacksmith, and, in lesponse to his summons, a great big, good-natured man stepped up and said, "I do a little horseshoeing myself." Mace gave him the order he wanted executed, and the man unrolled his leather apron, tied it around him, and started in at the work. Mace, with his accustomed acuteness, saw in the stranger what he considered al firstclass mechanic, and, as Huey put down the horse's foot, turned to him and said, ". If you will come to New York with me, I will see that you get a chance to make a foltune." The following spring Iney came to New York, and Mace fitted him up a shop in Broadway, between Fortyseventh and Forty-eighth streets, where, with Mace as a friend, and his own ability, he soon made himself a name second to that of no man in the business. When Lucy and Goldsmith Matid were campaigning the country, Huey was hired by Doble, at a large salary, to arcompany the outfit and do the shoeing. At the tine I speak of, he had located at Hartford, and had a shop. IVhen he came to the stable he sat down, and, in his good-natured way, commenced to talk to me about the time I used to play hookey from school in Buffalo to gro to the lase track there and drive horses for John L. Stevenson. When I callea his attention to Rarus, he looked his feet over carefully, and said he thomght he conld improve thent. I fold him I did not want to make any very serious changes, as he was going extremely well then. We talked orer the matter of the weight of the shoes, etc., and finally concluded to have him shod after certain 
ideas of our orvn, which, on the following day, we carried ont.

Rarus had rather peculiar feet, which always tronbled him more or less while I had him. They were inclined to be rely high, and rather narrow at the heel. They also had something in the way of thrush, or some such clisease, for which I nere: found, perhaps, the proper name. At times of the year there would be a discharge of a purtent substance, and he would seem to get very sore in his frogrs. Before I had him he had been tronbled with one or two quarter cracks. His feet were rather inclined to be dry and hard, with occasional fever. TVe had him shod, reducing the weight of his shoes to about thirteen onnces, lowered his heels some and shortened his toes a trifle. At this time his hind feet were inclined to be rely long, and low at his heels. We shortened his toes belind, and thonght they wonld bear to be shod with six-ounce shoes, fnll at the toe, to balance him behind. The first time I drove him, after' having been thus shod, I liked him better, and he conld go faster than ever I had seen him. I also reduced the weight of his quarter hoots, having them as light as possible. At this time we had on him nothing but quarter boots in front, with light scalpers and shin and passing boots behind. The following week, at Springfield, we met Carrie and Adelaide, beating them in 2:26, 2:261, and 2:25, in straight heats, without an effort, and then we started for Fleetwood Park, New York, to trot a match race for $\$ 1,000$ with Sam Purdy, to wagon, our opponent being a stallion that Doble had bronght from Cillifornia, that had obtained a record throngh the grand circuit of $2: 20 \frac{1}{2}$, and came from the Pacific coast with the reputation of being a great riagon horse. A great many people thought that, from Rarus's formation, he would not be able to pull weight, and believed that when he came to the hill in the last half mile at Fleetwood, it would anchor him. Mr. Conklin had often told me, in our talks abont Rarus, that he could draw weight, and draw it well, as in his work orer the sandy roads of Long Island he had shown 
him all that, long before the public ever thought of Rarus. I told Mr. Crawford I thought it wonld take more than one wagon to anchor Rarus, as by this time I was convinced that the horse was not foaled that could beat hinı. I communicated my opinion to Crawford at the time, although I had never driven him any fast miles against the watrl or in his races; but I had stepped him out for short distances in his work, and he had showed me so much speed and determination and such good behavior, that I could not see how they could possibly beat him. Rarus was the farorite in the overnight betting in the pool-room at the corner of Twenty-eighth street and Broadway, New Iork, where a good many of the sports and drivers of the present time took their first lessons in pool-buying, and that was run at that time by the Johnson brothers, WTilliam and Tom; and Davey Jolınson, who has since become the most notorious plunger on the running turf, but who was then a good-natured schoolboy and a great companion of Maces, was a boy about the place. We decided not to place any more money on the race until we would see what sort of a day and track we would have, knowing from our experience at Clereland that we lad no mud horse. It. was the fall of the year, and the weather looked as though we might have rain. IThen the horses were called for the word I concluded to go out and feel of Purdy, and see whether we could beat him or not. I did so, Purdy winning the first heat in 2:313. From what I saw I was satisfied that Rarus would beat liim easily. TVe so bet our money, and the result proved that I was right, as

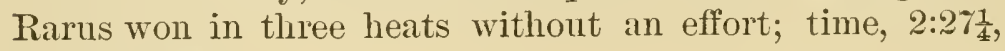
$2: 31 \frac{1}{2}, 2: 29 \frac{1}{2}$

By this time, Mr. Conklin, Crawford, and myself felt as though we were ready to tackle the world, and looked about for new opponents to conquer. It will be remembered that this was the season when Goldsmith Maid, Smuggler, Lucille Golddust, and Judge Fullerton trotted their wonderful series of races in the free-for-all class through the central circuit, Smuggler beating the Maid at 
Cleveland and at Rochester making a record of 2:15 which was then by far the best for a stallion. The Maid did not start in the Rochester race, on account of reasons personal to Mr. Doble, and as Fullerton and Lucille Golảdust were out of the contest at various other points, it so happened that the only horse that took part in all of the seven free-for-all races throngh the circuit that year was Bodiue. This horse was a big bay gelding by Tolunteer, that had been purchased a couple of years before by Mr. H. C. Goodrich, of Chicago, and that was driven by Peter Johnston. Bodine did not win a heat in any of the races, being out-classed in speed by Smuggler and the Maid, but he had always given the other's a good race and, muder Johnston's careful management, had shown himself a dangerous horse in any company. The Western people were wild about Bodine, and with some reason, since he was the best one in that part of the country. At Hartford, Mr Goodrich had a talk with Mr. Allie Bonner, son of Mr. Robert Bonner, and in the course of the conrersation the performance of Dexter, who had some years previously drawn $\mathrm{Mr}$. Robert Bonner a mile to wagon in 2:21술, a performance that to this day has never been equaled under the same conditions, came up. Mr. Goodrich wanted to sell Bodine, and asked Mr. Allie Bonner if the offer that his father had made some years previous, to pay a good price for a horse that would do what Dexter did. was still open. Mr. Bonner, while not saying that the offer still held, replied that his father would be willing to buy any good horse that could do that. And so Mr. Goodrich shipped his horse to Chicago, he having no further engagements in the East, with the idea of showing what he conld do to wagon. The seren hard races that Bodine had trotted against the Maid and Smuggler had taken a great deal out of him, as it always does with a horse that is fighting against superior odds, he heing necessarily strung ont in every heat he goes. So when the son of Volunteer came back to Chicago, he was pretty thin in flesh, and not too exuberant in spirits. The weight 
drawn by Dexter in the fast drive by Mr. Robert Bonner was 421 pounds, and in order to make this weight it was necessary for Mr. Goodrich to put a large bag of sand on the seat of the skeleton wagon in aldition to the weight of the driver, Mr. Johnston. It was perched on this piece of baggage that Jolnston, acting mner Mr. Goodrich's direction and not by reason of his own judgment in the ma'ter,

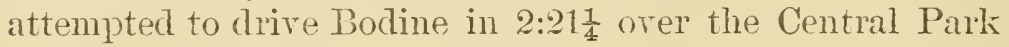
track in Chicago.

The result was that the best mile the horse conld show, rigged that way, was 2:2\%, and the look of disgust that came orer Johmston's fiace at the finish was something worth going a long way to see. After this trial $M_{1}$. Goodrich gave up the idea of selling Bodine to $\mathrm{Mr}$. Bonner. and retmmed him to the turf, entering him in the free-to-all race at Cincinnati. In looking orer the sporting papeis I saw an advertisement of this race, and, having nothing else on hand, I sent on an entry for Rarus.

On reaching Cincinnati we were surprised to find that the track was a half-mile one, and onr chance did not appear to me to be very rosy, as I had been told that Rarus would not perform well on a track of that length. The other starters were Silversides, Bodine, Cozette, Elsie Good, and Monarch, Jr. They were all TTestern horses, and considered good ones over a half-mile track. Mr. Conklin was a little worried for fear that something might happen to Rarus, but I told him not to fear. From what I saw before the race, it was plain that it would be the Westagainst the East, and I, being the only Eastern man, wonld be alone in the battle. I kept a little track of the other horses in their work, and the fastest mile that any of them went was one by Bodine in

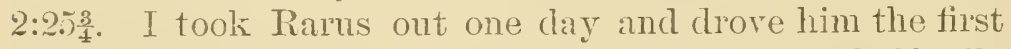
mile in 2:30. He seemed to take kindly to the half-mile track, and in repeating him lie stepped the mile in 2:27. A good many people were there to watch him, as they had heard about his performances, and were anxious to get a line on him. About this time the dimner bell at the club- 
house sounded, and everybody made a bee line for that point. I told Bamey to look after Rarus; that I would go to the club-house; that while I was gone, to put the boots and harness on him again, and that when I saw the boys comfortably seated at the table I would return and drive the horse a mile for omselves. When I came back Barney had Rarus ready, and I met Jim Murphy, a man whom I had known for some tine, and who is famous as a trainel of some of the most successful raceliorses on the rumning turf. I told Murphy my plans, and asked him to time Rarus for me from a big tree at the head of the stretch. I sent him a mile from that point, and when I came back, and he showed me his watch with the hands at

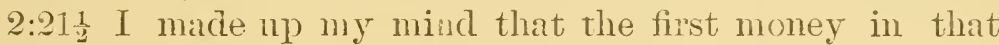
purse would go East. Then the day of the race arrived there was plenty of betting, Bodine being the farorite. Murphy had a commission from our party to put on the money, and it is not necessary to tell those who know Murphy that he did this, put on lis own money, and was willing to get on himself. Rarus won the race in the easiest possible mamer, not losing a heat, the miles being done in $2: 25 \frac{1}{4}, 2: 24,2: 25 \frac{1}{2}$. Silversides got second place, Bodine being obliged to content himself with third money, thereby carrying down in the pool-box all who backed him.

About this time the Fleetwood Park people in New Tork offered a purse free to all trotters with the exception of Goldsmith Maid. I had been driving the chestmut gelding, Juclge Fullerton, in the free-for-all class against Goldsmith Maid, and at this time had him in my stable. I said to Mr. Humphrey, his owner, that if he had no objection I wonld like to trot Rarus in the Fleetwood Park purse, and after talking the matter orer he conchled that he would give Fullerton to John Murphy to drive in this race. A great many people thought the purse would not fill, but, when the entries were opened, we found that a lot of other" drivers had figured just as I did, and thonght they wonld get some easy money by dropping into New York. The 
result of this was that, beside Rarus, there was also entered Great Eastem, who had been a winner in his class through the circuit, making a record of $2: 18$. This horse was the largest trotter I ever saw, standing orer seventeen hands high, and had been very successful that year under the managemen't of Jack Feek. Judge Fullerton was also in, as I have stated, and appeared for the first time with John Murphy behind him. Then came Lucille Golddust, who had always proved herself a first-class performer in any company. She had been trotting third to Goldsmith Maid and Smuggler through the circuit, beating 2:20 two or three seconds every heat. The great stallion Smnggler, with his record of $2: 15 \frac{1}{4}$, made only a few weeks before, was also one of the starters, and Frank Reeves, who was a little out of his element, completed the field. When Mr. Conklin saw that I had Rarus in this race he seemed quite pleased to think I would give up Fullerton, as fast a horse as people supposed he was, to keep his horse and trot him, and asked me how I came to do it. I told him I considered Rarus much the better horse of the two, and that I thought he would beat Fullerton easily. He asked me what I figured from. Fullerton had a record of 2:18, and had shown miles much better-was, in fact, considered a dangerous competitor for any trotter except Goldsmith Maid. I told Mr. Conklin that I could have driven Rarus in 2:20 over the half-mile track at Cincinnati, and I did not think Fullerton had ever seen the day he conld have done that. After our return from Cincinnati we had a week before the Fleetwood race, and $I$ gave Rarus very light work, the best mile being $2: 25 \frac{1}{2}$. I stepped him down the hill a way as fast as he conld go in this mile, to see what he would do on the down grade, and noticed that he wanted to break, and acted as thongh he was not properly balanced. In the last half of the mile 1 sent him 11p the hill fast, and this grade also bothered him. There was a reverse turn right in the sharpest part of the hill, and that seemed to annoy him, but I never saw him when he appeared to have more brush in the stretch. 
After thinking the matter over carefully, I concluded to change his shoes, and put a little more weight on the forward feet, to balance him going down the hill. I was sure he would out-trot every other horse in the race if it came to a finish. This was the first race I had ever had Rarus in where I felt that he was meeting horses that were anything like his equal in speed, and so I bent all my energies to have him in the pink of condition; my only fear was that the shape of the track might make him unsteady. In shoeing him I put about two ounces more on the forward feet, and when we scored for the word in the first heat I was in every way satisfied, and made up my mind that, if he was beaten, the one that did the trick would get a great mark. 


\section{CHAPTER IV.}

Rarus wins his first race against the crack trotters of the country- $\mathbf{A}$ private trial in fast time over the Fleetwood track-The trip to California with Goldsmith Maid-Another fast mile in private, and a refusal of $\$ 45,000$ for the gelding-Andy Daniels and the cattle raiser at Chico-Insile facts about the race in which Rarus beat Goldsmitl IIaid-Coming East again, and lowering his record to 2:16--The wonderful race against Great Eastern at Fleetwood Park.

In the betting, Rurus, Fullerton, and Great Eastern sold about eren, Lucille Golddust, Smuggler, and Frank Reeres composing the field. I concluded to follow the old plan of laying up a heat or so, and did this for two reasons. In the first place I knew Fullerton to be a fast horse, and felt that, with Murphy to drive him, he would make the fight from the first score, as that was the plan I had seen Murphy follow in all his races. Second, the rack was deep from rains, and I thought that every minute of wind and sun would make it better. Fullerton won the firstheat in 2:22, and I nerer saw any man show more pleasure and excitement than did the horse's orner, Mr. TVilliam Humphrey, at the finish of that mile. The New Yorkers go wild over John Murphy, and they gave him a cheer when he came back to the wire, the Irish contingent being specially rociferons. I think Murphy felt quite conficlent that he was going to carry off the race, In this heat I contented myself with just saving my clistance. After the finish Rarus cooled ont well, and I had never seen him when lie was a better horse. I talked the race orer with Mr. Conklin and Mr. Crawford, and we concluded to invest a little money on Parus at the odds, which had shifted in favor of Fullerton. There was a great deal of betting; the 
general public backing Fullerton. A few of my intimate friends, like Mr. Simmons, Jack Bachelor, and Mace, put down their money on my chances. We decided that if no one else gave Fullerton a fight for the second heat, we would make the battle with Rarus. In the meantime there was a rumor in the betting ring that Feek was rery sweet on Great Eastern's chances, and the betting soon showed that somehody was putting a lot of money on that horse. In scoring for the second heat Great Eastern showed as much speed as Fullerton, which somewhat surprised the crowd, as the chestnut gelding had the reputation of being able to outscore almost any horse when he would go on a trot. From the way in which Feek scored I was satisfied that he would make a fight for the heat, and sodetermined to lay up again. Great Eastern and Fullerton went at each other, hammer and tongs, and in a driving finish for the last two hundred yards, Great Eastem ontlasted Fullerton and beat him half

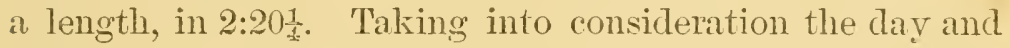
track, I have always considered this the best mile that Great Eastern ever trotted.

I now began to think that our chances looked rel'y rosy, as Fullerton and Eastern had gone two corking miles, and I was sure that Rarus could come back in 2:20, which, to my mind, was certain to win. In going off in the third heat I concluded that Fullerton and Eastern would make the pace" from the start, but I decided to drive my horse a rating mile, paying no attention to the brushes that they might indulge in. Sure enough, the pair went away with the lead, I contenting myself with fourth place. 'They out-trotted Rarus the first quarter, but in going along the Morrisinia side I spoke to him, and he mored up and closed a part of the galp. As we struck the hill coming to the Rocks, Fullerton broke, and Great Eastern drew away from Rarus. I could never. account for it, bnt I never saw a horse that could ontspeed Great Eastern going up this hill. What is usually termed the Point of Rocks on this track was where he ont-troted Rarlus this time, and in another race lo clich the same thing. 
After we were over the hill I set Rarus going, and he slowly closed on Great Eastern. Two hundred yards from the wire he had him beaten by a neck. Feek drew his whip and began to drive. Eastern responded very gamely, and went a hundred rards with Rarus, but from that point out he slowed a little, and, as my horse kept up his even clip, we were first to the wire by a head, in $2: 21 \frac{1}{2}$. 'The fourth heat Rarus won easily by two lengths, in 2:23, and then the race was put over until the following day.

Although the time of these heats does not in these days appear fast, yet when one takes into consideration the season of year, the condition the track was in from lain, and the further fact that, at that time, the fastest mile that had been made by any horse over Fleetwood in a race was $2: 19 \frac{1}{2}$, it will be seen that Great Eastern's 2:20 $\frac{1}{4}$ was certainly a first-class performance. Rarus did not seem to be much distressed after the race, cooled out nicely, took his feed well, and in every way showed me that the struggle had done him no harm. About the hotels and pool-rooms that night there was a great deal of gossip over the race. Rarus had rather surprised the people. While he had been wimning his races through the circuit, he lad not met a horse that was considered first class. The manner, therefore, in which he handled Great Eastern and Fullerton was a revelation to the public. Of course, as is always the case on lace-tracks, there were some people looking for an excuse when an unexpected horse wins. Some of them said that Fullerton was not himself, and others asserted that Feek had not driven Great Eastern very hard, but from where I sat in the race, I concluded that Rarus had beaten them both on their merits, and felt certain that he would win again the next day. That erening Dunn Walton came to me and asked if I would price the horse to him for a gentleman who wanted to buy. In our talk, he insinuated that Rarus had won because Fullerton and Great Eastern killed each other, while my horse was laid up. I told him that if he felt that way I would not price the horse to him that even- 
ing, but that when we trotted the following day, if either Fullerton or Great Eastern beat Rarus to the half-mile pole, I would price him much cheaper. He smiled, and commenced to tell me about some of the halres that Mace had driven Fullerton, but I told him that I thonght Rarus could beat Fullerton any race from the length of a corn-cob out to the Rocky Mountains, and, if I did not convince him next day that he could do so, I would buy him a red apple. Dumn and I were always good friends, and he was a very jolly companion. WVe staid around there for some time, talked the race orer, and Dunn told me that he had not got his winter's coal yet, and that, if Rarus was that kind of a horse, he would take a few tickets on him in the morning, and fill up his coal-bin with the proceeds, which he did. When the race was called the next day, the track was much better, but the weather was very raw and cold, and only a few of the great number of people that we had seen the day before came to witness the finish of the contests. I gave Rarus an easy mile about twenty minutes before the call of the race, not better than 2:30, but stepping the last hundred yards about as well as he could go. An idea of the estimation in which I held the horse may be got from the fact that when I stepped ont of the sulky, Mr. Simmons asked me what I thought of my chances of winning, and I told him that I thought he would win sure, and further that he could beat any horse that I had ever seen, Goldsmith Maid not excepted. There had been much talk abont Fullerton and Great Eastern out-trotting Rarus, and, when I thought the matter over carefully, I male up my mind that the surest way to beat them both was to carry them down to the halfmile pole as fast as they could go. Then the word was given, Rarus had the pole, and Eastern the second place, with a slight adrantage. In going around the turn, Feek's horse crowded me a trifle. I spoke to Jack, and he pulled him out. At this time, Feek's wheel was at my horse's neck, and from there to the turn beyond the quarter pole they never changed positions. When we struck that turn, Feek had 
a little further to go, and Rarus landed head-and-head with him. From that point to the half-mile pole they went like a pair of liorses in double harness. From there on, howerer, Rarus ont-trotted Eastern, beating him up the hill. As we came by Mace's stables, Dave Muckle yelled to me to look out, or I would beat 2:20. By this time Lucille Golddust had passed Fullerton and Great Eastern, and overhauled me in the stretch, but Rarus was going easy, and when she came up I spoke to him, and hemoved out, and beat her in the easiest kind of style in 2:20.

Thus ended the first race that Rarus had ever started in against a field of horses that I considered anything lilie his class. This performance conrinced me that I was right about his ability as a trotting horse. The easy manner in which he handled Fullerton and Great Eastern, when I had really set out to race with them, proved to me conclusively the truth of all that I had thought of him. Up to this time he won every race but one I had driven him, beating all the horses in his own class, and finally winning a free-for-all race with Goldsmith Maid barred, but all the other good ones in. In doing all this he had not beaten 2:20. This was a great comfort to me at that time, although, as I shall subsequently show, he might as well have gone in 2:16 that day, for all the effect it had on his future career. In'talling the matter over with Mr. Conklin that night, I found that he seemed very much pleased in anticipation of the satisfaction he expected to derive from hearing his neighbors take back all they had said about his being daft when he predicted that Rarus would some day beat all the best horses in the country.

The night after the race I met Mr. Doble in the Gilsey House, New York, and we naturally fell to talking about it. He told me he thought Rarus had the making of a wonderful horse. Up to this time I had known Budd only in at general way, he being a few years older than myself, and, as I had always been connected with Mace, I never trained in his line, as it were. In the course of our conversation, 
California, and the effect its climate had on trotting lorses, was mentioned, Doble giving me his riews in a general way, and it set me to thinking whether or not it would not be a good thing to take Rarus to California. The more I thought of it, the more I was convinced it would be al good plan. I went to Long Island, and talked the matter orer with Mr. Conklin. WVe staid up late in the night, and riewed the plan from every standpoint. Of comse there was a cliance of accident, etc., in shipping a raluable horse snch a long' trip; but, after a general discussion, Mr. Conklin agreed to leave the matier entirely with me. I came back to New York, thinking I would liare another talk with Mr. Doble, but was disappointed to learn that he had left for Philadelphia. The following week I went to Philadelphia, and spent the day with Bucld. I had a further talk with him on the subject in question, and the result was that I decided to ship Rarus to California. Budd said he was going io send his horses from Chicago in a short time, and that I wonld be welcome to go in his car if I liked to come. I went back to New York, and made my arrangements to go.

After concluding to talke my trip to the slope, I was rather anxious to see Rarus go a mile as well as he could. I met Mr. Arthn Gillender in the evening, and, in talking of the merits of the horse, I told him I thought he conld trot a mile over Fleetwood better than 2:18. He rather doubted that statement, and the conversation ended by my inviting him to go to the track the next morning and time him while I drove him a mile abont as well as he could go, as I thought then he was in shape to go a good mile. Then we arrived at the track we found it in rery good shape, but the (lay was rather cool. I gare Rarus a warming up) mile in 2:25, and twenty minutes later repeated him in $2: 1 \%$, which was three seconds faster than I had ever driven him before in pulblic or private. This I thought a remarkable mile, as I kept him well out from the pole all the way, and the track at its best was never rery fast. When Mr. Gillender came back to me, he said: "Splan, you match that horse against 
Goldsmith Maid for five or ten thousand dollars a side, and if she beats him I will do the losing." I had thouglit for a long time that Rarus would be able to beat Goldsmith Maid some day, and lower her record; but I was not quite so sangnine at that time as Mr. Gillender, for I knew that before my horse could defeat the Maid he would need some further education. I had seen a good many fast horses have a shy at her, and the consequence generally was that, sooner or later, they got beaten. I made up my mind to profit by their experience, and not give her a fight until I was sure I had everything right.

In the meantime the Utica Park Association had offered a purse for Rarus and Great Eastern to go a race to wagons. I concluded to enter Rarus there, as it was on my direct road to Chicago, and did so. In going to Ltica from New Tork it turned ont, owing to the delay from an accident, that we never reached the track until the morning of the race. The track was wet and muddy, and Rarus seemed sore from his long standing in the cars. Great Eastern beat him in straight heats, the time being $2: 35,2: 30,2: 24 \frac{1}{2}$. The canse of the first lieat being so slow was that Rarus threw a slioe. After this race I shipped Rarus to Chicago, and from there, in Mr. Doble's car, to San Francisco. Tre reached California about the latter days of November, and on my way there I improved my time making the further acquaintance of Doble. I thought to inyself: "Here is a man that has trained the only horse that ever trotted a mile in $2: 14$.' I knew enough about horses to be well aware that, be a trotter ever so good, the animal must be well trained to perform such a wonderful feat. Thinking that I had a horse that was able to go that well, if properly handled, I made up my mind to leam everything I conld from $\mathrm{Mr}$. Doble in the way of fitting a horse for such a performance. I stated the case to him, and he, with his usual modesty, told me that, if there was anything he could teach me, he would be glad to do it, but from what he had seen of me, skirmishing along the line with the boys, he thought, perhaps, I was as liable 
to hustle a lıorse around in 2:14 as anyone he knew. Then we arrived at San Francisco, and got ready to train the horses, I said to Mrr. Doble again that I would consider it a faror if he would give me his ideas about training that particular horse. I have always been a belierer in giving every man credit for what I thought was his due, and for that reason I wish to state here that Mr. Doble taught me many things about training horses that other people might liave known about, but which, up to that time, had never entered my head. He was one of the first men that erer taught me the danger of orerfeeding a hor'se. Rarus was, withont exception, the greatest feeder I erer saw. I held at that time what I have since considered a mistaken idea, that it was proper to give a horse all he wanted to eat in the way of grain, etc.

Another thing that Budd taught me was that a horse could be put in condition with a great deal less fast work than I had at that time supposed possible. His idea was to give them plenty of what we call three-quarter speed, with longer work from a mile to a mile and-a-half and two-mile heats, never under any consideration giving them what some of the boys term "reefing." He adrised me a good deal about the shoeing of Rarus, and about this time something happened to that horse that 1 nerer saw in any other. He had a quarter-crack in one of his hind feet. When I saw that, I thought the jig was up for the present. Budd told me that the Maid once had such a foot, and that he could fix the wound so that I could work Rarus without any trouble. IVe took him to the shop and had him shod with a bar-shoe on the affected foot. Then we took a saw and sawed the bearing out underneath and had the for.t sewed in a canvas bandage with some balsam of fir. I liejt him at work, seeing that the foot was always clean, and renewing the bandage occasionally, and I never saw any plan work better. For the first thirty clays I gave Rarus no work better than 2:25. 'The Californians who came out with their watches every morning to see him go became rather dis- 
gusted, and concluded that the stories they had heard about his speed were, to say the least, a little orerdrawn. After timing him a good many miles in from 2:25 to 2:27, and seeing no part of a mile done at any better rate, they shut up their watches and went to sleep. I think that before the winter was over they regretted having done so.

On Budd's return to San Francisco he had sent Sam Purdy to the stable of his owner. I met that gentleman one day, and he asked me how I explained Rarus beating Purdy at Fleetwood to a wagon. I told him I thought Rarus rather ont-trotted Purdy. This seemed to roil the gentleman slightly, and he proposed a match. I arranged a race with him on the spot. At this time there was in California quite a celebrated driver by the name of Tom McClellan. The people there seemed to have a great deal of confidence in his ability, but I always thought him a little on the slam-bang order. He weighed at this time about 190 pounds. Purdy was placed in his hands to condition and drive in the race. I made up my mind that, if Purdy conld draw 190 pounds against Rarus' 150, and beat him, I would not have any money left when the race was orer. Purdy was rather a lazy horse, and the people of California fancied that McClellan could drive him better than Mr. Doble, arguing that Budd was not severe enough with him. The race came off., and Rarus beat Purdy in straight heats, the fastest being 2:201. This was in the last mile. I made a close race of this at the fini-h, just beating Purdy and that was all. I trotted Rarus three races that winter in Caliornia, which he won, the first being against St. James and May Howard, and another against Bodine, and then came a race about which I desire to say something in detail.

Having no further engagements for Rarus, I thought this a good time to find out something about his speed under the watch. Abont this time Mr. Conklin paid California a visit to see Rarus and mrself, and I told him that if he wished to see Rarus go a mile under the watch I would put him in order and we would give him a mile to 
get a line on him, as I had nerer driven him a mile better than 2:20 but once, and that was for Mrr. Gillender, at Fleetwood, where he went in 2:1\%. The day Goldsmith Maid was twenty-one years old Budd drove her for Governor Stanford a mile in 2:16, a performance that I never expect to see any other animal make under similar conditions, and that I think spealis volumes for Mr. Doble's ability and care as a trainer and driver. To have had a mare under his charge all those years, and to have driven her over all kinds of tracks, travel the country with her in steam ears fiom one end to the other, and then drive her a mile in 2:16 the day she was twenty-one years old, stamps him in my mind as a trainer without a peer, if he had nerer done anything else in the line. Trhen Mr. Conklin saw the time on the board he asked me if I thought Rarus could do that, and I said, "Tes, sure." The day following Mr. Conklin and myself drove out the Bay District road, and I gare Rarus a couple of miles in about 2:25. Twenty minutes after, I brought him to the track, and asked $\mathrm{Mr}$. Corey, at that timf the superintendent of Governor Stanford's farm, to go with Mr. Conklin and time him. I scored up for the word, and at the first attempt Rarus went the first quarter in 34 seconds, the second in 34 seconds, the third in 34 seconds, and the fourth in 33 seconds. I spoke to him at the distance stand and from there to the judges' stand he stepped off at a pace that I have never seen any other trotter make. He finished strong' in $2: 15$.

I don't think Mr. Conklin was much surpurised, and I myself was not in the least, as I was sure he could do all that and more; but Mr. Corey was about as astonished a man as I saw while I was on the coast. He immediately asked me what I would take for Rarus if he was for sale. I told him that Mr. Conklin was the only man I knew who could answer that question. When he asked Mr. Conklin if the horse was for sale, "Pap," as we always called him about the stable, said, no; that he did not think thit he would care to part with his horse. After considering a moment 
Mr. Covey said: "Mr. Conklin, I will give you $\$ 15,000$ for that horse, and you need not take the harness from him." I expected to hear my partner say, "I am going to let you have the horse," but he answered "No," in about the same tone of voice that he might have used had he been offered a respectable price for a barrel of flour. When $\mathrm{Mr}$. Corey left us, Mr. Conklin asked me how well I thought I conld drive Rarus a mile if I sent him 'for' all he was worth. I told him I thought about 2:12, and asked him if he did not think he had better take the $\$ 45,000$. He said, no; that Rarus could earn that much money, and that he thought he would be able to sell him for that price at almost any time, all of which became history afterward. I afterward learned that Mr. Covey made the offer for a wealthy citizen of San Francisco, who was anxious to own the best horse in the world.

After I got my horse in condition Mr. Doble and myself started out to trot a few races with the Maid and Rarus, it being now the latter part of March. These races, by the way, were adrertised as exhibition purses, it being announced on each occasion that there would be no poolselling; and that Goldsmith Maid would try to beat her record. The reason why we advertised it in that manner was that I did not think that Parus was in order to beat the Maid, and I did not want to go out and tear him to pieces against such a mare as I knew she was. I never deceived anybody in any way with regard to my trying to beat the Maid with Rarns, and no one ever expected when they paid their dollar at the gate that I would. The reason I make this explanation is, that a race came off afterward about which there was a great deal of newspaper criticism, and which I will explain when the proper time arives. At San José, on the 31st of March, we trotted the first of these races, the Maid winning in straight heats, going the fastest

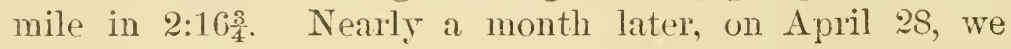
took the horses to Los Angeles to give another exhibition. Budd was taken sick, and was not able to leave his bed. 
What to do I did not know. The exhibition was advertised, and the town full of people. Right here I may tell a little story that will serve to show the uncertainties oilhorseracing. TVe also had with ms on this trip Bodine and Occident, the latter being a horse that at that time belonged to Senator Stanford, of California, and that had made a record of $2: 16 \frac{3}{4}$. which at the time of the performance was the best mile ever trotted on the Pacific coast. Occident was a horse of most romantic listory, having been taken out of a peddler"s eart and his speed developed when he was past the age of maturity in most horses, and further handicapped by not heing any too sound. The fact that Governor Stanford owned him, and that he had gone such a fast mile made Occident a great attraction on the coast, and he would always draw a crowd. Bodine, a horse that was in my string, had been sent to California from Chicago by Mr. Goodrich, his owner, who understood that a winter in that climate would help him a great deal, he haring been pretty well worn out by his races of the previous summer. These two were to trot for a purse, and I was always firm in the belief that Bocline could beat Occillent easily orer any track. At this time they had never trotted together. Budd concluded thint the best thing he could do was to get someone to drive Occident and the Maid for him, rather than disappoint the people. A leading driver of those parts was Ilenry McGregor, who originally hailed from Michigan. Budd arranged with him to drive the race, and it looked to me as though Bodine had a cinch on Occident, as I knew he was rather a peculiar horse to handle, and McGregor had never heen behind him. Uncle Ben Tright, of Boston, happened to be over on a trip for his health, and to his willing ear I confided the good thing I had on the boys and told him to play my horse. He asked me how high he should play him, and I told him just as high and as long as anybody would play the other one, and have always been sorry since that the other people lnung on so long, as the race came off and Occident beat Bodine in five heats. That was 
the first time I ever heard the remark applied to a horse race: "We have met the enemy, and we are theirs," which was the expression to which my partner gave utterance when I saw him after the deciding heat. In the race with Rarns at Los Angeles, G.Jlsmith Maid won, the best time being 2:19. It is needless to remark that Henry McGregor's stock as a trotting-horse driver went up a couple of points, after beating Bodine with Occident, and Rarus with Goldsmith maid, and for all I may know he may still be enjoying the fruits of that victory in increased patronage.

From Los Angeles we shipped to San José, where, on May 12, the Maid again went three heats against Rarus, the time being 2:161. Then we shipped to Chico, where there was a new and very fine track, and in this race occurred an incident which has always seemed to me one of the most ludicrous that ever occurred in connection with trotting. Among our contingent of side parţner's was Andy Daniels, then a hale, bright-eyed gentleman, who had been a horseman, trainer, and owner when I was a boy and used to creep in under the canvas, he having been one of the original party who purchased the mare Princess, that afterward became the dam of the stallion Happy Medium, and took her to California, where she trotted so many famous long-clistance races. Daniels had buffeted the wares of fortune for many years, sometimes being on the foam-crested billows of prosperity, and again on the rocks of disappointment and adrersity; but no shock, hurerer serere, could, for an instant, crusl his exuberant spirits, and he was always ready to again put on the glores with fickle fortune. When we got to Chico there was a great crowd that had come in from the surrounding country to witness the lace and the inanguration of the new race-track, which, in those days, in that country, was far more important in their estination than the dedication of a church. Among them was a wealthy ranchman, and who had never seen any really first-class trotter's. Some of the fastest ones in his country were able to step in 2:30, or thereabouts, and he had got it fixed in 
his mind that these figures represented the acme of trotting speed. As I stated before, there was no pool-selling at these exhibitions by Maid and Rarus; but, in some way or other, Andy Daniels fell foul of the ranchman an hour or two preceding the race, and the Californian at once stated his opinion of our combination, finclly winding up by offering to bet a large sum of money that there was not a horse in the outfit that could beat 2:17 orer that track. Daniels came to see me for a diagnosis of the case, and after he had stated the conversation I advised him to go back and bet the stranger a reasonable amount that $2: 17$ would be beaten. With his usual enthusiasm in such matter's, Andy hunted up his man at once, and before he had left him had bet him all the money he had and given his assurance that enough more would be forthcoming to satisfy all the cattle-raisers in that section of the country. Doble came on from Los Angeles on the morning of the race, and I told him about the money that Daniels had bet on 2:1 $\gamma$ being beaten. Budd was not very sanguine about the matter. but we went out to trot with the intention of doing all that we could to win the money for Daniels and ourselves. In the first heat the Maid went about as well as she could, Doble driving her almost all of the way ; but she seemed tied 11 ), and not exactly at herself, the result being that she finished the mile

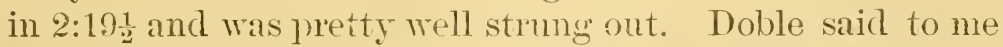
it was not possible for her to beat $2: 17$ that day. I thought the matter orer and then replied to Budd, "I'll give you one more chance to get the money, and then if you don't do it, I shall have to see how my old horse can go." IVhen we started for the second heat the Maid went away faster than before, and struck the half-mile pole in just 1:(1) $7_{\frac{1}{2}}$, beating Rarus to that point five or six lengths. From there he closed on her gradually until they tmmed into the stretch, when he was on her wheel. She nurle one break; but, to say the least, it was not a barl one, and she came to the stand on a trot at 2:14를 beating Rarus the heat. When they hung out the time on the board, the cattlemen took a 
look at it, turned to Daniels and said: "My pretty boy from San Francisco, you have had a shade the best of me. I have been betting you did not have one horse in your outfit that conld trot in 2:17. Jndging from the way these two acted, I don't doubt now that yon have a whole barn-yard full that can go that well." As Andy had won the money and was in a liappy frame of mind, he could afford to be pleasant with the comntryman.

As Mr. Conklin and myself were visiting a friend that evening, I told him I was sure that Rarus could beat the Maid a good deal oftener than she conld him-in fact, that I did not think, from the present aspect of affairs, that she conld beat him at all. Tre then came back to San Francisco, where we had other engagements, and there occurred a race which has already been criticised by the press, public, and pool-buyers, from every possible standpoint, and I have been accused in connection with it, of everything in the world excepting murder in the first degree, and, like the gentleman in the story who devoted most of his last will and testament to a vindication of a charge that had been made against him, I want to state my side of this race before I die, and while some of the other people that were connected with it are still on earth. Mr. Doble had of tentimes, when I had been otherwise engaged, driven ny horses in their work for me, and I had done the same for him. Perhaps ten or fifteen different times through the winter, I had driven Goldsmith Maid under his directions in his absence. After our return to San Francisco, omr first plans were to go East immediately. With this idea in view, we commenced rreparing the horses for the trip. One morning when I was going to the track, Mr. Doble asked me if I would not work Goldsmith Maid a comple of miles at a certain pace, and gave me an order on "Old Charlie," who rubbed the mare, to that effect. I worked her exactly as Mr. Doble directed. If I remember right, he told me to drive her two miles in abont 2:25. I recall perfectly that I drove her within three-fouths of a second of what he told 
me to do, which for a boy seemed to me pretty fair. Abont this time the proprietor of the Oakland track advertised a purse, free for all horses, entries to close at a certain day. I did not ask Budd whether he was going to trot Goldsmith Maid, and he did not ask me whether I intended to start Rarus. I did not think Budd would enter his mare, from the fact that I had often heard him say he would never start her in another purse. When the entries were opened, I was somewhat surplised to learn that Bndd had nominated Goldsmith Maid. I had entered Rarus, and I think sent a check for his entrance. I saw the proprietor of the track, and he informed me there were only those two entries, but that if I would guarantee to give Goldsmith Maid a race, lie would let the money go for these two. I never knew what he said to Budd, if anything; but I don't think he had any talk with him about it. I had alleady, in my own mind, concluded to give Goldsmith Maicl a race at that time, althongh I did not care to state so to the proprietor of the track, as that was a matter that I thougint would be worth something to me to keep to myself. Anyway, the proprietor accepted the entries, adrertised the race to come off in connection with the balance of his meeting, and I commenced to get my tools ready to give people what Jack Phillips calls "a yearly lilling:" I never talked to any one abont the race in any way, slimpe, or manner, with the exception of a gentleman of the name of Kenner, whose acquaintance I had made while in San Francisco, and who was in the habit of doing a little betting, occasionally. I worked my horse ont abont three days before the race, and then and there decided to back him and try to beat Goldsmith Maid. I went to Mr. Kenner, stated the case to him, told him that I was sure I could beat the Maid, pointed out that she was old, and that if it came to a long-drawn fight Rarus must certainly wear her out, and that I believed he conld out-trot her in the first half-mile in the first heat. I further told him that if Rarus did not beat the Maid, I would be more mistaken than 1 had been about a lace for a long time. 
Mr. Conklin was in San Francisco at the time, but he never seemed to take much interest in the details of the races. He always appeared satisfied to leave everything to me, and nerel wanted to bet any money, with the exception of what I bet for him, and for that reason I never said anything to him about this race. Mr. Conklin's son was there, but I did not even tell him, and if I remember rightly, he had a few small tickets on Goldsmith Maid. I told Mr. Kenner that I would like to have him manage the betting, that I had not told any one else what I was doing, and that he was to look after that part of the race entirely, while I took care of the other end of it. I think the arrangement was, that we were to divide the profits or losses of the pool-box into three equal parts, the sharers being $\mathrm{Mr}$. Kenner, Mr. Conklin, and myself. While this was going on, I saw Budd occasionally, but I did not consider that he had any claims to know my business, and I did not tell it to him. 'The betting' opened on the race two or three days before the day fixed for it, in the Lick House saloon, Goldsmith Maid starting off the biggest kind of a favorite. On the day of the race Mr. Kenner played Rarus rather carefully, not daring to pile it on too hard for fear it might spoil our chances. When the day of the race came on and the people arrived at the track, they were a little surprised to see a man continnally backing Rarus against Goldsmith Maid at the odds. So persistently did this man play my horse, that at the end of an homr he had forced him up in betting considerably. The effect was somewhat like that of a man buying all the wheat offered on the Chicago Board of Trade, thus forcing up the price of it. About the time the race was to be called, a sample pool was: Goldsmith Maid, $\$ 500$, Rarus, \$450. A friend of Budd's came down to the stable where he was standing and told him in my presence how the betting was. Budd seemed to realize that there was something going on, and he tmmed and asked me what I thought made that betting. I told him rery frankly that it was my money going on Rarus. He seemed surprised, and then I 
told him further that I would win, sure. At this tine it was raining and continued to do so until it was likely to make the track slightly disagreeable. Budd went to the judges' stand and objected to starting the Maid, on accomnt of the weather. The judges told him he would have to start her, and that if he did not they wonld pick ont some other man to drive her for him. I myself felt a little shaky, knowing that Rarus was a very poor mud horse, and I conchuded that if the rain continned for any length of time, I would try and draw him, and in that way get the money declared off. When we scored for the first heat, I found that Rarus could easily out-trot the Maid. She had the pole, and I concluded to trail until she turned into the stretch. Wre went to the first three-quarters of the mile in that way, but as we started home from the head of the stretch, Rarus threw off a quarter-boot and made a rild break, something I liad not seen him do in six months. I merely pulled him up, and made no further move for the lieat, Budd winning in a jog. When we got the word in the second heat I set sail to make the Maicl go from start to finish. She out-trotted Rarus around the first turn, but in going down the back stretch I got lıead-and-head with her, keeping very close to her. Budd called to me to pull ont, saying that, if the Maid made a break, she would certainly go into the fence. I did not pull out, simply kept my place, and, as we passed the hralf-mile pole, she made a lunge and a break, and tore off one of her quarter-boots, cutting her quarter. All this I saw at the time, as she was nearly as close to me as Rarns was. From there on, Rarus won easily, liis time being 2:191.

This was the first mile in a race he had ever gone better than 2:20. After the heat, Budd wanted the judges to let him draw the mare on arcount of her foot, which they declined to do, and Rarus beat her the two next heats, without, an effort, in $2: 19 \frac{3}{4}, 2: 20$. After the finish of the deciding heat a lot of people who had bet their money on Croldsmith Maid, thinking they had a sure thing, and who had gone 
around San Francisco all winter saying that I did not dare to beat Goldsmith Maid, and that Budd had control of both horses and a contract on Rarus, I being simply driving for him, set up a howl, and said they had been cheated ont of their money, and that they would stand no such nonsense. They did not propose to let a New Yorker come over there and trick them in that way. They asked the judges to declare the money of:, and at one time it looked as though they would accomplish their object. The judges, howerer, after a fair inrestigation, concluded that the race had been trotted on its merits. They so decided, and declared that the pools must follow the race. A good many people had over-played themselves. At this time a Californian could simply put his word in the pool-box, and it was a number of days before Mr. Kenner was able to obtain the money that was won on the race, some of it not being collected until after I left California for the East with my horse. This race probably shook up San Francisco as bad as anything since the last previous earthquake. Of course, there was a tremendous howl in the papers, and I think the reporters who wrote it up must have been the most industrions men in the world. Up to then they had always treated me fairly well. but from the time Rarus beat Goldsmith Maid until the first edition of their papers came out, they found ont mole mean things about me than I had been able to learn about myself in a lifetime. They did not blame Mr. Conklin nor anyone except myself. They seemed to think that I was the sole promoter of the "felony," as they were pleased to term it. A good many of Budd's friends sympathized with him, and, as they had lost their money, blamed me, for what reason I could never see, as I did not, I am sure, compel them to bet on Goldsmith Maid, and I always supposed until that time that a man lad a right to bet on his own horse. Budd, naturally enough, felt very badly. To begin with, he loved froldsmith Maid as no other man ever loved a horse, and he felt as $I$ or any other man of sentiment would at seeing the farorite animal of his life defeated. I 
don't think Budd ever accused me of treating him dishonorably in the matter, in any way, shape, or manner.

The curious feature of the case was, that the result of this race was not sent East by telegraph, and only became known there when the California papers arrived. I shipped for the East directly after the race, and my first intimation of the storm that had been brewing was at Chicago, when I read in the Tribune of that city a ferocions attack on me for my part in the affair, it being intimated that I had robbed the whole State of California, and had intentionally worked ont the Maid the day before the race in snch a manner as to deprive her of any chance of victory. I remember rery well the first time I met the young man who has assisted me in the preparation of this book. It was at Dexter Park, a day or so after I arrived. He was at that time the sporting editor of the Tribune, and we had never come together. He was fresh from an interview with W. H. Crawford, and both of them were pretty hot when we met on the quarter stretch. I had read the article in the Tribune, and, not being as familiar then as now with the ways of newspapers and editors, and having looked it over rather hastily, attributed to Mr. White many of the statements that were really made in the California papers. We had it, hot and heary, for awhile, but finally discorered that both of us were agreed as to many ficts, and from that incident sprang up a friendship that has contimued withont interruption erer since. It may be stated here that Rarus nerer again met the Maid, although there were some purses offered that Mr. Doble conld have started her for had he seen fit. As a matter of fact, she never started again against any horse, but, aitel' giving a few exhibitions in the early summer of $187 \%$, was retired from the turf, and put to breeding at the Fashion Stud Farm of Mr. H. N. Smith, who had owned her for many years, as well as Lucy and Lady Thorne, two other famoas mares of their day.

From Chicago I shipped Rarus to Michigan, and started him there on June $22,187 \%$, in a free-to-all purse, his op- 
ponents being Cozette, Little Fred, Slow Go, Lady Mand, and Nettie. This race came as near furnishing me a disagreable surprise as any in which the horse had ever taken part. After bringing Rarus from California, I had indulged lim in his work, thinking that I would not strike a horse that could give him a race. I had made up my mind to go easy with him through the early summer, and try to get him on edge for the grand circuit. I went to Giand Rapids with him in this condition, and struck there what was as good a field of hor'ses as erer started orer a half-mile track, Cozette having a record of :2:19, Lady Maud one of 2:18 $\frac{1}{4}$, Little Fred

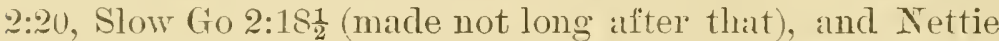
could beat 2:20 then, and eventually made a record of 2:18. I conchuded to lay Rarus up the first heat, and let the others make the tight; but I soon found that, if they did any fighting, it would be against me. Cozette won the first heat

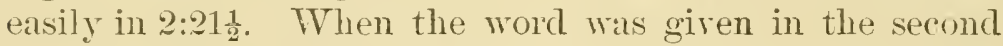
lieat, Slow Go interfered with Rarus at the first turn; my horse made a break, and I did not try for the heat, Cozette

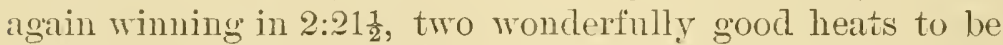
trotted orer a half-mile track. This convinced me that if I won the next heat. it would be necessin'y to set sail from the start, and this I did. Cozette and Little Fred made the race with me. The black mare, that has longsince gone from the turf and been put to breeding, was a steady trotter, and Little Fred was also a good trotter, as well as the best rinner I ever saw in harness. Morrell Highie was a little orer weight, but the most industrious man, with that sort of a horse, that had ever appeared on the turf. When George Toorhies, who drove Cozette, found that Rarus was beating his mare, he pulled up, and let IIighie see what he could do, and the result was that Little Fred gave me a hard race to

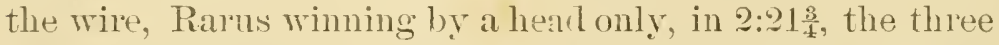
heats being the best at that time, and I think up to date, ever trottecl orer a half-mile track by a field of horses. In the fourth heat Toorhies again laid Cozette up, and the rest of the party went after Rarus. He stalled them off, how. 


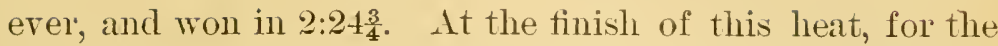
first time in his life, Rarus showed me signs of distress, seeming tired in his legs and affected in his wind, and I found that I had an even chance of getting beaten. Cozette had two heats to her credit, and had been laid up a part of

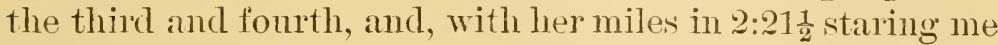
in the face, I thonght my chinces were not very rosy. In thinking the matter orer, I concluded to let some one else set the pace in the deciding mile, and try and win with my horse at the finish, a plan that I carried out, and, with the help of a mistake that Cozette made, it landed me the winnel in 2:23: The five heats constituted the best race of its length ever trotted orer a half-mile track. Then the word was given, Cozette took the lead, Rarms trailing her, and, after we had gone three quarters of a mile in these positions, there was about two lengihs of daylight between ns. In going around the mpper turn, Rarus closed the gap, so that, when swung into the stretch, his head was at the mare's wheel. From there to the drawgate, it was as desperate a race as one could wish to see. At that point Rarus commenced to tire, and the mare was ont-trotting him. For the first time in my life I drew the whip on Rarus. He responded to the blow with one burst of speed, moving up to Cozette's wheel, when she made a slight break, and he beat her to the wire, in $2: 23 \frac{3}{4}$. That was the nearest, with perhaps the exception of one other race, that he ever came to being beaten, after he began to win with me. I have been explicit about this race, in order to show my readers what condition does for a horse in a race. Here was a trotter that, when in proper fix, had shown me his ability to trot a mile in 2:14, and yet he was rery near being beaten by a field of horses, the best of whom, were at least five seconds his inferior; and at the best clip that Rarus could show, that means that they would be more than a distance behind him at the finish of a mile. If the public would make a little study of this, they would be able to understand how horses often lose races, and men their money, and then t!ink they have not had a fair drive, 
when, as a matter of fact. the condition of a lorse has all to do with it.

From Grand Rapids we went to Jackson, another halfmile track, where Rarus trotted an exhibition mile in 2:17, beating by a full second Goldsmith Maid's best time orer a half-mile track, which had stood unchallenged for years. This proved two things to me-that he was at that time the fastest horse in the country, and that the five corking heats at Grand Rapids had keyed hin np to his best form. At Detroit, Cozette was distanced in the first heat of our lace,

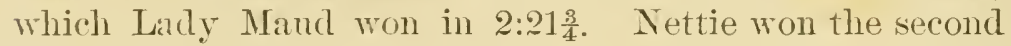

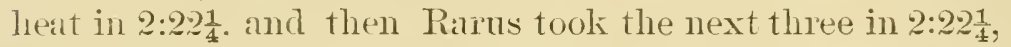
2:25, 2:3:3 $\frac{1}{2}$. The last heat shows a wonderful falling off in tine. In the betting, Rarus was the favorite, with Cozette well backed, the people remembering what a race she had given Rarus at Grand Rapids, and still loath to believe he was the great horse I had claimed him to be. The others had some incidental smpport in the betting, but the main money was on Cozette and Rauns. The only uneasiness felt by ne regarding the race was that the track was rery soft and uneren. I decided to lay up the first heat, and the result proved the plan a good one, although likely enough I conld have won in straight heats. In the first mile Cozette made a wild break and Lady Mand distanced her. With Cozette ont of the fight it was dollars to donghnuts that Rarus would win. I knew that Turner had a fair mire in Nettie, and as the General was rather inclined to lie around and give the boys a surprise party now and then, I concluded to keep an eye open and see what the little man from Philadelphia was up to. On this occusion, however, he was not canngerons, as after Nettie had taken the second heat in 2:22 $\frac{1}{4}$, I won the next three in the time stated above. In the last heat Nettie and Slow Go came together at the first turn as the result of a double break, and in the melee Lady Maud also injured her stifle, so that the three had a grand scramble to sive their distance in the slow time of $2: 33 \frac{1}{2}$. 'This lace, I think, was the last in which Lady Maud ever 
started. She was a very game and fast little mare, and but for an infirmity in her feet wonld undonbtedly have been a star performer and materially lowered her record of $2: 18 \frac{1}{4}$. After the finish of the last heat, Capt. John DeMass, a turf celebrity, and who, as the owner of tugs, sailing ressels, game roosters, and trotting and running horses, has been prominent on the sporting horizon for the best part of half a century, and is to this day considered the best assistant in a horse race of any man on the turf, called me to the judges' stand. In a few well-chosen words the Captain presented me with a handsome bouqnet that he said had been left there for Rarus by a lady, who had forgotten to say whether the gift was on account of the fast time or the slow time in which the hor'se had gone, a remark that seemed to me a very proper commentary on the last heat.

From Detroit we shipped to Chicago and trotted Rarus a race against Nettie, winning it with the best mile 2:2:31. At Cleveland we struck Lucille Golddust, Cozette, and Albemarle, and here Rarus made another great improrement in his record, trotting the three heats in $2: 18_{4}^{1}, 2: 18,2: 18 \frac{3}{4}$, the three being better than any previous mile he had trotted in a race. At Buffalo, the next week the same horses started again, but the best mile that Lncille conld make

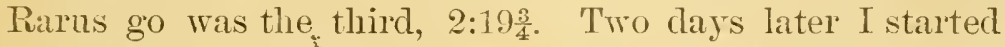
him against Lucille and Nettie in a free-to-all race, the first event having been for horses of the $2: 20$ class, and this time Green's mare made him go the second mile in 2:18. Then we went to Rochester, where Rarus trotted a wonderfully good race, and before allucling to that in detail, I will tell something of the manner in which I worked him while he was making this remarkable increase in speed. I gave him nothing in the way of training except very light jogging, with easy miles between $2: 30$ and $2: 25$, but at the end of every nile I would brush him a hundred yards or so as fast as he conld go. I reduced the number of miles in his work but kept giving it to him oftenel-that is to say, I would 
brush him a ways every other day, and found a decided increase in lis speed. There was no fearin my mind as to his staying qualities, as it did not seem to me possible for him to have any more speed than he had the stamina to carry. I lad also by this time learned another thing, which was, that when the tracks were not too hard he went better with about ten ol-eleven ounces on his forward feet than he did with more weight, and I shod him accordingly. When we reached Rochester it was apparent that Mr. Green and his friends were very sweet on Lucille's chances, she being a mare that had always improved in her campaigns, and as Cleveland was the first race of the seison for her, and she had gone well, they believed she had a chance to beat Rarus before the circuit was ended. Some people said that he had been screwed up in California all winter; that the length of the campaign had begun to tell on him, and that he would train off. Whoever thought this made a great mistake. Rarus hat not been keyed up in California, and with the exception of the Grand Rapids race had never been pinched at all. In the first heat of the Rochester race Green drove his mare from start to finish, but while the contest was close there was no place in it where Rarus was extended. The time was $2: 1 \% \frac{1}{2}$, the best mile Rarus had ever trotted in a race. I had heard a great many people say that Rarus was not a game horse, and that if he were taken by the neck he would stop. I felt, however, a good deal like the min that had a quarter-horse, and who was told that the first horse that took his animal by the head would beat him, but the old man only smiled sort of sadly, and replied that it might be so, he didn't know, but the trouble was to find a horse that conld get to his nag's head. In the second heat, Green made a desperate drive to the distance stand, where, feeling that he had no rhance to win, he stopped. When I saw this and eased Rarus, Green made another rush with his mare, and at the finish it looked to outsider's as though he came very near winning the heat, which was again in 2:17 $\frac{1}{2}$. As we walked to the cooling- 
groumds alfer this heat I overhead Col. John IV. Conley, a shrewd judge of horses and horse-ratcing, saly to Green: "You have got him now; you'll beat hin sure. He stopped at the finish of that heat." F'om Green's mamer I judged that he was of the same opinion, but they were wrong. I always formed my idea of what Rarts would do from the mammer in which he cooled out after a heat. He hand just gone the best two miles of his lift. and it wonld not have smprised me had he shown some distress, but, as Bamey Stanford remarked, he nerer drew a long breath alter either heat. I thought, from what I knew of the horse, that if Lucille beat him the next heat he would see a mark on the blankboald that had never been there before. IThen they ante to trot the heat I don't think Green was much to blante for the confidence he had in his mare, as she trotted ontside of Rarus erery step of the mile and then forced him to the wire in 2:16-at third heat which, even in these days when a two-year-old trots in 2:18, is not to be sneezed at.

At Utica, Rarus beat Lucille Golddust and Great Eastern, in the order named, the thind heat, the fastest of the race, being 2:17; and seven days later, at Hartford, we started him against Hopeful, Nettie, and Great Eastern. Hopeful won the second heat of this race in 2:19, Raums haring taken

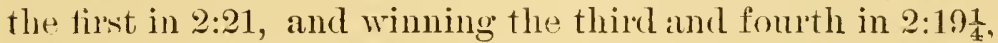
2:2.2. Then a special race for these three horses was allranged to be trotted two weeks later orer the l'muning track at Long Branch, and this event my horse also won, the best mile being 2:29:3. By this time Ralus was the recognized star of the trotting tuff, Goldsmith Maid with her faster record than his having been retired, and it was a little difficult to get engagements for him in ordinary class rares. Charlie Green had been working Great Eastern under the saddle, and the Fleetwood Park people offered a purse for Great Eastern to go that way against Rarus in harness. This proposition was accepted. As this was a remarkible race in more respects than one, and as in it the (r)eat kast- 
ern made his saddle record of $2: 12 \frac{3}{4}$, which is still the best at that way of going, I slatl tell about it in detail. In the first place, it furnishes another instance of the uncertainties of horse racing. To put it plainly, the conclition of the Fleetwood track at that time was villainous. Of course. Rarus was a tremendons farorite for the race, and so we started. In the first heat Great Eastem caught his boot right after getting the word, and Green had to pull him to a standstill, while I jogged Rarus the mile in 2:33, and had I gone in 2:30, which I was afterward very sorry for not doing, I would have distanced him. My leasons for letting Great Eastern inside the flag were that a good many people had come to see this special lace, and feeling sure that my horse wonld win in three heats I wanted to let the folks have something for their money. How near I came to being entirely mistaken the result of the race will show. In the second heat Green went away with the lead and I trailed until we turned into the stretch. In a driving finish Great Eastern beat Rarns in 2:18. This tanght me that I would have to follow a different plan in the next heat, and I conclucled to set sail from the start, having the fullest confidence in the ability of Rarus to stay, and thinking that in that manner T would force Green's horse to surrender. Down to the half-mile pole Great Eastern led all the way in the the third heat, having got the best of the start. From there to the three-quarter pole he increased his lead at least another length. As we rounded into the stretch Rarus began to close on him and had got to his saddle skirts at the distance stand. From there to the wire Great Eastern beat him out in what is to this day the best saddle record, 2:15 $\frac{3}{4}$. Had the race been over a track prepared like tlat at Cleveland or Hartford I am certain that this mile would have been as good if not better than 2:13, and in this opinion I have often heard $\mathrm{Mr}$. Green concur.

At this point in the race the betting changed, and there was one grand rush to hedge. I made up my mind that if Great Eastern kept going that kind of a clip he would cer- 
tainly win. Still, I conld haxdly believe that Rarns, a horse that had gone to California and back, beating ererything that he had started against, was to meet his Waterloo. Both horses showed distress after the third heat, and when we went away in the founth the clip was not as fast as it had been. Great Eastern led all the way to the head of the home stretch, and from there to the stand we had a desperate race. I was very busy watching and driving my own horse and could not see what Green was doing, but was told afterward, by men who are good judges, that he rode his horse as skillful a finish as was ever seen. At the last stricle Rarus got his head on eren terms with Eastern, and as they went under the wire I could not tell which had won. The judges at once decided that it was a dead heat, which I think was correct, as all the betting men seemed satisfied. This mile was in $2: 18 \frac{3}{4}$, a pretty gool clip to be going in a fourth heat over such a poor track. Wre lad now gone four miles, three of them having been fighting ones. Neither horse seemed to have much advantage orer the other in speed, the fact of Rarus going in larmess putting Great Eastern on even terms with him in that respect. Ihad often heard running-horse men talk of handicapping two horses so that they would run to a head-and-head finish, and after this race with Great Eastern could see how it might he done. One thing I believed about Rarus was, that he was game to the core. I had never seen Great Eastern tried in that sort of a battle, and, as a rule, turfites always doubt the gameness of a horse until they see him thoroughly tested. That, I think, arises from the fact that so few horses prove themselves fully game when tried by the fire of along race in which every heat is gone at top speed. In the fifth heat Eastern again went off with the lead, out-trotted Rarus to the half-mile pole, and from there to within twenty-fire yards of the wire we went like a double team. At the point named the big horse faltered, and Rarus beat him to the wire by a length in 2:21. After this heat Great Eastern looked as though he was through. Rarus was somewhat 
distressed, but not enough to (ause me any alarm, and I felt confident that, barring accident, we had the race in hand. Again thele was a flop in the betting. Ralus bringing $\$ 100$ to $\$ 10$, with little demand for the short end. In the sixth and deciding heat Great Eastern still had some speed, and led to the lall in about 1:10, hut then gave it mu,

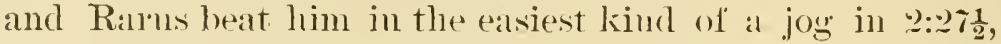
this ending what was consiclered by those who saw it one of the best races, from the standpoint of peed and endurance, ever contested on the American trottingtinif.

On September 28, Rarus beat Hopeful a race at Fleetwood Park in straight heats, the fastest mile being the second, which was done in $2: 16 \frac{1}{2}$, the best ever made 11 ) to that time orel the track. 'Then we entered in a special race with freat Eastern and Hopeful, at Cleveland, Great Eastern muler saddle, and the others in harness. The race occurred October 5. Great Eastern winning the first two heats in $2: 19 \frac{3}{4}, 2: 17 \frac{1}{2}$.

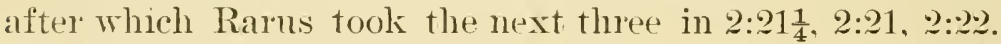
From there Great Eastern and Rarus went to Columbus, Ohio, and October 11, Raurus beat the saddler in straight heats, the best mile being $2: 17 \frac{1}{2}$. Five days later we trotted orel a half-mile track at Cincinnati, Great Eastern winning the first heat, alter which Rams won, his best mile being. 2:18, the best, up to that time, ever trotted over a half-mile track in a race against other horses. This was the last time Rarus trotted that year. Beginning on May 26, at San Franciseo, when he beat Goldsmith Maid, he had journeyed from the Pacifie to the Atlantic, and started in no less than tifteen races, all of them against fields of crack horses, the best in the land, and in no instance had he met with defeat, although in his contests with Great Eastern he was handicapperl by being obliged to pull a sulky, while the other horse went under saddle. During this time he reduced his record from 2:20 to 2:16, and made the best record, both in exhibitions and in a race, ovel a half-mile track. These statistics show what a wonderful horse Rarus was, even 
then, and, in another chapter, I shall tell of his exploits in 1878, when he set a mark for every trotter in the world to shoot at, showed himself the fastest, most reliable, and gamest trotter that had, up to that time, ever looked through a bridle. 


\section{CHAPTER T.}

How Rarus was wintered at Cleveland-Barred from the free-to-all races in the summer of 1878-He trots in 2:14 at Cleveland-Uncle Ben Wright's unlucky bets-The record lowered to $2: 131 / 4$ at Buffalo-A great race at Hartford-Gus Glidden and Edwin Forrest-Tronble at Minneapolis, and a great wagon performance at Chicago-Another trip to California-An accident in the stable, and what the veterinary said-Trotting in $2: 131 / 2$ to save Mr. C'onklin's \$10-The sale to Mr. Robert Bonner, etc.

The trotting season was now over, and after consmltation with Mr. Conklin. I decided to winter the horse on this side of the Rockies. After looking for an eligible place, I concluded to try Clereland, so Rarus was sent to the tratck there, winter quirters being arranged in the shape of an extra large stall. His shoes were taken off, liis feed reduced, and some light medicines for the stomach and blood given. The only exercise at first indulged in was plenty of walking. Had I not been afraid that lie would hurt himself in play, it would lave suited me better to have turned him out in a large paddock for awhile every day when the weatler was fine, but this I did not dare to dlo, and so a walk night and morning was the next best thing. This routine was kept up until about the first of January, by which time he had put on an eren coat of flesh, and seened entirely recorered from the natmal wear and tear of a long rampaign. There was plenty of snow on the ground when we first liarnessed Rarns, and I hegan driving him slowly two or three miles erery day barefoot, giving him regular walking exercise in ardition. The jogging was gradually increased, and his feed in the same ratio, so that before the snow wats off the ground, I was driving him six or eight miles a day. 'This was my own personal work, as I never' 
allowed anybody else to jog or drive this horse. There was nothing unkind about Rarus, or any disposition to be ugly, but he was about the best feeling horse I ever saw, and would in play do things that might have caused accidents with an inexperienced man liaving hold of the reins. I remember that one day during the winter I took Dave Hosmer, the driver of Abdallah Boy and other trotters, ont to ride with me. Rarus saw something in the road, and made a dart to one side so suddenly that he landed Dave light and diry in a snow bank. Then Hosmer picked himself up, he said he did not wonder at that horse trotting in 2:14 after the more he had just made. I had a rule with the boys that whenever we went to hitch or unhitch Rarus, one of them should always take him by the head, and the other one unhook one side of the harness, while I looked after the other. One day I drove him into the yard on retmining from exercise, and found $\mathrm{Mr}$. Crawford and some friends of mine there. I sat in the wagon chatting with them while waiting for the boys to come ont of the stall. Only one boy appeared, and he started to mnhitch Parus. I said to take the horse by the head and wait for the other boy, which he did. At this moment, something passed through the yard that Rarus noticed, and he at once made a dart, and tried to bolt. I had hold of the reins, and the boy had him by the head. I have often seen children play "crack the whip" at school, but it was not a circumstance to the way Rarus dashed the groom and myself about that yard. Fortumately, he did not hurt himself, or get away. I never saw another horse that could make such lightninglike moves.

In the spring, when the snow left the ground, I hitched. Rillus in double harness with Calmar and gave him all his exercise in that manner, thinking it safer than to hrive him single. 'The season was a late one, and I did not get to do much on the track before the first of May. Having no engagements for Rarus I began very moderitely, working him to a skeleton wagon, and gave him al gleat mally miles in from 
2:50 to 3:00, sometimes as miny as a lialt a dozen in a day, with twenty minutes rest between them. There was no attempt to drive at a high rate of speed, but after the weather became settled, I gradually improved his speed in the work, at the same time shortening the distance. About May 15, I made an engagement to show Rarus at Pitsburg two weeks later, stipulating, however, that I should not be expected to drive him better than about 2:21. I gave him a few moderate miles between $2: 30$ and $2: 25$, hrushing only at the finish of each mile. His best performance was

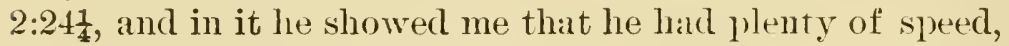
so I had no fear but that he would be able to fulfill the Pittsburg contract, which he did easily enough. The track there was a half-mile one with a good deal of grade in it, the first quarter being downhill and the last quarter uphill. Here I found the same tromble to exist that I had noticed at Fleetwood the prerious year. With his light shoes Rarus conld not get down the hil.l well, and this cansed me to at once shoe him heavier in front. On the day of the exhibition he went the second heat in $2: 21 \frac{1}{2}$, which was by long odds the best performance that had been made over the track. On the 12th of June we were at.Jackson, Mich., again, trotting the third mile in 2:2(1), with the track deep and slow from recent rains. Up to this time I had not done much with Rarus, as the stewards of the grand cincuit had seen fit to bar him in the free-to-all race at their meetings, something never heard of before-barring a horse in a free-to-all class before he had erer trotted there through the circuit. Several parties approached me with a proposition to show Rams against some pacers, but I told them no; that if they had a pacer capable of beating him to get him ready and come on with their money. The circuit people made me what I considered one-sided propositions to show him over the different tracks, but to all these I said no. Then they wanted to know what I was going to do with him, pointing ont that the horse was barred in the free-toall class, and without record low enough to make him a 
star performer. I replied that if necessary I would get the recond all right. After talking with Mr. Conklin, I decided that the first thing was to do this, and with that end in view, the rest of my stable being enteled at Saginaw, I took Rarns there, hoping to find the track and day favorable to last time. On the contrary, I found the track worn out, and the prospects anything but rosy, which decided me to give Rarrus only safe work, waiting for a better opportmity to smash the record. There was an exhibition by Rarus, and in this he showed me the three best consecutive heats he had erel trotted, the miles being $2: 17 \frac{1}{4}, 2: 16,2: 16 \frac{1}{2}$. In this exhibition, for the reasons stated, I did not pinch Rarus, simply letting him go three good rating heats. From Saginaw we went to Cincinnati, and gave an exhibition on the Fourth of July, the second mile being done in 2:17 over a halfmile track. It had rained the previous night, which slowed the track some, but I liad never seen Rarus when I liked him as well. 'Toledo was the next place on the route, and here Rarrus tried to beat his own half-mile track record of 2:17. I was sure lie would do it. While the track was far from fast it seemed safe and the horse moved like a bird. Up to this time I had given him only moderate work and no fast miles, simply sending lim along in about 2:25, brushing him the last 150 yards as well as he could go. My aim still was to make with him all the speed possible, and I trained him as you would have handled a sprint rumner. When we came out at Toledo, Rarus went two trials in 2:19, 2:1 $\frac{1}{4}$. Darkness coming on, the exhibition was postponed nutil the following day, when Rarus trotted in 2:16, beating his own record a full second, and that of every ofher horse two seconds, so far as performances over half-mile tracks were concerned.

'The great summer' meeting at Cleveland was now at hand, and we went there to trot an exhibition, the terms being that Rarus was to go three heats that should avelage better than 2:18; and if Goldsmith Maid's recold was beaten, we were to get an adelitional s.000. In this raloe, I not only 
tried to win the money, but also to make the best showing I possibly conld, knowing that if he went well thele would be no trouble in making all the engagements I wished for the rest of the season. Had this Cleveland exhibition taken place on the day it was first adrertised to form part of the programme, I am sure that Rarus would have gone the three heats in 2:14, or better, but from the effects of a big gale and rainstorm the track was so bad that the race was yostponed, and did not come off mutil the next day, which was the last of the meeting, and the last of the week, and then not until very late in the afternoon. I was very busy that day driving two other laces, and did not have the time in which to give proper attention to Rarus. I will describe the race, and tell how near an intimate friend of mine came to losing a good bundle of money on the lesnlt. At this meeting Hopeful had gone thwe heats against Proteine, which were the three fastest consecutive heats ever trotted,

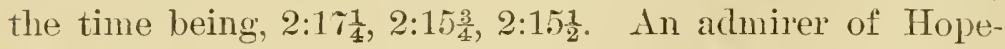
ful came across my friend, and bet him $\$ 500$ that Rarus would not in his exhibition trot three heats to arerage as good as Ilopeful's three. I told my friend that that money was won; that the trotting horse never lived that conld make a performance that Rarus conld not beat. In the betting on the race, it was $\$ 100$ to $\$ .50$ that Rallus would trot three heats to average better than $2: 18$; it was $\$ 10$ u to $\$ 20$ that he would not beat 2:14. My friend said to me, "I am going" to bet a couple of thousand dollars that he don't beat 2:14, and at that odds I will win abont $\$ 3,500$ or $\$ 4,000$." I told him not to do it, as I thought Rarus had a chance of beating 2:14, and thit I should certininly drive him as fast as I. rould. Anyhow, he bet $\$ 2.000$ that Rarus would not beat $2: 14$. Rarus went the first mile in $2: 14 \frac{1}{2}$, and the second in 2:15, after which my friend said to me that he was very glad he had bet his money as he had, for that, after going

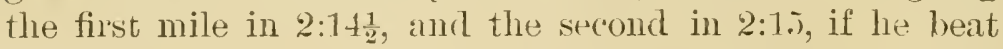
2:14 his opponent could have the money and welcome. In the third heat, I land a runner to go with him, and when 
the judges said "go," Rarus went away from the wire as though he intended to trot a mile in two minutes. At the quarter pole, the old r'mner took to the bushes and bolted. As soon as his company was gone, Rarus wanted to slack up; I kept him steady, however, and when we turned into the home stretch, I found waiting for me on his celebrated gray horse, that noted character, William Potts, at that time marshal of the Clereland track. I called to him to come on with his horse, but Potts did not get the gray going quick enongh, and was muable to reach me. When I went under. the wire, I guessed that something musual had happened, as I never heard such cheering before in my life. When I got back to the stand, the first man I happened to meet was my friend who had bet his two thonsand dollars. He says to me, with a peculiar look on his face, "Te are murdered; you went the mile in $2: 1: \frac{3}{4}$ !" $\quad$ The time that the outsiders, I found, had made it to a man. In the judges' stand there Was a disagreement, two watches making it 2:14, and one $2: 13 \frac{3}{4}$. They hmig it ont 2:14. and my friend won his money; but he told me quietly, that night, that he wonld never bet that much again that Rarus would not trot in 2:14, whenever I was willing to try with him. This race not only proved that Rarus was the superior of every horse then on the turf, but that he had, in one race, equaled the best record of Goldsmith Maid, and gone three of the fastest consecutive heats ever trotted or paced by any horse, and everyone who saw him make the performance felt sure that he conld beat 2:14.

The following week we went to Buffialo, and under a special arrangement were billed to try and beat $\%: 14$, and here I want say that I made a very serious mistake in the start. Rarus was a horse that had ahways gone with a rery light shoe, and I knew conld always go better orer a trick not too liand, but, as I suppose many a man has done before, I allowed myself to be advised as to the condition of the track, and the superintendent had it made harder than I had ever' seen it. The soil of the Buffalo track at this time wats just fit for 
making bricks, and with a little water and straw the track would have been as hard as a brick. The superintendent being anxious to have the record beaten orer that track did only what he thought was best, but I was sure at the time, and am more positive now, that Rarus, or, in fact, any other liorse, can go better over a track not quite as hard. I had done but very little with him in the way of work, being satisfied that the three heats he had gone at Cleveland would give him all the preparation he wonld need. There was a good deal of betting on the event, a wonderful crowd of people, and great enthusiasm. In the auction pools the betting was on the result of the three trials that he was to have. In the French the betting was all on the result of the different heats, and the odds were about $\$ 100$ to $\$ 60$ that time would win. In the first heat I simply drove Rarus a good stiff mile in 2:17 $\frac{1}{4}$. Of course, in the second heat everyone expected, as I did myself, to make the grand trial. My friend, Uncle Ben IVright, whom everybody, from the ticket taker to the president of the track, knows on every race track from Boston to Australia, came and asked me what I thought of the heat. I told him I thought Rarus had a chance to beat $2: 14$, and said to him that if I made a mistake in getting off I certainly should lay him up, supposing, of conrse, that he was going to bet his money in the auction on the result of the race. Instead of that he walked over to the French and played his money there, which went on the decision of that heat. IVhen I commenced to score Rarus for the heat, and he extended himself as a horse wonld going at a 2:14 gait, the track hurt him, and he broke several times-something entirely new with him. Everybody had a different reason for this unsteadiness, but I was positive at the time it was the track, and now I know.it was. IVe finally got the word, but he had not gone far before he mate a wild break, and I simply jogged him the mile in 2:50. In the ineantime, Uncle Ben, seeing Rarus acting badly in scoring for the heat, thought he wonld make a liedging bet and went to the anction pools and played his money 
there that he would not beat 2:14, expecting to save the money that he had in the French pools; but as the sequel will show, he misunderstood the terms of the betting in both pools and lost his money two ways. In going the second heat in 2:50 Rarus lost the money that Uncle Ben had in the French pools, and when we got the word in the

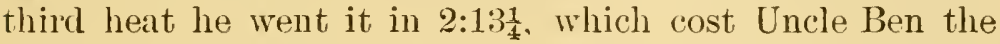
money that he had bet in the aluction pools, being thereby, as . Jack Bachelor would say, "whipsawed on the last turn." The only mistake that I think I made in this trial was in allowing them to have the track so high, and then in driving him away from the wire faster, I think, than I ought to have done; at least, this was my opinion after the race was orel. I think that when the judges said "go" in the last lieat, Rarus must have been going at least a 2:10 clip. On the second turn I took him back the least bit, and when we swung into the back stretch I cut him loose again. He dial not drive as he did at Cleveland, but seemed to have a disposition to pull all the time-something that was very unnatural with him, as he never wanted to do this unless the trark was wet or muddy. Rarus pulled less than any horse I ever saw, and went his heats with just the least hold of the bit. He wanted to be driven abont as a man would play a violin, with the ends of the finger's. He went steadily true all the waly to the head of the stretch, and there he made a wobble, as though he was going to break. I steadied him around the turn and at the distance stand commenced to drive him. He did not finish as well as at Cleveland, but still went the mile in $2: 1: 3 \frac{1}{4}$.

As I turned him around beyond the judges stand to come back, my old friend Jack Feek lan down, and with as much pleasure expressed on his face as there was on mine when I bought my first drum, he announced to me that Rarus had beaten the best record, having gone the mile in $2: 13 \frac{1}{4}$. By this time, it seemed as though every man, womar, and child on the track had been apprised of the fact, althongh the judges had not as yet given their decision. 
By the time I returned to the stand, the quarter stretch was one mass of howling, screaming, and surging men, boys, and women, and the grand stands looked as though they had been depopulated by an earthquake. After a moment or two of this sort of thing, the judges were able to get partial qniet, and amnonnced the heat, and then commenced such an uproar as I had never mp to that time seen or heard of. As Barney led Rarus to the stable, a crowd gathered about them, and it was with great difficulty that he could get the horse through the people. The judges insisted on my making a speech. Someone had advertised me as being a great talker, but at that particular moment, and, as I believe, the only time on record, I had lost my talk. To me it seemed rather strange, that here over this race-track, where I used to come in my boyhood days to play hookey from school, and where I took my first lessons in the trotting business, I shonld in after years accomplish a feat that had been tried by the whole world, but in which no one had erer before succeeded. Goldsmith Maid's record had stood for six years, and I think the man that would not have been prond to have the horse to beat it must, to say the least, be a little cold blooded.

My only regret in the whole affair was that Mr. Conklin, my partner and friend, was detained at his home by illness, and was not able to witness the result. But as soon as the telegraph wire could be brought into use, he was made acquainted with the fact that his wildest dreams had been more than realized. They afterward told me that every fisherman on the Long Island shore blew his tin horn the most of the night after the news had come that Rarus had beaten Goldsmith Maid's record. I hardly think that General Harrison received any more congratulatory telegrams on the night of his election to the Presidency than I

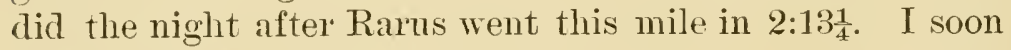
had from Mr. Conklin a dispatch in which he said: "Hurrah for Splan, and hurrah for Rarus."

The following week, at Rochester, Rarus's performance 
proved to me that what I had said about the Buffalo track was light. Knowing that the track was rery hard at Buffalo. I was extra cautious in the way of care, and the attention that the horse should have after the race, and in bringing him out free from soreness, etc. But when we arrived at Rochester, and I went out to work him, I found that in spite of all the attention and care he was sore, had no speed, and I was rertain could not make a good performance. My arlangement with the association at Rochester was that I was to try and beat $2: 18$. They came to me and wanted to make a new contract, and have me try to beat the horse' s new record. I told them I could.not undertake to do it, and explained why. I was sure my horse wonld not be able to beat 2:14, and I did not want to announce to the public that I was going to try and do something that I knew I was unable to accomplish. I told them, however, I would try to beat 2:18. Of course, the public and the pool-buyers thought that to do this, Rams had only to jog around the track. The sequel will prove that they were wrong, as the best he could do was three heats in $2: 18,2: 19$, and $2: 17 \frac{8}{4}$, thereby losing the race.

The following week, at Utica, he had recorered a gooddeal of his old-time form, as he went the first mile orer the Utica track, which was never considered fast, in 2:15; the

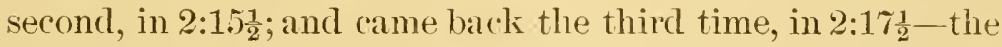
best three heats ever trotted orer that track to this day.

From there we went to Hartford, the following week. where Rarus trotted the three best heats he ever went. He also beat Goldsmith Maid's best record in two of the heats, and made what was looked upon by most people as his best performance up to that date. At Fartford we had a good week, the weather being fine, and the track in good condition. This year Gus Glidden brought out Edwin Forrest. and, before going any further, I want to say a few words about Gus as a horse trainer. There was one point in which I think Gus excelled every man I ever saw. You give him one of those double-gaited, shifty, pacing horses that are 
occasionally met with, and he could come nearer straightening him ont, and making him go on a straight trot, in less time tham any man I ever saw. In fact, so impressed was I with his ability in that line, that I took a few lessons from him. which I afterward found rery useful. Is I am writing this book for information. I wonld be glad to tell the public all about this double-gaited business, but like many other things in which men excel, I think the ability to drive such lorses is a gift, and in Glidden's case proved rery profitable, as. ont of that lind of material to develop race-horses, fins made enough money to buy one of the tinest farms in Indiana, and, while there are some people in Rush County who dress better than Gins. there is no man who pays any more taxes or lives higher. In 1878. (Hus hove in sight at Lonisville, with a bay gelding called Edwin Forrest, "with more speed and less sense," Gus said. "than any critter I erer set eyes on." I saw him working him from Louisville through the Michigan circuit, and he had tools enough with him to bieak into a safe or build an engine. About the time the grand circuit meetings commenced, Gus's horse began to grow better. and at Cleveland he won a race, and got a record of $2: 18$, in a large field of horses, thereby placing himself at one bound in the front rank. and adding sereral acres of ground to Gus already baronial lioldings. About the time of the Hartford meeting, on friend, Charley Green, got Edwin Forrest, and stated his willingness to show him a mile against time, and try to beat the best heat that Rarus should make. I thought Chardey was flying at pretty high game, but for a consideration that the association promised him, he started ont on the same day that Rarus did to go against the watch. In the morning I met Messrs. David and Allie Bommer. Mr. Allie Bonmer asked me what I thonght my chances were with Edwin Forrest, and I told him I did not think there was any chance at all about it; that I was sure that Rarus could trot three heats that would average better than the best heat Edwin Forrest could go. When Green brought Edwin 
Forrest out, he looked and acted as though he was fit to trot for a man's life. When they gave the word, he was going true as an arrow, and as he turned into the back stretch he cut loose at a rite of speed that looked to me as thongh he was not only going to beat Rarus's time, but knock the watches ont of their cases as well. He went down to the half-mile post better than 1:06. Of course, I did not want anybody's horse to beat Rarus, but at that particular time it looked as though he was going to get a horse race. Forrest came on into the stretch at what appeared a terrific gait, but about an eightl of a mile from the judges' stand, the ligh rate of speed commenced to tell on him, and he finished

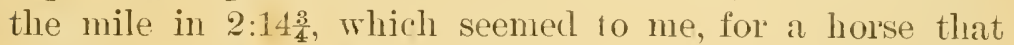
never had any more training, certainly a wonderful purformance, as I, myself, with one of the grandest horses I ever saw, had been hard at work for two or three years before I conld make him go that well. Edwin Forrest was afterward sold to Robert Bonner, and made some wonderful performances both to hamess and wagon. Ifter this heat I net Allie Bonner, and he asked me what I thonght about the red apple that I had agreed to forfeit in case Edwin Forrest made a better performance than Rarus. I told him that I would not have to buy it, as Rarus would trot three heats that would average as good or better than 2:14: which he

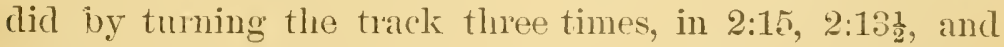
$2: 13 \frac{3}{4}$, making the great arerage of $2: 14 \frac{1}{2}$, and thereby making good all I had clained in favor of the horse. I think this performance setled in the minds of everyone who saw it, that, beyond all doubt, Rarus was the king.

The only other races trotted that season by Rarus, that would interest the public, are the ones at Minneapolis, where the people fancied they were being wronged, and that at Chicago, between Rarus, Hopeful, and Great Eastern, that drew 40,000 people to the track, and demonstrated the ability of Rarus to pull a wagon in 2:15⿺ over a track that had junt been made, and, in addition, was dead and damp from late. rains. My first engagement in the far Trest was made wit: 
Col. William King, of Minneapolis, who has been a Congressman, and held several offices of public trust, to which he has been elerated hy the votes of the people of that section, and a leading man in all the public undertakings of Minnesota. I contracted with him to go to Minneapolis and show Rarus three heats at the fair. At this time there was a great strife between Minneapolis and St. Paul. The St. Paul people concluded they wonld have a fair at the same time, and $I$, not knowing abont this feeling, engaged with the president, Mr. Finch, to show Rarus at that fair also. I agreed to show at St. Paul on Tuesday and at Minneapolis Friday. Long before I arrived in that country, Ihad learned, by both the newspapers and the telegraph, that unknowingly I had got myself in hot water, as the Minneapolis people claimed that, having engaged with them, I had no right to show at St. Paul. While I wonld not have done it had I known the feeling that existed, I had, at the same time, as much right to trot my horse at St. Panl that week as I would have to do so the next year, and I saw no way to get ont of it. When the Minneapolis people found that I had my horse at St. Paul, and intended to start him there on Tuesday, they opened up on me in the newspapers, and I got more abuse than any politician that ever ran for office. Every thing they could think of to say was said with a vengeance. I saw Mr. King, and we talked the matter over, and we both viewed the affair in the same light. He expressed regret that the newspapers had given me such a going over, but I saicl to him, "Let them go on. It is the best advertised affair" that las come off in these parts for a long while."

The day of the St. Panl race, I showed Rarus to a crowd of people, such as I had never before seen, they, of conrse, taking my part on every turn. Rarus went in $2: 16$, which I thought a good performance, considering the track. From there we journeyed to Minneapolis, and the reception that I received on all sides there, made me think that I must be a very mean man. Still, as I was to receive $\$ 3,000$ in money for the exhibition, and hat already earned the same amount 
for that in St. Paul, I concluded that I could afford to pocket my feelings. The papers came out with all sorts of statements, one man going so far as to say that I did not intend to drive my horse a good mile, and that, if I did not beat the record made at St. Paul, the public ought to come down and hang me. The only fear I had was that the track would not be in such a condition as to make it possible for Rarus to go a good mile. The cattle and horses had plowed it up until it looked like a garden. Mace had shown Hopeful a

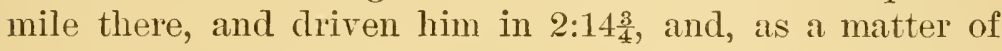
course, I was anxious to beat that. I set to work myself on the track, and got it into the best possible condition I could. Mr. Charles M. Smith, the best starter in the country, was there in charge of the judges' stand. The night before the race, in a talk at the hotel, Mr. Smith told me that he was afraid there would be a riot in case Rarus was unable to go well. Of course, I knew that Rarus conld not be right on an edge, having traveled so far in the cars, and having already gone three heats in the same week, and I thought myself it would be very doubtful whether he would be able to beat IIopeful's mark of 2:14 thought it would be a good idea for him, on the following day, to make a little speech to the public, state the facts of the case, and to try and make them understand that I had come there to give them the best possible race I could with my horse. When the time of the race arrived, and I brought out the horse, Mr. Smith, in a very neat speech, stated the case to the public. They didn't seem to notice much what he said, and took it very coolly.

When I brought Rarus ont to warm him up there was a disposition on the part of a good many to hiss, and in other ways to show their hostility to myself and horse. The weather was varying, and looked as though it might rain at any moment, and I concluded that, contrary to my usual method, I would warm Rarus up, and try to give him his best mile first. I got the word and drove him in 2:15. thereby beating the best mile that had been accomplished 
orer the St. Paul track, which fact seemed to mollify the populance to a large extent. Of conrse, this mile was too fast for a rarming up heat, and not fast enough to beat 2:14, thereby diminishing my chances of doing it. The next mile I again essayed to beat Hopeful's record, but failed,

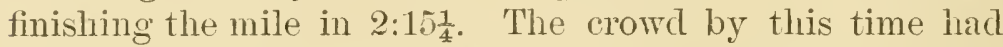
worked itself into good nature, and were willing to cheer and shont as hard and as long as they conld. When I took Rarus back to the cooling shed, I told Barney and Dave to take care of him and to cool him out; that I would drive him an easy mile in the third heat, as I was not going to try to beat Hopeful's record. If I had reduced their wages the boys would not have felt half as badly. 'They could not bear the thought of Hopeful's $2: 14 \frac{3}{4}$, and said so. Dave snggested that we cool Rarus out and get a rumner to go with him, as he felt sure that under those circumstances he would do the trick. To satisfy the boys, more than anything else, I consented to this arrangement. When we came out in the third heat the wind had lowered. I had a man run a scraper round the track, and when the judges said go, and Rarus and the rumer started on their mile, the crowd gave a cheer that I have never forgotten. The horse went straight from start to finish, and trotted the mile in 2:141 $\frac{1}{2}$, beating Hopeful's record by a quarter of a second, and showing three heats better than the best he had gone at St. Paul, thereby making every man, woman, and child in Minneapolis sleeplessly happy, and my friends for life. For the balance of the week, they loaded Rarus and myself with fiowers, bouquets, and everything from a tooth pick to a fly-back watch.

From Minneapolis I made a circuit of the country, giving exhibitions at Dnbuque and Kansas City, and from there went to St. Lonis, where I staid two weeks, and was obliged to show Rarus under a tent, as the track was not large enough for him to exhibit on. In the meantime a race had been arranged by the Chicago track, between Rarus to wagon, Hopeful in harness, and Great Eastern 
under saddle. This race was trotted on the 10th of October, orer a track that had just been built, and that was dull and damp from rain the day before. Rarus came to Chicago at the end of one of the sererest campaigns that a horse liad ever made, and in no condition to show his best. In the betting. Hopeful was a long farorite, he luaving shown some grand miles. I told my friends I had no faith in the lace, and I think they did not put a dollar on. For the day and track, the race was a first-class performance, Hopeful winning in straight heats, in 2:17 , 2:17, 2:1\%, Rarus second all the time, and Great Eastern third. At this race there was the greatest crowd of people I ever saw at a regulax horse-trotting event, it being estimated at all the way from 30,000 to 50,000 .

Two days later, when the track was much faster and the weather bright and warm, Hopeful made his wagon record of 2:16 $\frac{1}{2}$, and this set some people to thinking that Hopeful could beat Rarus at even hitch, both going in harness. 'The first that I heard about that was when Mr. Conklin broke into my room one morning in a heated condition, with a newspaper in his hand. He pointed excitedly to an article in it which stated that the public thought Rarus had luad his day and that Hopeful could beat him. He said he would like to have me answer that article over his name.

"Well," said I to him, "what will I say to them?"

"Tell them for me," lie replied, "that Rarus can beat Hopeful any kind of a race that two horses ever trotted."

"How much money will I say you want to bet on him ?" I asked. Said Mr. Conklin: "Ten thousand dollars in money and this year's crop of hay." There was some newspaper correspondence, but no race.

Talking about matching Hopeful against Ralus bring's to my mind some other people who were anxions to match their horses against Rarus. The previous winter, while Rarus was being wintered at Cleveland, the owner of the stallion Smuggler had announced in an eastern sporting journal his willingness to trot that horse against Rarus, and out of it 
grew a pretty lively newspaper controversy, but no horse-race. From Chicago Mr. Conklin wended his way to his Long Island home, and I started for the Pacific with Rarus, giving exhibitions in several places on the way there, to which he drew great crowds of people and always trotted the tracks faster than any other horse had up to that time. On my arrival in San Francisco I trotted Rarus in an engagement next Alay after getting off the cars, in which he went in 2:14, 2:141. I state this to prove what a wonderful horse he was. $\mathrm{He}$ had started in races all orer the country, been twice across the continent and as far north as Minmeapolis, and the next day after a ten clays' railroad trip beat 2:15 twice.

I have often heard people say that Rarus was a weak and washy horse. I don't think that needs any denial, as his performances are the strongest argument. Naturally, after a campaign of that length, he was reduced in flesh, and his feet had commenced to trouble him a good deal. I immediately concluded to stop driving him, reduce his feed, and commence to murse his feet. Rarus was a great horse to recuperate, and it was but a short time before he commenced to show his old-time appearance and spirit. I gave him very moderate work and trotted him at few exhibitions in Califormia that winter. In the spring I bronght him 10 Sacramento, thinking to prepare him for his trip home. He was a great horse to play in a stall and at the end of a halter. One day, while in Sacramento, as I stood watching him, he laid down and began to roll in the stall, and when he was through he sprang up suddenly. His hind feet went out from under lim and he fell. I was frightened lest he might have bruised himself in some way. I looked over lim very carefully, had him led out, but saw nothing to indicate that he had lumt himself. The next morning when I went out to work Rarus I thought he was slightly lame behind. I spoke to Dave about it, and he said he thought not; but I felt sure I was right. As the horse's shoes had been on for some time, I took him to the blacksmith's shop, hoping to find the cause of his lameness. At this time there was no swell- 
ing or any indication of puffing in his leg. We found nothing in his feet to indicate any soreness, so I brought him home, hoping that I was mistaken and that it was merely fancy on my part. When I harnessed Rarus the next morning there was no doubt about his being lame. I took him back to the stall, had the harness taken off, and examined every part of the limb and foot again carefully, hut was unable to locate the seat of the lameness. I sent for a veterinary, and he examined him with no bettel snccess. I have often lost the last dollar that I had in the world, and some that I did not have, but I can never remember the losing of my money having cost me a thought or a particle of trouble. If you have a brick house, and it tumbles down, and you have the price, you can go and buy another one; but if you have the best race-horse in the world, and he goes lame or dies, all the money in the world can not fill his place.

These were my feelings at that time. I had all the responsibility; the bor'se's owner was in Long Island, and Rarus with me in California. After the reterinary had examined him rery closely, and conld not find the tronble, I conchnded not to harness him again until I could locate it. The next morning, which was forty-eight hours after. I first discorered his lameness, I went to the stable, and found that the entire surface of one hind leg was very much swollen, with a good deal of fevel, and that the horse was very lame on it. I sent again for the veterinary, and he came and looked him over. He turned to me and said: "There is just one thing to do with that horse; get the fever out of his leg, and fire and blister him." I said: "Doctor, is that the only remedy?" He said yes; that nothing else would ever do. I said: "Doctor, it will never" be done. No horse that has been as good and brave as that one will erer be fired with my consent. I will take him home to Long Island, where he shall end the balance of his days in peace and plenty." Thereupon the doctor discharged himself, and left Ramus to Dave and me. Tre applied some simple cooling lotions, kept him tied mp by the head, so that he could not walk about, 
had his feed rednced, and postponed his training indefinitely.

This treatment we followed for about three weeks, and when the acute heat and ferer had been entirely remored, I found, close to his ankle, a small enlargement that had nerer been there before, and whirh was the canse of a good deal of the trouble. Of comse, I had no idea whether he would stand campaigning again or not. I gave him a few days' moderate jogging, and then shipped him East, stopping on my way at several places to trot my other horses. Ralrus's leg seemed to improre, and he showed no lameness. I think it is a true saying that misfortunes nerer come singly, and the truth of this was illustrated to me in this particular case. I went to Rarus's stable one morning, and found him the lamest horse forward I erer saw, and apparently in great pain. I examined his foot carefully, and found nothing to indicate where the lameness was. I was smre it was in the foot, and commenced to treat him with hot water and hot poultices, whirh I kept up for about forty-eight hours. His foot gathered and broke near the coronet; the wall separated on the right side of the foot, and we were obliged to rut away a great portion of the wall, and leave the live part exposed. I had a compress made with a strap and buckles, and put that on him whenerer I worked or jogged him. It looked to me at that time as thongh he wonld not be trained again that year. I jogged him along very moderately. Previous to this I had made an arrangement to trot Rarus against Hopeful over the Chicago track July 24. Then I arrived at Chicago, I immediately went and stated the farts of the case to Col. John $W^{r}$. Conley, the manager of the track, telling him that I had not the slightest idea that Rarus would be fit to start in any race that year. IJe said to me: "Let the mattel stand just as it is, and on the first of July you let me know what the prosperts are, and if you then say he will not be fit to start, I will arange for some other attraction. This race grew ont of a newspaper talk of the year previons about Hopeful and Rarms, and the Chicago 
Association generously offered $\$ 5,000$ to be trotted for, entrance free. I concluded to work Rarus along moderately, start him a lace or two, and see whether or not he would stand up. I did so, and started him the first race at Jackson, orer a half-mile track, where he went an exhibition

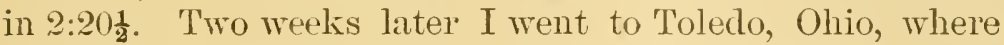
Rarus trotted in 2:20, and then I notified Colonel Conley that I would be able to start on the 24th of July in Chicago.

At this time I had not trotted Rarus at his best speed, nor did I think he would be fit to beat Hopeful in the race, but, rather than disappoint the association, I was willing to take the chances and trot him. As it turned out, Rarus improved faster than I thought he would, and won an easy race from Hopeful in Chicago, in 2:17 $\frac{3}{4}, 2: 21$, and 2:18. There was a big attendance, and a good deal of betting on the race. The following week he started against IIopeful, at Cleveland, and beat him in three straight heats, trotting the third mile in $2: 15$, which was the best of the race. It Buffalo, he went,

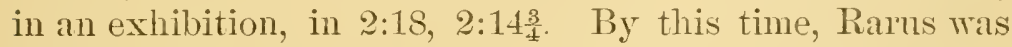
back to his old form, and, at Rochester, Angust 14, in a gale of wind, hetrotted three heats in $2: 17 \frac{1}{4}, 2: 16,2: 13 \frac{1}{2}$, the last mile being within a quarter of a second of his best record. When he came to go this mile, there was a good deal of betting on the time, with rery long odcls that he would not beat 2:14. I never knew his owner, Mr. Conklin, to put a dollar on hirn, or buy a pool ticket, always leaving that part of the business with me. This day, however, he heard some one say he would bet a hundred to ten, that Rarus would not beat 2:14. After I had gone the first two heats, the weather became rery bad, and I concluded not to drive him another mile, and so stated to the boys, whom I ordered to take him to the stable. About this time, "Pap," as we called him, came along, and told me what he had done, namely, that he had bet that Rams would beat 2:14. I told him I had notintended to trot another heat, and wished that he had not bet the money. He said: "That does not make any difference. Don't drive him unless you feel like it. 
Never mind the ten dollars." I said: "No; put th harness on him. I would rather win that pool ticket for you than to win the whole world for anybody else." I told the old man to put on his glasses, go up in the grand stand, and sit down and see what kind of a battle Rarus and myself would make for his money. When I went out for the third heat, it was late in the evening, the wind had died down, and most of the andience had left the track. When we took the word, Rarus was going straight and strong, with all his old-time speed and determination, and I said to myself: "The money is Pap"s." As we turned into the back stretch, I heard something clatter on his hind foot, as thongh his shoe might have been loose, and started to pull him up. About that time, one of his scalpers flew off, and, as I knew that would not make much difference to him, I kept him going, and, when we rounded into the stretch, I cut him loose for all that was in sight. True to his old-time record, he finished the mile in $2: 13 \frac{1}{2}$, thereby wimning the pool ticket for his owner, and coming within a quarter of a second of his old best performance. It never entered my mind that that would be the last fast mile I would ever drive Rarus. It so turned out, howerer, and the reader will see what a little incident cansed me to make such a fast record with him that day. Tre trotted the following week against Hopeful, and won, the best mile being 2:16.

I have now come to the sale of Rarus and his retirement from the turf forever. The night after the Utica race, my old employer, MIr. Z. E. Simmons, came to me at the hotel, and asked me if Rarus was for sale, saying that if such was the case, he would like to have a price on him. I told him that, as far as I was concerned, if I could be guaranteed that Rarus would be sold to a good home, I would consent to the sale and use my influence with $\mathrm{Mr}$. Conklin to that effect, providing, of conrse, that we agreed on the price. He told me that, while he was not at liberty to give the name of the would-be purchaser, he was prepared to guarantee me all I asked. He said he would leave that night 
for New York, and wished that, after talking with Mr. Conklin, I would come to New York and see him. I communicated these facts to Mr. Conklin, and by appointment we met in New Tork two days later. In our first talk, Mr. Conklin opposed the idea of selling Rarus very much. He said he thought that after all the good Rarus had done lim he was at least entitled to a good home in his latter days. I said that Mr. Simmons was ready to guarantee that the horse would have as good a home as any animal conld have. I also told him that I thought it was more humane to sell Rarus to a good home while in the prime of life than to keep him and trot him until he was old and worn ont and suffered defeat, as I had known a great many other first-class horses to do. This seemed to strike him rather forcibly, and after some further talk, he said to me, "You have attended to all the trotting of him, his training and driving, and have control of him, and if you see fit to sell him I will be satisfied with anything you do." I took a carriage and drove to Mr. Simmons's office, and told him that I had come prepared to put a price or Rarus. I then told him that the price was $\$ 40,000$ in cash. We had some talk, which ended by Mr. Simmons offering" me $\$ 30,000 \mathrm{for}$ him. I said "No, $\$ 40,000, "$ and left the matter there. Mr. Conklin and I took the train for Hartford that evening, where Rarus had already gone to meet an engagement. Our intention was to try and beat his record, which we were positive he was able to do at that time, having without extra preparation gone the third heat at Rochester in $2: 13 \frac{1}{2}$. I gave him careful preparations for the effort, and the last time I worked him before the day fixed for the trial, I thought him a better horse than ever. He seemed in the pink of condition, with unlimited speed.

The morning of his race, H. M. Whitehead, of New Tork, came to me on behalf of $M_{1}$. Simmons, with regard to the sale of the horse. I told him, as I had stated to Mr. Simmons, that the price was $\$ 40,000$, with the regular commission off for cash, which was 10 per cent. I also told him 
that the horse had engagements; told him what they were; said that if he bought Rarus it would be with his engagements, and concluded by telling him that I would not sell the horse without the engagements. He made several propositions, none of which I accepted, finally telling him as we stood in front of Rarus's stable, he with his head out of the door, that there was the horse, and that for $\$ 36,000$ he conld have him, but that I would not lead him over the sill of the door for him. He finally said that he would take the horse for Mr. Simmons, but was not prepared at that time to pay for him. I told him that if the horse was for Mr. Simmons he could pay for him whenever Mr. Simmons thought fit. I told him that he was now Mr. Simmons's horse, and that if he died or broke his neck, Mr. Simmons conld hand Mr. Conklin $\$ 36,000$ in money, just the same as if he got him in the best of order and condition, and that I expected him to do it. This took place about ten o'clock in the morning, and the holse's engagement was to trot that afternoon. I therempon waited upon the president of the association, and told him we had sold Rarus, with his engagements, to Mr. Whitehead for Mr. Simmons of New Tork City, as I-understood, informing him, in addition, that I had no further control orer the horse in any way, shape, or manner. The president interviewed Mr. Whitehead on the subject, and he said he had bought the horse, but declined to trot him, as his owner did not wish to do so. That was all that took place in my presence at that time. When I went to the hotel for dinner I met Mr. Conklin and told him that I had sold Rarus and delivered him to his ownel"s agent. He says, "TTell, I suppose it will have to be," and walked away. If I had been possessed of $\$ 36,000$ then, I would have given it for Rarus, just to have had the old man keep him. After dinner, of which neither of us ate much, Mr. Conklin and myself went to the track, and found a great crowd around Rarus's stall. Tre drove up, entered the back door, and I had Dare, the boy, lead Rarus out where Mr. Conklin conld see him. I never saw 
any man parting with a friend show more feeling than $\mathrm{Mr}$. Conklin did for his horse, and he bid him that day what I believe was his last farewell, as I think he never saw him afterward.

When the hour for the trot arrived, there was abont ten or fifteen thousand people on the ground. It had got noised abont that Mr. Whitehead had received orders from New York not to start Rarus. Of course, there was great hubbub and excitement, the association coming to me about the matter, but as I had sold the horse with his engagements, I referred them to Mr. Whitehead. The talk ended by his refusing, point blank, under any consideration, to trot the horse. The officers of the association therempon took action in the matter in a manner that calused, at that time, a great deal of unfarorable comment, and which they afterward, at their own motion, rescinded, thereby showing that they considered themselves to have acted hastily, and to have imposed an unwarranted and mujust pmuishment on an innocent man-a punishment which was nothing less than the expulsion of Mr. Conklin and Rarns.

The people were wonderfully smrprised when the presiding judge rose in the stand and amonnced that Mr. R. B. Conklin and the bay gelding Rarts were expelled from all tracks forever. This seemed to me a strange and pathetic ending of two such noted characters on the turf-the man, one who had bred, raised, owned, and trotted the grandest horse that, at that time, the public hat ever seen, and that probably had delighted more people with his feats of speed than any other horse up to that time; a man who had sconned to do anything unfair or unjust from the first to last of his turf career; while the horse was one that had gone trice across the continent, and had never failed to do his best. For those two to be expelled at the end of such a career, and that, too, by the oflicers of the track over which the horse had made what were then the three fastest consecutive heats on record, was a sad, as well as strange, termination to a course of honesty in both man and beast. 
When this amnouncement was read out from the judges' stand, I immediately stood up in front of it, and then and there protested against the judgment as being wrong in erery particular. First and foremost, I stated that Mr. Conklin did not control the horse; that he made no engagement with the association in any way to trot the horse for them, and finished by saying that, if anyone was to blame or to be expelled, I considered that it was myself. Thy they expelled $\mathrm{Mr}$. Conklin instead of me, was one of those things that I could never find out.

By this time it was rumored that $\mathrm{Mr}$. Robert Bonner was the real purchaser of Rarus, and a grand rush was made by all the newspaper reporters to see who conld first find out the most reliable information. Mr. Allie Bonner was on the track, and he was interviewed on every side. When asked if his father owned Rarus, I heard him say that he might own him, but that if he did he knew nothing abont it. I was rather anxions on the point myself, and asked $M r$. David Bonner whether Mr. Robert Bonner had bought Rar'us or not, and he said he could not tell me. Nothing had taken place in regard to the sale of a horse in a long time that was so much written and talked about as this. The telegraph wires to New York were bronght into play, and in that manner $\mathrm{Mr}$. Bonner was interviewed from all sides. In the next day's papers was the authentic news that $\mathrm{Mr}$. Robert Bonner was the owner of Rarus, and the next day I received a telegram from $\mathrm{Mr}$. Simmons asking me if I wonld bring Rarus to New York for him, and at his own risk. The following morning I prepared Rarns for the trip, got his traps together, and $\mathrm{Mr}$ Conklin and myself went with him to New York. Arriving at Forty-second street, we were met by Mr. Simmons, who directed the horse to be taken to Mr. Bonner's private stable on Fifty-serenth street, near Fifth arenue.

When I saw the boy lead Rarus into that stable all my fears with regard to his having a good home vanished. I had always felt that there was one duty I owed Rarus, and that was to see that he was given a home as good as could be 
furnished for any horse after he had become useless as a turf horse, and when I learned that the sale to Mr. Simmons was in the interest of $\mathrm{Mr}$. Robert Bonner all the anxiety and perturbation of spirit that had natmally resulted from the sale vanished as if by magic, for I linew that in Mr. Bonner, Rarus had acquired an owner whose fame as the purchaser of the fastest trotters in the world was accompanied by the knowledge that every horse belonging to him received during his lifetime as good care as could be given any hmman being. I knew that as long as Rarus might live it would always be his portion to receive from experienced grooms every attention that was necessary for his well-being and comfort. I knew that the bodily ailments that were to come with increasing age would be attended to in the most skillful manner, and that under no circumstance would he be parted with, for it is a rule of Mr. Bonner's life that no one of the famous horses that he owns shall be sold; and the history of Dexter, Pocahontas, and the two old mares-abont the first fast pair that $\mathrm{Mr}$. Bonner ever owned, Lady Palmer and Flathush Maid-had told this to the world. Not alone where the English languige is spoken or written, but wherever the blooded horse is an object of interest, the name of Robert Bonner is a familiar one, and a book of this kind would be imcomplete without more than incidental reference to him, since no other name is so intimately and prominently associated with the American trotter as his. 1 man of rare intellectual attainments and business ability, which is demonstrated by the accumulation of a large fortune obtained in a strictly legitimate manner, with a mind that probes to its uttermost depths any subject worth taking under consideration, Mr. Bonner has given to trotting horses more mental eflort than any other man in the world.

Beginning thirty years ago, he purchased his first trotter, an animal that conld step in about three minutes, in obedience to the directions of his physician, who advised him to try driving for his health. From that day to this, 
Mr. Bonner has been an enthusiastic road-rider, and in the pair of mares mentioned above, he had the first team capable of trotting a mile to pole better than 2:30, and of doing two miles in a fraction orer fire minntes. From this to the purchise of lexter for $83.5,000$, an amount that seemed fabnlous at the time, Mr. Bonner's name was famous, and the morning after the sale abore referred to was nuade, it was flished all over the world as that of the owner of the fastest trotter that had ever been seen. Then came in rapid succession the addition to his prirate stable of so many noted horses that a list of them would be wearisome, and after all these purchases the acquirement of Rarus for $\$ 36,000$. After Rarus had been retired from the turf, St. Julien was the first horse to beat his record; then came Mand S., and she had lowered the trotting record to $2: 09 \frac{1}{4}$, people said there was one horse, the best in the land, that Mr. Bonner could not own, becanse she was the property of a man many tines a millionaire, the late $\mathrm{IT}_{\mathrm{m}}$. H. Tanderbilt. But strangely enough it came about that Mr. Bonner eventually did own Maud S., and when he became her owner it was throngh the wish of $\mathrm{Mr}$. Tanderbilt, and not only for the reason that Mr. Bonner was his personal friend, but that, as in the case of Mr. Conklin and Rarus, it was his wish that the famous daughter of Harold should become the property of the man in whose possession she would always be guaranteed a life of ease, so long as she might live. The writer has seen an autograph letter from Mr. Tanderbilt to $\mathrm{Mr}$. Bomner in which this sentiment is given works, and he knows that Mr. Tanderbilt's expression of his feelings in the case of Maud S., and his reason for selling her were as much a pleasure to Mr. Bonner as was the ownership of the fastest trotter the world had ever seen. I have often heard people bewailing the fact that Mr. Bommer bought mp and retired from the turf the best trotters in the world, but it hals always seemed to me that his action in this regard was a positive blessing to the animals, as it not only insmed their comfort for life, but also prevented the necessity of 
their being contestants in laces long after their powers were on the wane, cansing them to suffer defeat from animals whom in their prime they conld easily have left behind. Another reason why Mr. Bonner is a benefactor to the turf lies in the fact that his willingmess to buy, no matter at what price, the fastest horse in the rorld makes a constant market at top figmes for animals that would otherwise be white elephants on the hands of their ownel's-something for which an adequate value conld nerer be obtained. Mr. Robert Bonner, above all men, has been the friend, patron, and in every sense the benefactor of horse breeders, horse drivers, and horses themselves.

But to return to Rarus and his sale. After leaving the horse in the stable, Mr. Conlilin, Mr. Simmons, Mr. Darid Bonner, and myself, adjomrned to the Hoffman House, where the money was paid over to Mr. Conklin. I told Mr. Darid Bonnel that I had left all of Rartis's effects, wagons, etc., at the stable with him, with the exception of one pair of blankets that I had promised Mr. Conklin, and wished he would say to $\mathrm{Mr}$. Robert Bonner that he was entitled to them all, but that, if he did not wish to keep them, he could send me word, and I would come and take them away. The next day, I received a note from Mr. Robert Bonner, asking me to call at his office, which I did. He thanked me for my attention in sending him Rarus's traps; told me he wonld be glad to keep them, and insisted on giving me an order to duplicate them new from a shop at his expense. This I declined to accept, for the reason that I believed any man, who had given $\$ 36,000$ for a horse, was entitled to his belongings, and so said. Mr. Bonner told me that he should send Rarus to his farm in a day or two, and invited me up there to see Rarus in his new home. I accepted the invitation, and the pleasing remembrance of that day, and the valuable hints that $I$ received in the way of training looses, are still fiesh in my mind. I there took my last ride behind

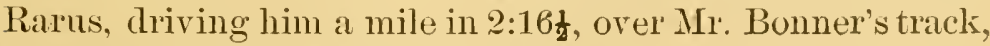
and left him with feelings of regret. 
I now come to what might be termed the personal history of Rarus; and, while it seems to me that his career in my hands had been at the least fairly successful, I feel like taking but a small part of the credit for his success to myself. First and foremost, he was a grand horse when he came into my hands, and his owner, Mr. Conklin, was a man that I think the owner of any trotting horse conld well pattern after. In the first place, he had what people would call a good deal of horse sense. In the second place, when he gave his horse to me to drive, his contract extended for four months. At the end of that time, he renewed his contract with me, and said to me, "Splan, as long as I own Rarus, he is your horse to do with in every way, shape, or manner as you see fit. No one shall erer criticise you or your actions to me. I will do nothing in connection with the horse without your freewill and consent. 'Take your time, and do what you can with him, whether it be in one, two, three, or four years. The greatest pleasure that I could have with that horse would be to see him beat the best record." When he told me that, I knew and believed that he meant exactly what he said. Few people imagine how the trainers of horses are annoyed by outsiders running to owners and criticising the actions of the drivers. It is an easy matter for a gentleman who never drove a trotter a step in his life, and who never did more than to sit up in the grand stand in a shady place, to saly to the owner of a horse how his driver should handle him, but if that same critic were asked to drive in a lace, he would have to be tied in the sulky, in order to insure his appearance when the horse was come under the wire. If I might be permitted here to give a little adrice to owners, it would be: If you get a trotter, pick out the man you think is the best driver and trainer in the world, gire him your horse, and treat him as Mr. Conklin did me, and, if you do not get that man's best efforts, I will be more mistaken than I have been in horse-lacing matters in a long while.

The next factor in $\mathrm{my}$ success with this horse, was, I be- 
lieve, the men that rubbed him for me. The first was Barney Stanford, who was a pupil of my old friend Mace, and learned the art of caring for a horse as well as it was possible for any man to acquire it. After having done this he was willing to give his employer his best services at all times. Barney came to rub Rarus in the fall of 1876 , and remained with me until the day I sold the horse. There was a good deal to Barney besides his ability as a horse rubber. He was dignified and obliging to everyone, attractive in his personal appearance, always dressed in the latest fashion, and possessed the taciturnity that is especially commendable in men who have to do with trotting lorses. In habits he was first class; he always managed to get a little money on all the good things that came off in the neighborhood, and took as much pride in Rarus as I did. In attending to a horse who was famous, it means that the head rubber must be, on every day of the trotting season, prepared to act as a reception committee to thousands of people, many of whom have apparently no idea of the responsibilities that are involved in the care of such an animal. In.dealing with over-enthusiastic folks, Barney displayed all the watchfulness of a Vidoeq and the diplomacy of a Talleyrand. He is now a stccessful trainer on his own account at Detroit, and I want to say that any man who gives Banney Stanford a horse to train and drive will place him in the hands of a capable, honest, industrious, and painstaking man.

The other boy's name was Dave Colross. He came to help Barney take care of Rarus in the spring of 1878. When he applied for the position he looked as though he might have been measuring tape in some dry-goods store. I asked him something about his ability in the care of a trotting horse, and he told me that Mr. Morrell Higbie, his former employer, had said he was the best rubber he ever saw, a statement which I wish to indorse. He remained with me until the day Rarus was sold, and afterward rubbed for me the pacer Johnston, in which capacity I shall have something further to say concerning him. 
In disposition, Rarus was a brave horse. not much inclined to be affectionate, but, at the same time, not a vicions animal. I never saw anyone that he seemed very fond of, except Mr. Conklin, Dare, and the dog Jinmy, without some mention of whcm no history of Rarus would be complete. This dog was a Scotch terrier that was presented to me in San Francisco by a fireman whell he was a youngster of about two months. I took him to the track and gave him to Dave, who advised that he be put in Rarus's stable. I cautioned Dave about the pup, as I had seeu. Rarus make the fur fly from one or two dogs, and told him that he might not have any dog, unless he put him in a safe place. In a few days I asked about him, and he told me that Rirus and the dog had got to be great friends. That appeared rather'strange to me, as, while I had always treated Rarus very kindly, he was never disposed to make filends with me. In appearance this $\log$ was a small, wiry-haired terrier weighing about fifteen pounds, and possessed of almost human intelligence. The admiration and love that this dog and horse liad for each other equaled anything that I hare ever seen in the liuman family. Not only were they extremely fond of each other, but they showed their affection plainly as did ever a man for a wonnan. We never took any pains to teach the dog anything about the horse. Everything he knew came to him hy his own patience. From the time I took linu to the stable a pup, until I sold Rarus, they were never separated an hour. Te once left the dog in the stall while we took the horse to the blacksmith siopl, and when we came back we found he had made havoc with everything there was in there, trying to get ont, while the horse, during the entire jommey, was uneasy, restless, and in general acted as bad as the $\log$ did. Dave remarked that he thought we laad better keep the horse and dog together after that. When Rarus went to the track to work or trot, the dog would follow Dave around and sit by the gate at his side, watching Rarus wich as much interest as Divedid. 
When the horse returned to the stable after a lieat, and was unchecked, the dog would walk up and climb up on his forward legs, and kiss him, the horse always bending his head down to receive his caress. In the stable, after work was over, Jim and the horse would often frolic like two boys. If the horse laid down, Jim would climb on his back, and in that way soon learned to ride him, and whenerer I led Rarus ont to show him to the public, Jim invariably knew what it meant, and enhanced the valute of the performance by the manner in which he would get on the horse's back. On these occasions, the horse was shown to halter, and Jimmy, who had learned to distinghish such events from those in which the sulky was used, would follow Barney and Rarus ont on the quarter stretch, and then, when the halt was made in front of the grand stand, Barney would stoop down, and, in a flash. Jinmy would jump) on his back. run up his shoulder, from there leap on the liorse's back, and there he would stand, his head high in the air, and his tail ont stiff behind, barking furiously at the people. He seemed to know that he was as much a part of the show as the horse, and apparently took great delight in attracting attention to himself. I had several tempting offer's for Jim in the way of cash, but such a thing as parting with him never entered my mind. When Rarus was sold to Mr. Bonner, Jimmy was not included in the bill of sale, but I felt that Rarus belonged to Jimmy and Jimmy to Rarus. After they botl became the properiy of Mr. Bonner, the affection of the dog and the horse for each other nerer abated, and this was well illustrated on one occasion. In Mr. Bonner's down-town stable was a bull terrier, a rather savage fellow, who had the run of the place, and naturally wanted to be boss. Jimmy, who was brave to a fanlt, attacked the bull terrier one day, and the result was that he was soon knocked ont. When his yelps reached Rarus, whose stall was adjacent, the old horse made a break for the center of the barn, and had he not been restrained, would have made short work of the bull dog. Mr. Bonner was much impressed with this 
incident, and afterward related it to the witer as evidence of how strong the bond of affection between these two animals was.

When I commenced to drive Rarus, I had some tronble in getting a sulky to which I could hook him far enough away so that he would not hit his hocks. While he did not have excessive action, when lee was strung out at his best clip he measured a good deal l'rom end to end. After several experiments, T. H. Brown, the sulky builder of Chicago, made him the first sulky that was really a success. It was the first one that I ever saw with an arched axle. which peculiarity of construction enabled the horse to be hooked close and still aroid any contact with the rehicle. What boots Raus wore I had made of the very lightest material. I used them as a preventive more than from actual need, as his gait was perfection, and I think a man could have driven him for years and never have hin hit himself. I drove him with an open bridle, and easy snafle bit, an orel-check and check bit. I used long martingales. Rarus was the most perfectly broken horse and had the best mouth I ever saw. No matter how high the rate of speed or how close the contest, with a simple word of month and the least shifting of the bit, a man was sure to attract his attention and meet a response in any way that he wished. A great many horses have to be taken hold of to scumare them and get them into their stride. Not so with Rarus. No matter how slow you jogged him he went with the same perfect motion he had at a high rate of speed. I never saw him hitch or hobble going either slow or fast. He was a good walker, and a pleasant horse at load gaits, and it seemed to make less difference in his effort whether he was going at a three-minute or 2:15 gait than with any other horse I ever saw. If he had grot up to $2: 40$ gait, you conld put him to his top speed in a rery few revolutions. A great many people imagine that he was not a very fast scorer. 'That arose from the fact that I knew he could win and always let him go away at a moderate pace. Some- 
times I would work him out with at rumner, and when we turned around about 150 yards from the judges' stand, Barney would have turned the runner loose at full tilt by the time we reached the wire. In carrying Rarus abont he never seemed to be tired. When we went to California and all the other horses would act as though they would like to be in their little beds, Rarus wonld be up and ready to kick the stall down. He knew as well when the ear pulled up to the platform as did one of the boys, and of ten gave us at good deal of trouble and fear lest he might hurt himself in charging about. I never knew him to miss a feed of any kind while I had him. His appetite was something wonderful. No matter how long the trip or how hard the race he was always ready for his meals. This was something very remarkable, as few horses go through a serious campaign without sometimes losing their appetites. 


\section{CHAPTER VI.}

The pacer Johnston, and the manner in which he was trained to beat all the records $-A$ nervous, fretful horse that would not feed well-Treatment at Cincinnati during the winter months-Slow work in the spring-Speed comes gradually-Dave Colross turns up in the nick of time, and takes care of the horse-A mile in 2:10 at Milwaukee, and then 2:061 1 at Chicago-Mattie Hunter, Sweetser, Gem, and other famous pacers.

I now come to the consideration of the fastest pacer that the world has ever seen, and to whom I gave his best record.

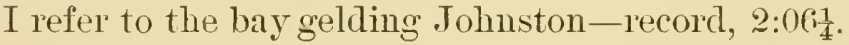

This horse was bred near Berlin, Tis., and was sired by a horse named Bashaw Golddust. His breeter was a German farmer, and, when the colt was four yeas old, he sold a half interest in him to C. M. Mather, a banker of Berlin, for $\$ 350$. The following summer the horse was taken to Chicago by a local driver named Bassett for the purpose of sale, the price asked for him being $\$ 5,000$. He was driven a number of miles better than 2:20 while in Chicago, the best exhibition being $2: 15 \frac{3}{4}$. No sale was made and in the fall the horse was sent home. During the following winter E. H. Smith of Milwaukee went to Berlin and bonght a controlling half interest in Johnston, paying therefor $\$ 5,000$, and a few weeks later the horse was sent to Chicago and placed in the stable of Peter $T$. Johnston, a well-known driver, after whom he was named. The horse had previonsly been called Charley M., and at the time of the change of name he was entered under that name for sereral events, but had never started in a race for money. Johnston drove him a number of races through the Michigan circuit, wimning then all, and came back to Chicago, where he won a purse and race, reducing his record to 2:13. In the first heat of this 
race, which was the fastest, he distanced Billy S. and Eddie D., and in the second Gurgle was behind the flag at the finish. On October 9, of the same year Johnston paced a mile in 2:10 orer the Chicago track, beating the then best pacing record of $2: 11 \frac{3}{4}$, which was previonsly credited to both himself and Little Brown Jug.

At this time I was training' Commodore Kittson's stable of pacers and trotters. The Commodore was approached by the owner of Johnston to buy that horse. In an interview with $\mathrm{Mr}$. Kittson he told me that if I thought Johnston was capable of beating his record he would like very much to own him. He said he wished I wonld investigate the matter and give him my opinion. At this time Jolnston was rather a delicate-looking horse, and I, with many other people, had fears about his staying abilities. I saw his owner's and they arranged to drive him three heats for me. When the day for the trial came it was raining. Finally, on the 23d of the month, the track was fairly safe, but, not at all fast. I asked Mr. Johnston to drive the pacer three heats, twenty minutes apart, and not to punish him in any one of them. I figured for myself how much slow the track was, and then took into consideration the fact that the horse had been interfered with in his training. In this

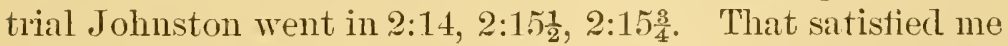
that he was game. I thought any horse that would pace the first mile in 2:14 and then finish the third one in 2:1.) $\frac{3}{4}$ had courage enough, and went home very much pleased with the performance, which, together with his mile in $2: 10$, convinced me that he had a first-class chance to make rery fast recold. I reported the facts to $M[r$. Kittson and told him I thought, without doubt, Johnston would beat erery pacing record in the world. On the strength of that recommendation Mr. Kittson gave $\$ 20,000$ for the horse and placed him in my hands, with the understanding that he would be trained expressly to go a fast mile.

When Johnston arrived at my stable I found him very low in flesh from the fact of his having been very sick 
through the middle of the season. His appetite was poor, and he seemed nervous and irritable with strangers or at noise of ally kind. My first idea was to take him to California, and winter him there, thinking the warm climate and plenty of grass would be beneficial. I finally decided, howerer, to take him to Chester Park, Cincimnati, my reason for selecting that place being that I had been there the previous winter with my horses and found it one of the most comfortable places in winter there is in the northern country. On reaching Cincinnati with Johnston, I called in a veterinary, and had the horse examined. The doctor prescribed some gentle physics and tonics, and suggested that he be turned out in a field of grass whenever the weather permitted. I took off his shoes and started on this treatment immediately. It was quite a while before Johnston showed any improvenent in his condition or apletite, but after being on the grass about thirty days, I saw a slight improvement. The veterinary still continued his tonic treatment and gave him some more medicine for his blood, which he decided was out of order, from the effects of his last year's illness. About the first of January the horse commenced to put on flesh. I had a large paddock built for him, and every day, unless there was a storm, gave hinı a run of abont thirty minutes in it. By this time he had got to be a good-feeling horse and took al great deal of exercise. His appetite kept increasing and I giadually added to his allowance of food. $\mathrm{U}_{\mathrm{p}}$ to this time I kept him in a comfortable stall with plenty of bedding and moderate clothing. If the thermometer fell I increased his clothing, and immediately reduced it when the weather moderated.

About this time we had a good fall of snow and I had a boy lead Johnston, by the side of a saddle horse two or three miles on the track every day. I kept his feet nicely rounded off, but had no shoes on him. I followed this treatment until the first of March, by which time he had grown and filled ont into a very handsome horse, and weighed a hundred pounds more than he did in the fall of the year, 
which is a good deal of flesh for a hor'se to put on in that space of time. Besides looking to his feet and exercise through the winter I studied Johnston in other ways, and tried to learn his disposition, temperament, etc. I noticed that he was a good deal inclined to be nervous and fretful, and ver'y much afraid of strangers, and, if you put him in a stall where anyone was working round he acted a good deal like a wild animal. If he was feeding, and a stranger stepped into his stall he would walk away from his feed and perhaps not go near it again. The result of this observation, together with some experience I had in training Rarus to go fast miles, was my determining on the following plan: The first of March I took Johnston up and had him clipped. There is a great difference of opinion in regard to clipping horses. My experience, after having tried it for years, is that in training a horse in a cold climate in the spring of the year clipping is a very important thing to do. Before the horse sheds his coat, if you exercise him enough to walm him, he will be sure to reduce himself in flesh more than you want him to. With a horse like Johnston, that is inclined to be soft, before you could get his legs in order, the flesh would be all off him, and I wonld advise that in the majority of cases it is hest to clip a trotter when he is in training, when the spring begins.

I had Johnston shod with about fourteen-ounce shoes in front, and seven-onnce onesbehind, and started in myself to jog him and superintend every thing about him. I lived within abont sixty yards of his stable, so that I think there was not much done that I did not see. I gave him, through the month of March, from six to eight miles a day, when the weather would permit, in the way of moderate work on the road, to a calt that weighed about 200 pounds. He had at this time about eight quarts of oats a day, with plenty of hay. He appeared to do well all the while. The flesh hardened on him and he seemed in the best of spirits. By the first of April the track was in good order and I commenced to give Johnston less jogging on the road, and moderate work on 
the track, never better than a three-minute gait, and after at couple of weeks of that I began to drive him a great many slow miles in from 3:00 to 2:50, kept all the flesh on him that I could, was rery careful abont clothing him, and did not blanket or scrape him in any way. I gradually increased his feed to about ten quarts a day. He seemed to be ery strong on his legs but acted as though he did not have much speed. I had, by this time, increased the work to about a 2:35 gait, and would drive him five or six heats a day about twice a week in from 2:50 to 2:35. I did not attempt to brush him, but simply rated him along, and sometimes would drive a mile and a half or two miles at a 2:40 clip. In this way I got his flesh very hard and smooth. I found that he kept to his feed well, but still continned to act as though he did not have much speed. The latter part of May I commenced to reduce the number of miles 1 gave him, shortened his work, and brushed him in places nearly as fast as he could go. Instead of giving him slow miles, I worked him oftener, and brushed him a way nearly every day, and, in a short time, I found he had plenty of speed. He had by this time wom his shoes off until they weighed abont twelve ounces. His feet were naturally rather long at the toe and low at the heel. I shortened his toes all I could and raised his heels.

The best mile I drove Jolnnston orer Chester Park was in about 2:25. I then went with the balance of $m y$ horses through Indiana to trot them, and took Johnston with me, but as the tracks there were all halt-mile ones, and rather bad, I did not do much with him excepting to give him plenty of slow work, and nothing in the way of trying to speed lim. I gave an exhibition with him at Indianapolis, but did not try to drive fast as I considered the track unsafe for that sort of a performance. From there I brought him to Chicago, where I had an engagement to show him, and, one week before this race, gave him five heats, twentyfive minutes apart, commencing at 2:25 and gradually improving the pace, so that his last heat was in 2:16. I drore 
him the final 250 yards in the last heat as fust as I could, and thought he went about a 2:10 gait. This work seemed to draw him up some, and also impaired his appetite. I had found that in shipping. Johnston about from one track to another he became more nervons and irritable. If you left him long in the stall he would tramp aronnd like a wild animal and get himself into a perspiration. I think he was the most nervons horse that I evel saw. If anyone went into the stall next to his, and commenced to hammer or make anything like a lond noise, he would try to climb ont of the window. If a stranger stepper into his stall he would give a snort and back into the farthest corner. I made up my mind that it would be a pretty hard job to train that kind of a horse and make him beat 2:10. At this time I changed his shoes, pntting on a ten-onnce shoe in front, with leather pads and a sponge between the pads and his foot. I did this for sereral reasons-first, I wanted to lighten the weight on him, as I fonnd that one onnce on a pacer tells more than two on a trotter, and in shoeing him with a very light shoe I was afraid that the track might sting his feet and make him unsteady.

When the day of his trial came I drove him in 2:11 $\frac{3}{4}$. This pleased me, as the day and track were not favorable for fast time, and I did not drive him a real scorching mile. I think he could have gone that clay a mile in 2:10. From there I took Johnston to Cleveland, and there his condition manifestly improred. The track and roads were fine, there was plenty of grass, and the cool nights that are common on the shores of Lake Erie seemed to brace the pacer mp. I gave him all he wonld eat, plenty of moderate exercise, worked him ont about twice a week a mile ancl repeat, in abont 2:20, and would brush him the last part of the mile. About this time John Campbell, half owner of the pacer

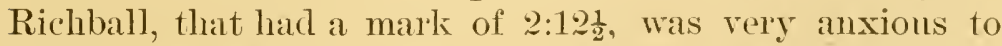
make a race with him against Johnston. I talked the matter over with Mr. Woodmansee, Commodore Kittson's superintendent, and Dan said he would like to have me make 
up my mind whether I thought it a good scheme to make a race with Richball or not just then, and if I thonght it was he would accept the challenge. I worked Johnston a little way on Tnesday, and on Wednesday morning went out and scored him down seren or eight times and sent him a mile in 2:15, going both halves about alike. After twenty minntes I scored him six or seven tintes more, and went the

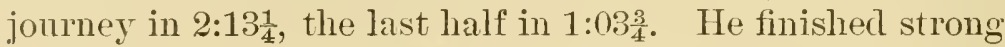
and good, and I told Mr. Woodmansee that was speed enongh to go against any horse in the world. He took my advice, and made a race with Richball, to come off over the Chicago track later on.

From Cleveland we went to Buffalo, where the following week we paced Johnston in a race that had been arranged by Mr. C. J. Hanlin, and in which the winner of the first heat went to the stable, and the winner of each successive heat then retired, until three heats had been trotted or paced. Then the horse having made the fastest mile was entitled to first money, the others taking their positions in the summary according to the speed they had shown. Johnston won the first heat and the first money by going in 2:12. I conld have driven him faster, bnt carried my watch, and was satisfied that 2:12 wonld win the money. The following week we went to Rochester. All this time I had as rubbers for Johnston two boys that was I dissatisfied with, and often wished that I might secure Dave Colross, the boy that took care of Rarus 'for' me.

The morning after we arrived at Rochester, who should walk into the stable but Dare. I asked him what he was doing, and he replied that he was engaged in some business in town. I finally asked him if he would come and rub Johnston for me, saying that if he would I would make it an object to him. I told him that I was very anxions to have Johnston beat his record of $2: 10$, and thonght he could do so, everything being favorable. Dave finally said that he had made up his mind to never rub another 
horse, but to oblige me he would come and stay until the end of the season, which he did; and I want to say here that I think to his care and attention, more than any other one thing, is due the fact of Johnston's haring the fastest record of any trotter or pacer in the world. I have always said that Dare deserved as much credit, if not mole, than I clir, for the result of the effort. The next morning Dave came to work; I told him all I knew abont Johnston's peculiarities, and I saw right away that the boy had entered into the affair with his whole heart and soul. The first thing he did was to get a dog and put it into the stall with the horse, claiming that it would be company for him. From that day on Johnston improved, ate more, was less nerrous and fretful, and, in fact, did better in every way. I paced him two heats over the Rochester track, the second one of which he went in 2:113. From Rochester we returned to Chicago and paced a match against Richball over the West Side track, and Johnston beat him easily in three straight heats, the time being $2: 13,2: 11 \frac{3}{4}, 2: 13 \frac{1}{4}$. From there we went to Minneapolis, and paced another race against Richball, a mile and repeat. Johnston won the first heat easily; in the second heat he threw a boot, and Richball beat him; but in the third Johnston won the race withont an effort. At Stillwatel we paced our last race against Richball, again winning. About this time Johnston commenced to show the form and speed that afterward made him famous. From Stillwater we went to Milwankee to pace an exhibition. The weather was not rery farorable and the track was far from heing good. But, in spite of this, Johnston's exhibition was so satisfactory that ereryone thought, with a hetter day and track, he would certainly beat his record, and alragements were therempon made for him to pace the following week. He failed to beat his record, but tied his best mile, going in 2:10. I told Mr. Woodmansee I believed that, with anpthing like a fair day and a good track, Johnston wonld certainly make the fastest record that ever was heard of. He therenpon armanged to have the 
holse brought to the W'est Side track at Chicago, to make a grand effort.

At this time Johnston was doing as well as I could wish. He had, to a great extent gotten orer his disposition to be nerrous, ate heartily, took to his work kindly, and rested well. Dave never left him alc for a moment, not eren to go and get his meals. He latd them brought to the loose's stall, and ate them there. He slept there, and I nerel saw him away from the stall all this time, further than to go to the pump. After his hor'se was done mp in the morning, Dave would go inside the stall, shut the door and stay there. This treatment was just what Johnston wanted, as, with Dare and the dog in sight, he felt contented and lost his nelvousness. On onx amival in Ch.cago we found the track rather heary from recent rains and set to work to try and put it in first-class condition, which we succeeded in doing to our entire satisfaction. I nerer for one moment donbted that Johnston would go a grand mile, for ererything about him pleased me. At this time I had him shod with a shoe and pad and sponge forward, the whole weighing nine and one-lialf ounces, with a five-ounce shoe behind. When the bell rang for his trial I never saw everything appear to be in better shape for fast time. The day was simply perfect-warm, with plenty of sun and no wind; the track as fine as yon could wish for, being perfectly smooth and not too hard. I gave Jolnston four slow hoits, twenty minutes apart, before the trial, commencing with a mile in 2:40, winding up in 2:19, the last half in 1:07. The reason 1 gare him these slow miles was that I wanted to have his stomach thoroughly empty before making his effort. Johnston was a horse that did not need any particular. warming up to thaw him ont, as he always had his speed with lim, and was not tied up from being sore.

In tilking the matter orer with Mr. Woodmansee, I said that I was sure Johnston would beat 2:08. Mr idea was to drive him to the half in 1:04 and then step him home as well as he romld go. Mr. Woodmansee eantioned me not to 
try to do too much with him, for fear he might make a break and spoil it all. He thought that, perhaps, driving him to the half-mile pole in 1:(04 would be too fast, and make him stop, but I figured that the Chicago track was at least two seconds faster than the one at Milwankee, where he paced in 2:10,and I also thought that that effort liad done the horse good. I told Mr. Woodmansee I was sure that I would be safe in trying to drive him to the half-nile pole in 1:04. So when the time came I scored Johnston down a couple of times easily, took my watch in my hand, and brought him to the stand at about what I considered a 2:08 gait, got the word at the third attempt, and went the first eighth of a mile in just sixteen seconds. Inerer clucked or spoke to him in any way, he simply swinging along at a great big open gait, as thongh he was ont for exercise. He went this clip to the quarter pole, where he landed in thirty-two seconds. The sime eren stride was continued down the back stretch, and I timed him to the hall-mile prole in just 1:04. In going around the.upper turn, I pulled him a trifle wide on the turn, as the water had washed the track ont a little next to the pole. That quarter we went, by my watch, in $31 \frac{1}{4}$ seconds. I had not yet spoken to him, but he seemingly increased his speed from the half-mile pole on. At the three-quarter pole I found we had landed in 1:3.), and knew, from the ease with which he went there, that he was bound to beat all the records that had ever been made, unless he fell down. I never spoke to him until he was within an eighth of a mile of the judges' stand. There I pulled the bit throngh his mouth gently, and spoke to him once. He seemed to straighten ont and go lower to the gromnd, and the sulky conmenced to weave a little, as though it were hooked to an express train. After he got well straightened out into his stride I leaned over and touched him gently with the whip, when we were within about 100 yards of the wire, and he shot ont at a rate of speed that I never before saw any horse attain. Te passed the stand going better than a two-minute gait. finishing the mile, as I made 


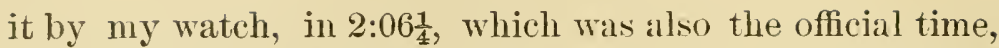
beating the best racing record $3 \frac{8}{4}$ seconds and setting a mark that, to this day, looks a good way off to any pacer or trotter.

It so happened that although the day was a pleasant one the audience was not large, and this was not the first time that a great harness performance has been made with a small crowd in attendance, as a few years previons to this when Mand $s$. beat all the trotting records by going a mile in 2:10 $\frac{3}{4}$ over the same track, there was hardly a corporal's guard on the ground, no one expecting to see a fast mile. But those who did see Johnston make this performance were mostly practical horsemen and when the judges announced the time; the shout that went up made up in enthusiasm what it lacked in rolume. The trial did not seem to distress the horse in the least and I am positive that he could have gone some faster, and his yerformance the following week prores to me conclusirely that this is the case. He went directly from Chicago to Lexington, Ky., and, being detained in a smash-up on the train, Inerer had a chance to put the harness on him until he came out to pace for the money. He was to pace for a purse to beat the best time ever made over the Lexington track, and won by going in 2:08, pacing the last half up the hill in 1:02-a performance that it would take a pretty fair runner hitched to a sulky to accomplish. This was the last time I ever drove Jolnnston, as my commection with the Kittson stable was then severed.

I have heard a great many people say that Johnston is a soft horse. In condition, I think him as game a horse as I ever saw, and by long odds the fastest one. Ont of condition, he is about as helpless a lorse as can he imagined; and that is not the rase with Johnston alone. Some of the gamest horses that I ever saw when in condition, were the most helpless when out of form. Rarus, a horse whose stamina and courage no one ever doubted. was the same. Wedgewood, who proved himself to be possessed of as much 
bulldog determination as any horse I ever saw in a race, would give it mp, when short of work, at the slightest notice. I have been told that game chickens will run away quicker when ont of condition than a dunghill bird will, and I believe it is the same with horses. It is my idea that the more finely organized and better bred a horse is the more liable he is to quit when out of condition. I have been asked whether I thought a horse that conld go in 2:06 $\frac{1}{4}$ was not more finely organized, and more delicate in his nervous system than one that could not go a mile better than 2:40. I answer yes. I think a high nervons organization is what makes a horse go a mile in 2:06 $\frac{1}{4}$, and I think, further, that it requires more skill to drive a horse a mile in 2:10, provided that is his limit, than a loorse that can trot in 2:30, provided that is his limit. My friend, William McGuigan, explains this by saying that there is as much difference between training a 2:10 and a 2:20 horse as there is between sharpening a razor and an ordinary jack-knife; that any boy can sharpen a jack-knife, but that it takes a barber to keep a razor in order.

I have already alluded to some peculiarities of Johnston in the stable, and will finish by stating what boots, etc., he wore. I used on him a very light knee boot, and an extra light pair of quarter boots, with shin boots in front, and nothing behind. I drove him with an orercherk, and open bridle, and a smaftle bit, covered with rubber. I covered his bit because of Johnston's having such a tender mouth that he seemed afraid to take hold of the bit enough to steady himself. I used long martingales on him, and checked him moderately. In his trial he pulled a forty-two pound sulky, and I weighed 153 pounds. Johnston was a very steady horse. I think he never broke with me orer three or fom times in his work or racing. After everything was just right, track, etc., it was al good, safe bet that he would never make a break.

The day that I drove .Johnston to his record at Chicago, was a sort of gala occasion in my career as a driver and 
trainer, and what took place that afternoon has seemed, both to myself and my friends, as the best exhibition of training and driving that I ever gare, as it included the driving of a pacer a mile in 2:061, in single harness, unaccompanied by a rumer or other incentire to effort; the reducing of Fanny Witherspoon s record to $2: 16 \frac{1}{4}$, and driving the pareing mare, Minnie R., a mile in donble harness, with a running

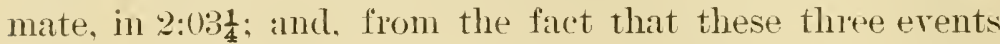
were so closely associated, all the horses being owned by the one man, and all having been trained and driven by me, I think this an appropriate place in which to say something concerning the other two amimals:

Fanny Witherspoon was a handsome chestnut mare, sixteen hands high, very dangy looking, with the grandest set of feet and legs that one could well imagine. She commenced her turf career' when a colt, having been trained to trot, I think, as a tro-year-old. In her younger days, she did not give much promise of the speed that afterward made her famons. She passed through a number of clifferent trainers hands, and was finally sold to Commodore Kittson, and was in his stable when 1 took charge of it, in 1882. At that time she had a disposition to be a rather unsteady, disagreeable mare, a fact which she proved to me beyond a doubt after I commenced to train her. She seemed to have a great deal of speed, but not the least idea of being driven. She wanted to do everything when and where she liked. The effect of her natural disposition and of having had her own way was something that it was rather difficult to orercome. I do not say this with any disrespect to any of the gentlemen who drove her, because I think that no one man had Fanny long enough to give her what she really needed-a thoromghly good schooling. I think that great man y horses are spoiled, because their trainers do not have a chance at them, from the fact that they keep them one season, which is just about long enongh to learn what to do with them, and this mare, I think, proved it. 'The first year I had her, while she showed me a great deal of speed, and I drove her some good heats 
and won some races with her, I thomglit her, on the whole, rather msatisfactory. I drove her' a trial orer the Cleveland

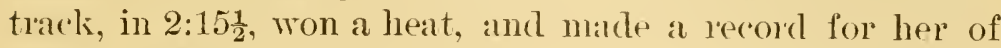
2:17, in a \$10,000 pirse, but got beaten a good many slow and unsatisfactory laces, sometimes not as fiast as 2:20. At the end of the season, I took her to Cincinnati, at the same time I did Johnston. I made up my mind that there could be a great deal of inprovement made in the way of training and driving her, and made a study of it through the cold months. I wintered her abont the same as Johmston, the only difference being in the feecl. I gave her a little less to eat and more work, she being a very strong and lobnst mare. with a disposition to put on a good deal of flesh. When the spring arrived I commenced to work her. She lad always been driven, before I got her, with an orer-check and no martingales. At this time she was rather slow to score, and if yon pulled her out after a horse and she could not rush by in an instant, she would be almost sure to break. I told Mr. Woodmansee that, if she could not be hroken of all these habits (as she was in a class where she must not only be able to trot fast but also behave herself well to get any of the money), it would be better to give up trying to make a trotter of her.

Almost everyone thinks a trotting horse onght to be driven with an over-check, a mistake that I have often made myself. In talking to Orin Hickok abont this peculiar mare, he suggested that she be tried with a side-check and an overdraw bit. I conchnded to try the plan, he telling me at the time that that was the first andangement he could drive St.Julien with. I gave Witherspon thirty dass work on the load to a cart with this arrangenent. I then put a halter on her, or what is better known as a halter with a standing maltingale, and fastened the martingale uncler the girth so as to thaw her head down; kept letting hel check ont, and shortened the martingale by degrees till I got her head on abont a level with her back. I drove her with an easy, covered bit, and a nose band. Ifter giving her six weeks' work on the 
road I took her to the track and rommenced to give her a great many slow miles. Some days I gave her as many as six or' seren miles between 2:50 and $3:(0)$ 'This treatment rather dulled her spirits, but I gave her plenty to eat all the time, and after this commenced to teach her to score fast. We did nothing at all in the way of giving her fast miles, but let her lave all her work in scoring. I would take her" out some days and score her an hour at a time. At first she did not take very kindly to it; she would either want to rush up against the bit or else break; but I kept perserering with this treatment, and after a month or so of that sort of work saw some improvement in ler beharior. Then Ishortened her work and increased the speed. After I had driven her two of three moderate heats in the morning I would - take a rumner out with her. It first she would seldom let the rumner get within hailing distance without wanting to break. I kept this up, trying to acenstom her to the runner, and after awhile commenced scoring him with her.

It was quite awhile before she took kindly to that, but after awhile she gave up entirely and allowed me to place her anywhere I liked in company with other horses. I then stopped giving her the long, slow work, but changed it to plenty of road work, and brushed her every day from a quarter to a half a mile. I took her with me on our trip' to Indiana, and gave her lots of moderate work, and when we arrived in Chicago we had her entered to trot against Edwin Thorne. Her feet and legs looked to be in as good conclition as it was possible for them to be. A week before the race I gave her five heats between $2: 30$ and $2: 24 \frac{1}{2}$, twenty minutes apart, with plenty of scoring, giving her abont as much work as she wonld have got had she been in a race with that number of heats. In this work she was rery steady and showed plenty of speed when called upon. I may say that she beat Erwin 'Thorne one of the best contested races I ever saw, of five heats. He took the first two, she the third, fourth, and fiftl. I will describe the last heat in detail: The went away from the wire together, and in going down 
the lack side I felt as though Fanny was able to out-trot Thorne, but concluded, as she was going safe and steady, I would remain where I was. But she was a peculiar mare, and the least little thing would attract her attention on the track, so that she was liable to jump over it. At the threequarter pole there was a path where the people had walked across the track, and in crossing that in every heat she showed a disposition to break. This time I held her well in hand, thinking that I had Thorne beaten sure, and that there was no chince for her to make a break; but when she came to the place she seemed to notice it, and, in spite of all extra caution and effort, she made a phunge and jumped over it. John Turner, who drove Thorne, knowing my mare's peculiarities, took advantage of the circumstance, and made as much noise with his whip and voice as the law would allow, and at the same time got me in pretty close to the fence, as I thought, hindering me from having a chance to swing Fanny out and catch her. My first thonght was that the race was over, but as she broke I swung her to the inside fence and let her go as though I intended to rum her against it. 'This had the desired effect, as she canght and came on with one of the bursts of speed that she was noted for, and in spite of all of 'Tumer's efforts, she beat 'Thorne, thereby winning the race. I think Tnrner was a little bit surprised, and I know I was.

I have heard a good many people saly that it is impossible to condition a horse and make him go his best race without having had him in two or three races. I think, in some instances, that may be the case, but not always. I believe, if you have time enough and give him work enough, you can condition a horse and bring him to his very best efforts withont a public race. This I consider the best race that Fanny Writherspoon ever trotted before or atter, and I refer to it in proof of my argument. If a horse is idle or inclined to be lazy, it might need the excitement of al race or two to get him to his best efforts, but I believe any fair horse can be taken out with a runner and trained to his very 
best condition in that way. These impressions I obtained from Orrin Mickok, and on this subject he knows more than any other man I ever saw. In my hints on training, I shall give some of his ideas as he expressed them to me.

From Chicago we went to Kalamazoo, and had identically the same battle there between IVitherspoon and 'Tholne. Before this race came ofi, I net Mr. Stewart, an old and respected citizen of Kalamazon. He told me that, in his younger days, he timed Floua 'Temple when she made lier record of $2: 19 \frac{3}{4}$ over the Kalaniazoo track, and lie remarked at that time that he did not expect to time anotlier horse faster. In a conversation on the moming of the race, he said he had heard a great deal of other horses going very much faster than Flora Temple, but it had nerer been his privilege to time one of them. I told him. if he wonld come to the track that afternoon and did not get such a chance, I would buy him a red apple. He said: "I am get ting old and feeble, but, if I thonght that I would hare that opportmnity, I would make an effort and come down." In the afternoon as I drove on the track, I met him there; and he said, "I am here, and have got my watch with me, and if I don't see some horse go better than $2: 19 \frac{3}{4}$, I will be disappointed as well as win a red apple." In the first two heats Witherspoon was slow in getting off, and a little inclined to be unsteady, and Thorne beat her in 2:20. In the third heat she got well thawed out, and they had a battle which ended by her getting home first in :2:17, which, taking into consideration the condition of the track, I ronsidered the best heat she ever trotted. At the end of the heat my friend Stewart said: " WVell, you have won. I am going lome now, and I think that is the last time I will ever see a horse trot in 2:1\%, as I fear my health will nerel artmit of my coming to a track again." Witherspoon beat Thorne in the fomrth heat: in the fifth she broke at the halfmile pole, and it looked as though the race was ended, but when she grot straightened ont she came with one of her tremendons hursts of speed, and while 'Turner' drove Thorne 
with more determination than I ever saw him display before or since, she canght him a hundred yards from the wire, and, after a desperate struggle, beat him out a head, thus winning the lace.

I now come to the trial at Chicago, in which she went against Fritz, a pacer, for a special pnrse. She beat him the first and second heats handily, but before the third heat I told Mr. Woodmansee that I thought I could give hel' a very fast record if he wished to have me do so. He replied: " cut her loose; that is just what the Commodole would like." When she got the word in the third heat, she went away straight and fast, reaching the quarter-pole in thirtythree seconds; she went the back quarter in thirty-three seconds, making the half in 1:(1). I eased her a little in the third quarter, but she went it in thirty-four seconds. After she got straightened into the stretch, I commenced to drive her. When I got within 150 yards of the wire, Mr. Woodmansee ran ont and motioned to me to stop her. which I did. She tinished easy in 2:161. Mr. Troodmansee explained to me afterward that he thonght it better to keep the mare in the $2: 17$ class. I am sure that she would have gone a mile in 2:16, or better, had he let me timish with her as I was going.

I have alluded already to some of Witherspoon`s peculiarities. She was a little inclined to shorten "1) her gait behind. The last year I had her she improved very much in hel disposition, and also in her gait, and I believe that had she been trained regularly afterwards. must have made a very fast record. as, at the end of her trotting career, she was one of the soundest animals I ever saw. She was letired from the turf without spot or blemish of any kind. I wore on her in front about a ten-ouner shoe and a light quarter-boot, with buckskin rolls above her ankles behind; scalpers, light shin boots, passing boots, and a seven-ouncr shoe. After the breaking up by anction of Commodore Kittson's breeding establishment. Fanny was bought by Mr. E. C. Long, of st. Paul, who intends to use her strictly as 
a hrood mare, and that she will prove a great success in this department cannot be doubted, as, in addition to possessing wonderfnl speed, she had also the quality of stamina to a great degree, as was shown by her trotting two miles in 4:43, lowering the record for that distance three seconds, her performance being still the best. In blood lines she is of a most fashionable quality, being by Almont, one of the sons of Alexander's Abdallah, and ont of a mare by Gough's Wagner, thus miting in her the strains that produced Mand S. and Jay Eye See-the Hambletonian family on the patemal side and that of Lexington in the female line.

The third performance of that memorable day at Chicago, was with Minnie $R$. This was a remarkable mare in more ways than one. In the first place, she was not a trotting-bred mare, her pedigree being almost thoroughlored. In the next place, she was the only horse I ever saw that had a record at pacing and trotting, both better than ?:20. When she first came into my hands Minnie R. had a trotting record of 2:19, and with a disposition to pace. She had been trained and driven with heary toe-weights and from the nse of them had become very sore and lame, so much so that, in fact, it was almost impossible to make hrl strike a trot, no matter how mnch weight I would put on her. I told Mr. Woodmansee I thought it was very foolish to try and train her to trot, and suggested that he make a pacer of her. He seemed to think it better not to give up the idea of trotting her. As the first year I had her I had done little if anything with her, when I went to Cincinnati with Johnston, I took her along, took off her shoes and toe-weights, and went to work on her, with the idea of trying to relieve some of the soreness in her feet and legs. We succeeded in that very well, and when the training commenced in the spring, I insisted on trying to make a pacer of her, and Mr. Woodmansee finally consented. When I first began to work her on a pace I had to put about sixteen omces on her in front, and about nine ounces behind. She rould pare about a 2:40 gait. I commenced very moderately with her, the same as 
with a horse that had never shown any speed at any gait. I kept increasing the weight on her hind shoes, and decreasing the weight in front, and, after about thirty days of that sort of training, I paced her a mile in 2:30. At this time she had on abont fifteen ounces behind and not more than twelve ounces in front. She handled her forward feet all right when I began to work her, but her hind feet would get ont of place occasionally, and she would make a break. That was the reason I liept the weight on her behind. After training her thirty days more with the weight in this manner, she got to be so steady and true that I drove her a mile in 2:25, and she could have gone some faster. I gradually rednced the weight on her hind feet; the only change I made on her forward feet was that I shod her with leather pads and a sponge of oakum. I then took her, with the balance of the stable, to Indiana, and paced her several races, all of which she won with ease.

From there we went to Chicago and Michigan, and she never lost a race. At Buffalo, during the summer meeting, Minnie R. paced the race of her life. That year "Knal" McCarthy had Jewett. He had been a trotter, with a disposition to pace, and "Knap," seeing Minnie R. going so well, conclnded to try it on Jewett. 'The report had got out that he had shown him a very fast trial, which I think must have been true, as, when the bell tapped for the race at Buffalo, "Knap)" had Jewett in the race, and Peter Schatz, his owner, was there, with all his relatives from orel the line, to bet their money on him. I thought Minnie R. onght to beat him pretty handily, as I had rated him to go a mile, in about 2:18, but, for fear that they might have a "sleeper," I concluded to lay up a lieat or two. It was very fortunate for us that we adopted that plan, as I now think that, if we had gone ont in the first heat, we would have been beaten in the race. When the judges said "go" in the first heat, Jewett went ont in front, and was never headed, winning in the fast time of $2: 16 \frac{1}{4}$, and Peter Srhatz was correspondingly happy. In the next heat, Jewett led from start to finish, in 
2:158. I clid not make a more in either one of these heats, and of couse there was nothing left for me to do in the third mile but to go out and make a fight. When they gave the word Jewett went awaly with the lead. At the quarter pole he was two lengths in front of us, and groing down the back stretch he ontpaced me at least another length. but at the half-mile pole I set sail, and, when we turned into the stretch, Minnie R. rommenced to gain on him, but rery slowly. From there to the judges' stand. both horses were driven for their lives, and Minnie R. beat Jewett a nose in 2:16 $\frac{1}{4}$, which most people thought a pletty good third heat for two companatively green pacer's to make.

Jewett was a good cleal distressed after the heat, and, while it did not look rery rosy to me, I felt faily conticlent that Minnie R. would beat him the race. She did, but not without a struggle, as he hung on and went one of the best laces of his life. Just before the racestarted my old friend Charlie Perkins, whom ererybody around a race track is on friendly terms with, eame and asked me what I thought abont the race. I told him to het every dollar he had on Minnie R., as I thought he would win it, sure and easy. After the race was over, Perkins came around and in his own peculiar manner, told me that times had changed considerably since he was a boy, as in those days men would not tell a friend to put his last dollar on as close a race as that was. But, after I explained to him that Jewett was about three seconds faster than I thought he was, Charlie said that as long as he had won his money, he would forgive me.

From Buffalo we went to Rochester, where Minnie R. met and defeated the same field of horses, in four heats, Jewett winning one heat. None of the pacers were at their best in this race, as they had not gotten over the scorching time they had at Buffalo. We retmmed West from there, and gave a number of exhibitions with running mate, in all of which Minnie R. acted well and went fast. In this performance at Chicago, where Minnie R. made her record, the runner was not right up to his best form, as he had taken 
part in a good many races of that kind and become stale. Minnie R. went to the half-nile pole in one minute, and covered the third quarter at the same gait, and, I am sure, if the rumner had not tired, they would hare gone the mile better than two minutes, but 200 yards from the finish he gave up the ghost, and Minnie R. had to do all the work from there out. landing at the stand in $2: 03 \frac{1}{4}$. 'This was her last performance in public, and she retired from the turf with three rec-

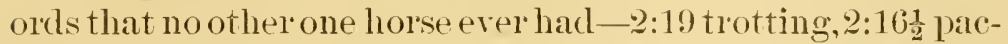

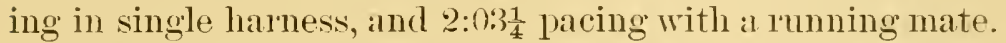

Here is a problem for the breeders and trotters of pacers to solve. This was a mare without any pacing or trotting' blood to speak of, and for her to go out and both trot and pace so well seems to me considerable of a mystery. She was a rery blood-like and racy-looking mare, abont fifteen and one-half lands high, with head and neck like a race horse, and long, round, smooth body and hips. She did not look at all like a typical pacer, was a good feeder and easy trainer, and a good campaigner. She had the rery best of legs, withont any bunches or puffs of any kind, and her feet, with the exception that they had become rery much bruised and sore from the use of toe-weights and heary shoes, were remarkably good. That she was rery game was demonstrated both at the pace and trot. I think that she should have had a good deal better record at both gaits than she got, and as she has been put to breeding, I shall watch, with a good deal of interest, what her produce may do.

While on the subject of pacers, I will give a little history of my star side-wheeler, Mattie Hunter. She came on the turf in an era of pacers that has never been equaled, and looks as though it never would be. She was one of what was once called the "Big. Fonr" - namely, Sleepy Tom, Lucy, Rowdy Boy, and Mattie Hunter-but I will not undertake to tell all of the wonderful races that these horses paced. I have a fair knowledge of them, ass, at one time or another, I drove, I think, all of them. I drove Mattie Hunter a race or two for Mr. Pate, of St. Louis, and I liked her so well 
that I induced my friend, C. F. Emory to buy her. He did so, thinking she would be useful as a race horse, and that when her career on the turf was finished lee would like to have her for a brood mare. I think the result has proved. that his judgment was wise in the matter, as, after he owned her, she beat more horses than ever beat her, and her career in the stud promises to eclipse her turf careel. She was a mare fifteen hands one and one-half inches high, a chestmut with four white legs, white face, and I can't remember now, in all my career, a handsomer or more blood-like animal than Mattie. She was the universal farorite of all the women and children. In motion she was grace itself. her gait being perfect, and her disposition the finest. She was a fast scorer, and a good finisher, two things that are hard to beat in a lace horse.

In the summer of 1879 , Sleepy Tom electrified the country by his wonderful pacing performance, having beaten all previous trotting and pacing records in Chicago that year. At Rochester Mr. Pate asked me to drive Mattie Hunter, saying that he thought she had a chance to beat Sleepy Tom, a statement that I was hardly prepared to believe; but the result proved that in Mattie Hunter Mr. Pate had a great mare that day, as she forced Sleepy Tom to go the best race that has ever been paced. I laid Mattie up in the tirst heat, which Rowly Boy won in 2:138, giving everybody a surprise, as no one expected him to go at that rate.

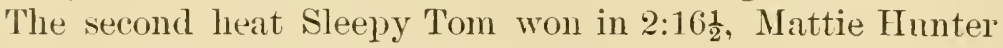
again just dropping inside the distance flag. In the third heat we went out for a battle, and IIunter beat'Tom in $2: 15$. She beat him the fourth heat in $2: 15 \frac{1}{4}$. The fifth heat he defeated her, after one of the most desperate finishes I ever saw, in $2: 13 \frac{1}{2}$. In the sixth heat they fought every inch of the road from start to finish, the others being out of the race, and Tom beat Mattie the shortest kind of a head in $2: 14$, thus winning the fastest race of the number of heats ever paced or trotted in one day, the average being $2: 14 \frac{2}{8}$ for the six heats. 
This a very good story for people who are breeding and training pacers to read whenever they get to thinking they have the only pacer that ever was. Another thing that impresses itself on my mind is the fact that both these horses were pacing-bred pacers. Of late years nearly all our fast pacers have been trotting-bred, and Jewett, Mike Wilkes, Westmont, Roy Wilkes, and a dozen others that I coukd name that have beaten 2:20 a good way, are by trotting sires, the Alexander's Abdallah and George Wilkes branches of the Hambletonian family having given us more pacers than any other trotting strain. Still, there has never been a pacer that has gone as good a six-heat race as both Mattie Hunter and Sleepy Tom fonght out that day at Roehester, nine years ago. Mattie Hunter is by Prince Pulaski, a pacing horse from Tennessee, and Sleepy Tom was by Tom Rolfe, a descendant of the famous old-time

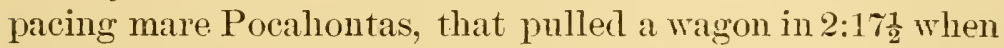
she was four months in foal with the colt that afterward sired this very pacer Sleepy Ton. Mattie Hnnter's best record was made under the following circumstances: At the July meeting at Pittsburgh in 1881, Maud S., trotted against the watch, and went a very fast mile. The public and the association thought that she would be able, with another trial, to beat it, and they arranged for her to trot against the watch again. On the regular programme Mattie Hunter won the free-for-all pacing race that week, and took the deciding heat in 2:143. The association offered an extra purse for her and Sorrel Dan to pace the day that Mand S. should make her trial against the watch, with an extra inducement if $2: 14$ was beaten. The race was to be a mile and repeat. Mattie Hunter won in straight heats, going

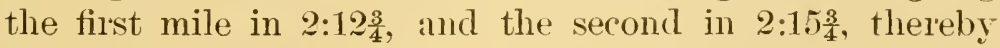
winning the race and the extra money that was given for time.

One of the best races Mattie ever paced, taking into consideration the slowness of the track, wats at Springfield, where she defeated Lucy and Rowdy Boy a contest of six heats, going the last mile in 2:15: I have mentioned only 
a very small percentage of the great number of races that she took part in, always being in the thickest of the fight, and I think, with the exception of once or twice, getting some share of the purse. She wore no boots of any kind, and paced all her races with an eight-onnce shoe in front and fire onnces behind. I wore leather pads on her all around, latd a bar-shoe on in front, with calks at the toe and heel. I know it is rather musual, either with a trotter or pacer, to use calks, but I have done it with a number of horses, with success. Mattie's feet had been neglected in her early life, had gotten ont of shape and were very much hruised. she having what people term corns, but which are neither more nor less than severe bruises, on the heel. When yon shoe a horse with a very light shoe, withont any leather or other protection, and drive him orer a track as hard as they have them nowadays, the result is almost sme to be that the horse's feet will become more or less bruised and very much inflamed. I think that a small calk helps to break the concussion, and for that reason I have often used them. I drove Mattie with an open bridle, long martingales, and an easy orer-check and check bit. She drove very straight, never pulled, and never wanted to break. After her turf career Mr. Emory put Mattie to breeding. He mated her with strictly trotting-bred horses. I have watched all her colts with a good deal of interest, and have never seen any one of them strike a pace under any circumstances, but, on the contrary, evely one of them trotted naturally, light from the start, withont shoes or weight of any kind. Mattie herself had a nice, open gait at the trot, and I have sometimes seen her strike at least a three-minnte gait at that way of going. I always felt that, if she had been weighted and trained to trot, she would certainly have gone very fast, and I predict that some of her colts will prove winners at that gait, and, in fact, one of them has already done so, as her danghter, Mattie Mentone, as a two-yearold, in 1887, captmred a stake and beat 2:40.

One other pacer I had that had a good deal of speed, but 
lacked the other qualities that go to make up a race horse, was the gray gelding Sweetser. IVhenerer I hear his name it brings to mind the time I sold him to my life-long friend Capt. John De Mass of Detroit. When I bought Sweetser I gave $\$ 2,500$ of my own money for him, and while I owned him gave him a record of 2:17 to wagon and 2:15 in harness, but for all that I decided that he wonld not do for a race horse. One day at Cleveland we were discussing the qualities of the different horses, and Sweetser's name was mentioned. I said that I owned him, and that I would be glad to sell him at a loss. De Mass asked how much of a loss I would stand, and I told him I gave \$2,500 and was willing to lose \$1,250. He said that if I split the balance he would take the horse, meaning of course that he would give me $\$ 625$ for him. I told him that was a good ways to fall, from $\$ 2,500$ to $\$ 625$, but I shonld let him have Sweetser. He got his money out, paid me \$500, and said that he would give me the other $\$ 125$ at the hotel. I told him that he need not do that, I would bet him $\$ 125$ that he had cheated himself, give him thirty days to figure, and let him decide it. I met De Mass a few days afterward. He handed me the $\$ 125$ and said he was glad he did not accept my proposition to bet, as lie had clecided, withont waiting thirty days, that he would lose. As De Mass is one of the men that never cry if they do not get the best of everything, this horse trade never interfered with our friendship.

Gem, another pacer, that I had, was a handsome bay mare by Tom Rolfe. The only remarkable thing that I can think of about her was that she got a record of $2: 13 \frac{3}{4}$, which I gave her, and that she nerer won for me but one race, and tried to lose that one. the only reason that she did not do so being that the other horses conld act worse than she conld, one of her opponents getting distanced after beating her two heats. 


\section{CHAPTER VII.}

The story of the fast, game and reliable stallion Wedgewood-A horse that had a succession of hard races during his career-Going close to 2:20 the first time he started--Desperate contests in the mud at St. Louis and Cincinnati, and a glorious victory at Washington-Down the central circuit the next season, winning every race in which he started-A peculiar horse to train and drive-What came of trying to please a friend-Laying up heats, and sparring with the judges as well as the other drivers-A welltold tale of a great horse's campaigu from the lakes to the sea.

The best and fastest stallion that ever I drove, and one of the most successful horses that ever appeared on the trotting track, was the brown stallion IVedgewood that came into my stable late in the fall of 1879. Wedgewood is by Belmont, one of the stallions in use at the Toodburn farm of Mr. A. J. Alexander, where he was bred, and his dam was Woodbine by the thoronghbred horse Woodford. This mare Woodbine also prodnced Woodford Mambrino, another stallion that proved himself most successful on the

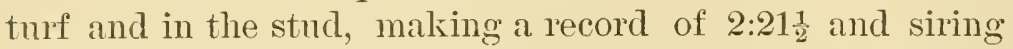
among others the famous stallion Pancoast, that was sold for $\$ 28,000$, the highest price ever paid at auction for a trotting stallion. Pancoast made a name for himself when his son Patron came ont as a three-year-old a few years ago, and trotted in 2:19 $\frac{1}{2}$ that being the best record for a trotter of that age. This he accomplished in a well-contested race. Two years later he reduced that record to $2: 14 \frac{1}{4}$ in the third heat of a race over the Cleveland track, in which he beat Harry Wilkes. I state these facts to show that W comes honestly by his trotting speed and race-liorse qualities, and also his success in the stud. 
After selling Rarus to Mr. Bonner, myself and a friend were looking around for a trotter. Mr. Emory liad called my attention before this to Wedgewood, telling me he thouglit liim the making of a good horse. This talk left an impression on my mind, and I decided that we would take a trip to Kentucky and see the horse. On our way there we met $\mathrm{Mr}$. Emory, and he rather surprised me by saying he liad already bouglit WVedgewood. I asked him if he would sell him, and if so at what price. He told me he would, and fixed $\$ 10,000$ as the price. WVe went to Kentucky and spent a week looking over the trotters, and listening to the stories that wére told us of the wonderful horses that were owned at that time in the State. IVe finally decided to buy Wedgewood. The horse had a public record at this time of 2:38, and had shown a trial orer the

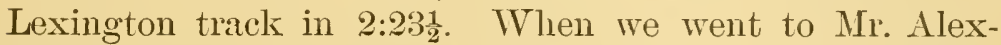
ander's place in company with Mr. Emory to see the liorse, we found that he was certainly one that his breeder and trainer conld be proud of and the first time I drore him, I decided to buy him, which we did witlıont any delay. As I remember lim on that morning he was a handsome brown stallion about fifteen hands, two and a half inches high, with the best of feet and limbs, had no wind puffs, bunches or blemishes of any kind, and looked what he afterward proved to be, a first-class race-lıorse in every particular. Mr. HuIl, Mr. Alexander's trainer, had nothing but praise for the horse, and predicted that he would certainly beat 2:20. He told me that he had never done much with him in the way of hard training, had given lim plenty of moderate work, wishing rather to have a good horse than a fast colt.

It seemed to be IVedgewood's fate while on the turf to have nothing but hard battles to fight. In the first lace I ever started him, at St. Louis, he made a horse trot in 2:20 to beat him. In this race no one had any idea that they would go better thian 2:27 or 2:28. I knew Wedgewood was not in good shape for a hard lace, but thought at that rate of speed he would have no trouble to win, and on the 
strength of that started him and put my money on it. This race will prove that even the people on the inside of a horse race are sometimes seriously mistaken. I for instance in this race thinking 1 had an easy thing to win in 2:26 or 2:27, and betting my money on that basis, realized before the race was over that I stood a good chance of getting beaten, losing my money, and ruining my horse. The race was a hard fight of seren heats, and before it was over the track was a sea of mud from the effects of a storm that came up. As this was my first race with Wedgewood in I decided to lay him up. The first heat was won by Green Charley in 2:26 $\frac{1}{2}$. The result of this heat rather convinced me that I would have no trouble to win, and when they gave the word on the second heat I started out for the front. Fanny Robinson, a mare who up to that time had the reputation of being very fast but uncertain, more liable to be distanced than to win, took the lead, and I followed with Wredgewood in second place. At the half-mile pole I moved up and tried to beat her, but was very much surprised to have her stay through a hard fight, and lead me to the wire by a neck. As I came back to the stand Mr. Goldsmith was there, and said: "He beat you, but you have got a good horse." The heat was in 2:201. I . I knowledged that I was surprised as I never for a moment supposed that she could make such a performance. In the next heat we went at it hammer and tongs when the judges said "go." Fanny Robinson beat me all the way to the distance stand. There Wedgewood closed with her, and they came to the wire a

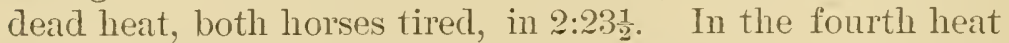
they had another struggle from start to finish. Fifty yards from the wire, when Wedgewood had the mare beaten, he pulled off a shoe, made a break, and slie won the heat in 2:23.

We were then overtaken by a tremendous shower of lain and the race was postponed until the following day. When we were called ont the track was so bad that I was afraid to start my horse, and I tried to induce the judges to agree 
to a postyonement, saying I thought it inhuman to compel horses to trot orer a track like that, and pointing out that I had just paid a long price for my horse, and was afraid that I might ruin him. The gentlemanly judge, whom I shall never forget, gave me a pretty short answer, said he thought the track was too good if anything, and cautioned me to bring my horse out and use my best endearors to win. This last suggestion he might as well have kept to limself, as I had my money on Wedgewood, and did not intend to give up without a fight. The other gentlemen who thought they had such good mud horses were a little surprised when IVedgewood went ont in the morning and won the fifth heat in 2:31 going through the slush like a dnck on its way to breakfist. He was beaten the next heat after a driving finish and was as tired a horse as ever I saw. An old friend of mine, J. C. Kelly, who had some money on him, told me that my chances for winning the race were gone, that lie did not beliere it possible for any horse that was as tired as Wedgewood was to go another heat fast enough to win. I told him that I was not worrying about getting beaten, but I was sure that it would ruin the horse to give him such a race as he was getting in the condition I knew him to be in. I took him into a field behind the judges' stand, called for a comple of pails of warm water with which I bathed him thoroughly, washed off the mnd, gave him a good fomenting with hot Pond's Extract, threw a light blanket over him, and walked him about. In a short time he stopped trembling on his legs, seenred easier in his wind, and I made up my mind that the rest of them must be a little tired, as they too had been going their best through the mud. In the deciling heat Fanny Robinson beat Wedgewood all the way to the distance stand, but there he carried her to a break, and won in $2: 27 \frac{1}{4}$.

This being the first lace in which IV edgewood started, and taking into consideration his condition, and the other circumstances that I have allnded to, I should not have been at all surprised if it had ruined him, and so stated at the 
time. The following week at Cincinnati, he trotted two races, and here the luck of St. Louis followed him, as they were both desperate affairs of fire heats each, where he was defeated after winning a heat in $2: 23 \frac{1}{2}$ orer a lalf-mile track. I then said: "No more hard races until he is in order, if I don t win a dollar with him." Right here I wish to state that I have seen a great many horses cruelly punished and injured by trying to win with them when they had no chance, and were in no condition, simply to please the spectators, and pool-buyers and satisfy the judges. In the second Cincinnati race I soon found that it would be impossible for me to win. There were sixteen starters, and as IVedgewood was the favorite over the field they combined to at least not give me any the best of it. I believe that when a man knows he can not possibly win, he ought to have the right to drive his horse as easy as he likes, but in this instance, as in many more, after the horse had made erery effort to win, and conld not, the judges called me up and wanted me to punish him just to satisfy the public, something I very plainly told them I would not do. I informed them that I would rather have the public dissatisfied than to punish the horse, as I saw there was no chance for him to win. One of John Turner's strong points to my mind; is that when he is beaten and he knows it he stops punishing his horse right there, and instead of wearing him out trying to do something impossible, saves him for another day. The best race-horse trainer I erer saw had one rule in regard to this. The order he always gave his jockey was: "Then you find you are beaten, stop liding; don't punish your horse to win second or third place," and I believe that the trainer who does this will save his horse and make more money than the man who hammers him out and drives him those several races for the sake of getting a place.

From Cincinnati, I took IVedgewood to Pittsburgh, where I stuck to my resolve, as I drove him a very easy race. From there we went to Philadelphia, where he had another easy race, and was a much improved horse. About this time 
some of talent remarked that I had paid pretty well for a poor horse, and when I started him in Washington the following week in a large field of pretty fair campaigners, he was entirely orerlooked in the betting. I thought he had a chance to win, and told some of my friends so. W $\mathrm{V}^{\mathrm{e}}$ got our money on at good odds, and when it came to the race I laid Wedgewood mp the first heat, wimning the second with him in 2:25 $\frac{1}{4}$. I then made up my mind that everybody was getting ready to have a battle, and that it was a safe conclusion that I would have a chance to lay up a heat or two, which I did. Wedgewood won the sixth and seventh heats of this race and convinced me that I had not overstepped the mark when I bought him. That was the last lace he trotted that season. I sent him to Long Island to be wintered, where he was jogged and well cared for until the following spring. He was then allowed to serve a few mares before leaving Long Island, after which I took him in hand, trotted a few preparatory races, and went to Chicago, at which place the grand circuit of that year properly began, my iclea being to trot him in his class all through circuit, feeling confident that he would make a record and perform in a manner that wonkl justify all I claimed concelning him.

Wedgewood did more than this, for from Chicago to Hartford, or in other words from Lake Michigan to the Atlantic Ocean, he trotted and won every race for his class in the grand-circuit meeting, placing a succession of victories to his credit that have never been equaled by any trotting stallion, as he was successful at Chicago, Cleveland, Buffalo, Rochester, Springfield, and Hartford, and to show the wonderful endurance of this horse I may state that in these six races, the number of heats trotted was twentynine, or an average of five to a race. In the Chicago race, I had only Lucy and Katie Middleton as opponents, and as Wedgewood had the foot of these two he won in straight heats, the time of his best mile being 2:21. It may be noted that in this mile he redneed his record of the previons year two and one-half seconds. At Clevelund there was a remark- 
ably strong field to start against, as the lot contained Kentucky Wilkes, Deck Wright, Kitty Bates, Palma, and Katie Middleton. By this time I learned that to give Wedgewood a sereie first heat, either in his work or in a race seemed to distress him rery much. I thereupon concluded that the best way to win with him was to lay him up until I saw that he was in condition to do his best. He was rather a close-made horse, sometimes would not sweat ont freely, and was rather slow about emptying himself. When I would first take lim out for work it would seem as though it was impossible to make hin extend himself, and if I drove him hard heats he would be rery much distressed, both in wind and limbs. He being the farorite orer the field in the Cleveland race I expected a battle and was not disappointed, as I got all I had bargained for, and more too. My opponents gave me the best they had in hand and the judges annoyed me all they could by trying to compel me to go off in the lead in the first heat and win all the time. I think it is all right for the juclges to see that everybody tries to win when they can but I believe that the driver and the owner of a horse are the best judges of how and when to win with their own horse. It seems to me that if a man pays 10 pel cent. entrance money he ought to have the privilege of saving how lis horse shall be driven, prorided of course that he is trying to win. Some people may get back with the remark that men lay their horses up in lieats to work the pool-box. I wish to deny right here that I erer drove a horse a heat in the interest of the poolbox. I never played my horse, for or against, in a lieat and I never saw a man that dici do it make a great deal of money at the game. In this race I backed my horse for the race right from the start and went out to lay him up the first heat, which I did, but it seemed to me, in this heat that he could not go much, Kentucky Wilkes winning in 2:22. Then I determined to try to win the second one, but when I scored up with Wedgewood I fomnd that he had no speed, and I thereupon made np my mind to lay him up 
again. Before we got the word the judges called me to the stand and lectured me roundly, saying they wanted me to try and win right there and then. When they gave the word Wedgewood threw off one of his toe-weights, and I

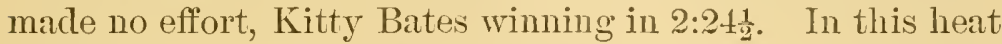
Wedgewood acted to me as though he never would win a heat. The judges called me into the stand again and said they were thinking of taking the horse away from me. I told them rery plainly that they might expel me, but that I would not give the horse up; that I was trying to win with him, that I had my money bet on him, and I further added that I did not propose to be treated in that manner. I told them they conld investigate the matter if they wished and if they found that I was not trying to win, they could punish me, but give up the horse I would not.

By this time the boys had taken WVedgewood to the stable, where I followed. He seemed quite distressed, did not sweat ont any, and in several ways convinced me that he was out of condition. I took two pails of warm water and gave him a shower-bath with it, and after that gave him a thorongh rubbing with hot Pond's Extract, and went out and scored up for the third heat, but did not get the word until the judges had given me another good lecture. I state this to show how far wrong the judges sometimes are. When we got the work, Deck Tright sped away with the lead. I never made a move with my horse, and Tright won the heat in 2:22:3. Then I turned into the stretch in this heat I spoke to Wedgewood, and for the first time in the race, he showed.that he had his speed. After the heat was over, I told Mr. Al Carlisle to get a few pool-tickets on him, as I believed he would win. By this time the judges had exhausted their fund of talk, conchuded that Wedgewood was unable to win, and said nothing more to me. In scoring for the fourth heat, Tredgewood showed plenty of speed. When the word was given I trailed to the half-mile pole, there cut him loose, and he won landily in 2:2:2 He won the next heat in $2: 23 \frac{1}{4}$, and the last in $2: 24$. No nuatter 
how hard I might have tried in the first part of the race, he would not have won a heat, and. I beliere, would have hurt his chances of winning the race.

The following week we went to Buffalo, and the same field of horses had a fight that would do credit to any field of trotters now. In the betting Wedgewood sold even against the field, and from what I saw abont the pool-boxes before we started I made up my mind that my opponents were there to give me a battle royal, and the result proved that I did not make any mistake. The only error they did make was that instead of "bunching their hits" as they say in the prize-ring, they sparred with each other while I laid up, and at the finish they fell victims to IT edgewood's gameness and sveed. Kitty Bates won the first heat in 2:19, knocking sereral seconds off her record, and in the second heat that world-renowned campaigner Deck Wright made his star performance, winning in $2: 19 \frac{3}{4}$, which is his record to this day. The third heat Kentucky Wilkes won in 2:211, which is also his best mark. In these three heats I had not made a move, but when they scored for the fourth Mredgewood and myself had on the war paint, and we needed it, as Kentucky Wilkes gare us such a fight that from that clay to this he has been always borne in my mind as not only one of the best sons of that greatest of all sires Geo. Wilkes, but I believe the gamest Wilkes that I ever saw. Wedgewood and Wilkes fought the lieat from start to finish, both horses being driven for all they were worth, and at no time in the heat was there daylight between them. Wilkes broke in tine last twenty-five yards, and Wedgewood beat him to the stand in $2: 21 \frac{1}{2}$. I made up my mind that this would about finish WVilkes for that day, as he had gone four heats and had been first or second in every one, but I counted wong. When they said "go" in the fifth heat he immediately mored up to the front, out-trotted Wedgewood to the half-mile pole about a length, and from there to the judges' stand they fought out another desperate finish in which TVeclgewood beat him in 2:20. 
By this time I had made up my mind that in Wilkes I had an opponent that it would hardly do to overlook. He did not show the slightest disposition to surrender at any part of the mile, and Wedgewood only beat him in the last stride. Mr. E. H. Brodhead the owner of Kentucky Wilkes who lived in Milwankee, was unable to be present and see the gallant fight his horse made, but his interests were ably represented by my friend H. D. McKinney, who ably seconded Kentucky Wilkes. contesting every inch of the ground on the quarter stretch and under the judges' stand. Mr. Mcckinney protested everything that day, inclnding all the heats I won and those I laid up, telling me afterward he did this for two reasons, to keep in practice on the law points and to be sure that no technicalities were overlooked. There was no chance for Johnny Grier to miss a point, as Henry was there with the laws and rules.

In scoring for the deciding heat, everybody was determined to get away first. The judges scolded, threatened, and at last fined several of the drivers. When the word was given there was a general scrimmage to the quarter pole, in which everybody indnlged and the hickory flew in a manner to lead the spectators to believe that they were looking at a toothpick factory in operation. Deck Tr'ight, who was always famous for his ability to hurdle, outdid himself in this case. By the time we reached the half-mile pole, they were strung out, and the race was again between Kentucky Wilkes and Wedgewood. Whether McKinney's coaching or Grier's natural disposition to see how fast he could drive a horse did it. I don't know, but if I had not known Grier, I should have imagined from the way in which he hustled Kentucky Wilkes along that he was a Dan Mace. He out-trotted me through the third quarter a little, and as we turned into the stretch, took me right up against the inside fence. From there to the stand the horses changed position at least half a dozen times. First one was ahead and then the other, but in the final stmggle Wedgewood showed in front at the wire by a head in $2: 20 \frac{1}{2}$. 
The following week at Rochester we struck some new talent in Wedgewood's race, which we disposed of without much trouble, winning in four heats, Kitty Bates taking the first. In the second heat of this race Wedgewood re-

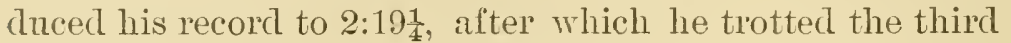
heat in 2:20, and the fourth in 2:23, winning easily. In this race I made one of the greatest mistakes of my life. I was more than ever convinced that for IT edgewood to go a good race he must be laid up at least one heat, and maybe a little more, it depending a good deal on his condition. The newspaper reporters and a few other's who go to the races commenced to abuse me roundly; said that I wasdriving Wedgewood simply in the interests of the pool-box; declared that the judges ought to compel me to win in straight heats with him, and if I refused or did not do it, take the horse away from me. This did not affect me much, as long ago when I was a boy and worked for Mr. Simmons, I once went to him, complaining that the newspapers had criticised me very severely, and he said to me: "TVell, Splan, if you are going to make your living out of the public, you will be bound to be criticised, and sometimes very severely, but you can rest assured of one thing-you had better have them criticise you severely than to say nothing at all about you." Mr. Simmons told me many a good thing, but I always considered this one the best. I don't believe that newspaper criticism can make or ummake man. If he is made of good stuff, all the newspapers in the world can't write him down, and if he is made of soft material there is no real merit. The higher the newspapers write him up, the harder he will fall when he comes down, as he is certain to do. A friend of mine who, like the newspaper reporters, thought I could win whenerer I liked, came to me at Springfield, and said that as a personal favor to him he would like me to win in three straight heats; and to please him, and thinking perhaps I conld drag it off in three heats, I put my money on my horse and started out with that determination. The track was soft and deep and 
the day very hot. I tried for the first heat. Deck Wright did some trotting and a great deal of rumning, and beat me to the stand in 2:201 $\frac{1}{2}$, and the judges gave him the heat. I punished Edgewood in this heat, and drove him for his life, and when it was finished he was a good deal distressed.

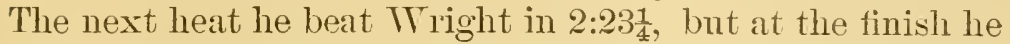
was so badly distressed that I decided to lay him np the next heat. I took him down mnder a tree, and Orrin Hickok, who had some money on him, went along and helped cool out the horse. I got plenty of warm water and gave Wedgewood a shower bath, took him orer to the bank of the river and walked him there in the shade. It seemed as though he never would stop blowing, and he came as near having the thmmps a horse very well could. Then the bell lang he was still very much distressed, and I went to the track determined to lay him np, no matter what hap-

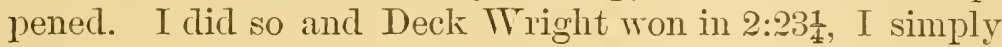
saving my distance. By the time they rung the bell for the next heat, Wedgewood was a good deal better, and it looked as though he might have a chance to win. Then the word was given the others went off in front and I trailed to the half-mile post, but drove from there home, beating TTright

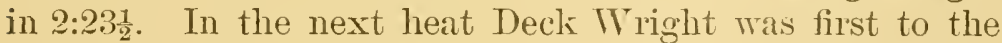
stand, in 2:261. He did not do as much running as in the first heat, and I think to this day was entitled to the last heat, but the judges took it from him and gave it to Tredgewood. I thereupon made the resolve that in any race I might ever drive, no remarks that the public might make and no criticism that might be written about me in the newspapers would erer have the least effect as to how I should manage my horse

I do not wish to be understood as saying that I will not take adrice, because I am always ready to do so, and have often asked it, but what I do wish to say is, that I should be the judge of who is the one to give me the advice. I think it a good thing for the trainer and drivel to counsel with competent persons. If you have a particular case in hand and 
you don't seem to get on as well with it as you could wish, pick out the man that you think would be the most liable to be well posted on that particular subject and go and get his opinion. You are not obliged to follow it after yon get it, and in finding out his opinion, you may learn something. I have many a time asked advice from different people, and have received some that has been of great ralne to me, and to illustrate this I may state an experience that I had with Dan Mace on one occasion. It was when Hopeful first came on the turf. I saw Mace drive him, and also some other people try their hand, and he seemed to me to be very notional about scoring. In talking with Mace about it, he acknowledged that he was, and he told me what the peculiarity was. He said Hopeful could not bear to have another horse score up head-and-head with him to get the word, and in such an emergency he was almost sure to break or pace. He told me the way to do was to take Hopeful down behind the other horses, and bring him up on a bulge-that is, to let him go as fast as he conld, and if he was within striking distance to take the word, and Hopeful with his extreme speed would be able to rush by almost any horse, and take the pole from him.

I never thonght any more of this until a lace when I was asked to drive Hopeful after he had lost two heats. The first time I scored down I turned round head and head with the other horse, but at the wire Hopeful broke, and paced. That brought to mind the conversation I had with Mace two years ago, and I resolved to act on what he told me. I went up and turned him round, as Mace had directed me, following his instructions as nearly as I could, and when the horses came to the wire, the others were going abont a 2:25 gait, and Hopeful was about at a 2:22 gait, they pulling back, and Hopeful going at full sail. I nodded for the word, the judges said "go," and before it was cold ont of their mouths Hopeful had the pole and was never headed. Mace always said: "If Hopeful is in the lead, and another man comes along head-and-head with you, take him right out, 
and after you get in front ease way on him, keep him there, and don't let the other horse get too close to you." Later in the season Mace had Hopeful at Buffalo, and as he had a misunderstanding with the association there he declined to drive the horse. There was a great deal of talk about who was to drive him, etc., one paper stating that Dan would send for his brother Ben. Dan came to my loom and said to me: "I think this association has been treating me badly and I won't satisfy them well enough to drive over their track. I want you to drive IIopeful. I think there will be pretty fair betting on the race. He will have no trouble to win, and we will try and get ourselves some money." There was nothing said in public about my driving Hopeful until the bell lang for the horses to come ont, when I appeared behind Hopeful and won the first heat easily. In going away in the second heat I took him back a trifle, and when the judges said "go" steadied him around the turn and Great Eastern rushed up head-and-head with him. The moment he did this Hopeful broke. Great Eastern took the pole and I could not get Hopeful to try to beat him after he had lost the lead. When I got out of the sulky I told Mace it was my fault that I lost the heat. He said: "Ion't tell anyone, as they all think that Eastern will beat him, and we will have a good chance to win something." Then they scored for the next heat I had the long sights on Hopeful and when they said "go" his head was at Great Easter'n's heel, but when they struck the first tum he was in the lead and if Rarus himself had been there after him he would not have been going faster. I took him back there, but I had never let Eastern get closer than within three lengths of me, and won the heat without an effort. The last heat I followed the same tactics, and he won the race. I doubt very much if he would have done so if it had not been for whit Mace told me.

There are a great many little things about horses that it takes time for a man to learn. Of course I think the man that is driving every day and is behind a great many differ- 
ent horses has a sort of kuack, and gets on to a horse's peculiarities rery quickly. That was one of Mace's strong points. He wonld look a trotter orer and tell at a glance a'out what sort of a horse he was. There was another thing abont Wace that a good many people overlooked, and that was that if he was out to trot or work with you he was studying your horse at every opportunity, and if there was any peculiarity about him he was pretty apt to see it, or in other words he would try to get the best of everything that was going. He said to me once, when I was a boy: "TVhenever you go into a fight with a man, the first thing you do is to find ont what kind of tools he is going to have, and be sure and hit him first." That was invariably Mace's way in a race. He found out all he could about the other man's horse and his ability and was prepared to take advantage of all the weak things. In regard to this peculiarity of Hopeful's that Mace told me of, and that I learned when I came to drive him to make use of, I was also prepared to take advantage of it when Hopeful came to trot against Rarus, as I never allowed Mace to go up and come down with me on a bulge. No matter how far he went back, I went back and turned with him. Mace was pretty cute, and often tried his old tactics, but I had just as good a horse, if not a little better than he, and I had him at a disadvantage. I often heard people say that Hopeful always made a better race against any horse than he would against Rarus, and I think that was the reason why. The man who drove Rarus was well acquainted with Hopeful, both from hearsay and by having driven him, something that might not seem like muclı of an advantage, but it woull be enough to win a close race.

Returning to the story of IVedgervood and his races, I may say that after the contest at Springfield, where I distressed the horse somewhat in an effort to please it friend, he went to Hartford, trotted five heats there, and made the star performance of his life against a fresh lot of timber, which included Charley Champlain, Iron Age, Knox Boy, 
Golden Girl, and Keene Jim, our late opponents, Patchen and Deck Wright being also on hand and in better form than ever. This was one of the betting races of the canpaign, and the public and my opponents concluded that Wedgewood must be getting stale and off on account of his race at Springfield, and as he was farorite orer the field, they took the field for all there was in it. In his preliminary work at Hartford TVedgewood pleased me in every way. Among the number on my sicle was uncle Ben IVright who again went through a Turkish bath performance on account of the precarious situations and the hazardous events of the race. It was in this race that Doc. Appleby made one of the most original remarks and at the same time one of the most appropriate ones on record. The Doctor did not know exactly what horse he wanted to pliay when the race began, but was sure that he did not want Wedgewood. With Johnny Murphy behind Patchen he concluded to back that horse, and for a while the chances looked roseate. Then Deck Wright took a heat in such commanding style, that he looked all over a wimner, and Mr. Appleby made another plunge in that direction, and backed the horse from the TVest for enough to get back all that he had put on Patchen and land a goodly pile beside if Deck IVright won. When Patchen captured the third heat the Doctor stole another base and played the field against IVedgewood, a horse that had not yet come to the front. After IVedgewood had won the race and someone asked the Doctor what he had done for himself, he said: "I have done badly. I kept climbing from one rotten branch to another until finally the whole tree fell on me."

I determined to follow my old plan and lay up, and Murphy showed the boys what he had in hand, by winning the first heat with Patchen in 2:18 $\frac{3}{4}$. He led all the way in the second heat to the distance stand, where he broke, and

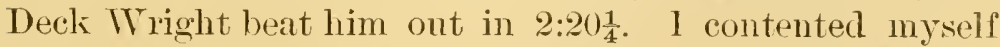
with dropping inside the distance flag. In scoring for the third heat I determined to try and win, but in the score 
Wedgewood broke, and I had no thought that the judges would give the word. He came galloping to the stand and they said "go" with the horses strung out like Brown's cows. Keene Jim had at least twenty yards the lead of everybody, and sped away as though he cid not intend to be canght. Patchen broke immediately after the word was given. I was sure Mfurphy wonld not try to win the lieat with him, and if he did I was positive they would beat him, so felt no uneasiness, thinking that Keene Jim a lion'se that had not yet won and was not dangerous in the race, would take the heat, but I figured wrong. Mmrphy canght his horse and set sail. He overhauled Keene Jim at the distance-

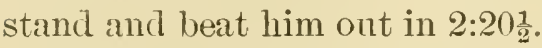

From where I sat the race looked a little "binding." Here was Patchen going every heat in 2:20, or better, and he had just won the third heat in 2:20 $\frac{1}{2}$. It was a prospect which, to say the least, I saw nothing rery rosy abont, with myself and all my friends up to our necks in the pool-box, and from what I knew of the gentlemen driving the other horses they would be delighted to pour ice water down om backs. I saw that I liad a few first-class heelers to cool Wedgewood ont after this heat. Jack Phillips had the price of a few barrels of flour on the horse, and after the heat he came down to the cooling ground and took off his coat in abont the same mamner I had seen him do when he was a farmer boy around Watertown. He told me to sit down in the shade and cool myself ont, and he wonld see to the cooling out of the horse. This is a matter that people sometimes overlook. If you liave driven a lorse a hard heat and you are tired, and your nerves unstrung, it is not likely to aid you much to get ont of the sulky and go to work to help cool ont the horse. I think that after a severe heat a diver needs some time for rest and to get lis nerves in order for another trial. While as a rule the drivers of trotting horses are necessarily men of strict sobriety, it is notwithstanding true that in situations of this kind some of them at times resort to a stimulant to brace themselves up for the impend- 
ing struggle. In all my life I have never tasted a drop of liquor, and as I do not use tobacco in any form, this stimulus is denied me, so that in my case, the only relief in situations of the kind mentioned is that of solid rest to mind and body. I do not mean to say I do not think that there is no time when something of a mild stimulant will do a man good, and I believe there have been occasions after driving a severe heat when a glass of wine has been a good thing, just as it is to celebrated riders of runners. I lave given my horses champagne and Seltzer water as a mixed drink, and found it one of the most beneficial things to a tired horse I have ever tried.

While Jack Phillips with the rubbing cloth and Turner with a sponge and Mace as general director of the work were engaged on WVedgewood, Uncle Ben and Terry Barden and AI Carlisle sat around in the background giving us the latest reports from the pool-box, and the general public looked on, feeling that for once the most noted talent on the turf were in a tight place, and it seemed to me as though they rather enjoyed it. They regarded ns with looks which seemed to say, "IVell, you have often had us in tight places; how do you like it?"

When the bell rang for the last lieat and the horses showed up in front of the judges' stand, a row of people stood opposite with abont as much interest in the expression of their faces as yon will often see. I told the judges before getting the word that this was a race in which there was a great deal of money bet on Wedgewool, and as he was a horse that never cansed any trouble in scoring or anything of that kind, I conld not see why he was not entitled to his position when the word was given, and I asked them as a special favor to have the kindness to see that lie had his place when they said "go." Deck Wright rushed away with the lead, but pulled np at the turn and gave his place to Patchen. In doing that he convinced me that it was Patchen to win and Deck Wright to hold me. I concluded that for the safety of my chance, as well as for the safety of 
my sulky, it would be well to keep awaly from Deck TVright. I therefore trailed away behind him until we turned into the stretch, Patclien still at the pole, Deck Wright outside. After we rounded into the stretch I pulled TTedgewood well ont into the track, and as they say on the ruming turf, I sat down and commenced to ride him. I never saw him show any more determination than he did right there. Every time I spoke he responded, but while he was doing that Murphy was getting Patchen one of those drives that he is noted for. It took Tredgewood all the way to the wire to beat him, which he finally did by a head in 2:19, the best and fastest heat he ever trotted. Between Patchen's trotting, Deck Wright's rumning, and the lunstling tactics of the others they kept me busy the balance of the race, but Wedgewood won, guing the fifth heat in 2:201 and the sixth in $2: 22 \frac{3}{4}$.

This, I believe, was the last race of any prominence that Patchen ever took part in. Patchen was a horse that came to his speed very quickly, having never beaten 2:231 until this day. He made this one skyrocket performance, and then went down in the same manner, never having been heard of after that season. From Hartford we went to Boston, where he beat IVedgewood, Driver, Sheridan, and Lady Maud, in $2: 20 \frac{1}{2}, 2: 21 \frac{3}{4}, 2: 21 \frac{3}{4}$, Driver winning the third heat in $2: 21$. There were some very unimportant races in which he took part during the following month, and on October 1.) he wound up the season with a first-class contest at Prospect Park against Patchen and Driver, six heats being required to settle the money, three of them being trotted better than 2:20; and taking into consideration the time of the year, and the fact that it was the end of a long campaign, this was looked upon as a wonderful performance. It was the last star race for Wedgewood, Driver and Patchen, and one of the last races in which TTedgewood took part.

In this race I expected to have both horses to battle with. I had learned in a second-hand way that Murphy intended to lay his horse up. I hardly believed that, as I had never 
seen him do it before. I had also been told that Johnny Goldsmith was going to do the same thing with Diver. I thought, if that was the case, it would be a good scheme to get my horse well warmed up, and go out and perhaps win the first heat withont an effort. I followed this plan, and when they said "go" I cut loose and won the first heat,

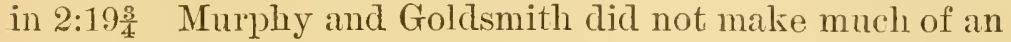
effort, as I thought, to win, each one expecting the other one to make a fight. The next heat they were both ready

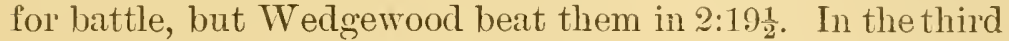

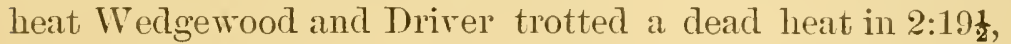
making the fastest three consecutive heats that IT edgewood had ever trotted in any race, all being better than 2:20. After this heat IVedgewood was somenhat distressed, and I made up my mind to lay him up. In the fonth heat Patchen and Driver finished so close that no one but the judges conld tell

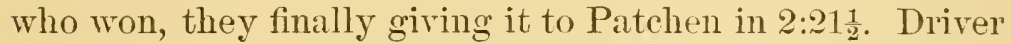
won the fifth heat in 2:213. In both these heats I was satisfied to save my distance. In the sixth heat they all rushed away together when the word was given and at the quarter pole Patchen broke. From there to the stand, Driver and Wedgewood had a battle royal. By this time it had grown so dark that the judges could not see us as we went down the backside, and it was a case of give and take all the way. These horses were about as closely matched as inything' I ever saw. 'They were both game, good breakers, would stand any amount of driving, and at that time Goldsmith was not much more than a boy, but as industrious a fellow with a horse sulky and whip as I have ever seen since. Anyway, we fought it out on that line, and Wedgewood beat him to the stand and won the heat in $2: 20 \frac{1}{2}$.

Wedgewood was a grand horse for me, an honest trotter if ever there was one in the world, and since his retirement from the turf he has been doing great work in the stud, as is plainly shown by the character of his get. Favonia, a daughter of his, that is out of a mare by Alexander's $\mathrm{Ab}$ dallah, was quite the star of the trotting firmament last 
season, beating Rosaline IVilkes and all the other cracks she met, and making a record of 2:15. This mare displayed a good many of the characteristics and qualities that I had noticed in Wedgewood, and as she was by my old favorite, I took particular notice of her. W'edgewood's home is at the Hermitage Stud Farm, a magnificent estate near Nashville, Tenn., and there is no stallion to whom I would breed with greater confidence. 


\section{CHAPTER VIII.}

Trotters with romantic histories that I have driven-The gray gelding Charlie Ford, that was first a turt outlaw, then made a record of $2: 16 \frac{3}{4}$; was valued at $\$ 15,000$, and fiually sold for $\$ 300$-Ford's match with the stallion Bonesetter, and how he was trained for it-He is the only horse that ever won a heat from Maud S.; the story of the incident-The great race at Chicago with Haunis, where "the taleut" was on the wrong sicle-Adelaide, a little mare that had one remarkable peculiarity; no matter how hot the day, or severe the race, she would not sweat-Drawing wood into Walertown, N. Y., by the side of her dim, she is purchased by a horseman and makes a record of 2:193-A pony in size and weight, slie beats some of the best horses in the country, evely ounce of lser being race-horse materialPlanter and his good qualities-The wonderful affection of the trotter Bay for an old white horse.

If ever a horse had a romantic history, the gras gelding Charley Ford is the animal. Beginning his turf career by trotting in classes where le was not entitled to start, heing for this offense expelled from all National association tracks, then found to have more speed than it was dreamed lie possessed, and for this reason reinstated after a great effort; then sold for $\$ 2,500$ to a noted Chicago sporting man. he passed throngl the hands of several drivers, moler my management made a record of $2: 16 \frac{3}{4}$; was worth at one time $\$ 15,000$, that amount in cash having been refused for him; is the only horse in the world that ever beat Mand S. a heat: lost his speed, and was sold for $\$ 300$ when still comparatively young, and now jogs soberly along the streets of Chicago, an animal that never would be taken for one abont whom at one time the trotting world was considerably excited.

Charley ford was a light gray gelding. nearly white, stood sixteen hands high, with as fine a heal as yon conld 
find on a trotting holse, it being of good shape, not too large, and the handsomest eyes that I ever saw in a trotter. He was bred in Racine County, Wisconsin, and was sired by a horse known as McKesson's Gray Lagle. When he was about five or six rears old, a local driver developed some speed in the gray gelding. and he trotted a few races under the name of Billy Basteder. The following year, not being supposed to he able to trot to his record, which was then not as good as 2:30, he was taken to the Pennsylvania oil regions, and took part in a number of races. During that trip. he displayed so much speed and gameness over the half-mile tracks where he trotted, that the following winter he was looked after a little more carefully, and along in the summer of 1879, he was brought to Chicago, and over

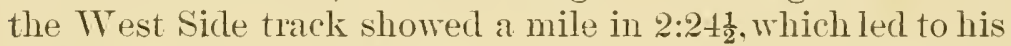
purchase by Jerry Monroe, an all-around Chicago sport who knew a good thing when he saw it. That season, Charley Ford-he having by this time having been given that name- was driven in some races by Dan Brown, after which Jimmy Dustin took him in charge, and late in the fall he was driven a time or two, I think, by Dan Mace. It was during this season that the horse first attracted public attention. He trotted a number of races in the grand circuit, and in the fall came to Cincinnati, where he was entered in a race over a half-mile track at that place against Driver-those two being the only starters. It was this race that first particularly attracted my attention to Charley Ford, and made me think that he had in him the making of a great race-horse, because in beating Driver he was forced to trot one of his heats in $2: 20 \frac{1}{2}$, and this performance over a half-mile track was equal to 2:18 or better over one a mile in circumference.

One evening the following winter while in conversation with a number of Chicago gentlemen the names of Bonesetter and Charley Ford were mentioned. Bonesetter was

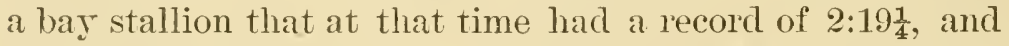
was quite a noted horse. He belonged to Mr. H. V. Bemis 
of the Bemis Brewing Company, who gare for him $\$ 10,000$. $\mathrm{Mr}$. Bemis was at this time the leading owner on the IV estern trotting turf, having in his stable such well-known ones as Bonesetter, Silverton, Fred Douglas, Little Brown Jug, and Sorrel Dan, the two last named being pacers, and the lot about as formidable a one as has ever been owned by one man. In the discussion as to the merits of Ford and Bonesetter I expressed the opinion that Ford was the better of the two horses, and from that came a match, the owner of Ford and myself backing him against Bonesetter in a race of mile heats, three in five, to come off the 12th day of June over the West Sicle track at Chicago, for $\$ 1,000$ a side and the gate money, $\mathbf{M r}$. Bemis backing his own hor'se, and Jolnn B. Drake, of the Grind Pacific Hotel, was appointed final stakeholder. From the moment the race was made until the day it was trotted there was a great deal of talk and excitement and a large amount of money was wagered on the result, Bonesetter being a favorite in the betting from the start, a position he held until the race came off. I had not seen Ford from the time I witnessed his good work at Cincinnati until after the race was made, and the forfeit put up. The next morning I went to his stable, to look him orer, and I found him in what seemed to be rather bad condition. His legs were very much swollen, with a great deal of fever, and his system seemed grenelally ont of order. While I was considering what conrse of treatment to gire him his groom applied some patent lotion to his legs to reduce the swelling, which had the effect of blistering hin in the most frightful manner, from the effect of which his leg's never entirely recovered.

My first efforts were directed to reducing the swelling and inflammation caused by the blister, which was so painful to the horse that he neitler ate, slept nor lay down for at least ten days, and it seemed to me at one time that he would certainly die from the effects of it. One word here abont blistering horses. I have known in my time sevelal animals to lose their lives from the effects of a blister. My 
rule has always been that if I want my horse shod to get the blacksmith to do it. The same rule holds good in case of sickness. If my horse needs blistering or any other medical attendance, I get what I consider to be the best veterinary surgeon within leach and let him take charge of the case, and I know of no reason why this rule should not be followed at all times. "Every man his own lawyer'" generally gets the prisoner locked up, and I think every man his own doctor would be a great scheme for the undertaker's. In this case, that the horse did not die was due, I am satisfied, more to grod luck than good management. I called in a veterinary, and he snggested a treatment that he thought would serve to allay the inflammation and pain. He managed to effect this result, but the swelling never entirely left the horse's legrs.

As the season for training approached, I commenced giving Ford moderate exercise on the road, and then took him to the West Side driving Park to prepare him for the race. The spring being very backward and cold and the track unfit for fast work I made up my mind I wonld either have to hunt another training ground or I would not have my lorse in any condition by the 12 th of June. I concluded that Indiana would be a good place to go to, as they have an early spring and 'sandy tracks there, but when I suggested this to Ford's owner I met with opposition that I had not expected, as he did not see why a horse conld not be prepared just as well in Chicago as at any other place, and freed his mind to that effect. I was so sme that my judgment was right that I told him to do one of two things, - he could take my interest in the race, and have Ford trained wherever he chose, or I would take his interest in the race and have my way abont it. Under this pressure he finally consented that I should use my own judgment, and so I took Ford with my other horses to Elkhart, Ind., where I fonnd a good half-mile track, first-class stabling, good roads, and everything farorable for an early preparation. I discovered when I begun to drive Ford along, that his 
legs would swell very badly. This is the greatest trouble I had with the horse. About the twelfth of May I was able to drive him miles in abont 2:33. In watching Ford the year before I saw that he had a disposition to want to break and run, being what they call a first-class breaker. This I consider a grievous fanlt in any horse, and one that will ruin many horses' chances of winning where they would otherwise get the money. My idea about horses of this kind is that if the time and strength expended by them in breaking and catching were to be put in at honest trotting it would give them a very much faster record. Iliave heard people say that Goldsmith Maid gained when she broke, but I noticed that when she trotted miles in 2:15 or better she never made more than one break in the whole mile. Deck Wright, Grey Salem, Lem Scott, and all that tribe of hurdler's made their best records in the heats in which they ran the least and trotted the most. In training Ford, I drove him on a trot all the time, never allowing lim to get close enough to the top of his speed to have him show a disposition to break. He seemed uneasy when a liorse took him by the head, and sometimes when he was being outtrotted tried to break with you. I worked him alone a great deal at first, and when I did take a horse out to work with him I did not allow the other one to pinch Ford hard enough to make him want to break.

As we were to trot the match race with Bonesetter on the 12th day of June, I felt anxious to give Ford one or two races before that event came off. I entered him in two laces, both of which he won, trotting five heats in each race. He beat Will Cody over the Elkhart track a five-heat race in which 2:30 was the fastest heat, and he had all he could possibly do to win. This race acted on Ford as I expected it would; made him a better horse. The other race was against Lucy, a black matre owned in Canada, driven by a man named Palmer, and called among the boys "The Queen's Own." 'They trotted over the Adrian track, which is rather slow, and Ford won in five heats trotting one of 
the miles in 2:25. He showed me so well on this occasion that I was satisfied that, barring an accident, he would beat Bonesetter in the match. I had a man watching Bonesetter all the time, and he wrote me that the weather in Chicago had been very bad, Bonesetter had been given but little work, was high in flesh, and any holse that conld trot three heats in from 2:25 to $2: 22$ would certainly win the money. The result of the race proved that my tout knew what he was talking about.

We came directly from Adrian to Chicago, where I found all the horse talent very much excited over the race, Bonesetter still having the call in the betting. I don't remember of ever having had a lace that I was any surer that I would win than this one, and I not only put my own money on Ford, but advised all my friends to do so. But Bonesetter had such a hold on the public that he remained the favorite until they got the word, with the odds about $\$ 100$ to $\$ 80$. My friend Capt. Tohn Dumas saw the race at Adrian and gave me $\$ 500$ to put on Ford, as he said he would be nnable to attend the race. A great many of my personal friends advised me not to bet my money, as they were sure Bonesetter would heat Ford. One of them said that he did not beliere. I wonld be able to drive Ford well as he had always been driven by a comtry boy who whipped and rum and scuffled him along, and that was the way he had always won his races. He thonght that I wonld try to keep him on a trot, and that he would not be able to get around the track fast enongh to head the other horse. On the day set for the race it rained, and it was postponed until the following Monday. The story of the race is soon told-Ford won in straight heats without an effort or without ever being headed. The best time was 2:23, in the first heat. In this race Ford was very steady and I could have driven him to his record. Bonesetter was high in flesh and several seconds from the mark. In training Ford for this race some people criticised my methods, as being different from the way other people had handled the horse. I trained 
him in the following manner, and for the following reasons: He was inclined to be rather a sluggish horse when worked alone and would not try to extend himself. I did not like to work another horse with him, as that kept him pulling all the time. I confined his work to rery little walking; short jogs, repeating him slow miles, and brushing him the last part of the mile as fast as I conld and lieep him on a trot. In getting ready for the Bonesetter match I drove him a mile in abont $2: 30$ twenty minutes before the race, letting him cone the last half in abont 1:10. Some of the critics said I drove him a great deal too fist, but I had my watch in my hand, and I knew just what I was doing, and as I wauted to be ready to go with Bonesetter as fast as he conld make me right from the start, I knew that it would take good sharp work to have Ford well opened ont for his effort. Everyone supposed that Bonesetter would be able to outspeed Ford, and the only hope I would have of beating Jim would be to force the pace and beat him at the finish, but I felt differently. I wanted to out-trot him right from the start, thinking that was the surest way to get the money. Whether or not my theories were right, Ford won the race.

After that I trotted Ford several races through the Michigan circuit with more or less success, and in this campaign came across General Turner and his wonderful horse Hamnis. I had seen enough of Hamnis and Turner to know that they were about as formidable a pair as a man would want to meet with a horse and sulky, and made up my mind that no matter what else happened I would keep my eye on them, whether they won or not. I dicl so, and for my pains had the satisfaction of learning enongh to save my money. I had noticed this abont 'Turner's horses, - that in the spring he works them just enough to see whether they are good or not, then he starts them out on an easy campaign, or, in other words, insteal of training them gets them out and trots them in public laces, and lets them trot themselves into condition. When he gets them to what he thinks is an edge, he makes a raid on the pool-box, and in this 
campaign he followed his old tactics. In the different races that Ford trotted against IIannis, I saw maneuvers that made me believe the little chestnut stallion was a much better holse than the public rated him, and when I came back to Chicago for the summer meeting, I found him entered in the same race with Ford, and they were the only ones of any note in it.

Here, I think, I made a mistake in training Ford. His owner and groom both thonght that I worked him too severely and often criticised me on that point. They said so much about it that finally I thought that perhaps I was wrong, and gave way to their opinions. This fact, and a bad decision that the judges made, cost Ford the race and his backers more money than I think was ever lost on a trotting race. A few days before the Ford race came off, Tnrner had Hannis in a race against Monroe Chief and Wedgewood. They finished the race with Monroe Chief first, Hamis second and Wedgewood last. I saw enough in this race to convince me that Hannis was a race-horse of the first water, and made up my mind that he would certainly trot a mile in 2:16, and when 1 went out with Ford to contend with him, I thought I had a chance to win, but did not look upon it as a sure thing, as the owner of Ford and all his friends did. They backed lim for every dollar they had in the world, and some of them have not yet recovered from the shock. When I tried to tell them that in IIannis and Turner they had a pair that wonld bear a great deal of watching they langhed and said I was cowardly. In this race the judges made what I consider one of the most outrageous decisions that ever I heard. Ford beat Hannis in the first heat half the length of himself, nerer was headed in the heat, never swerved or made a break of any kind, led from start to finish, and I conkd have beaten him further if there had been any necessity, and to the surprise of myself and every body, on the track, Turner included, the judges decided it a dead heat. They explained to me, after the race was over, that they expected it would be a very one-sided affair and 
wanted to give the public some amusement: that they thought I would surely win and the decision would only make one more heat in the race.

In the second heat Ford led from the start to finish, and won by a length. In the next heat he led all the way, and when they tumed into the stretch Hannis was on his wheel. Fs om there to the distance stand they had a battle, both horses being driven under the whip. At this point Hamnis commenced to gain upon Ford in spite of his efforts. Here I saw something that the public dicl not. Hannis orerreached with his hind foot and stepped on his quarter boot, which caused him to break, and Ford beat him to the stand in $2: 16 \frac{3}{4}$, which was the best mile he ever trotted. I said to some of my friends who were plunging on Ford after this heat at the rate of $\$ 100$ to $\$ 10$ that they were doing a very dangerous thing, as Ford had only beaten half a length in 2:16, and Hannis had met with an accident in the heat. Another thing I knew was that Turner's horse was a tried campaigner, had been in races where he had been ont-trotted, and his gameness had never been questioned. His breeding and all that went to make him a dead game horse. Thile Ford had a reputation with some people of being game, I considered that he had never been tried in a manner to satisfy me of his gameness, and while I do not want to slander a good horse, I have always had my doubts about Ford being dead game where he was in a race with a horse of equal speed or a little better. Another reason I had for doubting his ability to win was that he had nerer before been asked to go a mile better than 2:20, and to be called on now to go four or five heats better than 2:20 I thought a contract that he would be unable to fulfill. When we scored up for the next heat I found that my fears were only too well founded. Ford lacked the dash and speed he had previously shown, and I went out with my mind made up to keep Tumer on the ontside as long as I could and make him go round me and leave the battle to the last hundred yards unless Turner forced the pace. Turner seemed determined to do this right 
from the word " go," and in going down the back side Hannis out-trotted Ford, and took the pole, and from there home he went with something to spare. After this, Ford gave up the fight, and I think finished the last mile in about 2:26 or $2: 27$.

At the time I was rery severely criticised about this race. A great many people thought I did not try to win, but I never took the trouble to deny any of the statements. The only fanlt I had to find with myself was that I allowed people who were not in a position to be able to form an intelligent opinion about training the horse to tell me how I ought to work him for the ratce. But even witl all that bad management had Ford got justice out of the judges' stind he would have won in straight heats. I think that if I had taken him ont about a week before his race and giren lim severe work, driven him a conple of miles in about 2:16 or 2:18, that he would have been able to have dragged off the race. He was never so good a horse afterward as he was that day, and I am satisfied that the severe strain lie underwent, being at the time short of work, had a good deal to do with liis subsequent defeats.

The nost notable thing that Ford accomplished while in my hands after tlis was to beat Maud $\mathrm{S}$. the only heat she ever lost to any other horse. 'This was at Buffalo, in the first heat of the race. Mand S., Ford, Diriver and Hannis were the contestants. Mand S. being such a farorite, there was no betting, except for second place, and on this point there was a great cleal of money wagered, Tnrner and his friends backing Hannis, Junkey Goldsmith and the cheesemakers from Orange County pinning their faith and money to that reliable race-horse Driver, while my friends and a fair share of the public took tickets on Ford. In driving this race, each man had to help himself. We all knew that Bair would win with Maud S. in two straight heats. Neitler of the other men I think ever had an idea of attempting to beat her a lieat - I am sure I did not. After the word was given, Maud S. led right from the start until we turned into 
the stretch, the other three horses behind her, each driver eatching the others, and all apparently waiting to make a drive at the finish. These tactics snited me exactly, as I was sme that Ford had the speed of Driver and Hamnis and was willing to leave the race to be lecided in the last fifty yards. As we turned into the stretch, I noticed Mand S. trip with one of her hind feet. I have often had horses do that with me, and when going at a high rate of speed they would almost always make a break. I'lid not wait to see whether she broke or not, but as they say on the running turf, I commenced to "sit down and ride" Ford. I think my two opponents must have seen what I did at the same time, for Maud S. had not faily left her feet until I conld hear Turner anc Goldsmith driving their horses as thongh it was a life-and-death struggle. I never saw a more desperate finish between three horses, or one much closer. Erery liorse was driven to the best of his driver's ability, withont regard to the number of times they hit them on the back with the whip. They all finished lapped on each other, Ford coming to the wire first by about a head, Driver second, and Hannis third; time, 2:1\%; and I may say that this was the second best heat of Ford's life, the best heat i crer saw Driver trot, and as good a one as IIannis ever trotted. Mand S. then went on and made short work of the race, winning in three heats, thereby giving Ford the second money and to his backers the money that was bet on the place.

This was about the last season that Ford erer made any showing on the turf. His orner got in reduced circumstances, and this horse, which had attracted the attention of thousands of people, and for whom a cash offer of $\$ 12,000$ was refused, was finally sold to a private citizen in Chicago for $\$ 300$, and is now being jogred around on the roads by him. The last time I saw Ford I was going ont on TI ashington boulerard, and noticed a rather matter-of-fact looking g'entleman and lady jognging along behind an old white horse that neither looked nor acted as though he had ever shown any disposition to trot. As he drew near there seemed 
to be something familiar about him, as there often will abont an old friend that you have not seen for a long time. As I looked him over carefully it came to my mind, "There is my old friend Ford." A feeling came over me about the same as if I had seen some old friend that had been rednced from luxury to poverty. I asked some people who were with me if they thonght the horse going by would ever be taken for a race-horse. They said no, they did not think there was any possible chance of that, and when I told them he was the only horse in the world that had erer beaten Maud S. a heat, they were greatly surprised. In disposition, Ford was a rery mild and pleasant horse; he was a good feeder and not a hard horse to train. He wore quarter boots and knee boots, shoes and scalpers behind. I drove him with an open bridle, and orerhead check, long martingales, and a Dexter snaffle bit. He was a horse that when it came to the finish needed considerable driving, or hustling along, as the boys call it, but in other respects there was nothing remarkable about him.

A horse of as marked peculiarities as I ever saw was Adelaide, once a member of my stable, and she was a very handsome small bay mare, less than fifteen hands high, and when in condition did not weigh orer 800 pounds. But erery ounce of her was first-class race-horse material, as she proved orer and orer again in her battles with some of the biggest and best trotters that erer took the word on a race track-and when I say this, I mean that Adelaide was a great one in her day. Trotter's shonld always be ganged as to their merits by the position they attained at the time they were in their best form, and when Adelaide had the most speed of her life it was at a day when a 2:15 horse was practically unknown, and not as now when every year a new one of that speed comes out. Adelaide was a daughter of Phil Sheridan, out of a mare that was brought to Watertown by an English officer, and owned by a farmer, and commenced her careel by drawing wood to town by the side of her dam. She finally fell into the hands of a local 
driver named Irving Harris. He drove her a mile in about 2:30. Then Dan De Noyelles, who used to drive horses with Dan and Benny Mace when they were boys, having owned at that time the trotter Frank Ternon, afterward known as Panic, went up to Watertown and gave a long price for the little mare. Someone snggested that Dan bonght Adelaide for a book-mark, saying she certainly was not big enough for anything else. But the little mare's career proved that Dan knew what he was about, as she was a mark for a good many horses to shoot at that were not able to hit her. She passed through the hands of Mose Whipple into Jack Phillips' stable and then came to me.

The first time I worked her and brought her to the stables she did not sweat a particle. This being such an unnatural thing I was rather alarmed, but when I spoke to the boy about it he said it was nothing unsual-that she never would sweat. I could hardly believe that statement, as in my career up to that time, I had never seen a horse in heal th that would not sweat after violent exercise. I interviewed De Noyelles abont it, and he said that the most he ever saw her sweat was to moisten under the harness just a little. I studied the mare carefully, but was never able to account for this peculiarity. In training Adelaide, I took extra pains to handle and care for her in a manner that would cause her to perspire or sweat freely, but nothing I ever did in the way of medicine or attention seemed to have the slightest effect on her. She was a good feeder, carried but very little flesh, and even in winter when allowed to eat all she wanted to, would not increase her weight more than fifty pounds. In the two years I had her she trotted some great races. The most notable one, perhaps, was where she defeated a field of a dozen that were considered first-class horses at that time. This race took place over the Cleveland track in 1878. The two horses between whom the race was supposed to lie were Prospero and Midnight, a couple of black geldings that had shown the ability to trot in $2: 20$, whereas Adelaide was looked upon by horsemen and the 
public as equal to a mile in about 2:23 when at her best. In the betting the night before the race Aclelaide was entirely overlooked by the public-so much so that De Noyelles, her orner, gave Dempsey an order to put $\$ 250$ on her. Dempsey told me we conld win all the money in the pool-box with $\$ 100$ on Adelaide-provided of course that she was rictorious. Dempsey put $\$ 163$ on her for De Noyelles at the odds, which netted after the race was orer something in the neighborhood of $\$ \%,() 00$.

Then Dan came ont the next morning and showed me the tickets, I gave him what the boys call the laugh. He said that was all right, but that if I would drive the race as he told me and he did not win he would be perfectly satisfied. I told him he conld have absolute command, and to be around with his orders when the bell rang. IVhen the time came De Noyelles just asked me to go easy the first heat, simply saving my distance, which I did, and was far behind Prospero, who rushed away the lead, was nerer headed, and won the heat in abont 2:22. De Noyelles told me to lay up the mare again in the second heat regardless of what might happen. I did this, and Midnight, a horse that belonged to $\mathrm{Mr}$. C. M. Reed, of Erie, Pa., and one that was looked upon by the talent as a sure wimner went ont to the front at the word and won with seeming ease, the time again being about 2:22. When we were ready for the next heat De Noyelles said : "Lay up again," and I did, Midnight again winning. When they called for the fourth heat, De Noyelles said: "Have your war-paint on, and when the judges say go, let us see how fast you can get away from the wire." Adelaide was a good scorer, a first-class breaker, and could be relied upon to do her very best when asked. At this time I had heard that Midnight had a solt spot in him, and on the strength of this I took him well down the stretch, scored up a few times, and when tlley said "go" he and Adelaide went off at a great clip. Midnight broke at the first turn, which gave Adelaicle the lead and she was never headed, wimning the heat with something to spare. In 
the next heat, Adelaide was too much for the others, none of them getting to her. This being the fifth heat all the horses that had not won a heat were sent to the stable, which left the race to be finished between Adelaide, Prospero and Miduight. Prospero and Midnight had given up the battle, for that day at least, and it looked then as though De Noyelles had the boys sure. Midnight's party held a council of war, as a last resort put Turner up to drive the black fellow, but it was of no use, as they never headed her, she winning the heat and race in 2:30, and conld have shut out both horses.

Adelaide was a very mild, pleasant mare, both in the stable and on the track. Her legs and feet were simply perfection. She wore about a ten-once shoe in front, and no boots with the exception of a light pair behind. I drove her with an open bridle, an overcheck, no martingales, and she was as easy a mare to drive as I ever had. After her turf careel was finished, De Noyelles bred Adelaide to Nutwood, 2:18 $\frac{3}{4}$, and her filly by him has heen sent to California to be mated with Sable Wilkes, 2:18. The result of this mion, according to the records in his family, ought to be a prince of trotters, as his dam has a record of 2:19: her

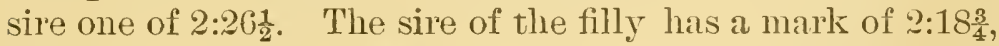
and the sire of Sable Trilkes one of $2: 15 \frac{1}{4}$, while his sire, George Wilkes, placed 2:22 many years ago.

On one of my trips to California, I went on a social visit to a place called Marysrille. While sitting in the hotel one day a rather queer-cut looking little man came in and introdnced himself to me. He said his name was James B. McDonald, by trade he was a bricklayer, a statement that I judged was true from the brick and nortar dust that had gathered on his clothing. I supposed that he might want to sell me a brick house, but was surprised that he came to interview me on the horse question. McDonald told me that he owned a bay stallion that he had bought in Kentucky. He said that Gen. John E. Turner had bought the horse at an anction sale in Kentucky, and the next day he 
gave Turner $\$ 25$ profit on the colt and took him with some horses to California. He added that he did not pretend to know much about trotters, but had been some with racehorses when a boy, and all the training this horse had received was done by himself. He wanted to know if I would oblige him by going to the track some day driving his horse, and telling him what I thought of the animal. To please Mr. McDonald I said I would, and on the following day we met at the track by agreement, and he had his horse there. When I saw the animal I was not particularly impressed with him as he was a low-headed horse, with rather a slouchy way of moving. McDonald asked me to drive him from the half-mile pole to the judges' stand. I did so, and when I set him going he moved out at a nice cleam open gait, and went the half in 1:11. Mr. McDonald seemed rather excited at this, and when I told him that I thought I coild have driven the half from one to two seconds better, I think it pleased him more than would, just then, a contract to build a brick block. On the strength of this performance, I arranged to take the horse back with me to San Francisco and train him. He showed me a trial of 2:221, and Mr. McDonald and myselt brought him East, and trotted him a number of races with more than ordinary success. He had a record of abont 2:30 at this time, and was called Brigadier.

We trotted "Brig" through the Michigan circuit, where he won all his races. People say there is nothing in luck. I hardly think there is myself, but this was one of the luckiest horses I ever had. If ever it came to a close decision out of the judges' stand, Brigadier al ways seemed to get the best of it. I can give a little incident which illustrates this, and also shows the meertainty of horse-racing. We had Brigadier in a race at Toledo, Ohio, over a half-mile track. When we got there we found a large field of horses and a very rough track. Mrr. McDonald liked to back his horse well whenever he had a chance to win, and as we thought we could handle the field easily, he put on about all the 
money that he could get judiciously, and I went out to trot and win in three straight heats. He drew the pole, but when the word was given in the first heat the horse next to him broke and swerved, and I took Biigadier back to aroid a collision. Just then he caught a hind foot in one of his quarter boots, and came near throwing himself down. By the time I got him stopped the other horse was going down the back side of the track and Brigaclier was more than a distance ont. I took in the sitnation at a glance, made up my mind I had no chance to save my distance, and merely jogged him round the track. When I arriverl at the judges' stand, I found there rather an excited party, and among the lot was a very pompous inclividual who had a poolticket on Brigadier the amount of which did not represent perhaps one-half of one per cent. of the sum that BrigaGier"s owner had on him. This man was telling the judges in langnage more forcible thin elegant that he clid not piopose to be robbed by Splan or anyone else. He wanted a show for his money, or there would be a fight. He knew I had thrown the heat away for a purpose and had my horse distanced intentionally. Of course Mrr. McDonald and myself expected Brigadier to be distanced, and had already commenced to figure up our losses. The juclges held a consultation and then called me into the stand, and I will never forget the expression on their faces, as they looked at me as much as to say: "Yon are perhaps a pretty cute driver, but you can't come up in this comntry and swindle our patrons," and they opened their conversation by asking me if my horse was in the habit of making that kind of breaks. I told them no-it was the first time he erer broke with me in a race. In a very dignified manner, they informed me that they were not satisfied with the manner in which I harl driven the heat; that they were not gुoing to take me out, as they believed I was as good a driver as there was on the track, but would insist on my starting my horse again, and that if he did not win they would perhaps relieve me from driving any more that season, meaning that I would he sus- 
pended if I did not win. They then ammonnced their decision to the crowd and told what course they had taken in regard to Brigadier.

Of course Mr. MeDonald and myself felt as if our lives had been spared. When they gave the word in the next heat Brigadier went out to the front, and was nerer headed. The people who had bet their money against him were disposed to kick up a row, but the judges awarded him the lieat and race, and we not only got the purses but the poolbox as well. Now here is a case where $I$ think the judges erred. This horse was distanced fairly, and they had no right to allow him to start again under any rule in the book, unless they thought I had willfully had him distanced. Brigadiel was a horse with a wonderful turn of speed, a good actor, feeder and campaigner, and with horses that were no faster than himself he was pretty hard to beat. Mr. McDonald aftelward took Brigadier back to California where he improved his record to $2: 21 \frac{1}{4}$, and is now used in the stud. He was by Happy Medium, and his dam was a mare by Jack Pierce. The best race Brigadier ever went to my knowledge was when he beat Chestuut Hill at Bufiralo in a race of five heats. The public thought that if Brigadier did not win in three straight heats le would not win at all. In this race we let the other people do the fighting and laid Brigadier up the first two heats, and when it came to the finish in the next mile he outstaid Chestnut Hill, beat him the heat, and finally won the race.

Among my old-time horses was the chestnut gelding Planter, who came into my hands with a record of $2: 29 \frac{1}{2}$, and was owned by a gentleman of the name of Andrews, a contractor from New Jersey. Mr. Andrews was not very much posted about trotters, but he had unlimited confidence in his own horse and a disposition to back him every time he started regardless of the class he was in or what I might think about the matter, and as it often occurs in these cases he made some winnings that a more careful and prudent man would not have made, as Planter dragged off 
one or two races where a victory by him seemed next to inpossible. The first race I won with Planter was at Lica against Marion, a horse driven by D. P. Bissell, one of the old school of triiners, a first-class blacksmith by trade, who now lives and runs a shop at Indianapolis, Ind. Bissell first macle his reputation away back when I was a boy by driving such well-known horses as Jolnn A. Logan and Billy Barr. In this race Marion was a long farorite, Planter. selling for nothing-his owner backing him and I telling lim I was sure he was wasting his money. They fonght out a desperate race of six heats and in it Marion made the best record of his life, as also did Planter. Dan Mace was there and bought a few cheap tickets on Planter, more, I think, because I was driving him than becanse he thought the horse would win, and after each heat came down, took off his coat, and with his usual enthusiasm helped the boys to cool ont the horse. Planter was rather a hard horse to drive, having a disposition in the first half of a mile to run a good deal, and the last half he wanted a good deal of carrying.

The only other race of any note Planter trotted was one over the Springfield, Mass., track the same season. Here he had a large field of horses to contend with, sold for nothing in the pools again, lis owner backed him, and the public refused to have their money on him at any price. The race proved a disastrous one for the talent, as 'Trio, the farorite, was distanced in the first heat, and a bay gelding called Bay, that belonged to a band of people that I have never seen on the turf before or since, won it. There was a peculiarity about this trotter that made an impression on my mind that has never been efficed. On the farm where he was bred was an old gray horse that ran in the field with Bay while he was colt. As Bay grew up to a horse's form, he and the old gray formed a strong attachment for each other, and it was with difficulty that they could be separated. The colt being trotting-bred, his owner concluded to lave him trained, but found. when he sent him to a trainer's that 
he was apparently wild from the loss of his old gray friend, he refused to eat, thrashed around in his stall, and made things uncomfortable generally.

They took him back to the owner, and when he was again turned in with the gray horse he seemed perfectly satisfied and quiet. They thereupon concluded to return him to the trainer, and send his old gray chum with him for company, and ever afterward the two were not separated. Then Bay showed speed enough to warrant his being entered through the circuit the old gray gelding had to be shipped in the same car. When they went to the race track with Bay the gray had to be taken along and kept at the cooling-ont ground where Bay could see him while they were cooling him out between heats. The nearest to this attachment that I ever saw shown in a horse, was the love of Jim the dog, and Rarus. People often say that horses cannot thinkwell, maybe they can't, but just such things as the incident related make me positive that horses are as near human as anything can be without the ability to think. The talent thinking that Bay was not being driven by an expert, induced $\mathrm{Mr}$. Doble to get up behind him. It came to a battle between myself and Planter on one side, and Budd with Bay on the other, with the old gray horse thrown in for company. I learned something about Budd that day that I have not forgotten. I had heard people say that Budd drore well if he had the best horse but they didn't believe that in a tight race he would be dead game. In this fight between Planter and Bay it came down to the deciding heat, and as we were going down the back side of the track, head and head, Budd's horse broke. In every other heat where he had broken I had beaten Bay easily, and of conrse when he made this break I thought the heat was orer, but such was not the case. Budd nerer let go his hold and caught his horse on a trot without even having lost his position. I immediately climbed ont on Planter's back and ererything I had ever heard about hustling a horse I practiced on him right there. They came to the three-quarter pole in just 
those positions and as they rounded into the stretch both horses showed a disposition to give it np. I perserered with mine and Doble did likewise with his. At the distance stand they were both staggering like a comple of drunken men. There was a big darky that rubbed Planter who always went around bareheaded. Abont this time he rushed ont on the track like a wild man and shouted ont to me, loud enough to be heard all over the grounds: "Reef him, boss! reef him!" Whether it was the darky's encouragement or not, I never conld tell, but I hit old Planter again and he fell under the wire first by about a head. Whenerer anybody tells me now that Budd Doble cannot drive a tight race I do not have to take out my book to figure on it, I merely think of the heat when he drove Bay against Planiter, and while I might not try to prove to the other man that he is wrong in his argument, it is enough for me to remember that Budd will do to drive for the money, no matter how tight the fit.

In the spotted gelding Prince, I had another horse which proved the uncertainties of race-horses. This animal was of humble birth and beset with misfortunes besides. A circus company of rather moderate renown was exhibiting through the State of Georgia. Among their teams ras a blocky bay mare that proved to be in foal and gave birth to a spotted colt that was totally blind. Thinking that the colt wonld be nothing but a nuisance, the circus people gave him away to an old lady and gentleman, who in the kindness of their hearts took him home and raised him on a bottle. He grew up one of the most knowing horses that I ever saw. The old man tells me that he could be tanght anything that any horse ever learned. When lie was about five or six years old he was sold and came into the hands of Mr. G. J. Fuller, a man who at that time was the star trainer of the Southern country, and originally went there from the State of Ohio, where his family were born, were first-class farmers, and always good horsemen. Since that time Fuller has made a reputation as one of the most suc- 
cessful colt and horse trainers in this comntry. Among some of the most noted trotter's he has trained and dereloped are Frank Reeres, Elvira, with whom he beat the fouryear-old record when she was of that age, trotting a mile in 2:18 $\frac{1}{2}$, Patron, with whom he beat the three-year-colt record, and afterward gave a record of $2: 14 \frac{1}{4}$ at five years old, beating at that time the star trotting horse of the year in Harry Wilkes. As a colt handler, Fuller ranks as among the best in the country. While he was with the Glenview farm he brought out a number of good ones, among them Nutbreaker, a son of Nutwood that was one of the first horses to beat 2:30 when two years old. Of late years, Mr. Fuller has been the trainer and driver for the Forrest City farm of $M r$. C. F. Emory, and in that position he has attained marked success. 


\section{CHAPTER IX.}

How Iaud S. trotted in 2:08: as seen by the man who drove a runner alongside of the mare-What Splan knows of Guy, the sensational trotter

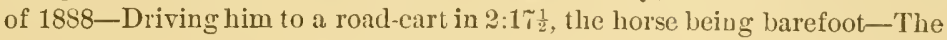
story of how Colonel WVest discovered Kentucky Prince, the sire of GuyTrotters are born, not made-Jay-Eye-See's good races down the circuit in 1887, beating Arab, the crack trotter of the yeir-Clingstone's race against the watch in 2:14-His great victory over Harry WVilkes at DetroitHow he was trained for this race and driven in it.

To return to the history of Prince. In Mr. Fuller's hands he obtained a record of about 2:20. I bought him for a friend of mine, drove him on the road through the winter, and in the summer of $18 \% 6$ took him up and trotted him a few races. The best race he ever went for me was one in which he beat Slow Go at Philadelphia. In that race I had for a side-partner Gus Glidden, and as Philadelphians were not very well acquainted with Gus and myself they lated us just a little too cheap. Slow Go was in Tumer"s stable, and as he lad shown some fast trials in his work his party backed him as thongh the money was won. Then the day of the race came 'Thmer was ill and confined to his bed, and he intrusted Slow Go and the money of the Philadelphians to his lientenant, James Pettit. This was Glidden's first appearan'e on the Philadelphia turf, and when he drove on the track attired in his Indiand costmme the hoys were a little disposed to gny him, and when I asked the pool-man whether he hadn't better get a ticket on Prince, he said No, he did not want any. Princes's owner left a fair-sized check in Mr. Barker's pool-box to he? put on his horse; told me if I won the race I rould heely myself to whatever part I thonght myself entitled to, and 
he would take the balance. When it came night we had the money. Slow Go won two heats, but as he was a trifle out of sorts Prince hung on a little the longest and won the race. Pettit insists to this day that Glidden and I rather double-banked lim, but Gus allowed that as long as we got the money we conld afford to let Pettit have his say about the race.

Prince was a dead game horse; he could have gone two miles well, and although he had the misfortune to be blind he was one of the best race-horses of his speed I ever drove. He was a good scorer, very steady, and a first-class finisher. His infirmity appeared to make all his other senses more acute. He seemed to know that he was blind, realized the fact, and left everything entirely to the driver, and I noticed that in shipping him about in the cars all the other horses took a great deal of interest in this blind one, and as I watched them I thought that perhaps they realized the fact of his being sightless. If you left Prince alone in the field he would not stir until you went for him, being apparently afraid to take a step on his own responsibility. If after trotting a severe heat, you took the harness off him he would lie down and roll exactly like a mule after a hard day's work, get up and shake himself, and seem ready to go at it again. In connection with Prince, it may be said that the boy that took care of him was a character. He was so plain and homely in appearance that the other boys called him "Danger," which nickname he carried to his grave. Prince became as fond of "Danger" as a dog would of its master. I think they were the best assorted pair, horse and man, that erer I saw.

Inasmuch as I drove the runner with Mand S. when she made her greatest effort, and succeeded in beating not only the whole world but her own record, I feel that it will not be out of place for me to give what I know will interest the readers - a short sketch of this mare as I have seen her from my standpoint. The public is already well informed about the history of Mand S., and I will confine myself strictly to 
the inside view of her great mile in 2:083. This trial took place orer the Cleveland track. She was adrertised to give an exhibition and I was asked to drive the rumner to accompany her, something that I was pleased to do as I always greatly admired this mare, and was glad to see a horse whose owner was brave enough to buy the best trottter in the world succeed. After Mr. Bair had his mare properly warmed up, as he considered, we went out and tied to do the trick. I have heard a great many people remark that nobody is interested in seeing a lorse trot to beat the watch. In some cases I think they are right; for instance, if some cross-roads man comes out with a cheap horse and wants to try to make him beat 2:35 and he can not go better than 2:34 $\frac{3}{4}$, people talie no interest in it, but in ny turf career I have always noticed that when some horse that the public thinks has a reasonable chance to do something that no other lorse has ever done, whether it is to go against another horse or against the watch, comes on the track, they take interest enough in the performance to give their time and money for the privilege of seeing the animal try. I have seen Dexter, Goldsmith Maid, Rarus, St. Julien, Jay-Eye-See, and Maud S. successfully lower the trotting record, and when they would do it the large crowds that saw them would clreer in a manner to convince the most skeptical that they were deeply interested in the matter.

I had for a rumner the day Maud S. trotted at Cleveland, a handsome brown horse called Dart, that belonged to $\mathrm{Mr}$. W. J. Gordon. After we scored down two or three times the judges gave the word, and after goingabout seventy-five yards the mare broke. Bair stopped and returned, and on getting the word the next time she went away steadily and fast, the pace seeming to me a little too speedy. Bair said nothing to her as she mored by the quarter pole at a rate of speed that rather frightened me, as I thought no liorse conld live at that pace. She went on down to the halfmile pole at the same terrific gait. I staid well back with the runner, as I thought the mare was going fully as fast as 
she ought to. At the half I looked at my watch and told Bair that we were certainly going fast enongh, and to not increase the speed. As we moved around the mpper turn it seemed to me that withont any nuging on the part of her driver the mare put on increased speed. Turning into the stretch it seemed to me that for a stricle or two she faltered, and I said to Bair, "Better take her back a little." He did so, and at the seren-eighths-nile pole he straightened her out, drew his whip, and tonched her very lightly. At this point I bronght the runner up $h_{1}$ ad and head with Maud and from there to the judges' stand the mare showed all the determination and bravery that you could imagine any animal or man capable of showing. If a man lad been in her position and making a struggle for his life he could not have put forth a more superhmman effort than that mare did, and how anyone can see a horse struggle as trifly and bravely as she tid and not admire him is more than I can tell. It took the andience but a rery few seconds to learn that Maud $s$, had beaten the record. They did not wait for' the judges to announce the fact from the stand before they set up such a cheer as it seems to me Mand $S$. and Bair will never forget. After they had given rent to their first enthusiasm Mr. IV m. S. Edwards, the president of the association, and the presiding judge in the stand, was enabled to call them to order long enongh to annomnce that Maud S. had beaten her own previous record, and made the wonderful matk of 2:083. I have nerer scen iny man muder any circumstances receive a greater ovation than this mare did right there. She was literally loaded down with flowers and bonquets enough to have gladdened the heart of the most exacting prima donna.

A great many people naturally thought that because Mand S. had beaten her own record everything in connection with the matter in the shape of weather and track must have been first class. I have had some experience in driving horses against the watch and find there are several things often orerlooked that have a very material effect on the 
result. First and foremost, of course, is the kind of a horse yon have; second, the rondition that he is in; third, the track. At the time of the Cleveland trial there had been more or less rain. and the weather was very unsettled for two or three days. 'This I ronsidel a vital elenent in making a great performance. Unsettled weather not only interferes with the regular training, which it did in this case, but the atmospliere is apt to be in a state that also has more effect on the track than people inagine. When in the best of condition the (leveland track, to $m y$ mind, is the fastest one I have ever seen. On this particular day, the track, from recent rains, while it looked good from the stand, was inclined to be cuppy and moist, and there were sereral places that cupped ont nnder the mare's leet, and I noticed that when she struck them they retarded her progress quite perceptibly. In talking the matter orer afterward with Bair and telling him what my impressions were, he agreed with me, and stated one instance in particnlar, where she turned in at the head of the stretch. I simply tell this to give my riews of the case from where $I$ sat, and as I was very close to the mare think perhaps I was in a good position to be able to judge of it as well as anyone except Mr. Bair.

This mare came honestly hy her spoed at the trot. In the first place, her sire, Harold, is an inbred Hambletonian, being by Rysdyk's Hambletonian, and ont of a mare by Abdallah, that was the sive of Hamblotonian. This roncentration of blood that has fomnded the most remarkable trotting family in the world gave Harold a manifest adrantage as a sire, and time 1 as shown that when he has been mated with mares of the Pilot Jr. family, of which the dam of Mauds. is a member, his success in the production of a ligh rate of speed and the ability to carry it the mile has been most marked. The fact that the dams of the two fastest trotters in the world, Mand S. and Jay-Eye-See, are daughters of Pilot $\mathrm{Jl}_{\mathrm{r}}$, and that the granddams are of the Boston family of thoronghbreds must not be orerlooked. To say that Maud 
S. was bred at Woodburin would not be enough in praise of that establishment, which is the oldest of its kind in this country, as well equipped in all the fashionable strains of blood as any and conducted in a manner that has made its name known throughout the world, not only by the fame of the horses that have come from there but also by reason of the business-like methods and the strict integrity of purpose which have always characterized its dealings with the public. To have produced Mand S. were sufficient to give any breeding farm a great reputation, but when one examines the list of American trotters that have beaten 2:30 and scrutinizes their pedigrees closely, it is simply wonderful to note the frequency with which strains of blood that may be said to have been originated at Woodbum are found. It was at Woodburn that the stallion Pilot.Jr., whose danghters have become so famous as the prodncers of trotters, was given his first opportmity in the breeding ranks, and with copious infusions of this blood, together with that of Mambrino Chief and a number of his sons, topped by the best thoronghbred crosses, the result has been a constant succession of trotters, trotting sires, and mares that have produced trotters of the highest type, -animals that not only have speed, but also possess the vim, determination and stamina to fight out a race of split heats and contest exery inch gamely when they are orematched as well as when they are wimning easily, and, as the owner of the famous race-horse, Longfellow, said, "to go from eend to eend." It was from Woodburn that Wedgewood, of whom 1 have previously witten, came, and, as I have also noted, the foundation of Mr. Emory's farm was laid by the purchase at Woodburn of a large number of colts and fillies, whose prodnce are making a reputation with each succeeding trotting season. When one looks orer the catalogne at the Eorest City farm, he sees that the blood that has made it known is that of the IV oodburn animals, and the same is true of other prominent establishments in other parts of the comntry. Messis. Baker \& Harrigan, a well known New York hreeding firm. at one 
time purchised the entire ('lop' of yearlings at Woodburm. Mr. W. R. Allen, whose breeding establishment at Pittsfield, Mass., has started out in a mamner which shows him to be not only motinted in the expenditure of money but also the possessor of a keen judgment and extensive knowledge in the matter of trotting blood, made a large draft from Woodburn. Ot!er instances might be noted, but this will suffice to show the influence which one establishment, properly conducted, can have on the breeding interest of the conntry, and how that influence will continue for genelations. With Harold, the sire of Mand s., Belmont, the sire of Wedgewood, Lord Russel the brother of Maud S., King IVilkes, sire of Oliver K., and other liorses of less prominence, but perhaps not less merit, on its roll of stallions, it can not be but that Woodburn will al ways keep to the front. Its policy, moler the management of $\mathrm{Mr}$. Brodhead, has always been an intelligent and progressive one, and this was never better shown than last season when Mr. Brodhead sent the dam of Mand S. two of her danghters, the dam of Pancoast, and one or two other famous mares clear across the continent to be bied to Electioneel. He had noted the successes of the Californian stallion, and, as he has since said in print, it was the Electioneer cross that he wantednot any particular one of the strains that go to make up the pedigree of Senator Stanford's premier stallion. It is this policy that pervades all the branches at WToodburn. There is no narrow-minded plan of breeding, but the cential idea of the management is always to secure, retain and develop the most promising strains of performing trotting blood, no matter from what somree they may come, and it was this policy that dictated the recent purchase of King IVilkes. Men from all parts of the country go to IToodhurn every year and hny horses with as much confidence as they would go to Tiffany's in. New Tork to bny jervely. 'They know that the reputation of the place will not allow of nisrepresentation being made, and that the goods are standard. And what wonder that a mare bred at a place 
like this should enhance itsalready good reputation by trotting the fastest mile that the world has erer seen.

The sensational trotter of 1888 was the black gelding Guy. My experience with Guy was very limited, as I started him in but one lare. When I took change of Mr. W. J. Gordon's stable and horses Guy was lather an uncertain quantity, ho having alpearly shown all the speed that has since made him famous to the public. I will cite just one instance of what he diel for me to prove that this horse was a wonderful trotter from breeding and inheritance. I drove him a mile to an ordinary road cant in $2: 17 \frac{1}{2}$ over the Clerelant track, going eighteen feet ont from the pole. In this performance he wore nothing except the harmess, no shoes or tips of any kind, no boots or weights. This performance, while it may not seem nuch to a casual observer, now that Gry has gone in 2:12. impressed me more than his perfornance of $2: 12$ afterward. To see a horse go out without mechunical appliances of any kind, as you would take him ont of the pasture, and hook him to a rehicle which, with the driver, wighed orer 300 ponnds, and with the poles haid down so that he could not go within eighteen feet of the inside rail, and in those conditions trot a mile in 2:17 $\frac{1}{2}$, the first half in 1:10 and the last half in $1: 07 \frac{1}{2}$, and do it in a manner which led a man who was a rery close observer, and saw the performance, to remark that it was not the 2:17 $\frac{1}{2}$ that he was wondering at, but what he could have done had I turned him loose from the stant to finish, is what stamps the performance as al rery notable one.

Having shown by this what a wonderful trotter Guy is, brings to my mind a conversation that I had had years before with that estimal) gentleman and excellent judge of horses, Col. Richand West, of Georgetown, Ky., concerning Kentucky Prince, the sire of Guy. Long before Guy or any of the Kentuck Prince family had attrated the attention of the trotting world by their extraordinary flights of speed Colonel Trest purdicted for Kentucky Prince the great reputatien that he has since achiered. Epon my asking hin one 
day what horse to breed a mare to, and giving him her pedigree, he advised me to send her to Kentucky Prince. I was ra:her surprised, as at that time I had not heard much of Kentucky Prince. He belonged at this time to a gentlemim who bred more for his own ammsement than for public patronage. Nothing muth was ever done in the way of advertising Kentucky Prince, and fur that reason he was partially orerlooked. I knew that Colonel West must have some very good reasons for adrising me to breed to the horse, and asked him to state them. His first reason was that his breeding was good; then he said that as an individual horse Kentucky Prince was simply perfert. He then went on to explain to me in his genial manner how he had receired a letter from a man down in Bourbon County of Kentucky, telling him that the writer hard a wonderful stallion that he would like to sell. The letter made such an impression on Colonel West that one day he took his team, and his trainer and friend, Geo. Brasfield (a man who, though now retired from the turf, has handled many famous trotters in their babyhood, among them Director; Jay-Eye-See, and Santa Claus), and started for the farm of the man who had written. He said that when they arrived at the farm they found the best crop of weeds, and the poorest cattle, he had met in a long time-in fact the whole comnty had an aspect of going to seed. On inquiry for his man Colonel West was told that he had gone down to the bottom-lands to drive up the cows. He aslied about the horse, and an old darky said they had such a hor'se, bit the farmel had ridden him after the cows. Ite said while wating for the farmer's return he interviewed the colored person on the subject of trotters in general, and this horse in particular, and his ideas about a trotting horse were something wonderfur. He finally volunteered to show the Colonel the track on which this trotting horse was thained the days that the farmer did not have to ride him after the cows, and as the Colonel lad nothing else to do he bethought himself to pace off the track, and see whether it was half a mile or not, which he did, and 
satisfied himself that it was mole than that distance. When the farmer. returned he introduced himself and hitched up his trotter to a rehicle that Colonel Wrest told me he had never seen the like of on any of the circuit tracks, and under these conditions the sile of Gny showed him a half mile in 1:12. People may say: "What of 1:1\%! I have colts that "an beat that." Ies, but a half mile under these conditions convinced Colonel West, than whom no better judge of trotting horses ever lived, that Kentucky Plince was a trotter of the first water, and he never for one moment lost his faith, and lived long enough to hare the pleasnre of seeing the horse demonstrate all that he had ever claimed for him.

At the time of which Colonel West spoke there was not much done in Bourbon County in the way of breeding trotters. A man named Willets, who lived in Bourbon County, came up to Edge Hill, Colonel IT est's farm, on business, and while there told abont a wonderful three-year-olel colt that was owned by a neighbor of his named Thomas. This colt, he said, was a son of Clark Chief, and had shown half. a mile in 1:16. Colonel West, was always on the lookont for last colts, and he and George Brastield marle the trip to above. They drove their own team to Paris, and there hired another conveyance with which they malle their way across the combtry to Thomas's farm. Brasfield says the place had the forlorn and deserted appearance described by Colonel West. The track was in a cornfield and all that conld be seen of it was a space wide enongh for a sulky to travel upon.

When the horse (ame back from the trip after the rows he was pretty wet, having forded a creek only a little while before, but when Thomas hitched him ul, Brasfield remarked at once how wonderfully handsome he was. They had previously paced off the track and found the length to be all right. The boy who was to do the driving was rather excited and started across the field from the stable at a good stiff, lhree-minute gait. After he reached the track he drove the horse to a break and this put 
Kentucky Prince and his jocky so much at variance with each other that the colt became excited and refused to trot at all. Seeing this Colonel WVest told them to put the animal in the stable until after dinner, when he wonld let Brastield get up behind him. This was done and Brastield drove Kentucky Prince a qnarter in forty seconds, repeating him in thirty-seven seconds. This was enongh for Colonel IVest, because at that time the best mile by a three-year-old trotter was the 2:29 of Lady Stont, and it was evident that with rery little handling Kentucky Prince conld beat that. Colonel IVest thereupon bought the colt for $\$ 7,000$, and the next day he was taken to Edge Hill.

About ten days later Col. John IV. Conley, now of Chicago, but who was at that time a resident of New York City reached Edge IIill during one of his numerous trips to Kentucky, and of course he was told about the colt. It was arranged to show him the following day and althongh he was still fir from being in condition to do his best Brasfield drove him half a mile in 1:10 $\frac{1}{4}$. Colonel Conley had at this time a standing commission from Mr. A. B. Darling of New York, to buy for that gentleman any stallion that came up to certain requirements as to physical appearances laid down by Mr. Darling, and that conld also show speed. The Coloniel felt satisfied that in Kentucky Prince he liad found a horse that would exactly suit Mr. Darling, and so bought him for $\$ 12,500$ and shipped him to New York, upon arriving at which place Mr. Darling at once look Kentucky Prince, being more than satisfied at Colonel Conley's action in the matter.

There is a rather funny story in connection with the subsequent sale of Kentucky Prince at auction, that has never before been made public. When Thomas, the breeder of the horse, learned that the horse was to be sold he had an idea that perhaps he wonld go for far less than his value, and so withont saying anything to his neighbors he packed his grip and started for New York City, having decicled to pay as much as $\$ 2, \pi 00$ for the horse. He was on hand bright and 
early on the day of the sale, but when Kentucky Prince wais led out the first bid on hin was \$i, $(0) 00$, and in a little while he was struck off at $\$ 10,1)(00$. Mr. Thomals took one good look at the horse and went back to Kentucky, and it was a year later that he first mentioned the circumstance.

That Kentucky Prince must have impressed his present owner, Mr. Chas. Barkinan, of Stony Ford, N. Y., in the same mamner that he did Colonel West is show by the fact that when the stallion was put up at anction sale in New York several years ago, and at a time when the depression in all values had afferted the horse market to a marked degree. Mr. Backman was present and paid \$10.000 for him, fully believing there was areat future for the son of Clark C'hief. At this time the premier stallion of Mr. Backman's farm was Messenger Duror, a horse of marked success as the sire of trotters, and in addition to him Mr. Backnan had numerous sons of Rysdyk's Hambletonian. and a band of brood mares of the American Star, Mambrino Chief and other fashionable families, whose leputation was known in all parts of the country. It is moler Mr. Backman's management that Kentucliy Prince has attained a foremost place among the stallions of America, and with the exception of Electioner there is no stallion to-day who so completely fills the public mind. In addition to the $2: 12$ of Guy last season, Kentucky Prince had another notable representative on the turf in the black gelding Spofford, that won the $\$ 10,000$ stake at Hartford, beating a large field of the best horses, and making a record of $2: 18 \frac{3}{4}$. Spofford is faster. than his record shows, as I have seen him go hall a mile in a race better than 1:06 and timed him a mile in 2:16:3. Like Woodburn, the farm at Stony Ford, of which Mr. Backman has long been the owner, has an important effect on the trotting interests of this comntry. Animals bred there are representative ones, the strains of blood from which they come are those that have been tested in the fire of the grand circuit races, and they have not been found wanting. Green Momntain Maid is, in the opinion of 
many horsemen and breeder's, the greatest brood-mare that the world has ever seen, for in addition to having six sons and daughters in the 2:30 list, and another one with a record of 2:31. she is also dam of Electioneer, the most famous stallion now alive. More than this, the blood of Green Mountain Maid is potent on both sides of the house. Not only has her son Electioneer sired the fastest young trotters in the world, but one of lel daughters, Elaine, that beat ail the records for three-year-olds when she was of that age and afterward obtained a mark of $2: 20$, is the dam of the filly Norkine that in 1887 set the yearling record at $2: 31 \frac{1}{2}$. a performance which no other trotter of her age has approached. and had not Norlaine been destroyed by the fire at Palo Alto the following spring there is little donbt as a two-year-old she would have beaten 2:20. Notonly have the produce of Stony ford made themselves famons on the turf but that establishment has been the fountain from which other breeders have made drafts for the purpose of establishing breeding farms in various parts of the country, and these have been uniformly successful. Then Governor Stanford began lis operations at Palo Alto one of his first mores was to risit Stony Ford and purchase $\$ 43,000$ worth of hreeding stork, among the animals being Electioneer, for whom he paid $\$ 12,500$, and to this horse is due the fame of his sons that made Palo Alto famous thronghout the world as the birthplace of the fastest baby trotters. At that time it was thought an extraordinary occurrence for a man to invest so much money in animals for breeding purposes, but Gorernor Stanford has proved the wisdom of his investment, and shown that the money has rome back to him one hundredfold.

This has been the experience of other men who have made drafts from Stony Ford for breeding purposes, and the most noticeable illustration of the esteem in which that establishment is held is shown by the fact that Mr. WVm. Russell Allen, whose farm at Pittsfield, Mass., starts out under auspices singularly favorable, went to Stony Ford and at 
one purchase transferred from the ownership of Mr. Backman to that of himself no less than $\$ 44,000$ worth of trottingbred stock, the largest purchise of the kind ever made in the world for breeding purposes. 'To mention Stony Ford without bringing in the name of Johmny Hoag would leave the subject incomplete. He is like some of the colts, took his tirst lessons in horses at Stony Ford, and to say that he has improved, and kept $n 1$ with the colts, and with the breeding, only partially tells the truth. As a handler and trainer of colts he is rated by those who are supposed to be judges as in the first class of that profession.

In this comnection I might mention a grandson of Kentucky Prince which I had in my charge for a short timeI mean the black gelding J. Q. by Kentucky Prince. When I say that I consider this horse one of the fastest I ever drove $I$ think his performances will bear me out. J. Q., like Guy, seemed to be born with his trot in him. 'The first time I saw him he was in the hands of a man who at that time had not made much reputation for himself as a horse trainer. J. Q. is one of the best evidences of my argument that all great horses, like poets, are born and not made; in other words that their speed is a natural gift and not a developed quality, and I can rite some rery notable instances in support of this idea. 'The first time I erer' saw Jolinston the pacer he could pace for a short distance as fast as I ever saw him go afterward. By this I do not want to be understood as saying that he could lave gone a

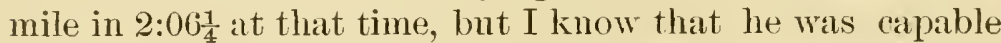
of pacing 100 yards at that rate of speed. 'The first time I saw Mattie Hunter she had all the speed that she had when she went a mile in 2:123. The same can be said of Little Brown Jug, Rarus, and Maud S. St. Julien is a very noticeable instance. I saw him brush close to a 2:20 gait the day he was sold for $\$ 600$.

In the case of .J. Q., at the commencement of his career he was fast elough to warrant the belief that some day he would go a very fast mile. He was handed abont from one 
trainer to another, which, by the way, I consider a very bad practice, as no matter how much experience a man may have hald or how capable he is, you need never expect to get the best results out of a horse by having him trained and driven by a number of different people, even if they are all first class. Every man trains a horse differently, every man drives then differently and when you take into consideration the fact that in order to bring a horse to his best possible condition and speed, years of careful training are required, you can perhaps see that frequent changes of trainers are a detriment. When J.Q. was placed in my charge I for one thought his days of usefulness were about over. He at that time had a record of $2: 17 \frac{1}{4}$. He had been rather unfortunate, having been ont of condition and lost races to horses with slower records. The first race I dore him he was defeated, but still his performance rather opened $m y$ eyes to the fact that. J. Q. was a little better horse than either myself or the public gave him credit for being. That the public realized the fact I doubt very much, as I noticed that whenerer' J. Q.'s name appeared as a starter in a race it nerer created any very great semsation among the betting fraternity.

The second race still further convinced me that I had made no mistake about his ability and that he was liable to be a right good horse. The third race made such an impression on my mind that I took his ownel aside, and we commenced to lay plans to spread our net and make a haul that would inchude the sturgeon as well as the suckers.

This was in the snmmer of 1887, and I had taken J. Q. to the Detroit meeting and trotted him there and at Cleve land and Buffalo agaiust Alab, Charley Hilton, and some other horses that were supposed to out-class him a great deal. Arab was a star trotter through the circuit that year. Orrin Hickok had him in charge, and as the next best one in his class, Charley Hilton was driven by my friend William H. Crawford; these two gentlemen from California had thus far generally been able to take first and second 
money in free-to-all ralces at every place, and J. Q. was left with what he could find. But at Rochester the pie was cut in a different manner. In the betting Arab sold for $\$ 100$, and the field, including J. Q., Hilton, and other performers, went for anything that you would bid. In the previons races I had put in some of my spare time watching the peculiarities of the horses I had to contend with and trying to see what my chances were for beating them. I did not think it was $\$ 100$ to $\$ 10$ that Arab could ont-trot J. Q., and when I imparted that information to Mr. Temple, J. Q. 's owner, he quietly placed some of his money on the black horse at those odds, and we went ont for the money.

I think there was hardly a man on the track who expected to see the great race that took place between Alab and J. Q. In the first heat I laid my horse up and Arab won easily. In the next heat in getting the word Alab was a little back, and Jack Feek with Kitefoot cut him off at the tum, which pnt him in a pocket and Hickok, seeing the disadrantage that he was at, immediately pulled his horse mp. I set sail with J. Q., and won the heat in about 2:19. This made no change in the betting; if anything Arab was a bigger favorite than before, thus enabling us to place some more of onr money at the same odds. When they gave the word in the next heat Hickok rushed ont with Alab and took the lead. I contented myself by trailing within a length of him. We reached the quarter pole in that order, and there was no change at the half-mile pole, where we turned mp in about 1:10. Around the upper turn I moved up so that my horse was as close to Hickok as was sife, and sat still until we got well into the stretch.

Arab and J. Q. were two very brushy horses. I had often talked with Ilickok about the two horses, and he had always said they were not to be mentioned the same day, and rather lost patience with me as I undertook to argue that J. Q. might be able to give Arab a very fair race. At the seven-eighths-mile pole I pulled .J. Q. ont into the track and took off the brakes. From there to the judges' stand 


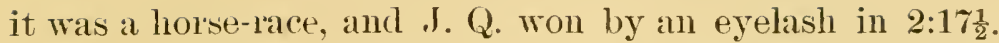
From the look on Hickok's face after' we finished I imagine that he was as surprised a man as you would often see, and the public commenced to realize that they were to be treated to a gennine horse-race.

When we came ont for the next heat Hickok asked the judges to be sure and see that he was in his place when they said "go," which they promised to do. I made the same request of them. When the word was given both horses were ou their stride, and again Arab rushed out with the lead. The heat was trotted identically as the one before, with the exception that we might have commenced our brush a little further down the stretch. I went to the half-mile pole in about 1:10, and home in about 2:17 , J. Q. beating Arab a head in the last stride, thereby winning the race and money, and giving the cheap boys a chance to get a few good tickets cashed at night.

J. Q. was a peculiar horse, and often trotted in-and-ont races, and sometimes the public imagines of such a loorse that his driver is not lonestly trying to win, when the facts of the case are otherwise. In disposition J. Q. was rather a high-strung, thin-skinned, nervous horse, inclined to be peevish, and after making an effort like the one he made in this race it seemed to take him weeks before he recovered the form that enabled him to perform at his best speed. I have had other horses that possessed the same pecnliarities, although perhaps not in as marked a degree. At Utica he was beaten, and at Albany the same, but at Hartford I had my revenge, as he beat Spofford in a race that General 'Turner had set his heart on winning, for which he had got the watermelon all ripe, and the New Tork men came orer in a body with their cash and check-books, and backed the little General and Spofford in a manner that showed their confidence to be unlimited.

This was rather a peculiar race, as both horses were bred much alike, and Mr. Albert Hall of New York and David Bonner, two reliable men, told me that I. Q. trotted a half- 
mile in one heat in $1: 0,5 \frac{3}{4}$. In all the races 1 had seen Turner drive Spofford he went easy with him until he reached the half-mile pole, and made his brush from there home. I had repeatedly seen him come home in 1:061, but for all that 1 thought J. Q. could come home better than Spofford, and the result of the race proved that I was right, as Spofford trotted two of the fastest heats I had ever seen him trot in a public race, and J. Q. beat him. Both Turner and myself laid $и$ p in the first heat, each seeming to think that the other was the only one they had to beat in the race. In the second heat Turner scored up as though he was out for the money, and I determined to keep my eye on him alone. We went to the half-mile pole in about 1:12, the other horses some distance in the lead. At that point Tumer tumed his horse loose, and I did likewise and J. Q. won in about 2:18. The next heat was the same, Turner and myself trailing side by side to the half-mile pole. Spofford led into the stretch and all the way to within 'about three lengths of the judges'

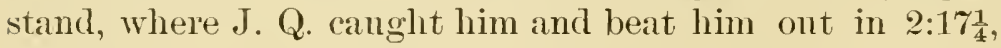
equaling his own best record. The next heat, having two to my credit, to make it doubly safe, I laid J. Q. I1), and Spofford won from the other horses in about 2:21. When they gave the word in the next heat I trailed away until well in the back stretch, where I set J. Q. going. At the half-mile pole he had the lead, and from there home won easily, thereby furnishing a good day's racing for the public with a son and grandson of the same horse Kentucky Prince.

On two occasions when the well-known trotter Clingstone, one of the fastest hor'ses of his day, performed before the public I had to do with the transaction, and consequently it will not be out of the way to say something of those events.

The first time was when Mr. Dunbar asked me to acconpany Clingstone with a rumner in a trial against the watch that Dunbar was booked to give him at the Cleveland meeting in the summer of 188.). Dumbar told me at the time that he thought Clingstone would go a mile in 2:14, which was his best record. I was a little surprised to hear this, as 
Clingstone had been practically retired from the turf for a couple of years, and I did not imagine that he was back to his old-time form. 'The sequel proved that Mr. Dunbar was right, and it also showed that Mr. Dunbar was not only a good reinsman but also a good conditioner and an excellent judge of pace, two very important things in a horse-trainer. When the trial took place Clingstone trotted in exactly $2: 14$, but I have always been positive that Mr. Dunbar could have driven him faster. His reasons for not doing so were that this was the first time he had attempted anything of the kind with Clingstone, and le was naturally anxions to avoid any mistakes that would turn the trial into a disappointment to the public, but as matters turned out both the public and $\mathrm{Mr}$. Gordon, the owner of the horse, were greatly pleased.

In the latter part of that season, Mr. Dumbar having in the meantime serered his connection with the Gordon stable, Clingstone was entered in a lace against Harry Wilkes, to be trotted orer the Detroit track, and it was in this erent that I first sat behind him in public. Iarry Irilkes was at this time the star of the trotting turf, having beaten all comers and made a record of $2: 15$. There is a little history about this race, or rather preceding it, that will read well in this connection.

At the time the match with Clingstone was made Harry Wilkes was at the Cleveland track, and it was reported around that he had gonea moonlight trial in 2:09. 'There were some people credulous enough to take stock in this story. I was one of the unbelievers, but the men who were booming Harry Wilkes stuck to their tale, and even went so far as to talk about trotting him against Laud S. One evening Mr. Gordon called on me with a letter he had received from New York, and said he would like to read me a portion of it, which he did. I have in my time seen some very flowery horse letters, but to this particular epistle I award the pennant. I have never to this day learned the writer's name, but would like to know it, in order that he might be given a niche in the Temple of Fame alongside of Swinburne and others who 
have gained a reputation in that line. 'The gist of the letter' was that Harry Wilkes could easily beat Mand S., and it closed by saying that he could trot a mile in 2:09 and "finish as calm as a summer morning." Mr. Gordon seemed to think there must be something to this, but I told him it was too calm to be true, and further said that if Clingstone was himself he would beat Harry Willes sure. We had eighteen days in which to get Clingstone ready for the race, and the first time I worked him I was a little surprised and disappointed. He seemed dnll, sluggish, and without much speed. After careful inquiry of Phil Riley, the boy who rubbed him, I fomnd that there had not been much donewith the horse in the way of speeding. He had been given a good deal of long, slow work on the track, and long jogs on a sandy road. He showed a disposition to want to lie down and sleep a great deal in the daytime, which I think very unnatural in a horse. I asked Phil how much he had been feeding Clingstone, and he replied that the horse had been getting abont fifteen quarts a day. When I weighed the oats I found they went about thirty-six pounds to the bushel, and this proved to me that he was being a good deal overfed. Clingstone always looked to me as though he carried too much body for the size of the horse. Phil said they had a great deal of trouble with him, and were obliged to keep him muzzled in order to prevent him eating his bedding, etc. I made mp ny mind that if Clingstone's condition did not alter very perceptibly he would not cut much of a figure in the race with Harry Wilkes.

My first more was to call in Dr. Fair, the veterinary, to whom I gave a description of the horse's condition as well as I could see it. Dr. Fair decided to give Clingstone medicine to act on his stomach, said the horse had been orerfed, and advised me to not let him have more than eight pounds of oats a day, a moderate feed of hay, with plenty of grass and occasionally a comple of tablespoonfuls of Glauber's salts in his feed. I had myself often tried the plan of giving a horse salts while in training, and always with the best 
results. If your horse gets what the boys call "burnt up" give him a few doses of salts instead of bran, and you will find the result much more satisfactory. I have given a horse thirty doses of salts in as many successive days with good results. Dr. Fair said that if Clingstone did not improve he would change the medicine, but as his condition at once altered for the better we followed this treatment until the race was over. In working Clingstone I gave him very short, shirp jogs, stepped him a three-minute gait for a little way almost every day, and every three days worked him out a couple of heats close to $2: 20$ and brushed him the last part of the mile as fast as he could go, the result being that every time I drove him I liked him better.

Eight days before the race I took him to Detroit, and on reaching there about five o'clock in the morning the first man to meet me at the dock was Capt. John DeMass, who had appointed himself a committee of one to receive me. We rode to the track together, and after having Clingstone placed in a comfortable stall I was introduced to the superintendent, who invited me to go out and inspect the track and see what I thought of its condition. I found the course as near first-class as anything I ever saw, and the superintendent one of the few men who knew how to keep it in really superb shape. I think that if track owners knew how many horses are injured by tracks being out of condition they would pay more attention to this matter. They seem to think that any man who can follow a harrow around is good enough to superintend a track, but if they will go and spend one day with "Race-track Jack" at Cleveland when he is getting things ready they will learn something that I am sure will be of advantage to them. The next day I gave Clingstone some work, and for the first time was really pleased with him. I drove him a mile in $2: 19$, the last half in 1:06, which was the best mile I stepped him in his work before the race. From that day I never missed giving him a mile as good as three minutes, never jogged lim more than three miles, and walked him but very little. 
I could see that the medicine was operating on his stomach. Te kept him tied up through the day so that he conld not eat his bedding, but did not muzzle him. I divided the eight pounds of oats into five feeds, and gave him in addition a small quantity of hay night and morning. Every day he seemed to get brighter, sharper, and have more dash and speed. From what I had seen of the horse in lis turf career I made up my mind that whenerer he had plenty of speed it took a race-horse to beat him. I had heard people say that he was what you would call a soft horse, but as good a judge of a trotting horse as Darid Bonner once remarked in my presence that there was nothing in Clingstone's breeding to indicate it, he having in his pedigree a combination of the blood of Rysdyk's Hambletonian, American Star and the best thoroughbred cross that was ever in a trotting pedigree, that of Lexington.

This race was in some respects a battle between strains of blood that had their respective partisans. I have told how Clingstone is bred, and Harry Wilkes was also in fashionable lines, his sire, George Wilkes, like the sire of Clingstone, being by Rysdyk's Hambletonian, while on his dam's side there was the blood of the pacer Captain Walker, a horse that in addition to the dam of Harry Wrilkes had also sired the dam of Black Cloud, a stallion that had made a record of $2: 17 \frac{1}{4}$, and went some good races where the heats were split. People from all parts of the conntry came to Detroit to see this race, among them many breeder's, and prominent in this section of the throng were Mr. Samnel A. Browne and United States Senator Stockbridge of Michigan, who were then, as now, proprietors of one of the largest breeding establishments in t're $\mathrm{W}$ est, it being located at Kalanazoo, Mich. As they were natmrally anxions to liave on their place stallions and mares of the best strains of blood they had come to see the race between these two representative horses. To show that Messrs. Browne \& Stockbridge are men of liberal and progressive methods, once their mind is made $u p$, it may be said that they were 
the first breeders in the country to 1)ay $\$ 5,000$ for a yearling colt, they luaring purchased at that figure the stallion Bell Boy, a son of Electioneer and Beantiful Bells, that at the time of this transaction had already prodnced Hinclaa Rose,

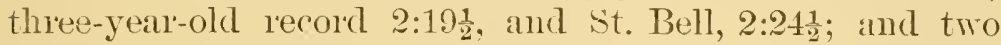
others of the produce of Beantiful Bells have since entered the 2:30 list. After keeping Bell Boy a year and winning at large number of valnable stakes with him, Messrs. Browne \& Stockbridge sold lim for the long price of $\$ 3.5,000$, and at once filled his place with animals of equal merit in the matter of breeding. 'They have on their farm Ambassador, a son of George IVilkes, that is not only a trotter himself, but that is siring extreme speed, as is shown by Lady TTillins, Harry Wilkes, and others of his get that have beaten 2:20.

Another stallion of wonderfully good blood lines owned at the Browne farm is Wralock, and there is quite a story to be told in connection with him. Warlock is by Belmont, perhaps the best son of Alexander's Abdallah, and his dam is the famous old mare IVaterwitch, that has produced

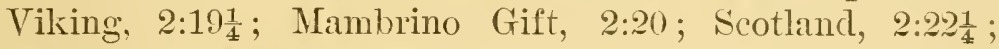

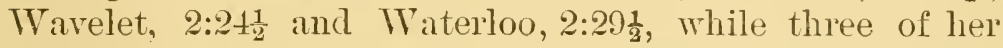
daughters have already become the dams of four trotters that hare beaten 2:30. While still a youngster Warlock was purchased in Kentucky by an English gentleman of horsey tastes who was traveling in this conntry and shipped across the water. After Viking had shown great speed J. E. Madden, better known as "Happy Jack," a young man than whom there are few better judges of blood lines and other things pertaining to trotters, discovered that Warlock, the full brother of Viling, had been sent across the sea, and the next steamer that lelt New York had Madden for a passenger, his mission being to find TTarlock and bring him back to this comntry. Arrired on the other side, Madden lost no time in sight-seeing, but took train for an inland county, where Wralock, his tilil banged in the most approved style was doing duty in the stud, being advertised as " an Anrerican hackney stallion." 'To hear Madden tell 
the story of that trip is worth a long journey, but suffice it to say at this time that he got the horse for $\$ 5,000$, shipped him to America, and soon after reaching here re-sold WTarlock to Messis. Brown \& stockbridge for $\$ 15,000$. That this horse will get trotters is not to be doubted, as his relatives trot fast, and his pedigree contains the strains of blood - Rysdyk's Hambletonian and Pilot $\mathrm{Jl}_{1}$. - that have given us Maud S. and Jay-Eye-See, the two fastest trotters in the world.

The brood-mares at the Browne farm are standard under the highest mle that has yet been formulated. They are either the possessors of records of $2: 30 \mathrm{or}^{\circ}$ better themselves, have produced a 2:30 trotter, or are out of mares to whom the same distinction attaches, and when it is said that every one of them-100 per cent-cone nuder this head the high standard of the farm in regard to blood lines is seen. Some of these mares are by Grand Sentinel, a horse that Mr. Browne selected many years ago, when he was alone in the breeding business. Being by Sentinel, a full brother to Tolunteer, it was natural that Grand Sentinel shonld trot fast, and had it not been for an accident in training he would undoubtedly have greatly bettered his record of $2: 27 \frac{1}{2}$, as in his work he could trot quarters in 35 seconds, and that he was a brave, level-headed and determined horse he showed in his races, winning the ones in which the heats were split. Empire, another stallion on the Browne \& Stockbridge farm, is already well known by reason of having sired Eminence, that as a four-year-old last season showed herself one of the best of her age that has ever come out, winning nearly all her races and making a record of $2: 21 \frac{1}{4}$.

The night before the Clingstone- Wilkes match the town was filled with people who had come from all parts of the country. All their talk was of the race, and the chances of Clingstone beating Harry Wilkes were eagerly discussed. The friends of Harry were very sanguine, and the betting was $\$ 100$ to $\$ 50$ in favor of their horse. Mr. France, Harry's owner, told Mr. Gordon that he was sure TVilkes was in first- 
class condition and would win the race with ease. Mr. Gordon asked me what I thought about it, and I made answer that I thought it took a pretty smart man to be in New York, while the horse was in Detroit, and tell anything about the animal's condition, and so, while we did not go about advertising the fact, both $\mathrm{Mr}$. Gordon and myself felt that our horse had a chance to win. The morning of the race dawned clear and long before noon the crowds began to wend their way to the track. I had Clingstone shod with shoes weighing eleven ounces apiece, with leather pad and sponge. The track was as hard and smooth as it could be. In the betting Wilkes was the favorite all the time and the talent put their money on him at $\$ 100$ to $\$ 50$.

In warming up Clingstone I gave him two slow heats, stepped him out at three-quarter speed in the last eighth of a mile, and liked him so well that I told $\mathrm{Mr}$. Gordon that if we drew the pole we would win the race sure. I had seen Van Ness behind Wilkes so often I thought I knew just how he would drive this race, which would be to go moderately to the half-mile pole and then cut loose and try and win. When they drew for positions Clingstone won the pole. We scored, I shoula think, five or six times, each driver watching the other like two men who get up to spar. The word was finally given, when Clingstone stepped out and took the lead and went to the half-mile pole two lengths in front. There Tan Ness began driving Willies, and when we made the turn at the three-quarter pole they were head and head. From there to the seven-eighths-mile pole they went like a double team, and both horses doing their best.

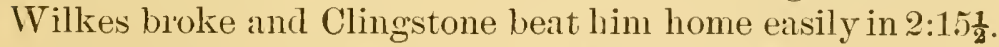

This heat resulted just as I expected it would. I told Mr. Gordon before we got the word that I believed Clingstone would out-trot Wilkes when it came to the struggle, and that I thought the heat would all be decided in some one-quarter of the mile. I was satisfied to go as slow as Van Ness wanted to and leave the battle to a brush, as in his work Clingstone had shown speed enough to convince me that 
Wilkes could not by any possibility out-trot him. At the half-mile pole when I heard V'an Ness cut Wilkes loose, while I did not sit down and drive Clingstone, I let him sail along at about the top of his speed. Wilkes closed the gap and came to Clingstone's head and in doing so had to trot ont around him on the turn. I made up my mind that when he turned in at the head of the stretch I would send Clingstone for all he was worth, which I did, and he did to Harry IVilkes what I had not previously seen a horse do, and that was to fair]y trot him off his feet. When Wilkes broke he acted to me like a horse that had for once found out when he had enough,

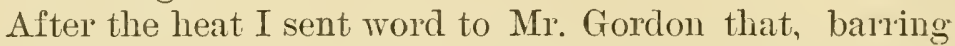
an accident, the race was over, Clingstone would win sure. To show the difference between the public and the driver sometimes, I will state that after the first heat Wilkes was a bigger favorite in the betting than he was before the horses started. In the second heat Clingstone beat him easily from start to finish in 2:17 $\frac{1}{2}$. In this heat Wilkes gave it up at the head of the stretch, having had made his brush early in the mile. About this time the boys about the pool-box who had been betting on Wilkes commenced to trim their sails for a storm. When the horses scored for the third heat and got the word they went away head-andhead, and trotted like a team to the half-mile pole in 1:08. From there to the judges' stand the race was as close and exciting as one could wish, and ended by Clingstone winning by a short head in 2:16, Wilkes making a much better finish than he had in the heat before. I have been asked how I accounted for WVilkes trotting himself to a standstill in $2: 17 \frac{1}{2}$ and then coming back the next heat in 2:16. I do it in this way: Van Ness had not come across any horse that Wilkes could not out-trot easily, and for that reason the horse har not been keyed up or asked to go his best for a long while, and when he struck Clingstone, who had speed enough to go a 2:10 gait, it put what the boys called "a crimp" in him. 
When the race was orer Clingstone received an ovation, was given one of the handsomest floral pieces I ever saw on the track, one that would have made glad the heart of the most exacting prima donna. This race proved to me one thing, that if you are selected to drive a race don't be afraid to go ont and take the chances, or in other words, you are the doctor and the one to decide whether or not to cut off the patient's arm. In training Clingstone for the race I had been cantioned by a great many people not to work him too hard, they saying that he was one of the kind that did not need any work. I liave never yet seen a horse that could trot a hard race of mile heats, three in five, at anything like the top of his speed and not have plenty of work. I gave Clingstone all the work I thonght he onght to have. was not backward in changing his shoes or doing anything for him that I thought would be for the better, and the result showed the wisdom of the course, he not only winning the race, but the average of the three heats was nearly as good as he or Wilkes had ever trotted in public in their long career. Mr. Gordon seemed much pleased at the result of the race, complimented me on what he considered my ability, and paid me a fee that would have made glad the heart of a star-route lawyer.

Incidental reference has been made to the breeding farm at Pittsfield, Mass., of Mr. W. R. Allen, a man young in year's, as well as experience in breeding trotters, but that his ideas are of the right kind, founded on a careful and intelligent study of the subject of blood lines in trotters, can not be doubted after one looks over the list of animals he has collected at his farm, and sees with what mniformity the lines of their pedigree go in the direction of actual speed production of the highest type, and that it has been tested on the race-track and not been found wanting.

$\mathrm{Mr}$. Allen became famons as a breeder by one stroke, so to speak, he having gone to Stony Ford farm, and made a draft of very choice animals, the same including representatives of its most famons animals, and for these he paid the 
sum of $\$ 44,000$. A purchase at Woodburn, which amounted to nearly $\$ 25,000$, preceded this, and since then he has at valious times and places, added to his establishment animals of the choicest breeding, never letting values stop him where the strains of blood represented, were such as he desired. It was this spirit that led him to visit the farm of Robert Bonner not many montlis ago, and pay $\$ 15,000$, for Miss Majolica, a full sister to Majolica, record 2:15.

In the way of stallions at his farm, Mr. Allen has a remarkable lot of horses. His premier sire is Lancelot, by Messenger Duroc, dam Green Mountain Maid, thus making him a full brother to Elaine, 2:20; Dane Trot, 2:22; Pros-

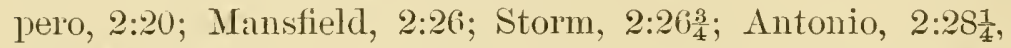
and Miranda, 2:31. It will be seen that in Lancelot, $\mathrm{Mr}$. Allen has a horse that in blood lines is as nearly a dnplicate of Electioneer as conld have been produced at the present time, he being out of Electioneer's dim, and by one of the best sons of the horse that sired Electioneer, so that so far as pedigree is concerned there is but little difference between the two animals, except in the fact that Lancelot is so young that his snceess as a sire of trotters is still to be attained. It shonld be remembered that not only in the male line has the blood of Green Mountain Maicl proved wonderfully successful, but that one of her daughters, Elaine, is alreacly credited with the fastest yearling that the workl has ever

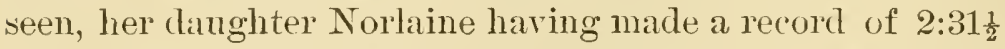
at that age. Some of her sons have also been siring trotters that have become distinguished by their performances, and, on the whole, it would be difficult to imagine a better horse than Lancelot, when all the circumstances are taken into consideration. But not content with securing a representative of the blood lines that prodnced Electioneer, Mr. Allen determined to so equip himself in the matter of stallions that by no possibility conld he be at any time, through the death of any one of them, seriously impeded in his plans, and with this end in view he pmchased America, a black horse by Kentucky Prince, and ont of Alma that made 
a record of $2: 28 \frac{3}{4}$ in her old age, and that is a full sister to

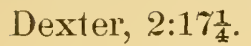

Two famous sons of Kentucky Prince are Guy, 2:12, Spofford, 2:18 $\frac{3}{4}$, that won a $\$ 10,000$ purse at Hartford last year. In Amelica we have this blood joined with that which produced Dexter, who was far and away the fastest, gamest, most reliable trotter of his time, and that this blood is more than ordinarily potent is seen by the fact that Dictator, Dexter's full brother, has given such wonderfully fast, game, reliable trotters as Jay-Eye-See, 2:10, Phallis, 2:13 or, 2:17, and more than a dozen others that have beaten 2:30.

Ordinary men would have been satisfied with the possession of such stallions as Lancelot and America, but Mr. Allen recognized the fact that while they were from strains of blood that had produced very high speed at the trot, his idea was to get as near, relatively, to Mand S., the fastest trotter in the world, as was possible. With this end in mind he purchased at Woodburn the stallion Yarrow, whose sire is Lord Russell, full brother to Mand S., and

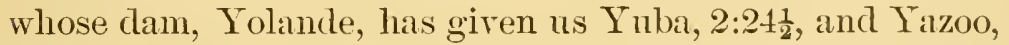
$2: 34 \frac{1}{2}$. Tolande is a danghter of Belmont, one of the fastest sons of Alexander's Abdallih, so that in Farrow Mrr. Allen has a horse whose lines of blood have been uniformly successful. Mention lias already been made of the fact that Mr. Allen, in selecting brood-mares, had in riew the indisputable fact that trotting blood is on the whole, the most suecessful in the propagation of speed at the trot, and the animals on his place trace back without exception to the best trotting mares in the land. More than this, their near relatives are in every case trotters themselves. He his for instance, Rusina, that is by Belmont ont of dam Maud S.;

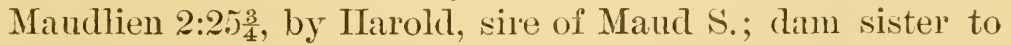
Nutwood, 2:18 $\frac{3}{4}$; Elista full sister of Elaine, 2:20; Malvasia by Lord Russell, brother to Maud S., out of Malmuison, that produced Mannette, trial 2:164; Ashima, by Lord Russell, dam Alice West, 2:26, that produced Altamura, 2:30; Salve, by Lord Russell, dam Noonday, her dan Midnight, 
the dan of Jay-Eye-See, 2:10; Waterleaf, by Belnont, third dam the famous Pilot $\mathrm{Jr}$. mare Waterwitch; Edita by Kentucky Prince, ont of a sister of Elaine; Mirella a sistel of Edita; Brencla by Kentucky Prince, dam Miss Brunette, the dam of Black Prince, 2:2.) $\frac{1}{2}$; Fedora, by Kentucky Prince, out of a sister of Hogartl, 2:26; Guyda, by Messenger Duroc, dam sister to Gny, 2:12, and a dozen others whose blood lines lead directly to turf performers and whose names are well and farorably known.

That Mr. Allen's venture in the breeding of trotters will be a successful one is not to be doubted. He is a man of great executive ability, of marked enterprise, and with a firmness of purpose that will attain almost any end which it seeks. His investment thus far is the most extensive ever made by a beginner in the ranks of breeders and is a notable instance of what wealth and well-directed energy may accomplish. 


\section{CHAPTER X.}

Nobby, the most peculiar horse Splan ever drove; a wild, scary fellow that had a wonderful flight of speed-The race at Cleveland in which Nobby beat a lot of cracks-Mr. David Bonner's well-remembered complimentStuffing a horse's ears with cotton, and some incidents connected with the practice-Needle Gun, and the trouble he made on a ferry boat-W. J. Gordon's horses, his breeding farm, and his character as a man - Chat about what certain drivers have done with particular families of horses Protection's great race against J. B. Richardson.

The bay gelding Nobby was the most peculiar horse that I ever trained or drove. Peculiar in disposition, peculiar in formation, and peculiar in gait. The first time I ever saw him George Saunders was working him out over the Cleveland track. Nobby belonged to Mr. Gordon, he haring bought him in Kentuck $y$ for $\$ 5,000$ the previous winter. He had more of the grayhound appearance about him than any other trotting horse I ever saw, being extremely long in neck, body, etc, and when in motion looked to be at least two inches higher behind than in front. Then I first saw him he was indnlging in some rery wild breaks, and don't think I ever saw a trotter that conld rum any faster and jump any higher in harness than he could. At this particnlar time he seemed to be using every effort in that direction. When he did go on a trot it was with a long, low, easy gait that took him orer the ground at a much faster pace than one would imagine by looking at him. He put me in mind some of Calmar, a horse I had driven some years before for Mr. George Baker of Cleveland. In looking Nobby orer carefully I was very much struck with his race-horse formation. Asking the groom about him I found he had been trotted with some surcess and had a record of about 2:25. I never 
saw anything more of him until the summer meeting that came off at Cleveland, but heard that he had been trotted some, not, however, being able to win. From the first time I saw him I had an idea I would like to drive liim, little dreaming that I ever should. One day in talking about him in the presence of Mr. William Edwards, I remarked that Nobby was one horse I would like to drive. The next day Mr. Edwards said he wanted me to do something for him, which was to drive a horse in a race. I told him that I would. When he told me that Nobby was the animal, I was a little astonished, but he explained that he had seen $\mathrm{Mr}$. Gordon and arranged with him that I shonld drive the horse in his race, which was to come off on Friclay, this conversation taking place 'Tuesday. Wednesday morning I went out to make Nobby's acquaintance. In talking the matter over with Mr. Samnders, Nobby's trainer, he gave me all the points he could in regard to the horse's peculiarities, and ordered the boy to hitch him up for me. My first trip behind Nobby was rather discouraging. While he had plenty of speed he seemed thoroughly uncontrolable; acted sore all over, and after thinking it over I went to $\mathrm{Mr}$. Edwards, tried to get him to release me from driving the horse and to induce $\mathrm{Mr}$. Gordon to draw him from the race, all of which he declined to do, and insisted on holding me to my contract of driving him. I had Nobby's shoes taken off, and on examining his feet found them somewhat bruised and fevered. I put his feet in warm water for an hour, then had them thoroughly poulticed and did not put shoes on him again until an hour before the race, when I had him shod with leather pads and a sponge and a light toe weight.

In the betting Secret, a mare owned by Mr. Emory, was the favorite. She having shown well in her race the previous week at Pittsburgh, the talent all thought she was the right one. Felix had the German rote with him. Florence M. represented Indiana, and President Harrison's neighbors all put their money on her. So little were Nobby's 
chances thought of that at the finish of the race the only man proven guilty of having had a pool-ticket on him was a Tankee of the name of Skinner, who was Mr. Gordon's superintendent, and had been instrumental in haring him buy the horse. In rigging Nobby for the race, I put a rel'y easy bit on him, with a nose-band attachment, an over-check and long martingales, and stuffed his ears with cotton, als at this particular time the twitter of a canary loird on a limb would have more effect on Nobby than a full brass band on an ordinary hor'se. He could jump higher, farther, and quicker without any provocation than any house I ever saw.

I decided to lay him up the first heat, and Florence

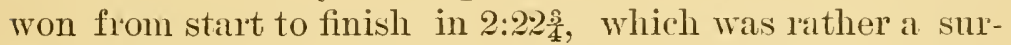
prise, as she had never before shown anything like that speed. In this heat Nobby seemed to have his mind on everything else except trotting, but after giving him a thorough cooling out I found, in scoring for the second heat, that he acted somewhat better, and determined if he got off well, to try and get as good a place as I could. When the word was given Nobby was the last horse, which position he held mutil they turned into the back stretch. Going from there to the head of the stretch he trotted by about half the field. At this point Felix, Florence M., and Secret liad the stretch to themnselves and the only open place that I conld see was in the middle between Secret and Florence M. I drove Nobby in there, but as the hole was not very large it made him uneasy, and just as he reached the wire, which he crossed first, he and Secret made a break and finished the heat with Nobby first, Secret second, and Florence M. third, all lapped on each other. In deciding the heat the judges gave the heat to Florence M., setting the other two horses back for the break, and no time was given. In the thiud heat, Felix rushed away and at the half-mile pole Nobby, in trying to out-trot George Toorhies, who had his long whip with him, went to a wild break, and I made no further attempt with him that heat. 
In the fourth heat, Felix went aray first and Nobby last, which positions they maintained until the half-mile pole was reached, and then Nobby began one of his wonderful brushes, and when he turned into the home stretch I took him to the extreme ontside of the track, so that he should have no excuse for making a break, thinking that if he staid on a trot he would surely win the heat, which he did, but there was nothing rery sure about it, as he was first to

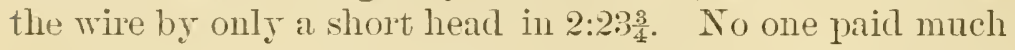
attention to this, as it looked to me, and 1 think everyone else, like a scratch heat. In the fifth heat the word "go" was not cold out of the starting judge's mouth before Nobby indulged in some of the tallest brealing I erer saw, which of course lost him all chance of the heat, and Felix won easily in 2:25. As all the horses with the exception of Felix, Nobby, and Florence M., were then sent to the stable for not winning a heat in five, ererybody wanting a poolticket bought it on Felix. The odds did not seem to make any difference, as it looked like a sure thing. By this time the Blue Bull quality had come to the surface in Florence M., and she was practically out of the race.

When the judges gave the word in the sixth lieat it was raining slightly and the track was a little muddy. At the half-mile pole Felix was at least ten lengths in the lead and going as though he nerer expected to surrender. At that point Nobby commenced gradually to close the gap, and at the head of the stretch was within abont fire lengths of Felix. From there to the judges' stand they had one of the best contests I remember of. At the distance stand Nobby got his head to Felix's wheel. McCarthy drew his whip and the crowd shonted for him to "come on!" but it was too late, as Felix had shot his bolt, and Nobby beat him to the stancl an eyelash.

The betting now took a change, and the speculators seemed about to lose their lives. They lad first played Secret, then Florence M., and hedged on Felix, and then to have Tobby come along and look like a winner made 
them, as Paddy Dooley said, think that another Black Friday was at hand. I myself had hnt very little confidence as to Nobby's wimning the race. I knew that at the least provocation he would break, and that would end whaterer chance he might have to beat Felix. The track had by this time become soft and sticky, and with Nobby's long, low gait I considered that against him. They gave the word and I went off with the lead. On reaching the back stretch I pulled ont from the pole abont the width of the sulky. Knap came along with Felix and tried to go through between me and the fence. I didn't make the space any wider just then, so he had to pull out and go around me; but he did this, and at the half-mile pole was three lengths in the lead and driving Felix for all there was ont. When he turned into the home stretch he pulled well out into the middle of the track, thinking, as I imagine, that I wonld go outside of him, but that was not my intention. I took Nobby in close to the pole, and when he was straightenel well into the stretch gave him his head. The heary footing did not suit him, howerer, and he seemed willing to give it up. As he had his ears full of cotton it was of no use to speak to him, so I took the last dying chance and reached over and touched him with the whip, not knowing what he might do, but he staid on the trot, and at the distance stand again had his head on Felix's wheel. Knap used his whip and voice the best he could and those who had backed Felix shouted for him to come on. Both horses tired verybadly, and Nobby tried to break, bnt staggered ont and won the heat by a short head in 2:28 8 .

The winning of this race pleased me more than all the other performances with a trotter that I had taken part in, and I want to record the fact right here. It may seem strange to my readers, when they take into consideration the fact that I have driven some of the best and liastest hor'ses the country has ever seen, that it shonld be such a gratification to me to win a lace with a holse I had no interest in, and with the time as slow as 2:28 $\frac{3}{4}$, but nevertheless such was the case. 
Of the only two compliments erer paid me that I took much stock in, one was by Mr. David Bonner in regard to this race, he saying that he had been going to trotting races for thirty years, and that this was the best driven one he had ever seen. 'The other compliment might be considered rather' a second-hand one by most people, but it pleased me immensely at the tinie. I was once introduced to a lady, and after a pleasant chat she asked a friend of mine what my business was. He said I was one of the celebrated horse drivers of America, and she said: "Trhy, how mistalien I was. I took him for a gentleman." The boys all thought they had the langh on me. While I was sorry to have the lady deceived I was glad to know that my appearance was even that good.

I have spokell of filling Nobby's ears with cotton, and want to give a word of caution in regard to the matter. A great many lorses treated in this manner will act as thongh they were dumb-will not try to go, and will stop to shake their heads when they are asked to trot. If you have a horse that you think will do better with this treatment commence with lim gradually. That is, in his work put just a little cotton in his ear's at first, or, what is still better, put it in his ears while he is in the stable, and let him get used to it in that manner. After you have done this a few times the horse pays no attention to it. Bella, the bay mare that I won a good race at Springfield, Mass., with, as told in a previous chapter, would go out and work alone, be very steady, and break and catch as well as any horse I ever saw, but in company she seemed uneasy, wanted to break more, and would not catch as well, particularly in a close place. We tried the cotton dodge on her, and after she became used to it the scheme worked to a charm. There are a great many horses that will do well with the same treatment, but I would not advise its indiscriminate use. There is a fumy story in connection with this subject that is well worth telling. A good many years ago $\mathbf{M r}$. Frank Ferguson, of New Tork City, was training a horse called Needle Gun, and it was, by the way, 
the most appropriate name I ever knew a trotter to have, as he was always cocked and primed and ready to go off at the slightest notice. Then in the vicinity of the steam cars or ferry boats Needle Gun was perfectly wild, and in order to handle him at all it was necessary to always stuff his ears. One day they shipped Needle Gun across on the Thirtyfourth street ferry. About the time the boat landed at Hunter's Point Needle Gun got the cotton out of his ears and started in to unload himself. Although everybody on deck at the time turned to stop lim he tore ont through the ferry house and injured himself so seriously that he was never afterward of any account.

Years ago, when Inan Mace was a kind of handy boy abont Buston, one of the old-time sports made a race and started in to drive his own horse. He broke and acted wild in the first two heats, and the owner invited Mace to take a seat behind him. Mace put some cotton in the horse's ears, drove him the balance of the race, and won it. That night the owner took his old horse home and the next time he drove the animal found a great change had come over him. Nothing in the way of noise seemed to have any effect on the horse, and when he spoke to him the old fellow waited to be hit with the whip before he moved. The owner was somewhat alamed and wondered what Mace liad done to the horse that he did not get over the effects in three weeks. He sought out Mace and interviewed him confidentially on the subject. Mace immocently told him he conld not imagine what ailed the horse, but on eximining him the thought struck him that the cotton had never been removed fron his ears, which proved to be the case, and when they took the cotton ont the old horse seemed to heave a sigh of relief and the owner found he was himself again.

This race with Nobby was the first I evel' drove for Mr. Gordon, anc as I have been connected with that gentleman's horses more or less ever since, a short history of his establishment may not be ont of place. In manners, appearance. etc., Mr. Gordon is a reritable Chesterfield. He is a success- 
ful business man, an excellent judge of luman nature, a lorer of a good horse, and a true friend. I can not now recall any man who has been more successful on the trotting turf for the time he has been connected with it than Mr. Gordon. One of the first horses he bought for the turf was Clingstone, who has always been a star performer and one that $\mathrm{Mr}$. Gordon has had a great deal of enjoyment and comfort with. Not only has he had the pleasure of seeing him win some grand battles on the turf, but his also enjoyed many a ride behind him. Clemmie G., another one of his early pur-

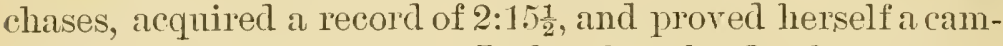
paigner of the first water. In her loss by death, not only Mr. Gordon but the breeding public, I think, met with a serions loss. Clemmie G., being out of a mare that had produced six with records better than 2:30, and noted for her good disposition and constitutional soundness, must have, if mated with some first-class stallion, produced results that the world would have been prond of. Guy, the star performer of this year, and for whom Mr. Gordon paid $\$ 10,000$ as a colt, not only proved his good judgment but also his willingness to pay for horses. Gny is the only hor'se that ever I saw that could trot a mile better than 2:20 driven without boots or shoes of any kind. He also has the distinction which no other horse occupies of having made a record of 2:12 in one season, having started ineligible for the threeminute class. In Mambrino Sparkle Mr. Gordon lias a mare that has proven her right to be called a race-horse in every particular, and I anı anxious to see what the result will be if she is used for breeding puryoses.

Mr. Gordon has also taken more than a passing interest in the interesting subject of breeding horses. He has invested in this enterprise, animals and other property that, I should think, valued at low estimate, would be wortl $\$ 200,000$. His farm, called Gordon Glen, is a picturesque spot just outside of the city limits of Cleveland on St. Clair street, and runs back to the Lake Shore Railroad. As a gentleman's establishment it is the most complete I lave ever seen, having 
plenty of gool water, is well fenced, nicely divided into paddocks and pastures suitable for stallions, brood-mares, fillies and colts, the best of stabling, a three-quarter mile working track, drained in such a manner that it is safe and pleasant to use at all times of the year; an eighth of a mile covered track where in disagreeable weather the horses may take their regular exercise, - in fact everything in the way of convenience and comfort for man and beast that noney conld buy or brain invent are to be found there. Amongst Mr. Grordon's brood mares the first by right of merit is Gretchen, she having produced Clingstone, 2:14. Largesse has a record of $2: 25$. Leontine has a record $2: 23 \frac{1}{2}$ over a halfmile track, and her first foal, when eighteen montlis of age, brought $\$ 2,500$, at a public sale. She now has a handsome colt by an own brother to Clingstone. All the most fashionable and valuable strains of breeding are found represented on the Gordon farm by one or more animals that are known to be the best that conld be bought.

In the stallion line Mr. Gordon has Rysdyk, the sire of Clingstone, and a number of others with records better than $2: 30$. He also has what is to my mind one of the most promising horses in this country, Clingstone 1I, an own brother to Clingstone. In color, formation, etc., this young horse resembles his illustrious relation and has the prond distinction of being, after Lord Russell, the brother of Maud S., full brother to the fastest horse in the land. His education as a trotter has never been attempted, he having shown enough in the way of speed to entitle him to be bred to some of the best mares that Mr. Grordon has. Fis first crop of colts, numbering less than half a dozen, contains one or two that bid fair to be great performer's on the turf.

Writing of breeding takes me back to my boylood days. I had for a chum, and companion a good old soul of the name of John Lindley, a man whose highest ambition in life was to shine as the owner of the best game chickens, and all the time that he conld spare from liis daily libor was spent in the care and breeding of his favorite fowl. One 
invariable rule he had was that when he found a chicken that was an extraordinary fighter he always bred the own brother, and never the chicken himself, and in explanation told me he was sure that when a clicken had gone through a severe process of training and then had the strain of a severe battle with the steels it would leave his whole system in a weakened condition and he would not be as liable to transmit to his descendants the qualities necessary to make them snccessful as would an own brother to him that had not gone through such a severe preparation. In talking with Colonel West abont Dictator before that horse had made his reputation, I told him what my friend had said. It seemed to strike him very forcibly, and as I was always a great almirer of Dexter I told the Colonel that I considered him the greatest race-horse I had ever seen and gave him my reasons for thinking so, which were that Dexter had beaten every horse of his day every race that horses had trotted from one to three miles, in harness, to wagon, under saddle. He had also beaten every other horse's time, and long before we had the developments in the way of tracks, hamess, sulkies, boots, etc., that we now have, and in the hands of a mere boy, Budd Doble, showed his ability.to trot a mile in 2:15 in public. Taking into consideration all those facts, Dexter was certainly a wonderful horse. Dictator, I think, is a good example of the success of the theory my old friend claimed was the proper one. If this is so Clingstone II must certainly be a success in the stud, he being an own brother to a horse that has proved by public performance that he is entitled to be called first class in any company. Mr. Gordon has always shown the greatest confidence in Clingstone's ability. Having made races for him at different times when, from want of condition and other things he had him orematched, Clingstone has always repaid his confidence by winning when it looked like a forlorn hope. As an employer Mr. Gordon is kind and just. In some of what I consider the star performances of iny life I have been in connection with his stable. Whaterer 
doubts the public may have had regarding my honesty and ability I think $\mathrm{Mr}$. Gordon never shired. as he always seemed willing to trust me implicitly with his horses in every way. I do not wish by this to be mnderstood as finding any fault with the public in their treatment of myself, as I think it has always been as good or better than I deserved. Not only has the public treated me well but with rery few exceptions my employers have been the kindest friends to me a man ever had.

It has always seemed to me that members of the horse family have more peculiarities of habits, formation, disposition, etc., than there is in the human family. Take, for instance, the trotting family among horses, and the most of them that are bred now trace their pedigree back through some of the numerous channels to Rysdyk's Hambletonian. Each family seem to have many things about them distinctly their own, which always appears to me rather a strange thing, seeing that they all come from one fountain head, and I have never been able to find a satisfactory reason for this. We see a great many different drivers that seem to have made their reputation with some particular family. For instance, Crit Daris, one of the best known and favorably thought of reinsmen in this country, while he has been more than ordinarily successful with different families of horses, has made his great reputation in connection with the Red Wilkes family, he haring given Prince WTilkes, one of the star performers of 1888 , his record of $2: 14 \frac{3}{4}$. Prince Wilkes has fought his way to the front in trotting circles purely by his own merits. His owner, a sportsman of the old school, not wishing any, particularly newspaper, notoriety in regard to him, has never lial his horse "boomed," as has so often been done with inferior animals. $\mathrm{Mr}$. George $\mathbf{A}$. Singerly is a great admirer of the horse, he having owned, driven and bred trotters long before it was considered highly fashionable for a gentleman to do so, and in my younger days I remember of often having seen him riding trotters to saddle on some of the tracks about Philadelphia, and he was 
always conceded to be the best amateur rider in the country, and not averse to taking a shy at the professionals, as is shown by his having ridden the bay gelding MrcLeod to his best record, $2: 19 \frac{1}{2}$, in public, there being only two horses in the world, Dexter and Great Eastern, with faster records under saddle.

$\mathrm{Mr}$. Singerly thinks every horse ought to stand on his own merits, in which opinion I fully concur. I have noticed that such men are the ones who, as a rule, make a success of what they undertake. Mr. Singerly, or "George" as all his friends call him, was admired by Dan Mace as much as any man that I ever knew. Mace once bought a stable of rumners and the first good horse he owned lie called George Singerly. He told me that if he was as good a race-horse as his namesake was a man lie would get the money, and seemed more delighted on account of this when the horse commenced to win than on account of the pecuniary benefit derized from the animal's success.

Besides Prince Wilkes, M[r. Davis drove Repetition, another son of Red Wilkes, three years old, a mile in 2:21 in public race. He also won with him a race against a field of aged lorses in the 2:30 class, and showed that not only was he a youngster of plenty of speed, but more determination and the other qualities that it takes to make a race-horse than are ordinarily found in a colt of that age. He also gave Phil Thompson a record, while a colt, of 2:21 and afterward drore him to his record of $2: 16 \frac{1}{4}$. and performed a feat that day that I never have seen any other man do, and that was to win two races in one day and drive each horse to his best record of $2: 16 \frac{1}{4}$, the other performer on this occasion being Maud Messenger. In disposition, Davis always seemed to me what I called a brave man. No excitement bothers him, he is kind to his horses and ererything abont him, always seems to have them well harnessed and booted and properly shod; always aims to be a fair driver, never wanting to take undue adrantage of other people, and in driving in a race $I$ have always noticed that he is what $I$ call a rating driver; he seems to know about how well his horses can go. 
before they start and then rates them along to accomplish the mile in that way. I think that a man's character often has a great deal to do with the horse, - that is if you have a brave man it will help to make a brave horse. I do not think I ever saw Crit driving a cowardly horse; they all seem to hare plenty of courage and determination. I lave repeatedly seen Prince IVilkes out-trotted in a manner that would have been very discouraging to some horses, but have never seen him show the slightest disposition to want to surrender at any time or place. Crit always seemed to be a good deal of a genius, having invented a number of boots, bits, etc. One of his bits I hear very lighly spoken of as being a good thing to break a horse from lugging or pulling. If Crit says it is good you can rest assured that is a first-class indorsement.

The Blue Bull family does not cut as large a figure in trotting now as formerly. Fifteen years ago in the IV estern and Southern country the Blue Bulls were a very large faction. They were owned, driven and managed by a family of the name of Wilson, the heal of which was better known as "Blue Bull Wilson," he having got the name from his horse. With this family of trotters Samp and Dick IVilson and Gus Glidden seemed to be more successful than any other men I know. While there were not many 2:20 performers amongst the Blue Bulls, Gus always said they were a good poor man's horse. Whaterer speed they had could be attained with but very little training, and Gus's idea was to earn all the money as quickly as you could and when the horse got to the end of liis string sell him and get a new one. And there must have been some method in his plan, as Gus and the IVilson family both have real estate that is not only good to look at but brings them the wherewith for all their wants.

One or two of the best things I have ever seen Hickok do in the way of training and driving horses, and what gave me a great idea of his being a trainer and driver, was in races where he drove some member of the Sultin family. Hickok, 
I think, was the first one who brought any of the Sultans east of the Rocky Mountains. They are, strictly speaking, a family of Californians. Sultan himself belonged to Mr. Rose of Los Angeles, a gentleman who has made himself a reputation as a very successful breeder, he having bred and owned some grand horses. I think Hickok trained Era, a three-year-old, when she won one of the grandest batthes that I have ever seen trotted, and that gave me an idea of what a task it was to train a horse and propery condition him without starting him in races. This feat he accomplished with Eva, and by winning the race referred to perhaps did more in the way of making a reputation for her sire than anything that had ever been done for him up to that time. In fact, it made such an impression on some of the more intelligent breeders of this country that they made orertures to Mr. Rose for some of his stock to bring East with the view of crossing it on some of the well-known strains of the Eastern comtry. Among the gentlemen who were successful in acquiring good representatives from the family was Mr Frank S. Taters of Chicago, who owns a handsome farm near Genoa Junction, Wis., he having bought the bay stallion California, foaled in 1882, who has the right to be considered first class in every respect, he not only being' by Sultan, but having the further prestige of being an own brother to three with records in 2:23 or better. His dam also produced Beautiful Bells with a record of $2: 28 \frac{1}{2}$, who was the dam of Bell Boy that sold as a colt for $\$ 50,000$ and also

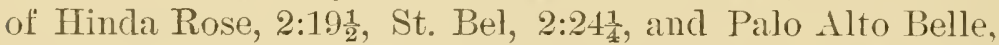
that beat 2:30 last season as a two-year-old. California himself is a trotter of the very first water. Mr. Waters did not stop here, but went further and acquired Nutmeg, who showed himself a trotter from the beginning of his education and with but rery little training made a record of 2:2.5 in a public race. He is by Nutwood and in that way traces back to the best in the world, Maud S. Erelong, another one of the Waters stallions, is by Belmont, the sire of Wedgervood, 2:19, who in turn got Favonia, 2:15, which is 
enough to say about any horse in a country where people go to see trotting laces, as Favonia and ITedgewood have, by their public performances stamped their family as first class. Sprague Pilot, the third stallion at the Waters farm, is by Governor Sprague, a horse who year's ago electrified the world not only by his extreme speed but by the beanty of his gait and his wonderful intelligence compled with a formation of legs, body, etc., that made him an animal withont a peer. On his dam's side Sprague Pilot may be said to trace back to the Irish Kings, his first dam being by Pilot Temple, a horse that needs no enlogy here, as his public record has done all that for him, he being by Pilot Jr., a horse whose danghters have produced two of the grandest trotters the world ever saw, and back of all that comes the dam of Flora 'Temple, the first horse that erer' beat 2:20, and beyond that the thoronghbred cross that has proven so valuable in the pedigree of a first-class trotter. This shows to me more than anything else what a wide interest the public takes in the trotting horse. When a gentleman who has devoted his time entirely to business and takes up the breeding of horses for pleasure or otherwise can select with such excellent judgment a good combination of the best strains of blood of performers, he certainly must have given the matter a great deal of thought and study. I man might hit the bull's-eye once by accident but he will not shoot all day and keep hitting it unless he is a good shot.

Hickok not only drove Eva to a world-wide reputation, but after Stamboul, a son of Sultan, had been beaten some races last season took him in hand and very soon gave him a mark of $2: 14 \frac{3}{4}$.

I noticed that Hickok in training members of the Sultan family worked them differently from any other horses I ever saw him handle. 'They always seemed to have their speed, whether in condition or not. Hickok seemed to bend all his energies to conditioning their body, legs, wind, etc., and bringing them to the race fit in that manner. He often told me that if a Sultan conld trot he always had his trot 
with him. Have them thoroughly conditioned, he said, and they always prove themselves race-horses. The resnlt of my observations was that Hickok was right. Speaking of the difference in horses, there is also a very great difference in drivers. Take a dozen of the best reinsmen, and they vary greatly in disposition, looks, build and in their general system of driving and training horses. Hickok I have known for years. His forte, I think, is determination. In training a horse he pays more attention to having the horse thoroughly bitted and educating the mouth than any man I ever saw. After Hickok has had a horse a reasonable length of time you will see one that makes very few mistakes of any kind and is generally very easy to drive. He has had some ups and downs in his life, always been a bold operator on the turf and elsewhere, is a shrewd business man, and perhaps has owned an interest in more first-class horses than any other man in this country. To appreciate Hickok you have to know him well. If he is your friend you can rest assured of one thing, that he will never leave you in the storm. If he goes in ont of the wet he will take you with him.

The Goldsmith boys, Johnny and Jim, and the Tolunteer family of trotters are the most distinct example of breeding that I ever saw. 'The boys came honestly by their' horsenanship as their father was a horseman all his lifetime. The old gentlenian was a distinctive character in his way and one that would have made his mark in any walk in life in which he might have been placed. When I first knew him thirty years ago he was an extremely handsome man, very affable in manner, always dressed well, and his language at all times was good. At that time a man who owned a trotter and trotted him for money was looked upon, to say the least, with a little suspicion. That is, it was not considered anything to be particularly prond of, but Mr. Goldsmith like the intelligent man that he was, could see nothing in the owning of a first-class horse that was low or degrading and so expressed himself. He lived long enough 
to not only see his name compled with some of the best horses of the country but also to have the world acknowledge that his theories in regard to them were right.

The Goldsmith boys had advantages that seldom fall to the lot of a horse driver. They had the benefit of their father's experience, also an opportunity to acquire a good business education, which I think goes a long way toward making a man successtul in any line,--not that I think it is necessary in order to be a good driver, for a man to liave gone to college, but to manage a valuable stable of horses and to get the best results financially, I think it very essential that he should have a fair education. This will also expand his mind and teach him to think, which is absolutely necessary. As the Goldsmith boys and their horses have been important figures on the trotting turf I will give a sketch of them as they appeared to me, which facts I have been able to glean from close observation, as some of the greatest efforts that I have been able to put forth have been made in a struggle to keep John and Jim from getting my money in many closely contested races.

The first time I saw Joln Goldsmith he was a lad of twelve or thirteen years, and was even then just as willing to bet you he could name the winner as he is now. If he made a mistake and lost his money he stood it like a reteran. As an all-round driver and a shrewd manager under any and all circumstances, John is entitled to a seat in the front pew. He is a man of medium size, weighing about 150 pounds. "Jimmy," as the boys call him, differ's somewhat in his appearance and methods from John, greatly resembling his father. By general consent I believe he is considered the handsomest and best dressed man connected with the trotting turf. If Berry Wall had Jimmy's personal appearance and good taste in dress he would still be the " $\mathrm{King}$ of the Dudes." This part of Jim's character extends also to his business, as his horses are well harnessed, well booted, have the best of sulkies, and the general appearance of his stable would make glad the heart of an artist. Whether he has 
the ability that John has in what is called all-round driving I am not prepared to say, but any horse that Jim has in his stable will be as well trained and driven and will come as near performing in a manner to get him the money as any one I ever saw. His public record I think bears out all these statements.

The Tolunteer family of horses, with which the Goldsmiths made their reputation, are famous. Mr. Alden Goldsmith bought Tolunteer years ago when the horse had no reputation himself or as a sire of trotters. He was at that time one of the most stylish and finished animals I ever saw and with a little training gave promise of speed of a high order. The one trait in the Volunteers which gave them more reputation than anything else was their extreme gameness, their ability to hang on until every other horse and man had become tired, which has been proren, not only by their races of mile heats, three in five, but also by their grand performances in longer races, notably Huntress' three-mile race where she beat the record of the world. I have never seen a Volunteer act, under anything like favorable circumstances, as though he would show the white feather. Whenever I see a horse's pedigree with a Tolunteer cross in it I consider it a point in faror of the pedigree.

The first time I saw Protection, the only thing about him that $I$ in the least admired was his pedigree. WThen they informed me that he was by a well-bred son of Tolunteer and that his dam was said to be a thoroughbred mare I took some interest in him. On further investigation I found that he conld trot a quarter in thirty-five seconds. After that he showed a disposition to give it np, as it were, was liable to break, act badly, and get distanced, the direct opposite of what I expected to see in a Volunteer. I kept an eye on Protection and in two years from the first time I saw him indnced a friend of mine to buy him for $\$ 1,500$, with the privilege of training and trotting him whenever I wanted to. The following spring I sent for the horse, and, thinking that it may be of some interest to my readers, will give them a general 
idea of how I trained and drove him. In making a study of Protection the first few weeks he was in my hands I found him what I considered to be an overly large horse to be a successful campaigner, and a perfect glutton to eat; having in the stable more the mamner of an ox than a race-horse. His feet were very large; long at the toes, and with a low heel both in front and behind. In gait he went very low to the ground, and in jogging him on the road he would continually stub his toes and knuckle orer both in front and behind. He had always been driven with a heary shoe and toe-weight. I had seen him get a good deal of what I call rough training, and as that treatment had not made him a race-horse I concluded to try the opposite plan. I had at this time a young friend of the name of Harry Derereux, and for an anateur I considered him to have as many good ideas abont training as anyone I knew of. I knew Harry had seen a great deal of Protection and without his suspecting what I was really doing I interviewed him on the subject, got all the points from him that I could as to who had driven the horse, what kind of work they had giren him, and how well he had ever seen him go, and when he told me that he had seen his orner, Mr. William Fasig, whose reputation as a horse driver is not quite so good as it is as secretary of a racetrack, drive Protection to a road wagon a full mile in 2:26 $\frac{3}{4}$, I was sure he would certainly go in 2:20 or better in harness and so told Harry. He did not agree with me on this point, but nevertheless told me that he wonld be willing to help me train to the best of his ability, which he did and I was afterward glad to thank him for his services. The first order. in commection with Protection's training was to put him on a light diet, about one half the feed that he had been in the habit of having. I had his shoes taken off all around and found his feet in rather a neglected condition. One of them had a slight quarter crack and the rest were more or less dry and hard. He had at one time suffered sererely from the distemper, and I think that, as is often the rase, it had settled in his feet, and had it been winter, I would have treated 
them differently. I wonld have in that case poulticed them thoronghly and blistered them mildly and started a new growth before I started to train him. As it was I had his feet shortened up moderately, had a pair of bar shoes made weighing fifteen onnces, had him shod with leather and sponges, shortened his feet behind all I could, and put a ten-onnce shoe on him which would ordinarily be ont of proportion. But in this instance I wanted to change the horse's gait behind and took this way of doing it.

In training Protection, I gave him short, shar'p work, got the best boy I conld find to groom him, and began by giving him moderate working miles and brushing him at the finish, always well within himself. As soon as he was in condition to go along at about a 2:30 gait I got Dererenx to drive him and I worked some horse with him, being careful all the time to give Protection the best of it, never allowing the other horse to ont-trot him so as to disconrage him. I liked him from the first day I drove him and was sure he wonld go in 2:20 or better, but never found anyone else who shared my belief, and when I told the boys that there wonld be some day they wonld want Protection, they replied "All right, we will take our chances." I nerer had a horse in my stable that trained easier or gave me less trouble than he dic. The only thing abont him that seemed to need any extra attention were his feet, which I kept thoronghly poulticed, and stood him in warm water every day. When the spring meetings opened in Indiana, I entered Protection in his class and in his first race I liked him better than I expected to. The excitement of the race, etc., seemed to be just what he wanted. As I had not done anything in the way of keying him to a high rate of speed, and knowing that I had no chance to win the race, I contented myself with second position and as the race was decided in three heats it was nothing but a good day's work for him. I trotted him every week from there until the grand circuit opened and at Buffalo I started him for the first time in the big ring. And regardless of all that I had told the boys about 
his wonderful speed and race-horse qualities the book-makers were willing to bet a liundred dollars to five that he would not win the first lieat. But Protection came home first in about 2:20 and there were a few people at the track who did not get their breath again until the cold weather set in. He was beaten the race, however, liaving to content himself with fourth money.

The following week, at Rochester, he bettered his position a little by capturing a lieat in about 2:20 and winning second money. Again the book-makers got hurt by betting they could tell which heat he would win. At Utica he trotted a well-contested race, winning two heats, but was again beaten. At Albany he won the third and fourth heats in his race and at the finish of the race stood second. By this time everyone said he would do very well for a lieat or two, but was no good after that. I made up my mind that there wonld be a day when he would be able to win three heats. My opinion was correct, for the following week at Hartford he won over a good field with plenty of betting and acquired a record of $2: 19 \frac{1}{4}$.

But what I consider the star performance of Protection's life was when he beat J. B. Richardson a race over the Point Breeze track under unfarorable circumstances where it took five heats to decide it, they being the only contenders. The wimning of this race caused me some satisfaction as it proved what I had said of Protection-that he was a race-horse, and it gave me an opportunity to take the scalp of a gentleman whose hair I wanted. 'There was no pool-selling, but a good deal of old-fashioned betting ont of hand indulged in, and Dr. Frost, Protection's owner, and who they say is the best dentist in the workd, and whom I know to be a first-class sport, was tempted to lay a little money on hin at the odds, which were four to one. Richardson had beaten Protection every lace they ever came together, was known to be fast and a good actor, and proven himself one of the gamest Wilkes horses I ever saw. There was no laying up in the first lieat this time. Jimmy Goldsmith had the mount behind 
Richardson and as the other horses were not supposed to have a chance in the race, the fight started in between the two. In the first seven-eighths of the mile in the first heat, Protection and Richardson went like a team. Then Richardson broke and Protection beat him to the wire in abont 2:21. The second heat was almost identical with the first. They trotted yolied all the w:y to the finish where Richardson

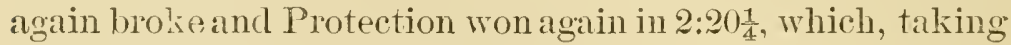
into consideration the day and the track, I consider the best mile he ever trotted.

After this heat Protection showed a good deal of distress and we decided that the best thing to do was to lay him up, regardless of whether there was any other horse to drive Richardson out or not. Richardson won the third and fourth heats easily in abont 2:24. Most of the people then left the track, thinking the race was orer, and those who staid got a gennine surprise party. By this time Protection seemed to have recovered his breath, and it looked to me as if we had a fighting chance to win. Having trotted all these races with J. B. Richardson, I had found out what I thought was his weak point, and that was that if a horse took him by the head and hung right on to him, he was almost sure to make a break, in fact wanted to keep breaking all the time. I had no idea of beating him to the wire, but thonght I might make him run enough so the judges would take the heat away and give it to me. When the word was given in the fifth heat Richardson led to the quarter pole, Protection a good second. In the drive down the back side Richardson broke and made a good run, and by the time Jim had him trotting again I had the pole. I then pnlled back and let Jim come up to my wheel and we raced in that manner to the three-quarter pole, where Richardson indnlged in another short break and landed on a trot at Protection's head. From there to the distance stand neither horse seemed to have any adrantage, both staying on their feet and trotting their level best. Here Richardson indulged in another break and we tinished at 
the wire so close that I hardly think anyone could tell which horse was first. Here Jimmy put me in mind of his illustrious namesake, James G. Blaine, because he claimed everything and conceded nothing. He told the judges that I had seared his horse off his feet, carrie him wide on the turns, and that my conduct had been unbecoming a gentleman and a scholar, and his friends who were many, and who backed the horse, thought the judges were bound to decide the heat in favor of Richardson whether or no. I thought at the time and still believe that Protection was entitled to the lieat and lace. He had trotted fire heats without nuaking a break, over a rough leavy track and there was no lieat that Richardson laad not indulged in a good deal of breaking. After the crowd had shouted themselves hoarse I got a chance to make a statement to the judges and they awarded the lieat and race to Protection. Some of the critics said that my talk got the race, but if the money is hung up for trotting horses I don't see why they should not all be compelled to go on a trot if they expect to win it. I don't think any horse should be allowed to run in a heat under any circumstances, unless it is a running race. In all the last races that I drove Protection in I had him shod with a light shoe, a two-ounce toe-weight, leather and sponge, and had him calked about the same as you would for the road. He hatil a low heel and a big frog and I found that the hard track seemed to hurt him. I put't'e calks on to break the concussion, and lie went better. All throngh this campaign Protection acted very steady, and contrary to what everyone said about him, proved limself much better than an empty stall and gave me renewed firith in the Tolunteer blood.

William Darling dates his connection with the turf many years back, from the same school with Peter Johnston, Ed Brown, Jimmy Boyle and others of that class. In his younger days Darling did not have the same opportunity to make trotters that trainers do in these times owing to the great difference in raw material, but that Darling 
was a horse trainer and driver is proven by the success he had with a great number of horses. At the present writing he is trainer and manager of Mr. Mortimer McRoberts' Rock River stock farm at Dixon, Ills., the only one in the country I believe devoted entirely to the breeding and raising of gentlemen's road-horses.

Jack Haverly, one of the best-known men in this country, whose large theatrical and other amusement interests have made him a public character for years, was always a lover of the turf, owned some good horses, and when they trotted was willing to back them as long as there was anyone to bet against him. It may be truly said that he is the only Jack Haverly. I have known him from my schoolboy days, and have seen him without a dollar in the world, and at other times with a fortune at his command. Whether broke or wealthy his manners and treatment of other people were the same. The boy who blacked his boots in the street was treated by him with the sane courteousness and consideration that a king would receive at his hands. Jack Haverly may die poor or nay die rich, but in either case he will leave a monument behind him in the number and love of his friends that I would rather have over my grave than a pillar of granite that would reach to the clonds.

"Con" Sullivan, also one of the old guard, was connected with the turf when Chicago was a village, and although his time is now entirely taken up with his large breeding interests, he enjoys a horse-race as well as ever. He made his bow to the public in connection with Joseph Cairn Simpson, a man whose connection with the turf has been one of long years and great activity; he havinglored, orned, trained and driven trotting horses all his life. Ile also owned some of the best thoronghbred race-horses in this country, and with all that fonnd time to edit a newspaper devoted to the turf and its interests, has written a number of very valuable works on the sime subject, and if the Society for the Prevention of Cruelty to Animals wants to do a humane act to horses, they should send a copy of his book entitled "Tips 
and Toe Weights" to every man who owns a horse in this country. No man that owns a horse or takes an interest in one, should be without this book. I own one, and study it every time I have a chance and always learn something new.

Speaking of newspaper men, brings to my mind a few other writers who have taken a prominent part on the turf. H. D. McKinney who writes over the name of "Mamblino," has given to the reading public a great many pleasant and valuable newspaper articles; has been a trainer and driver and owner, has invented several nseful and practical appliances for trotting lorses; and one, his patent check-hook, is the best thing of the kind I evel saw.

M. 'T. Grattan has proved himself by his works a capable breeder, a good trainer and driver, and one of the best judges I ever saw in the stand, and as a writer I think if he lad taken to romance and described a scene between some yomng lady and her sweetheart as well as he did the race between Edwin Thorne and Clingstone, his book would have had a greater" sale than "The Quick or the Dead."

The next man, E. C. Walker, who writes over the name of "Teritas" and has been connected for" a long time with the Chicago Horseman, has also served his time as a breeder, owner, trainer and driver of trotting horses, ind with a success that any man might be prond of. As a writer on all subjects connected with the horse he has made himself a trade-mark that many try to imitate, but none excel. 'There is one thing in connection with his writings that I never'saw but one other man who conld do any thing like as well, and that is, the fact that he can sit down in a chatty way and without pen or paper interview yon on any subject in the world and write it up, and have his article contain the exact language and meaning that you had used with him in your conversation. This certainly must be a gift, as I never saw but one or two men who conld do it with anything like accuracy.

The newspapel business must be bred in the Wralker 
family as E. C. Walker has a brother James, that has the same qualities as a newspaper man, and also the love of the horse in his character, he being an owner and breeder at this time.

Some of the other noted characters that I have met on the turf are the pool-sellers and book-makers. Ira Bride, of the firm of Bride \& Armstrong is one of the best known men in the business, he having hatd the pool-selling at different times on all the prominent tracks in this conntry. He has the dignity of a bank president and this, conpled with his handsonte appearance and gentlemanly manners, makes him a rery popular man.

Frank Herclic is a native of Pennsylvania and as a talker, pool-seller, and a violin player, he camnot be excelled.

Charley Stiles is willing to talk anybody in the world a race of mile heats three and fire and is just as willing to bet on his ability there as he is to guess the winner in a horserace.

Ed Morse; a Yankee pool-seller is a rery steady man about fifty years of age. His business methods are first class, his friends would make an army, and he would like to find a rule so that every man who buys a pool-ticliet might get a wimner.

In the West the pool-selling on trotting tracks has of late year's been pretty well monopolized by George Wild and $\mathrm{Al}$ Swearinger, a comple of young men who are abont as well known and liked as any in their line. Wild is a Britisher by birth, but for all that the trotter is his ideal horse, and if it were a choice as to whether he should see the Epsom Derby or a free-to-all pacing-race George would be with the side-wheelers every time.

Jim McCrea, Herdic's partner, deserves more than a passing mention, he having been for years comnected with poolselling and perhaps has business relations in that way with mole men than anyone else in the business. Jimmy is not a sport in any sense of the term, and never plunges, no matter how good the tip. The price of a barrel of flow laid 
straight and a ton of coal for a place, is as much as Jimmy cares to risk. Jim and myself claim Cleve'and for our home, and in the winter mornings as we wait for our butcher to cut off our steak or chops, we talk orer the prospects for the coming year and wish we might find a way to always win when we bet.

Another character, and the only one in his class, is Lem Ulman, the original and only American programme seller. He made his bow to the public as an owner of trotters. He and Herdic at this time own the relebrated bay gelding Clothesline, but after one campaign, which was rery disastrous, Lem wended his way home sitting astride of Clothesline and looked abont the same as a clothespin on a clothesline in the back yard. Tle, I believe, is the inventor of programmes on the trotting turf, and while he comes from the race of people who they say lore money, Lem likes to make it, but no man can spend it more freely or give it to a friend in need with a more generous hand. After the busy season is over, Lem and his first lientenant Master Fred Johnson, hie themselves to some beatiful climate and there live in clover until the bell rings again.

Harry Johmson and Johmny Green represent the French pool interest on the turf, and while their age and general appearance are very much different, their methods are about the same. 


\section{CHAPTER XI.}

Other drivers who have made a name in connection with certain families of horses-Morrill Higbee and the Spragne strain of blood-Frank Van Ness with Harry and Rosaline Wilkes-Jock Boweu, and how he fooled some people who inagined that he could not drive a pacer well-Horace Brown comes from a family of practical horsemen-Billy Weeks an excelleut ricler, as well as a good reinsman-Charles Marrin the man who has brought out nearly all the fast sons and daughters of Electioneer-Some facts about Governor Stanford's venture in the breeding of trotters-Pluck has a good deal more to do with success than luck-Governor Stanford in some respects like General Grant-A colt of his breeding sold for \$in0,000.

Another man who made his mark with one family is Morrill Higbee, he having given their records to the two fastest representatives in the Sprague family. Governor Sprague as a five-year-old obtained a record of $2: 20 \frac{1}{2}$ under Higbee's management and sold to Mr. J. I. Case for about $\$ 30,000$. I few years later he gave Kate Sprague her best record, 2:18. Morrill is a genial fellow, looks like a typical Westerner, although born near Utica, N.Y.; and has plenty of nerre, as I think Mr. Vail, ex-secretary of the National Trotting Association could probably prove if necessary. Higbee was always a fortunate man on the turf, having sold several other high-priced horses besides Goremor Sprague.

To Frank Van Ness is due the credit of giving to Harry Wilkes the fastest record obtained by any horse of the numerous Wilkes family. He also drove Rosaline Wilkes to her record, which is the next best one in the IVilkes family. Jock Bowen is one of the representative Yankee drivers of this comtry, he being a native of the East. Bowen has been successful with the Knox family, Pilot Knox and Camors both having received their education at his hands. 
There never was but one Jock Bowen and there will never be another. He has probably seen as many years of actice service on the turf as any man in the business. He does not care to call the whole world his friends, but those he likes he will go as far for and make as great an effort to serve as anyone. A rather amusing instance came under my notice in connection with Bowen that might be told here. A party from the IVest went down to Boston to show the Yankees how to race with pacers. The judges, not liking the complexion of afiairs, concluded to change driver's. They sent for one of the owners, told him they thought they would like to put Mr. Bowen behind his horse, to which he readily consented, stating that nothing would please him better. The judges asked Jock to take the seat. He declined, and in a quiet way informed the owner that he was not in the habit of going about and interfering in other people's business. The owner insisted that Jock drive the pacer and by all means to win with him if he could. Jock took the mount and won the race, and all his friends realized well on it, and, as it leaked ont afterward, the owner of the pacer lost his money, having bet against Jock after being told by someone that Jock had never driven a pacer and would not be able to win with this one. I have always thought that any man who could play one violin well would be apt to make some music with almost any one. I think the same in this case. You find a man who can drive a trotter as well as .Jock Bowen, and he won't he entirely lost when he gets up behind a pacer.

Horace Brown is entitled to be classed with the free-forall drivers. His father before him was a trotting-horse driver of reputation and a man of ability. Horace drives all classes of horses well, and as a conditioner has always been considered first class. William IVeeks is also entitled to be classed with the old brigade as he has been a horseman from boyhood. He shines particularly in the saddle and whenever Billy rides the ladies have a treat. He has given any number of horses their best records and as a manager in the 
stable he leads them all. 'This part of his education I think lie learned from his old friend Mr. William Van Cott, who, his been for years the stable-keeper in New York City where gentlemen board their valuable horses. T'an Cott's stable represents to the horses what the Mnrray Hill Hotel does to the human race.

Charles Marvin has made his greatest reputation in connection with the Electioneer family. He first made his bow to the eastern public in connection with Smuggler, and he landled that uncertain horse with so nur.l skill that when Governor Stanford asked Mr. Doble to names a maln to take charge of the training of his numerous stable, Budd, always a conservative man, withont any hesitation named Marvin. The result proves that Budd knew his man, as in the years in which Marvin has been connected with Gorernor Stanford's place he has accomplished more than has ever been done by any other man. I am willing to concede that Marvin has had good material to work on. But if yon give a man the best. piece of cloth in the world and he is not an artistic tailor he will be mable to make from it a suit of clothes that looks well on his custonter. 'The winter of 1876 I spent in California and was one of a party who arrepted Governor Stanford's invitation to spend a day at his farm, he having purchased it a short time previously. I little thought what relation it would in a few years occupy to the trotting world. TVe spent a pleasant day and were greatly entertained by Governor Stanford giving us a slietch of his early life in connertion with California. He told us how he and his partners had struggled along in the greatest railroad undertaking that ever a few men were engaged in. At this time the fruits of his labor lad just commenced to retmrn. I think he was more pleased as it was abont to be proven that in building the railroad he was a benefactor to the State that he loved so well. In appearance and numner he reminded me very much of General Grant; was perhaps a little more of a talker, but with that same magnetism that affected everyone with whom he came in contact. As Mr. Doble had Oc- 
cident in his stable that winter. I had many a pleasant chat with the Gorernor: I soon learned one thing, that he was not an imitator. When he talked of breeding horses I found that lie had his own ileas of what would constitute a racehorse and what would produce that animal. IThen it was announced through the press that he lad paid $\$ 14,000$ to Mr. Charles Backman for animals to found a breeding establishment people little thought that he would in a few years produce one colt that would at public auction bring more than that amount of money, which he did as Bell Boy, bred at his place, brought $\$ 50,000$.

An instance happened in connection with this colt which gave a friend of mine an opportunity to langh at me. In my list of friends I had one, a character of the name of Pollock. He was a native of Ohio and had the love for at horse born in lim. He was a self-made man, having fought his own way up, therefore thought he had the right to use his money in any way he thought fit, and for a man who worked for his money was abont as reckless with it as anyone I ever saw, being always willing to loan it to me on $\mathrm{my}$ word. It was suggested to him by a friend that it would be a good plan to buy Bell Boy, then a yearling, for $\$ 5,000$. He interviewed me on the subject and asked ne if I would like to have an interest in him. I told him he might be able to buy yearling colts at $\$ 5,000$, but in the present state of my finances I would not be able to pay for more than one hair ont of his tail at that price, and as I gave him no encouragement he let the matter drop. But I do not consider we lost the $\$ 50,000$ that Bell Boy hrought, for he might not have brought that much if we had owned him. Goremor Stanford has also sold a yearling for $\$ 12,500$, and any number of other horses at rery long prices, and it looks as if his harvest had just commenced. Matrin's strong card, I think, is his everlasting industry. He has probably ridden more miles in the last ten years than any two horse trainers that I know of. Some men imagine that a man gets to the top of the ladder in his profession by pure luck. I am a good 
deal like Mr. Baldwin, known as "Lucky Baldwin"; he says a man is more liable to get there by pluck. While Marvin has had plenty of raw material of the best quality to work on, to work ont the result that he has I think proves that he must have been a man of great ability and industry. That he has filled his position with satisfaction to lis employer is proren by his being able to hold it for so long a time. Not only is Marvin capable of training and driving a colt but I have seen him handle aged horses equally as well. His training and driving of Smuggler stamped him as a mechanic of the first water.

I have spoken of Golden and Bowen as men who have made their mark in their profession, and between them they have done more than any other men to bring into prominence the Lambert family, which I consider to be in some respects one of the very best strains of trotting blood. It is true that extreme speed on the race-track is not a merit of the Lamberts, but nevertheless Daniel Lambert nas sireck something like thirty horses that have made records of 2:30 or better, and for road driving they are in my opinion unsmrpassed, being beantifully gaited, with as pleasant mouths for the bit as one could imagine.

A breeder of whom the public will know more in the future than it has in the past is Mortimer McRoberts of Chicago. A few years since his physician advised that on account of fiziling health Mr. McRoberts should purchase a fine road-team. He took pains to secure a perfectly matched pair that were fast, and at the same time pleasant to drive, and the trouble he experienced in doing this resulted in his establishing the Rock River stock farm at Dixon, Ill. Mr. McRoberts, who had been successful in bnsiness life, saw that the breeding of trotters that were distinctly road-horses had been overlooked, and it was with this in mind that his breeding venture was begun. 'The premier' sire, at this place, McRoberts' Venture, is a sixteen-hand dark-brown horse, that has aptly been called "The Lambert of Lamberts." He is by Aristos, son of Daniel Lambert who made a recoid of 
better than 2:30, out of Famny Jackson by Stonewall, her dam being Betty Condon by North American. Tenture's dam was Kate by Abraham; and his second dam was Polly. Cook by Vermont Blackltawk. Abraham is a son of Daniel Lambert, and as Vermont Blickhawk is of the same strain of blood that prodnced Fthan Allen, sire of Daniel Lambert, it will be seen that the pedigree is a phenomenally rich one in Morgan blood, especially when it is added, also that the second dam of Venture was a Morgan mare.

The Morgans are typical road-horses and the Lamberts are kings of the Morgan family, so that in Ventme Mr. McRoberts has the essence of blood that has amply proved itself by far the best for the prupose for which he has used it. He does not claim that he is a breeder of race-horses, believing that if they have any speed at the trot, they will show it for themselves, but in the matter of gentlemen's hor'ses for road driving, he takes second place to nobody. Another wonderfully well-bred stallion on the McRoberts place is Wanderer, a son of Grand Sentinel, which last-named horse has been previonsly referred to in these pages. The first dam of Wanderer was Ag:atha by Abdallah Mambrino, son of Almont, and her dam was by Goldsmith, a son of Rystyk's Hambletonian. 'This is performing trotting blood on all sides, as Grand Sentinel was by a full brother to Tolnnteer, and ont of a mare by Mambrino Pilot, one of the best sons of Pilot $\mathrm{Jr}$, and thit, in addition to being well bred was a trotter himself, and sired two such fimons ones as Mambrino

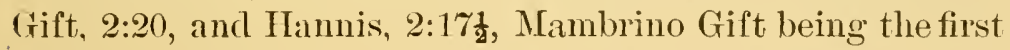
stallion to trot in 2:20, while Hamnis made a reputation that is natnral. Looking in anotler direction, Mr. McRoberts salw how potent had been the blood of Mambrino Patchen in the production of 2:30 trotters, and with this in mind he purchased Mambrino Empire, by Empire, a son of Manıbrino Patchen. Empire's dam was the famous mare Favorite by Alexander's Abdallah, dam of Favorite Wilkes and other' well-known horses. Mambrino Empire is out of Casella, by Mambrino Baslıaw, grandson of Mambrino Pilot. Cunard 
is also on Mr. MeRoberts" fillu. He is hy Venture ont of Namnie Thorne, a well-bred daughter of Hamlet, her dam being by Seeley's American Star. To show the potency of her blood, it is only necessary to say that she is the dam of Thornless, whose record is better than 2:20, and who I saw

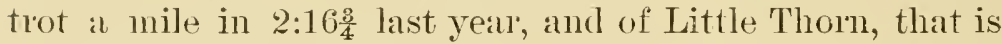
also standard by performance. Chelmistord, another son of Tenture is out of Gypsy, daughter of Mambrino Pilot $\mathrm{Jr}$. her first dam being by Royal Revenge, her second dan by Simpson : Blatkbird, hoth horses of remarkable individnality themselves, and with power to impart speed at the trot.

In brood-mares, Mr. MeRoberts' collection is a choice one, Nannie Thorne being at the head, and from her he has secured two fillies that are very fast. Josephine, another brood-mare, is by Louis Napoleon, sire of Jerome Eddy,

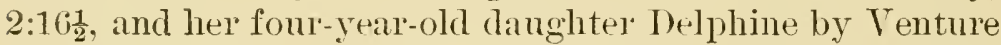
can already show a better than 2:30 gait. Bessie Rysdyk is by Trilliam Rysdyk. One of her foals is a three-yearold pacer called Pamela, whose speed is something phenomenal. Indian Qneen is by Indian Chief, that has given us Lady de Jarnette, and her dam is by Selim, sire of S:ranger, 2:281. She has a four-year-old by Grand Sentinel that can beat 2:30. Halca is a full sister to Theta, that has a record better than 2:30, and that is best of the Almont Rattler family. Heroine is full of Morgan blood, being by Leon by Anthony IVayne, ont of a mare by Vermont Hero, son of Sherman's Blackhawk.

It will be seen that in the breeding of road-horses Mr. MrRoberts has not in his operations confined himself to one family, but has selected his brood-mares from the most approved strains of trotting blood, that have been tested by performance and not found wanting for the purpose of ascertaining which strain was best to accomplish his purpose in breeding. He has bred six horses that can beat 2:30, and the success of his operations has but just begun.

A. J. McKimmin is one of the "befoh the wah, sah" Southerners. His first appearance in the North was in con- 
nection with Blackwood, $\mathrm{Jr}_{1}$, and at the end of his first campaign was the black stallion called " The Iron Horse of 'Tennessee," a name he richly deserred from the great number of hard contests he had taken part in. 'There was one thing in McKimmin's character very necessary in a horse driver, and that was he was not afraid of anybody. IVhile he was not a quarrelsome man I have seen him on one or two occasions with a look in his eye which showed that he was not to be trifled with. In appearance he is a little large for a driver and has the general air of a well-to-do farmer. Not only is he a successful horse driver, but in a newspaper war with some of the trotting associations he made not a few centre shots and showed his opponents that the whip was not his only strong suit. At present he is the possessor of a breeding farm and confines his attention almost wholly to that, leaving the excitement of driving to his friends. Robert Anderson, another Southern production, luas made several raids on the Norther'n country with his race-horses. His most notable charger' was Argyle the pacer. This horse in Bob's hands went some good races and some bad ones, but in the wreck Bob must have saved something as I understand he is the flomrishing proprietor of a first-class livery stable. I want to say here that it was through no fault of Bob's that Argyle used to make those "Jimtown" breaks, as he has on several occasions done the same thing with me. Dod Irwin is a Quaker and a representative driver of the Quaker City. To say that he learned his trade with IVilliam Doble is enough to convince anyone that he will do to go for the money, and if he divives your holse and does not win you can rest assured the horse is troubled with the slows. Engene Rood hails from WVisconsin. Tears ago he showed the boys a taste of his mettle by dragging off the pool-box with Mazo-Manie, and would have dragged off the track if it had not been fastened down. George W. TTebber, another native of $\mathrm{IT}$ isconsin, is noted for his easy manners, his qualities as an all-round horseman and the size and brilliancy of his diamonds, he having more money invested in 
gems than any other driver that I know of excepting Bobby Stewart. George has made several successful campaigns, the most notable one perhaps being with St. Albans who acquired a record of $2: 20$ and at the same time made his driver plenty of money.

Mr. ITilliam Doble, or " [ncle Billy" as everyone loves to call him, is, I think, the oldest driver in the country. He commenced his career year's ago when a horse that trotted in three minutes was considered a veritable racer. He has had a long and pleasant life, made many friends, his reputation as a driver and manager of trotting horses has been first class, and Orrin Hickok has often told me that to Uncle Billy more than to any other man was he indebted for the success of Lucy after the mare came to his stable. Not only has Uncle Billy a reputation as a great driver himself, but he is the father of a family of drivers, having three sons who have made reputations in the sulky. He has never lost his interest in trotters, is just as willing to back his opinion as when he was a boy, is not at all backward about going out and driving for his money against any of the present generation of experts; and I will give the boys one word of caution: Don't make a race with Cncle Billy with the expectation of being able to ont-drive him, for 1 have seen some good men try that and fail.

Bob Kneebs is one of the men who took Horace Greeley's adrice and went IVest to grow up with the country. His natural love of horses led him into the business and in the first part of his career in racing horses with the Indians lie did nothave the opportunity to show his talent that has since made him famous through all the IVestern campaigns. Some men say that good horses make good drivers. That may be so to a certain extent, but I have seen Bob drive some bad horses and do it well. I think the best breadwinner he ever had was Elmwood Chief, who made a record of $2: 18 \frac{1}{2}$ and has for years won a large percentage of his races. Of late year's Bob has devoted a part of his time to the breeding and raising of horses. In this line he has also been successful. If 
you go West expecting to get Bob's scalp with a trotting horse, take a good one or you may find yourself at a disadvantage. George Cook, the little man who on the turf goes by the name of "Cooky," made his greatest reputation in connection with the Wilkes family, he having given Rosa Wilkes and Joe Bunker records better than 2:20, and won some well-contested battles with both of them. He is at present the trainer at Hermitage farm, the home of Wedgewood, and I expect to see him out with many a winner by my old favorite.

To show that the trotting-horse owners of the future will not be short of good drivers, I will give a few tips on the younger generation of drivers now coming out. As this book treats entirely of facts and records, Ed Bither is entitled to first position in this class, he having done more by the records than any man living or dead, that is to give two trotters records better than 2:14, namely Jay-Eye-See, 2:10.

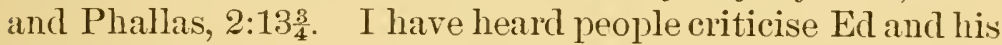
methods of training and driving, and I do not wish to say that no other man could have driven the horses as well, but Ed did do it and I think he is entitled to all the glory arising from the feat. There is one thing I am sure of, that no horse, no matter how good, can make the public performances that these two made for Bither without being well trained and properly driven. In appearance Bither is a young man of medium height, well behaved, with a comfortable bank account and I know it will be of interest to my lady readers when I say that he is still a single man.

Next by the record comes Millard Sanders. His public career on the turf has been very short but brilliant, he having won some grand races with Clingstone, given Guy his record of 2:12 in his first regular campaign, has the best record for four-in-hand, and to have done all this in a short time shows that his early education in the horse line was not neglected. He has charge of Mr. IV. J. Gordon's breeding and training establishment, and a visit to that place will convince the most skeptical that he thoroughly understands 
his business. Next we have Scott Quinton of New Jersey, who is a very dressy young fellow. Scott has given Favonia a lecord of 2:15, and the pacer Gossip Jr. a mark of 2:14. He comes honestly by his love for horses, his father having been a first-class horseman. Mr. Quinton is a very genteel looking young man and with his dress suit on at a swell dinner or theatre party is simply immense. Next in line is Bob Stewart, he being entitled to fourth money, having given White Stockings a record of 2:16. Bol comes under the head of a gentleman driver, - that is he owns and drives his own horses, and in that class he leads the list. Whenerer Bob's horse trots through the grand circuit it is considered ladies' day, as Bob always has a handsome horse, is well dressed himself and his diamonds are the enry of more than one man. The love of the horse in the Stewart family is not all centered in Bob. John, his younger brother has never yet made his bow to the public as a professional driver, but as an enemy of the book-makers and a plnnger in the pool-box, he is only equaled by their father, who makes occasional raids from the far West and if he does not beat the pool-box he gives it such a shaking up that it does not get back to its normal condition before he is ready to take another fall ont of it.

In the pacing-horse division Rody Patterson takes the bamner, he having given Bessemer, a four-year-old stallion, a record of $2: 15$ which is the best up to date for an entire horse of that age. In this Rody did more than many drivers have been able to accomplish in a lifetime. Two fifteen may not seem fast on paper, but there are few men who have ever had the pleasure of riding that fust in a sullsy. Budd Doble, with all his experience, never rode a mile in the sulky better than 2:14 until last year. For Rody Patterson I predict a brilliant future. His business education and moral training has been of the very best, as no boy was ever more carefully reared. His father before him was a horseman and his grandfather followed the same rocation for a living. Rody's father as secretary, owner and dricer was always closely conmected with the turf and his record was 
that he was honest, kind and true, and treated everyone as he wished to have them treat him. This was his religion, and he lived up to it withont a miss-score or a break. What wonder then that young Rody with that example before him should alrearly have made for himself a record as a man and a driver? I do not remember of having seen anything pleased an andience more than it did when Rody won a race with Bessemer and gave him his record of $2: 15$ the day he was twenty-one years old. I know one handsome young lady who was particularly happy. Besides being a trainer and driver, Rody manages, together with his mother, one of the handsomest breeding farms in Kentucky. He also trains, drives and keeps all kinds of animals for other people and he has my indorsement as being able and willing to fill the position in a satisfactory manner to anyone wishing his services.

M. E. McHenry is, I believe, a native of Illinois. In size etc., he reminds me very much of Turner. My first introduction to McHenry convinced me that size cut no figure with him. We were both driving in a race on one of the outside tracks where everyone takes the pole at once if they can get it, and the first I knew I was having a battle royal with sone young man I had never before seen. I returned to the stand after the heat and asked a friend of mine who he was. He replied, "McHenry, from 1llinois." I replied that McHenry from Illinois was about as industrious a young man as I had ever seen out with a horse and wagon trying to make a living for himself. I put him down in my book as one of the young men not to be overlooked any time he was in the ranks. In Shnler, Johnny Kelly and a number of other young men whose nimmes I do not at present recall, the Western country has material to always keep the rank of the trotting-horse drivers up to the standard. In the East, among the shining lights in the new division is Mr. WVilliam Snyder. I think the first lessons lie ever took in connection with trotting horses he learned in my stable. In the early part of my career I trained a horse 19 
for Snycler's father, and in that way made his acquaintance. He is not only a good horse driver and a good trainer but has proved himself a successful business man. By trade he is a first-class civil engineer, and between lieats has managed as superintendent the building of a good many miles of railroad.

Captain Boyce's title is no empty one, as he was one of the men who went to the front and was just as willing to defend his country in times of trouble as he would be now to win first money in the $\$ 10,000$ purse. The Captain has always had a more or less active life with trotting horses, has given a great many of them their best records and is at present manager and trainer for one of the largest stock furms in this country, and if the produce of the farm do not put their names on the roll of honor it will not be the fault of the Captain. In Kentucky among the leaders in in the business are the well-known Bowerman brothers, Mike and George. Together, they are a strong team. Each has in himself the elements that the other seems to lack, George, I think, being the strongest in laying out the plan of battle. But when it comes to the part where the shooting takes place, with all dne regard to George, I want my money on Mike. I have had a great deal of respect for Mike's ability in matters pertaining to a trotting lorse since the day that J. Q. and Sparkle had their memorable contest over the Cleveland track. That the Bowermans have not, in the hurry and bustle of the trotting-horse excitement, neglected to look after their bank account is proven by the fact that their checks are always honored. They number among their patrons some of the leading breeders and owners of the country who are always sure of fair and honest treatment at their hands. Gus Wilson learned his trade in what is considered the old legitimate way, that is, went as a boy and served his time with Horace Jones, one of the leading horse trainers of that day. As proof that he did not waste his time or talent, he gave to Hattie Woodard a record of $2: 15 \frac{1}{2}$, and had she not met with an 
accident would without doubt have improved that. He also won the $\$ 10,000$ stallion race with the stallion Alexander and gave him lis best record. Gus is one of the sort of people a good deal like some horses, they have a little more to them than you expect, and for that reason when he starts in a race he never disappoints the public.

John Call, who dates his connection with the turf way back wheu Belle Patterson and Annie Collins were youngsters, derotes his time and attention more particularly to the training and developing of young horses for people who do not keep a private trainer of their own, and in this line he has been particularly successful. He steps out occasionally and makes a raid on the boys and shows them that he is not afraid to go out in deep water. He makes his home at Cleveland, and has the advantage there having the best training ground that I know of for all kinds of horses. Alta McDonald, of Albany, is entitled to be classed with the youngsters, and a cute one at that. IVhat Alta does not know of the ins and outs of a plain everyday horserace is not worth knowing. He is always willing to bar age and size and take whaterer the judges read ont to him for his share of the money, and up to the present time, I think, he has been enabled to get all he was really entitled to, As a trainer, he has shown from his boyhood his ability to not only condition his horses, but what I consider a much harder feat, to keep them in condition throngh a long campaign. He always drives to win, which I think rery commendable in a young man in these times, where there is often a temptation to do differently.

Tom Grady, another Albany trainer, is an Irishman by birth and a gentleman in conduct. He lias made a study of trotting horses both in books and by actual experience the greater part of his life. He and Charlie Nolan have always been great friends. Whenever I see them in consultation on the race-track I make up my mind that the Fenians are going to book a winning. Nolan luas been one ol the strongest supporters of the trotting turi, a sportsman for pleasure, 
a railroad contractor by occupation and while he does not go around the country making bonfires of his money, he is always willing to pay the top price for a good horse, and whenever General Turner say's so he is ready to win, backs lis opinion till the books are closed. John Driscoll, a young man whose name has long been before the public, he laving started in his public career as a boy under the tutelage of the world-renowned TVilliam Heywood, trains for Mr. Shults of Brooklyn, a man who has expended as much money of late years for horses as anyone I know of. For Driscoll to be placed in charge of all these valuable horses and property by a man of Mr. Shults's business experience is recomendation enough for anyone. John is a little nnder the medium size, weighs about 135 or 140 pounds, has plenty of determination, and his early education could not have been better to fit him for a trainer and driver.

Hiram Howe, one of Hiram Wroodruff"s scholars, made his mark in connection with the American Girl. Of late years he has given up training and trotting, is the proprietor of one of the best hotels on Long Island, and in the winter days more races have been trotted around Hiram's stove than on any other part of Long Island. The two Perrin boys, George and Ed, trace the trotting-horse strain in their pedigree back to the third generation. Not only their father, but their grandfather was always a lover and strong supporter of the trotting turf, and their father at one time owned Flora Temple. The boys in their yonthful days brought up in lnxury, did not like some other young men when the storm came and swept their fortune away, sit down and wait for someone to bring them another. They took off their coats and went to work. While neither one of them has ever been fortunate enongh to have a star performer, should they erer get one that can step a mile in abont 2:10 I will guarantee they will not have to be tied in the sulky to keep from being blown ont. Stere Phillips sprung to the front with one bound as it were with the celebrated pacing horse Sleepy Tom. Many people 
imagine that this horse did not come honestly by his wonderful speed, but such is not the case as he traced his pedigree back to one of the most wonderful performers the turf has ever had. I speak now of his granddam Pocahontas, who years ago made a record of $2: 17 \frac{1}{2}$ to a wagon, she being in foal at that time, and the produce proved to be the sire of Sleepy Tom. She was owned at the time by a man of the name of IVoodmansee, a resident of Ohio, who afterward sold lier to James D. McMann of Flora Temple fame. That the horse interest did not die out in the IVoodmansee family is shown by his two sons Dan and Ben, who were in his lifetime the managers and contidential adviser's of Commodore Kittson. Being first-class judges of horses in all their branches, good business men and strictly honest they were of great value to Mr. Kittson in all his connection with the turf".

Sleepy Tom was unfortunate in his younger days by being very much neglected and ill-treated by his owner and from this cause lost his eyesight. But after coming into the hancls of Phillips, who bought him for a small price, under his better care and management he showed symptoms of speed which afterward made him famons. He beat all the best pacers of his day and was the first horse to beat

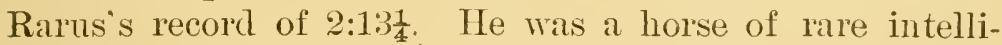
gence, and, as in the case of Prince, the loss of his eyesight seemed to increase the acuteness of all his other faculties. In chiving him Phillips always talked to him a great deal which I think is a good idea to do with any horse. I once drove him in a race for Phillips, he having met with an accident. In talking the race over he adrised me to lay him up the first heat, saying it wonld give me a chance to learn the horse and we could put our money on at a better adrantage. At this time there used to be a great deal written in the newspapers abont Tom and his peculiarities and how Phillips drove him, and some of these stories were very much exaggerated. After I drove in this race I was interviewed by a reporter of a country newspaper who was 
very anxious to have a scoop on all the rest of the boys. He asked me if I bad any difficulty in wimning with Tom. I told him no, that $\mathrm{Mr}_{\mathrm{r}}$. Phillips in driving the horse had set speeches that he made to him at different parts of the track, and for fear that I would get tangled up in it, he wrote them out for me, I pinned the paper on my knee and when the word was given kept Tom's head steady and read the instructions and in that manner won the money. The reporter published this and I received many letters of inquiry asking me if such was the case; if I had driven Tom by the paper. Phillips sold the horse at a long price, retired to his rural home, bought himself a farm, was I beliere elected sheriff, a position I think he would have been well fitted for as it would have taken a pretty hard prisoner to have gotten away from Steve.

Joe Rea had the love of the trotting horse bred in him. A native of Indiana, the home of the pacer, I have often heard lis father tell of races that had happened before Joe was bol'n. Joe made his greatest success in connection with R. C. Pate's stable when that gentleman occupied a prominent position on the trotting turf. He also gave the boys a general shaking up with Amy King, going through the grand circuit with her and winning a majority of the races in which she started. Charlie Forth, also a native of In-

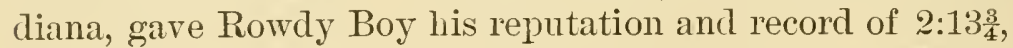
driving him in many a well-contested race with Mattie Hunter, Lucy and Blind Tom when they constituted what was called "The Big Four.' Sam Keyes, of Pittsburgh, needs no introduction from me. He is considered the father of all pacing-horse men, as years ago, when no one but a butcher cared to own a pacer, Sam was the only professional man who took an intelest in them, and as the public gradually became interested in that style of racing Sam still continued his connection with the side-wheelers, and he and his gray mare Lucy probably did more toward making pacing races popular with the public than any other pair. Sam is a character, true to his friends, had a deserved 
reputation of being honest with the public, would bet his money like a sailor on Lucy when it looked sometimes as though she would not be able to win, and $I$ think his horse account has always been on the right side of the ledger, as he is a good business man. He was always a great admirer of Mace and whenever not able to drive his own horses Mace was out belind them.

Moore Floyd, another Pittshurgh man, came prominently to the front in connection with Slow Go and won some grand races with him in the big circnit, making a record of about 2:18 Of late years Moore has changed his business and with the exception of an occasional visit to the race-track, has severed his connection with the turf. The name of Shank is familial to all the people in Ohio, there being a large family of them and all horsemen from the youngest to the oldest. Their name was brought prominently to the front in connection with Olnver $\mathrm{K}$. They had a horse called Rutherford Hayes, which rumor said would some day be a world-beater. These wonderful horse stories came to the ears of $\mathrm{Mr}$. Emery and he and a friend of his formed a combination or trust, so to speak, and at a long price bought of the Shank family this going-to-be beater of all records. When Shank delivered the horse at Mr. Emery's place he said he would like to invest a little of the money in a colt, Mr. Emery at this time having begun to lay the foundation of his now extensive brerding establishment. In looking over the list of colts which came under his standard of price, etc., he picked ont one, a large awkward-looking yearling, and paid for him $\$ 150$ and with the balance of his money safely tucked in his boots started for the rural districts. After Mr. Emery had given Hayes a thorough trial and made up his mind that the horse he had bought from Shank would never beat 2:08 $\frac{3}{4}$ he concluded to try and sell his interest. After some correspondence he induced his partner to accept his lialf of the lorse as a present. Not so with our friend Shank. He broke his colt and after a short term of education started for the pumpkin firis, where the ani- 
mal performed in such a manner that again the story went forth that Shank had a sure-enough world-beater. If $\mathrm{Mr}$. Emery ever heard the story lie conld not have paid much attention to it as he didn't buy this one.

The fall the colt was four years old Shank entered him in a race at Cleveland under the name Oliver $\mathrm{K}$., and with the help of Dary Muckle bankrupted the whole northern part of Ohio. That Mr. Emery's feelings were when he saw his $\$ 150$ colt and thought of the animal he had bonght from Shank, I will not undertalie to describe. Shank sold his colt to George Forbes for $\$ 5,000$ in money. A gain loaded down to the high-water mark with Gorernment bonds he retmrned to his rural home and built himselï a brown stone front where he passes his time in luxury and comfort recounting to his neighbors how he beat the city horsemen. The following spring after Forbes bought Oliver $K$. he sent him to me to train and drive. In his preparatory work the horse showed some lameness, but not milil I had seen enough to convince me that he was another Rarus, which is another instance of the argument that great hor'ses are born, and not made, for at this time Oliver $K$.' s training had been very limited, but he showed me so much speed that I was sure that he would be a star performer. After a consultation it was decided to let him up in lis work, which was done. Misfortunes, they say nerel come singly, and Forbes had proof of this in the disasters that followed. He had always been what the boys call a hustler, an all-around sport, admired everything from a hundred-yard foot-race to a fourmile running race, was himself at one time champion sprinter of Cinada, and entirely by his own exertions had acquired a comfortable fortune. He invested the most of it in business in Cleveland and had the misfortme to stand by and see his property. which represented years of toil and labor, swept into the lake; and after the flood lod subsided found himself thousands of dollars worse off than nothing on the debit side, and on the credit side there was one lame trotting horse and an interesting family of children. 
He stuck to the children and tried to sell his horse, but as it had been reported that he had been lame no one took any interest in him. I, knowing what a wonderful trotter he was, tried to induce a wealthy friend of mine to buy him and take the chances of his recovery. He thonght that would not be a good business scheme, so Forbes was compelled to keep his horse, and has had occasion ever since to thank his stars that he did, as the next year he trained and drove Oliver $\mathrm{K}$. himself, won all his races including the $\$ 10,000$ purse, and sold him for $\$ 17,500$ to $\mathrm{Mr}$. Charles Schwartz, of Chicago. Flom that day until this fortune has smiled on Forbes and it will take an old-time flood to carry his property into Lalie Erie again. A handsome painting of Oliver K. adorns his parlor walls and his children look upon it as though it was the picture of a hero. In Mr. Schwartz's hands Oliver $\mathrm{K}$. has performed some handsone feats, having beaten Harry Wilkes while in his prime and gone a mile against the watch in 2:15. This horse is not considered giltedged in breeding, but in my judgment, if he had been fortunate enough to have staicl sound, he would have compelled the public to have said in his case that a gilt-edged pedigree was not absolutely necessary in a race-horse. I do not wish to say that I do not like pedigree in horses, as I do, but I do not want all pedigree and no horse. If I hare a good horse that has a good pedigree, I hare more confidence in his improving, training on, and lasting than I would in a horse withont a pedigree.

One of the old-time drivers whose methods etc., made a lasting impression on my mind was Simon James. He was the pride of the Queen's Own, being a native of Canada and one of the Qneen's subjects. Canadians are a sportloving people and years ago had a hreed of horses that could all trot some, their particular forte being speed and not staying qualities. In those days to win a lace at Buffalo was considered of as much importance as to win now the English Derby. Simon made occasional raids across the American border, and, stlch high esteem and confidence was 
he held in, there always came with him a goodly share of Canada money to back his chances. One of the best races he ever drove where the Canuclis carried Uncle Sam 's money back by the bag full was with a gray horse called Milton, that could trot a mile in about 2:30, but was credited with staying qualities equal to ten or twenty miles. In this race he was not the fastest but he staid th- longest. It was looked upon by the Canadians as a national victory, and he was lionized by the natives accordingly. Among Simon's patrons were the two Ensigns, men of fine reputation in business, great lorers of the horse, and who always owned a good stable of trotters and race-horses. They are liberal with their money, as I can bear testimony, as in the days before I had ever won first money with a trotting horse, when five dollars a month was abont the legitimate size of my income, they sent me to school and in other substantial ways showed their kindness of heart toward me. James always drove their horses and drove them well. He is retired from the turf, but is considered authority on trotting horses by every subject of Queen Victoria.

John Trout's name is very appropriate, as in habits, general disposition etc., he puts you in mind of a fish that is hard to catch. There is nothing in the way of driving a horse from the tow-path to the white house that John is not prepared at all times to take a hand at. In a field of horses he is quick to see and take advantage of every weakness on the part of his opponents and can do more toward making a horse a good breaker than any man I ever saw. That he is a first-class judge of pace is proven by his having given Huntress her three-mile record, which is best up to date, and he rated her along in that race as evenly as old Father Time himself could have done. Sam Caton is a gentleman whose long connection with the turf has given him a world-wide reputation. His campaign in 1887 with the Kalamazoo stock-farm stable was perhaps his most brilliant effort; in that year he won more races than any trainer in the country; not only with old campaigners, but also with 
colts and green horses, and by so doing refuted the oltrepeated story, that old trotting-horse trainer's were not good colt trainers. Sam not only won with his colts, but kept them in such condition that they made long campaigns - won a lot of races, and, what is more, they came ont the following year and trained on. He gave Bell Boy a record of 2:191 as a three-year-old, and convinced me that he is a wonderful horse from the fact that his training was very limited; his owner using him almost entirely for breeding purposes.

"Tobe" Broderick is considered one of the shining lights at the huckleberry shows, he having made the world's record of 2:07: orer a half-mile track with his celebrated pacer You Bet, and running mate Gooseberry John. I think, taking: into consideration the difference between a mile and a halfmile track, that this is as good a performance as any team ever made that way rigged. Hawley Cole, by the fashion of his garments may ante-date the war, but his training, driving and management of trotting horses is after the most approved latter-day methods. He formerly devoted a part of his time to his large railroad interests, but the interstate law interfering with his usefulness, he now puts in all his energy and talent to training a public stable. That he gives his patrons satisfaction is proven by the number of them. John Holstein made his mark in connection with the Wood's Hambletonian family, having given many of them their best records and campaigned them very snccessfully. In connection with John I might relate rather a strange accident, something that I never saw happen before, and one of the many proofs of how uncertain horce-racing is. In a race at Utica several years ago he was driving Nancy Hackett in what would have been perhaps the deciding heat had she not met with an accident. I had $T V$ olford 7 . in the race, and after trotting for the first three-quarters of a mile to beat John with Hackett, she, without any apparent cause, plunged sidewise, and stopped almost instantly. So sudden was it, that I pulled my horse up, thinking that 
something terrible had happened, and sure enough she had dislocated, as we afterward found ont, the main bone in her hip, and had to be destroyed. John had two heats won, and every horse beaten sure at the three-quarter pole in the third heat; his mare was well barked in the pool-box, and then all his chances rere destroyed by this inexplicable accident. Johmny Grier comes under the head of the light weights. I think he does not weigh orer 120 pounds, but I don't see as that is a drawback to him, as he has made some as good finishes as heaviel men could lave done in the same position. Jim Boyd may surely be called an all-around horseman; he is a horse trainer, driver, owner, breeder, livery-stable keeper, secretary of a trotting track, and of a breeding association-smrely irons enough for one man to have in the fire. With all this, he has plenty of time to be considerate and polite to not only his numerous friends, but anyone who may have a chance to meet lim. He is one of the fixtures of Milwaukee. Woodard \& Brasfield, the founders of what has grown to be a very large business, combination s:les, are both horsemen of rare ability. They are different in disposition and character; together they made a sncessful team, and since they hare separated their interests, each one has shorn himself capable of filling a place in the business world. Brasfield has been connected with some of the leading breeding farms in Kentucky, haring trained for H. C. McDowell and others, and in fact gave Trinket her colt record of 2:19 $\frac{3}{4}$. Woodard \& Brasfield once owned Harry Wilkes and gare him a record of $2: 23 \frac{1}{2}$. Woodard is considered more of a plnnger than Brasfield, and any time that he is not engaged in his legitimate business, he is ready to take a whirl at the pool-box and will try just as hard to guess the winner as he will to get the top price for a man's horse that he is selling.

John E. Madden, the boy turfman, has never aspired to be a driver, and I believe has nerer made his bow in a public race, although in private training he has shown marked ability as a horseman. He has owned some very 
promising animals and is willing at all times to pay the top price for anything that looks as though it would be a worldbeater. James Boyle dates his connection with the Western turf to before the Chicago fire, when such leading lights as Harry Holmes, Al Gage, Charley Schwartz and a host of others were out in force, and before they hatd settled down to everyday business. At this time, George Mansur was proprietor of Dexter Park and Billy Boyle (Jim's brother) was the leading secretary of the country. Since then he, too, has settled down, and has proven himself to be as good a business man as he was a secretary, which is proven by the fact of his having made a fortune for himself with his chop house in Chicago, an establishment that has attained more fame than any other place of the kind in the country, and to which horsemen gravitate as naturally when in Chicago as they do to the quarter stretch when at a race track.

George Hayes, made his star performances as a driver in connection with Colonel Pepper's stables at Frankfort $\mathrm{Ky}$. In his management and driving of the celebrated mare Catchfly Hayes stamped himself a trainer of rare judgment and ability, Catchfly being a mare that had baffled the efforts of a number of people to train and drire. But Hayes soon got the hang of the mare, and in his hands she proved herself one of the few first-class race-horses of the year, beating among other good ones Harry Wilkes in a race of five heats. Hayes is rather a mild-mannered young man, but with plenty of determination, as was proven in this case.

The Coates brothers come under the hea d of gentlenen horsemen, and are, what I would call, two of a kind. In ways, looks, disposition and traits, they are as near alike as a pair of aces. They have owned and raced some of the star performers. Joe always does the driving and Arthme attends to the finances of the concern, and in this manner they have been able to give talent some pretty severe blows. They also take an interest in breeding, and own a fine property at Goshen, N. Y., where they spend their time when not ont on they ruad. They are both well-educated yonng 
men, and might be taken for a couple of students. Joe is particnlarly fond of music and has given to it a great deal of attention.

George Robens, native of Michigan, has the distinction of giving the record to the fastest Blue Bull, also the fastest three heats in a race $b_{z}$ the same horse, namely Georgetown, the pacer, that was afterward sold to a foreign market. George has been rather an active young man, and while he has never had a real star performer, the horses he has handled have always been used to the very best advantage.

Col. George IVashington Dickey, a gentleman whose commection with the turf dates back to the time that Dan Hace was a boy, Mace being a great admirer and friend of Dickey's, is one of the heavy weights of the turf, he being without doubt the best driver of his weight known. In regard to his name, his parents christened him George Dickey, but in later years, as lis character was fully developed, his friends made the additions. The title of colonel was given to Mr. Dickey on account of his bravery, and the Washington part of his name was added to indicate his truthfulness. He was the son of a minister, and was educated with the idea of his following in his father's footsteps, but the Colonel had other views, and struck boldly out for himself on the turf. He made his greatest reputation as a trainer and driver of trotting teams and was the first man to drive a team in 2:30 which he did with Jessie WTales and Darkness. He has traveled in every country in the known world where the trotting horse is mentioned, counts his friends by the thousand, and is the man that, Jack Phillips offered to bet, conld borrow \$25 from a lamp post in any country in the world.

George Starr, although connected with the turf for a number of years, has not yet made his bow as a public trainer, having filled the position of second trainer to Budd Doble for a number of years with the idea of fitting limself thoroughly for the position of a public trainer and driver. In doing this I think he has showed commendable wisdom, 
that is, in first thoroughly learning his trade before he hangs out his shingle. He has already to my knowledge refused some very tempting offers to train and trive different stables of horses, thinking it better to first completely master every part of the business; I think this is a plan that erery young man should follow. After you have made up your mind that you want to make training and driving horses your business, consult with whoever you think is the best trainer in the land, take his advice whether you are fitted for the work, then place yourself under his charge and every day try to learn all you can in regard to the details of the business. In that way you will have a chance to not only use your own judgment, but you will obtain the benefit of your employer's education and experience. All the success that I have had in life in my business I thank my early employers for. Nace took as much jains to teach me how to train and drive a horse as any school teacher would have taken with a boy if he had known he wonld have lived to be President of the United States. It would have been impossible for a man to have taken more interest in a scholar than Mr. Simmons did in me; and when I drove the first horse for him in public races, he seemed to take a greater pleasure in making me a competent driver than he did in having the horse win. Trhen George Starr offers his services to the public I shall be willing to indorse him, and think he will prove that my theory about learning to be a horse trainer is correct. In size, appearance and manners, he looks and acts more like his employer, Mr. Doble, than any man I ever saw. George perhaps has a little the adrantage of Bucld in years, being somewhat younger, but has those same careful methods in his character that have made Budd in my opinion the greatest holse trainer I ever saw. 


\section{CHAPTER XII.}

How to train the trotter and keep him in good fettle-His mouth the first thing to be looked after-An experience with Fanny Witherspoon-Don't pull a horse, and he will not pull you-Overfeeding and its consequences-Give water at all times-The groom must be neat in appearance and not a drinking man-Too many blankets a bad idea-Some points about boots-The use of pads and sponges-MIambrino Sparkle's bad fect, and the great races she trotted-Why clipping is beneficial-Work in the early spring-Teaching trotters to score well-Sulkies, road-carts, timing-watches, etc.

The first thing in training a holse is to make a careful study of the animal, learning all his peculiarities, faults, weaknesses, habits, etc. I think one vital mistake made by men training horses is that they do not seem to think that horses are made of flesh and blood, and very nearly human in all their ways.

The first thing to be looked after in a horse, is his mouth, for two reasons: In the first place, the mouth is used for a donble purpose, to drive the horse by, and to eat, two rery essential things in a race-horse. In a race, if you beat the other man a head, you win the inoney; if he beats you a head, he takes the money, so that your whole year's work may be decided for or against you by the length of a horse's head. If two horses are in a race, equal in every particular as to speed, etc., and one of them is a disagreeable driver and can not be entirely controlled, and the other one perfectly controllable to the will of his driver, easy to manage, and quick to respond to every touch of the bit, that horse will win the money erery time. I simply state this to show that in horse training it is the small things that make or mnmake the success of the hor:e and trainer. Some horses naturally (298) 
have a better mouth than others, but, with time, care and attention any horse's mouth, no matter how bad, can be improved. My idea is first to see that the horse's teeth are in proper condition. Unless you are a veterinary dentist yourself do not undertalie to fix his mouth. Get the best veterinary dentist you know of, tell him if the horse has any peculiarities about driving on one rein, lugging or pulling in any disagreeable manner, and if the dentist understands his business and the habits are cansed by any trouble with his teeth or mouth he will be able to remore the cause and in time the horse will forget his bad habits. Horses are a good deal like men abont that, it takes them a good bit longer to forget a bad habit than it does to learn one, so that it sometimes requires a great deal of patience to overcome a slight fault.

After the teeth ind mouth are properly looked after, the next thing in line are the bits. My experience has beell that no horse can be successfully driven with anything like a severe bit. I nerer saw one that was even broken of the habit of pulling in that wily. If you put a severe bit in a horse's month and pull on it it makes the horse mad and irritates him; the further you drive him and the harder you pull him, the more he will pull against it. When I was a boy almost erery trotter I saw would pull in a disagreeable mamner when being driven at top speed. At the present time I can not think of one lrorse that is anything like first class, that pulls enough to mike it disagreeable for a man at any time. I great many people think that every horse should be driven with an orercheck. I can remember when I had the same opinion myself. I am now satisfied that it is a serions mistake. There are a great many horses that will not take kindly to an overcheck, and if you insist on using it on them it will sooner or later spoil the horse's disposition to a great extent. The plainest calse of the kind that ever came into my hands was Fanny IVitherspoon. She liad been trained for a number of years and always with an overcheck. I myself trained her for orer a year in the same 
manner, but with rery little satisfaction, as she seemed to continually have trouble with lier month. In talking the matter orer with my friend Hickok, he advised that I try her with a check bit, side check, and nose-band attachment. I did so, and had Mr. J. H. Fenton make me a bridle according to Hickok's suggestion, the same as the one he wore on St. Julien, and in the shortest time imaginable the mare showed a very marked improvement in h r driving. I think a horse shonld never be checked on the bit you drive him with; always have an extra check bit in his mouth. For bits, I find that most all liorses drive well on an ordinary size snaffle bit corered with rubber. I do not mean what they call patent bits with guttapercha covering. I take a steel bit, have it nickel-plated to prevent it from rusting, take a piece of white rubber hose, and have my harnessmakel cover the bit with it. Manmfacturers tell me there is nothing about the white hose that is clisagreeable to the taste of the horse, while there is in the patent covering. I also cover the check bit in the same manner. A great many people who break colts, I imagine, do not realize how inportant a pirt this is in a horse's ectucation, as a majority of them nerer drive a race in their lives. They seem to think that if the colt is broken so he won't jump the fence or kick you out of the sulky that is all that is necessary. Years ago, when I was a boy and lived on a farm I saw more pains taken with a hundred dollar colt in breaking him than I see now sometimes with a colt that the owner expects to get thonsands of dollars for. Ihave found that with horses that have disagreeable habits of pulling on one rein, etc., it is a grand idea to put a bitting harness on them, and turn them loose in a large stall or paddock. Do not check them high enough to make them fight the bit, nor leave it on long enongh to tire them. The oftener you put it on in that manner, the better. It is an easy matter in winter when they are not in training to put it on them a comple of times a day.

We lave now discnssed the pulling question from the horse's standpoint; the other side, the trainer and driver, 
I often think, cuts a very important figure. I am sure that not one man in a hundred driving a trotter erer realizes how hard he pulls the horse. A good way to find that out is for a man to step into some gymnasium where they have a pulling machine and pull against it about as hard as he does a horse in a race, and in that way, if he is in the habit of pulling his horse liard, he may learn something that will be to his advantage. I drive all my horses with holders on the reins, and I think no man should ever drive in a race without them. A great many say: "Why, if your horse doesn "t pull, do you use holders?" For the reason that I can drive a horse easier to myself and him also with holders than I can without. If you drive the horse without holders you will have to grasp your hands so closely about the reins that it will stop the circulation so that before you have gone a half-mile you will have to change the position of your hands; then if the horse makes a break you are obliged to take a wrap on the reins before you can catch him. You do not have to pull a horse any harder with holders than is necessary, and if it comes to a desperate finish where he makes a break the advantage is all on your side instead of his. In working your horse, always try to see how little you can possibly pull him, as it will help make him a better race-horse and you a much better driver.

In the training of a horse to bring him to his highest state of condition what he eats and drinks cuts a very important figure. There are some horses that from one cause or another, will not eat enough to stand the severe preparation, but as a rule I think most horses eat too much. I think eating gets to be a liabit with some of them, and a bad habit at that. If a horse is inclined to be "washy," sweat freely and lose his flesh, that horse, I think, needs more feed than one of the opposite disposition. While Rarus was a delicate-looking horse and people often asked me if he was a good feeder, he was the greatest feeder for a race-horse I ever saw. Through all his serere campaigns 
with me I never saw him when he was not ready to eat, and in the hardest part of the season I fed him abont fifteen pounds of oats a day. In their stomachs horses differ more from the human being than perhaps in any other part of their physical structure. A man in the course of twentyfour hours will take into his stomach more different kinds and sorts of fool than a horse wonld in a lifetime. and for that reason, I think what a horse does take has more effect on him than it otherwise would. Whatever a horse eats should be of the cleanest and best. I think on an aremge that ten pounds of oats a day with a fair amount of hay, is enongh for a horse to be trained on. I think that all horses in the training season should have plenty of grass. In winter, I like carrots in small quantities, and for a change boiled oats have proved themselves a rery satisfactory food to me. Some people say: "IT'hat about bran?" I am a good deal like Dr. Weldon about that; sawdust will answer the purpose just as well, and it is a good deal cheaper.

After deciding what to feed the horse, next comes how to feed him, This depends a good deal npon the horse. If he is a good feecler my idea is to feed him often, and a small quantity at a time. In this way you get the greatest amount of good ont of the smallest amount of food. When you take into consideration the size of the horse's stomach and extraordinary strain that is put on erery part of a horse in a race, you can plainly see that with an overloaded stomach you are liable to meet with rery serions consequences. I think a great many cases where horses drop dead in harness are due to some derangement of the stomach. In feeding a horse ten pounds of oats a daỵ I would suggest to have it divided in not less than four feeds of equal proportion. Nerer give a horse his hay and oats at one time, for if he is a free feeder he will be sure to gorge himself more or less. Is to water, I think every horse shonld liave all he wants and at all times. A man says: " VThỵ, will you give your horse water before a lace!" Tes, before the race, in the lace, and after the race and any other 
time the borse wants to drink. I have been told by people who have made a study of it that thirst in an animal is one of the most cruel tortures that can be applied. I once had a most interesting conversation with a man who had made the taming of wild animals a lifetime study, and he told me that the severest punishment that could be applied to animals was to put them in a rarm room until they became thirsty, and that treatment would subdue the animal when nothing else wonld. In my boyhood days I knew a man who was a rather strange character; he was a crank, the neighbors said, on training horses. His way of breaking a balky horse was, when he refused to draw the load, take him ont of the harness and tie him up where he could get nothing to drink. When he thonght the prisoner was in condition to appreciate a good drink of water he would take him ont and put him to the load again, give him a few swallows of water ancl ask him to work. If he did so, he was given all he wanted to drink; if he did not work he was allowed to go withont, and I have often heard the man say that he had never come across a horse that conld not be conquered in that way.

In training a horse, his system will become more or less fevered or dry from constant sweating and scraping and he will naturally take more fluid into his stomach than he would muler other conditions. IVhen I say give.your horse all the water he wants before the ruce I do not mean that you shall tie him up where he can not get a drink for five or six hours on a hot day in a varm stall, and then take him to the pump and give him all he wants. What I mean is to give him watel often, and in that way he will take but a small quantity at a time. I think it a bad iclea to set a pail of water in a hor'se's stall and leare it there until he has drank it up. Physicians tell me there is nothing that will absorb bad odors and become unhealthy quicker than water. I am satisfied from my personal experience that good water is absolntely necessary to train a horse to perfection. Some of the best points that I ever got abont horse training I 
have learned from physicians and men who have trained people for athletic feats where it required the highest standard of physical derelopment to succeed. They tell me that the foundation to build on when training a man is to first have his blood in perfect condition; then the stomach, and if he is a well-bred and game man the rest will come after. That is my idea about a race-horse. If, from any symptoms you may see in your horse you think the blood or stomach is out of order get the best veteinary surgeon you know of to take charge of the case. Do not undertake to doctor him yourself unless you consider yourself a tirstclass reterinary. I am of the opinion that no man ever lived who was an expert at more than one trade. We often see a great many things advertised as being good for this and that ailment of the horse. When I read them orer I always think of what my colored boy "Senator" once said to me. On retuming home from a trip he told me that one of the horses had been slightly ill and he had given him some medicine out of a certain bottle that he had formd in the chest. I asked him why he had given the horse the medicine, and he replied it was printed on the bottle that it was good for a horse, and he didn't suppose anybody would print a lie; but as the horse died, Senator lost confidence in published statements. No matter how smart a man is, no matter how well he may have learned his particular trade, nothing but constant, every day practical experience will make him an expert in his chosen profession. That is why I say never call in a blacksmith, no matter how well he can make a horseshoe, if you want the horse doctored.

After having made a perfect study of the hor'se's habits, how to feed and manage him in the stable, etc., you should by this time have some plan as to how you think he ought to be worked or trained. Never start in to train a horse without having some idea in your mind as to how you are going to do it. That is, about how much work he ought to have, what kind of work, whether fast or slow, on the track or on the road. IVhen you commence training a hor'se, make 
sure that you have a first-class man to groom him. This is the part of the training to which all successful trainers have given a great deal of attention. If a young man applies to $\mathrm{Mr}$. Doble for a position to rub a trotter he would liave to come as well recommended to gain the position as a man would to get a place of trust in a gentleman's banking house; and why should he not? When you place a trotter in charge of a groom you not only have the value of the horse at stake to a large extent, but you also have the money that you may have invested in races, either in entrance money or in wagers. No matter how well you train the horse or how carefully you drive him, if the groom, from ignorance or carelessness, neglects his part of the business you can not hope to have more than a partial success.

In selecting a groom, never under any circumstance take one addicted to drinking liquor. Their mode of life and temptations abont a race-track, will certainly make them drink more, and I have one absolute rule, and that is I will not keep a man abont me a moment after he has shown a disposition to drink. The more intelligent, the better behaved, the better dressed the groom is just so much better will he take care of your horse. People say: "That has the dress to do with it?" If a man is neat and tidy about his owu personal appearance he will be correspondingly neat abont his lorse and tools. Trainers and owners often make a mistake by thinking to employ a man with all those traits, honesty, industry, sobriety and brains enongh to be a good horse rubber, for small wages. That is impossible. I once knew a man who had a good horse and he told me with seeming pride that he only gave the boy fifteen dollars a month for rubbing him. The horse caught cold one day from being carelessly neglected by the groom, and the owner lost the use of him for that season. In talking the matter over with me he said he thought the boy should have known better. I told him he must not expect to hire a man to do much thinking for fifteen dollars a month. I have seen 
ormers trust an ignorant man with a $\$ 15,000$ horse where they would not trust the same man with a ten-dollar bill. Few people realizehow important a part the rubber occupies in training a loorse, or how many hours he has to be on duty. In the actual training season the rubber does not have one moment that he can call his own. A man that works by the day at ordinary labor puts in eight or ten hours, the balance of the twenty-four hours is his own. Not so with the rubber; he is on duty the whole of the twenty-four hours, sometimes having barely time to eat his meals. People say: "That has he to do all that time?" His duties are to take care of his horse, stable, harness, boots, blankets, sulky, whips and a thousand and one things that a man needs in training a horse. Then when the night comes, instead of going off and haring a good time with the boys, he has to stay in the stable and sleep in the stall with his horse for fear of fire and other accidents which might happen if the horse was left alone. I think such men as "Old Charlie," who took care of Goldsmith Maid; "Lucy Jimmy" ; Little Dave, who took care of Ralus and Johnston for me; Bill, the rubber of St. Julien, and a number of other men whom I conld name, deserve as much credit for the success of the horses they cared for as the men who drove them. No one realized this fact more than Mace; he took better care of his mbbers, gave them better wages and was kinder to his men than any other trainer that I ever saw.

The next thing in order is the tools to train your liorse with. Here again the trainel wants to be more than careful. Do not fill your stable up witl worthless traps that you have no use for, as the care of them will only take time and trouble. In regard to blankets. I often think they are a nuisance; not but that I think a horse wants a reasonable anount of clothing, hut I have seen horses in the hottest part of the year' with blankets enough on them to make them uncomfortable in winter. I lave seen the same horse in winter turned out in the coldest weather with nothing to protect him except his coat of hair-that's what I call the 
two extremes. My idea is to have a few blankets and have them made very light. Bandages are another thing which I think are greatly abused. Why a man will bind up a horse's leg with a flannel bandage and leave it there all night is something which I could nerer find out. If you try the same treatment on yourself and go to bed I guarantee you won't rest well. If your horse has a bad leg, attended with ferer and inflammation, a bandage saturated in some cooling lotion might have a beneficial effect in case it is not left on too long. I think that between heats in a race, or after severe work. if some light, stimulating liniment or wash is applied and the bandage is notput on too tight, it acts as a preventive against soreness in those particular parts.

In regard to harmess, almost every trainer has different ideas. A great many use what is called the single-strap harness. I have tried them and do not like them, as they are almost sure to chafe the horse. Thatever liarness you use be sure that there is none but the best of leather used in the making of it. Ion't buy a ready-made harness for your horse, as in that case nine times out of ten yon will not be able to make it fit him. If your larness-maker is a mechanic he can measure your horse and make the harness fit him as well as Joe Day, the "swell" tailor of Chicago, could fit Berry Wall with a suit of clothes. Be sure and have a good strong saddle and an extra wide soft girth, as there is where most of the strain comes on a track harness. Put some secure fastening on the check hook so that your check can not fly off; don't trust to a cork, as that will be sure to give way at the critical moment. The bridle, anotler very essential part, if with blinds, wants to set close to the horse's head. Have the holes punched in it close together, then you can make it fit well withont pinching the horse. Have the reins made the right length, and don't lave three or fonr yards of leather hanging down behind the sullky. Have the holders on the reins good length and wide, and be sure that you have them in exactly the right place, so that if the horse from any cause, either from breaking or otherwise, should 
take an extra hold of the bit yon are ready and in the right position to handle him with ease.

Now we come to what I call the mechanical part of the horse's training, that is the boots and shoeing. Here again I consider this a vital part of the ontfit. I man to be a good maker of horseboots has got to be a natural mechanic. It takes a very much better mechanic to make a boot to fit a horse properly than it does to make boots for the human race. There has been a great deal of time and skill expended by people in trying to invent boots to improve the speed of hor'ses, and of course out of all this amount of exertion we hare a few really valuable articles. A great many men object to boots upon a horse, say they are a nuisance, and that if the horse can not trot without them, let him go. A liorse may go for a montl or a year and never hit hinself, and then some day he may step in a hole or some other accident befall him, and for the want of a boot in the proper place ruin him as a race-horse. A good deal can be determined in regard to what boots a horse needs by his general gait and formation. No horse shonld ever be driven withont shinboots on the hind legs. Tery few, if any, horses can go without scalpers. I think it absolutely necessary that a horse should have quarter boots. We often have a great deal of trouble getting quarter boots to properly fit a horse. Unless they do fit you are apt to get your horse chafed and sore, and this will canse you no end of trouble. I find $J$. H. Fenton's No. 202 quarter boot very satisfactory in nost cases. Some horses wear knee and arm boots, a few wear elbow boots, and still others have to wear what is called a brisket pad, and if a horse shows a disposition to hit himself in any place the first thing to do is to have him properly booted. After a horse has hurt himself a few times he gets timid and won't try to extend himself. In having your boots made, use nothing but the very best quality of leather and work and be sure above all things, that they fit the horse that you want them for. Never undertake to train several different horses with one set of boots; if you do, it will prove 
unsatisfactory; it will be sure to spoil the shape of the boots so they won't fit any of the animals. If you do not live in a town where there is a first-class boot or harness maker and want either one of those articles, or in fact anything that appertains to a race-horse in the way of tools, you can write to Fenton \& Co., of Chicago, give them your order, and you will be sure of getting the best goods in the market, at a moderate price and with the least possible tronble

Next we come to the shoeing. So many older, smarter, better educated men than myself have written, lectured and said so much aboutshoeing trotting horses that I approach the subject with very little confidence in being able to give it any new light. Theories I find to be all very well in books, newspapers, lectures, etc., but when those same theories are put into actual practice they derelope some mulookedfor weakness which lets the whole strncture fall to the ground. The same I think, can truthfully be said in regird to shoeing a trotter. Any knowledge that I have in the matter I have gained from actual practice, together with hints and pointers from men like Mr. Robert Bonner and a few others I conld name who have made a lifetime study of the matter. The first thing to be decided upon is how little weight you can possible use in the horse's shoe to protect the foot and at the same time-balance the horse so he will be able to go at his highest rate of speed on a trot. What makes it more difficult than anything else to give rules to shoe a lıorse by is the fact that no two liorses can be shod alike. All horses are formed differently, gaited differently, and have different dispositions. In all the great number of horses that I have had I can not now remember of any two that I shod exactly alike. I hardly think that anyone ontside of an expert erer realizes how much difference it makes to a fist horse to make his shoes a couple of ounces hearier or lighter, but I know plenty of horses with whom to take off or put on two ounces on eacli forward foot wonld be enough to change the result of the race. Now if this is true, and I am sure that it is, the shoeing of the horse is of very great im- 
portance. In this connection toe-weights come in play. I would rather a horse would go without the weights than with them. The great trouble with toe-weights is that people use them when there is no necessity, and nine times ont of ten have them hearier than they need to be. I use toeweights a great deal; if I have a horse that has to wear over a fourteen-ounce shoe, unless he has an extremely large foot, I put on a toe-weight. I think there is less strain on a horse's leg with a very light toe-weight and a light shoe than there would be with the weight of shoe you would have to put on the horse without the toe-weight.

There has been of late years a good deal of attention given to shoeing horses with a pad made of leather or some other substance, and the practice has its opponents and adrocates. The first man that I ever saw use anything of that kind was Dau Mace. One of the strong arguments against a pad on a horse's foot is that it is unnatural to close up the bottom of the foot and keep the air and moisture from it. Granted this is so, it is not the only unnatural thing that we do with horses or ourselves. When I first saw a pad in use it struck me as being unnatural, too. I once had a horse sent to me for training that seemed stiff and sore, and at the first glance I thonght he had been foundered. I showed hin to Mace, and he said: "Bring him orer to my shop in Broadway and I'll show you what ails him." Upon arriving there with the horse Nace ordered his shoes taken off in front, told the blacksmith to cut out the rough sole in the bottom of his feet, and there we found what people term corns; the whole surface of this horse's foot was bruised and congested until it was about the color of a piece of liver. Upon examining his hind feet I discovered, much to my surprise, the same state of affairs. Mace ordered the horse sent to his stable, had his feet put in warm water for thirty minutes twice a day for three or four days, and at night he applied a poultice of boiled turnips and bran, having the turnips put on warm. When I asked him why he used turnips instead of oil-meal he 
replied: "Oil-meal would be too drawing, what you want in this case is something to cool the parts and not draw them." After a few days of this treatment he took the horse to the shop and asked me how much weight I thought he ought to have in his shoes. I told him sixteen ounces each. He turned to Charley Huie, the blacksmith (a man than whom no better friend the trotting horses of America ever had), and told him to make a pair of twelve-ounce shoes, and shoe my horse with leather pads. I watched the operation closely, and I think it has been of as much benefit to me as any one thing I ever learned abont training hor:es. After the foot was properly prepared and the shoe fitted, Huie took a piece of soleleather and riveted it to the heels of the shoe and trimmed it off the exact size of the shoe. Don't cut your leather smaller than the shoe; have it flush all the way around, then take a sponge abont as thick as your hand, and after covering the bottom of the foot with tar lay the sponge on and nail your shoe over all. As near as $I$ can remember that is about the way Huie treated this particular horse. He shod him behind in the same manner, and the result was so satisfactory to me that from that time on I tried it, and if there is any one thing about shoeing a horse that I stand ready to recommend to the public and horse trainers it is that mode of shoeing. You will find that in shoeing a horse with leather pads the shoes can be made from two to four ounces lighter than without. Then you take into consideration the fact that our race-tracks are made very hard and smooth, and see a horse that weighs ten or eleven hundred pounds going orer them better than a 2:20 gatit you may be able to form some idea of what the concussion to a holse's foot is. Some people use oakum instead of the sponge. I like the sponge best as it is more easily applied and keeps its place better. I have been asked how long I thought it could be nsed on a horse's foot without detriment. I have tried it on horses for years and never yet have luad one instance where I could find the least harm arising from it. If I have a horse whose feet trouble him 
much I remore the shoes as often as twice a month and sometimes even more frequently, and in that case try and give the horse a day off from his training, and if there is any fever or inflammation apply something either in the way of a lotion or poultice to counteract the ferer.

Among some of the notable instances where I have shod horses in this manner and proved to my own satisfaction that it was a benefit, I can name Johnston the pacer, Mimnie R., Fanny Witherspoon, J. Q., and that reliable horse, the book-maker's farolite, Protection. The most marked instance that ever came under my hands was Mambrino Sparkle. When I first saw this mare she had a record of 2:30. In watching her I noticed she showed a great deal of speed and for a big mare went with a short, jerky gait. I think that sometimes we are attracted toward horses the same. as we are toward people, without being able to tell the reason why; I know I was in this case and took an interest in Sparkle the first time I saw her. I watched her that year in her work and races, and while she seemed to improve in her record she was not, on the whole, a very satisfactory horse, going a good many in-and-ont heats. The next year I had a better opportunity to watch her and I noticed when the track was soft she would go fast and on a trot, and when she struck a hard track she shortened up her gait and wanted to rum a good deal. I made up my mind from this that her feet certainly hurt her. The next winter she was offered for sale and to the astonishment of all I induced $\mathrm{Mr}$. W. J. Goldon to buy her, not, however, until I had explained to him all about her feet, etc. The old heads were rery much surprised that Mr. Gordon should buy this mare, as it was known that he nerer wanted to own anything but filst-class animals. On taking Sparkle to Mr. Gordon's stable and having her feet examined I found them very dry and hard, a good deal of fever and inflammation, and she acted rery sore on them, and on having the blacksmith shape them, saw they were rery much worse than I had expected. I ordered her grain rednced to 
about one-half the usual quantity, and had Dr. Fair come out and look her orer for me; he gave her a conple of light doses of physic and a light blister for her feet, which treatment we followed and after the effects of the blister had worn off we poulticed her feet faithfully until the training season opened. TVe then conchided to use tips on her, and for the first two months of her training she was shod in that way, and I think it was a very good thing for her. I hardly believe that a horse can be shod in tips and trained and trotted over our hard tracks successfully. At this particular time I was more anxions to improve the condition of Sparkle's feet than I was to train her. Mr. Gordon has on his place a very fine working track, and on this I gave the mare most of her preparatory work. When I took her to the mile track, I had the track especially prepared so as not to hurt her feet. All this time I kept up a constant course of treatment for her feet in the wily of poulticing and soaking in warm water. I have heard a great many people sily that is a rery wrong idea, constant poulticing and soaking, but I notice that physicians frequently cut off a man's alm to sare his life.

I gare Sparkle a great deal of moderate work and occasionally brushed lier through the stretch. I was sure any horse that had trotted as well as I had seen her in the condition her feet were in would certainly go much better with her feet in an improved state. In working Sparkle I gave her most of her exercise to a road-cart, as I dich not want the weight on her back, prefering to lıare her draw it. In this case I was very fortunate in having a good boy to take care of her. His turf name was, I believe, "Gladiator Bill." I don't see why they called him this, as he was one of the most harmless and peaceable men I erer met, never spoke unless he was spolien to, and his attention to Mambrino Sparkle liad a great deal to do with her subsequent success. Before the grand circuit opened I took Sparkle to Pittsburgh and trotted her in a race in the $2: 19$ class, where she was a farorite over the field in the betting, but had to content herself with 
fourth money. After the race when I asked Mr. Gordon if he was disappointed, he said no, that he had never had a great deal of faith in her. I explained to him that I thought that race would put the mare on edge, and when she started at Detroit against the same field of horses I thought he would see a far different result. My prophecies prored true, as she won a well-contested race of six heats and trotted in 2:19. In this race she wore a ten-onnce shoe and two-ounce weight forward, with a leather pad and sponge, and a seven-onnce shoe behind. The reason I used the toeweight on Sparkle was that without it she scalped a good deal, with the toe-weight she carried her forward feet ont, of the way, and I thonght went easier to herself. Someone must have given Captain DeMass a tip on this lace, as it was reported afterward that he won handsomely. I was more than pleased with the mare, and felt sure that, barring accident, I would win my share of the money through the grand circ'uit.

From Detroit I took her to Cleveland, removed her shoes, jogged her about on the working track barefooted, and the day before her race had her le-shod, and drove her a couple of miles in about three minutes. I never remember of seeing a better field of horses face the starter than there was in this race. I never saw a harder contest on the part of the horses and drivers than here, and when I say that Mike Bowerman was there with his coat off and his walr paint on to drive J. Q., who had already shown a trial in $2: 15$, and half a dozen other horses able to beat 2:20 also in the lists, you would naturally expect a battle. I laid Sparkle up the first heat in which Felix won in about 2:19. After this heat I stood Sparkle in a tub of water as hot as I could bear my hand in, and gave her body a thorough fomenting with a bottle of George Pelrin's Body Wrash, after having it heated blood warm. I did this to get up a good circulation in her feet and legs. The second heat I laid her up again, and followed the same treatment after the heat. I don't think there was a man on the track that experted to see Sparkle do what she did in the 
next heat. There was a great crowd of people there and I asked Mr. Gordon to take a position where he could watch the heat all through, as I knew he always enjoyed a good battle and I thought he would see one. Bessie had captured the second heat in about 2:17, and everybody, including the plungers and talent, considered it a sure thing for her to win the race. In scoring for the third heat I changed my tactics a little and came up in the front lank. For this Mr. Edwards reprimanded me, threatened me with the usual penalty, and I believe did fine me once or twice. After scoring ten or twelve times they got the word. Sparkle and Bessie rushed away like two quarter-horses, and J. (2. broke in a wild attempt to keep pace with them. From there to the head of the stretch Bessie and Sparkle fonght it ont alone; Sparkle staid the longest and won the heat in 2:17, which is the fastest heat she erer trotted. Billy Button beat her the next lieat, and the race was postponed on account of darkness until the next day, when it was fonght out from end to end, Sparkle winning the eighth and ninth heats. To show that this was a more than ordinary contest, I will state that the nine heats in this race arerage better than $2: 20$, which is the fastest arelage in any one race of the same number of heats ever paced or trotted. Some of the horses which took part never were heard of afterward, and when you take into consideration the distance they must have gone in scoring from ten to fifteen times in each of those nine heats and the rate of speed that they went a part of the way it is not to be wondered at. After the race I took sparkle's shoes off, turned her out in the paddock for two or three days, re-shod her and took her to Buffalo, where she won a five-heat lace in the same class. She was not as good a mare in this lace, the severe ordeal in Cleveland having taken the edge off her to a great extent. The following week at Rochester J. Q. beat her in fonr heats. I gave Sparkle scarcely any work between her laces, contenting myself with musing and trying to allay the soleness and intlammation in her feet. At Utica the next week in the 2:19 class, the battle narrowed down 
to her and I. Q., the rest of their opponents having gone to the hospital. Neither one of them was at an edge, being sore, stale and short of speed. The public made J. Q. favorite orer the field. He broke and acted badly in the first heat, but after that they fought it ont, and it took all the afternoon to decide the race and in the last heat, after Sparkle had been driven to the best of my ability from start to finish, she did not beat the gelding over a head. 'This is the last race Sparkle ever won for me. At Hartford Arab beat her a five-heat race, and from there she was sent to winter quarters. While this mare was not born in the purple, nor fashionably bred, she proved to everyone by this campaign that she had all the qualities that go to make up the firstclass race-horse. She was about sixteen lamds high, a very handsome upheaded mare, very steady, a first-class breaker, and I drove her with an open bridle, long martingales and an ealsy bit.

The best time to commence to get a horse ready for the summer campaign is the previous fall. After a horse has closed a long and tedions spell of training if you expect to trothim the next year you do not want to neglect him throngh the fall and winter. If you bring him home poor in flesh, worn ont in his nervous organization, more or less sore and tired, pull the harness off lim, get a cheap boy who doesn't know or care anything to take care of him, and leave him in that condition until spring, and then have a good horse I shall be mistaken. My idea is to give the trotter a short run at grass through the pleasant days in fall, take him up every night, give him just as good a bed and just as much attention as yon would through the summer, and give him what grain yon think he ought to have. If he has any weak or sore places call in the veterinary and try and get them strong and well before spring. Now is the time to look after his feet. In the winter a horse's feet will not grow as well as in summer, so you may have to use some extra exertion in that direction. In regard to the amount of flesh a horse should be allowed to put on in 
winter, it all depends on the kind of a horse you have. If he is soft and washy and scrapes easily there is not much danger so long as you do not allow the flesh to get baked on him. If you give your horse a good field to run in and he is in good health and spirits he will take a great deal of exercise himself. As the weather grows colder leave him in the field only as long as he wants to stir abont. Give him thirty minutes in the morning and the same in the afternoon. If the ground gets hard put tips on him so he will not break his feet; weigh him about once in thirty days and then you will not be deceired in his condition.

As to blankets in winter, Ilike a comfortable stall and the less clothes the better. If it comes to a cold night and you think you want an extra blanket on your own bed, see that the horse has one. Keep everything about your horse and stable in winter just as clean as you would in summer. A horse is different from a hog, he never thrives in dirt. As to when you will take your horse up in the spring and commence to work him depends entirely upon what part of the season you want to trot him. If you think he will not be good enough to go through the grand circuit get ready and take in Michigan and Indiana for a little early corn. When you have made up your mind just what you want to do with him, then you should decide on your training ground-something very important in the Northern country, where at the best we have a good deal of uncertain weather in the spring. What you need now is good roads, early grass, good water, good stabling and a track that dries off quickly after the rain, and wherever that is take your horse there and train him.

There has been a great deal written and said for and against clipping horses. I myself have clipped at some time in their career all the best horses I ever trained. IVhen you take a horse up out of his winter quarters, he will naturally have an excessive coat of hair, his flesh will be soft, and with very molerate exercise he will sweat more or less. If the weather is cold it is impossible to rub him 
dry, and he may sweat off the flesh a good deal faster than you want him to. Under those conditions I invariably clip a horse, and the result has always been perfectly satisfactory to me. I clipped Johnston, Rarus. Fanny Witherspoon, Mambrino sparkle and a host of other horses that have been successful on the turf. After locating your training ground and getting your horses in shape to work, you must be controlled entirely by the dispositions, physical characteristics and other peculiarities of the animals which compose the string, and also what sort of races you expect to trot them. If you are going to trot them races of mile heats, three in five, or if you have a star performer and are going to give some exhibition miles, you will natulally treat them differently. A great many people give their horses all their work to a sulky. I do not. Every man shonld have in his stable two different weights of roadcarts; one strong enough to give work on the road with, and the other lighter to use on the track, for the reason that it takes the weight off the horse's shoulder's and back, and if his leg's are weak or sore, it will naturally relieve those parts. I have used rarious different carts in this work, among them that manufactured by IT. S. Frazier \& Co., of Aurora, Ill., and have found them the best, they being durable, with good rumning action, and easy on the horse. Other drivers have expressed the same views to me.

I do not beliere it is necessary to give horses as much walking and jogging as they often get. In preparing a horse for mile heats, speed is, I think, the element to be sought after. When you have hardened your horse's legs and body by road work you commence his work on the track. Be sure that you have a good track to work him on, and above all things do not work him at a high rate of speed in the mud. I have seen men take a horse out two days before his race and work him in the mud, and when the day of the race came and the horse had no speed they wondered what ailed him. Is good a man to copy after in this respect that I know of, is Gen. John E. Turner. Some people, seeing 
this title applied to Turner in the newspapers so frequently, have come to regard it as an empty one, but such is not the case, because if there erer was a Napoleon of the trotting turf Turner is the man. A leading characteristic of Thisner's methods in the conduct of a trotting stable is his care of the horses during every part of their preparation, and in the matter of working fast on a deep or heavy track he is as much horrified to see it done as the ordinary citizen wonld be at meeting the devil, horns and all. And to prove my statements abont him, I will say that Thrmer has taken part in every campaign since trotting has become a National pastime, and judging from the taxes he pays he has at least gotten his share of the money. When you see a man who takes a horse and campaigns him for three or four years you can rest assured that he lias exercised a great deal of care and attention in the matter.

If your track gets hard hire some man to harrow it, but don't work the horses on a hard track. In the spring, when the horse is soft, you can do him more liarm in five minutes than you can undo in the balance of the year. Nerer be in a hurry about speeding a trotter, give him plenty of slow heats. If he is any good when he gets in condition he will show you the speed. If you have a horse that has any peculiarities in the way of driving now is the time to orercome them. If lie is unsteady in company or a slow scorer, get out your old runner, set a day, and go to the track and give him a regular race. I do not mean to drive him as fast as he can go, but go down and score him up in company, and keep repeating it. I scored Fanny IVitherspoon a hundred times in one day - in fact, for a month I gave her all the work she had in scoring, and for my pains was repaid by making her a fairly good scorer. After seeing Orrin Hickok train St. Julien, I am sure that no horse lives tlat with plenty of time and patience can not be conquered. I think Hickok's training of St. Julien was the best example I ever saw of the persistent application of brains and bulldog tenacity in the driver against willulness and obstinacy in a horse that was 
known to be worth all the trouble taken with him, if only he could be made to obey the will of his trainer. And if Hickok had never trained or driven another hor'se my rerdict would always have been that he was a first-class hor'seman. In training your horse, dont give him the best of it all the time; try him in every position yon think he might be placed in during an actual race. Try and teach lim at all times to let yon do all the driving. If he is afraid of the rumner and tries to rush away, bring the runner to him carefully. 'The only thing I ever' saw in the shape of a horse that Rarus was afraid of was a runner. Hickok told me that St. Julien was the same, and for that reason Orrin always worked him witl a pacer. If your horse is particularly rank work him alone until you get the wire-edge off him, then take your prompter and show him that he is not going to be hurt.

Nerer try to do anything with a horse by main strength and ignorance. You can not make a good hack-horse in that way, let alone a race-horse. In training horses never try to do too nucls. I have leard men talk about training twenty horses, bnt that seems inpossible to me. The minute a man overworks himself he will get nervous, cross and irritable, and neglect some rital point and thereby lose his money some day. In training a horse a man has to nse his brains as well as his hands, and he had better train one horse well and have plenty of time to lay out his campaign, than to train a large stable poorly, leave tine door open some day, and let the boys get in on him. After you have given the horse his preparatory work and his body, legs and wind are in condition to move him along faster, hitch him to your sulky. I think that in this matter it is well to have two weights of sulkies, one to work a horse to, and one to trot him races in. Every driver has his own ideas about which is the best sulky. I myself have no delicacy in stating that I think S. Toomey \& Co., of Canal Dover, Ohio, make the best sulkies I ever saw. They sit the best, wear the best, and it is almost impossible to hook a horse to one 
of them in a manner to make them hit him. Toomey \& Co. made for me a forty-pound sulky strong enough to drive any ordinary horse to. In ordering a sulky tell your maker the size of your horse, the peculiarities of his gait, if any, how tall you are yourself, which will give him an opportunity to build you a sulky that will be comfortable for you and the horse. In sitting in your sulky you want your stirrups long enough to give you an easy position. If yon have your stirrups short it cramps your body and limbs in such a manner as to make it hard work for you, and if the horse pulls the least bit, you are at a disadvantage. Never throw your weight on one side or the other of the vehicle; distribute it as evenly as possible over the whole. Never use a sulky after it gets old and worn out, as it draws hard and yon are liable to meet with an accident which will cost you both your life and money.

In training horses, always lave some fixed plans or rules and train them according to those rules until you are satisfied you have found out some better ones. Never train him in a haphazard way, as you will find that horses are like men, creatures of habit to a large extent. The old-tashioned idea of guessing how fast you are going has gone ont of date. I train my horses with a watch; it is a good thing for the horse and the driver too. It teaches the driver to be a good judge of pace, which is a very essential thing in a race and a very vital point if you ever have Mand S., and want to beat the watch. Don't be satisfied with any cheap watch or timer; go to some first-class maker like Giles Bros., of Chicago, tell them what you want and what you want to use it for, and they will furnish you with something that will help you train your horse right to the letter. TVhen I decide just what work I want my horse to have, I go about it with just as much care and attention as if I was going to drive in a race for money. Never allow yourself under any circumstance to become careless. Remember that you not only want to train your horse, but you also want to keep yourself on edge. In these times when you have to contend with 
ten or twelve horses in a race, driven by the same number of active young men who are all looking for first money, you will find it very necessary to keep your right foot forward. at all times.

In working your horse, be sure and teach him to go on a trot, if that is the kind of horse you are training. At one time there was an idea it was a good thing to teach a horse to be a good breaker. Trotters always go best when they go on a trot. If you see a man working his horse and he is continually breaking in his work, you watch that same horse in a race and you will motice him doing it there. If on the contrary you see a man working his stable of horses and they are always on a trot you will find hin with his horses on a trot in a race. It is a difficult thing nowadays for a horse to make a break and win a heat. In the first place the judges are very strict, and if there is any doubt about it the horses which go on a trot generally get the benefit of the doubt. I for one believe the time will come when no horse will be entitlel to a heat if he makes a break in it, and I would vote for that now. In order to teach your horse to go on a trot at all times be careful and never let him break. If he should leave his feet don't snatch him to one side as if you intended to uncouple his neck, and never whip him under any circumstance. I think a whip in the hands of an ordinary horse trainer is far more dangerous than is a revolver in the hands of a school boy. If a man looks orer the list of his acquaintances who have been successful as horse drivers, he will find that as a rule they are men who are not much given to whipping their horses. A man who loses his temper and whips his horse in anger will never succeed. If you are not able to control yourself you will not make much headway in controlling your horses. With an intelligent man driving a horse he seldom breaks. A horse may hit himself, step in a hole or some uneven place and thus be made to leave his feet, and to whip him for it will canse him to break all the sooner the next time. After your horse has broken, take a gentle hold of him, attract his attention by speaking to him 
and almost instantly you will see he shows a disposition to want to catch. Most horses will catch better by swinging them slightly to one side. Find out which way you think the horse catches the best and every time he breaks pull him exactly the same way and use the same language to him, and an ordinarily intelligent horse will soon learn to look for it, and if there is any way for it and if there is any way to teach him to make a good catch I think that is the way. Always try to teach a horse to eatch on the inside rein, for if you were going round the turn in the lead and someone trailing and he should break obliging you to pull your horse on the ontside rein your opponent might slip through between you and the fence and beat you the heat where he wonld not be able to go round you and do it. Then too if you are head-and-head with a man he might, when your horse broke, crowd you in so close that you would be unable to pull him to the ontside without rumning into him, whereas if he caught on the left rein you would have no trouble. If you are fortunate enough to have a horse that is a first-class breaker never let him or make him break in a race unless it is a case of life and death. If he is continually breaking the public and judges will get down on him, and he will sometimes be punished when he does not really deserve it. Mambrino Sparkle was as good a breaker as I ever saw. In her campaign with me she made, I think, four breaks. One of those I caused her to make, and it won her the deciding heat of a race. I guess Van Ness remembers the circumstance. 


\section{CHAPTER XIII.}

Work a horse with the watch, but don't try to make him beat it-Doble and Goldsmith Maid-The pacer Johnston never worked out at top speedOne speeding each week is ordiuarily sufticient-Preparations for a raceDeportment on the track-How to talk to the judges-Laying up heats an important matter-How to drive after the word is given-A case of bad judgment in a postponed race-Shipping horses from point to pnint-The training and management of trotting stallions.

In working your horse with the watch never try to make the horse beat the watch; that is the hardest task ever set for a horse-or in other words do not try to see how fast you can drive him in his work. People imagine, when you have had some very fast horse in your stable, that you must have some day given him a wonderful trial. The best mile I ever saw Doble drive Goldsmith Maid, was 2:16, and when he did that he had her especially prepared for it. The best mile

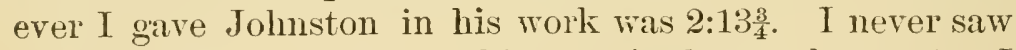
Hickok drive St. Julien in his exercise better than 2:15. I never heard of such men as Golden, Jock Bowen, Turner and that class of drivers giving their horses any wonderful trials. You may ask: "How do you know your horse is able to trot a good mile?" A good baker ought to be able to tell. whether his bread is baked or not withont having to cut it up and put butter on and eat it to find out. It is the same with a horse trainer-he should know about how well his horse can go withont stringing him out all the way. Every time you drive a trotter a mile against the watch as fast as he can go you discourage the horse. If he is the least bit out of condition you are liable to injure him permanently. If you keep repeatedly trying him and stringing him out to 
his utmost capacity, no matter how game he is, it will have a tendency to discourage him, and when you want him he will fail to give you his best efforts. Keep a little speed bottled up in him, never let him know just how fast he can go, and when it comes to a case where you need it he will make a better effort for you than he otherwise would.

After you have given your horse all the working miles you think it is necessary for him to lave and you are thinking about getting him ready to enter in races, my idea is to give him all his fast work then in the form of a race-that is to set a day, have your track and everything put in order, make up your mind about what you want to do with him, how many miles he ought to have and how fast he ought to go, whether you want to score him or not, etc. My advice is to always score a horse; that is the first thing you have to do when you go in a lace, and if you do not teach him that in his work, you are at a disadvantage when you start in a lace. If you have a horse that has any wealnness in his legs, instead of driving that animal at a high rate of speed to condition him drive him slower and farther, or to explain it, instead of driving him one mile in 2:30, drive him a twomile heat in 5:20, that would be each mile in 2:40, which would condition his body and help to strengthen his weak legs, where a mile in 2:30 might strain the legs and retard his training. It is not the distance that a horse goes that tires or strains him; it is the high rate of speed. Then you have decided how fast a mile to give your horse and how fast he ought to be sent each quarter of it, then drive him there and take pains to see how close to the mark you can go each time. I have seen men go out and drive a horse five or six seconds faster than they intended to. If I sent a man out to drive one of my horses and he should make such a mistake as that he would lose his position. I might for'give him for driving his horse too slow, but never for groing too fast. In being careful in training your horse not only will the horse do well but you will make a very much better driver of yourself. 
After you give your horse his day's work, you then decide what work he needs and when he ought to have it again. I think a day's work like that given him once a week, with modelate jogging the balance of the time and a little opening-out the day before you want to work him again will be all that will be necessary for him to have. I hate to have a horse continually worked without regard to system or time, as in that way you nerer know just how much work you do gire him. The nearer you get to your race, the shorter work the horse shonld have; that is, instead of giving him four or five heats, give him two or three, with occasional brushes at nearly the top of his speed. If you have a horse that is dull and lazy, don't be continnally clucking and whipping him along. When you do speak to him, give him to understand that you do mean just what you say. When you work such a horse have plenty of company. Give him a little the best of it. Give him the lead the most of the time, and don't let the other horses out-trot him. In that way you will encourage him and he will take more interest in his work. If I have a horse that has a bad leg, or in fact almost any other weakness, the day after his work I give him absolute rest and put in the time doctoring the weak place. In that way yon will be able to keep the inflammation and ferer, if there is any, subdued until the leg becomes strong again. If you have a horse that you expect simply to trot exhibition miles, de will not need nearly as long and hard work as a horse that is going to trot in races of mile heats, three in five. When I train a horse for exhibition I train him for speed alone, as I have found that an ordinarily game horse, if he is conditioned to go a quarter of a mile at the top of his speed and properly rated, onght to go a good mile.

I think there is no place where scientific driving counts for more than in trotting a horse against the watch. The watch never makes a mistake, and if you have a close race with it and you make one that costs you the money. A very good way for a beginner, I think, is to keep a memorandum 
of all the work he does with his horse. I think the tendency of most people is to overwork their horses-that is, they give them too much work at a high rate of speed. If you confine yourself to a working gait it will be almost impossible to orerwork a horse. I have often worked horses seven or eight heats in one day, but perhaps none of them was within twenty seconds of where the horse could go at his best; in that way yon will get him strong and not strain or sore him.

When yon have arrived at the time to start your horse in the race there is a good deal to be thonght of. The first thing to find ont is what chance, if any, have you to win. This you can only determine by a careful study of all the other horses and drivers and having a correct line on your own. It is not a bad idea to have some good man watch the other horses, if you can not do it yourself. If you conclude that you have a chance, I am not going to advise you to bet on your horse, that's entirely outside of training, although I occasionally put a little money on my horses when I think well of them. When the bell rings for the race, be sure that yon are on hand to get the word. Have your horse well harnessed and well shod, and it is not a bad idea to have his shoes examined the morning of the race to see that they are all in proper place. When yon go to the track take everything in the way of tools that you think you can possibly need. Take plenty of good help to take care of the horse between heats.

Here is a very good time to pay a little attention to your own personal appearance. I believe that to be well dressed is a dnty every driver owes to the public, as the people pay to be pleased and I think to see a man badly dressed certainly detracts from their pleasure. There is one other thing that the driver will find of great importance, and that is the judges' stand. My plan is to see how well I can get on with the judges, for they often judge races that are so close that a very little thing will decide for or against you. I think no one understood this part of the business better 
than Dan Mace. He never disobeyed orders unless it was a case of life and death. Never make a complaint to the judges unless you think it is going to do you some good. If you have a complaint to make never do it when everybody else is talking; be sure that you have the judges' undivided attention, and then make your statement, and always remember that, everything else being equal, the driver who makes the last statement to the judges has the best of it. I think it a very good idea to be on good terms with the public. I mean that part of the public who pay their money, take a seat in the grand stand and are there for amusement alone. I myself, do not take much interest in the few professional people who go to the race-track to gamble. They generally squeeze in without paying a cent and imagine that they are the only ones whose interest ought to be looked after. They are willing to go to the stable and arail themselves of information that they know we do not want them to have. They, as a rule, have no regard for the rights of trainers, owners or anybody else. And the less a driver has to do with that class of people so much the better he will be off, both financially and otherwise. There are some men who go to a race-track and bet their money in an honorable and straightforward manner. Their word is as good as gold. You will never have any trouble with this class because of their obtruding themselves on your private affairs.

As a rule I decide to lay my horse up the first heat or two. Here is something that the rules say you have no right to do. There has been a great deal written and said on the subject, but I insist from my standpoint that every man should have the right to lay his horse up, or drive him in any manner that he sees fit, providing that at all times he is driving at the best of his ability to win the race. I do not think that any man should have the right to lay his horse up for the sake of beating the pool-box or playing the books, bnt if in his opinion, he can win an easier and safer race ty laying up, he should have the privilege 
of doing it. If a horse gets a bad send-off and you are compelled to drive for the heat when you know you have no chance to win it may cost you the race then and there. It has for many years been the custom that a man always had the right to lay up when he thought best. I can look back and see where I have won some of the best races of my life by laying up, where I know I would have lost had I gone about it in any other manner. In driving a heat no rules that a man could lay down can make you win. You may get some hint that will do you good, and the best way to do that is to carefully watch every good driver that you see and learn his methods.

If you clecide to lay your horse up the first heat, there is some method in even that. You need not be particular about rushing off in the lead, nor yet would I go off too far behind, as in that case you would lose so much ground in the start that at some time in the mile you wonld have to drive along much faster than you ought to save your distance. Of course if the distance is 150 yards that gives you a long leeway. I have seen men go out to lay up a heat and lay it all up in the first half-mile and then have to drive the last half as fast as they could, and in that way make the heat as hard on the horse as thongh they had tried to win the heat with him. The proper way, I think, is to lay up so much in each quarter, and while you are laying. your own horse up, try and keep your eye on everybody else in the race. There may be some other man doing the same thing. By this time you have probably decided which is the best horse in the race. If so, don't waste your powder shooting at lame birds but keep your eye on what you really think is the best horse. If you fancy there is a chance of anyone else giving him a corking heat don't be afraid to lay up and take the chance. After you have laid up two or three heats and you can't win then you may rest assured you could not have won had you made a fight from the start. Remembel one thing always, that a general will win more races than any man can by main strength and 
ignorance. I never saw a man that could go in a heat and drive against eight or ten people, handle his own horse well and come back and tell you what all the others were doing better than Mace could. He also had a way of making everyone believe he was driving all he could sometimes when such was not the case. In that way he found out at great deal about the other horses and kept their drivers in the dark about his own.

There is one thing a driver should always remember, and that is that in driving a horse his first duty is to the owner and his interests. After driving a heat if you have any information that you think he would like to know let him be the first to know it, and from you. In that way you relieve yourself of a good deal of unnecessary responsibility at certain times. After the heat is over take personal charge of cooling out your horse. If you want any information as regards the betting or anything else that may arise get someone else to do all that for yon and give your undivided attention to the horse, as I consider this one of the vital parts of success in racing. Not only see that your horse is properly cared for but also that your harness and boots are properly cleaned, as in that way you may often prevent a horse from being chafed and sore. The oldfashioned method of rubbing a horse sererely between heats is entirely out of date. Never allow a man to rub a horse in a severe manner, as that hurts the horse more than you can imagine. It will make his skin so sore that he will want to fight if you look at him, and the time that he should be resting he will spend in kicking and fighting the boy. The better plan is to rub him but very little and then with soft cloths. Use just as few blankets as possible. I conld never see any reason why a horse after trotting a serere heat should be loaded down with heary blankets and compelled to perspire in a manner that will certainly make him weak and dill. If you trot a horse five or six heats in one afternoon and force him to sweat very freely every time you will have him very much weakened by night. If your 
horse is inclined to be sore and stiff in any way and hard to warm np you will find that warm applications of stimulating liquor to the body and legs will have a very benefical effect. Standing a holse's feet in warm water I have found a very good thing. A great many horses alter a severe heat will get corded in their muscles. After this has happened once it comes on very much easier the next time. If you have a horse subject to this the more you keep him moving about on a walk the less liable he will be to be taken. Blankets wrung out of warm water and laid across his back and shoulders are very good at such times. The best thing I ever tried for this is a quilt filled with hops. Have it wrung out of hot water and laid across the horse's shoulders; this will often give relief when nothing else will. Severe work at a high rate of speed when a horse is not conditioned for it is almost sure to bring on this state of affairs. If you know your horse has a werinness of any kind the safest plan is to always use a preventive, as they say "am ounce of prevention is worth a pound of cure," and I think in this case it is true.

Be sure and be ready when the judges ring the bell for the second heat. Don't keep the people and judges wait. ing for you as that gets everyboly out of patience. If anything should happen that you are obliged to have a shoe lemoved or any other reason why you can not be there when they ring the bell send word to the judges what the difficulty is and ask them for time, which they will always willingly grant. By this time you will have your mind made up whether you are going to try to win the second heat or not. If you decide to go for the heat and you should get a bad send-off or your horse make a break under no circumstance persist in trying to win the heat. You may win it but the chances are that if you do yon will so have pumped your horse out that it will cost you the race. In driving a lheat never forget that a mile is a long way for a horse to go at a high liate of speed. If you brush your horse a quarter or half at anything like the top of his speed 
that is as far as you can naturally expect him to go. If yon do not give him a breathing spell he will either breali or slow up, two things you want to aroid. I think the safest plan is to keep a little power and reserve speed in your horse until the last struggle, then drive him in a manner to try and get his very best effort, and the chances are that by this time your opponents ale pretty well trotted out, and if you do not win you will have the satisfaction of knowing you have made the very best effort nnder the circumstances. If after you win a heat or two in a race and find your horse distressed and no other horse that looks dangerous has two heats, be sure and lay your horse up for one heat at least. You will be surprised what a relief it will be to him, and if he is anything like a game horse he will come back with renewed rigor' and make a good fight for the money.

In scoling your horse you can save him a good deal by keeping a sharp lookout for what the chances are for getting the word. Never score him any more that is absolutely necessary. If yon score a horse fifteen or twenty times, as I have often seen done, it will distress him more and tax his strength to a greater extent than it would to trot a heat. Be very careful in a leat about going out wide on the turns. If one man lias the pole and the other is out in the middle of the track and goes around both turus of a mile track in that position the pole horse would have five or: six yards the best of it, which would gire him the heat to a certainty, barring accident. I think it much safer to trail around the turn and take the chance of getting through on the straight side. Never run into an opponent willfully or do anything to him that you would not be willing to have him do to you under the same circumstances, but if anyone undertakes to crowd or interfere with you in a wrongful manner do not have any delicacy about trying to make him take his place. I consider it a rery bad thing lor a driver to get a reputation of allowing people to push him abont, as there are always plenty of men willing to take advantage of you 
if they think you will stand it. Give them to understand that you know what your rights are and that you are bound to have them at any and all times. In that way you are not liable to have much trouble with the boys building fences to try and stop you from going through, etc.

If it comes to a long race and it is postponed from darkness or any other calise you will find there is no time in your experience where good care and attention will count for more on your horse than right here. After having him properly cooled out and in shape to feed after the race, if he is a delicate feeder give him anything to eat or drink that yon think will stimulate his appetite. If he will not eat get your veterinary to give you something for him in the way of a tonic. I have often seen horses given eggs and milk in a case of this kind, with a lit tle stimulant added in the way of whisky or wine. If the horse is a good feeder give him what you consider a fair feed of oats and hay, and plenty of water; the following morning hare him led out at the end of the halter in the grass and dew and let him have some grass to eat. Thirty minutes before the time for the race to be called take him ont and jog lim two or three miles moderately and give him a slow working mile. The great trouble with people going out to give a horse a slow mile is that they drive some parts of it too fast and do not rate the horse properly. I remember of seeing one of the star performers in a postponed race badly handled in this respect. The driver took her out and in warming her up drove her a quarter in thirty-two seconds on as hot a day as I ever saw on a race-track. I concluded to watch her closely in a race and see what the result wonld be. In the first heat she led the first seven-eighths of a mile, then stopped and was beaten ont by all the other horses. As I looked her orer after the heat she was greatly distressed in wind and limb and I was satisfied at the time that the quarter she got in thirty-two seconds caused her to lose the heat. If you start in a postponed race and none of your opponents has two heats you will find it a pretty safe plan to lay up a 
heat there. As a rule most men rush ont and try to win the first heat in a postponed race. I have tried laying up a few times, and always with good success. If you are in a race and have no chance to win see how careful you can be with your horse and how little use you can make of him. In that way he may be good enough to win the next race where he would not be if you gave him a bruising contest in which he had no chance to win. Nerer talie a chance of straining your horse mnless you are obliged to.

While trotting a race if the track lias become muddy be sure and have on yonr mud shoes, which ${ }^{-}$you should always have fitted to the horse before you start on your campaign, and in that way when you need them you will need only to have them nailed on, which any blacksmith can do with little trouble. Always be sure to have in your ontfit blackismith's tools enongh to take off or put on a shoe at any time; and also hare an assorted lot of Putnam nails. They have been thoroughly tested and have proven themselves without a doubt the best nails you can use. You may think that the nails in a shoe do not amount to much, but if you use one or two worthless nails they may break off, and if the horse loses his shoe in the deciding heat, you will be very apt to lose your money along with the shot.

Do not be afraid to give your horse plenty to eat during a long, hard race. I do not think that at such times hay does a horse much good. He wants something more stimulating. To my mind oatmeal gruel is one of the best things I ever tried. A couple of hours before the race talie your oatmeal and pour boiling water on it; then let it stand until it is thoroughly rooled, and in that way you will get all the strength ont of the oatmeal and secure a very pleasant drink for your horse. I think a few oats between heats very good for horses. The best thing in the way of a stimulant I ever tried for a horse was champagne and Seltzer water. 'Take a pint of champagne and half a pint of Seltzer' water; give that to your horse when he is tired and you 
will be surprised what an effect it will have on him. I gave this drink to Mambrino Sparkle very often in those long, hard races she went. I think whisky and heavier liquors given to a horse oftentimes lave a bad effect. Some people give a horse a shower bath of cold water in case he shows extreme distress from heat or other canses. I lo not like this treatment, and think it is very dangerous. My plan in case a horse is clistressed in his wind or any other canse and does not scrape ont freely is to give him a sponge bath with warm vater of the same temperature you would use on yourself for a sinilar purpose. After scraping the water out of him as much as yon can, have some stimulating liquor warmed to the same degree of heat as the water and give the horse a thorough bathing with it. In using washes for a horse's legs or body be very careful you know what you are doing. I have seen a great deal of this so-called wash used that I am satisfied does more harm than good. There are two things that I have nsed with perfect satisfaction: Pond's Extract and Perrin's Body and Leg Wash. I find there is a great deal of comnterfeit in the Pond's Extract which people peddle abont and sell becanse it is cheap. Don't use it if it is given to you for nothing. After your race is over I think it a good thing before you move on to the next town to give your horse one day of absolute rest if possible. Feed him modelately, have him either led to the halter or turned ont into the paddock if you can, but do not put the harness on and give him a day's work. What he wants more than anything after a race is a chance to let his nervous organization get back to its nomal condition. While he is having this day's rest if there are any soles or weak places about him you will have an excellent opportunity to nurse and doctor them, and by so doing he will not look at the end of the campaign as if he had come from the Russian war instead of the hands of a horse trainer.

And now in regard to shipping. Years ago this was looked upon as a matter attended with a good deal of danger, but in these times with our improved railroads and 
cars there ale very few accidents considering the number of horses being shipped about. Never ship a horse in an ordinary freight or cattle car, for several reasons. First, if you meet with an accident, the car's will break up like so many dry-goods boxes. There is no way of rentilating them, and to put half a dozen horses in an ordinary freight car on a hot day will do them more harm than you can undo in a month. Some of the wealthier owners have private cars built expressly to ship their stables in. This is the most convenient and comfortable way. The Arms Palace Car Company of Chicago have met a long felt want with horse shippers by constructing a line of cars on scientific principles expressly for that trade. Their new cars built solely for trotting and race horses are a mirvel of comfort and strength. A trainer can hire from them a car by the month at a very moderate price, and it is large enough to transport his horses, wagons, sulkies, men and baggage and whatever feed it is necessary for him to have. The rentilation is perfect and there is capacity for carrying plenty of water for the horses, which I think is a very essential thing, as in going from one part of the country to another, and using different kinds of water is almost certain to have a bad effect on the animals. Especially is this the case if they have any chronic disease of the kidneys.

Always ship your horses by passenger train. The difference in expense does not amount to anything in comparison with the wear and tear there is on your horse in being jolted orer the country in a freight train. In getting ready to move take everything you actually need, and no more. I think it a grand thing to take oats and liay enongh to last ont the campaign. When you go to a strange town you may have tronble in finding the best hay and oats, and if you have to feed your horses something that is poor it will be sure to have a bad effect on them. It is an easy matter to have your hay put up in small bales so that it can be handled without any trouble and a few of these will last an ordinary stable of trotters some time. When it comes 
to the oats I do not believe in feeding extra heavy ones. I think oats weighing thirty-two pounds to the bushel are more easily digested, and you are less liable to overfeed the horse than you are with heavier ones. Never keep your feed where it is liable to absorb any unpleasant odors, as grain, hay and water will rely easily berome affected from this cause. I think horses are often affected with malaria and other kindred diseases the same as the human race and from the same canses. You train a horse at a race-track where the trainers and grooms all have the ferer and agne and yon will find it impossible to bring him to anything like perfect condition. In honsing yom oats keep them in a clean, dry place. Be sure that no rats or other animals get a chance to run orer them, becanse if they do and your horse is the least bit delicate it will get him off his feed. I have attached to my granary one of Cleares \& Co.'s patent grain separators, which is an invention that I think no stable should be without. If you want to find ont how much refuse matter will be stored in a hundred bushels of oats, rum the oats through this machine and I think you will be surprised at the result. In loading your traps wrap your sulkies with cloth so that they will not scratch or mar. Have yonr stalls nicely bedded down with clean sawdust, then back your horses into the stalls and tie them each way. Have your stalls about fire feet wide and seren or eight feet in length, and store your baggage in the car where it will be ont of the way and not liable to canse harm shonld your car meet with accident. Alrays have a car that has two sets of doors on each side and nerer under any circumstances block np the door's, as if your car takes fire or if you get tumbled down a bank you want to be able to get ererything out at a moment's notice. In traveling keep your car cool; at the same time do not let a horse stand in a draft, as it does not take long to founder a horse if he is in that position. Give the animals all the water they want, and be careful and not orerfeed them, particularly if you are on a long trip. The worst thing about shipping horses 
is the want of exercise. A horse that is used to being exercised every day, if made to stand still for any great length of time and orerfed wonld be nore or less liable to congestion and other difficulties. Some horses are tronbled with swelling of the legs. Here I think the bandatge is more useful than in any other place. Have some nild, cooling lotion, keep your bandages wet with ice water, and have the legs moderately rubbed by hand. I think this treatment will go as far toward keeping the legs in a noimal condition as anything that can be done. If a horse is in first-class condition and sound every way he can stand a heap of railroad travel. To show how little effect it will have on some horses, I took Rarms to California the fall of 'rs and in less than forty-eight hom's after lie arrived there trotted him an exhibition in which lie went the first mile in $2: 14$ and repeated in $2: 14 \frac{1}{4}$. I think you want to be careful about giving your horse any rapid work slortly after coming off the cars. I find there is more danger of their becoming corded in the muscles after a railroad trip than at almost any other time. Remember also that at horse gets a certain anount of work in a car, the constant motion of the train acting upon the muscles will sometimes key a horse up more than a severe day"s work. If you have your horse in good condition, trot him a race once a week, ship him from one town to another, you will find there is no possible chance of his being short of work. The season I had J. Q. I trotted him from Detroit to Hartford, and the fastest working mile he got in all that time was 2:35. I occasionally brushed him through the stretch a $2: 25$ gait, and with that kind of work he made the star performances of his life. In warming a horse up for a race and you find him sore or tied up from any cause, don't be afraid to give him al couple of slow heats. If you have a horse that has a habit of throwing his head in the air when he breaks, or at other times, do not make the mistake of putting short martingales on him, or, what some people use at times, a standing martingale. With his head checked up with an 
over-check and short martingales you have him in a position to torture him without any relief. The best plan in this case, I think, is to put what we call a standing halter on him. Have a halter made to fit his head, and fasten your standing martingale into that instead of into the bit. Have your martingales, if you drive him with any, long enough so they will not cause any friction on the rein or bit when the horse has his head in a natural position. Never check your horse with any patent springs in the check. $\mathrm{He}$ will be apt to get in the habit of teetering his head up and down on the check in a disagreeable way. Always remember in training and driving a trotting horse that the horse stands to you in the same position that a merchant's bank account does to him. Every time your horse makes an effort for you you make a draft on your bank account, 'so it stands you in hand to be very careful how you draw on the horse's strength, and use every effort at all times to protect him in every way.

Trotting stallions have generally been considered rather uncertain track performers. With few exceptions I think this has been the case, especially where they have been used for breeding purposes before their racing career began. The only gennine race-stallions that I call to mind now are Hannis, Wedgewood, Director, Jerome Eddy, Monroe Chief and Phallas, these six haring in their time gone through the grand circuit and showed the ability to win a majority of their races in some one campaign. They were all notably gime horses, but as two of the lot are by one sire it may be well to allude to them somewhat in detail. These two are Director and Phallas, one with a record of $2: 1 \%$, while the

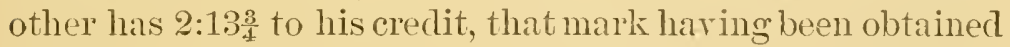
in the fourth heat of a race against other horses, while the record of Director was made in one of the best contested battles it was erer my good fortme to witness. These two stallions I consider first-class race-horses, and I think I know whereof I speak, as they both made their best records in races where I was a contender. Both of them are by Dicta- 
tor, a stallion that, both on account of his superlatively good breeding and the remarkable performances of his full brother Dexter should nerer have been neglected during the best years of his life, as he certainly was during the seasons he made in New York and the first part of his career in Kentucky, this neglect being so marked that at the time he was thirteen years old he had sired barely a dozen colts. But when Director, Phallas and Jay-Eye-See came out in one season Dictator attained a fame equaled by that of no other trotting sire of the day, and the extreme speed, racehorse qualities of his get were the theme of conversation among horsemen and breeders. I think that Jay-Eye-See is one of the best examples of intelligent breeding I have ever seen. As conservative a man as $\mathrm{Mr}_{\mathrm{r}}$. Doble told me, after driving him a losing race that he was the only horse he had ever seen that put him in mind of Dexter, and he was very positive that sooner or later he would beat ever? record that lad been made by a trotting horse, which subsequent events amply proved. His performances, as well as those of Phallas and Director, greatly increased the value of his sire, and Dictator has for several years stood at the highest fee of any stallion in the land: $\$ 500$. He is the property of Maj. H. C. McDowell \& Son, who also have on their historic farm, "Ashland," the stallion King Rene, a son of Belmont whose get are entering the 2:30 list every year, while their beanty of form and elegance of carriage have gained for them and their sire the blue ribbons on many occasions where the bluest blood in the land was shown against them, and for several seasons, when the McDowell farm made a specialty of these show-ring exhibitions King Rene and his sons and danghters were easily victorious over all competitors. In the race where Director made his record of 2:17 I drove the bay gelding Wilson against him, winning two heats and making a dead heat with Director, giring Wilson that day a record of $2: 16 \frac{1}{4}$. This horse was by George Wilkes, a horse that had been owned during the major part of his life by mỵ old-time 
friend and patron 7 . E. Simmons, who was, at the time of which I write, enjoying the ease and comfort of a breeder's life at Lexington, Ky., where he has gathered about him some of the most notable sons of the brown stallion that he lored so well and that won so many races for him.

And while on the subject of trotting stallions I want to say something about one that attracted my attention in a marked degree the first time I ever saw him, and that I then and there predicted would some day in the near future prove himself one of the fastest and best in the country. This horse is Jerome Eddy, and he is also another example of the truth of my argument that great horses, like poets, are born, and not made. The first time I saw Jerome Eddy was at Jackson, Mich., where he took part in a lace against some of the best horses in their class of that day. As I sat mnder a tree with my friend Don Robinson watching a heat that I luad no financial interest in in a lazy sort of a way, I saw a large bay horse pnil out of the ruck on the extreme ontside of the track and go by his field of horses in abont the same manner that Rarus would have done. Not knowing the horse I asked Mr. Robinson what his name was, and he replied that it was Jerone Eddy, a horse that belonged to a couple of farmers at Owosso. I remarked that the Michigan famers had what Bill Wroodruff called "a sure enough trotter." I was so much interested in the animal that after the heat I went to the stable to get a closer look at him, and found a bay horse about sixteen hands ligh with feet and legs that looked as though they had been made to order, with a head shaped well enongh to have been the central figure of an oil painting. The following week I saw him in another race, and his performance there only served to increase my good opinion of lim, and before the season was over I had the pleasure and satisfaction of having my judgment verified by Jerome Eddy obtaining a record of $2: 16 \frac{1}{2}$ in a contested race against one of the best fields ont that year, and it was the opinion of most people who saw the race that he conld easily have beaten the best 


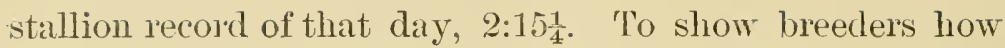
the fact of having a horse developed will increase his value, I may say that when I first saw Jerome Eddy his owners asked for him. I think, about \$5,000. After he obtained his

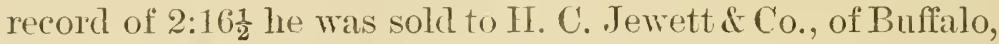
N. Y., for \$2., 000, and is to-day at the head of their great breeding estaklishment. The liessrs. Jewett are firm in the belief that early maturity means early decay, and with this idea in riew they have not trained their colts while young, thinking it better to give them an opportunity to be fully developed in their physical structure before they are asked to show their best syeed. From the standpoint of a man who makes his living by the lacing of a trotting horse they have adopted, I think, the surest plan to raise a family of race horses. Of conrse if a man wants a fast colt the way to secmre this is to begin training him early, but all our best campaigners have been holses that were not phenomenal as speedy youngsters.

Trotting or pacing horses with a running mate has never taken a very strong hold on the public. It seems to have been always rather spasmodic. About once in so often there comes along a horse that proves himself to be able to go well with a runner; then we hare a few races of that sort and then it dies ont again. The first race of that kind that attracted anything like widespread attention was the one between Ethan Allen and Dexter. At this time Dexter had shown that no horse lived that could give him a race. He had demonstrated his ability to beat all comers one, two and three mile heats in harness, to wagon and under saddle, and his owner was looking around for new worlds to conquer. At this time Mr. E. Z. Simmons owned Ethan Allen, and declated himself willing to match Ethan to go with a runner against any horse in the world in harness. The race was made with Dexter and the public said that Mr. Simmons had overmatehed his horse. For once the public was sadly mistaken. Mr. Simmons placed the horse in Mace's hands to train and drive and said: "Dan, you train him and bring him 
to the track in condition the day of the race, and I will make it the best day's work that you have ever done." Ethan had been used on the road for a long while and Mr. Simmons had always said that he had never had a horse with him that conld rum as fast as he could trot, and was sure that with a good running mate he conld go a mile close to two minutes. Mace latd for a muning mate Charlotte F., a thoroughbred bay mare about fifteen and one-half hands high, that he bought from Dr. Weldon. In appearance she did not have much of the thoroughbred abont her, being rather a strong mare on short leg's with a good deal of bone; went with her head rather low, conld trot a three-and-a-half gait and run a nile in harness close to two minutes. Her' disposition was perfect. She was withont exception the best horse of that kind I have ever seen. I find that most runners get rank and want to rush off after being driven a few times. When this lace was made I consider that Mace was in his prime, and with a backer like Mr. Simmons he had the nerve to try anything. In talking the matter over one day with Mr. Simmons in my presence Mace made a remark that I never forgot. Mr. Simmons was cautioning him about training Ethan when Mace remarked: "Never mind Ethan; have the runner in good shape, as he is the one that has got to do the work," and went on to say that a man might as well undertake to run an engine without paying any attention to making steam as to try to win a race of that kind without having his runner in first-class condition, and I doubt whether or no in all his active life he erer said anything that contained more facts in the same number of words than that.

I will describe as near as near as I can how Mace trained and drove his team in the race. Ethan was a horse that did not need a great deal of work, always seeming to have his speed, and Mace worked him in single hamess a great many slow miles. After he had his leg's and body thoroughly hardened and in shape he would occasionally hitch Ethan up with a runner and brush him a little better than a 2:20 
gait. He gave Charlotte F. stronger work, and generally after working her and Ethan together he would take her out to a sulky or skeleton wagon and drive her a good stiff mile, say in about 2:15, and occasionally he put the saddle on with a light boy and ran her through the stretch as fast as she could go. I think that one day I saw her mo mile in 1:50 with a boy on her. There are a great many trotters that when you hitch them to a running mate have to be shod heavier in order to be balanced, than they do driven any other way. That arises from the fact of the runner taking all the weight and dragging them too and going along at that tremendous pace, and then again the driver does not have the sime chance to watch them he would driving one horse alone. Ethan Allen was a perfectly balanced horse and needed no extra shoeing, and was the only one I ever saw that was a first-class breaker going that way rigged. While Mace was conditioning Ethan Allen and Charlotte F., $\mathrm{Mr}$. Simmons was not idle. In those times such well-known sporting men as John Morrissey, Harry Genet, John C. Heenan, Ned and George Maynard, Barry Cornell, Louis Burrell and a host of others that I could name stood ready to bet their last dollar on a horse-race that they thought well of. They, togethes with the owners of Dexter, thonght the horse did not live that could beat their farorite. In the betting Dexter was a favorite four to one. The public were anxions to back Dexter at those odds and Mr. Simmons was just as willing to back his horse and announced publicly that he would bet all comers, be they great or small.

Abont ten days before the race Mice, in a rather open way, told the boys that took care of the team to take them to the blacksmith shop, as he wanted to have them shod. But as it came ont after the lace, instead of going to the blacksmith shop with them they went to the old Union track where Mr. Simmons was waiting for them, and gave them a trial, and it was so satisfactory that Mr. Simmons went back to New York that night and bet everybody to a standstill. The result of this race shows how near a man 
may come to winning a great deal of money and yet not do it. Twenty-four hours before the day of the race Charlotte F. got cast in the stall and lamed herself in the shoulder and as the boys said "here was a pickle." At this time Jim Dougrey who has since made himself famous as a politician and a horse-driver and a good one at that, was a boy. He had in his stable an old brown horse called Brown George that he had been working with a runner that belonged to Fred Pence, a black horse that had been ridden in the war and had been carried North. But Dougrey rather condemned him saying that after going three-quarters of a mile he would quit, but as he was the best one in sight they were obliged to take him if any. The council of war between Mace and Simmons, Mace insisted in paying forfeit in the match and in that way having all the outside money declared off, saying that he would not trust all that money on a horse he knew nothing about. Mr. Simmons was anxious to have the race stand and go for all the money, but finally gave Mace his way and paid forfeit in the match and the outside bets were all declared off and they arranged to go for a purse given by the proprietor of the track. Everybody in the ricinity of New York was present to see the race, from Commodore Vanderbilt to the bootblacks, and in the betting after the new race had been arranged Dexter was the favorite at any odds, $\$ 1,100$ to $\$ 10$ being offered by his backers. Regardless of Mace's caution Mr. Simmons bet everybody that the team would win, and was the only man in all that vast throng that had the slightest idea that Ethan would win. That he did so is a matter of history, and one of the heats, done in 2:15, was the best mile gone by a trotter up to that time, any way rigged, and Dexter was timed separately in 2:16.

As Mace's system of hitching a trotter and running mate has never been altered much I will give it as I saw it that day. In hooking the team Dan's idea was to not only hitch the runner so that he wonld draw all the weight but have him able to also help the trotter along. He had a 
strong breeching for the trotter, covered with sheepskin. He had a wide girth made of strong canvas to go around the horse moder the harness saddle; made it with buckles and straps, so as to be able to girt the horse moderately close with it; had the saddle of his harness fastened to this girtli, and in that way he was able to girt it tight enough to keep the harness in place. From the breeching he had side straps to r'm up and buckle into the tug bnckles. He also had straps from the breeching run up and fastened into the choke-strap that ran to the neckyoke from the girth. 'To keep the breeching from getting up under the horse's tail, which it will often do when the animal is rigged in that manner, he had a steel shank made out of steel wire inserted in the hij)-strap, which went through the barkstrap over the holse's hip, all the way, except a couple of inches at each end where it bnckled into the breeching. This I find a rery good invention to use on a single harness for the same purpose. By hooking a loose in this way all the trotter had to do was to lay in the harness and keep his legs going, letting the rumner do all work.

In later days we have had some phenomenally fast time with pacers and rumning mates, as well as with trotters. With the pacers that way hitched the two star performers have been Westmont and Ninnie R. I have already told what the mare did while she was in my stable, and it only remains to say of Westmont that Johnny Campbell, now on

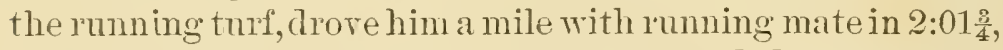
Peter Johnston taking him a little later and doing the distance in 2:02. Johnston came naturally by his ability as a driver of trotter's, haring been educated to it while a boy in Michigan, and since then las made a great reputation as a successful handler of stallions, while the good work he did with Bodine has been alluded to elsewhere. With trotters and running mates John Murphy and James Golden have been most successful of late years. For benefit of my readers who do not know Jimmy Golden I wish to say that I consider him well up in everything appertaining to a trot- 
ting horse. from the mbbing cloth to the judges' stand, as he is one of the old-time drivers who had to serve an apprenticeship at the business when a boy, and one of the self-made men of the turf. John Nurply is perhaps the most rersatile man comnected with the trotting turf, and in the matter of riding a trotter or pacer is unquestionably at the head of his profession. To begin with he was the first man to ride a trotter a mile better than 2:20, having performed that feat when a mere boy, the orcasion being

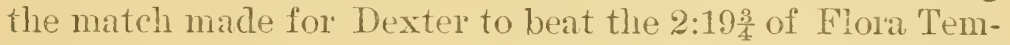
ple, then the best on record, and Hiram Woodruff, who was training Deriter, paid Murphy the compliment of selecting him as the jocky on this most important occasion. In a previons chapter I have told how Mnrphy rode the pacer Billy Boyce to his record of $2: 14 \frac{1}{2}$, a mark that never was beaten until last year.

IThen trotters and running mates were in fashion a few years ago, Murphy gave the bay gelding Frank, that is a member of the Ethan Allen fannily, a mark of 2:0s at that way of going, and this was the hest on record until Colden came out with H. B. Winship, anotlier menber of the same family, and went the distauce in 2:06. Murphy has ridden and driven a great cleal for Mir. Robert Bonner, and on two occasions when I hare seen him ride in a manner that made a great impression on me. The first trotting race I ever saw, Murphy rode the winner. I did not at that time consider myself much of a juclge of trotters, but there was one thing I was sure of, that being that I would never see a better rider than Murply, and on ti.at point I have nerel changed my mind. The last time I saw lim on a horse's back was a few years ago when I fell in one bright morning with Mrr. Robert Bonner while he was on his way to Fleetwood. Mrr. Bonner said to me that if I would accompany him I would see a man do something better than I had ever seen the same thing clone before. I accepted the invitation, and when we arrived at Fleetwood Mr. Bonner asked Murphy to put the saddle on his mare Pocahontas and ride lere a slow. mile, 
which he did, and after giring her a short breathing spell Mr. Bonner told him that if he wonld ricle the mare a mile and then guess within two seconds of how well he had ridden her he wonld make him a present. He rode her the mile, and if I was sure of seeing a horse as well ridden again I would go a long way to see the two perform. After ricling the mile Mrupliy came back and told Mr. Bomner within a second of how well he had gone, which shows that he not only rode the mare well, but was also a first-class judge of pace. Murphy has one grand thing in his character that some other good drivers lack, a reputation for honesty that a king might be prond of.

In training a pair of horses to go a race in double harness, do not think that you are obliged to give them all their work together. You may have two horses whose disposition, temper, etc., are wholly at variance. They may require entirely different work to prepare them for the same race. If that is the case and yon gire them all their work together one or the other of them is bound to be out of condition on the day of the race. The first thing to do is to clecide how you will drive them-that is which horse you will put on the off side and which on the nigh side. Ererything else being equal, always put the fastest horse on the off side. In hitching a pair of horses I wonld always use a breeching. If they make a break yon will find that yon are in better shape to catch them with the breeching than without. If you have one lorse in the team that you think from lack of education or otherwise ought to be worked in donble harness, and his mate does not need that sort of work, get some extra horse for a mate and work him in that way. If your trotting horse is of a mild disposition you will find that a lunning horse is very good to use in this case. 'The only thing to be careful of in using a runner is not to go too fast for the trotter. Work them well within themselves at all times. I think it is a good idea to jog the team often together and give tinem all their slow work that way, provided they work withont friction. In getting a team rearly for a race I wonld suggest 
to hare them warmed up in single harness first; in that way you take the wire-edge off from them and they are less liable to get to breaking in scoring in the first heat. Dun Walton was considered by old-time judges to be one of the best double-team men in the comntry. His name may be a little strange to some of the new boys on the turf, but years ago when the Fashion track was the head centre of trotting Dun Walton was almost as much of a character as Dan Mace, and a New York gentleman would hardly hitch up a team without asking Dun's advice. I have heard him express a great many good ideas that were original with himself, and I know he often gave Mace advice, as in those days double-team trotting was quite the rage. 


\section{CHAPTER XIV.}

Calmar, a horse that needed ouly proper shoeing to improve his record eight seconds and make him win good races-His gallant fight with Woodford Chief at Cincinnati-A kind word for George A. Baker, once a prominent figure on the trotting turf-How Lady DeJarnette was giveu a fast record by changing her check rein-Hints to owners of horses-IViison's race in which he went a mile in $2: 16 \frac{1}{3}$, and the mistakes that caused him to be defeated-Sufficient preparation is what makes good campaigners, while lack of work results disastrously-Fred Folger's career an illusiration of this-Why Budd Doble put tips on Jack the day before the $\$ 10,000$ race at Rochester-The peculiar manner in which Wolford's Z. was shod and how it improved him-The pacer Argyle, and the trotter Colonel Lewis-Trotters affected in a marked degree by changes of climate-Little Gypsy's great race at Cleveland-Pen sketckes of noted characters on the trotting turf.

In 1878, Mr. George Baker of Clereland, Ohio, owned a bay gelding called Calmar, that he bought from Mr. Charles Railley of Kentucky, a horseman whose reputation in his particular line was world-wide, he being considered by good judges the best ladies' and gentlemen's saddle and harness horse trainer in the world. At this time Railley gave trotting horses some attention and trained and drove Calmar to a record of about 2:30. He was a rery handsome bay horse by Bourbon Chief, one of the strongest made fellows I ever saw. It would hare taken, to have fitted him, a collar as large as for an ordinary carriage-horse. So well proportioned and evenly made was he, that no one ever noticed this peculiarity about him mnless they looked him over closely.

After leaving $\mathbf{M}_{1}$. Railley's stable Calmar passed throngh the hands of two or three trainers and came to me with his record of 2:30. The first time I druve him was at Utica, 
where Mr. Baker came to me and asked me to get behind him the last heat in a race, which I lid, where he tinished last in a large field of horses, a place $I$ had noticed he al ways occupied in every race in which I had ever seen him started. Although finishing last, Calmar showed me so much speed in this heat that he interested me, and after the race was over I made an arrangement with Mr. Baker to train and drive him the balance of the season. On examination I found that he wore shin boots and scalpers behind, both of which he hit very hard. His hind feet were long and his ankles very much swollen. The first time I drove him in his work I lenrned that he hit himself very hard, when he die was sure to break, and the minute you took hold of the bit to steady him, he would commence to buck. Bnt when he did trot lie could step a good 2:20 gait without apparent effort. As few people realize what it will do to a liorse to have him continually hitting limself, even though you have boots on him, I will describe exactly how I shod this horse, why I did so, and what effect it had on him.

At that time Mace hal in his employ a man of the name of George Staples as a blacksmith, whose tmrf name, I believe, was "Blacksmith George" and to whom Mace willed his blacksmith shop and other property of that description at the time of his death, and Staples is still, I believe, the proprietor of the same in Fifty-eighth street, New Iork City. I stated to Staples the facts about Calmar as I lod learned them, showed him the boots where the horse had hit them, and then we decided on the following plan of shoeing him. IVe shortened his liind feet all that we possibly could, my idea being that there would be less strain on his ankles if they wre made short than if we left them long. I had a calked shoe made that weighed twelve onnees, made it the longest on the ontside so as to carry Calmar's hind feet outside of his forward ones when in motion, set his heels well ul, as I had learned by experience it was a good thing to do with a horse that had ailing ankles. This ilea I obtained from Dr. Poberge, a man of unlimited resourses in shoeing a 
lame horse. I had the idea strengthened in me by seeing Mr. Robert Bonner shoe his horses in the same manner. We alecided that in place of putting all the weight in shoe on his forward feet we would put a light shoe on him and toe-weights. Calmar wore at this time a sixteen-ounce shoe. We made a ten-ounce shoe with a spur to carry the weight, after a pattern that Andy Porter, the popular blacksmith of Chicago had once made for me, which was to have the spur long enongh to reach up to the top of the horse's hoof; then have your weight fixed with a set-screw so that you could raise and lower it on the horse's foot at any point you like.

I found that Calmar's mouth was a good deal of trouble to him; he seemed dreadfully afraid of the bit, and was the first lorse I erer drove with a nose-band. In some of my Western trips I had seen the Mexicans ride their horses without bits and with the bridle arranged across the nose. This gave me the notion of trying it on Calmar. I took off his orer-check, put on a side-check, arranged the nose-band so that I could buckle my reins into the nose-band and bits at the same time and so that a good deal of the pressure would come on the nose when I took hold of them. The first day I arranged to work lim in this way, George the blacksmith came ont to see the effect the shoeing would have on him. I drove him the first mile in 2:35, and while he did not break he seemed very measy and acted rery much as though he wanted to. In twenty minntes I drove him another mile in 2:30, which he went withont a break. Before putting his boots on I had them rubbed over with chalk so I could see just where he brushed them. I found that he marked the shin boots a little above the ankle and did not brush the scalpers ato all, We decided that the next time we worked him we would raise the weights higher on the spur, which we did and I drove him several heats in about 2:30, without a break or without his showing any disposition to want to break.

The following week at Hartford, where I had him 
entered in a race, Calmar showed me so much speed in his work that I concluded to give him a trial and if he suited me back him and try and make a little money for myself. In talking the matter orer in a quiet way with General Tumer, he adrised me not to put my money on him as he had seen enough of him to know he was a bad horse. However, I set a day and asked the General to come out in the morning and time him for me, which he did. I drove him a mile from a certain point in the back sicle of the track in

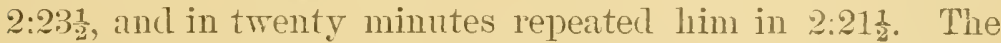
General reconsidered his decision, and we concluded as the odds wonld be rery long against him we would put a little money on and try and win a good deal. We got the money on all right but, as the General remarked after the race was over; we cut our watermelon before it was ripe. The race came off, Calmar was beaten and we lost our money. Still I was not displeased or disconraged as he acted so much better in the race than he erer did before. I was sure that some day he would prore a winner. I concluded to start in orer again and be sure that the next time I put my money on him to have him right. In this race I found that by raising the weight well $u p$ on his hoof it changed his gait so that he never tonched his scalpers and rarely touched his shin boots.

I worked him along rery carefully for two or three weeks, and every time I drove him he pleased me better. I entered him at the fall meeting at Fleetwood Park, where he won a race of fire heats against a bay mare called Rosewood that was sired by Blackwood, and that was driven in this race by .James B. McMann of Flora Temple fanı, and which was, I believe, the last race which that celebrated driver took part in. In this race Calmar again sold very cheap in the pools. The betters and the public, linowing that I had backed Calmar at Hartford and had lost my money were not at all frightened when they learned that I was doing the same thing again. In the first two heats Calmar was unstealy and the mare beat him easily in about 
2:30. He seemed rery much mbalanced going down the hill. Before the word was given in the third heat, I increased the weight on him by putting on a six-ounce toe-weight instead of a four-ounce. This seemed to steady him, and while my friend McMann gave me a pretty hard race in the next heat, Calmar beat the mare and then put the race to his credit. I made a fair winning. and Calmar proved to me that he wonld certainly be of benefit in tiding orer the long winter before uls.

I went from New Iork to Cleveland where I had C'almar entered in two races. When I arrived there and told $\mathrm{Mr}_{\text {r }}$ Baker about Calmar"s success at Fleetwood, he did not enthuse much about him as the time had been slow; and he thought his winning the race was more of a scratch than a proof of merit. Mr. Baker was a man who if you gave him a good deal of enconragement was apt to orerbet everything. The night before Calmar's race at Cleveland, I told him I thought I had a chance to win, and that we had better have some money on him. I do not know what kind of an order Mr. Baker gare Dempsey the pool-seller, but it must have been unlimited for he played it from the green cloth to the bine sky, as Jack Batcheldor says. The race came off and Calmar won in straight heats lorreling his record, and thereby winning the money for us. In this race he had two or three seconds to spare in each heat, but I kept him well in hand and only won at the finish, and I think the public did not realize we had anything more than I showed. Two days afterward we started in another race orer the same track in a field of horses where it was known we would have to trot in 2:23 or 2:24 to win. Again I suggested to Mr. Baker he had better back his horse, and also cantioned him that he was in with the best field he had ever struck and he had a chance of being beaten. The last part of my advice I hardly think $\mathrm{Mr}$. Baker took as between himself and his partner, Ira Holmes of Chicago, they bet about all the money that was on Calmar. The race came off and Calmar won in three heats easily. trotting the last 


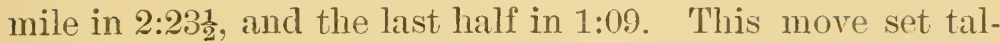
ent to thinking, and after that when Calmar started he was not overlooked in the betting. The following week at Columbus he won another race and fron there he went to Cincinnati where over Chester Park, he made what I consider the star performance of his life

At this time Chester Park was under the management of John Sullivan, a business man of Cincimnati, and Capt. G. N. Stone, who afterward became famous as the owner of Mand S., and who sold her to Mr. William H. Tanderbilt, and it is reported with the money that he got for her has amassed a fortune. Chestel Park was considered one of the best betting places in the comntry. The Kentuckians always came over there in full force, and are always as willing to bet their money on their own horses as they are to swear that they have the best whisky in the world. In overnight betting before the race, Woodford Chief, a handsome stallion driven by Gus Macey, had the call. I learned in a second-handed way that the horse had showed his owner a great trial. By this time Mr. Baker, always enthusiastic, had made up his mind that no comparatively unknown horse could beat Calmar, and on the strength of this and not to have the Kentickians ont-bet hin, put his money on his horse without stint. 'The Kentuckians barked IT oodford Chief from start to finish. The public were abont evenly divided, and the result was long before the race was called there was as much money on the contest as an ordinary horse could have drawn if it had been in silver dollars.

S. T. Harris, who has since made himself famous by the brilliancy of his newspaper articles on turf subjects, was the presiding judge. Deception, a horse by the waty who did not fool the public half as often as his owner did, won the first heat. From that time on the race lay between Troodford Chief and Calmiar, and proved one of the most determined struggles I ever saw between two game liorses. In the last heat at night, it being nearly dark, a large field of 
horses and a good deal of tedious scoring, Calmar sometimes not being a good horse to get off, caused a great teal of friction. When they did get the word, Calmar was at the distance stand, he being entirely orerlooked by the judges, as they never saw him until after the word was giren. I set sail with the intention of doing nothing but saving my distance if I could, which I was successful in doing and TToodford Chief won the heat. After the heat Calmar's backers made a great noise and disturbance, accused the judges of all sorts of dishonest things, and made themselves generally disagreeable. Being dark the judges postponed the race until the following day, and that night about the hotel nothing was talked about except the race, the betting on it, and censuring the judges. The only calm man I saw about the place by the way, was the owner of Woodford Chief, to whom I was introduced that evening for the first time, and while we have had some severe battles on the race-track since then, the Colonel's friendship and acquaintance I prize as one of the pleasant spots in my life.

Mr. Baker came to me and wanted I should insist on the association changing the judges. I reasoned with him, told him while I had no personal acquaintance with any of the juclges, that if I was a judge of human nature they were honest, had simply made a serious mistake, a thing I had often done in my own profession, and something that any man is liable to do. The judges hearing Mr. Baker's wishes, declined to act in the deciding heat in the morning and withdrew from the stand. I insisted on their judging the race for two reasons: First, I did not want to be a party to accusing a man of something I was sure he had not done, that was to act in a dishonest manner; and second, they were as capable men as the association could get. They finally accepted the situation and rung the bell for horses. I had given my horse a thorongh warming up and time to cool out, and while all this argument was going on with the judges, the plungers and talent surrounded Ira Bride`s poolbox as though they intended to tear it asunder. The Ken- 
tuckians never for one moment losing their faith in Woodford Chief"s ability to win, staid by hin to a man. Ira Holmes, whaterer he might have lacked in size, made it up in game, and he called the Kentuckians and went them one better every hand they showed. In scoring for the word IVoodford Chief had the pole and Calmar the extreme outside, having finished last the night before. When they got the word, they were as near even as possible for two horses to be and both on a trot and there conmenced one of the most determined struggles that one could imagine.

I trailed around the turn, Wroodford Chief in the lead, and in this position we struck the back stretch, where I pulled Calmar out to give him a brush. Still IT oodford kept the lead, and so we romded the mpper turn I again trailing. I made up my mind by this time that Calmar could not out-trot him to take the pole from him, so concluded to lay on his wheel and force the pace all I could and take the chance of beating him at the finish, knowing that Calmar was a grand finisher. IVoodford Chief seemed to have the speed of him and two or three times Calmar was on the point of breaking. They turned into the stretch in that position, and for the first two or three lengths the Chief out-trotted Calmar: from there Calmar gradually gained, and when they came to the stand I conld not tell which was in the lead. The judges decided that Calmar had won the heat and race, and of conrse our party was correspondingly happy. Woodford Chief died the following winter. Had he lived and met with no accident I am sure he would have been one of the star performers of his day, and I consicler the loss of such a horse greatly to be regretted by all breeders. Macey, who drove him, has developed from a boy into a man, and while his interests are all with horses, and he has often had good ones since, he told me that he had nerel had one that quite took Woodford's place.

I never think orer my career in connection with horse racing but this race comes to my mind. The coulatge and determination shown by both these animals impressed me 
so that I shall never forget it. I think if the public knew and could appreciate how a game horse will struggle, strive and strain every muscle to win under unfarorable circumstances, they would treat them in a rery much more humane manner than they sometimes do. It seems so strange to me that the noblest, truest, kindest and bravest animals in all the Lord's creation should be placed in a position where to say the least 50 per cent. of them are badly if not cruelly treated. I often hear people say that the Society for the Prevention of Cruelty to Animals has too much power. I think not. If I were a judge on the bench and a man was proven guilty before me of beating his wife or abusing his horse in any mannel, I should certainly want to give him a life sentence.

ITriting about this race recalls to my mind the sad ending of Mr. Baker's career. At the time he owned Calmar he was wealthy, prosperous and the world was his friend. He lost his fortune, and as is very often the case, his friends with it ; lired some years in next to actual porerty and died a violent death. Mr. Baker may have had his faults ; I never saw a man who did not. I have heard him sererely criticised and by those whom I think should have befiended instead, as I know he had befriended them. I believe in the old adage of speaking well of a bridge which carries you safely orer. To me Mr. Baker was a true friend, a lind employer; helped me in every way it is possible for one man to help another, and I always pitied him in his trouble and misfortune.

I have often heard people remark that they wondered at blacksmiths and horseshoers being such an ignorant class of men. I know this is the repntation they have among some people. I perhaps have as large a personal acquaintance among that class of mechanics ans anyone in the world, and I wish to deny emplatically that such is the case. I know any number of blacksmiths who in their own business are first-class artizans, and with brains and intelligence enongh to fill almost any position in life with success. I 
myself am inclebted to this class of men for very many valuable points in the way of shoeing a trotter. If I have a horse with any peculiarities in the way of shoeing that I can not master, I do as I did with Calmar : find a good blacksmith, state the case to him, tell him what I know and think ahont it, and nineteen times ont of twenty I find this method a success. As I hare said before, it is the little things in horse-racing that make or unmake the success of the affair. With Calmar it was simply a matter of having him properly shod and his month rigged right. He was not a hard horse to drive. My foreman, Walter Dwyer, could hare driven him anywhere. I often had George Perrin work him for me and lie used to say that instead of being a bad horse to drive he was one of the easiest he erer saw. He not only got to be a very steady horse after he stopped hitting himself, but also became a first-class breaker ancl a good scorer.

Lady De Jarnette was one of the handsomest and highest-styled mares I erer saw. Her omner, Mr. Wr. H. Wilson, showed her at many fairs and horse-laces, where she invariably took the first premium. She went with her head high naturally, and I also noticed that Mr. Wrilson seemed to have a short orer-check on her. I often saw Lacly De Jalnette go miles close to 2:30, and while she went square and lerel, she acted to me as though she clawed the air a good deal, and I was positive that Mr. Wilson had her checked too short. One day at Iexington he asked me to drive her for him to obtain a faster recold. When I went to the stable I found the mare harnessed and her head high in air. I suggested to the young man who had her in charge that her head was a little high, I thonght, but he answeled that it was all right; she would not go with it any other way.

I went out and scored her down a few times, diore her down to the half-mile pole at abont a 2:30 ginit where she commenced to hitch and hobble, and by the time she had got into the head of the stretch acted as if she was choking, and for fear she would I pulled her up and let her jog home easy in about 2:35. Mr. Wilson was rery anxious to know what 
I thought ailed her. I told him I was sure she was checked in a manner that cansed her to choke, and suggested that he rest her twenty minutes and try again, which we did, when I gave her a long check, made one or two other slight changes in the harness, went out and drove her a mile in

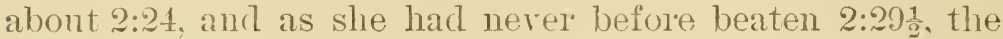
auclience and Xr. Wilson were very much surprised. Some of them were disposed to give me a great deal of credit for my driving. Anyone could have driven the mare the sane mile, as she was very steady and it required no particular skill to manage her. She simply wanted to be properly harnessed. It is just as easy to choke a horse by checking. them too high and forcing the tongue back into the entrance of the throat, as it would be in any other way. I have seen one or two horses die in hamess that I am sure rere choked to deith.

The bay gelding Wilson, owned by Mr. Z. E. Simmons, sired by Greorge Wilkes dam Miss Coons by Clarke Chief, was a horse that took all his education at the hands of Gus Glidden, who won a good many laces with him and gave him a record of 2:22. He was different in shape, disposition, etc., from any other Wilkes I ever sar. The first race I ever drove Wilson was in Chicago, and as there was a good deal of talking and betting about this race, I will give a slight sketch of it.

At that time Mr. William Dumn of Cincinnati, a man famous as having bred and owned Guy Wilkes and several other valuable trotter's, owned the gray gelding Joe Bunker, another hor'se he bred, and had been trotting him with a good deal of success. This year Bunker started in at Lonisville in the spring, making an early campaign and winning. all his races, beating among others the stallion Director, that at that time Johnny Goldsmith did not have keyed np to a winning point, he having just bronght him from California. Bunker also defeated Orerman, a horse owned at one time by Orin Fickok, and sired by St. Ehmo, one of Hickok's early performer's. Joe Bunkel' came to the Chicago 
stmmer meeting with a great deal of reputation and with as nituch money to back him as often goes on one horse. Mr. Dumn, his owner, always trots his horses to win. This the public knew, and as Bunker had not lost a race that season they made up their minds he nerer would. In the work I saw Bunker get before his race, I was satisfied he had trained off, lacked speed and condition, and I was sure under those circumstances the more he was worked the worse it would be for him.

It was known that Bunker would be the farurite orer the field in the betting, and Glidden suggested to me that I take his place behind Wilson in the race on acconnt of the difference in onr weight, Gliclden being much the heariest man, and that we should play our money on the field against joe Bunker and take the chances that if Wilson did not beat him some other horse would.

Before the race came off I found that Hickok thought well of Oreman. In the betting Bunker was farorite $\$ 100$ to $\$ 60$ orer the field, and the public and $M r$. Dumn's friends put their money on as though they would never get enough. While the public often gets the talent's money, here was a race where I think the talent had the best of it, as Orerman won in three straight heats, thereby landing the fielder's money for them.

The next race that I drove WVilson was at Cleveland against Director, where Wilson made his best record, and although beaten he again proved that he was a fist racehorse. I have often heard people say that a trotter does not need much work to trot a race of mile heats, three in five; also that old trainers work their horses altogether too much. Owners frequently say: "Don't work my horse, he doesn't need any work." I have often found that those horses are bad feeders, with a delicate constitution and can not stand a preparation for a campaign. That kind of a horse often wins a race or two, but there never yet was one of them that made anything like a successful campaign. And whenerer you have a trotter that does not need any work, do not enter 
him for a long campaign, as before you get to the end of it, you will not only have to pay his expenses, but his entrance money too.

In the Cleveland race I made two mistakes with Milson, and one of them I consider a rery serious one and am sure that it cost him his chances of beating a first-class horse, which I have no doubt that he wonld have done had he been fortmnate enongh to have been mansged differently. At this time the best mile Wilson had erer gone was 2:20, either in his races or work, and as I found out afterward, he had been given a rery short preparation and a rery little work of any kind. I supposed that he had plenty of work, and as he showed me minlimited speed before the race, adrised Mr. Simmons to back him ind we would try to win. This was the tirst mistake, inasmuch as we were wrong as to the condition of the horse. I second mistake was that we underrited Director. Johnny Goldsmith bronght him from California in the spring and trotted him a number of races, had won some of them and giren the horse.a lecord of about 2:20. That rate of speed was smpposed by most people to be his limit. The Clereland late was a great struggle of six heats between these two, Director and Trilson, each getting two heats apiece and making a dead heat, and Director winning the deciding heit. Wilson that day made his record of $2: 16 \frac{1}{4}$, which is his best. Director also made his best record, $2: 17$, in the same race. The public showered their money into the poolbox and were pleased to think they had seen a grand battle, and Mrilson being a game and ambitious horse and out of condition from being short of work was rnined, as his career after that was short. He never vent anything like as good a race again; he struck his hind leg in this race and was always more or less tronbled by it and this was his last year on the turf although a young horse.

If Wilson had received a long and careful preparation, such as Goldsmith had given Director, I am sure that he wonld have won the race and not only that race, but a good 
many mole. Anyone else might have made the same mistake which I did, whether they would or not I do not know. I simply state the facts in the case and what my opinion is as a word of caution to other people who are in the same position, and that is ; before you give your horse a hard race be sure that he is in condition to take it. The strongest proof that my argmment is right is this: If Turner, Doble, Hickok, WV. H. Crawford, Jimmy Golden, Jock Bowen and many others of that class of men whom 1 could name start a horse at the beginning of the circuit and he shows himself a good lace-horse, you may expect to have trouble with those people all along the line, for instead of the first race doing the horses harm, if they are in condition to take it it will do them good and they will steadily improve to the end of the journey, as is proven in many cases by a horse's beginning at the first part of the circuit and trotting a race a week and going their last races best. On the other hand, you watch the man who comes to the circuit with his horse that does not need any work, says he hasn't given him any, goes one good race and wins, and the next week he can't understand why he doesn't get better than third or fourth in the race. The reason is, that from lack of condition the first race has done the horse harm.

As plain a case as ever I saw of the kind came into my hands last year in the bay gelding Fred Folger. He belonged to a friend and old-time patron of mine, and a man who from long experience and associations with Mace, Doble and Jack Phillips ( they all having driven for him at different times), has ideas abont the training and management of the trotter that I think makes him a very useful man during a campaign. As the financier of a stable of trotting horses he will come as near having the account on the right side as any man I ever saw. Mr. D. B. Herrington, the gentleman who trained Fred Folger in his early career, deserves a great deal credit, as he bought him at auction when he was an undeveloped horse, and if he had shown any great speed no one seems to have known it, as 
he was only considered worth about $\$ 600$, which was the price he brought. As the horse came into my hands afterward and Mr. Herrington criticised my treatment of him it may not be out of place for me to give my opinion of the horse here. The first race in which Herrington started Folger in was early in the spring in a climate which at its best, is cold and disagreeable, and orer' a track that has been notorionsly bad ever since the day it was built. And while I did not see $\mathrm{Mr}$. Herrington work this horse nor drive him in his race, from evidence which I consider thoroughly reliable I am satisfied he made the same mistake that I did with Wilson, that is, started his horse in a race when he was short of work, and while he won it in three straight heats, he went three-quarter's of a mile I am told in one heat at a clip that would have strained any horse in the world unless he was thoroughly seasoned for an effort of that kind. The strongest proof I have that Folger was out of condition when he started in this race is his race of the following week, which he also won, but was so

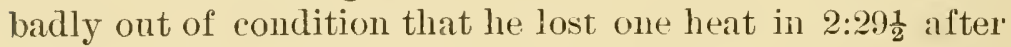
having made a record of $2: 20 \frac{1}{2}$ the previous week. In his second race Folger was unsteady, short of speed, and that he won it was no credit to a fist horse. The following week he won a race at Hartford after another struggle of five heats where the best mile was about 2:231. In his Poughkeepsie race he showed a record of three-quarters of a mile in abont 1:40, and to have a horse with that wonderful speed get off so that he could not go better than 2:23 or 2:24 there must have been some cause for it.

Wilson, I think, wore the lightest shoes of any Wilkes horse I ever saw, they weighing not over eight onnces in front and about five behind. I have since often thought that he would have gone well in tips. I believe that if onr trotting tracks were not quite so hard there are a great many horses that would go better if shod in that manner. I do not thmk it possible for horses to be shod in tips and trotted successfully while onr trotting tracks are so hard. I 
have watched this matter at every opportunity which presented itself to me, have tried tips on a number of horses, and am satisfied that for a horse to go well in them the track must be especially prepared. I presume the gray gelding Jack is the most celebrated horse that ever trotted a race in tips. Fortunately for me $I$ was in a position to observe this horse closely while he was being shod in this manner, as he was in the stable of $\mathrm{Mr}_{\mathrm{r}}$. Doble. In fact, if I remember rightly, Budd talked the matter over with me before he changed the shoes.

Jack is an instance of from what a humble beginning a great horse sometimes springs. While he has in his pedigree grand strains of blood that have proven themselves in breeding and on the turf first class, his dam being by Magna Charta, the family that gave us the dam of Belle F., $2: 15 \frac{1}{2}$, and several others that went in 2:20 or better, she was never considered of any great value, having been sold at one time for $\$ 60$. Coming into the world from such a cheap parent, Jack was not looked upon as a coming worldbeater, and his early education, etc., was not above the ordinary, and while a colt was offered for sale at very moderate prices. In his early training he did not show any very remarkable speed, but always made a better showing in his races than he did in his work, which I consider a firstclass symptom of a race-holse. As a five-year-old, he was sold with his mate to Mr. George Middleton of Chicago for a road-team, $\mathrm{Mr}$. Middleton giving for them $\$ 6,000$. I hardly think he realized when he bought the team that the following year he would have the pleasure of seeing one of them win more money than any other trotting horse in America would, which he did, as Jack in capturing a majority of the big stakes last year put to his credit that feat.

There are some things abont Jack which remind me of Rarus. In gait he is very easy and smooth, goes without a particle of friction, and when at his top speed does not seem to be making any effort. I have noticed, as with Rarus, that 
a great many horses beat him to the three-quarter pole, but from there to the stand he steals along and at the finish seems to out-trot them with something to spare. The first race Mrr. Doble drove Jack in tips was at Rochester, where he trotted and won the $\$ 10,000$ stake, beating the best field of 2:30 horses that ever faced the starter. The week of the race there had been more or less rain, which left the track soft, and with his shoes on Jack seemed to have hard work to get through the footing. The day before the race Mr. Doble decided to put tips on him and try them, which carries out my argument of nerer being afraid to make any change on the horse no matter how close it may be to a race, or what people may say about it, if in your judgment it is the proper thing to do. I don't mean that you shall change a horse's shoes from an impulse or whim, but after careful consideration, if you think that is the best thing to do, make the change by all means. I have seen Mace change a horse's shoes between heats of a race, and with good results. He always said: "If you can't win with one plan, try another; never give up trying."

In putting on the tips on Jack, Mr. Doble followed the rules as laid down in Joseph Cairn Simpson's book entitled "'Tips and Toe-weights," and in working him to see what effect the change would have, Doble was very much pleased with him and told me he was sure he wonld go the best race he had ever trotted, all of which he did, proving that $\mathrm{Mr}$. Doble's treatment of the case was right. If I had a horse on which it was necessary to wear toe-weights in training, I would certainly drive him in tips the balance of the season, as I am sure that in that manner you would teach him to go with lighter weights than you wonld by driving him in heavy shoes all the time. You will at the same time, if the footing is not too hard, get the pressure on the horse's frog, and if he is inclined to contraction from bad shoeing or other causes have a chance to counteract that effect. The great trouble I find with people who have theories about shoeing horses is that they want to shoe 
every horse alike, which is utterly impossible to do with satisfactory results.

Wolford's Z., was another horse that I had in connection with whom my blacksmith was a great deal of benefit to me, as he was a horse that hit himself on his frontlegs and every other place, I think, it was possible for a horse to do so. He wore arm and knee boots and shin and quarter boots when he came into my stable, and could not be moved without his hitting his boots very severely. Jim Brayton, of Elkhart, Ind., shod him for me after a plan which [ have found very satisfactory in cases of this kind. In shoeing a horse to prevent his hitting his knee, many blacksmiths file off the inside of the foot, and by so doing bring the foot to a point, or as it were, try to make the horse toe ont. Others have ideas about putting most of the weight on one side or the other of the shoe. I have tried all these plans but with poor result. Brayton leveled the horse's foot perfectly, shortened up the toe moderately, then made his shoe fit the foot with the weight evenly distributed and after it was ready to nail on, he heated the toe, placed the shoe in his vice, and with a rasp cut off the toe of the shoe square acloss so it would look about like the box-toe of an Englishman's shoe. After nailing it on the foot, with his rasp he cut of the toe of the fool back even with the shoe. After Wolford's Z., was shod in this manner he looked l"،ther peculiar, as Ihad never seen a horse's feet so treated, but the result was perfectly satisfactory, as he stopped hitting himself and was a much faster and better race-horse, improved his record and won some very satisfactory races. I tried this same plan on Argyle the pacer to my entire satisfaction.

In a trotting or pacing horse I object very much to having their feet allowed to grow out very long. I am sure that they are very much more apt to hit themselves and sooner or later strain their tendons. Argyle was a rather peculiar horse, his gait being different from that of any other pacer I ever saw, it being very much like that of a trotter. 
I believe Anderson told me he had driven him a mile in 2:30 on a trot. I divide the honor of laving driven him to his best record with Joe Coates, he having done likewise with him. In a lace at Kansas City against Mike Wilkes and others, I took the second heat with Argyle in 2:14. Mike Wilkes, driven by his owner Abe Rorhbach of Stillwater, Minn, often called "the Dan Mace of the Northwest" from his general appearance and style of clriving, won the race and also making his best record that day of $2: 15 \frac{1}{2}$. Mike Willies is one of the few I have seen that can both trot and pace fast. In his younger days he was rather unreliable, passed through the hands of several trainers, and was driven by George Toorlies on a trot a mile in 2:20. He was afterward sold to Rohrbach at a very moderate price, and in the hands of Spencer made quite a reputation as a pacer. But his owner put the finishing tonches to his repntation when he beat Argyle and he and his friends from the lumber district won all the money and left my partner Frank Herdic and myself to hold the sack. In my opinion there is not as much difference between pacer's and trotters as most people imagine. I am sure that Johnston could be driven fast on a trot with but little trouble. When I first got him, I often saw him step of letter than a three-minnte gait at that way of going, and with light shoes on. In fact would often try to score up with me on a trot in his work.

Colonel Lewis, a gray gelding with a record of 2:18 that I brought from California in 1879, wals a very peculiarly formed horse and had rather a strange history. He was not a trotting-bred horse, and in $i$ is younger dalys was hasshly treated and given no chance to show or develop the speed which afterward made him quite lamous. Before bringing him to this country from California, he showed me a good deal of speed with ability to stay the route. On this sicle of the Rockies he did not do as well. The climate seemed to effect him wonderfully, he lost his speed and his ability to stay a mile ont. This I believe has been the case with a. number of other horses brought from California, and the 
peculiarity is something that many trainers have to contend with in shipping horses long distances. My experience has been that in taking horses from here to California, they invariably do better. They can go faster and stay longer at a high rate of speed in that climate than they can here. A horse will take more work with a very much less feed and still keep plenty of flesh. These are matters of a great deal of importance, particularly with a delicate horse. In bringing a horse from the Pacific coast to the East, I think that the hot nights we experience here affect them more than any one thing.

In California, no matter how warm the day, when night comes a horse is always comfortable with a blanket on, and yon could not if you tried rednce the flesh on him there as fast as it will sometimes come off here in spite of all you do to prevent it. This I think brings on a weakened condition of the animal and he loses all chance of being anything like successful. Doble brought Occident to this country with the reputation of being a very fast horse, and he never was able to make any use of him, so badly did he lose his form. On returning to California, he again regained it, apparently from no other cause than the effects of the climate. In high countries we have another condition of affairs. In Denver, my horses never seemed to lose their flesh or their appetites, and always felt well and ate well. They would have plenty of speed, but after going a short distance at a high rate wonld seem to swell up, act very much distressed in their wind, and some of them would bleed at the nose. Some horses never get used to the rarified air of a mountainous country, and others it does not seem to distress so badly. When I had Sweetser in Denver he could not pace a mile in 2:35, while Rarus seemed to be affected less by the climate than any other horse I ever saw, as he made considering the circumstinces and surroundings, a first-class performance.

Doty, another native of California that I brought to this country, was a horse with a good deal of speed but not very 
reliable. The climate did not seem to affect him very much as he went about as well here as he could there. Harry, a

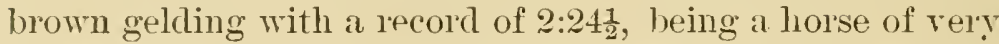
delicate constitution and a poor feeder, was never able to show any thing like his California form. In taking a trotting horse to California after a long and severe campaign here, the great est advantage derived is, not only the mild climate, which I think is a grand thing for a liorse's nervous organization in the reduced condition which it certainly must be after. his arduous work of the season, but in the fact that here you have a chance to give him a run at grass if you wish, which beats anything I erer saw in the way of tonics to build up a horse's reduced system. One other benefit I found was that you could at all times keep your horse partially conditioned. That is, you did not have to let mp on him entirely. If a horse has any weak places abont him and you throw him entirely out of training, when you commence to train him again you will find that you may have a great deal of trouble to get him back to his original form. I have seen many horses laid up in the fall with bright prospects for the following season. But from one cause or another their trainers would be unable to get them back after their winter's rest, and they never performed as well as they were expected to. A horse kept up throngh the winter, even in a cold climate, with moderate jogging and an occasional brush at a working gait, can be conditioned much easier to hiniself in the spring than one that is let up all winter, and I think it much the best plan. This was proven to me by the manner in which Mr. Simmons trained Kamsas Chief the first winter he owned him.

The nervous organization of the lorse is something which I think is often overlooked. Years ago, in a conversation with that celebrated horseman, trainer and veterinarian, Dr. Her', of Lexington, Ky., he advanced some ideas about this matter that I never heard from anyone else, and gave me points on the subject that have been of a great deal of benefit to me. No matter how sound your horse s feet and 
legs are, how good his wind is, low well you train and care for him, you may rest assured of one thing, and that is : If his nervous organization is weak or impaired from any cause, you will be unable to get him in the pink of condition or to get anything like his best efforts in the race. If such is the fact, and I am positive it is, then the nervous organization of the horse is one of the principal points to be looked after in training him. One other point I want to thank Dr. Herr for, and that was the adrice he gave me in regard to the horse's stomach. His plan was that if the horse was suffering from any disorder of the stomach or bowels, instead of continually overloading his stomach with bran mash and feed of that kind, to give him something in the way of medicine to comnteract or cure the disease. Someone might ask Would I give a horse medicine while in course of training? I certainly would. In these times of intelligent and educated reterinarians where all diseases of the horse are treated with perhaps as much intelligence as diseases in the human race, there is no more danger of giving a horse nedicine while in training than in taking medicine yourself if you need it. In talking with men who have trained some of the most celebrated athletes in this comntry, I find that the medical treatment of a man in training is one of great importance, and as I claim that horses are like hmman beings in more ways than one the sime treatment I think should be followed with them.

Governor Hill, a bay gelding with a record of 2:18 $\frac{3}{4}$, that was owned by Mr. Simon McMillan of New York City, a self-made man, and sold by him to a party in South America for $\$ 10,000$, made his debut to the public in the hands of Jesse Yearance of New York City, who I think deserves a good deal of credit for the manner in which he trained and drove him his races. He came to Yearance's stables in the spring, rot fairly broken, with some bad habits of unsteadiness, etc., in company, which had to be overcome, and to have a man start in with that kind of a liorse and in one season train and drive and win a majority of his races and 
give him a record of about 2:20, is a performance I think any trainer might be proud of. Hill, in breeding is a descendant of the American Star family and one of the handsomest-gaited and speediest horses I ever saw. I think he could trot a hundred yards at a 2:10 gait. In disposition, etc., he was rather inclined to be nervous, a delicate feeder; and for those causes more than for his having been a natural coward, I lay the fact of lis not having been a first-class racehorse, as he certainly har speed and gait enough to make him one. He obtained in my hands a record of $2: 18 \frac{3}{4}$, forced

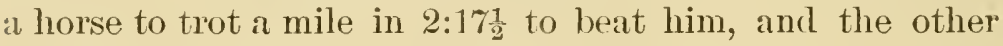
horse had to have the judges on his side in order to win at that. Hill is a horse that I think conld, in California, certainly hare gone a mile in 2:14.

One of the best evidences that ever I saw that waiting and taking plenty of time to condition a horse is the surest way to get money with him was in the mare Little Gypsy. I had seen her passed around from one trainer to another and handled and worked in rather a slipshod fashion, She finally came into the stable of Mr. William H. Crawford, who had never, on account of his poor health, considered himself a star driver, but who as a trainer and financier in the business, had made himself a reputation equal to that of Jay Gould in railroad circles. The manner in which Crawford trained Gypsy must have been a surprise to her, as I noticed he had her well harnessed, well booted, had a good boy to care for her, and in training her gave her his entire personal attention. Through the Michigan circuit in the spring she did not cut much of a figmre, but in a race at Dexter Park, the commencement of the circuit in which 1 drove Planter, I found that Mr. Crawford harl a pretty fair mare. In talking the matter over with him after the race, he acknowledged to me that such was the case, and further said that when he got her to what he considered a feather edge and was prepared to back her he would like very much to have me take his place behind her, as he lacked confi. dence in himself in that kind of an engagement. The follow. 
ing week at Cleveland Gypsy was entered in a race where if the betting fraternity and the public had ever heard of her they must have entirely forgotten the fact, as she sold for $\$ 30$ in $\$ 600$ pools the evening before the race, and in fact kept at the same odds mntil the race started. Some people took part in this lace who are celebrated not only in connection with the turf, but also in other wallis of life. Foster Dewey, who perhaps was the closest friend that William H. Vanderbilt ever had, at that time owned Richard, had him entered in the same race, and came on from New York with a number of his friends to see him trot, his party including such well-known men as Sheridan Shook, Ed Gilmore of theatrical fame, Charlie Reed, the owner of Midnight, and a host of others who always helped to make it lively around the pool-boxes whenever they appeared on the scene.

Mr. Crawford, Terry Barden, Charlie Harvey and Al Carlile formed a trust and at the odds placed money enough on Gypsy to win $\$ 12,000$. So well were all the details arranged and the money put on, that the unsuspecting public never thonght they were being lect to the slanghter. In fact, I myself never mistrusted there was going to be a "killing," Mr. Crawford not having said any further to me after our conversation in Chicago, and for that reason I supposed that he did not expect to back his mare. He drove her the first heat himself, which he won in $2: 23 \frac{1}{2}$. The next heat Mace beat him with an unreliable horse called Banquo, owned at that time by a Boston gentleman. The finish was very close between Mace and Crawford, and I thought at the time Gypsy ought to have won it. After this lieat Crawford asked me to take his place, which I did, and Gypsy won the race in the next two heats, but not until after she had had a fight from start to finish in the fourth mile with a bay gelding of the name of Jack, and he forced her ont to her, at that time, best record of 2:22. Here is where it is reported of Crawford that he made his famous remark. The finish of this heat was so close that many people did not know which horse had won. 'The judges 
were some time figuring the position of the third and fourth horses. Crawford became impatient and asked me what 1 thought about it. I told him his mare had won the heat sure. He wondered why the judges did not hang ont their decision. I told him they would in a minute, whereupon he remarked that would be too late for him, as he would be dead in a minute, meaning that the strain would be too great, he could not wait that long. I think he was mistaken.

No matter what the decision might have been I am sure from what I saw of the man at other times, it would have taken more than that to kill him. Once afterward when he was very ill and I stood at his bedside, he told his physician that he wanted to know just what chance there was of his living or dying. 'The physician answered that he had just an even chance for his life. Crawford replied to him that that was as good a thing as he had ever had in this world, and was willing to take an eren chance and try and live, which convinced me thist it would take more than an adrerse decision from the judges' stand to make him surrender. In appearance, disposition, etc., the four men who won the money on this race, besides being connected in business, were great social friends. 'The public, I think, are greatly mistaken abont the character and habits of men connected with the turf. As in other walks of life, there are a great many different kinds of people interested in trotter's, some for pleasure, and some as a means of livelihood. 'Terry Barden was a man of very delicate health and mildness of manner, and whether he was buying the first choice in the pool-box, or speaking to a lady, had the same polite manners and low tone of voice, always pleasant to meet with. He often lost his money, but nevera friend. He is one of the few men who lived and died and left behind him no word of censure. Crawford, a man of more nervous temperament, is the descendant of a well-bred family, received a good business education, served his time in the war, and proved by his conduct that whatever else was in his character fear was no 
part of it. After the war he engaged in some business ventures, bought a trotter for the love of the horse, and afterward bloomed out as professional trainer and driver, and in that connection has owned and driven some of the most celebrated horses in this country. Charlie Harrey is an Englishman by birth, an American by adoption, the proprietor of a hotel by occupation, and an owner of trotters for pleasure. He is always ready to trot his horses for the money, will back his opinion at all times, and as a neighluor and friend and a jolly companion rates first class. Al Carlile is always considered Ira Bride's running mate, a position which he is amply able to fill, not only from his size, as he and Ira are considered the heary weights of the turf, but from other traits of their characters. They have botin often lost their money on a horse-race, but when it comes to ordering and eating a good dinner, their speed and staying qualities are acknowledged by everyone who knows them. As a merchant, Carlile las proved himself a man of rare ability, very temperate in habits, never having smoked a cigar or taken a drink of liquor under any circumstances, always ready to back his opinion with his money on anything from the Presidential election to a hundred-yard foot-race. As a friend he is true blue, as many a man on the turf to-day las reason to know from the fact that at some time in his career Carlile has bridged him over a financial difficulty.

In this respect I think sporting men are much more liberal and charitable than business men. On the turf, no matter how poor a man may get, how bad his luck may be, or what misfortune may overtake him by loss of health or otherwise, you may rest assured of one thing, he will find plenty of people in his own line willing to help him in his time of distress, and if I were ever to have the plate passed for my benefit, with all due respect for the clumches, of which I am a great admirer, I would sooner have it sent around on the race-track than in the wealthiest church in the world. As a rule, I think the conduct of men connected with the turf will compare favorably with that of 
the same number of people in other walks in life. For instance, the pool-sellers and book-makers have and hold at different times a great deal of money which belongs to other people and that, too, without giving the slightest security for it. Wé often hear of bank presidents, treasurers and cashiers and other men holding positions of trust going off to Canada with other people's money, but who has ever heard of a pool-seller doing so?

I once had a horse-trade with a banker who told me he did not have much confidence in horsemen, but when I told hin there were more bank presidents than horse jockeys in Canada, he changed the topic. There are other men who love a trotting horse for the pleasure it gives them. While they do not from inclination or need trot their horses in public, they derive a great deal of pleasure from them, and add very much to the interest of the sport. Such men as Mr. Robert Bonner and Tilliam and John Rockefeller have made it possible by their example for a man althongh he be a minister of the gospel to own and drive a trotter without, causing any unpleasant remarks. I once trained a horse for a Catholic priest named Father Barry. who lived on Staten Island, and if charity toward the faults and weaknesses of others as well as their bodily ailments, a life of unceasing toil in behalf of needy creatures, and a love for all that was good and true, for humanity's sake and not for what anyone might have said of him, are the characteristics of a Christian. my patron, Father Barry, was surely one. 


\section{CHAPTER XV.}

The trotting interest one that extends throughout the land and is growing every year-Famous road riders of New York City and elsewhere-Commodore Vanderbilt's present to his spiritual adviser-Robert Bonner and his sons, the Rockefellers, Mr. Frank WVork, and others-Men in other cities who love the trotter for the pleasure and health they derive from driving-Some hints about the purchase and care of a road horse-Decide just what you want the animal for, and then use him for that purpose only-Don't expect your gardener to also be capable of taking good care of your road horses-A few practical suggestions that will commend themselves to all owners of horses.

I have olten heard it said that the interests in thoroughbred horses in America would gradually overshadow trotting interests, but I hardly think so, as in the first place a thoroughbred horse is only useful for two purposes-for breeding and racing. As a road horse, a thoroughored has never been considered a success. I can buy a better road horse for $\$ 250$, trotting bred, than the best race-horse in America would make. The love of a trotter is born with the American. It is not an acquired taste in any way; as soon as a boy is able to walk he wants a horse, and for awhile he has to content himself with a hobby horse. When he grows to manhood, if he is in position to do so, he gets himself a trotter, either to drive on the road, or for turf purposes.

The best reason why the people never lose interest in trotters is not the fact of their being used on the turf, as the percentage of men who own the trotting horse for turf purposes is very small in comparison with a large number of people who use him for pleasure. In most every city and village of this country there are people who own trotting horses for private use; horses that are able to go all the way 
from three minutes to 2:08 $\frac{8}{4}$, and a first-class road horse to-day will command a greater price for that use than he will for track purposes. Another reason why the trotter is bound to succeed is that foreign com tries are commencing to buy from our market, and as there is no other country in the world that can at present compete with America it looks as though in the matter of trotting horses we should certainly have the call for a long time to come. One can hardly realize the amount of money that has been paid for trotting horses that are used by gentlemen on the road. In a great many cities and towns there are either tracks or roadways arranged expressly for this kind of travel. In New York City there are whole families from the father to the youngest son each of whom has his own private turnont of trotters and light wagons, and drives them with as much regularity as he looks after his business.

In Commodore Vanderbilt's day that gentleman drove his trotters with as much regularity as it was possible for a man to look after any department of his business life. He had good ones, and occasionally sent them ont to take a whirl on the turf, but as a rule confined himself entirely to road driving. He thought a great deal of trotters as a medium of amusement, so much so, that he gave his minister, the Rev. Inr. Corry, a man whom he was very fond of, a pair, and I have often seen the Commodore and the preacher having a brush together down the road, and they appeared to enjoy it wonderfully. His sons had the same love for the trotter, and WVilliam H. was considered a good judge of a trotting horse, and a first-class road driver. When he owned Maud $s .$, he was not averse to having her appear in public, which she often did, and he must have enjoyed it, as I have known him to take very long trips to see her perform. The Bonner family, father and sons, have been regular road rider's as long as I can remember, and while the boys are not quite as well lnown to the public as their father, they love a horse just as well, are good judges of them, and I never saw one of them that could not drive a 
trotter like a Hiram Woodruff. Years ago, I was out for a drive myself one day, and was overtaken by what appeared to me to be a boy of about fifteen or sixteen years of age, with a small, smooth bay horse. I had a pretty fair animal myself, a regular 2:30 holse, and when the youngstel challenged me for a trot, expected to have a walkover. I was very much disappointed however, not only in the speed that the bay horse showed, but also in the masterly manner in which the youngster liandled him. On inquiring who the young man was, I was not so much surprised at his ability when I was told that he was the youngest son of Robert Bonner, and that the horse he drove was a colt that had for its clam the celebrated mare Flora Temple, the first trotter to beat 2:20. I afterward spent a day at Mr. Bonner's farm, and while the style and speed of the numerous horses he showed me pleased me very much, the greatest enjoyment I had was in seeing his boys drive them. They drove them against the watch, against each other, and at last they invited me to get behind a horse and take a shy at them, which I did, and the masterly manner in which they handled the animals under all circumstances gave me as much pleasure as it would a musician to hear an artist play a violin or piano.

The Rockefellers, of whom there are three, Joln, William and Frank, each own first-class private establishments. 'They buy any horse that strikes their fancy and are always willing to pay the top prices. John Rockefeller has in his stable a pair of horses, that before they came into his possession macle records better than 2:20 on the turf, and he has others that have shown that late of speed in private. He keeps a first-class trainer in Alex. McCrea, who looks after all the details of the establishment, and the horses are given as much attention with the iclea of developing their speed and to keep them in the pink of condition as a man would devote to a stable that he intended for turf purposes.

IVilliam Rockefeller owns a pair of horses that I drove 25 
together in public a mile in about 2:18; one of them has a record of $2: 18 \frac{3}{4}$ in a public race, and he paid for her about $\$ 12,000$. He has any number of horses that have cost him up in the thousands, and on his private farm he has a fine track. Mr. Geo. Saunders has the training and management of $\mathrm{Mr}$. Rockefeller's stables, which is proof enongh that the horses will always have the best of attention and care. The stables, horses, and ontfit of these gentlemen must have cost $\$ 100.000$.

Mr. Frank Work, I think, is perhaps one of the oldest road riders in New Tork. He was for years the bosom friend of Commodore Vanderbilt, and has one of the handsomest stables I ever saw. Among his horses are a pair, Dick Swiveller and Edward, that not only made for themselves an enviable reputation on the turf but a world-wide fame, having, while owned by Mr. Work, trotted a mile in a donble liarness to a gentleman's wagon in 2:161. Mr. Work has numerous other horses with records between 2:30 and 2:20, and although he is past the meridian of life, his interest in trotters is just as strong as in his younger days.

Capt. Jake Vanderbilt, the late Commodore's brother, is a genuine horseman, and I am sure if he had not been born with large business interests, he would have been a professional horseman with a love for the trotter, and he can, to this day, drive one right to the mark. Capt. John Dawson, or as his friends all call him, "Jack" Dawson, trots his horses in public, and backs them when he thinks they can win; keeps a stable of trotters to drive on the road, and if you shoull ever have a brush with him, I am sure at the finish you will not liave it to say that you outdiove him.

Col. Lawrence Kip in his stable of fine horses has as much pleasure as it is possible for a man to obtain, and at the horse-shows he generally manages to take away his share of the preminms, for his extreme taste in the beanty and finish of all his rigs.

Mr. J. B. Houston, president of the Union Pacific Mail 
Line, not only drives horses on the road, but has also had a stable on the turf for a number of years. Mr. Honston, Jr., is perhaps the youngest road rider in New York. From the manner in which I have seen him handle his trotters I believe I would be willing to match him to drive against any one of his age in the conntry. While his father has much the advantage of him in years, I donbt very much whether the young man asks any odds of his sire when it comes to driving a trotter.

Major Dickinson, one of the old school, and one of the few men that are left now who are willing to match their horses for five or ten thonsand dollars a side, keeps a very handsome establishment for road driving and also another for turf purposes. He enjoys driving his horses and also seeing them trot, which is attested by the fact that when they perform the Major with his pleasant ways is always on hand.

Nathan Straus also keeps two establishments, and in Majolica, record of $2: 15$, he has a horse that he has had a great deal of pleasure with. Majolica has quite a history, having been bred by Mr. Robert Bonner and sold for a very small price. It has always seemed strange to me that as a rule the men who breed horses do not derive the full benefit from them. Naming orel the list of our celebrated horses commencing with Maud S., who was sold by her breeder for about \$500, Jay-Eye-See, whom Colonel WVest disposed of for a small consideration, St. Julien, Goldsmith Maid, and so on down through a long list I find that most of them have been bred for trotters and by men who understood their business and then sold for comparatively small sums of money. Rarus was the only horse of the kind from whom lis breeder realized the full benefit.

In Boston the two representative gentleman lorsemen are John Shepard and Mr. Geo. Hall. In appearance Mr. Shepard is a tall, gentlemanly looking man, one of the most prominent dry-goods merchants in the Easteru country, and no Yankee erci lored a horse better. He has 
trotted his horses in public, and his road establishment has been for a number of years one of the most prominent features of Boston. Mr. George Hall may surely be called a self-made man, as from a clerk he has, by lis own determination and close attention to business, made himself proprietor of one of the handsomest hotels in this country. His attention to business and his methodical ways are seldom equaled. In appearance he is a handsome man of medium size with the appearance of an Englishman. His ability as a diver would certainly make him a success in the professional line. The speeding ground of Boston has a reputation nearly as great as the Bunker Hill Monument.

In Protidence, Messis. Barnabee \& TVinship, the leading clothing-house proprietors of that city, are perhaps the largest owners of road horses. They liave also owned many that have made their mark on the turf, among them H. B. Winship, that has made the best record, 2:06, with a running mate, and sereral others of greater or less fane.

In Chicago, we have Mr. H. T. Bemis, proprietor of the Richelieu Hotel, who has owned driving horses and trotted them for a long while, and lias in lis time had a fortune invested in that way. Mr. Chas. Schwartz has everything from a four-in-hand to a road horse with a record of $2: 20$ in the shaje of a gentleman's tumont. John Dupee, Jr., while he has not taken as active a part on the turf as his partner Mr. Schwartz, has always been as near the front with road trotters as it was possible for him to get.

In Rochester, N. Y., Mr. George Archer, one of the leading merchants, and president of the trotting association, has proven his taste for the trotter by the numbers that he has owned and driven. Mr. Jas. Whitney of the same city is never without one or more first-class road performers and occasionally takes a fly on the turf.

In Buffalo, IV. I. Mills, a min who trotted horses in Flora Temple's time, who at that time owned Belle of Saratoga, and has ever since been connected with the turf, has a small but select stable of first-cliss performers. Mr. 
H. C. Jewett is before the public more prominently as a breeder, but takes as mich pleastre and interest with his road horses as he does in his stock farm. Mir. C. J. Hamlin must have lad the love of the trotter born with him, for as long ago as $I$ can remember he owned something in the way of a speedy horse. Of late years he has had the pleasure of driving a pair of horses bred by himself, a mile better than 2:20, a feat that I believe has never been performed by any other man.

In Clereland, Mr. William Edwards, the president of the trotting association and a wholesale grocery merchant, always feels lost if he does not liave one or two road horses. Mr. W. J. Gordon often takes a spin behind Clingstone, and with his mate, William II., they make a very pleasant team and represent in cash $\$ 35,000$, which was the price he paid for them. Frank Rockefeller, the youngest member of the Rockefeller family, is a breeder who is not averse to trotting his horses on the turf and driving them on. the road, all of which he does with as much enthusiam as a professional.

In Philadelphia, the Bower Bros. are perhaps the representative men of that city in the number and quality of their road establishment. They both occasionally take a flyer at the turf, and in his palmy dars Uncle Billy Doble was their leading driver, he always having the mount behind their trotters. The "Bower Boys," as they are called, enjoy racing thoronghly, and for their vacation from business in summer, take a trip down the grand circuit. Colonel Snowden, a politician, and vice-president of the National Trotting Association, manager of one of the largest insurance companies in the world, and with many other irons in the fire, finds time and has the interest to always own some first-class dxiring animals.

In Washington City, the Naylor Bros. and F. M. Draney are the representative horsemen both on the track and road, as they are men who take an interest in everything pertaining to trotting horses. 
Mr. E. H. Brodhead of Milwakee, a banker, has always taken such a lively interest in trotting horses that he might almost be rated with the professionals, and when he drives on the road he seems as contented in that class as he does with the amateurs. C. C. Mhite, manager of the Plankinton House, is just as good a judge of a load horse as he is manager of a hotel. IT. R. Amstrong is another one of Milwaukee's citizens who invests his money in road horses with a view to pleasure solely.

In St. Paul, Mr. E. C. Long perhaps leads the way in the quality of his road horses, he having in his stable such tried turf performers as Fanny WVitherspoon, with a public record of 2:16: at a mile, and $4: 43$ at two miles, which is the best in the world for that distance. Goremor Memiam leads off with Belle $\mathrm{F}^{\mathrm{T}}$, that has a record of $2: 15 \frac{1}{4}$, and besides her he has Adelaide, 2:18, and any number of others that have proved themselves first class in gemuine battles.

In Louisville, the well-known Steve Maxwell and George Linderberger appear to carry the banner with the number and quality of their fast roadsters. These are only a very small part of the great number of people who interest themselves in owning trotters and if it could be greater computed, the amount of money that is yearly invested in hozses for this purpose it would, I think, appear wonderful, even to people who are used to large transactions.

Mr. Nathaniel Wheeler of Bridgeport, Conn., who has proven by his works that he admires everything that is" good and true, is a great lover of the trotter, and not only keeps and drives them himself but has also bronght his children up to believe it is perfectly proper for a gentleman to own and drive a trotter. He gave his boys a 2:40 trotter to drive at a time in their lives when most boys were amasing themselres with a top. That their education in this matter has not done them any harm is proven by their after life, as they have dereloped into first-class business men and citizens that any country might be proud of. Mr. Charles Clark of Pittsburgh, Pa., a pillar in the chincl, 
not only owns trotters, but as an amaten driver of the same ranks among the first in the land.

Mr. Albert Post of Chicago had the love of the trotter born in him, as he is a native of Orange County, the birthplace of Dexter and George Trilkes, two horses whose names will mark a mile-stone in the history of trotting no matter how long the world lusts. It was on Mr. Post's father's farm, thit moler the tuition of Mr. William Sargent, St. Julien learned his alphabet in the school of trotting. Mr. Post uses his stable of trotters not only for road purposes, but is willing at all times to have them appear in public in actual contests, and thereby get a correct estimate of their merits.

I often hear gentlemen complain that it is impossible for them to get a first-class road horse, and that they have all sorts of misfortunes with them after they do secure one. I think this is easily accounted for from the following reasons: In the first place it requires a combination of qualities rarely net with in any animal to make a perfect road horse. [ find it much easier to select and buy a first-class lace-liorse than a road horse which would please the ordinary road driver. In getting a road holse a gentlenan shonld know just what he wants to use him for: It will be impossible to find one that will be perfect in three oi fom different posilions, or in other words you can not expect to nse your horse in the ordinary family carriage five days in a week and then have hin ahle to go at a high rate of speed the other two. The simple fact of a horse having a record of 2:20, got under the nanagement of an expert, drawing not over two humdred pounds, having the benefits of all the mechanical inventions known to nan in the way of boots, toe-weights, etc., will not make him a first-class roadster. In picking out a road holse, always be sme and buy one that is perfectly somnd. Don't buy an mosomel horse any sooner than you would a second-hand wagon. 'Test the horse thoroughly as to kindness and ability to draw weight at a high rate of speed, and if you wish to huy hin for use in 
double harness have him thoroughly tried in that mamner. I find that many horses that are pleasant to manage in single harness do not always act as well when hitched double.

In buying a horse for present use, do not make the mistake of getting one that has been a fast horse, or one whose owner says will in some future day he able to beat Mand S., as in that case you are simply paying for his opinion and not for the fact. The safest way is, I find, after thoronghly trying the horse on the road as to lis weight-pnlling ability, kinlness, etc., to hilve the seller take him to some good mile track, let him drive lim as fast as he can and you hold your wateh on him. Then pay for just what you have seen. If yon can not buy the horse on those terms you will be better off without him, and will have the privilege of looking farther. I have had some strange experiences in buying horses, and this calls to mind an instance where an owner of a trotter male a mistake of nearly a minnte in the speed of his horse, and when I proved it to him, he didn't seem to think that it made any great difference.

I was one day approached by a gentleman who asked me if I would like to buy what was probably one of the greatest trotters in the land. I told him I would. He went on to say that he lad a horse at his farm that was sound and all right in every way, went without any boots or weights, and that he would gnarantee to show me with this horse a mile in 2:20 by the watch. I had heard so many ghost stories about horses that I generally divide the time stated by two, but in this case the man's appearance and manners made such a good impression on me that I arranged to go to his country home, time the world-beater, and should he go in $2: 20$ and fill all the conditions, I was to give him for the horse $\$ 7.500$ in money. I had on $\mathrm{my}$ list of acquaintances a very wealthy gentleman who was rery anxious to own a first-class trotter. When I told him the arrangement I had made he was as much pleased as I was with my first drum, and together we took a tedions railroad trip to the home of this going-to-be conquerol of Mand S., and on walking 
around the track where he was to be shown, I told my friend that one of two things was the case, and either the track was not a mile, or the man was crazy, as Rarus in his palmy days conld not have trotted a mile over as poor a track as that in 2:20. The gentleman bronght his liorse to the track, warmed him up with as much flourish as though the best record in the world wis in danger, and came up and got the word. We started our watches on him and he finished the mile in $2: 39 \frac{3}{4}$. As I do not want to jar the feelings of my readers I will not recold in this book the sentinents I expressed at tlat time.

I remember a man who in my younger days bronght a horse to New Tork to sell on a contract to show 2:45 with lim, and for every second he beat it, he was to receive one liundred dollars orer a stated price, and for every second he fell short of that time he was to take off a hundred dollars from the same price. When he showed the horse he went a mile in three minutes, which, if the man had been compelled to live up to the letter of the contract, would have cost him five hmonred dollars in money.

After a gentleman has bought a horse the next thing is the management of him. Then you buy a piano and pay four or five humdred dollars for it you carefully house it, no one is allowed to play on it unless they are known to be experts; you have it carefully examined at stated intervals to see if it is in tune, etc., and nnder such careful management it lasts a long while. Horses. as a rule, are treated rery differently. A gentleman of wealth buys himself a horse for which he pays a large price. Having perhaps nerer having had the time or inclination, and nerer having mate any study of the horse family, he places lim in charge of nome of the many men servants aronnd the house, most of whom are not eniployed on account of their ability as first-class grooms, but for their usefulness in taking care of the lawn and other duties about a gentleman's place. IVith this combination of driver and groom one would hardly expect any wonderful results in the way of speed. Taking it 
for granted that you have bought a horse that in disposition, formation, breed, natural gait, etc., is culculated for a road liorse, one that does not need boots or toe-weights and has no peculiarities about shoeing, with a little good horse sense brought to bear, you will be surprised how long a horse will last.

In proof of this, look at the length of time that Dexter lived and was useful. Mr. Work's team, Swiveller and Edward, the last time I saw then, looked like colts. They have not only had a long career on the road, but before he bought them were used as turf horses for some time. No type of horses that I know of live any longer or are able to do any more work of their kind, if properly cared for, than trotters. In the management of your horse in the stable, the first thing absoiutely necessiary is a man of intelligence. Ihare reac a great many books on the ventilation of stables, etc. but seldom see anything said in regard to the man who is going to manage the rentilation. Don't expect to find a first-class groom that will be capable of growing roses in your greenhonse, as with their limited chance for education they will not lave time to learn both trades well. I think that the same attention should be paid the ventilation and drainage of your stable that you wonld pay to your own house. I think artificial heat in a stable munatural and detrimental to horses. What they want is plenty of fresh air, to be comfortably clothed, and to have a good bed at all times. No matter how well you feed or care for a man, if you put him in a bad bed at night he will be very apt to find fault in the morning, and I think it is the same with a horse.

In the matter of feeding the lorse the attendant lias to be governed entirely by the disposition of the animal and the amount of work he is expected to do. These things come to a man by natural observation and tact. When it comes to driving, if you want to realize the greatest pleasure there is in the ownership of a horse learn to drive him well. I think there is just as much pleasure in the knowledge of 
being able to drive a trotter well as there is in the sensation of his diawing you orer the ground at a high rate of speed. Be just as careful in driving lim down the road for fun as you would if you were driving him on a race-track before a large audience for money, and remember at all times that to drive a horse at a high rate of speed with the weight of an ordinary driver and wagon, you have the animal under a greater strain than you would driving him at his top speed to a lighter vehicle. And if you persist in this sort of thing you will be very apt to spoil your horse's gait, get him to hitching and hobbling, and in other ways make him unsteady. My idea is to protect your horse in every way thit you can. Don't overload him; don't speed him where the footing is bad and deep. When you do speed him be sure that everything is favolable for the horse and that he is in proper condition to staud that sort of exercise. Most men who have raluable horses for road purposes and are successful with them keep a first-class man who trains and looks after them with as much care and attention as I would a stable of race-horses. If a man should hire a hod-carrier to run the engine in his pleasure yacht, and in that way get blown up, people would say: "What conld you expect?" Then what can you expect if you hire a man who is no more fit to take care of your horses than a hod-carrier is to run the engine, if your horses get lame, take sick and die?

Not only in the Eastern country, but all through the Western country gentlemen are greatly interested in trotters. In Cheyenne, Phil Dater, who used to be one of the pillars of trotting about New Iork, has been located for a number of years and took with him his love for the trotter as is shown by the large number which he owns, many of which he has bred. In Denver, Mr. William Bush, proprietor of the IVindsor Hotel, keeps a fine stable of road horses, as well bred and perfectin erery way as money could buy. His brotiler Jim, proprietor of one of the leading stables, keeps his horses both for turf and roal purposes. Is willing to tike a flyer at the turf at any time, and is always ready to pro- 
tect his money at the pool-box in a way which has kept his bank account in good order.

Driving trotters on the snow has come to be a great amusement with gentlemen, and a horse that can go well in that manner will command a larger price as a gentleman's road horse than one that can not. I fincl a great difference in horses abont going in the snow. Some very fast horses from their gait, etc., seem entirely helpless when hitched to a sleigh, while others take to it very kindly. One of the best snow horses I erer saw, perhaps, was Ethan Allen. He was my ideal of a gentleman's road horse. I think I have seen Mr. Simmons drive him and his son Honest Allen on the road to a sleigh faster than ever I saw a team go that way hitched. For a perfect sleigh horse you want one that does not pull, that is square gaited and will go without boots. If he is obliged to wear boots in the snow and they become wet they will be heary, and I also find that the water seeping throngh the hoots often poisons the horse's legs and in that way you are liable to have a great deal of trouble. Boots often chafe a horse in the snow from being wet, etc., while they wonld not at any other time. Speaking of a horse chafing, I find that a great many are troubled that way even in summer. If a horse pulls in harness, he is almost sure to chafe under the breeching, and there are some that chafe under the breast collar. If I have a horse that chafes from the breast collar, I always use an old-fashioned collar and hames on him. He will trot just as well, althongh it may not be quite as handy or look as well. The best remedy I ever tried for chafing is a solution of white-oak bark. Any druggist can make it for you. This recipe was given to me by an amy officer, who told me that he learned it from a groom in the army and he considered it one of the most valuable remedies he ever met.

In selecting the donble team for a gentleman's use, if you expect to drive them at a high rate of speed with ease and comfort, there is a great deal to be thought of. First and foremost, you must have two horses the same disposi- 
tion and temperament. Then you want them gaited as near alike as possible, and you will find that no horse that has to wear weights and a great number of boots can by any possibility be a first-class road horse. What you want is a horse gaited so that he will balance himself. If either one of them pulls at all, they will be both disagreeable and useless as a tean. I find that most horses when being used in double harness need to be shod a little heavier than the same horse would in single harness. This arises I think from the fact that you do not liave the same chance to balance him and steady him with the bit that you would in single harness. I think that as a rule road horses are checked entirely too high. To place a horse's head in that position and then ask him to pull 500 pounds in weight at a high rate of speed is wrong. The horse is not only uncomfortable but at a great disadrantage. I notice that in drawing weight most horses hold their heads in a medium position. I can not remember a horse now that carried his head extremely high and had to be checked in that manner, that I ever considered a first-class road hor'se. I think that weight has something to do with a road horse. Hopeful was not a racy-looking horse. He is what we would call a "chunk," hat a short, thick neck, strong shoulders, plenty of bolly, short, strong back, very stout legs, and here too'he wits short. By the recor'd he was the best weight puller we ever had, he having made the best record to wagon. I don't wish to say by this that I think there was no other horse could have done the same thing or gone bettel, for I am sure that there was. ilexter was a wonderinul horse for his size to draw weight, which is not only proven by his races to wagon, but also by lis being driven to a road wagon in $2: 21 \frac{1}{2}$ by his owner, which is a performance $I$ think nerer equaled by any other horse.

In shoeing a horse to drive in the snow, you will find that at all times he wants to be shod sharp. If the calls get dnll and he slips a little, he soon becomes discouraged and will not try. It is just as hard for a horse to go in dull 
shoes as it is for a boy to skate with dull skates. A horse should always be shod with leather in winter, or some other arrangement made to keep lim from balling in the snow. I have tried two plans with satisfaction. First, the leather pads, and if you use patent leather you can oil it a little and the snow can not possibly stick to it in the least. My other plan is, buy some sheets of guttapercha at the rubber factory, take a small quantity of it and put it in boiling water and in that way soften it, and while in that condition press it into the bottom of the lorse's foot the same as you would putty. It, will harden very quickly and cam be left in as long as you like without injury. One thing to recommend this plan is that it can be done without removing his shoes. In driving your horse on the snow, always remember to have him in good condition before you commence to work him, as one hard drive when out of condition in the deep looting is liable to sore his muscles and body so that you will not have any pleasure with him the balance of the winter.

I think most of the people who interest themselves in the thoroughbred horse do so not so much from a matter of sentiment and love for the horse, as they do for gain. I notice that when it comes to a matter of pleasure a great many of them keep a trotter or two. McLanghlin, the crack jockey, and Garrison, both keep private road establishments, and while they are both small men they drive extremely well, thus proving to me that it is not a matter of strength in driving a trotter, but of talent. Some of the most noted men now connected with the running turf have at some time in their lives been connected with the trotting turf. For instance, the Dwyer brothers long before they interested themselves in runners had trotters on the turf. John Campbell made himself famous with pacers and trotters before running reached anything like the proportions it has reached now. Ed. Corrigan, who has taken a very active part in rumning the last few years, used to train and own trotters, and was one of the first men I ever saw divive Rob- 
ert McGregor in a race, and some of the qualities that made him successful on the rumming track were just as usefnl to him with the trotter. Jack Batchelor trained and drove his own trotters for a number of years with success, and when he went into the running-horse business, he was able to train them and get his share of the money. Col. William McGuigan, who at one time made his mark on the trotting turf, a longer one perhaps than any other man ever did, has connected himself with the runners and is just as successful. L. C. Chase, who in his lifetime orned some of the best trotter's in this country and managed them successfully, proved himself just as handy with the rumers as he ever had been with the trotters, and before the talent about the pool-box realized it, he had given them some blows from which they have never recovered.

I think a man that is a first-class rider of thoroughbred race-horses can certainly be taught to drive a trotter well. I have watched William Hayward ride some of his longdistance races and I have always felt sure that if he had taken an interest in it, could have made himself a first-class driver. Speaking of light men driving a trotter well, we have a number of feather weights in the business who get along all right. In Bennie Mace's lifetime, while he was overshadowed by Dan's greatness to a certain extent with the public, I always gave him credit for being an artist. I think he never weighed over 115 or 120 pounds, and was rather a delicate man in health, etc., yet I have seen him drive all kinds of horses, and it seemed to me extremely well. Isaw him ride Panic for Mr. De Noyelles once, when he could not have weighed orer a hundred pounds. Bennie drove American Girl some of the best races she ever trotted, and he must have impressed her owner Mr. Lovell as being a good driver, as he had been connected with the turf long enough to know that talent is a very necessary thing to have in that position. Dan and Bennie were great friends. Dan looked upon him more I think as a son than a brother, and Bennie always deferred everything to him 
the same as he would have to his father. Bennie lost his health and Dan in making his will left the bulk of his property to be held in trust for Bennie's use. But as Bennie only outlived Dan about three nonths he had no use for it.

Dan had another brother that the public never heard much about, Joe Mace. He was by long odds the handsomest one of the family; sery much the best educated one, and had other adrantages over Dan and Bennie that would have helped to make him a success in the world. But he did not have the determination and will to apply himself to business that they did, and while he was very fond of horses and had some very good ideas about them, he seemed more willing to sit down and talk and read abont them than he was to try to make a liring with them. He always left that part of his affairs entirely to Dan. I have seen him drive a few races, but if it came to anything like a close finish he would send for "the old man," as he and Bennie always called Dan. I think that oftentimes one rery bright man in his business in a family is liable to overshadow the other members in such a manner that they do not appear to the best advantage. I am sme this was the case in the Mace family and also in Hiram Wroodruff"s family. He had two brothers, 'I Tilliam and Isaac, who in their' prime were horsemen of ability way above the average. In those days trotting horses were very scarce in numbers and those that were anything like good ones could be counted on the fingers of your hands. And Hiram with his great reputation of ability, coupled with his honesty which always gives any man an advantage in his business, as a rule had the pick of the world. Isaac and William drove all kincls of races well, and both were experts in the saddle and could ride a horse any distance. Isaac is still in the land of the living and it has never yetbeen proven that any of the new generation of driver's and trainers have outmanaged or out-driven him for the money. Budd Doble is about the only example $I$ ever saw of a man following in 
the footsteps and same profession as his father did, who did not labor under the disadvantage I speak of, and I think he has his father to thank for that. Boys are very apt to defer everything to their fathers if they are in the same business which I think is very wrong. If you expect to succeed in any business in life you must make up your mind to one thing, and that is to dlo some thinking for yourself. Don't expect your father or your brother to to your thinking, as if they do and you lose them in any way and you have never taught yourself to think, you will be very helpless. Uncle Billy Doble told all his boys if they were going to be horse-trainers they must work ont their orvn salvation, as his experience had taught him that was the only way they conld hope to be successful. My expel: ance has taught me that people who hare made a great success of anything have done their own thinking. This matter was greatly impressed on my mind by a sliort conversation I once had with General Grant. In our talk the subject turned on the criticism of the public, and I remarked that I thought the public had often criticised me rather sererely. General Grant asked me if I had erer read the papers through the war times and if so, what I thought of some of the criticisms which had been made on him. He said he read them all carefully and if he saw anything he considered good in them he jotted it down in his memory, but as he being at the seat of war, and the critics located thonsands of miles away in their peaceful homes, from his advantage of position better capable of judging what was the best thing to clo at the critical time, fonght the battles on his own plans and as he won, of course liad the satisfaction of being credited with having done right.

In training a trotting horse never take anything for granted. If he wins a race or goes a good trial do not close the account and sit down and think to yourself thit he could not have been better trimed or better driven. After your horse hils made a performance, while the matter is fresh in your mind, study it orer carefully and see whether 
there was not some place where you could have improved the training or driving of him. In driving against other people, study their methods and plans as much as possible. I do not wish to be understood as advising you to initate them at all times. That I mean is, to learn all you can by close observation, pick ont what yon consider the best points, and use them to make a trade-mark for yourself. If you expect to shine in the profession to any great extent, you will have to have methods that are recognized as purely your own. In Mace's style of driving, people often thought that his success was not the result of well-laid plans, but a sort of inspiration of the moment as it were. Such, I am sure, was not the case. W' Thile he had all the brilliancy and dash of what would be termed in army circles a "raider," he also appreciated the adrantage obtained by haring correct information as to the strength of the enemy, and a plan of battle to attack him from. At the last critical moment when a little thing would decide the battle, Mace would come with a wild rush that looked as thongh it did not contain much in its elements in the way of plans. This was only the finish of his plan of attack, as I have had proven to me without a doubt. He has often told me in talking orer some coming event, just what he wonld do, where he wonld make his drive, and what the result would be. The best driver in the world, with his nicely laid plans may make mistakes. But the driver who is the best lawyer and does everything after a plan, looks after the details the closest, and is naturally a reinsman, will with the same quality of horses obtain better results than any driver can who goes about it in a haphazard manner. In my younger days I made the acquaintance of IVilliam Hayward, the celebrated jockey, and in him was demonstrated the correctness of this pule more than any man I ever saw. I have seen him lide all-distance races and that he rode them extremely well has been proven over and orer again without any doubt. His judgment of pace is something wonderful. If he was to ride a horse a mile, he could tell you before he started how 
well the horse ought to go, each fractional part of it, in order to malie his best possible record. I have often seen men in running and trotting races both make a very serious mistake, particularly in riding or driving what we call a waiting lace. They would simply be governed by how slow the other man went. I saw Turner once win a race of this kind through a mistake of his opponent. In a race that came off in $18 \% 6$ one of the starter's was a horse noted for speed, and also lack of ability to stay, the other one with not as much speed but plenty of game. The speedy horse won the first two heats, the game one then came to the front and won the next two. As a forlorn hope, some one suggested putting 'Turner up behind the what looked to be at this time the beaten animal, and here is where Turner made an impression on some people that his title was not an empty one. In scoring for the fifth heat, Turner's animal seemed to be entirely without speed. They scored several times, finally got the word both horses going at a very moderate gait, Turner apparently clucking and switching his horse along for all there was in him and the other grntleman with his horse in front, driving him with as much confidence apparently as though the race was over. In fact, everybody who looked at the performance gave it up as a settled fact, and were very much surprised when the horses straightened into the stretch, Turner pulled his mare out and went at her about the same as Garrison would at a quarter horse, brushed the other man's horse off his feet, he being taken unawares, and thereby losing the race. If Hayward had been driving this horse from his knowledge of pace and his horse having the ability to go, he wonldn't have paid any attention to General Turner, but would hare set the pace fast enongh to have insured the General's defeat, or in other words wonld have driven his own horse in the manner he thought best culculated to win.

Always remember one thing, that you are not the only man that, as the boys say, is doing a little cheating. You may have your own horse mnder cover, know that he is 
in proper condition, and that you can drive him well. Always remember that some other man may have the tools to do just as well with. I have often lieard people say that a still tongue indicates a wise head. I think that to a certain extent this is so. There was one trait about Mace which resembles a point in the character of "Veritas," who was a warm friend of Mace, and that was this: If Mace had a race against you and was anxious to find out what you thought about your horse he would interview you on a plan of his own. He wonld not take you by the arm and walk you away into some sechuded spot in a mysterions manner and cross-question you as a lawyer would, but if he happened to meet you with a party of friends, wonk in a laughing, jolly manner turn the conversation on the matter of the race, and while he told you how well his horse was going and what he expected to do with him, would listen very carefully to any remark that you might drop about your horse. After you got through talking you would go away with the feeling that you knew all about Mace's business and that he had been mable to get any pointers from you. But if you would take the trouble to think it over carefully, you would find that while Mace had done a good deal of talking and said some wise and good things the information on a particular point would be very vague. I lave found that in interviewing" a man " Teritas" invariably follows the same tactics. If there is any subject that he wishes to get your opinion of for publication or otherwise, he does not aploroach you with his pencil and book in hand, but on the contrary strolls in as thongh he had come for a social chat. Does not eren start the conversation off on the subject he wishes to interview you on but leads up to it gradually and before the man fairly linows it he is interriewed and has unbosomed himself to the fullest extent. If you want to, as the boys say, throw the public off and keep them from watching and touting your horse, find ont how well they think he call go and whenever you are going to work him invite them out to time him. If he shouldn't happen to go 
as well as they imagine he ought to in his work after the trouble they have taken to time him, they will be more than likely to conclude they had him orerrated and will not take as much pains to watch him as they would if you had not asked them to time him. If, on the contrary, you act in a mysterious manner with your loorse, they will be sure to watch you all the closer. Never tell a man an untruth about your horse or business in any way. If you are asked any questions which you think you can not afford to give a truthful answer to, tell the gentleman in a polite and pleasant manner that you would be glad to give him a tip but on this particnlar occasion for reasons which you can not explain, yon are in a position where you will be unable to furnish the information lie desires and the chances are that by so doing you will make the man your friend instead of your enemy by telling him an untruth.

Many a man has labored under a disadvantage from the simple fact of his not being a good talker. Oftentimes points arise in races where the manner in which the facts are placed before the judges count for as much as it would in a lawyer making a plea before a juclge and jury. I once luad an acquaintance of the name of John Hornbeck, and with certain classes of holses in training and driving he was an expert, and the simple fact of his being mnable to express himself in proper language, I an sure often worked to his disadvantage. The smartest law yer in the world would not do as well before a jury were he vinable to express himself in a pleasant and intelligent manner as another man with less ability, who had more of the Daniel O'Connell style about him. Nerer feel that because you are a beginner that you will never make a reputation for yourself equal to that of Hiram IVoodruff or Budd Doble. Start ont with the determination of not only making a reputation equal to theirs but of excelling it, and if you are boln with the same natural ability that they had, it ought to be an easy matter for you to excel them from the fact of you having their experience to study from, sonething that I think of very 
great advantage. If I had my life to lead over, there are a few things in connection with my business which I would do differently. First, if I wished to learn to be a horsetrainer, I would take as much pains to edncate myself in every detail pertaining to horses as I would if I was going to fit myself for any other business in life. I would also by my acts make for myself a reputation for honesty, etc., that would never be questioned. The latter part of it not only from a feeling that it is right but also as a matter of business. Take two men with equal ability as horse drivels, one with the reputation of being strictly honest and the other perhaps with the disposition to cheat the public just a little, you will find that the man with the loonest reputation will invariably have the best of it. Time and again have I seen this when it comes to a close decision and Mrurphy or Doble are interested, they nerer get the worst of it and are almost sure to get a shade the best of it. This is perfectly natural in human nature, as if you are called upon to decide anything between two men in the same position, you would be almost sure to do the same thing. My advice is to not be only strictly honest in all your dealings but take pains to make that reputation for yourself. Do not be satisfied by saying that you are honest and you don't care what people think about you. Remember your reputation, to a certain extent, is to you what a bank account is to a business man. This I think was one of Mace's weak points. People often accused him of doing shady things which he never did, but he from carelessness or other causes did not take the trouble to deny it, always saying to me that so long as the people that he drove for were satisfied he never cared. Truthfulness to his employer was Mace's religion, and had he given me lis word in regard to anything connected with a horserace, it would have been worth just the same to mesas a Government bond, that is I would have given a premium for it. I am sure that men are born with certain characteristics. It is not very hard work for an honest man to remain honest. He will not have to watch or educate himself on that point, 
but should he find a little weakness in his character in that respect, by a little education he may be able to overcome it the same as he would any other fault. I do not wish to be understood by this that I am a reformer, as I always look upon that class of people with a good deal of suspicion. As this book is intended to a large extent to be matter-of-fact, and I hope it may be of some benefit to young beginners, I record my opinion after thirty years of study. 


\section{CHAPTER XVI.}

Budd Doble writes in a chatty and interesting manner of Goldsmith Maid and Dexter-How the famous brown gelding was placed in his stable by Hiram Woodruff-The young man's doubts and fears over the responsibility he had assumed-Lowering Dexter's record in the first race he drove lim, and becoming more confident-The season ends with a mile in 2:18 under saddle-Trotting in 2:1; at Buffalo the following year and beating the world's record-How the Joung reinsman felt on that momentous oceasion-Dexter is purcluased by Mr. Robert Bonner and retired from the turf-The story of Goldsmith Mairl, the champion trotter of her day, and that for many years was Queen of the Turf-She was rough-gaited when Mr. Doble got her, and coukl not beat 2:30-Her first race a disappointment to him-A new system of training adopted the following spring with good results-The wonderful intelligence di-played by the Haid both in the stable and on the track-She knew when a race was coming off and became terribly excited-Figuring to get the best of her opponents--Her wonderful aflection for Old Charlie-A happy family of three that was finally broken up.

In fulltilment of a promise made some time ago to the editor and publisher of this book I have consented to give, in a sketchy and desultory mamner, some facts concerning two horses that in their day had the fastest records of any animals on the trotting turf, both of them having been driven to those records by me.

I refer of course to Dexter and Goldsmith Maid, two trotters whose names to-day are as well known as those of other animals that have come upon the scene later and trotted even faster than they did, and whose performances are looked back to by horsemen with unibated interest.

It was in July, 1866, that Dexter went into my stable, the circumstances of my taking charge of the brown gelding, that even then was the most famous horse in the conntry, 
being as follows: I was at that time a resident of Philadelphia and had gone to New Iork at the request of my friend Sam Keyes (still alive and hearty and as fond as ever of pacers) to arrange if possible for a race between the pacer Magoozler and Dexter, both to go to saddle. Mr. Keyes liad told me to make the match for $\$ 5,000$ if I could, and the reason I was selecterl to conduct the negotiations looking toward the race was becanse it was intended that I should ride the pacer, and the further fact that I was well acquainted with Hiram Woodruff and somewhat a farorite of his made it natural that I shonld be sent on the mission. After reaching New Fork I made my ray to the Fashion course on Long Island, it being the day that Dexter was to trot against General Butler and Tanderbilt. When I reached the track $I$ met $\mathrm{M}_{\mathrm{i}}$. Woodruff and almost the first thing he said to me was: "Come over here, my son, and I will show yon a horse that is in condition." He referred of course to Dexter, and we went together to the gelding's stall, and I can remember perfectly well with what boyish admiration for the skill of Woodruff I gazed on the handsome animal as he moved abont the box-stall with that lithe, sinuous motion that was peculiarly his own. Having looked the horse over from all points I thought it time to broach the subject of my risit, and accordingly said: "I have a proposition to make to you, Mr. Woodruff," and was going to state the terms when he interrupted me by saying: "TVell, I have got one for you." Of conse that stopped my tongue at once and I waited for what was to come next. Said Mrr. Woodruff: "Dexter has been sold to go west. I cannot accompany him, and the man to whom he now belongs wants someone that can train, ride and drive him, and I am going to recommend you for the place."

I was practically speechless with a mingled feeling of astonishment, pride and gratification when the most famous driver in the world said this to me, but without giving me time to express myself in the matter at all he walked with me from the stables to the track and as we stepped on the 
quarter stretch in front of the grand stand said to me: "Yon stay here until I find the man who owns Dexter." In a little while he came with George Trussell and said to him: "Here is a young man that I can recommend." That night I arranged with Mr. Trussell to take temporary charge of Dexter and drive him in his race at Suffolk Park against George M. Patchen, Jr., of California, that event being fixed for the 9th of July, and also to ride him a week later in a race at the Fashion track against General Butler and Toronto Chief. Mr. Trussell said that he would send the horse to me at Philadelphia the following day and with this understanding I started for home.

It was only after boarding the railroad train that I fully realized the experience I had gone through with during the afternoon, and my first conclusion was that I had made a big mistake. I reasoned that for a boy likie me to take such a noted horse as Dexter from the hands of Hiram IVoodruff, the foremost trainer and driver in the conntry, was assuming too much, and all that night I conld not get this notion out of my head. The following day passed, Dexter did not come, and I felt immensely relieved, but that nigh I received word that the delay was cansed by the fact that Mr. Trussell did not like to send the horse through the streets of New York on the Fourth of July, and that lie would reach mystable the following morning, which he did. Of conrse I had been able to think of little else, and after learning that Dexter was surely coming to me, I began to reflect about his management. 'The more I pondered over' the matter the more it seemed certain to me that he was not in need of much training. I knew that he had been given plenty of work, and the fire-heat race that week had certainly supplied any possible deficiency in that direction, so that my notion was that the best plan to pursue would be to give the horse as little work as possible, devoting all my energies to getting him free from soreness and toning him up generally for the race that was to come.

Naturally enough all this responsibility made me anx- 
ious, and another thing that added to my nervousness was the fact that the newspapers warned the public against betting on Dexter. They said he had just changed hands, going from the stable of the best driver in the country to that of a young man who had had little experience, and that it was not reasonable to expect that he would be in his best form. At that time Dexter's record was 2:24 $\frac{1}{4}$. My plan of training, luckily for me, proved the proper one, and when the day of the Suffolk Park race came Dexter was in fine fettle, beating Patchen easily and trotting one of his

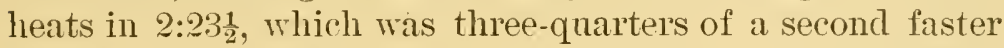
than his previous best record. This put me in high feather with the public, and, not unnaturally, I had more confidence in myself, so that when we went to the Fashion track to trot the saddle race against Butler and Toronto Chief I had my wits about me and won rather easily. These two races at two ways of going seemed to satisfy Messi's. Trussell $\&$ Fawcett, the owners of Dexter, that I was competent to take charge of the horse and we then made a contract for the balance of the season.

Dexter was the most nervous horse I ever handled when he was in the stable or while being rigged up, and he was not a pleasant horse to drive unless going at the top of his speed or nearly so. He was an irritable horse by nature, peevish in disposition, and an annoying one to handle at all times except in his races. This was the only time, as a matter of fact, that I enjoyed driving Dexter, but a safer horse or a more reliable one in a race I never sat behind. There were only two places in a mile where he needed watching, and these were at the first and thind tums. He was a rery lesolute horse on the track, had a bold way of going, and was so ambitions that in rounding the turns he was liable to orertrot himself and break. In those days trotters were trained to take hold of the bit pretty strongly, the idea being that they conld not be controlled and balanced is well by the driver under any other circumstances, although of course since then that idea has been exploded and horses 
are now taught to drive with a very light pressure of the bit. Dexter was in no sense a puller, although he would take hold well and it was from this habit that he was so liable to sore mouth, which was one' of the things that troubled him more or less during his entire trotting career.

As to how we rigged him, it should be remembered that in those days the manufacture of horseboots was in its infancy. All that Dexter wore in that line were invented and for the most part manufactured by his rubber, Peter Conover, a man to whom a great deal of the credit of Dexter's excellent condition was always due. He wore a knee boot on Dexter's near forward leg, a pair of speedy cut boots behind, and a pair of old-fashioned bell-pattern quarter boots. These boots Dexter wore in his races and work, but of the latter it was necessary to give him very little. Although a horse of fine physical organization and a good feeder, he did not make flesh fast, being so nervous and irritable that he was constantly on the move when nobody was about and seemed by this means to keep himself from getting gross. During the trotting season all the work Dexter received besides his races was a light repeat every week, and these miles were generally in from 2:28 to $2: 30$ - that being as slow in fact as I conld make him to go withont getting him to pulling and fretting. When it came to his jowgiug I always let Conover do that for the reason that Dexter, who was a horse of a great deal of intelligence, soon learned to know me and his idea was that when I got into the sulky it meant for work, and whenever I would try to jog him he would pull, and lug and fret somuch that it was hard work on me and did him more harm than good.

Omitting any detailed mention of the races which Dexter trotted for me during the season of 1866 , it may be said that I was successful and at the close of the year I had rednced his record in harness to 2:21 and ridden him a mile in 2:18, which was the fastest that a trotter had gone, any way rigged. As to the famous trial against the watch at Bufialo in $186 \%$, when he showed himself, by trotting a mile in $2: 17 \frac{1}{4}$, 
to be the greatest horse in the world, I can only say that before starting on that journey I had every confidence that the horse wonld do all that was asked of him. Just previous to this he had been going some very good races against Brown George and running mate, trotting at Troy, N. Y., on the 16th of July in $2: 22,2: 20 \frac{1}{2}, 2: 20 \frac{1}{2}$, and at Providence, doing a mile in 2:20) Dexter trotted the second heat orer a half-mile track in 2:19, that being the first time that he had gone a mile better than 2:20 in harness, the first time that Flora Temple's record of 2:19:3, made in 1859, had been lowered by a loorse trotting in hamess, and also the best time to that date over a halimile track. The Boston race took place July 30, and the trial against time at Buffalo was set for August 1t. The conditions were that the horse was to trot to beat 2:193.

I remember that the day was a very fine one, the track first class, and that a great crowd of people were present.

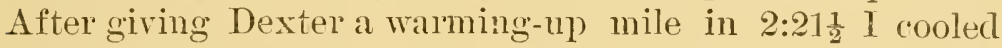
him out and came back in twenty minutes for the grand effort. Of comrse I was anxions that the horse should do the best work that he was capable of and at the same time confident that muless some mistake was made he would trot a mile in 2:18 or better. At that time the practice of drivers carrying watches and timing their own miles was not in vogue, we being obliged to judge of the pace as best we could and figure on how near to the limit of our horse's speed we were going. My idea was to get Dexter safely around the first turn, at which point as I have said he was a little apt to orertrot himself, and then let him rate along about as he saw fit. I knew that he was a horse of so much courage and ambition that he wonld do pretty nearly his best withont any urging at all, and it was my calculation to follow this programme until three-quarters of a mile had been trotted and then drive him through the stretch as well as I coukl. This plan was strictly adhered to. I knew the horse was going well all the time and as we finished the mile made up my mind that it had been done in 2:18 or a little better. Of 
course when 2:17 $\frac{1}{4}$ was hung out there was tremendous excitement and a crowd of my friends rushed out to congratulate me on what I had done. Mr. Fawcett, who owned Dexter, was a rery quiet man, not given to exhibiting his emotions in a marked degree, but all the same I saw that he was very much pleased. As soon as the excitement had in some measure abated it was annonnced from the judges' stind that Dexter had been sold to Mr. Robert Bonner for $\$ 33,000$ and after filling a few more engagements which had previously been made for him he was delivered to that gentleman and remained his property until the day of his death, which occurred during the last year.

A good deal has been said at various times to the effect that Dexter was a vicious horse, and people who saw him in his stable generally went away with that idea firmly inpressed on their minds. As a matter of fact Dexter was not nearly as bad as he pretended to be. It is true that if a person went into his stall he wonld run at them and if they retreated would follow them, although I do not think that even then he would have injured anybody. It was simply a bluff on his part, that trick of rushing at people, and he would stop quickly enougli if a man stood his gronnd and threw up his hand at him. He was certainly not a pleasan1-tempered horse, but I should not class him as a vicious animal. Like a great many other horses he had his farorites among men, and while to most people he was cross, he conceived strong affection for Peter Conorer, his groom, and would pay not the slightest attention to him when he was in the stall. In fact Conorer slept in the stall, which is pretty good evidence that Dexter never had any intention of haming him. I have said that Dexter was an intelligent horse, and he was also a fanciful fellow, one notion of his that comes to my mind illustrating this very well. Thenerer we wanted to take Dexter through the streets of a town or city we wonld put a boy on his back and then he would lead along as soberly as any horse you ever saw, but if you tried to take him over the same route without the boy 
astride of him he would carort about in such a manner as to be in constant danger of seriously injuring himself.

So far as Goldsmith Maid is concerned a book could be written about that wonderful mare, and for that very reason it follows that what appears in these pages must necessarily be of a sketchy churacter. Even now, a dozen years after she was retired from the turf, the public is perfectly familinr with Goldsmith Maid and her wonderful performances on the trotting turf, so that I shall not attempt in any man. ner to consider that phase of her career.

When I got Goldsmith Maid she was eight years old and had a record of about 2:32. Her early history was a romantic one, viewed from the standpoint of subsequent events, and it seems strange that a mare that for years was regarded as too willful for harness purposes on the farm where she was bred, and whose speed as a racer was put to the test by the farmer's boys on moonlight nights when there were quartermile running races to be decided in a lane not far from where they lived, should in a few years not only become famous as a trotter, but do a mile so much faster than any other liorse that from that time on there was nerer any question as to her supremacy; and that when she retired from the turf was just as much the queen as she was fire years before that when she had first trotted in 2:14. In those years she had fought hel way step by step to the rery front of the trotting turf, and once arrived there had held undisputed sway, not only in the matter of winning races against other horses, but also in trotting against the watch, a far harder sort of race, and had successively lowered the trotting record of the world from 2:17x, the time made by Dexter at Buffalo in 1866 when I drove him, to 2:14, which figures were the best when Goldsmith Maid retired in 18\%. But 2:14 was not destined for a very great length of time to be the limit of speed in the trotting horse, for the next season after the Maid went out of the harness for good

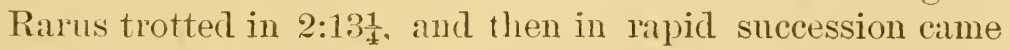
St. Julien, Maud S., and Jay-Eye-See. 
I have said that when Goldsmith Maid came into my stable she was about eight years old, and at that time she conld trot a mile in about 2:30. This was in the latter part of Ortober, 186\%. and it might be well to state here how the mare came to be driven by me. It will be remembered that after the sale of Dexter to Mr. Robert Bonner the horse still had several engagements to fill, and as he was transferred subject to these he remained in my charge for a month after the sale was made. Going from Bufialo to Hamilton, Canada, I drove him a race against Bolly Lewis, who went under saddle, and from there we shipled west to Chicago, where a couple of laces had been arranged, the tirst being against Silas Rich, Bashaw, Jr., Tackey and General Butler, in which Dexter went to wagon, the others in harness: and the second against Brown George and rumning mate. Dextel won both these races, the fastest mile he was called upon to trot being 2:22, and they ended my connection with the hor'se.

While I was at Chicago with Dexter I receired a letter from Mr. Alden Goldsmith, proposing that I train and drive Goldsmith Maid and asking me what I thought of the proposition. Another letter that reached me at the same time was from the owner of Lucy, a mare that at that time had a record of $2: 28$, was considered to be one of the best trotters on the turf, and that subsequently made a mark of $2: 18 \frac{1}{4}$. I har seen both of these mares trot, and while Lucy had a good deal the best reford of the two and could unquestionably go a mile faster than Goldsmith Maid, still I had noticed the latter particularly in a race that summer, and had seen hel at that time strike a clip that made me think she would be a first-class race-mare if only she could be taught to stay on a clean trot and notgo back to the rongh and hitching gait that she was at that time inclined to favor. So after giving the matter considerable thought, I finally decided to decline the proposition from Lncy"s owner and accept that of Mr. Goldsmith, hut subsequently Lucy was also in my stable, and I gave her' a record of $2: 22 \frac{1}{4}$. Conse- 
quently on my return to New York I met Mr. Goldsmith and arranged to take the mare, the first race in which I drove her being at Providence, R. I., in the latter part of October. The other starters in this event were May Queen, Confidence, Colonel Maynard, Crazy Jane, Old Put and

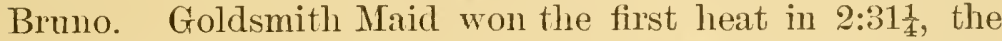

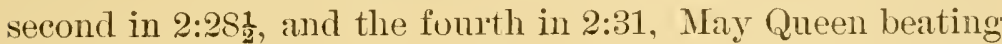
hel the third heat in 2:31. Now, althongh this was my first effort with Goldsmith Maid and she won for me, I did not feel particularly prond of the result, as she was unsteady, far from good-gaited, and more than all, by her getting a

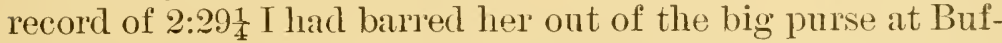
falo for 2:30 horses that was already announced for the following season, and all these things put together made me rather disgruntled over the matter, but I had not at all lost faith in the ability of the mare after she had been properly trained.

That was her last race in $186 \%$, and while I was having her looked after the following winter I gave the subject of her training considerable thought, as I felt that to make a success of her as a race-mare would require a good deal of study. It may seem strange to many people who afterward saw Goldsmith Maid when she conld trot five or six heats in one afternoon better than 2:20 and could go a mile almost any day from 2:16 to 2:14, that there could have been a time in her life when she was not a good-gaited trotter. Of course I know that she was, even after she became a very fast mare, what we call a handy one-that is, conld recover quickly from a break, but at the time I am now writing of she was absolntely rongh and broken gaited and would only occasionally strike a square, pure trot, but when she would do this she went faster than at any other time. I knew that at no gait except a square trot would she ever make much speed or attain prominence on the turf and so resolved that when spring came I would keep her on a square trot, no matter if she could not go better than a four-minnte gait. With this plan in mind I began jogging the Maid in 
the spring of 1868 and carried ont my system to the letter.

I looked after the matter personally, and the only point I had in view was to keep her on a trot. Of course this meant that I must go slow with her, just as it does with any horse that is inclined to be rough-gaited, beculse the instant they are driven a little faster than they can trot easily they will begin to roll in their gait and eventually hitch and adopt that scrambling motion behind that is so distasteful to the admirers of a pure trotting gait. I continued this for some time, and after awhile I conld see that the Maid began to go a little fister. She was not a mare that at any time in her career made speed early in the spring, or in fact had much speed at any time when she was out of condition, and of conrse at this time when her best gait was only a little better than 2:30 she was going very slowly indeed under the system I adopted. But, as I said before, there was finally an improvement and when the warm weather came and I could send her along some I was greatly pleased to find that she had lost much of the disposition to become rough in her gait and hitch when asked to go as well as she conld. I shall not attempt at this time to give any detailed acconnt of the work done that season, contenting myself by saying that I won eight good races with her against American Girl, General Butler, Rhode Island, George ITilkes, George Palmer, and other famous horses of that day, redncing her record to

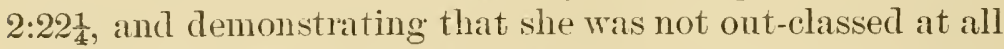
when going against the best ones in the land.

I have been explicit in what I had to say about this matter of Goldsmith Maid's gait becanse it seems to me to contain a valuable lesson to any man who is learning the business of training horses, or who may at any time have occasion to look alter a fast trotter. Everybody atall posted in matters pertaining to the trotting turf knows that in these lays a rongh-gaited horse stands very little rhance of winning in his class, and althongh there are a good many men who will contend that no animal can be broken of this habit, I think 
I have shown that in the case of Goldsmith Maid patient and careful handling accomplished the desired result.

In regard to the actual training of Goldsmith Maid after she became a first-class trotter, I can write but very little because no trotter I ever had needed less training than this mare. As a matter of fuct she did not want any training at all in the ordinary sense of the word so long ans she trotted a race every week, for the excitement and exprtion of these contests served to keep her in excellent physical condition, so that she was always ready to go at her best rate of speed and continued doing it as long as she possibly could. I have said above that she was a mare whose speed came to her only after she was in training, and as long as I had her I found this to be the case. Every spring she would show no speed at all until the season was pretty well advanced and then her old form would return and in a very short time she wonld be in racing trim. After that there was very little work needed. All she wanted was the jogging that would ordinarily be given to trotter's in training and between her races a repeat in abont 2:40. An easier horse to train than Goldsmith Maid, once I got the hang of her, was never under my care. She was a great feeder thongh, and I gave her plenty to eat, her specialty in that line being hay. I never saw a horse of her size that would eat anything like the amount of hay that Goldsmith Maid would. Of course she got plenty of it at all times, and on the erening before the day on which she was to trot a race I would have a big pile of it put in her stall-lhalf as much again as you would give a sixteen-hand horse that was a hearty feeder-mand in the morning every wisp of it would be gone. On the morning of the day that she was to trot in a race I would jog her three miles and at the finisl let her move through the stretch for a ways, and when she struck a gait that pleased me I would pull her np. She wonld get a light feed of hay after her work, and that was all the "drawing" that I found necessary in her case.

Of course so intelligent a mare as Goldsmith Maid and 
one that had been on the turf for so many years got to know a great many things, the recognition of which would appear strange in an ordinary horse. She was just as well aware when a race was coming off as was the secretary of the track over which it was to take place, and the way she found it ont was by the change in her food and other treatment that I have indicated. Of comse in order to keep her from eating hay on the day of a race it was necessary to halter her in the stable and as this was never done at any other time she knew, the minute that halter went on what it meant. After Old Charlie had tied her hesd up she would stand there contented enough until the fore part of the afternoon. She seemed to know that by this time her race onght to be called, and she would become nerrous, jump, kick, rear, and plunge about the stall in a manner that left not the slightest doubt in the minds of those who saw her that she knew exactly what was coming off and was anxious for the battle to begin. Even after we would put her harness on and take her out of the stall there was no diminution in the excitement, she showed. She would stind quietly enough while being hitched to the sulky, but she would shake and tremble until I have heard her feet make the same noise against the hard ground that a person's teeth will when the body is suddenly chilled-that is her feet actually chattered on the ground. The instant I would get into the sulky all this would pass away and she would start in a walk for the track as sober as any old horse you ever saw.

This faculty of remembering things and of actually seeming to draw conclusions for herself, which Goldsmith Maid possessed in a greater degree than any other horse I ever saw, was brought into full play when she went on the track to trot a race against other horses. She was always trying to get the best of her opponents and from the time we left the barn until the race was over there was nerer an instant that she was not fignring on some part of the race. For instince, when we would turn to score the Maicl would measure the distance between herself and the other horses, 
would seemingly calculate the chances of getting to the wire on even terms or ahead of them, and if she concluded that they would have the best of it there was no use of my trying to get her there first, because she simply would not go. I do not mean to saly that she would stop, or anything of that sort, but she would not get into her best rate of speed, nor would she try to do so, and the result wonld be that the judges, seeing that the start would be an unfair one, wonld ring the recall bell. On the contrary, if she had a good chance to beat the other horses in scoring she would go along gradually with them until pretty close to the wire and then of her own accord come with a terrible rush of speed so that when the word was given she would almost invariably be going the best clip of any horse of the party. Once the word was given she linew it as well as any of the drivers and there was no trouble with her from that time on so far as her behavior was concerned. If she had the pole she would make it a point to see that no horse beat her around the first turm, seeming to be perfectly well aware that the animal that trotted on the ontside had a good deal the worst of it, and she had no intention of losing her position next the rail nuless she was fairly ont-trotter.

And now in regard to Goldsmith Maid's habit of oceasionally making a short break while trotting a hear. A good many people who of course lad not given the matter close attention imagined that she gained by these breaks and this idea became prevalent with the public. Of course it came about from the evident fact that alter making a break the Maid conld watch again without losing any ground, and this was as far as people looked at the matter. It is true that she was a very handy catcher, and perhaps did not lose anything in point of position by her breaks, but she did lose very materially by not being able to get into her stride again at once, and to show that this is the ase I have only to saly that when she trotted, on three different occasions, a mile for me in 2:14, and another time in $2: 14 \frac{1}{2}$, she never made a breals in either mile and in none of 
her fast miles did she ever leave her feet. The first time she ever trotted in 2:14, by the way, she went every quarter in exactly $33 \frac{1}{2}$ seconds, which shows what a wonderful mare she was to late hel speed. I could go on and wite a long chapter about what a grand race-mare Goldsmith Maid was, but the public is well aware of that already. In this respert I think she was the greatest trotter that the world has ever seen and there are some very good judges on this point who agree with me perfectly.

I lave told how intelligent the Maid was, and she was also human in other respects, being very fond of certain people and not taking at all to others. Old Charlie, who took care of her for so long a time, and who for one period of five years passed only two nights away from her stall, was the one of whom she seemed to think the most and next to him came the little dog that was always with hel. But Old Charlie had the first place in the Maid's affections and this was very plainly shown on more than one occasion, when lee would be petting the dog and the old mare would notice it. It made her jealous right away and she would turn and run the dog ont of the stall, although when Charlie was not alound or when he did not pay any particular attention to the dog the Maid seemerl to think a great deal of it. They were a great family, that old mare, Old Charlie and the dog, apparently interested in nothing else in the world but themselves and getting along together as well as you could wish. When it was bedtime Charlie would lie down on his cot in one comer of the stall, his pillow being a bag containing the mare's molning feed of oats. The Maid wonld ensconse herself in another corner and somewhere else in the stall the $\log$ would stretch herself ont. About five o'clock in the morning the Maicl would get a little restless and hungry. She knew well enough where the oats were and would come over to where Charlie lay sleeping and stick her nose under his head and in this manner wake him and give notice that she wanted to be fed. I never saw any other horse that displayed half her 
intelligence on so many points, and I doubt if for many years there will be another one before the public with the same amount of brains and the ability to employ them that Goldsmith Maid larl. How I trotted her all over the country, from the Atlantic to the Pacific, was told at length in the daily papers and turf journals of those days. She was in my stable continuously from 1866 until the summer of 1877 , at which time she was in her twenty-first year.

The previous season, that of 1876 , there was no purse offered through the central circuit for an exhibition of speed by her and I was forced to trot her in the free-to-all race. For a number of years previous to this she had not taken part in races against other horses, and the result was that I had trained her simply for a mile dash, so to speak, once a week at her best rate of speed, generally going the other two heats in the exhibition in a manner that did not fully extend her in any part of the mile. After several successive seasons in this sort of training and racing it was very evident that, especially in the case of so old a mare, she conld not at once return to the old-style system of racing, particularly against a field of horses all of whom made her the target, and expect to beat them easily. It was this fart more than anything else that contributed to her defeat at Cleveland in 1876 by the stallion Smuggler. Lucille Golddust, Judge Fullerton, and Bodine were also in the race and after the Maid had won

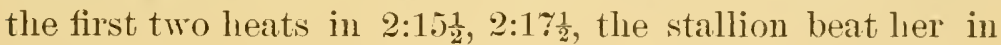
$2: 16 \frac{1}{4}, 2: 19 \frac{3}{4}$, and $2: 17 \frac{1}{2}$, lut after that he was never able to defeat her, although they trotted clear through the circuit together, winding up at IIatford with the famous six-heat race in which the average of the half-dozen miles trotted that afternoon was $2: 17 \frac{1}{3}$. It was wonderful to see a mare twenty years old going this sort of a race, and it should be remembered that in addition to this she had been winning all the way down the line, having trotted at Buffalo in 2:16,

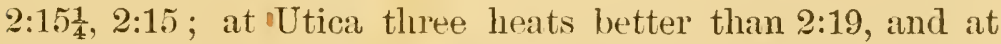
Ponghkeepsie three heats that averaged 2:18. She trotted 
a lot of other races that summer and fall, went to California with me in the winter, and came across the continent again in the spring of 187\%. At this time she had as much speed as ever, having shown this by her mile over the track

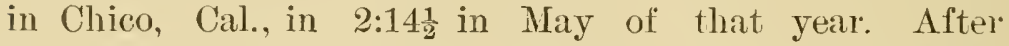
getting East I trotted her at Cinicinnati, Ohio, and Springfield, Mass., going from there to Chicago, where she went a couple of exhibition heats on the 20th of July. Then we shipped to Rochester and trotted an exhibition, dloing the second mile in 2:16䨔. Two weeks later we were at Cynthiana, Ky., where the mare went a mile in 2:21. At Kansas City, Mo., the following week over a half-mile track she trotted in $2: 20 \frac{1}{2}$, and was from there shipped to 'Toledo, Ohio, where over another half-mile track she went three

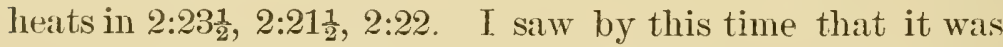
best to retire her, which was accordingly done, and she was sent to the farm of her owner, Mr. H. N. Smith, at Trenton, N. J.

Of comse when the Maid left the turf it necessitated a dissolution of the partnership between herself and Old Charlie, who had been her companion and groom for so many years, and I am sure that both of them were very sorry when the day came. I have told how intelligent Goldsmith Maid was and how much she thought of Old Charlie. Both of these traits of her character were well illustrated two years after she had quit trotting. By this time she had by her side at the Fashion farm a fine colt, and was very cross when any one came near her-in fact inclined to be vicious-and as she was always a willful mare when her temper was aroused. the attendants at the farm kept a respectful distance from her. Abont this time Old Charlie was in the East and went down to Trenton to see the Maid and her colt. The boys at the farm told him that she was very vicious and that it was not safe to go near her, but Charlie only smiled and told them to watch him. He went to a point near where the mare stood and placing himself in a position where she conld not possibly see him, he began calling her, using the name 
of "Mamie." by which she was always known in the stable.

The change that came over the Maid when she heard the familiar voice was an astonishing one. She whinnied with delight and began pacing restlessly up and down to discover where Old Charlie was. When he came in sight she ran up to him and was just as pleased to meet him as one human being who had a strong affection for another would have been. She was not only not at all cross, but seemed to call his attention to her colt and when he went away the old mare stood in the paddock and looked after lim with as much sorrow in her eyes as conld be imagined. After he had gone a distance she seemed to think that perhaps he was going to leave her for good, and so after a moment's hesitation the old mare started after him, leaving her colt behind, and it was only when she was ranght and haltered that she would return.

It is my intention to at some future time describe in detail the experiences that have come from a career of more than a quarter of a century on the trotting turf. At that time I shall write, not only about Goldsmith Maid and Dexter, but also have much to say concerning the many other horses trained and driven by me, and in that commection to give at length my riews on the subject of how trotters should be trained and driven, as well as to recount the various incidents of interest and value to horsemen and the general public that have come under my observation. When the time for this shall arrive the book will in all probability be published and edited by Mr. H. T. WurTe, the editor of this volume.
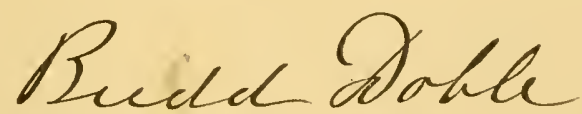

Chicago, January 21, 1889. 


\section{CHAPTER XVII.}

The education of trotting-bred colts-Early development, and the reasons therefor-Fast youngsters the ones that sell well-Colt handling now a distinct branch of the trainer's art-The man who handles a colt must learn to control his temper-Hints about the best time to have foals dropped-Treatment of the mare at this season-Teach the suckling colt that man is a friend, not an enemy-The story of a veterinarian, and what one experience taught Dumbar-Putting on the halter-Handle the colt frequently, but do not lead him much-How to put mares and their foals in a field-Aceidents on a stock farm generally due to carelessness-Management of the mare and foal in the stable- Turning out the youngsters during their first summer-Preparations for weaning time that will be found rery vainableLooking after the appetites of the colts when they have been weanedWhen the work of leading colts alongside of a horse should begin-The proper method of doing this explained in detail-A straight, covered track better than a circular one-Colts differ as much in disposition, etc., as matured horses, and nust be treated accordingly-No absolute rule by - which to train can be laid down.

"As the twig is bent the tree inciines"

This very trite saying is applicable to the title of this chapter.

The rearing, breaking and training of the trotting-bred youngsters is a subject which opens up a wide field for thonght and discussion; and the future pleasure or profit from them depends very much upon how well they are reared and handled in their young dars. It has become a fact at this stage of our progress in the development of the American trotter, that he must not only trot young, fast and steadily, but stay the route as well, to warrant the breeder a safe and profitable investment for his capital and labor. A tendency to the early development of speed has caught the masses, has become fashionable, and no doubt has come to stay, 
althongh it remains to be seen if the early-developed and speed-forced colt will prove the better hor'se.

With such bright stars before ns as Patron, two-year-old

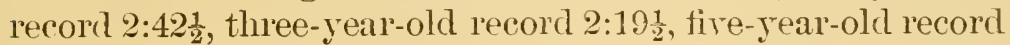
$2: 1 \frac{1}{4}$, and this made after a season in the stud, there is a grand argument for the advocates of early training. I will speak of another which has attracted my attention a good deal, and that is Bermuda, yearling exhibition 2:393, two-year-old record 2:29:3, three-year-old record $2: 24 \frac{1}{2}$, fouryear-old record 2:22, and five-year-old record 2:20:

There are other matters of importance to think of, one of which is this: If it is possible to raise hor'ses as well developed in speed at five years old, and that will stand the campuign and fight out long, elosely contested races (as Jack and Genera S. have done), will it not be more of an incentive for men looking for a place to enjoy their surplus capital to invest where they will get such speedy returns and not have to wait eight or ten year's, or mitil changes in business or tastes force them to deny themselves the rrivilege? The best time to catch fish is when they bite well; then with a tempting bait throw your hook. Show a buyer (whether he be breeder or speculator') a fast young one, and he will pay more, and bny much quicker, than for one as well bred that does not perform as well. How to do this is the theme which engrosses the mind of the breeder of trotting horses. The breeder who does not believe in early speed development, and practice it, will in time sink out of sight, just as surely as railways have superseded stage coaches. His capital may enable him to bear the expense and to sell at a low figure, until such time as the colts are developed by other people and demonstrate their ability to trot young, or a breeder may be so well stocked in speedproducing, fashionable strains, that the current may carry him along with it, but in the nature of things the boom will change. "Eternal vigilance is the price of liberty." Colt raising, as well as handling, has become an ant of its own, and apart from the training and handling of aged horses. 
There are personally known to me several noted drivers. who hare no taste, desire or pride to handle a youngster. They an not bear with them, and have no contidence they will not cut up a "dido" at any time. It can be safely set down as a rule that holds good in any land or clime, or under any circmmstances, "to do a thing' well and succeed in it," one must have a desire and interest to accomplish the object in view.

Anyone who can not control his temper should never be allowed to have anything to do with a colt. I do not mean by this only the groom, but the driveras well. Never allow either of them to have charge of animals they will not devote their time and attention to. 'The groomand assistants should be watched closely, and when there are any indications that they are petulant and cross, do not like their calling, and do not become devoted to and proud of the animals nnder their charge, their servires should at once be dispensed with.

It is an object to have the foals come as early as possible in the spring, always being governed by the climate where you reside. The foals in this latitude are generally dropped from the middle of April to June 1 and earlier than this is not considered to be to their advantage. At that time the young and tender grasses gire the dams plenty of milk and are soon learned to be cropped by the foal. In this way a good start in life is effected, which is of great benefit. for if the foal is stinted and does not thrive the chance for early speed is lost. An unthrifty, weak colt will not make a fast yearling, and the breeder needs wait another year to get a smaller price for his two-year-old, than his promising yearling, which had lost its chance by mismanagement. Two weeks before the mare is supposed to be dne to foal, hare the man in charge keep a watchful eye on her, and as the time draws near he must visit her often to assist in the event of any mishap or to help the foal nurse in case it comes weak or the mare is cross and mean. In this way the mare and foal become attached to the man and you begin to impress the colt from its earliest life that man is his 
friend, and the foundation of his education is laid. During the first few days in the life of foals much depends upon strict attention to their bowels, as they are apt to become stopped, and in this event an injection of soap and warm water invariably has the required effect, and the first danger is past. I had a little experience in an early day, which is not forgotten. A mare which I prized highly dropped a fine large colt, ant in a few days after it was foaled it seemed in distress. I started post haste for a full-fledged reterinarian, not wanting to leave anything undone to save the foal. Tre hurried back as soon as possible, the veterinarian felt of its pulse, he put his ear to its sicle, then went on with a long lingo about its internal structure, and the obstruction of its abdominal channel, and commenced asking me if it had passed the meconium. This was a new one to me, and before I recovered from the shock the poor little colt was out of his misery. I felt the loss deeply, buried my first venture in trotting stock, paid the bill, and have used soap and water since.

When the colt is about ten days old, put on an easyfitting lalter, being careful to have it fit just right, and let him wear it until you turn out to pasture for the summer. It is handy to have it on to manage him. It may be necessary to look at his feet, which ought to be handled often, the attendant holding him by the head, but not forcing him to lead much, as at this age we think it too early to trouble them. What we most desire at this time is thrift and prosperity. When the season has adranced enough to turn the foals out, take one mare and foal to the field at a time and let them loose, and they will soon have tyeir play out; then another, and so on until you get out as many as you desire. In this way you will aroid having the mares fretting and kicking one another, and lessen the chance of an accident. Let me saly right here that the majority of accidents on a stock farm can be traced directly to mismanagement and carelessness. The first week or two, when night comes, the mare and foal are taken $и$ and put in a box-stall, well 
littered down, which is kept as sweet and clean as possible, with plenty of ventilation without direct draft, and the mare liberally fed, having the feed-box low enough for the colt to muss with the feed, and watch its mother eat. After the weather has become settled and warm enough to leave them out nights, take the halter's from the foals and let them go. Experience has taught me that halters left on will sometimes get caught in the pasture, and often colts will get to chewing' each other"s halter, and it is better to lave them off. I can think of no advantage gained by leaving them on, for if the colt needs attention the proper way is to lead the mare to her stall, where it can be attended to better and more safely than in pasture.

With the colts all out to grass and doing well it is time to separate the oldest of them from the younger and commence feeding them grain, which is done in this way: Build a pen in some suitable place which is the most convenient, making it high enongh so the mare will not try to jump it and have the space from the ground to the bottom rail or board sufficient to allow the foal to pass uncer. Put in a handy gate or bars, then an ample feed trough. Lead your mares and foals singly into this inclosure and let them eat together two or three times and they will soon learn where the food is. Take out the mares, shut up the gate, leare the colts in, keep a good supply of oats there, and you will find the foals there regularly running in and out getting their rations. To induce the dam to loiter about this place keep a large lump of rock salt near it and occasionally a mess of oats, and there is no further trouble. In this way at weaning time, which is at the age of five montlis, the colts have learned to eat and the result is that when they are taken away from their dams they do not miss them so much, nor does it stop their growing. Now we put on the halters and keep them on, leading the foals more or less while weaning them. Leave them in their boxes, two or three together, several days, and have the boxes open into a nice grass paddock. Let them run out 
and in, give them oats mixed with bran and sorghum cut up fine, and in a few days more turn them ont in fields away from the dams, where there is plenty of grass and water, and a large trough with feed in it constantly. They have been in the habit of taking milk a great many times a day, and they need food just as often. The best way is to keep plenty of mixed food for then, using cracked corn and oats also unthashed oats run throngh acutting-box, then mixed with bran and water enough to moisten it to make the bran adhere to the oats. As the nights getcold take the foals in and shelter them from all cold storms. They can not get too much exercise or be out too early, and it is well to leave them ont as lateas possible. Lead them to and from pasture regularly and if not too far one at a time to keep the man in charge from letting two or three hitched together (as is often done), jam each other going through gates and into stalls. Handle their legs and feet a good cleal, and in this way they are gradually receiving an important part of their education.

On the first of January we are done with the weanlings; they have now become yearlings althongh but about eight months old. It is now time to commence leading them beside a liorse. We lave a covered track something over one hundred yards long, perfectly smooth and covered with tan-bark, which in my opinion is better than a ring, as it makes all straight work and no chance to spered anound at turn, which must necessarily be sharp if under an y ordinary cover. Beside this, on a straight track, you have to come to a walk at each end, and there is butlittle danger of over working. Now that we are to commence our leading beside a horse, the halter breaking (which has been gradnally going on until the present time) finds our colts thoroughly accomplished in this, and ready for the next lesson. Put a small open bridle on them, using a perfect-fitting snaflle bit, but do not lead from the bit but from the halter, as one of the most important things for a trotter to have is a good mouth. There is no troubIe in restraining or laundling a colt by the 
halter. If you have the lines attached to the bit, and the colt gets frightened and plunges ahead, of course he will receive the whole pull upon his tender mouth, and not only teach him bad habits, but probably sore his mouth so he will not eat well. The consequence is yon are doing more harm than good. I am anxious to impress mpon the novice, if possible, the great importance of doing these things well and so kindly that the colt will get no set-back, nothing to trouble or interfere with lis growing.

If this leading and training call not be accomplished without harassing and bothering the colt, your time is worse than lost, and it is much better to let the colts alone. The attendant bring's the colt out, leads him up to the off side of the horse, lets him smell of the horse, saddle and rider, and size them up; he then hands the halter stale to the rider with the lines hanging over the colt's neck; the man steps back, the rider starts up, the man follows along behind the colt for a few rods, the colt finds nothing to hurt him, and in his first lesson, which should not exceed thirty minutes, he is broken to lead beside a horse. In two or three days he will lead $u p$ and down before a crowd of people as proud now as he will be when he goes in 2:20. Judgment must be used as to how much or little exercise in the waly of leading, a colt needs. Like horses in training, one will require much more than another; some will thrive and grow, while others will fall away on the same amount of work. No absolnte rule can be laid down to train by. Be governed by the condition of the animal trained. Do not do enough of it to stop their growing; they very soon learn to enjoy it, and with us, they commence to improve in looks, and seem to take a new start.

After the colt becomes accustomed to leading, put on a surcingle with the back-strap taken up short enough to keep the girth from chafing his fore legs. Have side-straps that buckle into the surcingle about half way down on the side and snaps to attach them to the bridle, being sure the side-straps are long enough to not hamper the colt too 
much. Check lim up lightly and in this way you are beginning to make a mouth, as well as teaching the colt to keep his head straight while leading, and in training to move his body as well as neck. Do not forget that we are still leading the colt from the halter and not from the bridle. As the colt progresses the side reins and check can be taken ul, but of all things avoid being serere. It is not necessary to get the colt mad or sour. Our object is to have the colt become accustomed to the crupper, surcingle, and bit as easily and gradually as he was halter-bioken. Some colts are nore timid than others abont staying n] even with or abreast of the riding horse and will often stop suddenly. In this case I use a small rope, one end being fastened to the ring of the girth, on the opposite side of the colt from which you are leading him, rumning back behind him and abont as low down, as the breeching of a harness comes, and kept from falling any lower by a small strap, which is kept in its place like a hip-strap to a double harness with loops on each end of the strap, and the rope running through these loops to the leader's hand. A sudden pull upon the rope acts like magic to keep the colt to his place and does not need to be used but a few times, for the horse family never forgets anything. Their greatest stock in trade is memory.

The colt having been led long enough to thoroughly understand it, do not jog him till tired. Give him quick, active work, spurting hin and encouraging him to do his best, always being ready to colrect him by voice and line if he makes a mistake, and the natural result is that he soon learns that the proper thing to do is to trot and not run. When the thoroughbred rumer is bred so fine that he never trots, fifty years from that date I look to see the trotter never run or gallop, and if he loses his balance in any way he will have to fall and probably break his neck. It is necessary to have tips or light shoes put on soon after the leading commences, so as to use scalpers and protect them from speedy cutting. It is well to use a light quirter boot 
for fear of an accident. Ample protection must be afforded the colts wherever needed, or they will lose confidence in themselves. Avoid any boots or girths or, in fact, any harness that chafes. Follow the above hints to the letter and the colts will not fail to improve and please you for the pains taken. 


\section{CHAPTER XVIII.}

The training of colts gone into in detail-How the breaking harness should be put on and made use of-Proper adjustment of the lines an important feature-Teaching the pupil to obey the word of command-The first hitch to the breaking cart-Don't have visitors around at this time-Preparing for the stakes in which the young trotters are entered-Accustom the colt to other horses, and then speed him a little-Keep your own counsel as to what is being done-Don't be alarmed at what you read concerning other people's colts-June a good month in which to test your materia! a littleThe prompting horse should not be allowed to beat the pupil or carry him too fast-licep a reco:d of what each animal does and how he does it-No two colts can be trained exactly alike-The first trial of the most promising youngsters $-\mathbf{A}$ surprise often in store for the trainer at this time-Driving on the road occasionally a good plan-The earnest work to be done in August -Shipping the colts to the place where they are to trot-What to do when you reach the track $-\Lambda l l$ ready for the first race with the young trotter.

The colt has now been led and driven about in the leading shed for about three months and is ready to be driven with harness on. Put on your regular breaking harness complete, tie the tugs or traces into the breeching, fasten the ontside girth into the thill or shaft holders, rnm the lines through the shaft holders or lugs, using a long pair, so the driver will not be too near the rolt.

Dive him about the place, always carrying a whip. 'Teach him to guide and drive wherever yon wish ; drive him forward and back past objects that he is shy of. Aroid letting him turn around to face you, which he can not rery well do with the driving lines run through the shaft holders, or if they come directly from the bit to your hand. If the lines are put through the turets of the harness he can turn around at any time, as you can get no purchase on him such as you have when the lines rum along by his side. Drive 
him in this way until he will guide to suit you, stop at the command "Whoa," start when told, and back up at the word. Be sure he will turn or guide freely in all directions. To teach a colt this may take one day or one week, according to his attention to business, but when you commence a lesson keep at it until he learns it.

When this preliminary work is done properly the colt is ready to hitch to the breaking cart, with but little fear of his doing anything wrong. If the frost is ont of the ground and you are ready to commence driving him have the breaking cart drawn out into some large open space or field of at least three or four acres. Have your breaking harness good and stout, with a kick-strap attached. Drive the colt ont to the field, let him see the cart, pull it around behind him and about him for a few moments, then let the assistant hold him by the head while he is being hitched to it, and never have more than two men with you. Get on the seat, let the men lead the colt for a few rods, then step to one side and let him go.

If he wants to indulge in a few jumps do not pull and saw away on his month and tear it to pieces. Let him go; he will not do any harm, and will soon settle down and jog or walk around as you desire, and in thirty minutes you can drive out and around the track, then to the stable all right ; being very careful in unhitching him not to let him get frightened. Repeat the same thing daily, hitching up out in the field for sereral days, until you have perfect confidence in him, finishing your drive on the track or road. I first break colts with a blind br:dle on and finish up the job with an open bridle. Be rery particular not to check the colt up at all until he is thoroughly broken, as it only serves to make him mad. Do not have a lot of fellows about to see the colt handled; it is apt to make trouble and bother. A man wants his whole attention strictly on what he is doing and can not be entertaining risitors. It is not necessary to have a great heavy break cart, nor is it hest to have anyone in with you. Remember you are only breaking a yearling, 
not an old horse. Get the colt into a small cart or sulky as soon as safe to do so and do not let up on his work until he drives perfectly kind and gentle.

The colt is now about a year old; has been well raised and well broken ; was entered in the "Maturity Stakes," "Grand National," and the "State .Breeders'," and must start in Angust, to maintain the reputation and prestige of the farm, as well as to get back the money laid ont for developmentand entrance. Besides all this there is al great deal of pride at stake. There have been many arguments . pro and con about the various strains of blood, the different methods of handling, and the races of "years past have been brought up and discussed, in which one colt's granddam had beaten the other, and the talk has finally wound up with the invincible argument, "Blood will tell." The stimulation of the argument is beginning to act, and as the colt has had a nice rum at grass through April, he must be taken up and commenced with. He showed splenclidly in leading, acted well when broken, but no one has held the watch on him yet, and as he has been running ont the last month, those last starts and sudden rushes he would make to beat the pony while leading, are sort of forgotten. And then perhaps he wont like the track as well as the leadingshed, and possibly he may get lame. All these things will begin to arise and here is where the trouble comes. If you are not careful you will get in too big a hurry. Keep quiet, go slow, talie the colt up, put on his light shoes, drive him around some before hitching him up, then hitch to the break-cart first, go around the track slowly and carefully; it will look differently to him now the leaves are out.

Get the colt accustomed to the changes and to having horsęs meet and pass him; jog lim slowly for a few days, and you will be ready to let him go along some. Be sure you have the proper boots on, such as scalper's and quarter" boots, and the girth well back so as not to chafe him where the forward legs work back and forth. Let him spurt in places, about forty rods at a time, turning him around 
often, giving him sliarp, quick work and not too much of it. Take just as good care of lim as any trotter that can beat $2: 30$. If he is warm walk him ont slowly, have his leg's bandaged, and if he is rery heary coated, have him clipped. In the afternoon give him an hon's rmn in the grass paddock, or if it is not conrenient to do this have him led ont at grass with a short erening walk.

Keep this up for a month, and clon't let anyone know how fast he is going, not even the grooms about the stable, and there will be an air of mysteriousness abont it that will astonish the natives. The nods and sly winks will be many. Privately perhaps you may think the colt is not as promising as yon at first imagined, and you really do not like to tell that he could only go a quarter in fifty-five seconds, when you have been talking abont a two-forty gait all winter, and telling that the leading horse could not run fast enough to keep up with him. Well, you are excusable; there is no telling what may be said in the winter about speed, and $2: 10$ is a very common clip around the store. If your colt can trot a quarter the first montlis handling in fifty-five seconds he is a fair stepper but not fast. You must recollect it is now only one month that you have been liandling him in harness, and a good many wet days have intervened when you could not brush him along, and probably he has not yet come to the same speed that he showed you in the leading shed. The fact is he is not quite up to the game. The run through April, the not rery regular work through the dreamy montl of May, brings you to the first of June guessing about the August laces. You also have been driving older horses with fast records that whirl off their quarters in thirty-five seconds, and colt training is tame business.

I am afraid yon are getting impatient all for nothing, and it requires patience to train colts. The first week in June. The sporting papers have come; you lun them over' for news, especially colt items. 'The regular old stereotyped item is there fished up for use again-had been thrown in the 
early summer department. It runs about like this: "Your" correspondent made a flying trip to —_ and found track matters lively. In talking with one of the prominent driver's, he said Geo. Learitt's yearling had shown a half in 1:20, and no doubt would wipe ont all colt records this fall." More trouble in camp again, for that same colt is entered in the August meeting, and will no doubt have a sure thing of wimning. Do not get nervous over this old chestnut. If there is any truth in the report, he is already overworked, and it is dollars to doughnuts that he will not start. When you are trotting in August he will be out in pasture nursing a sore finger or gaining strength to winter on. If you area novice in the business, or even quite an old hand, but inclined to be nervous, snch items will set yon on edge a little, or serve to disconrage you somewhat for no good reason, because your colt has only been handled enough to fairly know the way around the track.

You have June and July to prepare in yet, and if you are training' seven or eight yearlings the one you work the most moderately and the one that keeps coming a little all the time, will be the best one yon will have to start. If yon have your colt keyed up to a high pitch now, he will have nothing left in August. It is important to understand how to get an animal up to the highest state of condition and perfect form, to accomplish a great feat. It is not done in a week or a month, and can not be done properly with too much haste. To do it well requires more than giress work, but also needs strict attention to all the details connected with it, and those with a natural tact for the business succeed the best.

June is a good month to commence sending the colt along. He is now in fair fettle, his muscles are hard, and he is beginning to get control of his legs, is not afraid if he makes a misstep, and has not been forced to trot very much faster than he has felt like going. It is a good plan to now get him into company occasionally, something a shade slower than he is. Teach him to score ul and start away 
within himself, but with a resolute air, going the first quarter slow, letting him ont the second quarter, close up to his clip. Continue this right along, but not always in the same place on the track. Be careful not to have the colt learn to speed in certain places on the track, but teach him that one place is as much a speeding ground as another and that his duty is to go when called upon. Keep the prompter a little back, as a rule, but near ellongh to enconrage the colt. If the prompter is too fast or is allowed to goahead too much, it soon discourages the pupil from doing his best. Recollect that you are now training and do it with a will and determination. When you speed push it witlı rigor, don't go droning along-that doesn't amount to shucks. Be careful to know just how far you drive, and if you have not learned to carry your watch in hand all the time without its being any bother or trouble, or so that you eren think of it (except when yon want to look at it) you are at a great disadvantage, for it is necessary to know how fast you go, to put it down when you are through in a book kept for that purpose, which will be a great help to you in training.

If you are handling many horses, both old and young, this book is convenient to refer to from day to day or from week to week to learn what they have previously done, and nnder what circumstances, what weight of shoes used, in fact noting all the changes, such as bits, boots, bearingreins, etc. You may be able to carry all this in your head, if so all the better, and the book will verify it for you; sort of double entry you know.

How far to work a colt, I can not tell you any more than I can how big a lump of chalk is. Colts differ in size, stamina, disposition, and strength. Some have got to indulge in a little foolishness before they are ready to do right-play with the birds along the fence, or the shadows of the poles, while others are strict business all the time. It is safe enough to figure not to exceed four miles with any colt and not less than two and one-half. With the proper care, such as walking and turning out, colts do not need much jogging. 
They are ready to speed very soon after getting to the track.

July is now close at liand and great reports of speed coming in from all sides-and as we have had no repeats yet, except those made on the track without unhitching (that is, speeding a quarter and then a little walk and back again), we will set apart the last week in June for a regular repeat, in company with two or three others if possible. The day comes ind is favorable, the track good, weather wam, and there are a few friends in the stand, which enlivens the occasion. Out of the three or four colts entered, or perhaps more, it is necessary to get a line on which are the best ones to keep up the payments. It is of no use to pay out more entrance than the stake is wortl. Of course you know which is the fastest by three or four seconds, and out you come with him. After a little warming up he steps off his first quarter in fifty-three seconds and repeats back in fifty. Take him into the stable, give him good care, and in thirty minutes bring him out again and he shows you a quarter in forty-nine seconds, and no better. You then get out the others which you think can not do quite as well, and to your surprise one of them goes a quarter in forty-eight and a half seconds.

You were quite sure he could not go as fast as the other one into two or three seconds. Now you conclude there is something wrong. You have been holding the watch on them and have timed all of them faster than this fellow when the track and conditions were less favorable. Now this goes to show you that it is best to have a little leeway or margin of a few seconds when you go into races. IIorses are not always up to their best form. You are probably worried about the Breeder's' Meeting in August and at a loss to know which colt to keep in the stakes, as the slowest one did the best and acted the most like a race-horse. You dislike to throw him overboard, so without any more ado will keep two of them in anyway. If you had analyzed the trial carefully, perhaps you would have done differently. Had 
you noticed that the first colt, which did not go the quarter quite as fast as the other, did the last forty rods of that quarter in twenty seconds easily, and was full of trot when you pulled up, you would feel differently. For some unaccountable reason you started off rery slowly with the first. colt and with a watch in your hand did not take notice that when you passed the furlong pole it was thirty seconds, while your slower colt had got there in twenty-four seconds.

This will teach you alesson. To snceed in this line of business as well as any other everything must be carefully gone over, looked into and digested. This very instance will illustrate it quite plainly. You are wondering which is the fastest colt; and one of them is showing a forty clip any day while the otlier one is about eight seconds slower. If the colts are growing and doing tirst rate, don't act stale, are gaining in speed a little all the time, and are square in their gait, it is well enough to keep them going; but if they are getting unsteady and mixed, let up on them for a comple of weeks, by turning then out to grass, continuing their oat lations, but in less quantity. Tou need a fresh colt not a stale one for August, and there is nothing gained by working them so much as to get them disgusted. Drive them out on the road occasionally, which affords a change. You will find a smooth piece somewhere; turn them around and let them start for home at their best clip. They will enjoy it and learn to go fast from their own inclination, and yon get at the object sought for better than by urging them. The colts use their own way and go with a free, open stride, which is so much admired when they are turned loose. They are young things yet and want fun, and it is recreation for them to have a change of drives.

If possible keep the colts where they can see one another; they will be more cheerful and brighter, thrive better and make better horses, from the fact they do not get lonesome and sour, and of course a cheerful, contented horse drives better and is safer than al gloomy, morose one. Bear in mind that some day you may want to sell this animal to 
Mr. Bonner and he will not want it unless it is the best one on earth; and you surely will be prond to have him speak well of the colt's intelligence. And in a very great measure the intelligence which the driving or track horse displays, is imparted to him by the man who rears and brings him ont. I mean by this the driver who takes a colt as a weanling, breaks him, drives him in races and gives him his first starts and records.

Angust has come; the races both with rumers and trotters are occulying the attention of vast andiences all orer the land. Daily reports are eagerly looked for and each item scanned with interest to find ont all the news pertaining to our great American sport. It really has fastened its enchanting and seductive grip upon the people of this comtry. From one end of our broad domain to the other, in almost every village or town, there is a speeding place, if not a race-track. There is no doubt in my nind that trotting races in this country are now but in their infancy. Trotting is the fashion, and will be, and will smrely become the popular sport in other countries as well as this. Why should it not be so? For trotting is truly a gentleman's sport, with less demoralizing influences than almost any other. and can not be diagged down to the level of a college foot-ball slngging match. The trotting horse does not lose his value or usefulness. His proper education on the track fits him for a perfect road horse for ladies and gentlemen to drive. It is a grand school, and the best driving horses graduate from it.

Our colt has had a run to grass for five or six days, but is taken up nights, groomed and fed, and is looking the picture of health. He jogs fresh and elastic and acts like a trotter. Inly fifteen days more and we must try his mettle in an actual contest. No foolishness now; the best colts in the State are entered against you, and it will be a matter of pride to win, and chagrin to lose. Now go on with the colt's work vigorously. He has not rum ont long enough to become soft, and the listances you speed him are short. The races for yearlings at the "State Breeders' 
Meeting" were made for half-mile heats, and you have trained accordingly. Repeat the colt quarters at nearly his best speed, starting from the wire. In this way you teach him to go away well, withont excitenent, and in short races with colts a good start is a winning point. Endearor now to give him such education as will help him in his race. Do not have your colt get a notion of hesitating and wanting to turn around to come back after leaving the wire, which they will do if you are not careful. To aroid this do not turn around twice in the same place. Be careful not to let the colt get so he knows better what is to be done than you do yourself. Arrange matters with him in a satisfactory manner, with the exception always that the driver is the head. The colt very soon learns to know if you are in earnest, and does not need much encomagement to have his own way, and will try to hold an argument with you.

Drive him in company a good deal, taking different positions. He will not get the pole except when entitled to it, and if accustomed to always having it at home, he will feel awkward without it when away. Teach him to drive close to the wheel of another sulky, use your whip around him in a noisy but gentle way, but never stinging him. Let it rattle in the wheel until he gets accustomed to the noise without frightening him. If you don't, some "Smart Aleck" with a dull, spiritless dung-hill of a colt that has no possible chance of winning will make it his particular business to have his whip in the wheel all the time except right under the judges' stand. In fact get the colt as nearly as possible accustomed to what may happen on a race-track in Jersey.

With this learmed and the list payment made in the stake, it is best to ship the colt two or three days before the meeting conmences. Put him in the car with a companion he is acquainted with if possible. Avoid making any change of the groom who takes care of him, because you are going to the races; keep the same man with him. If you do not the colt will miss his attendant and perhaps get 
nervous and not eat well. Do not be one of these fellows who are always complaining that in some most nnaccountable way their liorse is "dead off," vaguely hinting that there must be something wrong, declaring "they"ll never come to this track again," and all for no reason except their own neglectand inattention to business. Besure you have a man who will stay in the car all the time with the colt; if not you had better go yourself. It is time and noney well spent to make the acquaintance of the engineer, which can readily be done with a few good cigars, and a nice talk, politely asking him if he will be careful in stopping and switching the car as you have valuable stock going to the races. When you get to your destination take time and unload carefully; have no excitement and "hurral boys" abont it. Get your baggage drawn ont and have the colt led along with the outfit. If you have several animals with you keep them together and not strung ont all along the route, fretting and neighing because they are separated. Arriving at the track, if you have not had a man in advance to fix up the stall and hare it ready, find the secretary who has assigned stalls for your entries, get the numbers, and if the stalls are not thoroughly cleaned and fit to occupy, have it done, and done well, being careful about nails, broken glass and narrow doors. Get the colt in as soon as possible, have his legs bandaged, have him brushed off, his feet washed. and put him where he can smell of the other horses. Shut him up and let him rest, for riding in a car is tiresome work for a green colt. When evening comes walk him, give bim a little grass, and let the man in charge sleep in his stall; the colt will rest better and be more contented. 


\section{CHAPTER XIX.}

Preparing the colt for the yearling race-Accustoming him to objects about the track-No training necessary at this stage-Be on time when the race is called, and don't keep people waiting-Scoring half a dozen yearling colts a tedious job-What to do after the word is given-No occasion to be in a hurry to get the pole-Do your best work on the straight side-How to drive when you look like a winner in the home stretch-The secrct of your success is in careful and intelligent methods of training-Shipping the colt home agaiu and preparing him for another race in October-A mile once in awhile well within his speed-The quality of sulkiness-Some inside history about the famous trotter Guy-How he went a mile to pole in 2:17-An exciting experience with Guy when he ran away on a trot, and stopped only from force of habit-A terrible accident prevented by the horse's intelligence-What the writer accomplished in one season by the methods of training described.

Tuesday morning opens bright and pleasant. The colt eats well, is contented, and acts like an old campaigner. He appreciates the fact of his friends being with him, that is, having the same man to take care of him, and precisely the same attention he received at home, besides, a horse to see and smell of that he has known at home. Give him a walk about the grounds, hitch lim up and drive him on the track. Get him accustomed to grouns of men, standing here and there, also to the horses hitched to the fences inside and outside of the track, which is done by walking and driving past them slowly. Notice any particular object that he is shy of, and manage to get him acquainted with it if possible: you have plenty of time. The yearling race will not be caller until Thursday, and I think more of get(440) 
ting a colt acquainted with the surroundings than anything else at present.

If you can use what speed you had at home you will do well, and need not expect to gain much by training while here. You must get the colt thoronghly acquainted with the track. It is of different soil, the turns are much sharper and it is only a half-mile. All these things make a great difference with a youngster, and not so much with an old one. On Wednesday work him ont following the same general directions, being governed by your colt's disposition, regarding how much sharp work you give him. Have him led ont in the afternoon while the races are in progress, that he may see the crowd and know where all the noise comes from. In this way by Thursday afternoon you will be astonished at how well he will act. Thursday morning give him h is usual jog, also scoring up a little in company. Have him fed a little earlier at noon, look his boots over carefully, see that they are soft and pliable, and if any stitches are needed. Examine the shoes and clinches, as it may be necessary to have a mail taken out and a new one in. Have everytling ready to come out promptly when the bell rings. Keep it uppermost in your mind that a little delay on your part may destroy the pleasure of a great many people, and is amnoying to the judges and subjects you to a penalty, which in justice to the people who pay to see the entertainment should be strictly enforced. This meeting has been advertised, the people have been solicited to attend and are asked to pay admission fees; in this way they become partner's in the business, and it is due them that the programme shall be fulfilled promptly, honestly and expeditionsly. A few minutes after the bell rings, we find that ont of the fonrteen entries made in March only five make the last payment and come out for the word, and five starters in a yearling race is a good many. As a rule I would rather start in a field of ten with an old campaigner.

The judges draw for position, and assign you next to the 
outside. Everything is now ready to commence the race. You drive back to the distance stand, and turn around to score up. You get a little way, when you have to pull up suddenly as some fellow has a colt which will not turn around. You go back again, and try hard to get a start, but some of them will not come down a four-minute gait, and some will run and act badly. After sereral attempts in this way the juclges all you back, warning you not to come so fast, and wishing to obey them, your colt gets impatient under the restraint. It is almost impossible to get a good even start with five yearlings so early in the season, especially when sereral of them have never scored up before. If you think you have the most speed it is better for you to go well back and come down belind nodding for the word, even if pretty well back, provided you lave not found ont while scoling a hard one to beat. In this case do not throw away a chance to win by trailing; but keep an eye out for the one that is likely to make tronble and get off even with him. But if none seem to be dangerous, by scoring down behind you do not madden your colt by pulling him back, and if you win you will probably give the other colts the go by on the home stretch, which looks well and captivates the audience.

After seven or eight attempts the word is finally given to a straggling start with your colt fairly well up and trotting well. Some are running and breaking and some partly coming to a standstill, expecting to turn around and go back. Keep your whole attention on your own colt; do not be in too much haste to get around them on the first turn, it is better to drive a little wide than too close, to avoid accident. When you get on the straight side of the track let the colt go along to take advantage of the distance. It is much asier to drive by then than to wait until you get to the turn. You have disposed or them all but one as you enter the home stretch, and are right on the leader's wheel. Lie right there until fairly squared away for home, then make your drive and do it with determination. You started away 
next to the outside, the colt ahead of you had the pole, you have overtaken him at a disadvantage, which convinces you that you have the most speed. It is not best to overdo things and make a break. Gradually draw ahead and you will win easily. 'Turn around carefully, avoiding a collision with the other colts who come straggling along, dismount only by permission from the judges, have the colt unlitched from the sulky to avoid accident and attend strictly to his care for the next heat.

You look at the time-board and see you have won the heat in one minute and twenty-seven seconds (1:27), a good performance for a Northern-bred yearling in August in a field of five starters. They all come out to start for the next heat, as there is no distance recognized in half-mile heats, which is wrong, as there should never be any such race given, otherwise there should be a distance to prevent collusion in a close race.

The second heat you start away with the pole, and go through the regular scoring again, as the boys, if they can not win, are bound to try hard. Keep well up in your position at the pole, for it leaves you in an awkward place to lose your place going around the first turn. The judges will claim to protect you, but will often orerlook it, when the others are well in line, and it is best for you to look out for your own interest a little in this respect. Do not get careless and think you have a sure thing because you won the first heat, for a very little mismanagement will lose a race. With a fair start you get away and have no trouble to win, holding your position easily all the way. This heat is 1:26 and the colt was not pushed liard to win. All admire him and can see wonderful possibilities in his future. You are proud of him, as are all of the fellows from your section. Now you feel amply paid for your perseverance and close attention to all the little details of rearing and breaking. Several colts in the race had as much speed as your colt, showed faster in places, and would have won but for some cause which ought not to have existed. 
The secret is all in a nutshell: You have trained more systematically, more humanely and more consistently with all rules that govern health and strength. Your colt has never been whipped into obedience, and made snlky; has never been overdriven, and left to cool out too suddenly, and is willing to do his best, and tries to withont being afraid. The old farmers that had colts in the same race and were beaten ten or fifteen seconds, gather aronnd and look your colt over, and declare: "He must be overtuained, as he acted just like an old trotter," and they will beat him sule another year. They forget to look at his breeding, bnt not his make-np; and some old deacon with a good deal of sense takes out his tape line and finds that the colt's mechanical proportions measure exactly to his notion of the correct form. Had he looked in the catalogme and noticed that the colt is standard under Rule 6 , he might have known he would have measured right, for he has been bred for sereral generations in a way that begets trotting conformation.

You ship the colt home in the same careful way, and it will not need many instructions to the rubber to look after him carefully, for if you do not look out now, he will pay lis entire attention to this colt and neglect everything else. It is best not to overdo the attention; keep on in an even way, recollecting that the colt lias no mark that is admitted mpon the records. To get a record he will have to trot a mile. In this locality there will be no opportmnity to start in a race for' yearlings, except the " Midway Breeders' Meeting," which is now a fixed yearly event, takes place in October, and is open to all. It draws largely from New York, Pennsylvania, and New Jersey, and is the only one outside of a "State Breeders" " meeting, held in this portion of the country, to enable breeders to give their young things records, in actual contest; and its first meeting was liberally patronized.

The colt arrives home safely, and is at once made the pet of the farm and due respect is paid him which of course 
he is entitled to. He is but little over one year old, and has had his first engagement, and stood the fire well. You may have others as fast, but the people will not be as anxions to see them as this one, for his laurels were won in actual contest, not in the show ring. Continue his education about the same as before. A half-mile in 1:26 was abont the rate of the Northern yearling record, until 18ss. As you have never been a mile yet with him, you must have him in good condition. Keep up his work in company as much as is convenient when you speed him, but never take a colt out on the track or road, to have a visit with some friend or neighbor. They learn very quickly how to gossip, and rather enjoy it. It is better to teach them when alongside of other horses to be ready for business. Many a race has been lost that could have been won had the leading horse not fooled away his time by waiting for company.

In the latter part of Angust and throngh September the flies and mosquitoes are very annoying and worry the colts greatly, and much can be done to save them by nets and bars. A short, light leather net, to protect a colt behind the saddle of the harness, is sufficient, and will help to keep him in good humor, and when turned out to grass, a sheet well put on and fastened properly will sare more in the colt than the wear and tear of a sheet. Through September give the colt a slow mile about once a week. I mean by a slow mile, a mile always well within his rule of speed. For instance, if the colt can trot a mile pushed to his ntmost limit in 2:50, drive him a mile in 3:00 and the last quarter a 2:50 gait. In this way you do not take out of the colt all of his life and ambition, neither do you let him know that the mile is too long for lim or get him discouraged.

You will find there is a grain of sulk in the makeup of many good race-horses. It requires a good deal of tact and ingenuity to get ont of such animals their full measure of speed. Take the case of the black gelding Guy that was handled by me in 1885, when five years old. He would do 
anything it was fair to ask a horse to do, if he could arrange to do it exactly his own way, and I was happily situated to handle him. I also had the time to humor him, as the owner did not want him to start in races until the next year. Guy had a great aversion to going on a track, and acted disgusted at the sight of one; still I nerer could learn he had been overworked or overdriven. On the contrary it was said his work had always been short; fast quarters and sometimes a half. I used him on the road all throngh the month of May, both single and donble. When he was hitchèd to road cart and having driven five or six miles about the country, I would then drive in onto the track, and around once or twice, being careful to keep him from speeding; although it was always the mppemost thing in his mind, when he got to the track, to grab the bit and go. He seemed to have learned that was the game. Somehow or other he had got a wrong impression of what was wanted of him. He never acted badly with me, for the same reason that "Jack did not eat his supper"; I would not give him a chance.

I had no engagements for Gruy so I worked him with the sole object of getting him over his idiosyncrasy (more commonly calle 1 by hor'semen "bees in his bonnet"). I think my plan would have succeeded, as he constantly improved. But thinking he would go well to pole with Clingstone I trained them for a double team, giving them a pole record of $2: 17$, which mile could have been done in $2: 15$ with the circumstances all favorable. The second heat was 2:17 $\frac{1}{4}$ and while cooling out for the last heat a slight shower of rain fell, which moistened the track enongh to make the mud fly, causing Gruy to take too much hold of the bit, and trot overfast for Clingstone in places. I nerer had a good opportunity to beat $2: 17$ with them again, as after this performance we lad offers to exhibit them at different points in the grand circuit, the first place being at Hartford. Arrangements were defel'red until the time to show them was so close at hand that the team was not shipped from 
Cleveland until the 16th of August, arriving at Hartford on tlie 18th. In driving out to the track, Guy was so leg: weary, from long standing in the car, that he stumbled and fell, bruising and cutting lis knee severely, consequently the 19th was spent in nursing him, when he ought to have been exercised. On the 20th, with the track full of horses scoring up with him and annoying him, the team trotted in 2:19, the last quarter a 2:13 gait. This for a five-year-old with no record to harness, was, under the circumstances, a wonderfully good performance. I am not surprised that with three years more age Guy trotted in 2:12.

While the colt is resting I will tell you a little story about Guy which has not been in print. One fine morning in June, just after a nice warm shower, Guy was hitched to the light cart and I started to give him his work on a straight piece of road about a mile long, partly shaded by large maple trees, with their long low branches overhanging the whole roadway. At the end of this drive there is an old railroad track graded up much higher than the road, and very steep down on the other side. I seldom crossed this track, as my usual drive was to this railroad, then forward and back, until the amount of work necessary to be done was finished. The horses under my charge had the route well learned, and expected a little brush occasionally before returning to the stable. The morning I speak of, as I passed through the little town of Glenville my youngest boy was waiting there with the mail for me. He looked so entreatingly at me for a ride that I thought it best to take him in. IVe jogged along down to the speeding ground, Guy as full of play as a spring lamb, and as buoyant as the boy behind him, who thought he was driving him, as he had hold of the lines with me. The rain which had fallen was not quite enough to make mud under the trees, and it seemed to be about the proper thing to treat the boy and horse to a little spin. They were both anxions for it, and when the boy langhed the horse would follow suit by shaking his head and trying to get the bit. To please them was only to please myself, and I had 
no sooner thought of it than Guy knew it and was off. Great Caesar how he went! And how the sand and dirt did fly; Charlie crying "Let him go, pa!" and I suddenly finding out there were three jobs on hand needing immediate attention. First, to keep my eyes open; second, to keep the boy still and in the cart; and third, to stop the horse.

My mind was occupied also with the fact the cart might break, and also in figuring whether I could stop Guy before we got to the railroad. To say I was getting nervous puts it mildly-I was really beçoming frightened. With a good grip on the boy with my knees, a hold on Guy with all my might, and with eyes almost closed with the mud, matters were getting desperate. Guy was now fairly running away, was beyond control, but true to his breeding still on the trot. As we were nearing the railroad at every step the tension was getting stronger; something must be done. He had the bit-in fact he had me. It was Guy "cutting up that hog;" not me. I yelled "Whoa!" I tried to saw him to a stop. I pulled so hard the cart springs settled down until Guy looked like a seventeen-hand holse. But it was of no'use; he was "out" in earnest.

As we emerged from the shade of the trees the mud was thin, and it was flying over the cart like shavings from a planer. There was only one more chance; would he stop from force of habit or would he go on over the track? If he goes over we are gone. We are almost there. I must try something. I begin carefully to let up on him ; he hesitates a trifle, slows down gradually, comes to a walk, stretches out his neck asking to let go the bit, and we turn around to go back. TVe were much in the condition of the boy whom the mule had kicked-we were not as handsome as before, but knew a good deal more. You may safely guess I did not encourage Guy to speed any more that morning. We walked back and took a rest for the balance of the day. And that was Charlie's last ride behind Guy. He often 
said after that "If $\mathrm{Mr}$. Gordon had seen Guy go he g'uessed he would have been proud of him."

To return to our colt, who has had a few slow miles in September, sandwiched in with his short, sharp work, he will be fit and fine for a good fast mile in October. And if you land him a winner he will be deserving of a vacation. The Northern yearling record is $2: 41 \frac{3}{4}$, and is a good performance. It is a liard mark to beat, but with the start you have, and plenty of perseverance, you can reach it. The colt's work should never be severe enough to get him stale, and always keep near the shore in this respect; that is: Better do too little than too much. For if you do too little you can remedy it, but if too much the trouble can not be repaired the same season. I have seen you through the first race and about ready to start at the fall meeting. Now as you are in good shape, and feel so confictent of wimning, I will let you go and wait to hear the result; which I trust will be to suit you. Your colt has so far been handled with good judgment and the smallest details looked after with care. You feel well paid now, but if you can beat the record you may be prond. The successful training of two and three year olds is conducted very much upon the same general principles. More strong work perhaps will be needed; but aroid too much slow and tedious jogging. Too much slow work is monotonous, and does not quickly reach the point you are after, which is speed. Recollect that 2:30 is as fast as it ever was; and it is more satisfaction to break, handle and drive one from the paddock, and put him in the 2:20 list, than one that five or six other fellows have handled. and brought out. To do this quickly is an important feature, adding much to the profit as well as the pleasure. Take the case of the bay mare Beulah, broken in her four-yearold form, at five years started in seren races, winning five of them, and getting a record of $2: 29 \frac{1}{4}$. At six years old started in ten races, winning seren and getting a record of $2: 19 \frac{1}{2}$. This was not done by long, severe work, but on the principle of short, quick, fast work, muc'. after the manner 
of working colts. The abore way of working young things has developed from one farm, the past season, eight threeyear-olds with speed enough to beat 2:30, almost the same number at two years that could beat 2:40, and a yearling with a record of 2:413. "There would not be great ones if there were no little."

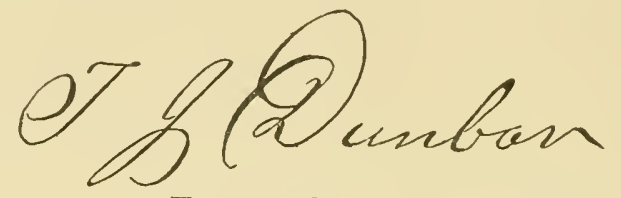

Fashiox Stud Firm, Trenton, N. J.

January $21,1889$. 


\section{2:083/4 and 2:15.}

\section{NUTBOURNE 漹 ELDRIDGE}

\section{NUTBOURNE, out of the dam of Maud S., record 2:083/4. ELDRIDGE, out of the dam of Majolica, record $2: 15$.}

\section{NUTBOURNE and ELDRIDGE,}

Will make the season of $1 \& 89$ at my farm, three miles east of Tarrytown, Westchester Co., N. Y., and twenty-five miles from New York city. Several prominent Kentncky breeders have urged me to let Nutbourne go to that State, but I have concluded to keep him at home. His full brother, Nutwood, is the only horse, living or dead, with a record under 2:20 having five of his produce with records under $2: 20$, thus showing his capacity to get a high rate of speed. Besides, be is the sire of 24 in the $2: 30$ list, eight of which were added last year.

Terms: For Nutbourne, $\$ 150$ for the season; for Eldridge, $\$ 100$ the season. Mares not proving with foal to either horse may be returned the following season free of charge.

\section{NUTBOURNE,}

g. b., 16 hands high, foaled 18\%, by Belmont (sire of Nutwood, record 2:183/4), dam Miss Russell, the dam of Maud S', record 2:08\%, by Pilot, Jr., second dam Sallie Russell, by Boston (thorongbbred), etc. As will be seeu, Nutbourne is not only out of the dam of Maud S., but he is a full brother to Nutwood, record $2: 18 \% \frac{1}{1}$, and Cora Belmout, record $2: 241 / 4$. As a five-year-old, Nutbourue trotted, with very little handling, in $2: 261 / 4$, last quarter in 35 seconds; but since then has not been trained, as he has been used exclusively for the stud. Nutbourne's full brother, Nutwood, is so popular that his services have been raised to $\$ 500$. The editor of the Turf, Field and Farm, in speaking of the foals at my farm by . Vutbo:trne, says of one, "It is a trotting gem of the first water," and of another, "There is no disposition to do anything but trot. I never saw so rapid a colt of its age."

\section{ELDRIDGE,}

b. h., 153/4 hands high, foaled 1877, by Edward Everett (sire of Judge Fullerton, record 2:18), dam Jessie Kirk, dam of Majolica, record 2:15. Jessie Kirk is by Clark Chef, sol of Mambrino Chief Edward Everett, the sire of Eldridge, is the sire of twelve trotters in the 2:30 list, among them the late Commodore Vanderbilt's favorite road horse Monutain Boy, record $2: 203 \%$. Eldridge is a graudly formed horse, 4 rich bay, with black points, and bas trotted a trial on my track at Tarrytown in $2: 201 / 4$. Ilis dam being the dam of M 1 jolica, he shonld make a great sire. Ile has sired only four foals, and I sold one of tnem - the two-year-old colt c'artridge, - for $\$ 4,000$. One of the best judges in the conntry says of him: "Eldridge has a aplendid hock, and a good, flat leg-in fact, the best set of legs I have ever secu; and his remarkably loose, easy way of going shows that he has an elasticity that he can impart."

Mares sent to be bred to Nutbourne or Eldridge can be kept on Mr. George W. Campbell's farm, just on the opposite side of the road from my place, on reasonable terms. Mr. Campbell makes a epecialty of taking care of trotting stock.

\section{Address}

\section{ROBERT BONNER,}

TARR Y TOWN, N. Y.

Mares can be sent to Tarrytown by boat from foot of Franklin Street, New York, or by rail to Tarrytown, by Hudson River Railroad, from depot foot of 33d Street and 11 th Avenue. 


\title{
ALLEN FARM.
}

\section{PITTSFIELD, BERKSHIRE COUNTY, MASSACHUSETTS.}

\author{
WILLIAM RUSSELL ALLEN, - - - - - - $\quad$ - Proprietor.
}

1889.

\section{STALLIONS IN SERVICE. LANCELOT.}

Bay, by Messenger Duroc, dam GREEN MOUNTAIN MIID, the dam of

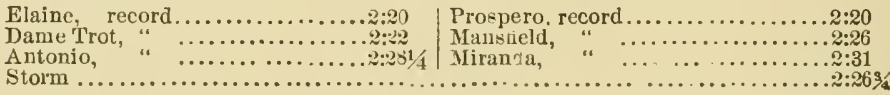

Electioneer (sire of Hinda Rose, yearling record, 2:261/2; Sunol, 2-year-old record, 2:18; Hinda Rose, 3-year-old record, 2:191/2; Manzanita, 4-year-old record, 2:16; Anteco, 2:161/2; Adair, 2:171/2; Bonita, 2:183/4, and many others in the $2: 30$ list.

\section{YARROW.}

Bay, by Lord Russell, dam YOLANDE (dam of Yuba, 2:211/2, and Yazoo, 2:311/2), by Belmont.

LORD RUSSELL by Harold, and out of MISS RUSSELL, the dam of

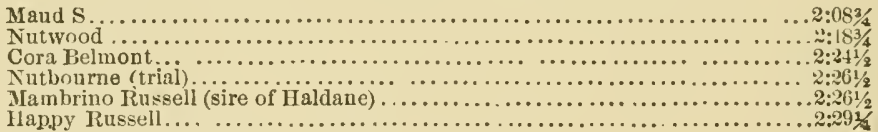

YOLANDE'S dam, YOUNG PORTIA, dam of

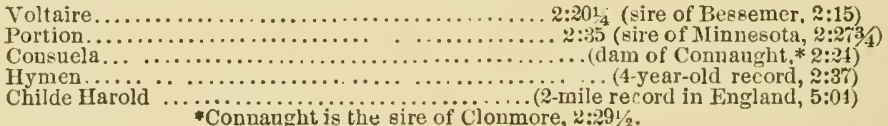

\section{AMERICA.}

Black, by Kentucky Prince (trial 2:28), dam ALMA, 2:283/, the sister to

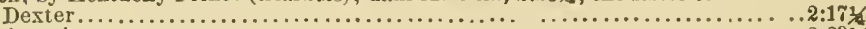

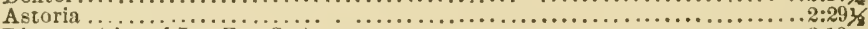

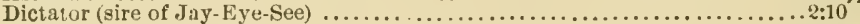

$\ldots \ldots \ldots \ldots$ "

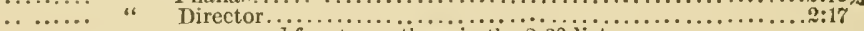

and fourteen otbers in the $2: 30$ list.

Second dam, Clara, by Secly's American Star; 3d dam, the AIcKinstry mare, dam of Shark.

Kentncky Prince, by Clark Chief, son of Mambrino Chief and first dam Kentucky Queen, by Morgan Eagle; 2d dam by Blythe's Whip; 3 d dam, by Nartin's Brimmer; 4th dam, by Quicksilver, son of imp. Medley.

Kentucky Prince is the sire of Guy, 2:12; Spofford, 2:18\%; Bayonne Prince, 2:2116; Company, 2:193/4; Compeer, 2:25:4 Problem, 2:211, Sweepstakes, 2:24t ct al. 


\section{ALLEN FARM.}

\section{BROOD MARES}

Are the immediate descendants of the greatest of producing Sires and DAMS.

RUSINA, by Belmont, out of MISS RUSSELL, the dam of MAUD S., 2:083\%.

MA DDLEN, 2:253, by Harold, out of NUTULA, the sister of NUTWOOD, 2:18\%/4.

ELISTA, by Messenger Duroc, out of GREEN MOUNTAIN MAID, the dam of ELECTIONEER.

MALVASIA, by Lord Russell, out of MALMAISON, the dam of MANETTE, trial 2:161/4. ASHIMA, by Lord Russell, out of ALICE WEST, 2:26, the dam of ALTANIURA, 2:30. SA LVE, by Lord Rnssell, out of NOONDA Y, 2d dam Midnight, dam of JAY-EYE-SEE, 2:10. RUBRA, by Lord Russell, out of PIRIMROSE, dam of Princeps, sire of TIINKET, 2:14. ESPEREXCE, by Пarold, out of ENGLEWDOD, the sister of WEDGEWOOD, 2:19. SUN MAID, by Belmont, out of SONNET, 2d dam LITTLE IDA, dam of SO SO, 2:171/2. WATERLEAF, by Belmont, out of WATER LILY, 3d dam WATERWITCH, dam of Viking. $2: 191^{1}$.

EDITA, by Kentucky Prince, out of ELISE, sister to ELAINE, 2:2).

MIRELLA, by lientucky Prince, out of MIRANDA, 2:31, the sister to PROSPERO, 2:20. BRENDA, by Kentucky Prince, out of MISS BRUNETTE, the dam of BLACK PRINCE, 2:251/2.

FEDORA, by Fentucky Prince, out of CASSANDRA, the sister of HOGARTH, 2:26.

NXDIA, by Kentucky Trince, out of CAMILLE, the dam of STETIE, 2:291/4.

ALFARETTA, by Kentucky Prince, out of BETTY, $2 d$ dam LADY FALLIS, dam of KISBER, $2: 2 \% 1 / 4$.

GUTDA, by Messenger Duroc, out of LESLIE, the sister of GUY, 2:12.

PH.LLAMONT GIRL, 2:30, by Phallamont, out of POCAHONTAS GIRL, the sister of IIGGHLAND MAID, $2: 291 / 4$.

POKIE PHALMON', by Phallamont, ont of POCAHONTAS GIRL, the sister of HIGHLAND MAID, 2:291/4.

LAURA PHALMONT, by Phallamont, out of LADY ELDREDGE, trial 2:26.

LIZZIE PHALMONT, by Phallamont, out of DAIST MeK., trial $2: 34^{1} / 2$.

REPOSE, by Conway, $2: 18 \% 4$ (pace), out of TULIP, dam of ULTA, $2: 2 \%$.

PRINCESS ROYAL, by Phallas, 2:13\%, out of HERMiA, 2d dam HAIDEE.

MAIRINA, by Sorrento (son of Woodford Mambrino, $2: 21 \frac{1}{2}$ ), out of MARY WHITMAN, $2 d$ dam NANCY WHITHAN, the dam of ROBT. MEGREGOR, $2: 171 / 2$.

EARLY DAY, by Erelong, by Belmont, out of LOTTIE MORGAN.

LOUISE, by Merchant, by Belmont, out of Pansy, by a son of HAMIBLETONIAN, 10.

CLOISTER, by Chichester, 2:251/4, out of CRACOVIENNE, gr. dam of KENILWORTH, $2: 18 \frac{1}{4}$.

MICA, by Chichester, 2:251/4, out of MARY BELLE, dam of PUELLA, 2:29.

MIN'TAKA, by Chichester, 2:25/4, out of MINNA WILKES, sister of KENTUCKY WILKES, $2: 21 \frac{1}{4}$.

VENEZ EELA, by Chichester, 2:251/4, out of VASSAR, gr. dam of ED ROSEWATEIR (pace), $2: 201 / 2$.

MARIOLA, by Chichester, 2:25/4, out of MARA, 2d dam Mary, dau of DICK MOORE, $2: 22 \frac{1}{2}$. 


\title{
THE

\section{STALLIONS IN USE:}

\section{WEDGEWOOD 692. Service Fee, \$150.00.}

The Great Race Horse and Sire-Record 2:19 Fourth Heat.

Sire of Favonia 2:15 fifth heat, Conway 2:183/2, Connaught $2: 21$ (sire of Clonmore (3) 2:291/4), Nugget 2:263/4 (sire of Nettleleaf (4) 2:231/4, Goldleaf $2: 231 / 4$, and Newton (4) 2:28), Ulva 2:27, Jesuit 2:321/2, Pagan 2:37, Mersburg 2:40, Mayenne (dam of Crescendo 2:24), Pluto (sire of Bluewing (4) 2:27), and Abbess (dam of Brandoline (2) 2:301/2). This showing from not more than fourteen living foals in Kentueky.

\section{BONNIE WOOD, $\mathfrak{c}_{2: 39}^{\text {Thal (2) }}$ Service Fee, \$75.00.}

\author{
Brother to Nutbreaker (3) $2: 2134$.
}

Bay, foaled in ' 85 , by Nntwood, first dam Bonnie Doon by Aberdeen, gr. dam Ariel by Ethel Allen.

\section{CANDIDATE, Ther Thl (2) Service Fee, \$7.00.}

Black, foaled in '85, by Electioneer, first dam Nora by Messenger Duroe, gr. dam Mary Hulse by Ameriean Star.

\section{PONCE DE LEON, Private Stallion.}

Black, foaled in '87, by Pancoast, first dam Elvira (1) 2:18 $\frac{1}{2}$, sister to Beatrice dam of Patron, gr. dam Mary Mambrino by Mambrino Patchen.

\section{BOW BELLS}

(Brother to Bell Boy).

Bay, foaled in 188; hy Electioneer, dam Beautiful Bells. Bow Bells is being handled this year in California, but will be brought over and placed in the stud in 1890 .

Well-bred daughters of Harold, Geo. Wilkes, Eleetioneer, Mambrino Patchen, and other sons of Rysdyk's Hambletonian and Mambrino Chief are to be found among our brood mares.

TERMS.-The usual privileze of return the next year if mare proves not in foal. Grase and attention during season at $\$ 3.00$ per month. Grain fed at $\$ \$ .00$ per month.

Catalogues will be issued in the early Spring, when we will be glad to furnish applicants.

The farm is five miles south of Nashville, and ean be reached either by Franklin Pike, Nashville \& Decatur Railroad, or by the Overland Dummy Line.

Address

MAY OVERTON, Manager,

Box 8, Nashville, Tenn. 


\section{ROCK RIVER}

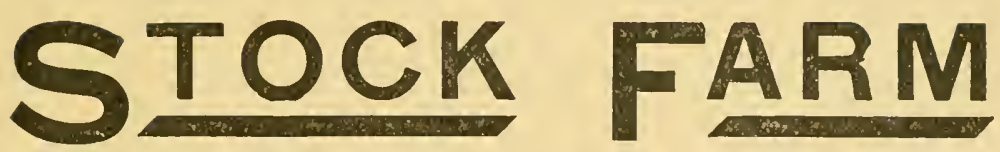

DIXON, ILL.

Western Home of the Morgans.

MORTIMER McROBERTS, Proprietor.

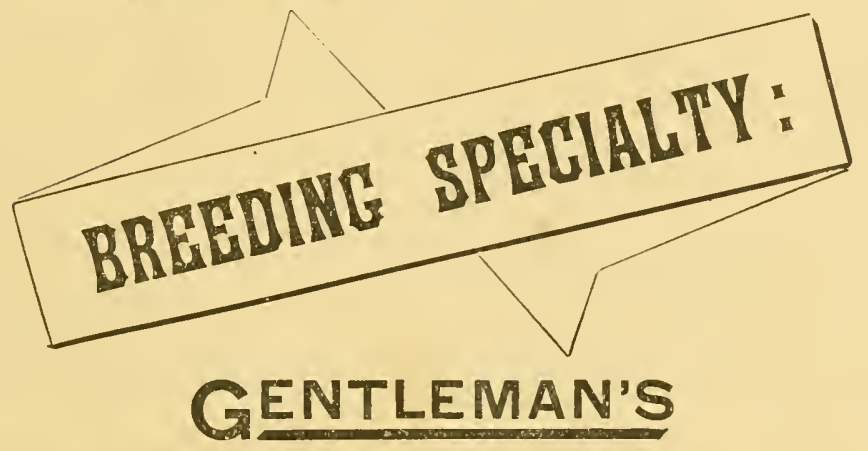

\section{FINE ROAD AND DRIVING HORSES}

Horses Bred from Mares of Different Trotting

Families by Stallions of the Morgan,

Hambletonian, and Mambrino

Chief Strains.

SINGLE HORSES AMD MATCHED TEAMS ALHAYS ON HAND.

Chicago Office, I 5 Lake Street,

WHERE ALL COMMUNICATIONS SHOULD BE ADDRESSED. 


\section{ESTABLISHED 1854.

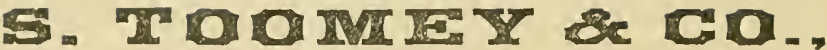 \\ CANAL DOVER, OHIO.}

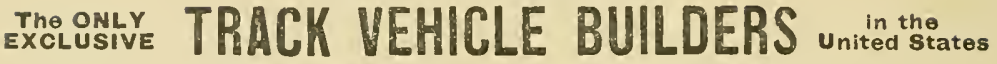

Truss Axle Sulky.

Thls Sulky holds an enrious position, and Is already so favorably known, that we deem comment unnecessary. For a Contested Race, fo: a Match liace, or for a Low Record the TRUSS AXLE SLLKY bas no Euperior. Made in five sizes, from 38 to 58 lbs. Send for full description of Truss Axle and Training Sulkies.

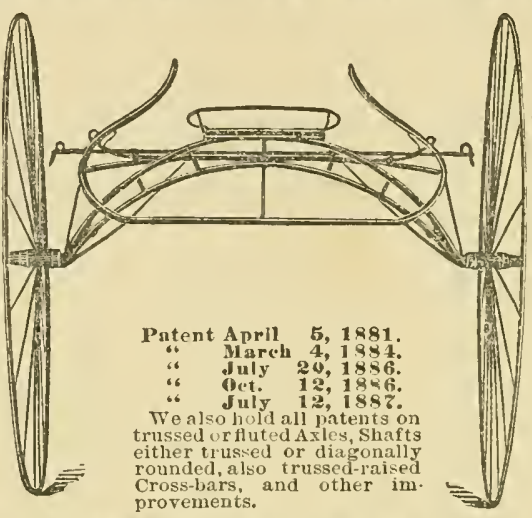

REFERENGES. John Splan, W. H. Ohio. Kentucky. o. A. Hickok, California. Ed. F. Geers. Peter V. Johnson. A. J. Feek Michigan. J. II. Gold New York. J. II. Goldsmith, York. S. L. Caton, California. Geo. J. Fuller, W. H. Crawford, Ohio. Kentucky. MIillard Sanders. And many others.

\section{OUR IMPROVED SKELETON WACON}

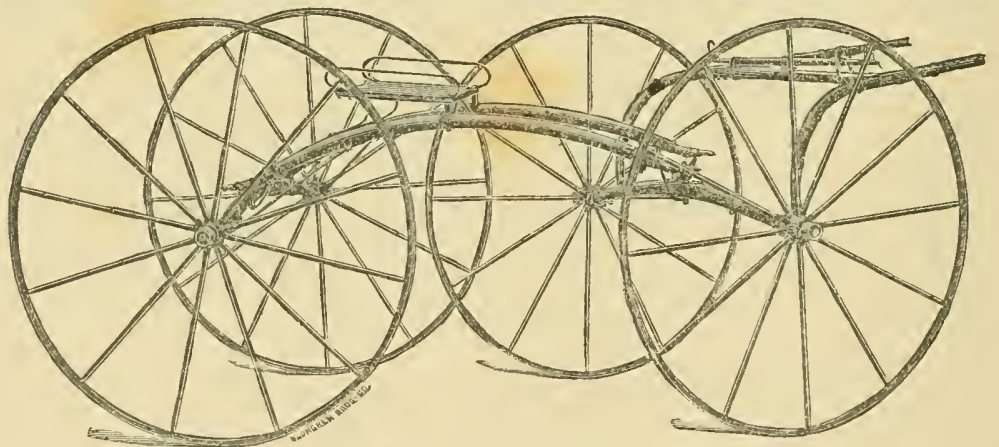

PATENT APPLIED FOK.

We beg to call the attention of Breeders, Trainers, and Drivers to tlie above cut, whlch represents our latest improved skcleten WVagon.

For a number of years past the ROAD Cart has been used as the principle vehicle for speeding and jogging the trotter, and upon its introduetion was considered a very gool thing for that purpose, but its use has failed to verify this fact, as the cart is heing discarded and is fast growing inco disfavor on account of its absolute tendency to ruin the pureness of gait of the trotter, which tendency is due to that peculiar bobbing motion and weight on the horses back, which is wholy unavoidable in div upon the introduction of the cart, has agni become cwith more favor than ever, the principle vehicle for jogging, training, speeding, and gaiting thetrotting hort all other skeleton Wasons is tho low side bar, which prevents a short turn, and is the cause of bending or breaking spindles and severe aceidents. It will be seen by tho abnve cut, with our high areh bar, a very short turn can be made, whicb is very esscntial, as it ohviates tho breaking of wheels and spindles, and avoids accidents. The general conatruction of this wagon is such as to prevent the spreading of wheels when under full speed. Can also he mado mueh lighter than on any other construction; therefore for jogring, for speeding. or for getting a conspicuous view of the gait of your horse, the Skeleton IV acon, as now improved by us, will fill a long-felt want. IIade in all sizes, from $651 \mathrm{bs}$, up. SEND FOR FULL DESCRIPTION.

\section{S. TOOMEY \& CO.,}

Canal Dover, Ohio, U.S. A. 


\section{WOODBURM

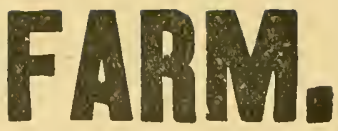

TROTTING STALLIONS.

\section{BELMONT,}

Sire of NUTWOOD, 2:18\%; WEDGEWOOD, $2: 19$, etc.

\section{HAROLD,}

Sire of MAUD S., 2:083/4; NOONTIDE, 2:201/4, etc.

\section{LORD RUBSELL,}

Brother to Maud S., 2:083.

\section{KING WILKES,}

Record 2:221/2 (sire of Oliver K., record 2:1614), by GEOIRGE WILEES, 2:ฉ2.

\section{PISTACHIO,}

Brother to Nutwood, 2:18\%.

\section{RE-ELECTION, \\ (Fioaled 1888)}

By ELECTIONEET, dam I.ADY IUSSELL, sister to MAUD S., 2:0834.

Woodburn Farm is the birthplace of Mand $s ., 2: 083 \frac{4}{4}$; Nutwood, 2:1834; Wedgewood, 2:19; Favonia, 2:15; Conway, 2:183/4; Viking, 2:191/4; Mambrino Dudley, 2:19\%; Miss Russell (dam of Maud S., 2:0S34); Midnight (dam of Jay-Eye-See, 2:10), and mauy other great horses.

\section{THE THOROUGHBRED DEPARTMENT}

EMBRACES TIIE STALLIONS,

\section{KING ALFONSO, FALSETTO,}

\section{LISBON,

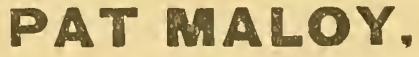

\section{POWHATTAN,}

AND EIGHTY-THREE BROOD MARES.

For Catalognes address

A. J. ALEXANDER, 


\section{JEWETT

Bay horse, black points, 15.3 hands high; weight, 1,175 pounds.

Son of Volnnteer 55 (sire of St. Julien, $2: 111 / 4$ ) and Ifattie Wood (da'n of Gazelle, 2:2!). Sire of Jerume Eddy, $2: 161 / 2$; Chas. Hilton, $2: 171 / 2$; Spinnclla, $2: 213 \%$; and five others in $2: 30$ or better.

1st dam Fanny Mapes, dam of Jerome Eddy

2:1616; Geo. Milo, 2:33; Hattie Mapes, 2:231\%;

Joe Gavin (sire of Cora Belle, 2:50); Larry

IT. (sire of J. I. R., $2: 248 / 4)$ ) and Frank $2 \mathrm{dam}$

Noble (sire of Harry Noble, $2: 26$ )

3d dam.

4tb dam.

Terms, \$200, due at timo of service, with the usual privilege of return.
By Alexander's Abdaliah 15, slre of the dams of Favonia. 2:15, and $t$ went $y$-three others In 2:30 or better.

By Burr"s Napoleon, sire of Rhode Island, $2: 35$ in 1851 By long Island Black Ilawk 21, stre of Prince,

Dy imp. Trustee.

\section{SHERMAN 1506.}

Record, $2: 231 / 2$.

Brown horse, 16 hands in height; weight, 1,200 pounds.

Sire Genrge Tllkes วั19, sire of

Harry Wrlkes...................... 2:131

Guy Wilkes........................ $2: 151$

1st dam by Belmont 64, sire of

Nutwood.

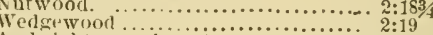

And eighteen others in.................

Terms, $\$ 100$, payable April 1st, 1890 , with the usual privilege of returu.

\section{CORONET 1035.}

Brotber in blood to Ambassador, $2: 21 \frac{1}{4}$.

Bay horse, 152 hands in height; weight, 1,100 pounds.

Sire George Wilkes 519, sire of

Thirty-two suns that have produced

performers with reenids of ..... $2: 30$

1st dam. hy Ameriean Clay 3.l, sire of the dams of sixteen in $2: 30$, or better.

And the dams of twelve in 2:30, or better.

$2 d$ dain, by Mtimbrino Chief 11 , dam of Allie West. ......................... $2: 25$

Terms, $\$ 50$, payable A pril 1st, 1890 , with the usual privilege of retur.

\section{HOMER 1235.}

Bire of Lelah H. (at 4 years) $2: 21 \frac{1}{2}$.

Own brother to the dam of Baron Wilkes, $2: 18$.

Brown horse, $15.2 \frac{1}{2}$ hands in height; weight, 1,20 ) pounds.

Sire Mambrino Patehen 58, slre of

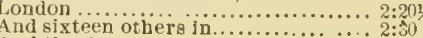

And the dams of twenty.eight from

$2: 151 / 4$ to $2: 30$

1st dam Sally Chorlster, dam of

rruteine ....................... 2:18

Belle lsrassfield (dam of Holstein)... $2: 20$

Ad liration (trial) ............

Belle Patehen (da 11 of Baron Wilkes, $2: 18) \ldots \ldots \ldots \ldots \ldots \ldots \ldots \ldots \ldots \ldots, 2 ; 301 / 4$

Terms, \$100, payable April 1st, 1990 , with the usual privilege of returu.

\section{FIELDMONT 5050.}

Own brother to Almont, Jr., 2:26.

Bay horse, 15.3 hands in he'ght; weight, 1.175 pounds.

Sire Almont 33 , sire of

Fanny WItherspoon

And thirty-four others in........... $2: 161 / 4$

The Jewett Stock Farm is situated two and one-quarter miles west of East Aurora station, sixteen miles from Buffalo, N. Y., on the Western New York \& Peansylvauia Railroad.
HENRY C. JEWETT \& CO., Post Office address, Buffalo or WIIllnk, Erie Co., N. Y. 


\section{J. H. FENTON,}

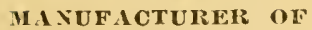

\section{Fine Track and Road Harness} SWEAT, COOLING, WORKING, and WALKING SUITS. THE BEST AND ONLY PRACTICAL

\section{TOE WEIGHTS, HORSE BOOTS}

IN THE MARKE'T,

And appliances of every description used in EDUCATING THE TROTTING HORSE.

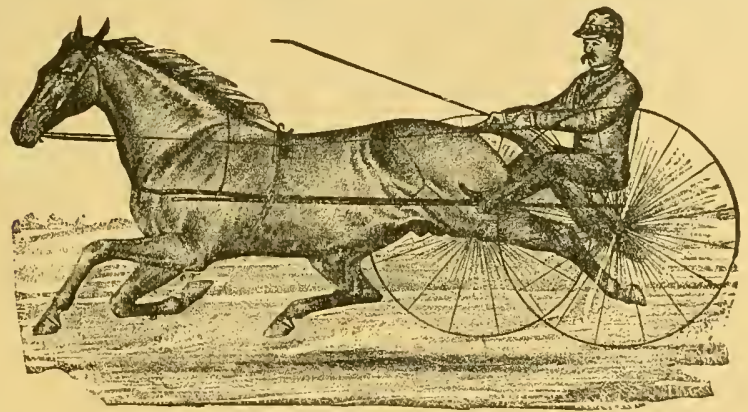

THIS LEADING

\section{HORSE GOODS EMPORIUM}

Has facilities for manufacturing unequaled by any other house in

$$
\text { AMERICA, }
$$

And makes intricate and practical IIORSE APPLIANCES A SPECIALTY.

WE ARE AGENTS FOR THE CELEBRATED

\section{TOOMEY AND CAFFREY SULKIES ALSO}

JOGGING AND BREAKING CARTS.

Send for Catalogue to

$$
\text { J. H. FENTON, }
$$

211 \& 213 Wabash Avenue, CHICAGO, ILL. 


\section{DR. ROBERGE'S \\ PATENT HOOF \\ EXPANDER}

Which Cures Corns, Contractions, Quarter-Cracks, Etc.

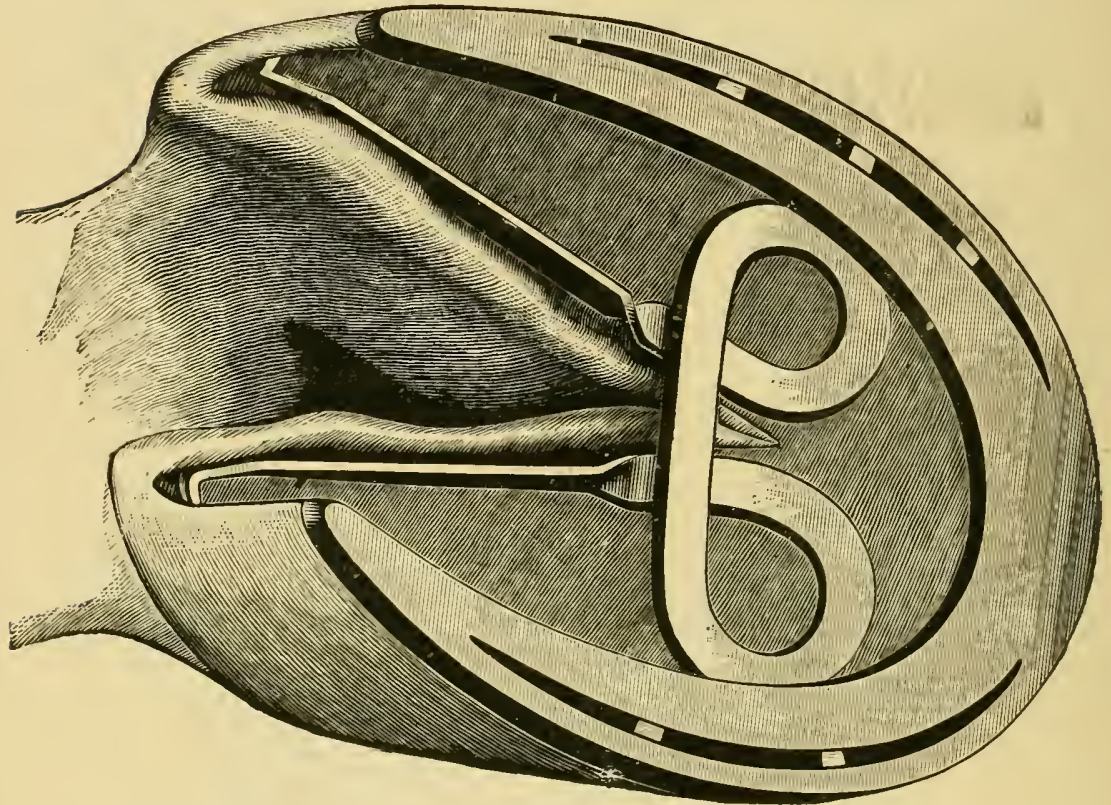

It is the best invention for expanding a contracted foot or keeping a sound foot in its natural shape.

It is used and approved by the leading horse owners of the New York Driving Club, such as ROBERT BONNER, FRANK WORK, and hundreds of other gentlemen of repute.

"I received your Patent Hoof Expander, placing it in "AkroN, O., Jan. 24, 1837. I must say I never saw such a for the other foot by retin a change in a hoof in six weeks. Please send another Expander pairs for my own horses as soon as I I will send an order for an assortment. I want a dozen by me is unnecessary, as I am convinced your Expander knocks them all out.

$$
\text { "Yours, }
$$

"DR. F. P. RoBErge, 1,741 BroAdWAT, N. Y.

"OFFICE OF DR. H. D. Brown,

"DEAR SiR: Inciose "Potsd $भ$, N. Y., March 14, 1887. inclosed diagrams, No. 1 and No. for which send one pair of your Hoof Expanders for the my other colt by using the Expanders I ordered of you to show you the improvement made in more in a short time for a friend of greatest boon for contracted feet mine, who has seen the improvement. I think they are the you would be made a hero at once.

\section{"Yours respectfully, \\ H. D. BROWN." \\ One Pair, $\$ 2$. - $\quad$ Three Pairs, \$5. \\ F. P. ROBERGE, Veterinary Surgeon, 1,74I BROADWAY, NEW YORK CITY.}

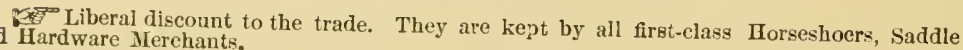




\section{Kalamaz0o Farm Stallions}

AMBASSAOOR 1496

Record $2: 211 / 4$, trial 2:18.

By GEORGE WILKES, dam Lady Carr (the dam of Alcandre, $2: 261 / 4$, and three more that can beat $2: 30$ ), by American Clay 34.

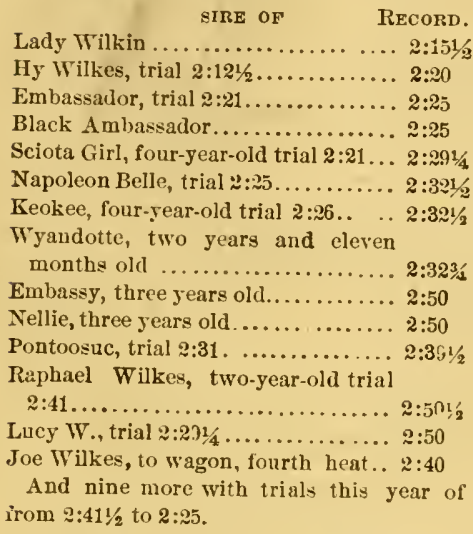

\section{Limited to Thirty Mares at} $\$ 150$ the Season.

\section{WaRLOCK 3378}

Trial, a mile in 2:38 on half-mile track; quarter in 36 seconds, the serenteenth time jn harness.

By BELMONT 64, dam Waterwiteh by Pilot, Jr. 12, the

$$
\text { DAM OF }
$$

RECORD.

Viking, brother to Warlock ...... 2:191/4

Mambrino Gift, sire of six in $2: 30$ or better.................... 2:20

Scotland................... 2:221/5

Wavelet, sister to Warlock........ 2:241/3

Wraterloo, brother to Warlock...... 2:28

Warder, brother to Warlock, trial 2:291/2.................. $2: 371 / 4$

Fairy Belle (dam of Nymphia, $9: 263$; Elf King, $2: 30 t / 2$, and Fairy Gift, 2:291/4), sister to Warlock........

Peri (dam of Alice Tyler, $2: 30$, and

General Haneock) ...............

Sprite (dam of Sphinx, 2:23; Spry, trial 2::0, four-year-old record 2::83/4), sister to Warlock... ..... Naiad (sister to Warlock), trial 2:301/4 Undine, trial $2: 27 . \ldots \ldots \ldots \ldots \ldots \ldots . \ldots . . .2: 351 / 2$

Limited to Twenty Ma:es at $\$ 100$ the Season.

\section{EMPIRE 2378}

(Matinee record 2:35), by MAMiBRINO PATCHEN 58, dam Favorite, record 2:34, the dam of Favorite Wilkes, $2: 2514$, and three more, including Bonrbon Wilkes, that could beat $2: 30$. Sire of Eminence, four-year-old record $2: 211 / 4$, and others quite promising.

\section{Stands at $\$ 25$ the Season.}

Our brood mares all trace to producing dams; are speed producers, or lave records of $2: 30$ to $2: 191 / 2$, or have a dam or grand dam that have proluced one or more $2: 30$ or better trotters, and are by fashionable anıl speed-producing sires of a high order. We are breeding REAL trotters and campaigners, and our stable of young trotters won more races, and we put more in the $2: 30$ list in 1887 , than any other stock farm ever did in one season.

\section{Young Stock for Sale, and at Reasonable Prices, considering the High Standard of breeding and individual excellence.}

For Catalogues, Prices, or otlıer information, address

$$
\begin{aligned}
& \text { S. A. BROWNE } \underset{\text { Kalamazoo, Mich. }}{\text { CO. }} \\
& \text { Kala }
\end{aligned}
$$




\section{GORDON GLEN STOCK FARM}

W. J. GORDON, PROPRIETOR, CLEVELAND, OHIO.

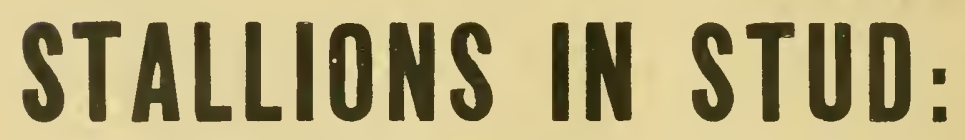

\section{CLINGSTONE 2D}

(Full brother to Clingstone, 2:14).

\section{RYSDYK 653,}

Sire of Clingstone, 2:14, and four others in the 2:30 list.

\section{THOMAS RYSDYK,}

By Rysdyk, dam Largesse, 2:25.

\section{JOSIAH A.,}

By Clingstone 2d, dam Miss Wilkes, 2:29, by Geo. Wilkes.

THE

\section{BROOD MARES}

Are Standard, among them being

MAMBRINO SPARTIF, 2:17.

IFOINTINR,

$2: 23 \quad 1-4$.
IAFGFSSE, FTC. $2: 25$.

SEND FOR CATALOGUE. 


\section{ASHLAND}

STALLIONS IN USE:

\section{DICTATOR :}

Sire of Jay-Eye-See, 2:10, Phallas, 2:1 $3^{3}-1$,

Director, 2:17, etc.

\section{KING RENÉ:}

Sire of Fugue, 2:191/4,

Prince Edward, 2:241/4,

Sarcenet, 2:251/2, etc.

Colts and Fillies by DICTATOR and KING RENÉ out of superbly bred mares by George Wilkes, Volunteer, Belmont, Harold, Mambrino Patchen, Princeps, Cuyler, etc., for sale.

Catalogues sent on application.

H. C. MCDOWELL \& SON,

Lexington, $\mathbf{K y}$.

\section{JOHN E. MADDEN}

\section{I I - BRED}
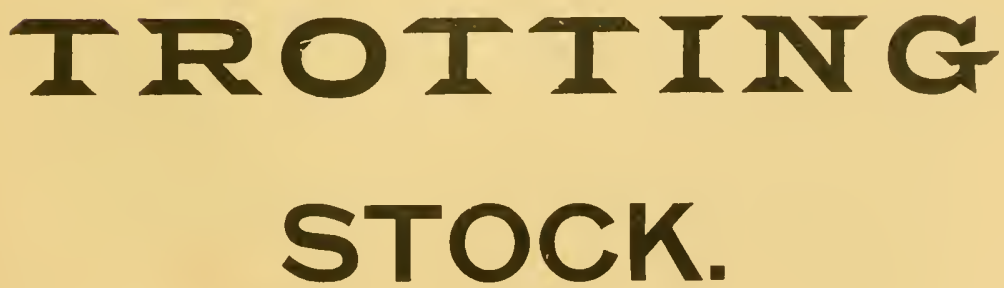


\section{SIONY FORD SIUD}

MESSENGER DUROC 106.

Bay, 16 liands, sire of fifteen trotters with records ranging from $2: 20$ to $2: 30$; also sire of the dams of ten with records ranging from $2: 20$ to $2: 30$.

\section{KENTUCKY PRINCE 2470.}

Bay, 15.3 hands; sire of eleven with records ranging from $2: 12$ to $2: 30$; also sire of the dams of Saxon, :2:28; A. A. Bonner's borse, trial $2: 201 / 4$; and C. A. Pond's horee, trial $2: 221 / 4$.

\section{LELAND 1300.}

Brown, 16 hands; sire of Miss Leland, $2: 25 \frac{1}{4}$; and 1Iaides, $2: 273 / 4$; ont of the first five foals he sired. The next year he sired Clara, $2: 21$.

\section{MANSFIELD 1358.}

Chestnut, 15.3 hands; record $2: 26$; sire of Foxie, $2: 23 \frac{1}{2}$ : and out of Green Monntain Maid, dam of six in the 2:30 list. Mansfield is a brother of Elaine, dam of Norlaine, that has the fastest yearling record, $2: 31 \frac{1}{2}$.

ANTONIO 2823.

Bay, 15.1 hands; record 2:28\%; ftall brother of Mansfield and Flaine.

HOWLAND 2832.

Brown, 15.3 hands; brother in blood to Guy, 2:12, and Fred. Folger, 2::01/4.

PRINCE GEORGE 2948.

Bay, 15.2 hands; by kentucky Prince, out of Lady Dexter, sister of Dexter, 2:11:4.

NEWBOLD 5080.

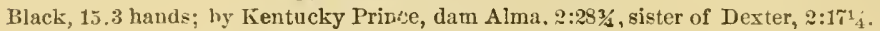

MELVILLE 5079.

Chestnut, 16 hands; by Kentucky Prince, out of a sister of Leland.

CHARLES BACKMAN,

Stony Ford P. O., Orange Co., N. Y.

IIARRISON ARMS

President.
H. G. ALLEN,

Manager.
W. A. YAGER, Sec'y and Treas.

\section{The Arms Palace Horse Car Co.}

General Offices, "The Rookery,"

CHICAGO, - - - - ILLINOIS.

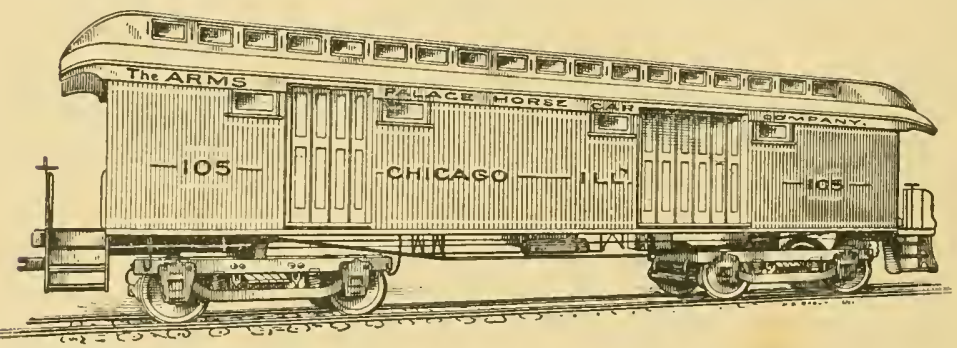

The above is a cut of our new Special Car, built expressly for the campaigning of racing stables, and to which we desire to call attention.

This car is vastly different from our regular line cars, and is only leased for the season. Send for descript ve and fully illustrated pamphlet. 


\section{WATERS STOCK FARM.}

TROTTING STOCK.

GENOA JUNCTION, WIS.

STAI,LIONS IN SHRVICE:

CALIFORNIA 4132.

Bay, black points, 16 hands, 1,185 lbs. Foaled, 1882.

\section{NUTMEG 2459.}

Three-year-old record, . . . .2:3:3/4 Five-year-old record.......2:25

Chestnut, foaled in 1883.

\section{ERELONG II 1 I.}

Bay, black points. Foaled. $18 \pi 8$; sire of Solong, $2: 2, \frac{1}{2}$, Fan nette, 3 yrs., $2: 32$,

There are also : SPRAGUE PICOT 2458 ; Record, 2:21; by Gov. Sprague 444, dam by Pllot Temple, son of Pilot, Jr., 12; $2 \mathrm{~d}$ dam by Ole Bull, 3d Inp. Glencoe, and to 13 th dam thorougbbred.

TACKS 4664; Record, 3 yrs., 2:47; by Egbert 1136, dam by Howard's Mambrino, son of Mambrino Chief $11 ; 2 \mathrm{~d}$ by John Innis, pacer.

THE BROOD MARES on the Farm are richly and Pashionably bred, mostly young, all vigorous and sound, and $0^{\circ}$ great individual nerit. Toung Stock, and Mares in Foal, for sale. Send for Catalogue glving description and pedigrees, and arranged so as to be valuable as a book of reference. Addregs

WATERS STOCK FARM, Genoa Junction, WIs.

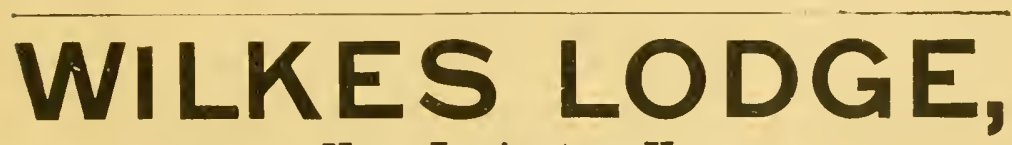

Near Lexington, $\mathbf{K y}$.

\section{BREEDING,}

\section{SOUNDNESS, \\ SPEED, SENSE, \\ and COURAGE.}

The Hambletonian Family • and • George Wilkes Branch ITE PILIARS.

Young trotting stock, out of standard-bred mares, and by Lord Russell, Pancoast, Florida, Jay Gould, Jay Bird, Ferguson, Monte Cristo, Sultan, Robert McGregor, Socrates, Director, and Dictator FOR SILE AT REASONAIBE PRICES.

For catulogues or infolmation address 


\section{FRAZIER ROAD-CARTS.}

\section{STYLES OF CARTS.}

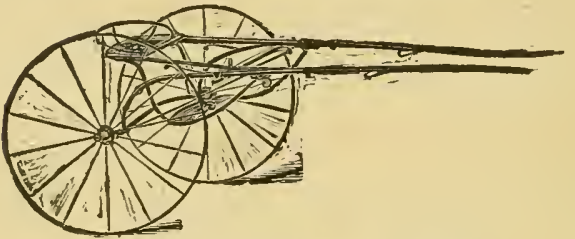

ROAD WAGONS. SKELETON WAGONS.

WRITE FOR ILLUSTRATED CATALOGUE.

Chicago Repository, 373 Wabash Avenue. Address

W. S. FRAZIER \& CO., AURORA, - - - - ILLINOIS.
Breaking Carts.

Speeding Carts. Physicians' Carts.

Pole Carts.

Business Carts.

Ladies' Carts.

Pony Carts.

THE ORIGINAL ROAD-CART.

THE LEADING ROAD-CART.

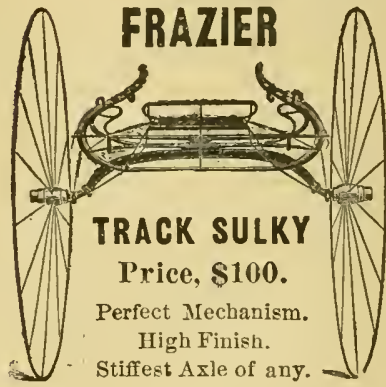

\section{THE IEADING}

\section{HORSE OWNERS, DRIVERS, AND BREEDERS}

IN THE COUNTRY ENDORSE

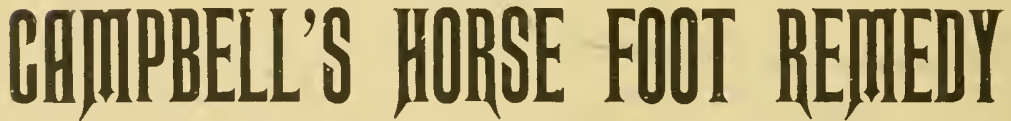

As the best and only preparation that will do all that is claimed for it in preventing and curing ailments of the feet, such as

Corns, Quarter Cracks, Brittle, Contracted, Sore, Tender Feot, etc.

IT SAVES ALL PACKING AND SOAKING.

Keeps the feet in better condition with less time, labor and money, and gives better results than can be obtained in any other way.

Sold by all dealers, with a guarantee to give satisfaction or money refunded. TRY IT. Send for testimonials, etc.

\section{JAS. B. CAMPBELL \& CO.}

Proprietors and Manufacturers, 


\section{HOW THE WINNERS ARE BRED!}

If you wish to study the question of

The Successful Breeding of the Trotting Horse,

You can not afford to be without

\section{THE BREEDER'S GAZETTE}

The Great "All 'round" Live-Stock Journal of the day.

\section{IMPARTIAL, THOROUGH, AND RELIABLE.}

Its discussions of blood lines, as applied to the production of speed, are conceded to be the clearest and most valuable now appearing in the American Press.

\section{Turf Department in Charge of Mr.H. T. White,}

The editor of this volume--"Life Among the Trotters."

TERMS : Single Subseriptlon, $\$ 3.00$ per annum; Two Subscriptions, remitted together, $\$ .00$ each. 24 to 28 pages weekly. Send stamp for specimen copy.

Address, J. H. SANDERS PUBLISHING CO.,

226 La salle street, Chicago, 111.

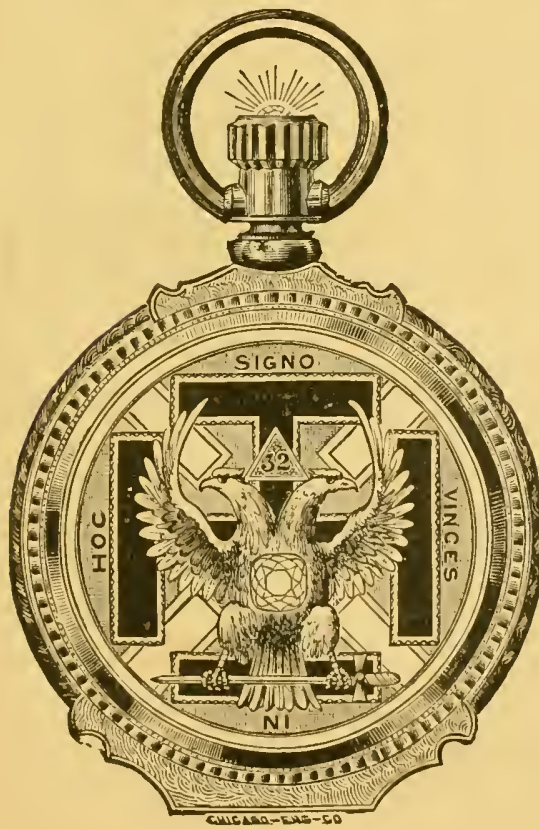

GILES BRO. \& CO. Watch makerers AND Jewelers. Sporting Watches A SPECIALTY.

A complete assortment of fine and complicated watches, such as CIIRONOGRA PIS, REPEATERS, QUARTER-SECOND FLYBACKS, ETC., constantly on hand.

Giles' Anti-Magnetic Shield for Watches.

Every fine watel should bo protected with one of these shields if absolutely correct time is recuired.

State and Washington Streets, CHICACO, ILL. 


\section{HORSEMEN'S HEADQUARTERS}

\section{The English Chop House,}

No. 5 CALHOUN PLACE, CHICAGO, ILLINOIS,

\section{WILLIAM M. BOYLE, \\ PROPRIETOR,}

EX-Secretary DEXTER PARK and CHICAGO DRIVING PARK.

Horsemen Welcome Twenty-four Hours in the Day. A Coterie of kindred spirits always there, telling stories about the trotting turf.

\section{CHICAGO}

VETERINARY ROLLEGE

(Chartered by the State of Illinois, 1883.)

2537 and 2539 State St.,

CHICAGO, ILL.

TRUSTEES :

R. J. WITHERS, - - - - - - President A. H. BAKER, - - - Treasurer and Registrar JOSEPH HUGHES, - - - - - Secretary

For prospectus and further information, write to the Secretary. 


\section{A GREAT BOOK FOR HORSE BREEDERS.}

No book upon any branch of live-stock breeding ever moblished in the United States has met woith so favorable a reception as has been recorded to "HorseBreeding," by J.II. Sanders, senior editor of "The Breeders' Gazette." Since this book was issued, a little over three years ago, eight large editions have been printed and hisposed of. Since the first editions were printed the work has been thoroughly revised, considerable nevo matter added, and the demand for it in foreign countries has been so greal that it has been translated and published in the German language, a compliment, we betieve, which has never before been accorded to any book upon any branch of live-stock breeding voritten in the United States. H. D. McKinney ("Nambrino"), of Janesville, Wis., says of it: "I consider it almost invaluable, and could I not procure another copy zoould not talie tacenty times the price of it." IIon. John Landrigan, ex-President of the Illinois State Board of Agriculture, says: "I have no hesitancy in saying that it is the ver'y best book on the subjectread by $m c$, and should be in the hands of every person interested in horses." C. A. DeGraff, of Minnesota, says: "It is by long odds the most thoroughly praftical book upon the breeding and management of horses ever written. The chapters devoted to the management of stallions, brood mares, and young foals are especially valuable." The price is \$2 by mail, prepaid. Address

\section{J. H. SANDERS PUBLISHING CO.,}

226 La Salle Street, CHICACO.

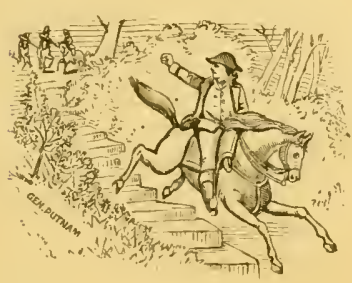

PutNay Hot-Forged NaIL.

Nails mace of the Cold Rolling, Punching, and wheariog Process.

From a iīorse's Foot. Providence, R. I.

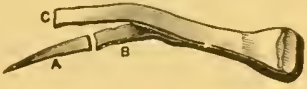

From a Horse's Foot, St, Louis, Mo.

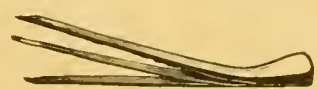

\section{Look well to your horse's feet}

For unless you know what Nail has been used in shoeing him, you are liable at any moment to have him lamed by a Split Nail which has po etrated the wall of the foot. resulting in lockjaw or death. as has been frequently the case since the introauction of coldrolled nails.

\section{THEPUTNAM NAIL}

Is the only Hot-Forged and Hammer-Pointed

\section{Horseshoe Nail in the World}

that is not CUT, CLIPPED or SHEARED upon the point and will not split in driving. In pointing, as well as making, these Nails the OLD HAND PROUESS has been followed as nes iy as possible, with such complete success thai they are the IN T W ORT in INU incin is impossible to $n$ driving.

OTHAT YOUR HORSE IS SHOD WITH OUR NAIL, and avold all risk. For sale by all dzalers in Horse Nails. Sample sent free by mail by addressing

PUTNAM NAIL CO., - BOSTON, MASS.

7. O. AdIress, NEIONSET, HASS. 


\section{FEED ALL HORSES CLEAN OATS \\ Patent June 8th, 1886.

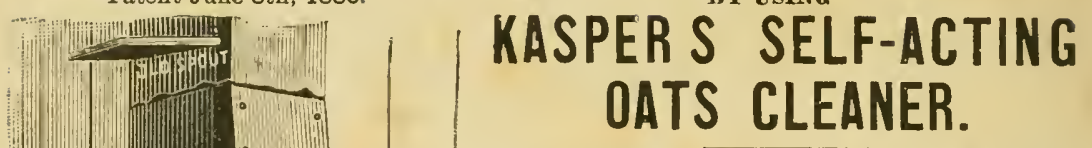

This is the most perfect Grain Purifier known. Can not get out of order and will last for years. No power necessary. It saves sickness among lorses, money, time and trouble. All private, livery, boarding and teaming stables and stock farms should have one. The oats are cleaned as they pass through the spout.

FOREST HIJL, Sept. 10, 1886. To Whom it Iay ConcernThe Uat Cleaner put in my stable by C, Kasper is a perfect success as an Oats l'urifier. J.D. ROCKEF',LLER,
Per H. M. Sinclair.

CLEVELAND, O., Sept. 29, 1886,-Kasper's Oats Cleaner is the best and inust effective device that I have ever seen or of the Cleveland Driving Park Ass'n.

CLEVELAND, O Sept. 21, 1886,-I would advise anvone keeping horses and desiring to feed clean oats, to purchase one of your Oats Cleaners. It certainly does all you elaim for it, and works to my entire satisfaction. Yours truly. Of the Cleveland Druving l'ark Ass'n.

ST. LOUIS, MO, Dec, 20, 1886.-Mr. Chris. Kaspe--In reference to your Kasper Oats Cleaner, it is one of the best arrangements tlat Thave ererseen, and I would not be without it if it cost three times the price. And no stable should be without one, as it is necessary for the health of the animals that they be fed clean food. A. MURRAY.

Supt. American Express Co.'s Stable.

CHICAGO, April I8th, 1887,-MIr O. C. Cleave-Dear Sir:You may say that the Clicago Fire Department has placed Kasper's Oats Cleaner into general use, aud that I an fully satisfied tbat it is a grand articlo for all stables, and especially where horses are urged to sueed and need good wind. Clenn oats sbould always be fed to all horses, and by using your Cleaner it can easily he done. Yours respeetfully.
D. J.SWENlE.

Chief of Chicago Fire Dept.

CHICAGO, April 1, 1887-MIr. C. Cleave-Dear Sir: The two Kasper's Oats Cleaners which you placed in the stables of J.V. Farwell \& Co. al'e giving the very best of satis. faction. I have used fans and other contrivances for cleaning oats, but have never before found any way to clean the oats as perfectly as with your eleaners. They remove all impurities that should not be fed to horses, and as all oats should be cleaned before feeding, I strongly reenmmend the Kasper's Self-Acting Oats Cleaner as tho best device made for this purpose. CAPT, PHILLJPS.

Supt. J. Y. Farwell \& Co.'s Stables.

Used in their stables and endorsed by STOCK FARMS.

M. W. Dunham. Wayne, Ill, T. W. Harres, Turlington.Neb. T. P. Phillips, Naperville, Ill. Clairview, Grosse Point, Mich. Gajbraitl Bros, Janesville, Hamlin's, East A urora, N, Y. Wis. Waters renoa Junction, Wis. Miller \& Sibley, Franklin, l'a. J. W. Wolcott, Hutchinson, Forest City Farm, Cleveland. Kan. WASIINGTON, D. C.
W. Wilson,

White Hnuse Stable. fovermment Printing Office. War Departmentstable. W. C. Whitney, Secrutary U. S. Senate Stalle: BUFFA LO. N. $\mathbf{Y}^{-}$

Dr. Hinekley, Veterinary. Harry Hamlin.

Dr. I. Stumpf, Yeterinars. S S Jewett.

C. J. Hamlin.

UIIICAGO, IILI.

Mayor John A. Roehe. Mrrshall Field.

Hon. C. B. Farwell. Henry Field.

ROCIIENTEIR, N. $\mathbf{T}$.

Hon. Frederick Cook. Jos, Cunningham.

D. W. Wright. Jas. Hart.

Wim. S. Kimball.

Send for Descriptive Circular and Price List, containing names and testimonials of pronincret lorse-owners.

\section{O. C. CLEA VE \& CO., Owners and Manufacturers, Office, 211 Wabash Ave., CHICACO.}





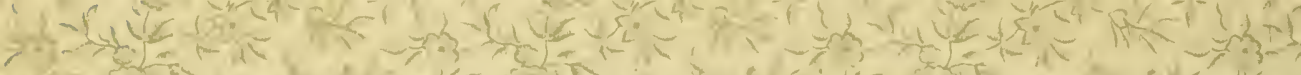
fe mo

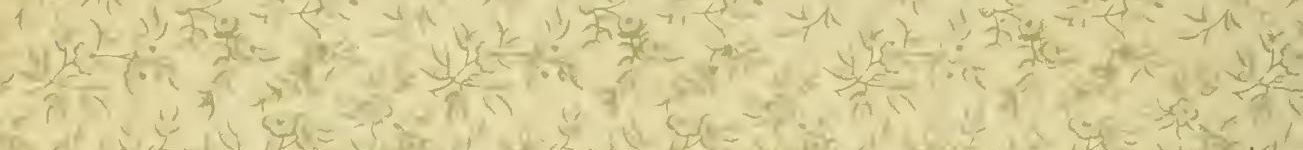
A th

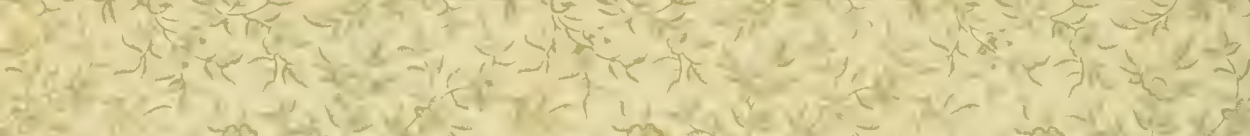

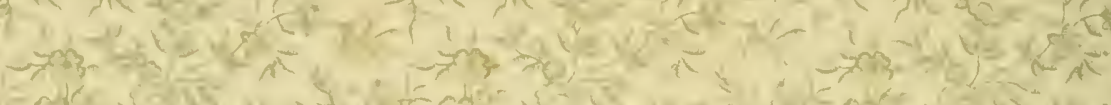

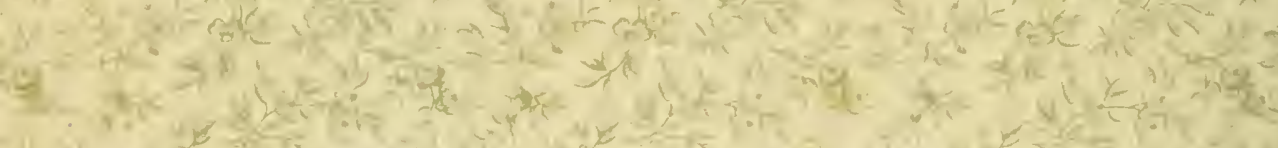

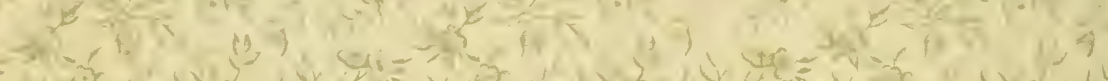
सै

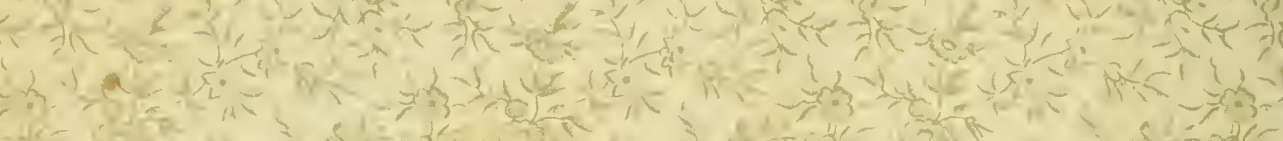

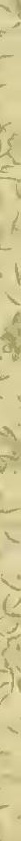

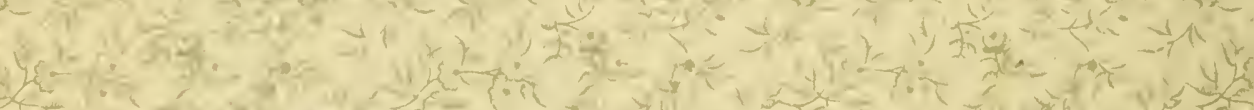

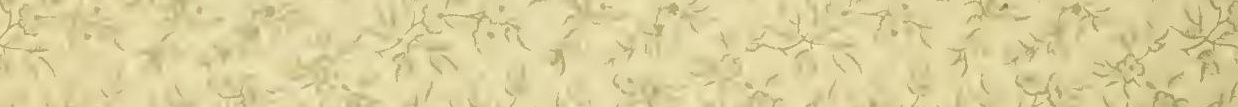

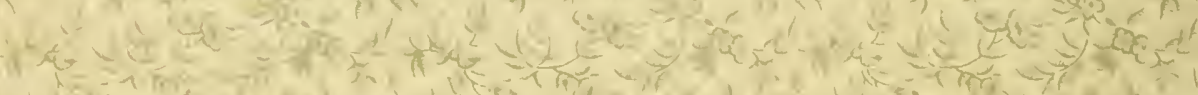

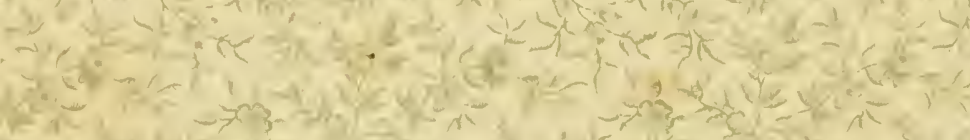
$-x^{2} x^{2}+x^{2}=4 x^{2}=$

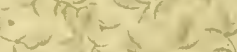

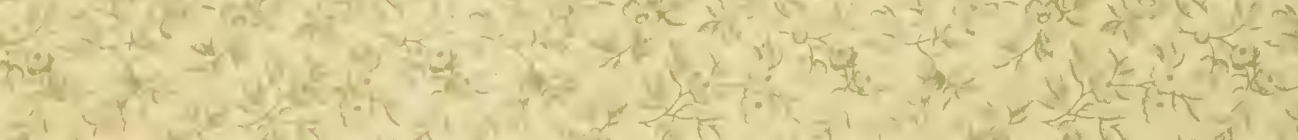

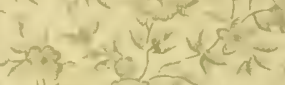
ac -ry 
